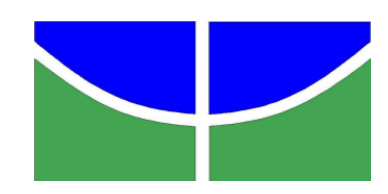

UNIVERSIDADE DE BRASÍLIA

INSTITUTO DE LETRAS

DEPTO. DE LINGUÍSTICA, PORTUGUÊS E LÍNGUAS CLÁSSICAS PROGRAMA DE PÓS-GRADUAÇÃO EM LINGUÍSTICA

\title{
DISCURSIVIDADES EM UM \\ PLANO DE DESENVOLVIMENTO AGRÁRIO: \\ FACETAS DE PRÁTICAS SOCIAIS (RE)PRODUZIDAS
}

CARINA APARECIDA LIMA DE SOUZA

Brasília

2015 


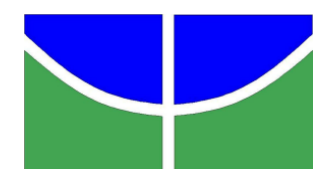

UNIVERSIDADE DE BRASÍLIA - UnB INSTITUTO DE LETRAS - IL

DEPTO. DE LINGUÍSTICA, PORTUGUÊS E LÍNGUAS CLÁSSICAS - LIP PROGRAMA DE PÓS-GRADUAÇÃO EM LINGUÍSTICA - PPGL

\section{DISCURSIVIDADES EM UM \\ PLANO DE DESENVOLVIMENTO AGRÁRIO: \\ FACETAS DE PRÁTICAS SOCIAIS (RE)PRODUZIDAS}

Tese apresentada ao Programa de Pós-Graduação em Linguística do Departamento de Linguística, Português e Línguas Clássicas do Instituto de Letras da Universidade de Brasília, como parte dos requisitos para obtenção do grau de Doutora em Linguística. Área de concentração: Linguagem e Sociedade.

Orientadora: Profa. Dra. Denize Elena Garcia da Silva 
Ficha catalográfica elaborada pela Biblioteca Central da Universidade de Brasilia. Acervo 1020894.

\section{Souza, Carina Aparecida Lima de.}

S729d Discursividades em um plano de desenvolvimento agrário : facetas de práticas sociais (re)produzidas / Carina Aparecida Lima de Souza. -- 2015.

$300 \mathrm{f}$. : il. ; $30 \mathrm{~cm}$.

Tese (doutorado) - Universidade de Brasilia, Instituto de Letras, Departamento de Linguística, Programa de Pós-Graduação em Linguística, 2015.

Inclui bibliografia.

Or ientação: Denize Elena Garcia da Silva.

1. Linguística. 2. Anál ise do discurso. 3. Reforma agrária. I. Silva, Denize Elena Garcia da. II. Título.

CD 801 


\title{
DISCURSIVIDADES EM UM \\ PLANO DE DESENVOLVIMENTO AGRÁRIO: \\ FACETAS DE PRÁTICAS SOCIAIS (RE)PRODUZIDAS
}

\author{
CARINA APARECIDA LIMA DE SOUZA
}

Tese apresentada ao Programa de Pós-Graduação em Linguística, Departamento de Linguística, Português e Línguas Clássicas do Instituto de Letras da Universidade de Brasília, como parte dos requisitos para obtenção do Grau de Doutora em Linguística, área de concentração Linguagem $e$ Sociedade: Discursos, Representações Sociais e Textos, defendida em 27 de fevereiro de 2015 e aprovada pela Banca Examinadora constituída pelas professoras:

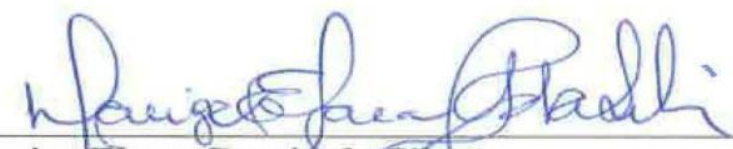

Dra. Denize Élena Gareia da Silva

Universidade de Brasília (UnB) - Presidente

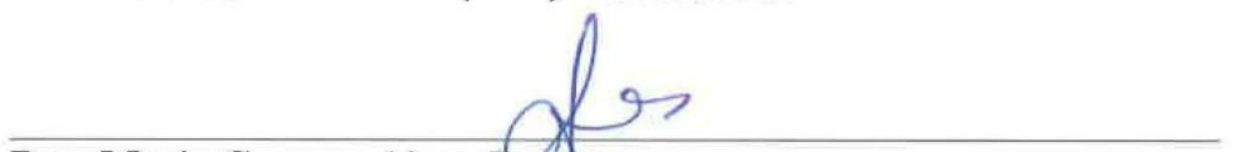

Dra. Maria Carmen Aires Gemes

Universidade Foderal de Viçosa (UFV) - Membro efetivo externo

Dra. Solange Maria de Barros

Universidade Federal do Mato Grosso (UFMT) - Membro efetivo externo

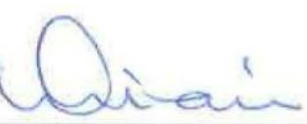

Dra. Viviane de Melo Resende

Universidade de Brasília (UnB) - Membro efetivo interno

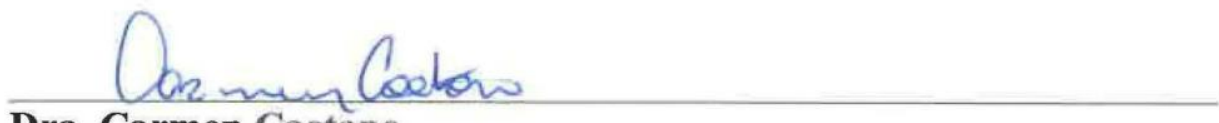

Dra. Carmen Caetano

Universidade de Brasília (UnB) - Membro efetivo interno

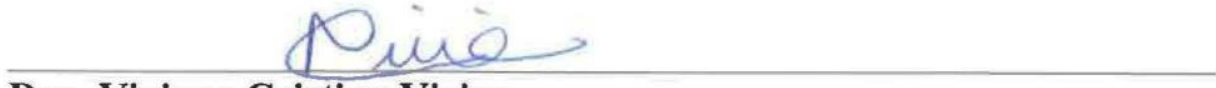

Dra. Viviane Cristina Vieira

Universidade de Brasília (UnB) - Membro suplente interno 


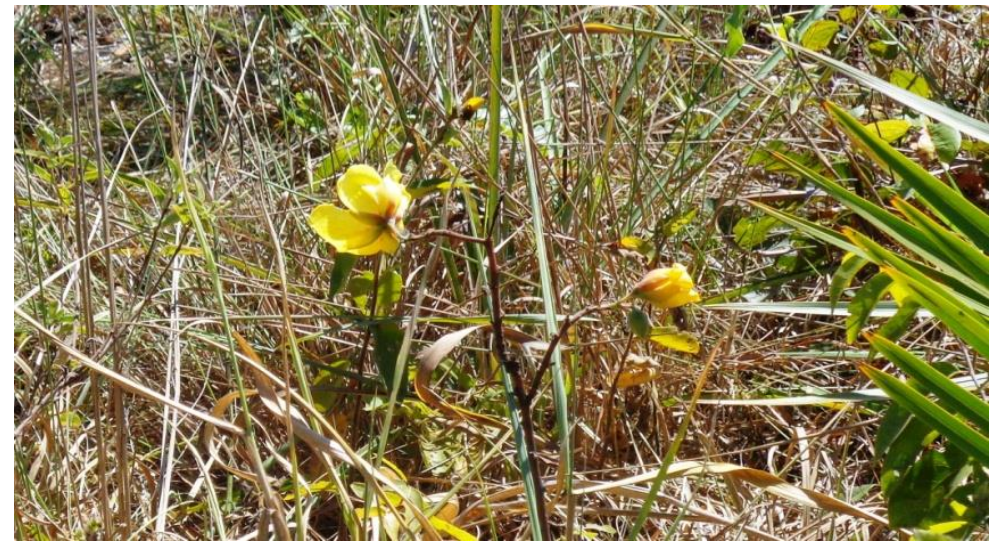

Assim como as orquídeas lutam para florirem no solo pedregoso do PA Santa Tereza I, seus/suas assentados/as também lutam para florirem a Reforma Agrária no Tocantins. Dedico, assim, esta tese àqueles/as que fazem de suas vidas uma constante luta para o reconhecimento da Reforma Agrária como manancial de justiça social: aos sem-terra e às sem-terra. 


\section{AGRADECIMENTOS}

Durante os quatro anos do Doutorado tive a feliz oportunidade de compartilhar conhecimento, amizades, conselhos, carinho e abraços. Agradeço infinitamente a Deus - "Lírio do vale, estrela da manhã... Alfa, ômega, princípio e fim" - toda graça concedida a mim.

Aos motivos da inspiração para a busca pela superação diária, meus avós Osvaldo, Zelita e Maria. À minha mãe Fátima, pelo exemplo de amor incondicional.

A quem eu fico sem palavras para expressar tanto carinho e gratidão, à família que me acolheu em Brasília, minha profunda admiração à Querida Ana, ao João, ao Nagib e à Edi.

À minha estimada orientadora e ativista política preferida, Profa. Dra. Denize Elena Garcia da Silva, pelos bons momentos de estudos, pelo profissionalismo, pela compreensão, pela doce companhia nos congressos, pela acolhida em sua casa e pela companhia sempre agradável do Roberto.

Às dádivas proporcionadas pela Micheli e pela Flávia - meu príncipe Pedro e minha princesa Maria Eduarda -, por tornarem o caminho do Doutorado mais leve e esperançoso.

Ao João Paulo, pela paciência, compreensão e por entender a minha ausência.

Às inspiradoras do desejo de fazer parte do grupo da ADC na UnB, desde os tempos da UFV, Viviane Resende, exemplo de responsabilidade e de dedicação; e Maria Carmen, professora, orientadora, exemplo de profissionalismo, amiga querida.

Aos amigos da UnB Ana Aparecida, Ana Cláudia, Sandra, Kelly, Cibele, Pablo, Alley e Fernando, pelo incentivo constante aos estudos, pelas conversas, pelo carinho e cuidado de sempre.

Às Profas. Dras. Viviane Resende e Maria Carmen Gomes, pelas contribuições dadas na Qualificação, o que muito contribuiu para a realização desta tese, e por participarem da Banca de Defesa. Às Profas. Dras. Solange Barros, Carmen Caetano e Viviane Vieira, pela disponibilidade em participarem da Banca de Defesa. À Profa. Dra. Edna Cristina Silva, pelos valiosos ensinamentos durante as aulas.

Às colegas de 'república' Geruza, Lia e Solange, pelo apoio e pela companhia.

Às colegas professoras do IFTO-Palmas Adriana e Sylmara, pela viabilização de parte deste trabalho. Às graduandas do curso do Letras-IFTO Bruna e Sara, pela disponibilidade em participarem do trabalho de campo no projeto de assentamento. Ao Instituto Federal do Tocantins, pelo afastamento concedido para os estudos.

Aos funcionários do INCRA/Palmas Geraldino, Flávio e Alexandre, pelo atendimento sempre cordial e atencioso. Ao Daniel, presidente da associação do projeto de assentamento Santa Tereza I, pela disponibilidade em colaborar para que as entrevistas ocorressem. 
Canção do ver

Por viver muitos anos dentro do mato.

Moda ave...

O menino pegou um olhar de pássaro contraiu visão fontana.

Por forma que ele enxergava as coisas Por igual como os pássaros enxergam.

As coisas todas inominadas.

Água não era ainda a palavra água. Pedra não era ainda a palavra pedra. E tal.

As palavras eram livres de gramáticas $e$

Podiam ficar em qualquer posição.

Por forma que o menino podia inaugurar.

Podia dar as pedras costumes de flor.

Podia dar ao canto formato de sol.

$E$, se quisesse caber em um abelha, era só abrir a palavra abelha e entrar dentro dela.

Como se fosse infância da língua.

(Manoel de Barros, 2011) 


\section{RESUMO}

Esta tese resulta de uma pesquisa de natureza qualitativa (descritiva e interpretativa) levada a cabo à luz da Análise de Discurso Crítica, com o objetivo de investigar discursos (re)contextualizados em um Plano de Desenvolvimento Agrário (PDA), de modo específico, do Projeto de Assentamento (PA) Santa Tereza I , localizado no município de Ponte Alta, no estado do Tocantins, com vistas a desvelar facetas de práticas sociais (re)produzidas. Para tanto, busco identificar e analisar representações linguístico-discursivas constituídas nesse PDA. De acordo com dados do Sistema de Informações de Projetos de Reforma Agrária (SIPRA), em março de 2013, houve 367 decretos desapropriatórios, com 41.978 famílias assentadas. ${ }^{1}$ No estado mais novo do Brasil, mais da metade da população rural é assentada. Nesse contexto, a precariedade social e econômica de pessoas que se dispõem ao meio de vida com o uso da terra tende a ser resolvida através do direito ao uso de uma parcela de terra/um lote em um projeto de assentamento. Ao INCRA, como representante do Governo Federal, no que se refere à Reforma Agrária (RA) no Brasil, cabe, dentre outras atribuições, instituir os PAs de acordo com a legislação vigente; selecionar candidatos/as; e fazer os/as assentados/as cumprirem a legislação referente ao uso da terra. Candidatar-se a um PA, ser selecionado/a a participar de um PA, tornar-se assentado/a não significa, porém, a erradicação de precariedades. Resulta que alguns modos de vida dos/as assentados/as, orientados pelo INCRA para que a concessão de uso de uma parcela de terra seja efetuada e mantida, podem ser influenciados por gêneros discursivos materializados em textos, como PDA, razão pela qual a presente pesquisa envolve procedimentos de coleta e seleção de dados tanto de natureza documental como de natureza etnográfica. O corpus documental se constitui de dados documentais do texto do PDA do PA Santa Tereza I, enquanto o corpus de natureza etnográfica envolve, principalmente, entrevistas realizadas com os/as assentados/as pioneiros/as do mesmo assentamento e com funcionários do INCRA-SR26/Tocantins. Ambos os grupos de entrevistados/as possuem participação institucionalizada obrigatória em reuniões para a elaboração do PDA. Na época, em 2007, a elaboração do PDA era uma exigência do Ministério de Desenvolvimento Agrário (MDA) para que os lotes de um PA fossem 'sorteados'. O estudo encontra-se balizado no arcabouço teórico-metodológico, principalmente, da Análise de Discurso Crítica, proposto por Fairclough (2003, 2010); e da Linguística Sistêmico-Funcional, nos moldes de Halliday \& Matthiessen (2004). Isso, porque o foco de interesse é a análise das discursividades e das representações constituídas no PDA Santa Tereza I. A construção do pensamento crítico, através do conhecimento de facetas do uso da linguagem escrita e oral como representação do mundo, no caso, com referência ao PDA, faz-se, pois, instrumento para que assentados/as possam buscar inclusão social, mudança social, no PA Santa Tereza I e para que seja inspiração para outras buscas no que concerne à vida no campo no Brasil. Os resultados alcançados significam uma forma de contribuição para desvelar facetas de práticas sociais (re)produzidas e, em condições propícias, para diminuir vulnerabilidades a que são submetidos/as os/as assentados/as, por vezes ratificadas em textos oficiais.

Palavras-chave: Análise de Discurso Crítica. Linguística Sistêmico-Funcional. Reforma Agrária. Plano de Desenvolvimento Agrário. Assentados/as. Inclusão Social.

\footnotetext{
${ }^{1}$ Disponível em: <http://www.incra.gov.br/index.php/reforma-agraria-2/questao-agraria/numeros-da-reformaagraria/file/1148-familias-assentadas>. Acesso em: 15 jun. 2013.
} 


\begin{abstract}
This thesis results from a qualitative research (descriptive and interpretative) carried out in the light of Critical Discourse Analysis, in order to investigate discourses (re) contextualized in a Land Development Plan (PDA), that is, the Santa Tereza I Settlement Project (PA), located in Ponte Alta, Tocantins, in order to unveil the nuances of (re) produced social practices. To this end, I attempt to identify and analyze linguistic-discursive representations made in the PDA. According to data obtained from the System of Agricultural Reform Project (SIPRA), in March 2013, there were 367 expropriating decrees, with 41,978 families settled. In the newest state of Brazil - Tocantins -, more than half of the rural population is settled. In this context, the social and economic precariousness of people is tackled by the right to use a portion of land through settlement projects. However, applying for a PA, being selected to join it, becoming settled does not necessarily mean exterminating poverty. Indeed, INCRA, as a representative of the federal government with regard to Land Reform (RA) in Brazil, among other things, establishes the PAs in accordance with the current legislation, selects candidates, and makes the peasants comply with the law regarding the use of the land. Hence, the prerequisites for INCRA to grant the use of a portion of land to them are materialized in texts through discursive genres, such as the PDA. This is the very reason why the research in question involves generation and selection of both - documentary and ethnographic data. The former is composed of written data from the PDA PA Santa Tereza I, while the latter complementary corpus - deals with interviews with pioneer peasants in the same settlement, and officials from INCRA-SR 26/Tocantins, both groups of respondents with mandatory and institutionalized participation in meetings to prepare the PDA. At the time, in 2007, the development of the PDA was a requirement from the Ministry of Agrarian Development (MDA) before conceding a piece of land. The study is grounded on the theoretical and methodological tenets of Critical Discourse Analysis proposed by Fairclough $(2003,2010)$, and Systemic-Functional Linguistics suggested by Halliday \& Matthiessen (2004) whose focus of interest is the analysis of discourses and representations made in the PDA Santa Tereza I. The constitution of critical thinking, through in-depth knowledge of aspects in the use of written and oral language as a representation of the world, in this case, with reference to the PDA, is an instrument for landless peasants to seek social inclusion and social change in PA Santa Tereza I, as well as other pursuits regarding country life in Brazil. The results obtained are prone to unveil and, more coherently, minimize the vulnerabilities which they have to undergo, sometimes ratified in official texts.
\end{abstract}

Keywords: Critical Discourse Analysis. Systemic Functional Linguistics. Agrarian Reform. Land Development Plan. Settlers. Social Inclusion. 


\section{LISTA DE FIGURAS}

\section{CAPÍtULO 2}

Figura 2.1 - Dimensões complementares do discurso .....................................................67

Figura 2.2 - Estratos do sistema de ordens do discurso ....................................................69

Figura 2.3 - Estratificação dos planos comunicativos linguísticos e contextual.......................71

Figura 2.4 - Variáveis do contexto de situação .....................................................................72

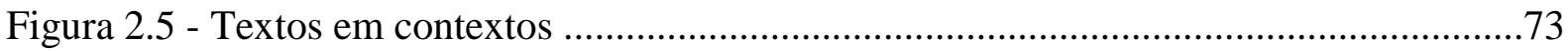

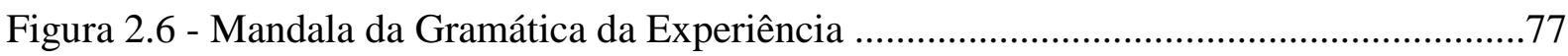

Figura 2.7 - Diagrama da relação de polaridade, modalidade e modo ..................................85

Figura 2.8 - As metafunções e os sistemas léxico-gramaticais .......................................... 85

Figura 2.9 - Textos referentes à reforma agrária .................................................................92

Figura 2.10 - A representação dos atores sociais no discurso ...............................................98

Figura 2.11 - Triangulação dos pressupostos teórico-metodológicos da pesquisa .................104

\section{CAPÍTULO 4}

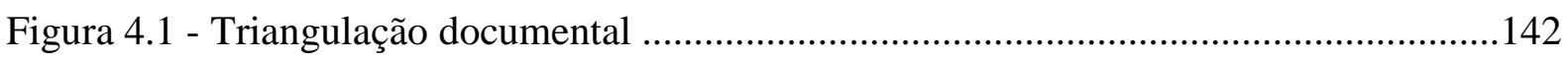

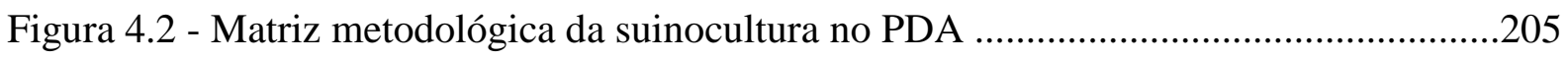




\section{LISTA DE FOTOGRAFIAS}

\section{CAPÍTULO 1}

Fotografia 1.1 - Capa do PDA do PA Santa Tereza I.............................................................44

\section{CAPÍTULO 3}

Fotografia 3.1 - Água disponibilizada à escola do PA.........................................................119

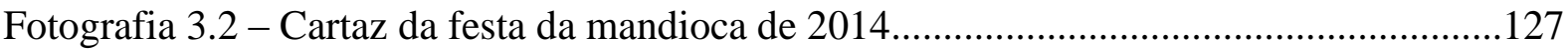

\section{CAPÍTULO 4}

Fotografia 4.1 - Obtenção de água em um dos lotes do PA.................................................192

Fotografia 4.2 - Único caminho para um dos lotes do PA......................................................202

Fotografia 4.3 - Frente do prédio da escola do PA Santa Tereza I........................................209

Fotografia 4.4 - Fundos do prédio da escola do PA Santa Tereza I........................................210

Fotografia 4.5 - Sala de uma casa construída com recurso público.......................................210 


\section{LISTA DE GRÁFICOS}

\section{CAPÍTULO 4}

Gráfico 4.1 - Processos mais frequentes no texto do PDA Santa Tereza I ...........................165

Gráfico 4.2 - Distribuição de processos no PDA Santa Tereza I .........................................166

Gráfico 4.3 - Processos materiais mais frequentes no PDA Santa Tereza I .........................168

Gráfico 4.4 - Distribuição de processos materiais na voz ativa e passiva no PDA................172

Gráfico 4.5 - Processos relacionais mais frequentes no PDA Santa Tereza I ........................174

Gráfico 4.6 - Distribuição de processos nos Agradecimentos do PDA ..................................177

Gráfico 4.7 - Distribuição de processos na Apresentação do PDA ........................................181

Gráfico 4.8 - Distribuição de processos na Metodologia do PDA …….................................184

Gráfico 4.9 - Distribuição de processos no Contexto socioeconômico e ambiental do

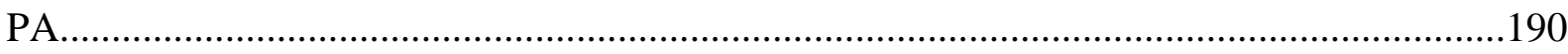

Gráfico 4.10 - Distribuição de processos no Diagnóstico do PA ............................................192

Gráfico 4.11 - Distribuição de processos no Prognóstico de impactos ambientais e medidas

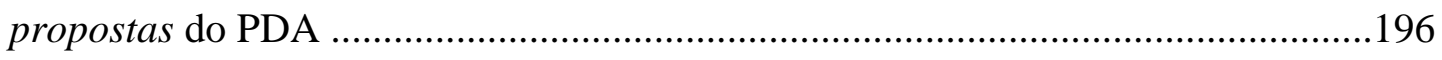

Gráfico 4.12 - Distribuição de processos nas Considerações finais .......................................198

Gráfico 4.13 - Distribuição de processos no Plano de ação ...................................................200

Gráfico 4.14 - Ocorrência de vozes e seus respectivos operadores modais ..........................235 


\section{LISTA DE QUADROS}

\section{CAPÍTULO 1}

Quadro 1.1 - Reforma agrária nas democracias contemporâneas..........................................34

Quadro 1.2 - Impactos do MST nos movimentos sociais brasileiros......................................39

Quadro 1.3 - História social do campo: Brasil 1945-2005 .....................................................53

\section{CAPÍTULO 2}

Quadro 2.1 - Linguagem como parte irredutível do social..................................................68

Quadro 2.2 - A metafunção ideacional e a realização léxico-gramatical................................76

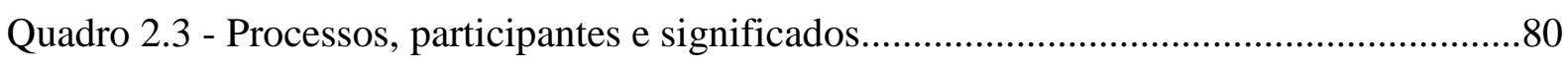

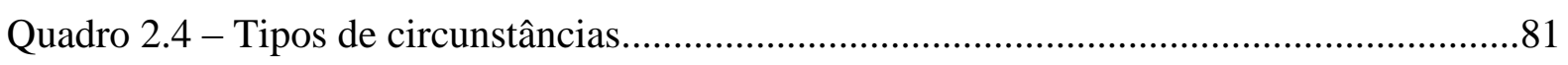

Quadro 2.5 - A metafunção interpessoal e sua realização léxico-gramatical..........................83

\section{CAPÍTULO 3}

Quadro 3.1 - Corpus ampliado para suporte à análise discursiva........................................115

Quadro 3.2 - Ficha de documentação de assentado/a participante da pesquisa...........................123

Quadro 3.3 - Questões das entrevistas dos/as assentados/as...............................................124

Quadro 3.4 - Ficha de documentação de funcionário do INCRA participante da pesquisa....125

Quadro 3.5 - Questões das entrevistas dos responsáveis técnicos pelo PDA........................125

Quadro 3.6 - Perfil dos/as assentados/as pioneiros/as entrevistados/as................................128

Quadro 3.7 - Perfil dos funcionários do INCRA entrevistados.............................................129

Quadro 3.8 - Arcabouço teórico-metodológico da ADC......................................................132

Quadro 3.9 - Arcabouço teórico-metodológico da ADC adaptado à tese..............................133

Quadro 3.10 - Quadro sinóptico da pesquisa...................................................................138

\section{CAPÍTULO 4}

Quadro 4.1- Estrutura composicional geral do PDA do PA Santa Tereza I..........................150

Quadro 4.2 - Estrutura composicional detalhada dos títulos do PDA...................................152

Quadro 4.3 - Estrutura composicional do Plano de ação para o desenvolvimento..................154

\section{CAPÍTULO 5}

Quadro 5.1 - Perfil das aves pioneiras do PA Santa Tereza I..............................................244

Quadro 5.2 - Razões para situação de projeto de assentamento...........................................248

Quadro 5.3 - Aves pioneiras com excertos na tese............................................................249

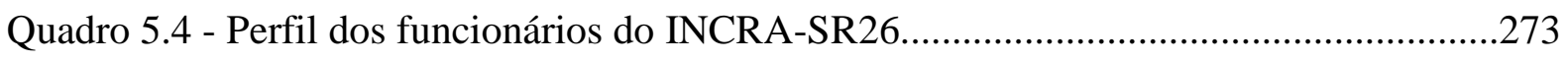




\section{LISTA DE TABELAS}

\section{CAPÍtULO 4}

Tabela 4.1 - Dimensões e densidade lexical (statistics) do PDA Santa Tereza I....................160

Tabela 4.2 - Palavras/substantivos mais frequentes no PDA Santa Tereza I..........................161

Tabela 4.3 - Processos verbais mais recorrentes no PDA Santa Tereza I..............................162

Tabela 4.4 - Atores sociais mais frequentes no PDA Santa Tereza I....................................222 


\section{LISTA DE SIGLAS}

ABI

ADC

CEDRS

CNBB

CNPJ

$\mathrm{CNPq}$

COOPVAG

CUT

FETAPE

FMI

GSF

IDH

INCRA

INCRA-SR26

LC

LSF

MAB

MDA

MMC

MPA

MST

MTST

$\mathrm{OAB}$

PA

PDA

PNB

PNRA

PRONAF

PT

RA

$\mathrm{RC}$

REDLAD

SIPRA

TSD

UAF
Associação Brasileira de Imprensa

Análise de Discurso Crítica

Conselho Estadual de Desenvolvimento Rural Sustentável do Tocantins

Conferência Nacional dos Bispos do Brasil

Cadastro Nacional de Pessoa Jurídica

Conselho Nacional de Desenvolvimento Científico e Tecnológico

Cooperativa de Profissionais Liberais do Vale Araguaia

Central Única dos Trabalhadores

Federação dos Trabalhadores na Agricultura de Pernambuco

Fundo Monetário Internacional

Gramática Sistêmico-Funcional

Índice de Desenvolvimento Humano

Instituto Nacional de Colonização e Reforma Agrária

Superintendência Regional do INCRA no Estado do Tocantins

Linguística Crítica

Linguística Sistêmico-Funcional

Movimento dos Atingidos por Barragem

Ministério do Desenvolvimento Agrário

Movimento das Mulheres Camponesas

Movimento dos Pequenos Agricultores

Movimento dos Trabalhadores Rurais Sem-Terra

Movimentos dos Trabalhadores Sem-Teto

Ordem dos Advogados do Brasil

Projeto de Assentamento

Plano de Desenvolvimento Agrário

Produto Nacional Bruto

Plano Nacional de Reforma Agrária

Programa Nacional de Apoio à Agricultura Familiar

Partido dos Trabalhadores

Reforma Agrária

Realismo Crítico

Rede Latinoamericana de Análisis del Discurso de la Pobreza

Sistema de Informações de Projetos de Reforma Agrária

Teoria Social do Discurso

Unidade Agrícola Familiar 


\section{LISTA DE SÍMBOLOS}

\section{Convenções de transcrição dos dados orais}

(Baseadas em Silva, 2001)

\begin{tabular}{|l|l|}
\hline Símbolo & Descrição \\
\hline$:$ & alongamento de vogal \\
\hline$::$ & alongamento maior de vogal \\
\hline$I$ & parada brusca \\
\hline$(())$ & comentários do analista \\
\hline$\cdots \cdots$ & discurso direto \\
\hline$\ldots$. & pausa \\
\hline MAIÚSCULA & ênfase na voz \\
\hline Itálico & expressões próprias da fala \\
\hline, & (vírgula) entonação média \\
\hline$!$ & entonação ascendente de exclamação \\
\hline $\boldsymbol{Q}$ & entonação ascendente de interrogação \\
\hline. & entonação descendente \\
\hline ....../ & transcrição parcial ou parte suprimida \\
\hline$(X X X)$ & fala incompreensível \\
\hline
\end{tabular}




\section{SUMÁRIO}

APRESENTAÇÃO 18

\section{CAPÍTULO 1}

\section{DAS REVOADAS PELA TERRA ÀS REVOADAS NA TERRA}

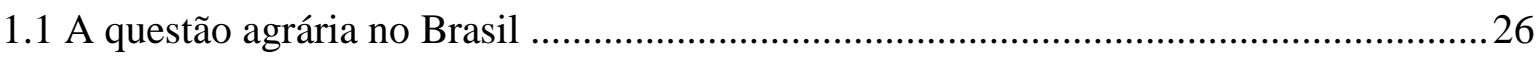

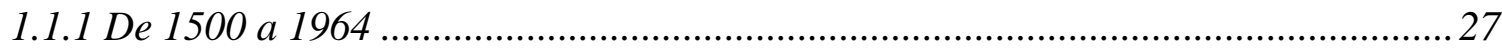

1.1.2 Do Estatuto da Terra à Constituição Federal de 1988............................................2 29

1.1.3 O governo Lula e o período de criação do PA Santa Tereza I ................................. 37

1.1 A reforma agrária e o estado do Tocantins ............................................................ 41

1.3 Sob a lona preta até a constituição do projeto de assentamento ................................... 46

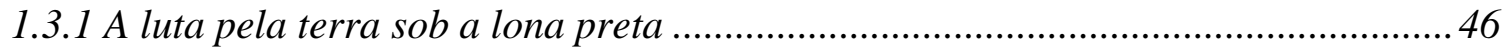

1.3.2 A luta na terra e a pobreza como restrição de liberdade ....................................... 47

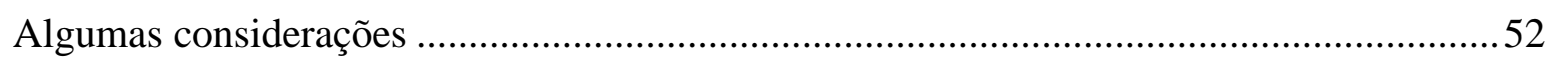

\section{CAPÍTULO 2}

\section{BASES DE PARTIDA PARA A REVOADA TEÓRICA: VIGAS MESTRAS}

2.1 Análise de Discurso Crítica: uma retrospectiva …........................................................56

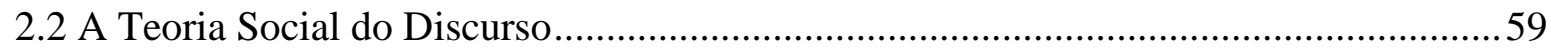

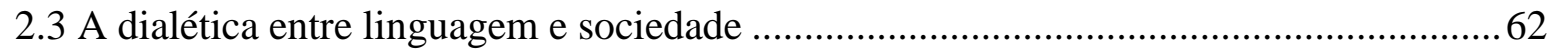

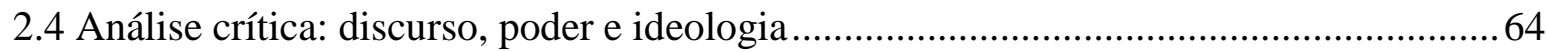

2.5 A interioridade da linguagem e a Linguística Sistêmico-Funcional.............................. 70

2.5.1 A oração como representação e a metafunção ideacional ...................................... 75

2.5.2 A oração como troca e a metafunção interpessoal ............................................... 82

2.6 A exterioridade da linguagem e $(m)$ ações, representações e identificaçõos.................... 86

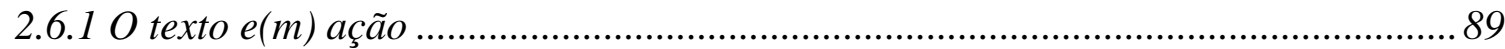

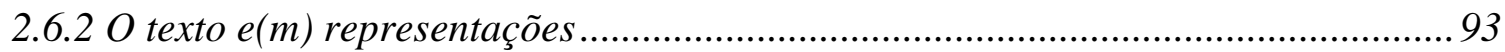

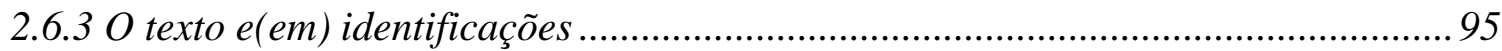

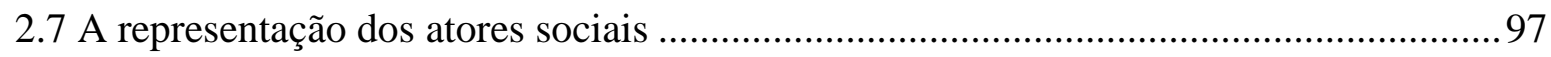

2.8 A interface entre a ADC e a LSF para a análise crítica ............................................ 101

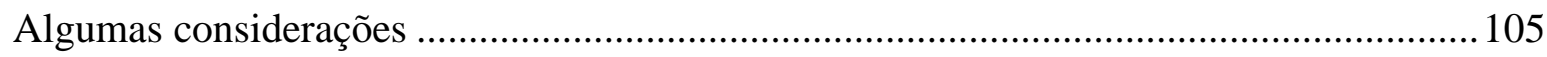




\section{CAPÍTULO 3}

\section{A CONSTRUÇÃO dA REVOADA: ESTRATÉGIAS DE PESQUISA}

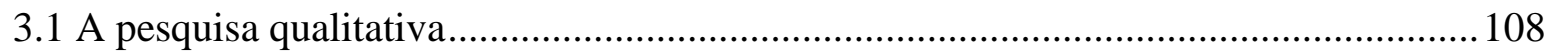

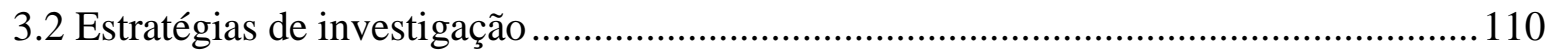

3.3 Coleta e seleção de dados de natureza documental .................................................. 113

3.3.1 O corpus de natureza documental ..................................................................... 113

3.3.2 Procedimentos de saturação do corpus documental ............................................ 114

3.3.3 A ferramenta computacional Wordsmith Tools e os dados documentais..............116

3.4 Geração de dados de natureza etnográfica ............................................................... 116

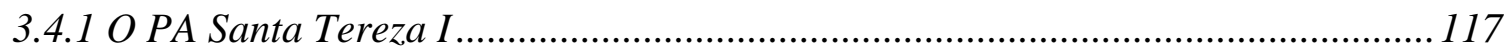

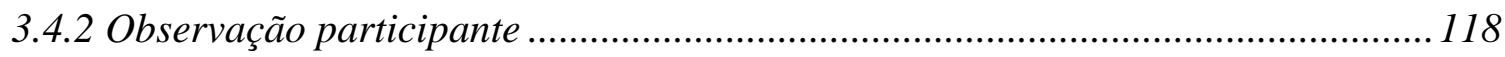

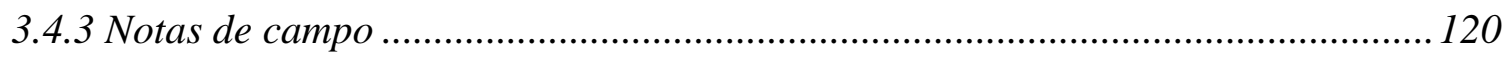

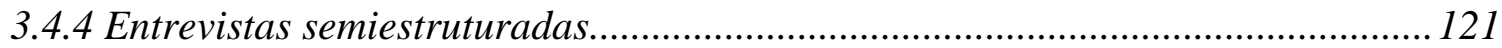

3.4.5 Os/as participantes das entrevistas ................................................................... 125

3.4.6 Sistematização dos dados de natureza etnográfica ............................................... 128

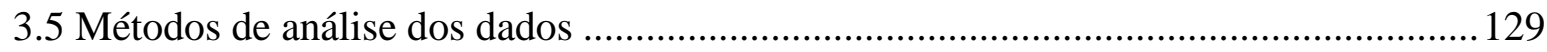

3.5.1 Abordagem teórico-metodológica da ADC .......................................................... 130

3.5.2 Abordagem teórico-metodológica da LSF ........................................................ 135

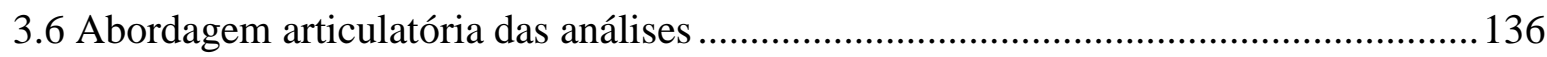

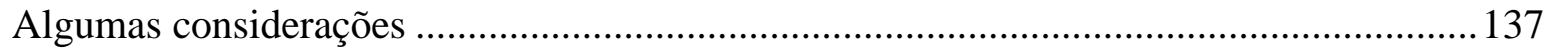

\section{CAPÍTULO 4}

\section{EM BUSCA DO NINHO: O PDA DO PA SANTA TEREZA I E(M) REPRESENTAÇÃO DE ASSENTADOS/AS}

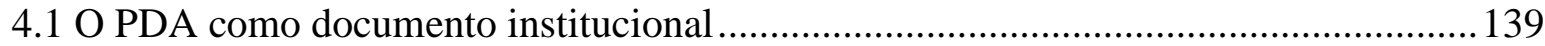

4.2 Modos de agir: a estrutura composicional do PDA ..................................................... 141

4.2.1 Textos articulados e a reforma agrária no Brasil.................................................. 142

4.2.2 A interface entre os textos institucionais ............................................................... 144

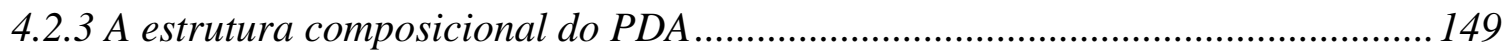

4.3 A inclusão do/a assentado/a: o PDA e(m) representações ........................................... 159

4.3.1 Percurso no PDA Santa Tereza I pelo WordSmith Tools....................................... 160

4.3.2 Representação de ações no PDA e o sistema de transitividade ............................. 164

4.3.3 Sete títulos do PDA em representações................................................................... 176 
4.3.4 O título de vôo mais extenso: Plano de ação para o desenvolvimento sustentável

4.4 A representação de atores sociais no PDA Santa Tereza I ......................................2215

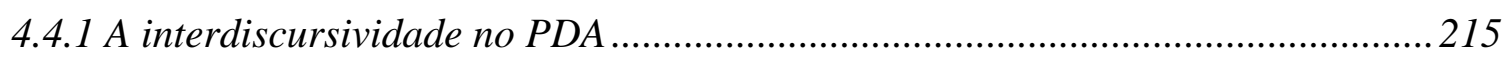

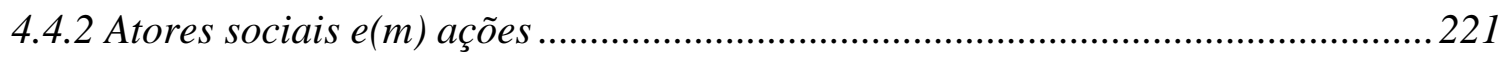

4.5 Da identidade de direitos aos deveres em grupos verbais do PDA ..............................234

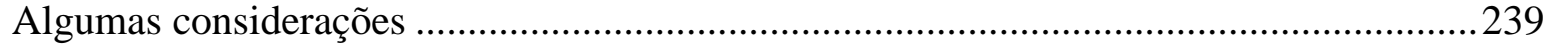

\section{CAPÍtULO 5}

\section{AVES PIONEIRAS E OS ORGANIZADORES DO \\ NINHO E(M) A REVOADA SOBRE O PDA}

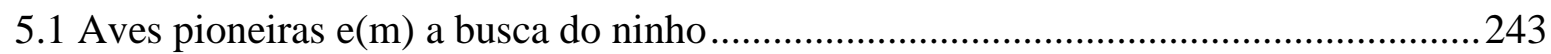

$5.2 \mathrm{O}$ planejamento de pouso sob perspectiva das aves pioneiras..................................250

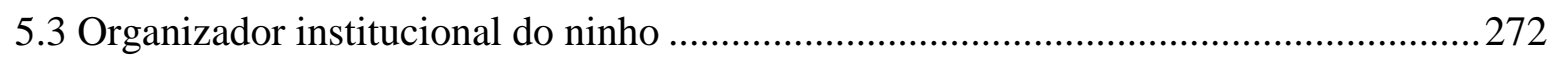

5.4 O INCRA-SR26 e uma das ferramentas para organização do ninho ..........................276

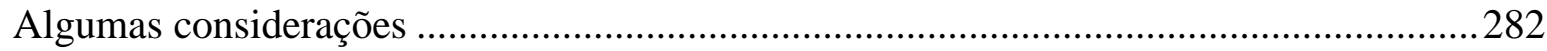

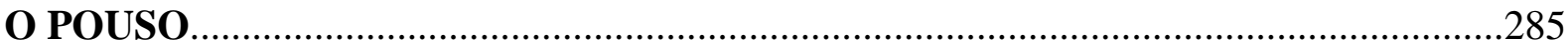

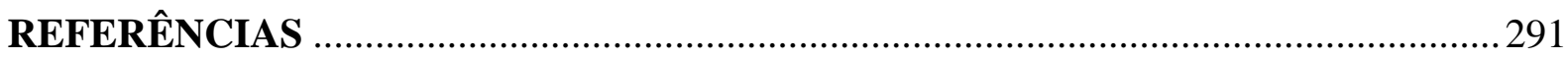

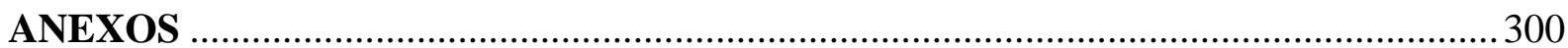




\section{APRESENTAÇÃO}

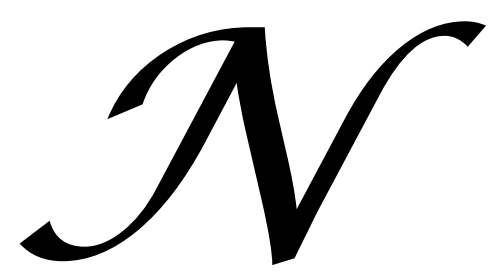

a perspectiva de inclusão social de assentados/as, o objetivo geral desta tese é investigar, à luz da Análise de Discurso Crítica (ADC) e da Linguística Sistêmico-Funcional (LSF), discursos (re)contextualizados no Plano de Desenvolvimento Agrário (PDA) do Projeto de Assentamento (PA) Santa Tereza I - em Ponte Alta-TO - e facetas de práticas sociais (re)produzidas. A elaboração de PDAs, em princípio, apresenta o propósito de funcionar como uma das ferramentas utilizadas pelo Instituto Nacional de Colonização e Reforma Agrária (INCRA) para planejar o desenvolvimento de assentamentos. A investigação se reveste, pois, do propósito de apontar práticas discursivas transformadoras que beneficiem essa parcela da sociedade sedenta por mais justiça social no que se refere à questão agrária no Brasil. A prática institucional de elaboração do PDA, que forma parte da política pública do governo federal nos mandatos do presidente Lula, configura-se como um instrumento criado pelo Ministério de Desenvolvimento Agrário (MDA) e executado sob a responsabilidade técnica do INCRA para o desenvolvimento de PAs. Os PDAs, como uma das ferramentas utilizadas para o desenvolvimento dos assentamentos, podem evocar aspectos que assinalam um contraste entre o par 'inclusão versus exclusão' social e/ou econômica. Por envolverem um planejamento para os PAs e, consequentemente, envolverem meios de vida dos/as assentados/as, busco analisar discursividades e representações que apontam a inclusão e/ou exclusão de um grupo de assentados/as de um projeto de assentamento que possui o PDA elaborado. ${ }^{2}$ Por um lado, há discursos em documentos oficiais, textos institucionais, no caso, o PDA do projeto de assentamento Santa Tereza I, no município de Ponte Alta, no estado do Tocantins. Por outro lado, há discursos em entrevistas semiestruturadas, tanto com assentados/as pioneiros/as desse assentamento, quanto com funcionários do INCRA, ambos envolvidos com a elaboração do PDA Santa Tereza I.

\footnotetext{
${ }^{2}$ A concessão de uso de uma unidade agrícola familiar/parcela de terra/lote, nos parâmetros do Programa Nacional de Reforma Agrária (PNRA) do governo federal, pode ser conferida tanto a um homem quanto a uma mulher como o mantenedor ou a mantenedora da 'família selecionada' a participar de um projeto de assentamento. Isto é, de acordo com o PNRA, os quesitos considerados na seleção remetem, sobretudo, à condição sócio-econômica da pessoa 'mantenedora' da família candidata a participar do programa, independente do sexo. Inclusive, a identificação de candidatos/as nos formulários de inscrição para o PNRA é marcada pelos usos masculino e feminino devido à consideração de igualdade entre homem e mulher no que remete ao direito de se candidatar. Diante desta postura e seguindo a prática corrente nas ciências críticas, optei por, no decorrer do texto, utilizar o masculino e o feminino quando a referência se fizer a ambos.
} 
O problema de pesquisa, destacado nesta tese, refere-se ao estudo de representações linguístico-discursivas configuradas no PDA do PA Santa Tereza I, em termos de discussões sobre o cumprimento de mais justiça social no contexto brasileiro, a partir de políticas públicas voltadas para a reforma agrária e, sobretudo, para a inclusão social e econômica de assentados/as, historicamente, à margem da sociedade brasileira. Ao adotar a premissa de que as sociedades representam o mundo, seus modos de vida, através dos mais diversos usos da linguagem eleitos com esse papel, a integração entre linguagem e sociedade se faz de maneira intrinsecamente dialética. Nesse âmbito, discursos e práticas sociais se perpassam e, por isso, a abordagem científica, aqui, proposta se reveste de uma natureza sócio-discursiva. Os gêneros textuais e os discursos constituem identidades, relações sociais e conhecimentos, de modo que o estudo das discursividades do PDA Santa Tereza I configura tanto questões linguísticas quanto questões sociais referentes à reforma agrária no Brasil.

Esta tese aponta um deslocamento de um projeto maior dentro do Grupo Brasileiro de Estudos de Discurso, Pobreza e Identidades - REDLAD, registrado no CNPq (DGP) e coordenado pela Profa. Dra. Denize Elena Garcia da Silva. O desenvolvimento da pesquisa justifica-se, também, por viabilizar o estudo de questões sociais no âmbito da Linguística, especificamente através dos pressupostos da Análise de Discurso Crítica (ADC) (FAIRCLOUGH, 2003), bem como da Linguística Sistêmico-Funcional (LSF) (HALLIDAY\& MATTHIESSEN, 2004) e por integrar a agenda da ADC nos moldes de Fairclough (2003). A ADC, como área interdisciplinar, compromete-se com estudos dos aspectos discursivos da mudança social e propõe investigar de forma crítica como as relações de poder assimétricas são expressas e legitimadas por meio da linguagem. Fairclough (1992) concebe a linguagem como um processo constituído por um contexto sócio-histórico e cultural. Por isso, a compreensão da esfera pública através dos diálogos produzidos por ela propicia o entendimento dos conflitos sociais e culturais.

A tese delineia, de modo especial, uma reflexão sobre meios de vida de assentados/as, materializados através de usos da linguagem escrita (PDA) e da linguagem oral (entrevistas) e ainda por possibilitar reflexões para os assentados/as e o INCRA sobre o PDA do PA Santa Tereza I. Observe-se que o termo meio de vida foi cunhado por Amartya Sen (2010) e consiste no acesso à capacidade bens e a atividades requeridas para a sobrevivência de um indivíduo. Essa reflexão tem como escopo central desvelar práticas discursivas que sustentam a deplorável situação de miséria material e moral da população trabalhadora do campo brasileiro. 
A relevância social e a pertinência acadêmica nos estudos linguísticos desta pesquisa estão diretamente imbricadas, haja vista a pesquisa partir da premissa de que a linguagem é a responsável pela interação entre o homem e a sociedade, promovendo a constituição, propagação, transformação de crenças e valores, nos moldes da ADC (FAIRCLOUGH, 2003). Nesse sentido, a pesquisa busca mecanismos discursivos, através da análise de usos de linguagem e suas práticas, para proverem reflexões e ações sobre a inclusão social, mudança social de um grupo à margem da sociedade, mesmo já sendo participante de, pelo menos, um programa assistencial do governo federal: o projeto de assentamento Santa Tereza I. Segundo Rajagopalan (2003, p. 125), “a linguagem se constitui em importante palco de intervenção política, onde se manifestam as injustiças sociais pelas quais passa a comunidade em diferentes momentos da sua história e onde são travadas constantes lutas". Pode-se afirmar que pesquisas que enfocam os usos da linguagem podem intervir na realidade social da qual ela faz parte, o que se reveste de uma prática social. Nessa perspectiva, a Linguística apresenta um importante papel diante dos conflitos sociais.

O estudo científico, aqui proposto, pode corroborar, por sua vez, para o entendimento de que a Linguística contribui para a compreensão de que questões sociais emergem através da linguagem e, ao mesmo tempo, disponibiliza instrumentos para que se proponha solução de problemas sociais. Diante disso, as questões de pesquisa que orientam este estudo, e que serão retomadas nos Capítulos 3, 4 e 5, são as seguintes:

(i) Que representações de atores sociais são constituídas na configuração linguística do PDA Santa Tereza I?

(ii) Como oslas assentadoslas do PA Santa Tereza I são representadoslas em seu PDA?

(iii) O/a assentado/a entrevistado/a se identifica com as representações expressas no PDA?

(iv) Que discursos e representações são constituídos quando funcionários do INCRA-SR26, responsáveis técnicos pela elaboração do PDA do PA Santa Tereza I, relatam sobre a constituição do mesmo PDA? $?^{3}$

No que se refere às pesquisas críticas, em que o discurso é concebido como modo de ação e de representação, o social se destaca de maneira que é intrínseco à sociedade (FAIRCLOUGH, 2003). Nesse sentido, a dimensão teórico-metodológica de natureza crítica

\footnotetext{
${ }^{3}$ Diferentemente da postura de uso do masculino e do feminino utilizada para a referência a assentados/as, optei pelo uso do masculino com referência às pessoas com responsabilidade técnica designada pelo INCRA para a elaboração do PDA do PA Santa Tereza I, uma vez que, no caso, estes colaboradores da pesquisa são do sexo masculino.
} 
possibilita a aproximação de respostas a questões de pesquisa. Para tanto, na primeira etapa da pesquisa, os dados de natureza documental foram coletados e selecionados a partir do PDA Santa Tereza I. Na segunda etapa, dados de natureza etnográfica foram gerados e selecionados a partir, principalmente, de entrevistas semiestruturadas com assentados/as e funcionários do INCRA envolvidos nas reuniões para elaboração do PDA do PA Santa Tereza I.

A análise dos dados de natureza documental e dos dados de natureza etnográfica, no que concerne a aspectos discursivos e a aspectos das práticas sociais, está balizada na proposta teórico-metodológica da ADC, de acordo com Fairclough (2003), sobre os significados da linguagem: acional, representacional e identificacional. Além disso, no que se refere aos aspectos linguísticos, a proposta está fundamentada na LSF, especificamente, na Gramática Sistêmico-Funcional (GSF), nos moldes de Halliday (1994) e de Halliday \& Matthiessen (2004). Enquanto a ADC embasa a análise da exterioridade da linguagem (macroanálise), a GSF constitui o passaporte teórico básico que respalda a análise da interioridade do texto em sua materialidade linguística (microanálise), tanto na análise de dados de natureza documental escrita quanto na análise de dados de natureza oral. Destaquese que a proposta teórico-metodológica da LSF, nesta pesquisa, consiste em ferramenta para a realização da microanálise da linguagem, principalmente, em relação ao Sistema de Transitividade em termos de representação, e ao Sistema de MODO em termos de identificação. Ademais, este estudo utiliza a proposta de van Leeuwen $(1997,2008)$ acerca da rede de sistemas para investigar como os atores sociais estão representados no PDA.

A tese ora apresentada envolve cinco capítulos, além desta apresentação e das considerações finais. No Capítulo 1 - DAS REVOADAS PELA TERRA ÀS REVOADAS NA TERRA -, delineio a contextualização sobre a questão da terra no Brasil em um recorte temporal: das capitanias hereditárias (século XVI) ao II Plano Nacional de Reforma Agrária (II PNRA) com a constituição de projetos de assentamentos. Em seguida, teço um breve panorama da reforma agrária no estado do Tocantins, o estado mais novo do Brasil. Com isso, proponho a constituição de um panorama de alguns eventos relacionados à questão do uso e da posse da terra ao longo da história do Brasil com o intuito de contrastar os caminhos da reforma agrária no país, avanços e retrocessos, mas que, de alguma maneira, corroboram para a fundamentação do entendimento sobre o tipo de reforma agrária implantado pelo governo Lula e que se configura, em parte, através da proposição da elaboração de PDAs para os PAs.

No Capítulo 2 - BASES DE PARTIDA PARA A REVOADA TEÓRICA: VIGAS MESTRAS -, apresento o arcabouço teórico e metodológico da Teoria Social do Discurso, a Análise de Discurso Crítica (ADC), que alicerça esse estudo. Enquanto ramificação da 
Linguística, é proponente de uma análise textualmente orientada. ${ }^{4}$ Em primeiro lugar, delineio um panorama sobre os estudos em ADC, considerando alguns conceitos basilares dessa proposta teórica crítica. Em seguida, abordo os significados acional, representacional e identificacional, no que integra gêneros, discursos e estilos, na perspectiva de Fairclough (2003). A proposta da análise textual em ADC é apresentada em termos dos significados acional, representacional e identificacional, concernentes a gêneros, discursos e estilos, de acordo com os estudos de Fairclough (2003). Depois, apresento parte do arcabouço teóricometodológico da Linguística Sistêmico-Funcional (LSF), proposto por Halliday \& Matthiessen (2004), que comporta uma análise da linguagem de acordo com uma perspectiva social. Certos aspectos da LSF baseiam a microanálise dos dados, já que, por ora, faz-se ferramenta de análise para a $\mathrm{ADC}$, no que se refere às metafunções da linguagem. Ao considerar o objetivo central dessa pesquisa referente às discursividades e às representações configuradas no texto do PDA Santa Tereza I, apresento, especificamente, enfoque nas metafunções ideacional e interpessoal. Em seguida, apresento aspectos da abordagem acerca da representação dos atores sociais, sugerida por van Leuween $(1997,2008)$. Por último, teço algumas considerações acerca de a ADC subsidiar teórico-metodologicamente a construção deste trabalho científico.

No Capítulo 3 - A CONSTRUÇÃO DA REVOADA: ESTRATÉGIAS DE PESQUISA -, apresento os procedimentos teórico-metodológicos da pesquisa, assim como os passos metodológicos que constituem a mesma. De início, apresento o tipo de pesquisa realizada nesse estudo: a pesquisa qualitativa - descritiva e interpretativa. Também defino a pesquisa qualitativa em termos de postura de investigação. Por isso, delineio os cuidados éticos relacionados à pesquisa, principalmente, por parte da pesquisa envolver dados de natureza oral, gerados com a colaboração de asssentados/as pioneiros/as do PA Santa Tereza I e funcionários do INCRA-SR26. Em seguida, explico as estratégias de investigação no que concerne à coleta de dados empíricos. Apresento também a composição dos corpora do estudo: dados de natureza documental (PDA) e de natureza etnográfica (entrevistas semiestruturadas). Na sequência, aponto os métodos de análise. A pesquisa envolve a metodologia da Análise de Discurso Crítica e da Linguística Sistêmico-Funcional, no caso, especificamente da Gramática Sistêmico-Funcional. A macroanálise dos dados, com o cerne social da linguagem, segue os passos do método proposto pela ADC, baseado nos pressupostos de Fairclough (2003), de modo que permite ao/à pesquisador/a explorar a

\footnotetext{
${ }^{4}$ Teoria social do discurso, no sentido de Fairclough (2001), que apresenta como base a concepção tridimensional do discurso: o texto, a interação/prática discursiva e a ação social/prática social.
} 
exterioridade da linguagem em termos de discursos e práticas sociais. Já a microanálise dos dados se orienta em algumas categorias de análise, cunhadas por Halliday \& Matthiessen (2004), o que promove a exploração da interioridade da linguagem e, como consequência, contribui para a macroanálise. Posteriormente, discuto o uso do programa computacional Wordsmith Tools v. 6.0 (SCOTT, 2012), uma ferramenta para a análise linguístico-discursiva do texto do PDA Santa Tereza I em termos de visualização, seleção e descrição dos dados.

No Capítulo 4 - EM BUSCA DO NINHO: O PDA DO PA SANTA TEREZA I E A REPRESENTAÇÃO DE ASSENTADOS/AS -, levo a cabo a análise do PDA Santa Tereza I, nos moldes dos estudos de Fairclough (2003) sobre os significados da linguagem com o objetivo de desvelar relações de poder nos discursos (re)contextualizados no PDA do PA Santa Tereza I, que institucionalizam e tentam organizar o PA para o qual foi elaborado. A partir disso, identificar e analisar as representações linguístico-discursivas constituídas nesse PDA. Para tanto, apresento o PDA como documento institucional e proponho um breve paralelo entre alguns textos institucionais relacionados. Em seguida, teço análises a partir da concepção do PDA Santa Tereza I como um modo de agir sobre o mundo (significado acional), um modo de representar o mundo (significado representacional) e um modo de ser no mundo (significado identificacional) (FAIRCLOUGH, 2003). Para tanto, abordo a inclusão de assentados/as em termos de representações configuradas no texto do PDA através da utilização da ferramenta computacional WordSmith Tools para balizar uma análise mais detalhada do sistema de transitividade, considerando os processos, os participantes e as circunstâncias. Depois, discuto a representação de atores sociais no PDA, principalmente, de acordo com a proposta de van Leeuwen (1997, 2008). Por último, delineio os estilos que constituem o aspecto discursivo de identidades no PDA Santa Tereza I, especificamente sobre direitos e deveres dos/as assentados/as. Há sistemas de poder na sociedade, os quais evocam valores simbólicos produzidos, reproduzidos e transformados nela e para ela e que são emoldurados na linguagem.

No Capítulo 5 - AVES PIONEIRAS E ORGANIZADORES DO NINHO EM REVOADA SOBRE O PDA -, apresento uma investigação linguístico-discursiva de representações tanto de assentados/as pioneiros/as sobre a elaboração do PDA do PA Santa Tereza I, considerando que participaram de reuniões com a COOPVAG para elaboração do mesmo; quanto de funcionários do INCRA-SR26, responsáveis técnicos, na época, pela elaboração do referido PDA. Trata-se de uma investigação com dados empíricos de natureza etnográfica, especificamente gerados e selecionados a partir da realização de entrevistas. No início, analiso entrevistas semiestruturadas com assentados/as que participaram de reuniões 
com a COOPVAG para a elaboração do PDA do PA Santa Tereza I no que se refere à representação dos mesmos. Em seguida, analiso entrevistas semiestruturadas com funcionários do INCRA-Palmas, com responsabilidade técnica sobre a elaboração do PDA Santa Tereza I.

No POUSO, considerações finais, teço algumas considerações sobre o percurso da pesquisa e algumas reflexões sobre os resultados obtidos no trabalho de tese. Sobretudo, delineio algumas implicações voltadas para os meios de sobrevivência dos/as participantes de projetos de assentamentos no Brasil e que fazem de suas vidas constantes lutas não somente no que se refere à luta pela terra, mas também à luta na terra. A partir da retomada das cinco questões orientadoras da pesquisa, proponho sugestões voltadas para a elaboração de textos institucionais, como os PDAs, dirigindo minhas palavras a agentes sociais que trabalham na elaboração e implantação desses textos (eixo do poder), a agentes que apoiam práticas sociais transformadoras (eixo do conhecimento) e a agentes que lutam pela inclusão, na linha dos direitos humanos (eixo da ética). 


\section{CAPÍTULO 1}

\section{DAS REVOADAS PELA TERRA ÀS REVOADAS NA TERRA}

Somente quando cada um ocupar seu próprio espaço político, a ponto de uma desobediência civil, se necessário, é que a capacitação significará algo revolucionário (FREIRE, 1987).

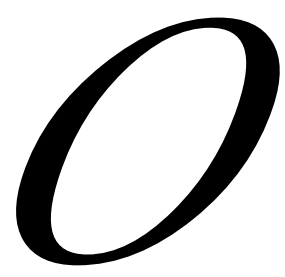

foco deste capítulo é a construção de um panorama de alguns eventos relacionados à questão do uso e da posse da terra no Brasil em quatro seções. A primeira seção propõe a contextualização da questão da terra no Brasil em um recorte temporal: das capitanias hereditárias (século XVI), passando pelo Estatuto da Terra (1964), movimentos sociais de luta pela terra, à Constituição Federal de 1988 e ao II Plano Nacional de Reforma Agrária (2004). ${ }^{5}$ A segunda configura um panorama da reforma agrária no estado do Tocantins e da constituição dos projetos de assentamentos. A terceira seção propõe alguns apontamentos sobre a luta pela terra e a luta na terra no Brasil em termos de inclusão e exclusão social. A última seção apresenta algumas considerações.

\footnotetext{
${ }^{5}$ Movimentos sociais, aqui, concebido como ações sociais coletivas de caráter sociopolítico e cultural que viabilizam distintas formas de população se organizar e expressar suas demandas (GOHN, 2003, p. 13).
} 


\subsection{A questão agrária no Brasil}

A questão agrária é inerente à história do Brasil desde o início do século XVI com a implantação de bases de exploração colonial no território recém-descoberto. $\mathrm{O}$ modo de apropriação e de exploração econômica de terras no país, do período colonial aos dias atuais, coaduna realidades não dissociadas. De acordo com Sampaio (2010, p. 397), "a carga simbólica desse passado está mais presente nas relações entre pessoas e as classes sociais do Brasil moderno do que os brasileiros gostam de admitir". Nesse contexto, as lutas tanto pelo direito de uso quanto pelo direito de posse de terras ocorrem em todo país, desde a implantação das capitanias hereditárias, em maior ou menor intensidade, e muitas delas são marcadas por violência, criminalização dos líderes e com ampla exposição midiática, o que beira nos últimos tempos a uma espetacularização.

Como bem observa Carter (2010) em seu estudo sobre reforma agrária, o Brasil é uma das nações com maior desigualdade social do mundo e suas enormes disparidades, em termos de distribuição de riqueza, têm profundas raízes históricas, como no permanente aspecto da injustiça social que se configura na acentuada desigualdade da estrutura fundiária do país. Adverte o referido autor que se trata de um dos países com maior concentração de terra no mundo, de modo que a atual estrutura agrária, forjada durante o período colonial, encontra-se mantida sob os sistemas políticos do império, república oligárquica, governo militar e democracia. Destaque-se a origem e o tipo de reforma agrária podem ser atribuídos a duas forças propulsoras básicas: uma proveniente da sociedade (ou "de baixo") e, outra, ancorada no Estado (ou “de cima”). Parece que, na prática, a execução de reformas agrárias implica de

algum modo uma combinação de impulsos por parte da sociedade e por parte do Estado, pelo menos, para sancioná-la.

De fato, do que trata e interessa na reforma agrária brasileira é a solução do que se propõe efetivamente na prática e, em profundidade, de acordo com a realidade do país. Por isso, segundo Prado Júnior (2014), a política agrária brasileira deve tratar de introduzir, estender e desenvolver nas relações de produção e trabalho rural, nas circunstâncias do país, condições de trabalho, subsistência e atividades em geral que proporcionem aos trabalhadores rurais um padrão de vida condizente com os níveis humanos dos dias atuais. No que se refere às estruturas agrárias, que mantêm uma parte considerável da população, o desenvolvimento em profundidade consiste na superação das atuais situações socioeconômicas a que é submetida, a saber, condições de sobrevivência miseráveis, materiais, culturais, sociais, em suma, humanas. 
Contrastes entre a posição defensora da reforma agrária e a posição contra essa reforma são tingidos por diversas percepções da realidade existente e configurados por interesses e valores diferenciados. Como implicação para a relação de ambas as posições, de acordo com Carter (2010, p 49), “o processo de reforma agrária no Brasil entre 1985 e 2005 está classificado em último lugar no índice da reforma agrária no hemisfério sul”. Por esse motivo, a reforma no país é considerada, em termos da valorização do ser humano e de contingências históricas desfavoráveis, atrasada em contraste com o mundo do século XXI, principalmente em relação a outros países da América Latina.

\subsubsection{De 1500 a 1964}

Inicialmente, pode-se afirmar que a evolução histórica do problema da terra no Brasil está intrinsecamente relacionada ao processo de construção do Estado nacional. Desde o período de "conquista" no século XVI, a coroa portuguesa - organização política da época assentou bases da exploração colonial no território através da escravidão dos indígenas assim como, posteriormente, da escravidão dos africanos com o intuito de gerar mão-de-obra escrava. A sociedade brasileira foi criada de maneira extremamente segmentada, com acúmulo de terras, escravidão e dependência das exportações, elementos estruturantes da economia, do poder político, das relações sociais e da cultura da sociedade colonial (SAMPAIO, 2010). Esse regime colonial de 300 anos perpetua traços de dependência externa, desigualdade econômica e social entre as pessoas e autoritarismo das elites dominantes, aspectos que podem ser observados até os dias atuais.

A administração colonial portuguesa implantou o regime de terras das sesmarias e tentava, de tempos em tempos, reorganizar esse regime, mas entravava na estrutura de poder que os senhores de terras formaram na colônia (SAMPAIO, 2010). Daí se constituiu o latifúndio existente até os dias de hoje. Ademais, a problemática da propriedade e da posse da terra, com características de uma questão nacional surgiu, de fato, na metade do século XIX, com a perturbação da classe dos fazendeiros com a iminência da abolição da escravatura e a necessidade de trazer mão de obra imigrante para realização do trabalho agrícola (SAMPAIO, 2010). A elite dominante temia que libertos e imigrantes ocupassem os imensos espaços despovoados do país e a maneira encontrada para que isso não ocorresse foi transformar a 
terra em mercadoria com preço inacessível aos pobres e impedir a apropriação das terras devolutas por qualquer outro meio que não a compra. ${ }^{6}$

As oligarquias regionais mais poderosas, após anos de debates, acomodaram seus interesses através da promulgação da Lei de Terras (Lei no. 601, de 18 de setembro de 1850), que proibia a aquisição de terras devolutas por outro meio que não a compra. Como efeitos dessa lei, surgiram tanto a legalização do latifúndio quanto da grilagem e a reforma agrária se reduziu a um conjunto de medidas destinadas a favorecer a exploração da terra, mas sem atenção alguma à questão das pessoas que dependiam do trabalho com a terra para sobreviverem. ${ }^{7}$ Esse universo rural se estendeu até as três primeiras décadas do século XX, desenvolvendo-se em várias regiões do Brasil.

Segundo Sampaio (2010), transformações mais significativas no meio agrário ocorreram somente com o início da industrialização, na medida em que essa se desenvolveu e os sistemas agrícolas regionais se desintegravam, implicando o início de amplo movimento migratório. Nesse contexto, houve empobrecimento material das populações rurais e perda de muitos de seus valores e referências culturais. Na década de 1950, o conflito social do campo brasileiro assumiu características de uma questão nacional e, por isso, suscitou resolução no âmbito do Estado para que houvesse maior desenvolvimento econômico, social e político do país. A agitação camponesa revelou aos que detinham o poder a emergência de um novo agente no processo político. Diante de tal constatação, o Partido Comunista Brasileiro e a Igreja Católica lançaram-se na busca do apoio desse novo agente social.

No Diário Oficial de 18 de março de 1963, foi promulgada a Lei no. 4.914, de 2 de março - Estatuto do Trabalhador Rural. O Estatuto do Trabalhador Rural - no Artigo $3^{\circ}$ define trabalhador rural para efeitos da lei: "toda pessoa física que presta serviços a empregador rural, em propriedade rural ou prédio rústico, mediante salário pago em dinheiro ou 'in natura', ou parte in natura e parte em dinheiro". Segundo Prado Júnior (2014), os legisladores limitaram com a Lei no. 4.914 transpor para o trabalhador rural as disposições legais que já faziam parte da legislação trabalhista e foram traçadas com vistas ao trabalhador urbano. O mesmo autor (2014, p. 413) caracteriza-a como "estatuto miserável do trabalhador rural brasileiro”. O Estatuto do Trabalhador Rural não considerou adequadamente a grande variedade de relações de trabalhos no âmbito rural brasileiro. A definição de trabalhador rural

\footnotetext{
${ }^{6}$ Terra devoluta é a dominação que se dá no Brasil às terras inicialmente concedidas pela Coroa Portuguesa a pessoas que se comprometiam cultivá-las (SAMPAIO, 2010, p. 399).

${ }^{7}$ A grilagem consiste na atividade lucrativa de forjar títulos de propriedades grandes extensões de terras vagas para vendê-las a grandes fazendeiros ou desalojar, com violência ou chicanas judiciais, posseiros estabelecidos por conta própria em terras vagas (SAMPAIO, 2010).
} 
é insuficiente para compreender sem deixar dúvidas, certas categorias de trabalhadores que, pela natureza real de suas relações de trabalho, existem como parceiros/as, meeiros/as e assentados/as.

Cabe, aqui, destacar que, em $1^{\circ}$. de abril de 1964, a conspiração contra o presidente João Goulart saiu vitoriosa e a questão agrária foi excluída da agenda política, mesmo que o regime militar editasse o Estatuto da Terra no mesmo ano. Essa questão foi, então, abafada pelo regime ditatorial de força, alcunhado pelo eufemismo da chamada "segurança nacional". Ressalte-se, ainda, que o governo militar, ao mesmo tempo em que minou a possibilidade de uma reforma agrária, iniciou uma política de subsídios à elite agrária que favoreceu sua expansão territorial e modernização tecnológica. Essa transformação capitalista da agricultura, impulsionada pelo próprio Estado, permitiu o surgimento de uma poderosa classe rural voltada para o agronegócio em grande escala.

\subsubsection{Do Estatuto da Terra à Constituição Federal de 1988}

Devido à ascensão do regime militar no início de 1964, qualquer mobilização popular em torno da reforma agrária tornou-se objeto de repressão. O golpe militar extinguiu a efervescência do debate agrário, favorecendo, aos poucos, pela força, a tese de Delfim Neto sobre a "modernização agrícola sem reforma agrária" (DELGADO, 2010). Sob influência da Doutrina Social da Igreja Católica, os militares promulgaram, porém, a Lei no. 4.504, de 30 de novembro de 1964: o Estatuto da Terra.

O Estatuto da Terra substituiu a tradicional concepção jurídica da propriedade, proveniente da Lei de Terras, de 1850, que trata a terra como uma simples mercadoria, pela inserção do princípio da "função social da propriedade" (DELGADO, 2010). Esse estatuto envolveu uma concepção diferente em relação à questão da terra no país. Nele, há a concepção da terra a partir da sua função social em detrimento da função meramente mercadológica. Faz-se necessário o reconhecimento de que o estatuto humanizou contratos, impediu velhas práticas semifeudais e pós-escravocratas e estabeleceu a possibilidade da desapropriação (MARÉS, 2003). A partir dele, houve a possibilidade de correção de algumas injustiças sociais agrárias.

Já no que concerne à questão da reforma agrária em termos de desapropriação, o Estatuto da Terra não alterou o conceito de propriedade privada da terra. Sobre isso, o seu artigo $2^{\circ}$., estabelece que: 
A propriedade rural da terra desempenha integralmente a sua função social quando, simultaneamente: a) favorece o bem estar dos proprietários e dos trabalhadores que nela labutam, assim como de suas famílias; b) mantém níveis satisfatórios de produtividade; c) assegura a conservação dos recursos naturais; d) observa as disposições legais que regulam as justas relações de trabalho entre os que a possuem e a cultivam.

De acordo com o artigo acima, o Estatuto da Terra não apresentou um posicionamento positivo em relação à concepção de reforma agrária. O estatuto estabeleceu normas para o uso da terra em termos de produtividade e não há item algum que se refira à desapropriação com a finalidade dessa reforma. Nessa perspectiva, a desapropriação de terra com configuração da diminuição ou do fim dos latifúndios e da promoção da alteração da estrutura agrária estabelecida no país ao longo dos anos depende do poder político do Estado e da interpretação dos tribunais. Observe-se que os termos latifúndio e minifúndio atingiram uma maior politização no decorrer da década de 1960. Esses termos "adquiriram o estatuto de categorias legais, com critérios precisos de definição quanto à dimensão de área, modalidades e graus de utilização da terra, natureza das relações de trabalho e outros" (MENDONÇA; STEDILE, 2006, p. 71). Prevalece, assim, a (re)afirmação da plenitude do direito de propriedade, através da configuração de normas sobre a produtividade no campo e a omissão de normas sobre a constituição das propriedades em termos de justiça social. Há reprodução e manutenção do pensamento de que poucos podem vir a produzir em grandes quantidades de terra desde que produzam. À maioria da população com interesse pelo trabalho no campo, cabe apenas lutar pelo direito de uso da terra que restou.

Diante de movimentos sociais reprimidos de lideranças perseguidas e de sindicatos sob intervenção, o Estatuto acabou por significar pouco em termos de medidas efetivas em prol das demandas por terra dos trabalhadores rurais (MENDONÇA, 2006). Por conseguinte, não interferiu na implementação de uma política agrícola voltada para modernização técnica, a qual não se refere à valorização humana dos trabalhadores rurais. Essa política visa à aceleração do crescimento da produção agrícola e, por isso, integrou com destaque a agenda oficial do governo, que a fomentou através do Sistema Nacional de Crédito Rural. Até então os procedimentos da agropecuária brasileira somente acertou para os fins a que se visou: maior soma de lucros no menor prazo possível e com o mínimo de despesa inicial. Sob esse ponto de vista - do negócio - a questão da terra alcança o objetivo para o qual foi planejada. Já, sob o ponto de vista da valorização humana, a política desenvolvida foi responsável pelo baixo nível de vida da população rural naquele momento. 
Em meio a esses contastes, em 1970, o Instituto Nacional de Colonização e Reforma Agrária (INCRA) foi criado pelo Decreto no 1.110, de 9 de julho de 1970, cuja "missão prioritária foi executar a reforma agrária e realizar o ordenamento fundiário nacional" (BRASIL, 1912). O INCRA é uma autarquia federal e está implantado em todo o território nacional através de 30 superintendências regionais, sendo a do estado do Tocantins, instalada na capital Palmas, a superintendência número 26 (INCRA-SR26). Sendo assim, o INCRA foi criado a partir do Decreto ${ }^{\circ} 1.110$, de 1970, resultado da fusão do IBRA com o INDA. Nessa época, mais do que reforma agrária, o Governo Federal incentivou a colonização da Amazônia. Muitos migrantes de vários estados foram levados a ocupar as margens da estrada Transamazônica e empresas de variados ramos receberam incentivos fiscais para grandes projetos agropecuários, mas a experiência não foi sucedida.

Além disso, o regime militar configurou o enfraquecimento da perspectiva de uma reforma agrária e com ele surgiu o impasse sobre o projeto de nação para o Brasil com influência tanto do processo de modernização e tecnologização da agricultura como também das articulações de movimentos sociais no campo. Nesse contexto político e social da década de 1970, o desemprego no campo cresceu, o Movimento dos Trabalhadores Sem-Terra (MST) deu os primeiros passos e as primeiras ocupações de terras também iniciaram.

Todos esses acontecimentos contribuíram para o surgimento do movimento de redemocratização política do Brasil na década de 1980. Observe-se que a crise da dívida externa deflagrada em 1982 configurou, porém, maior poder e relevância econômica aos fazendeiros e empresários agrícolas. Além disso, com o novo cenário mundial da economia global, o Brasil adotou o modelo econômico neoliberal e as agroexportações se tornaram a principal fonte de receita para pagar os credores estrangeiros.

A redemocratização, em 1984, trouxe de volta o tema da reforma agrária. O Decreto $\mathrm{n}^{\circ}$ 97.766, de 10 de outubro de 1985, instituiu novo Plano Nacional de Reforma Agrária com a meta utópica de destinar 43 milhões de hectares para o assentamento de 1,4 milhão de famílias até 1989 (INCRA, 2014b). Criou-se, para isso, o Ministério Extraordinário para o Desenvolvimento e Reforma Agrária (MIRAD), mas quatro anos depois os números alcançados eram modestos perante a meta. Esses números refletiram o intenso debate político e ideológico em torno da reforma agrária na Assembléia Nacional Constituinte. Deste embate, resultaram a extinção do INCRA (em 1987) e do próprio MIRAD (em 1989). A responsabilidade pela reforma agrária passou para o Ministério da Agricultura. ${ }^{8}$

\footnotetext{
${ }^{8}$ Disponível em: http://www.incra.gov.br/reformaagrariahistoria. Acesso em: 13 mai. 2014.
} 
Com o processo de redemocratização do país, movimentos sociais no campo insurgentes na década de 1950 - passaram por (re)articulações, dentre eles o MST. Esse movimento social surgiu oficialmente em 1984 com o apoio de padres, bispos e agentes da pastoral da terra. De acordo com Stedile (2006), o MST é constituído por um processo de organização social coletiva e assume cada vez mais um papel questionador da função social da propriedade e da necessidade de reformulação das políticas sociais no país.

Nesse sentido, o MST propugna a "terra de viver" em detrimento da "terra de negócio". 9 A primeira consiste no pedaço de terra com o qual o/a camponês/a sonha a fim de ter um lugar onde viver dignamente e reproduzir sua família com o produto do trabalho desta e a segunda consiste em servir os interesses comerciais dos latifundiários brasileiros (SAMPAIO, 2010). Esse movimento social parte da uma perspectiva de terra que se refere à inclusão dos trabalhos rurais ao direito de posse e de uso da terra de forma digna para a sua sobrevivência de modo a ocorrer uma mudança social no Brasil. A postura de luta do MST se coaduna com a concepção de que uma sociedade organizada é a raiz para a justiça social. Sobre isso, Resende (2010a, p. 162) aponta uma perspectiva de "movimento social associado à mobilização da sociedade civil e à crença na capacidade de atores sociais, engajados em ação coletiva, influenciarem no sentido da mudança social".

Para seus defensores e simpatizantes, ao subverter percepções, normas e costumes tradicionais, o movimento social perturba a "ordem natural das coisas", expondo e dando voz a tensões subjacentes na sociedade brasileira no que concerne à questão agrária, como uma fonte de inspiração na luta por concretizar a promessa da igualdade de direitos ao uso da terra (CARTER, 2010). Destaque-se o papel desse movimento em conseguir, ao longo das últimas décadas, a manutenção da reforma agrária na agenda política dos governos, alternando pressões diretas, pela via de ocupações de terras, com pressões indiretas através da articulação de pronunciamentos de políticos de instituições e grupos sociais formadores de opiniões.

Já para os críticos e opositores, esse movimento perturba o funcionamento dito “normal” do sistema jurídico brasileiro, pois as noções 'a-históricas' de neutralidade legal da retórica negligenciam deliberadamente as dimensões constitutivas sociais e históricas e exigem o cumprimento estrito e rígido do que chamam justiça (MESZAROS, 2010). Mesmo que as ocupações de terras, ora organizadas ora apoiadas pelo MST, sejam alvos de críticas de pessoas comuns da sociedade, da mídia e, sobretudo, dos detentores do poder político e

\footnotetext{
${ }^{9}$ De acordo com Sampaio (2010), os conceitos de "terra de negócio" e de "terra de viver" foram cunhados por José de Souza Martins e divulgados pela Comissão Pastoral da Terra da Congregação Nacional dos Bispos do Brasil (CNBB).
} 
econômico estabelecido; constituem parte indispensável das operações do movimento. Devido às mobilizações e ações do MST, o "Estado de Direito" no Brasil passou a incitar o governo e a justiça a "fazerem cumprir a lei" em relação ao movimento e esse procedimento, por sua vez, leva a cabo o questionamento sobre a 'lei de quem' e nos termos de quem (MESZAROS, 2010). Isto é, as leis são feitas por certos agentes sociais com interesses específicos e por esse motivo podem beneficiar, proteger e/ou desproteger outros grupos. Por um lado, o sistema jurídico brasileiro se configura conservador no que se refere às questões relativas à propriedade. Por outro, a principal questão não é sacrificar o Estado de Direito em nome do combate à pobreza e à exclusão, mas recuperar os aspectos da lei que lidam de modo favorável com questões de pobreza e exclusão social (MESZAROS, 2010). O MST sinaliza, porém, que se houvesse vontade política, não haveria necessidade de realizar ocupações de terra e, por isso, algumas autoridades da justiça brasileira apoiaram os argumentos do movimento no que se refere à função social da propriedade. Sob essa perspectiva, a propriedade não é absoluta e poderia, em certas circunstâncias, ser ocupada.

Ademais, com o fim do regime da ditadura, em 1985, houve o início do processo de redemocratização. No mesmo ano, diante novo contexto político, a reforma agrária voltou à agenda política e uma das ações do presidente José Sarney foi lançar o Plano Nacional de Reforma Agrária (PNRA), cuja meta era o assentamento de 1,4 milhões de famílias em terras a serem desapropriadas (SAMPAIO, 2010). No entanto, para Carter (2010), as democracias políticas têm poucas chances de instituir uma alteração revolucionária da estrutura agrária, uma vez que as garantias constitucionais e os mecanismos do Estado de Direito diminuem a possibilidade de realizar extensas transformações. O presidente Sarney corroborou com essa postura do Estado de Direito quando ficou temeroso da reação dos latifundiários e suspendeu a execução do PNRA.

Mediante essa situação, Meszaros (2010) argumenta que o Estado de Direito no Brasil depende de correlações de forças em um determinado momento, de acordos políticos e da disposição dos operadores do sistema jurídico de utilizar seus poderes de forma específica. Carter (2010) ainda aponta que, no que se refere à reforma agrária em democracias contemporâneas, há duas alternativas para a redistribuição fundiária: uma abordagem conservadora e outra abordagem progressista. O Quadro 1.1, a seguir, apresenta características dessas abordagens. 
Quadro 1.1 - Reforma agrária nas democracias contemporâneas

\begin{tabular}{|c|c|c|}
\hline & Conservadora & Progressista \\
\hline Motivação & Reage a protestos sociais. & $\begin{array}{l}\text { Motivada por uma agenda de } \\
\text { mudança social. }\end{array}$ \\
\hline $\begin{array}{l}\text { Alcance da política } \\
\text { pública }\end{array}$ & $\begin{array}{l}\text { Lida com demandas específicas, não com } \\
\text { problemas sistêmicos. }\end{array}$ & Orientação estrutural. \\
\hline Objetivo principal & $\begin{array}{l}\text { Aplacar conflitos rurais. } \\
\text { Limitar a mudança social. }\end{array}$ & $\begin{array}{l}\text { Promover a agricultura } \\
\text { camponesa } \\
\text { Transformar a estrutura agrária } \\
\text { e suas relações de poder. }\end{array}$ \\
\hline $\begin{array}{l}\text { Extensão e } \\
\text { velocidade da } \\
\text { distribuição da terra }\end{array}$ & $\begin{array}{l}\text { Mínima e prolongada. } \\
\text { A estrutura fundiária permanece, em } \\
\text { grande parte, intacta. }\end{array}$ & $\begin{array}{l}\text { Substancial e rápida. } \\
\text { O sistema de propriedade rural } \\
\text { passa por mudanças rápidas e } \\
\text { notáveis. }\end{array}$ \\
\hline $\begin{array}{l}\text { Forma de } \\
\text { distribuição da terra }\end{array}$ & $\begin{array}{l}\text { Favorece os interesses do Estado e dos } \\
\text { grandes proprietários rurais. }\end{array}$ & $\begin{array}{l}\text { Propícia ao desenvolvimento } \\
\text { dos camponeses. }\end{array}$ \\
\hline $\begin{array}{l}\text { Efeito sobre os } \\
\text { setores populares }\end{array}$ & Desencoraja novas reivindicações. & $\begin{array}{l}\text { Favorece a reivindicação de } \\
\text { novos direitos. }\end{array}$ \\
\hline $\begin{array}{l}\text { Impacto sobre } \\
\text { grandes proprietários } \\
\text { rurais }\end{array}$ & $\begin{array}{l}\text { Os proprietários podem lucrar por meio de } \\
\text { generosas compensações do Estado. }\end{array}$ & $\begin{array}{l}\text { Os termos da expropriação } \\
\text { favorecem o Tesouro público } \\
\text { acima dos interesses da elite } \\
\text { agrária. }\end{array}$ \\
\hline $\begin{array}{l}\text { Relação com o status } \\
\text { quo }\end{array}$ & $\begin{array}{l}\text { A distribuição de terra não altera as } \\
\text { relações de poder existentes. }\end{array}$ & $\begin{array}{l}\text { A distribuição de terra busca } \\
\text { alterar as configurações de } \\
\text { poder. }\end{array}$ \\
\hline $\begin{array}{l}\text { Relações entre o } \\
\text { Estado e os } \\
\text { movimentos sociais }\end{array}$ & $\begin{array}{l}\text { Criminalização do protesto social. } \\
\text { Violações dos direitos humanos ocorrem } \\
\text { com impunidade. }\end{array}$ & $\begin{array}{l}\text { Respeito pela autonomia dos } \\
\text { movimentos sociais. Proteção } \\
\text { dos direitos humanos } \\
\text { elementares. }\end{array}$ \\
\hline $\begin{array}{l}\text { Apoio do Estado aos } \\
\text { assentamentos da } \\
\text { reforma agrária }\end{array}$ & $\begin{array}{l}\text { A assistência do Estado responde } \\
\text { principalmente à agitação dos lavradores. }\end{array}$ & $\begin{array}{l}\text { Os programas públicos } \\
\text { promovem a sustentabilidade } \\
\text { dos assentamentos e da } \\
\text { agricultura camponesa, } \\
\text { favorecendo a agroecologia. }\end{array}$ \\
\hline
\end{tabular}

Adaptado de Carter (2010).

De acordo com as características sintetizadas no Quadro 1.1 sobre as abordagens da reforma agrária, no Brasil, há configuração da abordagem conservadora nos termos conceituais definidos. A Lei Magna, a saber, se constituiu com características conservadoras no que concerne à questão agrária do país, pois a classe latifundiária, proponente da abordagem conservadora, possui significativo poder político no Congresso Nacional e, com isso, mantém seus interesses por meio da legislação brasileira. A Constituição Federal promulgada em 1988 apresenta demandas específicas sobre a reforma agrária e não problemas sistêmicos; limita a mudança social; trata do lucro dos proprietários através de pagamento do Estado pela desapropriação de suas terras; não altera as relações de poder existentes com distribuição de terra. Na época, o foco político estava nos interesses dos grandes proprietários 
rurais com ampla representatividade no Congresso, na constituição do novo poder civil - a democracia - e nas mudanças do quadro internacional do Brasil. A nova ordem constitucional está submetida, assim, ao processo de ajustamento constrangido à ordem econômica globalizada (DELGADO, 2010), mas de qualquer modo, propiciou posteriormente a concretização de uma reforma agrária através da criação de projetos de assentamento por todo o país.

Observe-se que, apesar de poucas alterações acerca da questão da terra no Brasil em relação ao já estabelecido no Estatuto da Terra (1964) em função do cenário político que rege o país, a Constituição Federal de 1988 muda o estatuto da propriedade fundiária, legitimandoa por sua função social. Especificamente, o Artigo 147 da Constituição condiciona o uso da propriedade ao bem-estar social e autoriza a lei a promover a justa distribuição dela com igual oportunidade para todos (PRADO JÚNIOR, 2014). O dispositivo desse artigo regula, de forma implícita, a possibilidade de reforma agrária ao elucidar a tese da desapropriação da propriedade imobiliária rural para o fim de forçar a subdivisão de terras mediante "justa e prévia indenização em dinheiro" do proprietário.

Em 29 de março de 1989, o Congresso Nacional recriou o INCRA, rejeitando o decreto-lei que o extinguira, mas a falta de respaldo político e a pobreza orçamentária mantiveram a reforma agrária quase paralisada. A questão foi, então, vinculada diretamente à Presidência da República com a criação, em 29 de abril de 1996, do Ministério Extraordinário de Política Fundiária, ao qual imediatamente se incorporou o INCRA. Em 14 de janeiro de 2000, o Decreto no 3.338 criou o Ministério do Desenvolvimento Agrário (MDA), órgão ao qual o INCRA está vinculado hoje. Segundo o INCRA, dentre suas diretrizes estão:

Primeira Diretriz: O INCRA implementará a reforma agrária promovendo a democratização do acesso a terra através da criação e implantação de assentamentos rurais sustentáveis, da regularização fundiária de terras públicas e gerenciará a estrutura fundiária do país, contribuindo para o desenvolvimento sustentável, para a desconcentração da estrutura fundiária, para a redução da violência e da pobreza no campo e promoção de igualdade. Segunda Diretriz: O INCRA implementará a reforma agrária de forma participativa reafirmando os princípios da legalidade, impessoalidade, moralidade, publicidade e eficiência, contribuindo para o fortalecimento das parcerias e da sociedade civil organizada (INCRA, 2014a).

Cabe ao INCRA, assim, todo o processo de implantação da reforma agrária no país, desde a regularização fundiária para a execução da reforma até a fiscalização dos projetos de assentamentos. 
Somente, no governo de Fernando Henrique Cardoso, 1995, a questão da terra retornou à agenda política devido ao massacre de trabalhadores sem-terra no estado de Rondônia. Naquele momento, o MST iniciou uma nova fase e se articulou a setores influentes da sociedade brasileira - Ordem dos Advogados do Brasil (OAB), Conferência Nacional dos Bispos do Brasil (CNBB), Associação Brasileira de Imprensa (ABI), Central Única dos Trabalhadores (CUT), dentre outras associações profissionais e organizações nãogovernamentais - em apoio à reforma agrária (SAMPAIO, 2010). De 1995 até os dias de hoje, a questão agrária não saiu da agenda política em meio a grandes mobilizações populares por todo o Brasil, principalmente através do MST.

Deve-se destacar também que os oito anos do governo do presidente Fernando Henrique focaram na constituição de um estado liberal, integrado ao mercado global, com consequência direta na questão da terra. Para os defensores do neoliberalismo, a reforma agrária não cabe mais no projeto de inserção da economia brasileira na dinâmica do mercado internacional: "o Brasil já resolvera questão agrária que entravava o desenvolvimento do capitalismo no campo, e o que fizera pela via de modernização tecnológica, sem distribuição de terras" (SAMPAIO, 2010, p. 402). Por esse lado, a elevação do nível tecnológico das atividades rurais parece reunir todos os fios da meada e constituir a maneira de atender a todos os interesses mercantis em voga. O progresso técnico a que se almeja possui o fim preciso da rentabilidade da agricultura. Todavia, para Prado Júnior (2014), uma vez que o fim da alta rentabilidade do agronegócio é alcançado e ampliado, o seu "sucesso" tem sido superpublicitado por grupos midiáticos vinculados à elite agrária e que omitem o fato de este setor rural continuar se beneficiando de amplos subsídios públicos.

Por outro lado, o desenvolvimento agrícola e a inclusão social do/a trabalhador/a rural não se acham diretamente relacionados. A política governamental de elevação do progresso técnico com finalidade da rentabilidade da exploração rural, não constitui, por si, fator de elevação da melhoria das condições de trabalho. Há a institucionalização da desigualdade entre as pessoas a partir da implantação de uma democratização política específica para a nação brasileira, ancorada nas premissas neoliberais de modernização das técnicas de produção assim como dos padrões de consumo da sociedade (PRADO JÚNIOR, 2014). Nesse universo do capitalismo globalizado, a persistência da pobreza rural de milhões de famílias consiste, em parte, nas populações que não acompanharam o progresso tecnológico e também não foram absorvidas em outros setores da economia. Em parte, a pobreza rural persiste em um lastro de mão de obra estruturalmente excedente a que resta somente a ajuda de políticas sociais. 
Isso posto, o processo histórico de formação do Estado nacional brasileiro é sempre perpassado pelo processo da questão agrária, haja vista que o problema da terra no Brasil se situa no centro da contradição que emperra a transição do Brasil-Colônia para o Brasil-Nação (SAMPAIO, 2010). Sob a perspectiva crítica da reforma agrária - defensora do modelo político neoliberal -, os projetos de assentamentos, enquanto meio para resolver a questão agrária do país, constituem um fracasso econômico, retratam suas comunidades como favelas rurais, representam uma política obsoleta para o desenvolvimento econômico, concebendo o MST como um movimento anacrônico (SAMPAIO, 2010). Já sob a perspectiva defensora da reforma, os projetos de assentamento representam uma preocupação com a profunda injustiça social do Brasil, contribuem para a diminuição da pobreza como restrições de liberdades, promovem a inclusão social e reduzem a acentuada desigualdade social do país de modo a, pelo menos, atenuar uma dívida histórica para com a população do campo (CARTER, 2010). A questão agrária brasileira está intrinsecamente entrelaçada, assim, à problemática da dependência externa e à concentração de renda como constituinte do projeto nacional desenvolvido.

\subsubsection{O governo Lula e o período de criação do PA Santa Tereza I}

Na década de 1990, os laços entre o Partido dos Trabalhadores (PT) e o MST se estreitaram, à medida que o partido almejava apoio. O PT insistia que, apesar das diferenças com o MST na estratégia para conquistar o poder, o compromisso do partido com a reforma agrária era o mesmo do movimento social (SAMPAIO, 2010). Esse posicionamento se confirmou no programa de governo do PT à presidência da república em 2002, onde a reforma agrária se configurou como objetivo prioritário.

Com a vitória na eleição para presidente de Luis Inácio Lula da Silva (outubro de 2002), trabalhadores/as rurais sem-terra acreditavam que finalmente suas lutas pela terra seriam cumpridas. Devido a tal crença, fizeram mobilizações com centenas de milhares de pessoas no início de 2003. No entanto, durante os primeiros meses, o governo federal não implementou progresso algum em relação à reforma agrária.

Em julho de 2003, em meio a pressões do MST, o presidente da república solicitou, porém, a elaboração de um planejamento para a reforma agrária ao ministro do Ministério do Desenvolvimento Agrário (MDA) e esse atribuiu a coordenação do processo a Plínio de Arruda Sampaio, um dos mais proeminentes especialistas agrários do país e um membro fundador do PT (SAMPAIO, 2010). Para o desenvolvimento do plano, Plínio Sampaio 
organizou uma equipe que contava com professores/as universitários/as, funcionários/as do INCRA, membros de movimentos sociais como o MST.

Em outubro de 2003, o II Plano Nacional de Reforma Agrária (II PNRA) foi apresentado ao MDA, o qual previa o assentamento de um milhão de famílias do ano de 2004 ao ano de 2007. O coordenador do plano enfrentou, porém, resistências por parte do governo federal em considerar a implantação do plano um gasto alto. Na época, o país já se encontrava com uma alta dívida externa e, por isso, o governo precisava atingir um grande excedente primário no balanço fiscal para satisfazer o Fundo Monetário Internacional (FMI). Além do mais, o governo concebia os órgãos envolvidos com a reforma agrária (MDA e INCRA) mal equipados e em situação precária (SAMPAIO, 2010). Diante dessa situação, o governo escolheu não levar a cabo o plano elaborado, mas as mobilizações populares intensificaram-se e, a partir delas, ocorreu o Fórum Nacional pela Reforma Agrária e Justiça no Campo em novembro de 2003. Nele, o presidente Lula prometeu implementar a reforma agrária.

No ano seguinte (2004), o MDA apresentou e oficializou o II PNRA. No contexto de elaboração e implantação de políticas públicas referentes à reforma agrária, o governo federal anunciou o plano para a reforma agrária diferente da versão original. Esse plano com algumas alterações foi nomeado II Plano Nacional de Reforma Agrária (II PNRA). Entre outras mudanças, a nova versão reduziu o número de famílias a serem assentadas de 600 mil para 400 mil até o final de 2006. De qualquer forma, ocorreu uma ampliação da criação de projetos de assentamentos (PAs) por todo país, em resposta às mobilizações sociais do campo, sobretudo às mobilizações organizadas pelo MST. O ministro do MDA, na tentativa de melhorar a imagem do governo com o MST e de colocar em prática o II PNRA, também procurou dar visibilidade à agricultura familiar na mídia; empenhou-se em aumentar o volume de recursos dedicados aos/às pequenos/as agricultores/as através do Programa Nacional de Apoio à Agricultura Familiar (PRONAF); assim como beneficiou famílias assentadas com outras formas de assistência para instalações de infraestrutura e moradia (SAMPAIO, 2010).

Ressalte-se que, além dessa política preconizadora da criação de PAs (mesmo que de forma tímida), foi constituída uma política de apoio ao agronegócio no Brasil. Por essa conjuntura, durante o primeiro governo do presidente Lula, duas perspectivas de atividade rural se configuraram. Emoldurou-se um dualismo entre as necessidades dos PAs e as necessidades do agronegócio. Enquanto a atividade rural, constituída nos moldes da proposta para os assentamentos, objetivou a produção de gêneros alimentícios, principalmente, de subsistência da população local; a atividade rural, nos moldes do agronegócio, mirou a produção com alta expressão comercial, o que interferiu diretamente no equilíbrio da balança 
comercial brasileira. ${ }^{10}$ Por conseguinte, as pessoas envolvidas com o agronegócio pressionaram um maior apoio do governo federal. A economia rural brasileira se dispôs basicamente em dois setores onde parece haver uma hierarquização das culturas segundo uma valorização comercial. Segundo Carter (2010), o país se tornou um dos principais produtores e exportadores de importantes commmodities agrícolas, mas parte da população continuou enfrentando restrições ao acesso a necessidades alimentares básicas. Desse modo, a economia agrícola do agronegócio altamente modernizada em termos tecnológicos vem coexistindo com uma sociedade do campo pauperizada, vivendo abaixo da linha da pobreza.

Em meio a esses contrastes de interesses, para Carter (2010) e Rosa (2010), os movimentos sociais relacionados à questão agrária revelam um impacto no geral positivo para a democracia no Brasil nas últimas décadas. Sobre isso, Rosa (2010) elucida alguns impactos nos movimentos sociais brasileiros, sobretudo os do MST, e que serão apresentados a seguir.

\section{Quadro 1.2 - Impactos do MST nos movimentos sociais brasileiros}

\begin{tabular}{|c|c|l|}
\hline Início & Sigla & \multicolumn{1}{|c|}{ Movimento Social } \\
\hline 1991 & MAB & Movimento dos Atingidos por Barragem \\
\hline 1994 & FETAPE & Federação dos Trabalhadores na Agricultura de Pernambuco \\
\hline 1996 & MPA & Movimento dos Pequenos Agricultores \\
\hline 1997 & MTST & Movimento dos Trabalhadores Sem-Teto \\
\hline 2004 & MMC & Movimento das Mulheres Camponesas \\
\hline
\end{tabular}

Adaptado de Rosa (2010).

De acordo com o Quadro 1.2, as ações desenvolvidas pelo MST corroboraram para a criação de outros movimentos sociais. Com isso, o MST teve importante contribuição para o surgimento de uma nova forma de relação entre o Estado e os movimentos sociais, forma reproduzida atualmente nos mais diversos espaços sociais, sejam eles rurais ou urbanos. Podese dizer que esse movimento buscou e busca combater as enormes disparidades sociais do país; fortalecer a sociedade civil por meio da organização e incorporação de setores marginalizados da população; facilitar a extensão e o exercício de direitos básicos de cidadania - civis, políticos e sociais - entre os pobres; destacar a importância do ativismo público; e gerar um sentido de utopia e afirmação de ideais que impregnam a democratização no Brasil.

\footnotetext{
${ }^{10}$ Entenda-se aqui como setor de subsistência o conjunto de atividades econômicas e relações de trabalho não assalariado no meio rural que propiciam meios de subsistência a parte expressiva da população rural (DELGADO, 2010, p. 96).
} 
Ao Instituto Nacional de Colonização e Reforma Agrária (INCRA), representante do governo federal, sob subordinação direta do Ministério do Desenvolvimento Agrário (MDA), cabe, por sua vez, a incumbência do cumprimento da legislação federal no que concerne à reforma agrária em termos de execução direta de medidas preconizadas em políticas públicas sobre a reforma. Dentre suas incumbências, o INCRA deve executar a "desapropriação" de terras, criar PAs, selecionar pessoas para participarem de assentamentos, dividir e distribuir as terras dos assentamentos, elaborar e implantar ferramentas para o desenvolvimento dos PAs, bem como deve fiscalizar o cumprimento das obrigações legais impostas a proprietários rurais e a assentados/as.

Ainda há de se considerar que, apesar de o número de projetos de assentamentos ter aumentado consideravelmente durante o governo Lula, os assentamentos surgem depois e derivam do fracionamento de grandes propriedades, cujos proprietários obtiveram insucessos na exploração em alta escala, seja por a propriedade não ter logrado desenvolvimento, seja por não ter resistido a situações graves da conjuntura econômica do país. Ressalte-se que, no processo denominado de desapropriação de terras improdutivas, ocorre o pagamento aos proprietários, o que não atrapalha o desenvolvimento de latifúndios a serviço do agronegócio. De modo geral, o movimento político e econômico do agronegócio promove uma verdadeira cartelização dos interesses econômicos dominantes no meio rural e se faz a base do sustentáculo econômico de uma sociedade politicamente autocrática, autoritária e não democrática (PRADO JÚNIOR, 2014). Como consequência, a implantação de assentamentos não é sinal de garantia de inclusão social plena das pessoas participantes, já que as atividades produtivas agrícolas do Brasil sempre privilegiaram o atendimento de demandas do mercado externo. A escolha em se privilegiar a produção agrícola para o mercado externo influencia grande parte das decisões sobre investimentos produtivos, o que limita alguns anseios de soberania e alguns padrões distributivos da riqueza social.

Além disso, a reforma agrária foi pouco mencionada na plataforma de campanha eleitoral do PT à presidência no ano de 2006. Depois da eleição, o presidente reeleito continuou o apoio ao desenvolvimento do agronegócio e chegou ao ponto de se tornar um defensor entusiasta do etanol. O governo federal, apesar de ter ampliado o financiamento público para a reforma agrária, não procurou neutralizar ou diminuir as relações de poder dos grandes proprietários rurais. Pelo contrário, o governo fez concessões aos partidos tradicionais, ligados à bancada ruralista no Congresso Nacional, diretamente envolvida com interesses do agronegócio. Para Meszaros (2010), o poder dos grandes proprietários rurais se perpetua em todas as suas formas e com uma forte motivação ideológica até o século XXI. 
Mesmo com a tomada de algumas medidas favoráveis à agricultura familiar, as ações desse governo não alcançaram uma ruptura com o velho sistema fundiário.

Por um lado, as medidas da reforma agrária adotadas nas últimas décadas procuraram satisfazer exigências imediatas, neutralizar conflitos locais e, acima de tudo, evitar um confronto maior com os grandes proprietários de terra mantenedores do agronegócio altamente rentável. Por outro lado, faz-se necessário considerar que a questão da reforma agrária obteve certo impulso por pressões vindas das mobilizações sociais e através de iniciativas oficiais direta ou indiretamente estimuladas por tais pressões. As ações concretizadas não representaram, assim, ações contundentes com objetivo de transformação do sistema fundiário e suas assimetrias em relação ao poder de modo que o assunto se propõe de maneira mais insistente ao longo dos anos no Brasil.

\subsection{A reforma agrária e o estado do Tocantins}

O estado do Tocantins teve sua origem na promulgação da Constituição Federal de 1988 e é o mais novo do Brasil, com 26 anos. Mesmo criado relativamente há pouco tempo, reflete a realidade brasileira de concentração de renda e crescimento populacional dos centros administrativos e comerciais. Além disso, faz-se fronteira agrícola e portal de entrada para a floresta amazônica. E, por ser um local em formação, o índice migratório de pessoas em busca de novas oportunidades para melhorar os meios de vida é elevado.

Com estas características, o índice migratório para o Tocantins se faz em grande escala desde e o início de sua constituição, há 26 anos, através da chegada de pessoas oriundas de regiões urbanas e rurais do Brasil, a população rural do estado se compõe de pessoas que anteriormente residiam em áreas urbanas e de pessoas que residiam em áreas rurais. Em similaridade, ambas procuram um meio de 'mudança social' no estado mais novo do país.

Ademais, a organização agrária do estado não se encontra em uma economia camponesa e sim na grande exploração rural voltada para o agronegócio. No entanto, apesar de o estado do Tocantins ser o mais novo do Brasil, segundo dados do Sistema de Informações de Projetos de Reforma Agrária (SIPRA), em março de 2013, há 367 decretos desapropriatórios, com 41.978 famílias assentadas. Ocorre, pois, mais de 46.000 famílias na área rural do estado, tentando sobreviver através do trabalho com o uso da terra. ${ }^{11}$ Sobre isso, faz-se relevante destacar que mais da metade da população rural é beneficiada pela reforma

\footnotetext{
${ }^{11}$ Disponível em: <http://www.incra.gov.br/index.php/reforma-agraria-2/questao-agraria/numeros-da-reforma-
} agraria/file/1148-familias-assentadas>. Acesso em: 15 jun. 2013. 
agrária realizada no âmbito do governo federal e, por conseguinte, está atrelada a projetos de assentamentos. Observe-se também que as pessoas com a concessão de uso de um lote em um assentamento não estão necessariamente relacionadas, em termos trabalho, a atividades rurais, à economia camponesa, à agricultura familiar até serem selecionadas para participarem dessa política. $^{12}$

Em relação à origem dos projetos de assentamentos no cenário brasileiro, a Lei

Especificamente, na região do Tocantins chamada de Jalapão, foram implantados vários projetos de assentamentos nos municípios que compõem seu território. ${ }^{13}$ Os municípios que englobam o Jalapão são oito e localizam-se no leste do Tocantins: Ponte Alta do Tocantins, Lagoa do Tocantins, Lizarda, Mateiros, Novo Acordo, Rio Sono, Santa Tereza do Tocantins e São Félix do Tocantins. Esse território limita-se com o noroeste do estado da Bahia, com o sul do estado do Piauí e com o sul do estado do Maranhão. De acordo com Carter (2010, p. 74), “os assentamentos da reforma agrária diferem muito em termos de localização geográfica, tamanho, composição familiar, níveis de desenvolvimento econômico, conscientização política e recursos culturais". Sobre isso, o território do Jalapão - onde se localiza o PA Santa Tereza I, objeto de estudo desta pesquisa - foi incluído no Programa de Desenvolvimento Sustentável de Territórios Rurais (PRONAT), pelo Conselho Estadual de Desenvolvimento Rural Sustentável do Tocantins (CEDRS), em 28 de novembro de 2005, com base nas características socioeconômicas da região: baixo Índice de Desenvolvimento Humano (IDH: 0,63); alto índice de pobreza; baixa escolaridade dos habitantes, solos pobres e fracos; alta concentração de renda. Sobre a parte Norte do Brasil, Carter (2010) aponta em muitas áreas a quase inexistente ou imbricada presença do governo de forma patrimonialista com a oligarquia rural. Diante da conjuntura agrária implantada no Brasil, os projetos de assentamentos estão, de alguma forma, atrelados à grande exploração agrária voltada para o mercado, pois não cumprem a valorização humana das pessoas que os compõem.

Nessa perspectiva, os projetos de assentamentos foram instituídos nos termos da legislação brasileira e nos moldes dos atuais, de acordo com a Lei 8.629, de 25 de fevereiro de 1993: "Dispõe sobre a regulamentação dos dispositivos constitucionais relativos à reforma agrária, previstos no Capítulo III, Título VII, da Constituição Federal”. Especificamente, o Artigo $5^{\circ}$. aponta aspectos da aquisição de terras para a criação de assentamentos:

\footnotetext{
12 Para Prado Júnior (2014), a economia camponesa, típica na Europa, se constitui na base da produção individual ou familiar e da ocupação parcelária da terra.

13 O nome Jalapão deriva do nome de uma planta típica local, chamada jalapa-do-Brasil (Operculina macrocarpa (Linn) Urb.).
} 
$\S 4^{0}$ No caso de aquisição por compra e venda de imóveis rurais destinados à implantação de projetos integrantes do Programa Nacional de Reforma Agrária, nos termos desta Lei e da Lei no 4.504, de 30 de novembro de 1964, e os decorrentes de acordo judicial, em audiência de conciliação, com o objetivo de fixar a prévia e justa indenização, a ser celebrado com a União, bem como com os entes federados, o pagamento será efetuado de forma escalonada em Títulos da Dívida Agrária - TDA, resgatáveis em parcelas anuais, iguais e sucessivas, a partir do segundo ano de sua emissão (BRASIL, 2013).

O parágrafo $4^{\circ}$., do Artigo $5^{\circ}$., trata do pagamento das propriedades destinadas à criação de projetos de assentamentos. Já o Artigo 11 da mesma lei faz referência à função da terra:

Art. 11. Os parâmetros, índices e indicadores que informam o conceito de produtividade serão ajustados, periodicamente, de modo a levar em conta o progresso científico e tecnológico da agricultura e o desenvolvimento regional, pelos Ministros de Estado do Desenvolvimento Agrário e da Agricultura e do Abastecimento, ouvido o Conselho Nacional de Política Agrícola (BRASIL, 2013).

A função da terra, desde o estabelecido no Estatuto da Terra, de 1964, está atrelada à questão da produtividade. O Artigo 11 também relaciona a função da terra à produtividade, determinada e fiscalizada pelo Ministério do Desenvolvimento Agrário. Além disso, o Artigo 17 especifica a criação de assentamentos:

Art. 17. O assentamento de trabalhadores rurais deverá ser realizado em terras economicamente úteis, de preferência na região por eles habitada, observado o seguinte:

I - a obtenção de terras rurais destinadas à implantação de projetos de assentamento integrantes do programa de reforma agrária será precedida de estudo sobre a viabilidade econômica e a potencialidade de uso dos recursos naturais (BRASIL, 2013).

O Artigo 17 indica o tipo de propriedade onde os assentamentos devem ser criados além de reafirmar o Artigo 11 no que se refere à produtividade agrícola dos assentamentos. De acordo com esse artigo, os assentamentos devem ser criados em propriedades onde seja possível a produtividade agrícola para fins econômicos. Para tentar garantir essa produtividade, também é instituído o Plano de Desenvolvimento de Assentamento (PDA) no inciso III do mesmo artigo: 
III - nos projetos criados será elaborado Plano de Desenvolvimento de Assentamento - PDA, que orientará a fixação de normas técnicas para a sua implantação e os respectivos investimentos;

$\mathrm{V}$ - a consolidação dos projetos de assentamento integrantes dos programas de reforma agrária dar-se-á com a concessão de créditos de instalação e a conclusão dos investimentos, bem como com a outorga do instrumento definitivo de titulação (BRASIL, 2013).

O inciso III indica a elaboração de PDAs como ferramenta para o desenvolvimento de PAs em relação a normas para sua implantação assim como a investimentos financeiros. No caso do PA Santa Tereza I, houve a elaboração do PDA para que os lotes fossem concedidos às pessoas selecionadas, como elucida a capa desse documento na imagem abaixo.

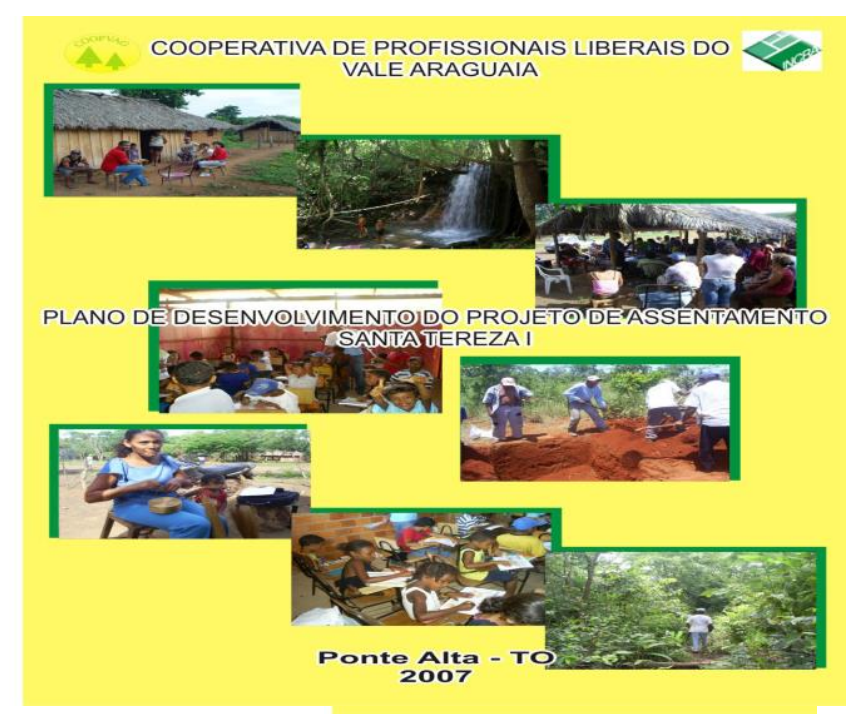

Fotografia 1.1 - Capa do PDA do PA Santa Tereza I

A capa do PDA Santa Tereza I aponta a Cooperativa de Profissionais Liberais do Vale Araguaia (COOPVAG), com CNPJ: 02.059.774/0002-02, como a entidade responsável pela elaboração do PDA Santa Tereza I. A COOPVAG prestou assessoria técnica ao INCRA através de uma equipe multidisciplinar, composta por profissionais da área social, ambiental e produtiva, tanto de nível médio como nível superior (engenheiros agrônomos, assistente social, cientista social, engenheiros ambientais e técnicos em agropecuária), a partir de convênio firmado com o INCRA/MDA, em janeiro de 2007, mas com o desenvolvimento de assessoria junto ao INCRA desde junho de 2006 (COOPVAG, 2007).

Por último, o Artigo 19 trata da seleção de pessoas para um projeto de assentamento: 
Art. 19. O título de domínio, a concessão de uso e a CDRU serão conferidos ao homem ou à mulher, ou a ambos, independentemente de estado civil, observada a seguinte ordem preferencial:

I - ao desapropriado, ficando-lhe assegurada a preferência para a parcela na qual se situe a sede do imóvel;

II - aos que trabalham no imóvel desapropriado como posseiros, assalariados, parceiros ou arrendatários;

III - aos ex-proprietários de terra cuja propriedade de área total compreendida entre um e quatro módulos fiscais tenha sido alienada para pagamento de débitos originados de operações de crédito rural ou perdida na condição de garantia de débitos da mesma origem;

IV - aos que trabalham como posseiros, assalariados, parceiros ou arrendatários, em outros imóveis;

V - aos agricultores cujas propriedades não alcancem a dimensão da propriedade familiar;

VI - aos agricultores cujas propriedades sejam, comprovadamente, insuficientes para o sustento próprio e o de sua família.

Parágrafo único. Na ordem de preferência de que trata este artigo, terão prioridade os chefes de família numerosa, cujos membros se proponham a exercer a atividade agrícola na área a ser distribuída.

O Artigo 19 confirma o que foi dito anteriormente neste estudo no que remete à concessão de uso de um lote de um PA. A concessão pode ser efetuada tanto para um homem e quanto para uma mulher, desde que a ordem de preferência estabelecida nos incisos desse artigo seja cumprida. Destaque-se que somente a partir do inciso IV há referência às pessoas com menos recursos financeiros e que não estão relacionadas diretamente à propriedade rural onde será implantado o assentamento. A preferência inicial da seleção não se atrela às pessoas, que trabalham com o uso da terra anteriormente ao assentamento, ou às pessoas, que participam de um acampamento como forma de reivindicar um lote, ou seja, às pessoas à margem da sociedade.

A partir dessa legislação, foi criado o Projeto de Assentamento Santa Tereza I. O PA Santa Tereza I é representado pelo código TO0376000 junto ao INCRA e foi criado no dia 13 de fevereiro de 2006, no local onde foi a fazenda Santa Tereza anteriormente. O PA Santa Tereza I está sob influência dos municípios de Ponte Alta do Tocantins e Santa Tereza do Tocantins, no estado do Tocantins, mas pertence territorialmente ao primeiro município. Por proximidade geográfica, as pessoas desse assentamento necessitam de alguns serviços do município de Santa Tereza, como saúde e comércio. Sendo assim, a área do assentamento está localizada a uma distância de 49,5 km da sede do seu município (Ponte Alta do Tocantins) e a 100 km do município de Palmas, capital do estado. No entanto, o PA Santa Tereza I situa-se a uma distância aproximada de $25 \mathrm{~km}$ da sede do município de Santa Tereza do Tocantins, o que faz com que a comunidade inserida no PA dependa em diversos aspectos dela. Esse PA 
possui uma área de aproximadamente 2.351 ha. $\left(23 \mathrm{~km}^{2}\right)$ e está localizado entre as coordenadas UTM 192.344 e 198.833 oeste e 8.846.871 e 8.841.022 sul (COOPVAG, 2007, p. 33). Em relação ao número de lotes, foi dividido em 47 lotes e possui 47 famílias assentadas.

\subsection{Sob a lona preta até a constituição do projeto de assentamento}

Esta seção envolve duas partes dedicadas à luta na e pela terra, de um lado, e à implantação de projetos de assentamentos por outro.

\subsubsection{A luta pela terra sob a lona preta}

A partir da década de 1990, os governos federais intensificaram alguma preocupação em "legalizar" a questão da reforma agrária no Brasil, de modo que cada governo propôs uma política com tal objetivo. Em similaridade entre esses governos, a reforma agrária no Brasil começou a se efetivar através da criação projetos de assentamentos (PAs) que, de alguma forma, tentam representar a efetivação de mudanças no campo e em seu entorno e geram alterações tanto locais quanto regionais. É dito que os assentamentos indicam a possibilidade de reconstrução do território e podem promover o (re)arranjo no processo produtivo, diversificação da produção e introdução de novas atividades.

Nesse contexto, a precarização social das pessoas que trabalham ou almejam trabalhar com o uso da terra tende a ser resolvida muitas vezes através de projetos de assentamentos. Diante da oportunidade de participarem de um projeto de assentamento, essas pessoas se submetem ao modo de vida de um acampamento ora às margens de vias públicas (rodovias) ora em propriedades rurais onde há a possibilidade de se constituir um assentamento. Segundo Carter (2010, p. 74), “esses precários acampamentos montados por trabalhadores rurais desempregados não constituem encontros improvisados, mas um instrumento ritualizado e simbólico por meio do qual os pobres do campo aprenderam a reivindicar seus direitos". A forma de acampamento se caracteriza como uma nova técnica de mobilização dos movimentos sociais do campo do Brasil.

Observe-se sobre essa técnica de mobilização que, diante da conjuntura social e econômica do país, não somente trabalhadores/as rurais se mobilizaram em acampamentos, mas também trabalhadores/as de áreas urbanas em condições miseráveis de sobrevivência, desempregados ou não, passaram a constituir acampamentos de sem-terra com o objetivo de 
lutarem pela reforma agrária em termos de haver mais justiça social. No caso, os acampamentos organizados por movimentos sociais no campo, com destaque para o MST, assumem o papel de instrumento de mobilização e reivindicação de pessoas acampadas diante o INCRA para a criação de PAs. O acampamento se tornou um símbolo da luta pela terra no Brasil e pode representar a participação do acampado/a como um/uma candidato/a a um lote em um PA, o seu interesse em participar de um PA. É fato que esse tipo de mobilização se concentra na questão da desapropriação das terras com o objetivo de loteamento e distribuição às pessoas selecionadas. Essa luta promove a criação de PAs, inclusive no estado do Tocantins, mas não assegura resolver a questão social. A vida sob a lona preta parece integrar uma etapa no processo que integra a seleção de pessoas que pleiteiam o direito de concessão de uso de um lote em um projeto de assentamento.

Resulta que a denominada luta pela terra sob a lona preta pode ser considerada desde uma perspectiva mais ampla que envolve a noção de contexto. Vejamos. Uma breve noção sobre a noção de contexto, iniciada em Silva (2005a), e retomada em Silva (2012), faz-se, aqui, pertinente registrar:

\begin{abstract}
para descrever e interpretar o uso da linguagem como prática social, discutir práticas discursivas e representações sociais, bem como identificarem escolhas léxico-gramaticais ou em estruturas linguísticas, pistas contextualizadas que veiculam efeitos ideológicos na gramática do discurso, faz-se necessário considerar a noção de contexto. Nessa perspectiva, parece razoável evitar qualquer tipo de autonomia ou predomínio, em termos de uma dimensão cognitiva (interioridade) de contexto com relação a uma dimensão cultural (exterioridade) (SILVA, 2012, p. 7).
\end{abstract}

A discussão mais ampla acerca de uma noção de contexto, como bem observa a autora, constitui uma oportunidade de reflexão sempre presente e, ao mesmo tempo, um desafio para estudos, como o que se nos apresenta agora. Em poucas palavras, a luta sobre a terra em qualquer tempo e em qualquer lugar encontra-se atrelada à noção de pobreza e deságua na restrição de liberdade, tópicos que discutirei a seguir.

\title{
1.3.2 A luta na terra e a pobreza como restrição de liberdade
}

A história do Brasil 'colonizado' é marcada por uma luta permanente de pessoas à margem da sociedade - os/as sem-terra -, e se acentuou nos últimos 50 anos, para poderem trabalhar e manter suas famílias com dignidade no campo. Como bem registra Marés (2003, p. 
103), "Desde o século XVI, com o sistema de sesmarias, passando pela concessão de terras devolutas instituídas em 1850, sempre houve no Brasil uma política de impedimento aos pobres, camponeses e indígenas de viverem em paz na terra". Questões relacionadas à terra, à reforma agrária perpassam toda a história do Brasil e são intrínsecas à constituição e à propagação da pobreza no país. Uma reflexão sobre concepções e aspectos da pobreza pode propiciar considerações sobre a constituição da sociedade brasileira como também transformações futuras.

Segundo Pardo Abril (2008), o conceito de pobreza consiste em um critério comparativo mediante o qual é possível definir o outro, tanto quanto a si mesmo, e implica um conceito concomitante que permite uma categorização populacional fundamentada no estabelecimento de parâmetros que se define que se é pobre em algo, sendo esse algo um valor.

La classificación pobre tiene su origen y fundamento en la determinación de las características de um sujeto, grupo o sociedad definidos por la inexistencia de los mínimos requeridos para garantizar la vida, la identidad y la interacción social, lo cual pone en cuestión la condición misma de 'humanidad' (PARDO ABRIL, 2008, p. 37).

As características que classificam uma pessoa como pobre, em estado de pobreza, são formas generalizadas de valores atribuídos a ela ou a uma sociedade, em que a exclusão social define em grande escala a estrutura das relações sociais.

Já Amartya Sen (2010, p. 120) diz que "a pobreza deve ser vista como privação de capacidades básicas que uma pessoa possui” no que concerne às liberdades substantivas para levar o tipo de vida que ela tem razão para valorizar e não pobreza meramente como baixo nível de renda. A renda não é o único instrumento de geração de capacidades. Para essa autora (2010), a relação instrumental entre baixa renda e baixa capacidade é 'variável' entre comunidades e até mesmo entre famílias e pessoas. Essa relação se faz, por sua vez, importante quando se examina e avalia a ação pública destinada a reduzir a desigualdade ou a pobreza no âmbito de contextos de elaboração prática de políticas. As capacidades básicas são meios para se conquistar a justiça social, inclusive no âmbito rural.

No caso do Brasil, Carter (2010) aponta que a pobreza se relaciona a altos níveis de desigualdade social entre as pessoas, gerados por privação de muitas capacidades básicas. Essa situação constitui consequências nocivas à sociedade, como desaceleração do crescimento econômico; prejuízo à redução da pobreza e fomento de maiores disparidades; redução da qualidade de vida geral, particularmente no que se refere à segurança pessoal; 
redução da confiança social; criação de um padrão dualista de desenvolvimento, produzindo uma sociedade desconexa e segregada; condicionamento do poder político e dos recursos culturais na sociedade; subversão d o Estado de Direito; enfraquecimento da democracia política. Todos esses fatores assolam a sociedade de modo geral, especialmente, aqueles/as que se vêem obrigados/as a se colocarem na luta pela terra e na terra como instrumento para a diminuição da situação de pobreza.

As lutas pela terra no país, como dito anteriormente, se intensificaram a partir da década de 1990 através de mobilizações populares que se fortaleceram e, com isso, surgiram os movimentos sociais, sobretudo, aqueles que se relacionam à questão da terra. Com a intensificação e diversificação dos instrumentos de luta dos movimentos sociais, como o MST, o governo federal necessitou dar alguma atenção a essa questão social e "responder" a apelos da população sobre a distribuição de terras no Brasil. Uma das respostas do governo federal às mobilizações pela posse e pelo uso da terra foi configurada durante os mandatos de Fernando Henrique e expandida nos de Lula: a criação de projetos de assentamentos de terra. Ressalte-se, nesse ponto, que ocorrem lutas durante todo o processo das mobilizações sociais, pois há luta durante o período vivido no acampamento enquanto candidatos/as a um lote de um assentamento, há luta quando ocorre a seleção para participar de um PA em termos de mudança para o lote, há luta para obtenção do mínimo de infraestrutura para morar e produzir no lote, entre outras lutas. A similaridade em todas essas lutas está na busca pela erradicação da pobreza nos moldes de Sen (2010).

Sendo assim, no Brasil, participar de um PA com um contrato de concessão de uso de uma unidade agrícola familiar (lote) não significa o fim da luta por melhores condições de sobrevivência e o fim ou diminuição do estado de pobreza a que as pessoas candidatas a um lote estavam imersas. Com o direito de uso de um lote, pelo menos, ainda ficam presos/as à mercê da "produtividade". Qualquer restrição de liberdade de participar do mercado de trabalho é umas maneiras de manter a sujeição e o cativeiro da mão de obra (SEN, 2010), de modo que a liberdade de participar do mercado de trabalho, assim como do intercâmbio econômico, configura papel básico na vida social. As pessoas, mesmo assentadas, necessitam ainda lutar para trabalhar, já que lhes faltam subsídios variados, como financeiros e técnicos.

Ademais, nessa situação, as pessoas selecionadas a participarem de um PA são nomeadas "não tituladas" pelo INCRA. Isto é, continuam em situação de pobreza, pois o direito ao uso de um lote não sinaliza autonomia sobre o uso da terra e melhores condições de sobrevivência. As lutas por sobrevivência e dignidade se estendem à luta na terra, no assentamento. As pessoas, que lutam pela 'posse' da terra, ao receberem o direito de uso de 
um lote em um PA, iniciam a luta por direitos referentes à sobrevivência no assentamento, haja vista passarem por privações de liberdades, restritivas de escolhas e oportunidades em exercer condição de agentes. Sobre a concepção de agente, ressalte-se a referência à pessoa que age e ocasiona mudança e cujas realizações podem ser julgadas de acordo com seus próprios valores e objetivos, independentemente de se avaliar ou não também segundo algum critério externo (SEN, 2010).

Para Carter (2010), os efeitos acumulados de um modelo de desenvolvimento excludente e um sistema oligárquico de representação política no Brasil têm gerado enormes obstáculos à participação e influência política de grupos do setor popular, como, aqui, ressalto os movimentos sociais de luta tanto pela terra quanto na terra. Neste estudo, interessa o papel da condição de agente como membro do público e como participante de ações econômicas, sociais e políticas do projeto de assentamento, onde possui o direito de uso de um lote.

Nesse sentido, a configuração dos Planos de Desenvolvimento Agrários (PDAs), parte de políticas públicas sobre reforma agrária no que se refere à organização da produção do PA, própria do governo Lula, aponta representações específicas sobre uma concepção de reforma agrária para o Brasil. Por isso, perfila-se como instrumento tanto para o planejamento do desenvolvimento do assentamento quanto para a orientação de ações de assentados/as para fazer cumprir a função social da terra, nos moldes Estatuto da Terra (1964), no que se refere à produtividade. Com parte integrante de uma abordagem conservadora de reforma agrária, a elaboração do PDA não significa, por si só, elevação dos padrões de vida de assentados/as. Somente a constituição de políticas públicas no que concerne à reforma agrária, como o PDA, não é garantia de efetiva valorização do trabalhador rural.

Em oposição a esse modelo de desenvolvimento excludente, Sen (2010, p. 10) aponta que "o desenvolvimento consiste na eliminação de privações de liberdade que limitam as escolhas e as oportunidades das pessoas de exercer ponderadamente sua condição de agente". As privações de liberdade dificultam a mudança social de modo que o desenvolvimento, para o autor, requer a remoção das fontes de privação de liberdade, que consistem na pobreza e tiraniza, na carência de oportunidades econômicas e destituição social sistemática, na negligência dos serviços públicos. Segundo Sen (2010), o desenvolvimento pode ser visto como um processo de expansão das liberdades reais que as pessoas desfrutam, o que contrasta com visões mais restritas de desenvolvimento, como as que o identificam com crescimento do Produto Nacional Bruto (PNB), aumento de rendas pessoais, industrializações, avanço tecnológico ou modernização social. A ligação entre liberdade individual das pessoas e realização de desenvolvimento social vai além de uma relação constitutiva. 
As realizações (de agentes sociais) são influenciadas por oportunidades econômicas, liberdades políticas, poderes sociais; e por condições habilitadoras, como saúde, educação básica entre outros fatores. É nessa perspectiva que Sen (2010) concebe a ideia de desenvolvimento como liberdade, pois as liberdades não são apenas os fins primordiais, mas também os meios principais para o desenvolvimento. Os fins e os meios do desenvolvimento, por sua vez, requerem compreensão mais ampla do que adotar somente a causa para o desenvolvimento voltado para maximização de renda ou riqueza. Isto é, o desenvolvimento tem de estar relacionado principalmente com a melhora da vida, no caso, dos/as assentados/as e das liberdades que eles/elas desfrutam.

De acordo com Prado Júnior (2014), de nada serve dividir a terra, se não se dispensar amparo ao pequeno proprietário. Para o mesmo autor (2014), a luta ou a 'pseudoluta' contra o latifúndio improdutivo nada mais é do que uma diversão, um escamoteamento do problema agrário brasileiro. A divisão e a repartição de terras para a reforma agrária necessitam ser atreladas ao amparo de um complexo programa de medidas que envolvem desde infraestrutura de moradia e à de trabalho para o assentamento no âmbito técnico e financeiro. Segundo Sen (2010), esse amparo tende a ter êxito quando o exercício da liberdade é mediado por valores influenciados por discussões públicas e interações sociais, que são elas próprias, influenciadas pelas liberdades de participação. Desse modo, um PA amparado por um programa de desenvolvimento com várias interações sociais parece apresentar maior possibilidade de desenvolvimento de novas relações sociais e políticas no plano local, ao tempo de fomentar arranjos comerciais alternativos, tecnologias inovadoras e a consolidação gradual de uma política pública de apoio à agricultura familiar (BERGAMASCO; NORDER, 2010).

Para tanto, Prado Júnior (2014) ressalta que o objetivo central da reforma agrária nas atuais circunstâncias do país deve possuir como foco a elevação dos padrões de vida da população rural assentada e sua integração em condições humanas de vida. Em suma, a reforma agrária necessita se centrar em duas frentes, a saber, a extensão da proteção legal ao/à trabalhador/a rural e o favorecimento ao acesso e à utilização do lote de um PA. Todavia pouco se investigou sobre as condições de sobrevivência a que são submetidas as famílias assentadas, principalmente em relação ao cumprimento da função social da terra. De alguma forma, ser nomeado/a sem-terra, seja em termos de luta pela terra seja de luta na terra, parece definir certas identificações específicas, já cristalizadas na sociedade e que tendem a perpetuar representações voltadas para a pobreza ao grupo identificado com tal nomeação. Segundo Sen (2010), há um terrível fardo das identidades estreitamente definidas, incluindo 
as identidades firmemente baseadas em comunidades e grupos, como ocorre com os/as semterra.

Assim sendo, o desenvolvimento de pesquisas críticas, através do conhecimento das facetas do uso da linguagem, tanto oral quanto escrita, quando há referência ao PDA, é uma estratégia para que assentados/as procurem meios que possibilitem a inclusão social nos projetos de assentamentos e para que a pobreza talvez possa diminuir (SOUZA e SILVA, 2013). Com a perspectiva da pesquisa social crítica como cenário de conhecimento, é que se desenvolve a Análise de Discurso Crítica, comprometida com aspectos fundamentais que remetem a desenvolvimentos teóricos em torno do discurso e à reflexão crítica sobre realidades sociais presentes nos discursos, inclusive no que concerne à pobreza (PARDO ABRIL, 2008). No âmbito da ADC na América Latina, destaco as investigações do Grupo Brasileiro de Estudos de Discurso, Pobreza e Identidades, registrado no diretório do grupo de pesquisa do CNPq (2008) e coordenado, no Brasil, pela Professora Doutora Denize Elena Garcia da Silva (já mencionado aqui na Apresentação), em parceria acadêmico-científica com instituições de quatro países da América Latina: Argentina, Chile, Colômbia e Venezuela, que compõem a REDLAD (Red Latinolmericana de Análisis del Discurso de la pobreza).

Isso posto, a partir desse contexto de situação, o presente estudo propõe uma investigação sobre as representações linguístico-discursivas envolvidas no texto do PDA do PA Santa Tereza I.

\section{Algumas considerações}

No Brasil, o tipo de colonização e o modelo político desenvolvido em relação à questão agrária constituem, até meados do século XXI, um empreendimento mercantil - o agronegócio -, com o intuito de abastecer, principalmente, o mercado externo para manter a balança comercial do país, pelo menos, equilibrada. Essas escolhas, por sua vez, marcam ampla desigualdade e injustiça social no campo. A alta desigualdade se faz uma característica secular da estrutura fundiária do país e perpassa todo o período da "modernização conservadora" e do "ajustamento constrangido", mantendo-se visceralmente arbitrada pelo poder do Estado (DELGADO, 2010). De certa forma, a "modernização técnica da agricultura" (proposta pelos conservadores em 1964) predomina sobre a "reforma agrária" até os dias de hoje sob um novo arranjo político, o da democracia contemporânea.

A utilização da terra sendo feita em função de interesses comerciais e de necessidades inteiramente estranhas à população que nela trabalha e exerce suas atividades (PRADO 
JÚNIOR, 2014). Desse modo, a luta pela reforma agrária oferece vislumbres de um caminho alternativo para a redução de desigualdades sociais duradouras, a partir da organização da sociedade em movimentos sociais de luta pela terra e de luta na terra. O Quadro 1.3 traz um resumo de mobilizações populares durante a segunda metade do século XX e o início do XXI.

\section{Quadro 1.3 - História social do campo, Brasil 1945-2005}

\begin{tabular}{|c|c|}
\hline Ano & Acontecimento \\
\hline 1945 & Aparecimento das primeiras associações de lavradores. \\
\hline 1949 & Aparecimento do primeiro número do jornal Terra Livre. \\
\hline 1953 & Primeiro congresso de lavradores. \\
\hline 1954 & $\begin{array}{l}\text { Criação da União dos Lavradores e Trabalhadores Agrícolas do Brasil (ULTAB). } \\
\text { Criação da Confederação Rural Brasileira (CRB). }\end{array}$ \\
\hline 1955 & Criação da Liga Camponesa da Galileia em Pernambuco. \\
\hline 1961 & Congresso Camponês em Belo Horizonte. \\
\hline 1962 & Regulamentação da sindicalização rural. \\
\hline 1963 & $\begin{array}{l}\text { Criação da Confederação Nacional dos trabalhadores na Agricultura (CONTAG). } \\
\text { Aprovação Nacional do Estatuto do Trabalhador Rural pelo Congresso Nacional }\end{array}$ \\
\hline 1964 & $\begin{array}{l}\text { Golpe militar ( } 31 \text { de março). } \\
\text { Aprovação pelo Congresso Nacional do Estatuto da Terra (novembro). }\end{array}$ \\
\hline 1970 & $\begin{array}{l}\text { Criação do Instituto Nacional de Colonização e Reforma Agrária (INCRA) a } \\
\text { partir do Decreto } \mathrm{n}^{\circ} 1.110 \text {, de } 9 \text { de julho de } 1970 \text {. }\end{array}$ \\
\hline 1971 & Criação do FUNRURAL. \\
\hline 1975 & Criação da Comissão Pastoral da Terra. \\
\hline 1979 & $\begin{array}{l}\text { Primeiras ocupações organizadas de terra no Sul do Brasil. } \\
\text { Greve dos canavieiros de Pernambuco. }\end{array}$ \\
\hline 1984 & $\begin{array}{l}\text { Greve de Guariba em São Paulo } \\
\text { Movimento das "Diretas já". }\end{array}$ \\
\hline 1985 & $\begin{array}{l}\text { Criação formal do Movimento dos Trabalhadores Sem-Terra (MST). } \\
\text { Início da Nova República. } \\
\text { Proposta do I Plano Nacional de Reforma Agrária (PNRA). }\end{array}$ \\
\hline 1991 & Primeiro Grito da Terra Brasil. \\
\hline 1996 & Criação do Movimento dos Pequenos Agricultores (MPA). \\
\hline 2001 & $\begin{array}{l}\text { Criação da Federação dos Trabalhadores na Agricultura Familiar do Sul (FETRAF- } \\
\text { Sul). }\end{array}$ \\
\hline 2003 & Proposta do II Plano Nacional de Reforma Agrária (II PNRA). \\
\hline 2005 & $\begin{array}{l}\text { Criação da Federação dos Trabalhadores na Agricultura Familiar do Brasil } \\
\text { (FETRAF-Brasil) }\end{array}$ \\
\hline
\end{tabular}

Adaptado de Medeiros (2010, p. 136).

Os textos oficiais, listados acima, foram elaborados com o intuito de promoverem a reforma agrária e precisam favorecer e fomentar não somente medidas adequadas ao acesso da mesma população trabalhadora à propriedade fundiária por meio da participação em projetos de assentamentos, mas também precisam operar uma organização em favor dessa população, funcionando como um instrumento para que seja assegurado nível adequado de 
sobrevivência através do trabalho nos lotes/parcelas dos assentamentos, como o PA Santa Tereza I.

No entanto, apesar do êxito de muitas mobilizações sociais - movimentos sociais em prol da reforma agrária - luta pela terra -, a distribuição fundiária no Brasil ainda se faz mínima e, mesmo com a ampliação da criação de projetos de assentamentos, não finda a dependência do/a assentado/a em relação ao governo federal no que concerne ao meio de vida proporcionado. No país, as políticas públicas voltadas para o desenvolvimento dos assentamentos, como a elaboração dos PDAs, são atreladas às escolhas do governo sobre reforma agrária. A simples criação ou a execução dessas políticas sem planejamento adequado em relação a especificidades de cada assentamento e de cada região do país, não garante melhoria das condições de sobrevivência das pessoas assentadas, além de parecer pouca autonomia ao/à assentado/a para gerir a parcela de terra concedida.

Segundo Carter (2010), a reforma agrária constituída com programas de apoio adequados poderá estimular a produtividade rural, em especial para o consumo interno; além de constituir uma "forma eficaz e barata" de gerar empregos. A distribuição fundiária, que conte com programas de apoio adequados, pode ajudar a promover um "padrão de desenvolvimento mais sustentável e endógeno, fundado nos princípios de justiça social e preocupação pelo bem-estar do imenso contingente de pessoas marginalizadas. É nisso que consiste essencialmente a questão da reforma agrária no país. Grande parte da população assentada se encontra ainda privada de meios que lhe assegure condições dignas de sobrevivência. Em face dessa diversidade de aspectos que compreendem a questão agrária no Brasil, um dos desafios para o país no século XXI é superar seus históricos padrões de exclusão social no meio rural e ampliar o acesso à riqueza e a outros meios de vida, podendo exercer uma função determinante na redução de severas disparidades sociais.

A inclusão social da população rural, principalmente, assentada, faz-se possível através da constituição e atuação de agentes da sociedade capazes de reivindicar intervenções estatais que promovam um processo de democratização da propriedade rural e, especialmente, de sua utilização para proveito próprio. A ação desses/as agentes pode contribuir para a retificação de enormes brechas sociais no campo, de modo que trabalhadores/as sejam cada vez mais incluídos/as em um processo produtivo, sustentável em termos ecológicos, e com acesso a bens de consumo e serviços sociais básicos. 


\section{CAPÍTULO 2}

\section{BASES DE PARTIDA PARA A REVOADA TEÓRICA: VIGAS MESTRAS}

A ADC está preocupada com efeitos ideológicos, voltados para projetos particulares de dominação, que (sentidos de) textos possam ter sobre relações sociais, ações e interações, conhecimentos, crenças, atitudes, valores, identidades (FAIRCLOUGH, 2003).

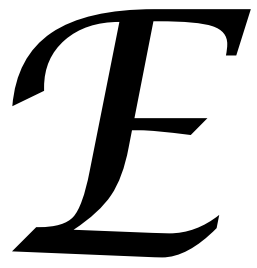

ste capítulo apresenta o aporte teórico e metodológico da Análise de Discurso Crítica (ADC), o qual embasa o presente estudo. Trata-se de uma parte principal, dividida em nove seções. A primeira seção apresenta um breve histórico da ADC. A segunda discute alguns de seus fundamentos enquanto Teoria Social do Discurso. A terceira seção propõe uma reflexão sobre a dialética entre linguagem e sociedade. A quarta destaca a imbricação entre discurso, poder e ideologia no âmbito da ADC (FAIRCLOUGH, 2003), o que configura uma justificativa para a articulação da análise da exterioridade e da interioridade da linguagem. A ADC propõe uma análise textualmente orientada, constituindo-se como uma pesquisa social crítica. A quinta seção envolve os pressupostos da Linguística Sistêmico-Funcional (LSF), de acordo com Halliday (1994) e Halliday \& Matthiessen (2004), como aporte teórico-metodológico para a análise da interioridade da linguagem, considerando os usos de linguagem constituídos em seus contextos de cultura e de situação. Especificamente, nesta pesquisa, interessa alguns pressupostos da Gramática Sistêmico-Funcional (GSF) em termos de aspectos da léxicogramática que formam parte da análise discursiva crítica. Destaque-se a ADC como um aprofundamento teórico da LSF para a formulação da teoria do funcionamento social da linguagem. Já a sexta aborda os fundamentos teóricos da ADC (FAIRCLOUGH, 2003) enquanto instrumento para a análise da exterioridade da linguagem. A sétima seção é dedicada à representação dos atores sociais, proposta por van Leeuwen (1997, 2008). A oitava seção apresenta alguns aspectos sobre a articulação entre a ADC e a LSF. A última tece algumas considerações preliminares. 


\subsection{Análise de Discurso Crítica: uma retrospectiva}

A Análise de Discurso Crítica configura-se como uma ciência social de cunho crítico, com início institucional em 1991, a partir do encontro dos estudiosos Norman Fairclough, Teun van Dijk, Gunther Kress, Theo van Leeuwen e Ruth Wodak. O encontro ocorreu com o propósito de discutirem sobre teorias e métodos de análise de discurso, principalmente sobre ADC, na Universidade de Amsterdã (Holanda). Apesar de esses estudiosos filiarem-se a diferentes abordagens teóricas, o consenso estabelecido entre eles está em considerarem um método de análise textual a partir de uma teoria social do funcionamento da linguagem em processos de ordem ideológica e política.

Nesse âmbito, os estudos da ADC estabelecem certa relação com os estudos da abordagem teórica Linguística Crítica (LC), desenvolvidos na década de 1970, principalmente na Inglaterra. Na concepção da LC, ao se estudar os mais diversos usos da linguagem, é possível intervir nas realidades sociais. Como bem aponta Rajagopalan (2003, p. 125), “a linguagem se constitui em importante palco de intervenção política, onde se manifestam as injustiças sociais pelas quais passa a comunidade em diferentes momentos da sua história e onde são travadas constantes lutas". Além disso, para Wodak (2004), a ADC, como a LC, tenta evitar uma relação simplista de determinação entre os textos e o social, haja vista cada discurso ser historicamente produzido e interpretado - situado no tempo e no espaço -, e as estruturas de dominação serem legitimadas pelas ideologias dos grupos detentores do poder. Sobre isso, Gunther Kress (1993) sinaliza que os discursos são ideológicos e que os signos não são arbitrários.

Observem-se as contribuições do trabalho de Kress para o desenvolvimento da ADC. Em seu trabalho de 1989, articula concepções básicas, fundadoras da ADC e que foram desenvolvidas posteriormente por outros estudiosos. Segundo esse teórico, a linguagem é um fenômeno social; os indivíduos, assim como as instituições e os grupos sociais, possuem valores específicos, expressos sistematicamente através da linguagem; o texto é a unidade básica de análise linguística; e o dialogismo é intrínsecos aos mais diversos usos da linguagem (textos). A partir dessas concepções, o referido autor busca estudar os modos de representação e sua utilização nas sociedades em termos de recursos representacionais disponíveis e da formação do indivíduo social.

Desse modo, a análise textual politicamente engajada pode revelar estruturas linguísticas de poder configuradas nos textos (WODAK, 2004) e nos gêneros discursivos (FAIRCLOUGH, 2003). Sob essa perspectiva, a ADC também dialoga com outros ramos da 
Línguística, como a Retórica Clássica, a Linguística Textual, a Sociolinguística, bem como a Linguística Aplicada, a Pragmática e a Linguística Sistêmico-Funcional. Todas essas ramificações contribuíram, de certa forma, para a interpretação ou explicação do texto em termos da análise textual proposta. Essas áreas da Linguística apresentam alguns fundamentos que propiciaram reflexões a estudiosos/as da $\mathrm{ADC}$, interessados/as na relação entre a linguagem e o social, como levar em conta a ligação entre linguagem e contexto, focalizar usos reais da linguagem, explicar as mudanças linguísticas dando atenção a questões de hierarquia social e poder - premissas e procedimentos ainda não conhecidos na Linguística Crítica.

Destaque-se, aqui, uma dessas influências. Para a Análise de Discurso Crítica, de acordo com Fairclough (1989, 1999, 2003), estudioso da escola britânica de Análise de Discurso, a Linguística Sistêmico-Funcional (HALLIDAY, 1994; HALLIDAY \& MATTHIESSEN, 2004) desenvolve uma proposta de análise de texto que contribui para o desenvolvimento da teoria social do discurso em termos de 'crítica'. A LSF não só contribui como base teórica para a ADC como também contribui para a constituição de análises linguístico-discursivas de textos em linguagens variadas (FAIRCLOUGH, 2003) ao propor a Gramática Sistêmico-Funcional, e que é utilizada no presente estudo. Nesse sentido, Fairclough propõe uma análise textualmente orientada, articulando a linguagem e o social que lhe é inerente.

Sendo assim, na década de 1990, o termo ADC tomou consistência como referência a uma abordagem particular de análise linguístico-discursiva, uma abordagem teóricometodológica que não se relaciona apenas a uma disciplina. Além de relação com ramificações da Linguística e com a tradição da gramática no que remete à análise textual, a ADC estabelece ligação com as ciências sociais pela relação complexa configurada entre a linguagem e o social. Os objetos de pesquisa investigados e as metodologias utilizadas por seus estudiosos/as também variam conforme as áreas e/ou subáreas do conhecimento a que se filiam (WODAK, 2004).

Com isso, na perspectiva da ADC, a relação entre o texto e o social é complexa devido à possibilidade de concretização tanto de situações antagônicas de dominação, com naturalização de ideologias e do poder, quanto de situações de resistência, em termos de rompimento de convenções e de práticas discursivas estáveis através de atos de criatividade (FAIRCLOUGH e KRESS, 1993). Através das análises propostas, a ADC busca propiciar possibilidades de resistência às relações desiguais de poder, configuradas como convenções sociais hegemônicas. 
Por conseguinte, o trabalho de Norman Fairclough possui destaque em termos teórico e metodológico. Esse estudioso da escola britânica possui um papel decisivo para a ADC ao conceber, de maneira específica e central, os conceitos de discurso, poder e ideologia para fundamentação e desenvolvimento do escopo central do tipo de pesquisa dedicado à análise linguística e discursiva a partir de várias áreas do conhecimento. ${ }^{14}$ Já em 1989, Fairclough aponta teorias sociais que sustentam a ADC. Em 1992, 1995 e 1999 elucida alguns avanços da teoria no que remete à perspectiva de análise da linguagem em relação ao poder e à ideologia e ao desvelamento da natureza discursiva de mudanças sociais. Sobre isso, há destaque para a obra Discourse and Social Change, publicada em 1992. Essa obra instaura uma ruptura conceitual e metodológica com análises desenvolvidas na Linguística Textual ou na Análise do Discurso de origem francesa, pois leva em consideração 'expressões de poder' nos processos de constituição de sentido e arrolamentos entre discurso e poder, aspectos fundamentais para o entendimento da função da linguagem na reprodução e manutenção do controle social. Também os estudos de Fairclough $(1999,2003,2010)$ contribuíram de forma ímpar para o reconhecimento da influência dos componentes do contexto comunicativo na constituição do(s) sentido(s) dos textos, com o objetivo de buscar o entendimento da imbricação entre o funcionamento da sociedade e os usos da linguagem de modo a explicar a (re)produção e manutenção do controle social.

Diante disso, os/as analistas de discurso críticos/as concebem a linguagem como 'prática social' (FAIRCLOUGH, 1989; 2001, 2003, 2010; WODAK, 2004; KRESS, 1989; VAN DIJK, 1993). A linguagem concebida como prática social alude questões de ordem econômica, política, cultural e ideológica. A ADC constitui-se, então, com o propósito de identificar problemas que as pessoas enfrentam em decorrência de formas particulares da vida social e de desenvolver recursos de que as pessoas podem se valer a fim de abordarem e superarem esses problemas (FAIRCLOUGH, 2003 p. 185). Para esses analistas de discurso, a linguagem não é algo puramente individual; é carregada de sentidos, subjaz uma ideologia.

Além disso, observe-se o fato de a ADC considerar várias abordagens teóricas (não somente a Linguística) e apresentar uma agenda internacional. Esse arcabouço teórico e metodológico tem feito história na América Latina com as contribuições teóricas e metodológicas de analistas, como Magalhães (2000), Silva (2007, 2009, 2012), Meurer

\footnotetext{
${ }^{14}$ Segundo Thompson (1995), a ideologia refere-se às formas e processos sociais dentro dos quais e, através das quais, formas simbólicas circulam no mundo social. E o estudo da ideologia refere-se, por sua vez, a como o significado é construído e transmitido através de formas simbólicas de vários tipos. Para o autor, esses estudos da ideologia são essenciais para a compreensão das relações de poder sistematicamente assimétricas baseadas em muitos fatores constituídos nas sociedades.
} 
(2005), Gomes (2003), Resende (2006, 2009), Ramalho (2006, 2011), Pardo Abril (2008), Barros (2008), Pardo (2008). De acordo com Silva (2012), a ADC se situa em um novo mapa conceitual que emerge do trabalho de linguistas contemporâneos, com pesquisas voltadas para práticas sociais transformadoras, atuando como uma forma de pesquisa social e uma prática teórica crítica. No caso do Brasil, Silva (2007a,b; 2009; 2013) enfatiza a importância em se desenvolver estudos cujos temas envolvam grupos sociais em situação de vulnerabilidade, considerando a situação socioeconômica e cultural de grande parte da população do país com dimensão continental.

Mantenho firme o propósito de levar a cabo trabalhos de pesquisa a fim de desnaturalizar e, em condições propícias, até mesmo desestabilizar o discurso do "senso comum", decorrente de práticas sociais repetidas de maneira convencional, associadas a relações de poder, o que, a meu ver, leva à banalização da pobreza e a práticas discursivas "naturalizadas" de discriminação, tais como as que associam pobreza à violência (SILVA, 2013, p. 89).

A referida linguista, ao propor estudos que buscam desnaturalizar discursos do "senso comum", objetiva o fortalecimento do paradigma crítico de estudos linguístico-discursivos no que concerne ao desenvolvimento da pesquisa social e de uma prática teórica crítica, contribuindo para uma agenda internacional de pesquisas. $\mathrm{O}$ desenvolvimento desses estudos tem êxito em termos de mudança social, segundo Silva (2013), quando favorecem práticas transformadoras e perfis de cidadania efetivos no contexto brasileiro.

Diante dessa breve retrospectiva histórica, a ADC leva em consideração o conceito de prática social para delinear a construção de um quadro analítico e de uma percepção de linguagem específicos, o que contribui para ser concebida como Teoria Social do Discurso, apresentada na próxima seção.

\subsection{A Teoria Social do Discurso}

Na contemporaneidade, a linguagem é concebida, por alguns arcabouços teóricos da Linguística, como a responsável pela interação entre o ser humano e a sociedade e que promove a constituição, a propagação e a transformação de crenças e valores. Através de usos da linguagem, as pessoas produzem, armazenam e fazem circular informações e conteúdo simbólico centrais na vida social. Especificamente, de acordo com a abordagem teórico-metodológica da Análise de Discurso Crítica, linguagem e sociedade são 
indissociáveis e mantêm relações dialéticas, visto que questões sociais são vistas como, em parte, questões de linguagem e vice-versa.

Nesse âmbito, situam-se os estudos de Norman Fairclough (1989, 1992, 1999, 2003, 2006, 2010). O autor propõe a Teoria Social do Discurso (TSD) enquanto pesquisa social crítica. Essa abordagem de ADC concebe a linguagem como um processo constituído por um contexto sócio-histórico e cultural e, por isso, a compreensão da esfera pública, através de diálogos produzidos por ela, propicia o entendimento dos conflitos sociais e culturais (FAIRCLOUGH, 2003). Além disso, essa perspectiva traz para a ADC a importância das relações entre linguagem, poder e ideologia - abordada na seção 2.4 - para a análise de discurso proposta, ao apontarem para instanciações discursivas específicas e para práticas sociais. A TSD propõe analisar, assim, os usos de linguagens nas instituições sociais e como as desigualdades sociais são constituídas linguisticamente.

Segundo Chouliaraki \& Fairclough (1999) e Fairclough (2003), a ADC propõe identificar problemas que as pessoas enfrentam em decorrência de formas particulares da vida social, bem como sugere desenvolver recursos de que as pessoas podem se valer a fim de abordar e superar esses problemas. Suas pesquisas buscam apontar mecanismos, através de usos da linguagem e suas práticas, para a mudança social.

Desse modo, a perspectiva crítica inerente à TSD, como aponta Fairclough (2003), surge na relação com a Linguística Crítica (já exposta anteriormente) e com o Realismo Crítico (RC) (BHASKAR, 1986, 1998), em termos de pesquisas sociais críticas. Tanto a ADC quanto o RC propõem o desenvolvimento de pesquisas que promovam a identificação de problemas práticos da vida social, materializados em textos em termos de um melhor entendimento da vida em sociedade. Sob a perspectiva do RC, esse tipo de pesquisa vislumbra uma 'crítica explanatória' (BHASKAR, 1986), na medida em que propõe investigações sobre como os significados são configurados na prática social com o objetivo de 'findar' ou 'diminuir' o 'problema' que integra o objeto de estudo. Há, pois, consenso nas abordagens dialéticas - como o momento discursivo se relaciona à prática social - da ADC e do RC.

Além disso, Fairclough (1985) destaca que, em questões humanas, as interconexões e as redes de causa e efeito relacionadas a usos de linguagem podem ser distorcidas a ponto de saírem do campo de visão. Isso implica a consideração de que os textos são maneiras tanto de representar o mundo quanto de ação sobre o mundo e sobre o outro. Sendo assim, a 'atividade crítica' consiste, sobretudo, em tornar visível a natureza interligada dos fatos e 
acontecimentos sociais concretizados em textos. Sobre isso, Van Dijk (1986) sugere que o ponto de partida desse tipo de ciência crítica está nos problemas sociais vigentes:

\begin{abstract}
Além da descrição ou da aplicação superficial, a ciência crítica de cada campo de conhecimento levanta questões que vão além, como as que dizem respeito à responsabilidade, interesses, e ideologia. Ao invés de focalizar problemas puramente acadêmicos ou teóricos, a ciência crítica toma como ponto de partida problemas sociais vigentes, e assim adota o ponto de vista dos que sofrem mais, e analisa de forma crítica os que estão no poder, os que são responsáveis, e os que dispõem de meios e oportunidades para resolver tais problemas (VAN DIJK, 1986, p. 4).
\end{abstract}

As pesquisas das ciências críticas, como a TSD, procuram devolver para as sociedades estratégias para a ação política, havendo uma interdependência entre os interesses da pesquisa e os comprometimentos políticos. No que se refere ao efeito de uma análise crítica, Resende e Ramalho (2006) também apontam que a postura crítica da ADC frente a problemas sociais relacionados ao poder e à justiça (que envolvem linguagem) pode levar a cabo transformações, mudanças em termos de sociedade. Diante disso, a postura dos/as analistas de discurso se vincula ao termo "crítica" no que concerne à Teoria Social do Discurso e à pesquisa social crítica.

Nesses termos, a linguista Silva (2007a) também sinaliza que a ADC é constituída em uma prática teórica crítica, principalmente, ao se basear na premissa de que situações opressoras podem ser mudadas por serem criações sociais e, como tal, são passíveis a transformações. Para tanto, Silva e Ramalho (2008b) incentivam o desenvolvimento de pesquisas linguístico-discursivas voltadas para causas sociais em favor das minorias. Cabe, pois, ao analista de discurso crítico identificar problemas sociais, configurados através de textos (orais e escritos) e analisá-los com o objetivo de desenvolver recursos para que as pessoas possam se valer deles para superar esses problemas.

Ademais, a ADC apresenta fundamentos importantes no que diz respeito à sua vinculação teórica de origem com pesquisa social crítica e com uma prática teórica crítica para a configuração de uma investigação crítica, como a 'transdisciplinariedade' e um 'caráter posicionado'. Como propõe a análise de problemas sociais manifestos através de usos da linguagem, a ADC dialoga com outras áreas do conhecimento, como a Sociologia e a Antropologia. Essa característica transdisciplinar incide no 'rompimento de fronteiras epistemológicas' com teorias sociais com o objetivo de subsidiar sua própria abordagem sócio-discursiva, assim como oferecer suporte para que pesquisas sociais possam contemplar aspectos discursivos (RESENDE \& RAMALHO, 2006). Como área transdisciplinar, 
compromete-se com estudos dos aspectos discursivos da mudança social e busca investigar, de forma crítica, como as relações de poder assimétricas são expressas e legitimadas através da linguagem (FAIRCLOUGH, 2001).

Por conseguinte, a ADC configura-se também com um caráter posicionado diante de problemas sociais, na medida em que busca contribuir para que mudanças sociais se constituam, mazelas sociais - como a pobreza e as desigualdades sociais - diminuam. Nesse ponto, a linguista brasileira Solange Barros (2009) sinaliza que, em relação ao caráter posicionado da ADC, os textos podem modificar os mundos sociais, uma vez que o mundo social é um sistema aberto em constantes modificações e os eventos sociais - configurados em textos - é parte da vida social concreta. Para Barros (2009), são necessárias ações para que novos horizontes emancipatórios transformem as vidas de seres humanos em algum tipo de vulnerabilidade. As pessoas podem reproduzir ou transformar modos de vida através de textos. Nesse sentido, a ADC enquanto ciência social crítica e ciência linguística se faz proponente de uma análise textualmente orientada (FAIRCLOUGH, 2003, 2010).

E é nos termos dessa abordagem teórico-metodológica crítica que se constitui o escopo principal do estudo proposto aqui, haja vista que seu objetivo está voltado para a investigação de discursos (re)contextualizados em um plano de desenvolvimento agrário, e que institucionalizam e tentam organizar o PA Santa Tereza I, no município de Ponte Alta, no Tocantins. O estudo das representações linguístico-discursivas constituídas no PDA Santa Tereza I vai ao encontro com as premissas da ADC que remetem às propostas de estudos que buscam desnaturalizar discursos com o objetivo do fortalecimento do paradigma crítico de estudos linguístico-discursivos em termos de desenvolvimento da pesquisa social crítica. A pesquisa pode propiciar, pois, uma atenção voltada para os/as excluídos/as historicamente da sociedade brasileira, os/as assentados/as - os/as sempre sem-terra -, que fazem de suas vidas uma luta pela terra e uma luta na terra. Há proposição do desenvolvimento de uma pesquisa voltada para causas sociais em favor de uma 'minoria'.

No sentido de compreender o processo de desnaturalização dos discursos, é apresentado, a seguir, um percurso sob o viés da dialética entre linguagem e sociedade.

\subsection{A dialética entre linguagem e sociedade}

Os seres humanos são capazes de definir e expressar em palavras a realidade que apreendida e as experiências cotidianas são construídas principalmente por intermédio da significação linguística. Segundo os sociólogos Berger e Luckmann (2004) (2004), a 
realidade é o resultado de uma construção social, o que torna a linguagem indispensável para vida social. Por meio dos usos da linguagem, o mundo inteiro pode ser (re)significado a qualquer momento, pois é capaz de se tornar o repositório objetivo de vastas acumulações de significados e experiências. Isso é o motivo pelo qual a linguagem pode ser uma das ferramentas legitimadoras de realidades sociais, pois possui a capacidade de edificar representações simbólicas para a realidade, o que a coloca em um mesmo espaço que o social, onde um é a realização do outro. Essa também é a perspectiva do linguista Michael Halliday (1978), proponente da Linguística Sistêmico-Funcional, para quem a linguagem é sóciosemiótica e a realidade social sujeita a processos de transformação:

Uma realidade social é, em si mesma, um edifício de significados - uma construção semiótica. Nessa perspectiva, a linguagem é um dos sistemas semióticos que constituem uma cultura; um que é distintivo porque serve também como um sistema de codificação para muitos (embora não todos) dos outros sistemas (HALLIDAY, 1978, p. 2).

Halliday (1978), ao compartilhar essa base sociológica de construção da realidade, sugere que a linguagem é um potencial de significados que expressa e simboliza em seu sistema semântico articulações inerentes com o social. Os estudos do teórico possibilitam revelar aspectos específicos que constituem a articulação entre linguagem e a realidade social, como a relação entre as três metafunções da linguagem, as três variáveis de registro e suas respectivas realizações léxico-gramaticais (HALLIDAY \& MATTHIESSEN, 2004). Desse modo, os usos da linguagem ocorrem a partir de um contexto sociocultural específico e a realidade social, por sua vez, é concebida sob pontos de vistas semióticos, um sistema de informação. Com isso, a díade linguagem e sistema social se articula em uma dialética natural complexa. A linguagem simboliza ativamente o sistema social, já que o cria e é criada por ele (HALLIDAY, 1978). O que se compreende como realidade (conhecimentos, valores, identidades, ideologias) é concebido na relação dialética entre a composição social e os sistemas semióticos (ou de significação).

Já os estudos sócio-discursivos de Fairclough não só dialogam com os estudos de Halliday como também os complementam, pois seu apontamento referente a discurso como prática social é um dos princípios estruturadores da sociedade. A sociedade estrutura e condiciona as diversas manifestações do discurso, mas também se influenciam mutuamente (FAIRCLOUGH, 2001). Isso implica a premissa de que todo discurso deve ser encarado na relação com a sociedade que lhe dá forma (GOUVEIA, 1998), haja vista o discurso, ao 
mesmo tempo, poder causar efeitos sobre a estrutura social, como a continuidade ou a mudança social; e ser constrangido ou coibido pelo domínio social ou institucional em que é gerado. Por um lado, aspectos discursivos de práticas sociais podem construir certos conhecimentos ou serem usados para construir identidades sociais. Por outro lado, as várias manifestações da sociedade também orientam normas e convenções para os aspectos discursivos. O MST pode conceber, por exemplo, a luta pela terra de um modo, enquanto o INCRA pode conceber de outro. Isso pode se dever ao fato de que são instituições diferentes e também são determinadas de diferentes formas pela sociedade.

Segundo Fairclough (1989), as estruturas sociais não apenas determinam discursos, mas também são produto de discursos e, por isso, o discurso se articula diretamente com a realidade, transformando-a de alguma forma. Como a linguagem é uma parte da sociedade, “os fenômenos linguísticos são fenômenos sociais de um tipo especial, e fenômenos sociais são (em parte) fenômenos linguísticos" (FAIRCLOUGH, 1989, p.23), a ligação entre linguagem e sociedade é interna e dialética.

Na próxima seção, teço uma breve apresentação sobre a articulação entre discurso poder e ideologia, termos centrais na ADC e essenciais para uma tentativa de compreensão da linguagem como parte essencial da vida social.

\subsection{Análise crítica: discurso, poder e ideologia}

De acordo com Fairclough (2003), as propriedades da linguagem são determinadas socialmente, visto que é concebida como uma forma de prática social. Sob esse ponto de vista, os textos estão condicionados e propensos a certas convenções sociais, o que implica uma recusa ao objetivismo linguístico. Enquanto, no objetismo linguístico, o texto é tido como espelho que reflete ou expressa os fenômenos sociais; na ADC, o texto é uma parte do processo de interação social e, portanto, do discurso. A análise textual corresponde a uma parte da análise do discurso (FAIRCLOUGH, 2003). Com isso, os usos de linguagem estão diretamente relacionados a questões de discurso, poder e ideologia.

Sendo assim, a linguagem constitui a realidade através de processo(s) representacional/is acionado(s) por sujeitos discursivos/históricos - atores sociais. Por sua vez, os processos representacionais são construídos a partir de 'escolhas' (linguísticodiscursivas), de certa forma, motivadas ideologicamente. Ressaltem-se, neste ponto, algumas considerações que concernem à perspectiva de representação que interessa à $\mathrm{ADC}$ e à 
pesquisa ora apresentada. ${ }^{15} \mathrm{Na}$ perspectiva discursiva da ADC, as representações sociais são concebidas como elementos sociais e históricos que se manifestam de forma dialógica nos discursos (FAIRCLOUGH, 2003). Considera-se, sobre isso, a orientação proposta por Bakhtin (1979, p. 66), para quem "cada palavra se apresenta como uma arena em miniatura onde se cruzam e lutam valores sociais e revela-se, no momento de sua expressão, como o produto da interação viva das forças sociais".

Como as práticas de linguagem se constituem em práticas sociais, na medida em que o(s) sentido(s) das interações humanas é/são negociado(s) a partir de percepções comuns de mundo, as representações, de certa forma, são discursos sociais que se configuram como saberes, crenças e valores. A linguista LYSARDO-DIAS (2005), situando-se em uma perspectiva linguístico-discursiva, sugere que as representações sociais são formas de conhecimento cultural construídas a partir de uma dada vivência do 'real' e através das quais a realidade cotidiana é apresentada e o mundo (re)significado. A este enfoque propriamente discursivo que se filia esta pesquisa. As representações sociais são concebidas como elementos históricos e sociais, envolvidas dialogicamente nos discursos. Observe-se, aqui, a configuração de uma relação indissociável entre linguagem e contexto histórico e cultural.

Isso posto, os modos de representação do mundo - enquanto funcionamentos discursivos do sistema semiótico da linguagem - possuem motivações ideológicas e, como tal, relacionam questões sobre linguagem, poder e ideologia. Nesses termos, a ideologia se manifesta através dos usos da linguagem e a busca da compreensão das imbricações entre linguagem, ideologia e poder pode propiciar a compreensão do papel do discurso nos processos de mudança social. $\mathrm{O}$ investimento ideológico da linguagem, que envolve consenso, possibilita a aceitação das relações de poder e, consequentemente, suas ações como naturais.

De acordo com Fairclough (1995a), a ideologia é uma forma de 'manufaturização' (produção) de consenso. Se compreendida desse modo, uma questão relevante é compreender o modo como as ideologias (re)estruturam a vida social através de discursos. No entanto, apesar de os textos serem espaços de investimento ideológico, não são única forma de controle social e exercício do poder. Para a ADC, interessa os efeitos ideológicos dos textos já que interferem nas relações sociais, seja para manter o poder seja para contestar o poder.

\footnotetext{
${ }^{15} \mathrm{O}$ conceito de representações sociais surge na sociologia quando Durkheim (1898) propôs a noção de representações coletivas como categorias de pensamento originadas a partir de fatos sociais e através das quais determinada sociedade elabora e expressa sua realidade. No entanto, essa concepção inicial não cabe a essa pesquisa.
} 
Van Dijk (1993) observa que o modo como o poder é exercido implica uma base definida pelo acesso a determinados recursos sociais. O poder pode estar normatizado através das leis ou de hábitos sociais em termos de consenso, denominados por Gramsci (1971) de hegemonia. Cabe, pois, aos grupos sociais a resistência, a aceitação, a condenação, o consentimento ou a legitimação "desses poderes hegemônicos", exercidos até então por um grupos dominantes. Segundo Assunção (2005, p. 10), das maneiras como o poder é exercido através de textos, advém o "interesse da ADC em se voltar para o modo como os grupos detêm e legitimam o poder, através de uma análise sistemática das estruturas e das estratégias textuais e de suas relações com o contexto de cultura".

Dessas considerações, segue a concepção de discurso como modo de ação e de representação - prática social -, refletindo o social (FAIRCLOUGH, 2003). Isto é, o discurso como prática social forma parte dos fenômenos sociais (que se concretizam em usos da linguagem), influenciando-os e sendo influenciado por eles. Destaque-se que 'discurso' pode fazer referência ao elemento discursivo de práticas sociais, visto que toda prática social é composta de momentos que se articulam e também pode remeter aos modos de representação da realidade, o momento discursivo de práticas sociais, na configuração de ordens de discurso (FAIRCLOUGH, 2001). Primeiramente, o discurso figura-se em "parte da ação", já que um dos caminhos da interação se dá através da fala e da escrita. Em segundo, o discurso figura-se em "representações", como parte de práticas sociais - representações do mundo material, de outras práticas sociais, representações reflexivas da prática em questão (FAIRCLOUGH, 2003). As (ações das) ordens de discurso apontam para a interdiscursividade. ${ }^{16}$

O entendimento dos efeitos sociais dos discursos depende, assim, de estudos das interações verbais e não verbais de falantes (textos) no curso de eventos sociais, conforme Fairclough aponta:

O discurso contribui para a constituição de todas as dimensões da estrutura social que direta ou indiretamente, o moldam e o restringem: suas próprias normas e convenções, como também relações, identidades e instituições que lhes são subjacentes. O discurso é uma prática, não apenas de representação do mundo, mas de significação do mundo, constituindo o mundo em significado (FAIRCLOUGH, 2001, p. 91).

A relação entre discurso e estrutura social é dialética e, da abrangência do discurso no que concerne às dimensões da estrutura social, a articulação entre discurso, ideologia e poder

${ }^{16}$ Para Fairclough (2001, p. 95), “a interdiscursividade é constitutiva dos eventos discursivos”, também entendida como intertextualidade constitutiva. E questões mais detalhadas sobre ela serão tratadas na subseção 2.6.1 desse capítulo. 
é basilar para a análise de discurso proposta pela ADC. Como consequência, Fairclough (2001) sinaliza que cada evento discursivo deve ser analisado em suas três dimensões complementares, como bem aponta a figura a seguir, baseada no referido autor (2001):

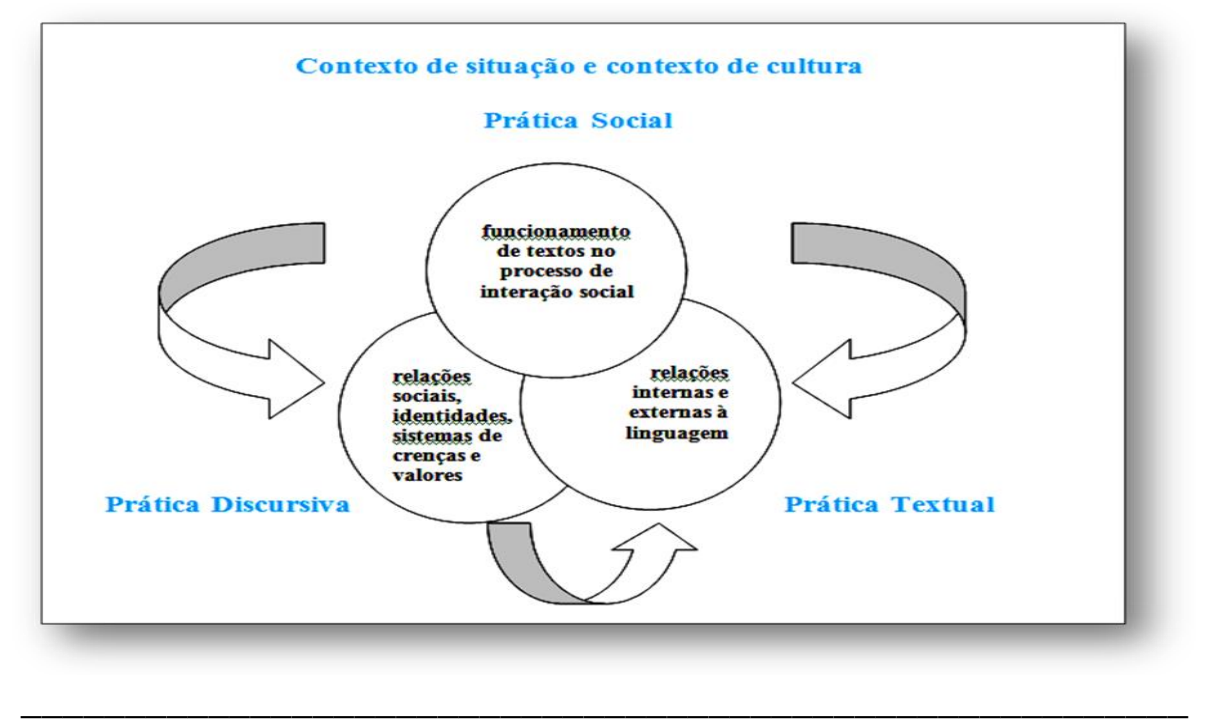

Figura 2.1 - Dimensões complementares do discurso

A Figura 2.1 apresenta a perspectiva tridimensional (FAIRCLOUGH, 2001) para a análise de discursos. A prática textual do evento discursivo está voltada para a descrição de textos, em termos de produção e de interpretação textual, que considera tanto o contexto de situação quanto o contexto de cultura. Já a prática discursiva remete à determinação dos aspectos dos recursos dos membros a que se recorre e como se recorre. $\mathrm{O}$ estudo dessa dimensão contribui tanto para a compreensão da reprodução da sociedade (identidades sociais, relações sociais, sistemas de crenças e valores) como para sua transformação. Enquanto que a prática social refere-se à explicação, ao funcionamento e aos efeitos de textos no processo de interação social, em termos de ideologia e de hegemonia, considerando-se os elementos das outras duas dimensões. Observe-se que a prática discursiva, de certa forma, pode ser considerada como uma forma particular da prática social.

Partindo da relação dialética entre essas dimensões do discurso, a preocupação central de Fairclough (2001, p. 99) é estabelecer conexões explanatórias entre os modos de organização e de interpretação textual e a natureza da prática social, considerando a relação com as estruturas e as lutas sociais. A constituição articulada de cada evento discursivo implica no fato de que há propósitos específicos de um grupo para produção ou utilização de 
determinado texto. Nesse sentido, para Silva (2012), as práticas discursivas são sempre práticas sociais e o discurso sempre deixa uma marca no texto/língua.

Observe-se ainda que a TSD, em termos de investigações sobre as dimensões discursivas da mudança social, sugere a perspectiva de prática social como constitutiva tanto da concepção de linguagem quanto do quadro analítico estabelecido pela ADC. A partir dessas premissas, há a compreensão de que a relação entre linguagem e (a vida) social é indissociável. O que aponta o Quadro 2.1.

\section{Quadro 2.1 - Linguagem como parte irredutível do social}

\begin{tabular}{|ll|}
\hline Níveis do social & Níveis da linguagem \\
Estrutura social & Sema semiótico \\
Eventos sociais
\end{tabular}

Baseado em Fairclough (2003).

O quadro acima representa a linguagem como um 'momento' da vida social (CHOULIARAKI \& FAIRCLOUGH, 1999) e por isso as relações envolvidas são consideradas em 'níveis'. Como aponta Fairclough (2003), a pesquisa social principia da análise da linguagem. Nela, os discursos devem ser desvelados para que mudanças sociais sejam favorecidas. Desse modo, há três níveis da vida social que se correlacionam com os três níveis da linguagem. O sistema semiótico se refere a uma estrutura social e se configura como uma rede de opções linguístico-discursivas no nível mais abstrato. Como um sistema semiótico, a linguagem relaciona estruturas e eventos, configurando práticas sociais. As práticas sociais, por sua vez, são concebidas como formas de controle da seleção de certas possibilidades estruturais e exclusão de outras possibilidades em áreas particulares da vida social no decorrer do tempo (FAIRCLOUGH, 2003), diretamente relacionadas com as ordens de discurso.

Observe-se, segundo Ramalho e Resende (2011, p. 46), a constituição da linguagem por dois sistemas e seus diferentes estratos, como sinaliza a figura abaixo. 


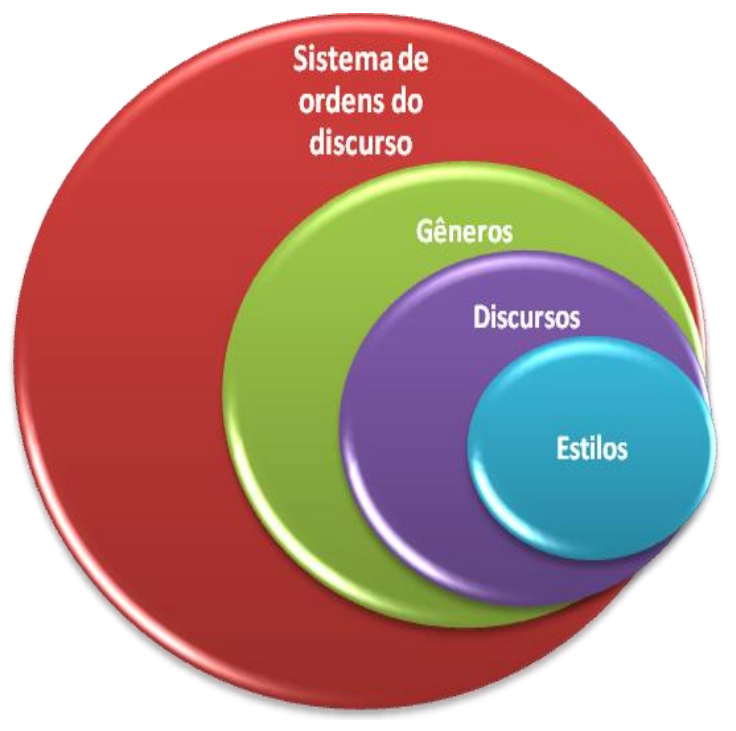

Figura 2.2 - Estratos do sistema de ordens do discurso

De acordo com a Figura 2.2, a linguagem é constituída pelo sistema semiótico (formado pelos estratos semântico, léxico-gramatical, fonológico e fonético) bem como pelo sistema de redes de ordens do discurso (com natureza sociodiscursiva). O sistema social da linguagem é configurado em gêneros, discursos e estilos, respectivamente, modos relativamente estáveis de agir, representar e identificar (RAMALHO \& RESENDE, 2011), detalhados na seção 2.6 deste capítulo. Já os eventos sociais, segundo Fairclough (2003), são representados em textos, ou seja, constituem um nível mais concreto. Nesse sentido, a ADC parte do conceito de prática social para traçar uma percepção de linguagem e, por conseguinte, o desenvolvimento de um quadro analítico com o objetivo de desnaturalizar práticas discursivas e práticas sócias, assim como prover reflexões sobre meios de inclusão social a grupos à margem das sociedades. A análise de um fenômeno social se configura, pois, como uma prática discursiva e uma prática social que se concretiza em uma prática textual.

Para a compreensão do funcionamento social da linguagem, a descrição e análise textual não devem ser vistas, porém, como anteriores à análise e à crítica social e nem independente dela. Devem ser vistas como um processo aberto o qual pode ser aperfeiçoado através de diálogo que atravesse disciplinas e teorias, ao invés de um código em termos de uma gramática ou moldura analítica autônoma (FAIRCLOUGH, 2003). A análise de texto é parte constitutiva da análise de discurso, mas a análise de discurso não é só a análise linguística de textos. Partindo dessa premissa, a principal referência da análise de texto da 
ADC é a LSF, de acordo com Halliday $(1978,1994)$ e ampliada em Halliday \& Matthiessen (2004), devido à análise linguística de textos pautar em seu caráter social. Fairclough (2003) aponta que, a partir da LSF, contribuições para análise de discurso crítica se desenvolveram apesar de existirem aspectos teóricos e metodológicos entre essas teorias que discordam.

Sob essa perspectiva teórica e metodológica é que o estudo ora apresentado é configurado. A pesquisa está tanto no espaço de certas ordens do discurso que constituem o PDA do PA Santa Tereza I, quanto no espaço de articulação dos discursos de atores sociais envolvidos na elaboração dessa ferramenta institucional. Há interesse na compreensão do funcionamento social da linguagem no PDA, de modo que aspectos teóricos e metodológicos coincidentes da LSF com os da ADC são utilizados nesta pesquisa para a microanálise dos dados de natureza documental e de natureza etnográfica, conforme a seção 2.5 a seguir.

\subsection{A interioridade da linguagem e a Linguística Sistêmico-Funcional}

A Linguística Sistêmico-Funcional (LSF) originou-se do trabalho do linguista britânico Michael Alexander Kirkwood Halliday (1978, 1989, 1994, 2004) que concebe a língua como uma rede de sistemas interligados de que o falante faz uso (base sistêmica) para produzir significados (base semântica) em situações de comunicação (base contextual). Observe-se que, além de Halliday, os princípios teóricos da LSF são esboçados nos trabalhos de Halliday e Hasan (1989), Halliday e Matthiessen (2004), Eggins (1994), Martin e Rose (2003), Thompson (2004). Em termos de similaridade, todos esses estudiosos consideram a importância do ambiente situacional e de cultura para a língua em uso.

Sob essa perspectiva, o estudo da linguagem faz-se 'sistêmico' e 'funcional' (HALLIDAY, 1994). É 'sistêmico' por conceber a língua como redes de sistemas linguísticos interligados, dos quais as pessoas se servem para construir significados, para fazer coisas no mundo. Também se faz 'funcional' ao buscar explicar as estruturas gramaticais em relação ao significado e às funções que a linguagem desempenha em textos. Sendo assim, a LSF propõe uma abordagem para o estudo da linguagem - rede de sistemas - centrada na noção de função. Halliday e Matthiessen (2004, p. 23) apontam que o significado está nos padrões sistêmicos de escolha. Já os padrões sistêmicos, como sugerem Martin e White (2005), possibilitam uma análise linguística a partir de um potencial de significados. Os textos são configurados, pois, a partir de um sistema de opções disponíveis na língua (a gramática) e com (re)produção de significados. 
Desse modo, a gramática é concebida como "a unidade central de processamento da linguagem, a base da constituição dos significados" (HALLIDAY e MATTHIESSEN, 2004, p.21). O interesse da LSF sobre a gramática está nos modos como ela é usada para produzir significados. Para tanto, Halliday (1994) desenvolveu a Gramática Sistêmico-Funcional (GSF), uma teoria sociosemiótica, que prioriza a íntima relação léxico-gramatical em interface com a semântica do discurso. Isto é, os textos possuem uma interface com o contexto de cultura (social) em que os usos da linguagem ocorrem, como ilustra a figura abaixo.

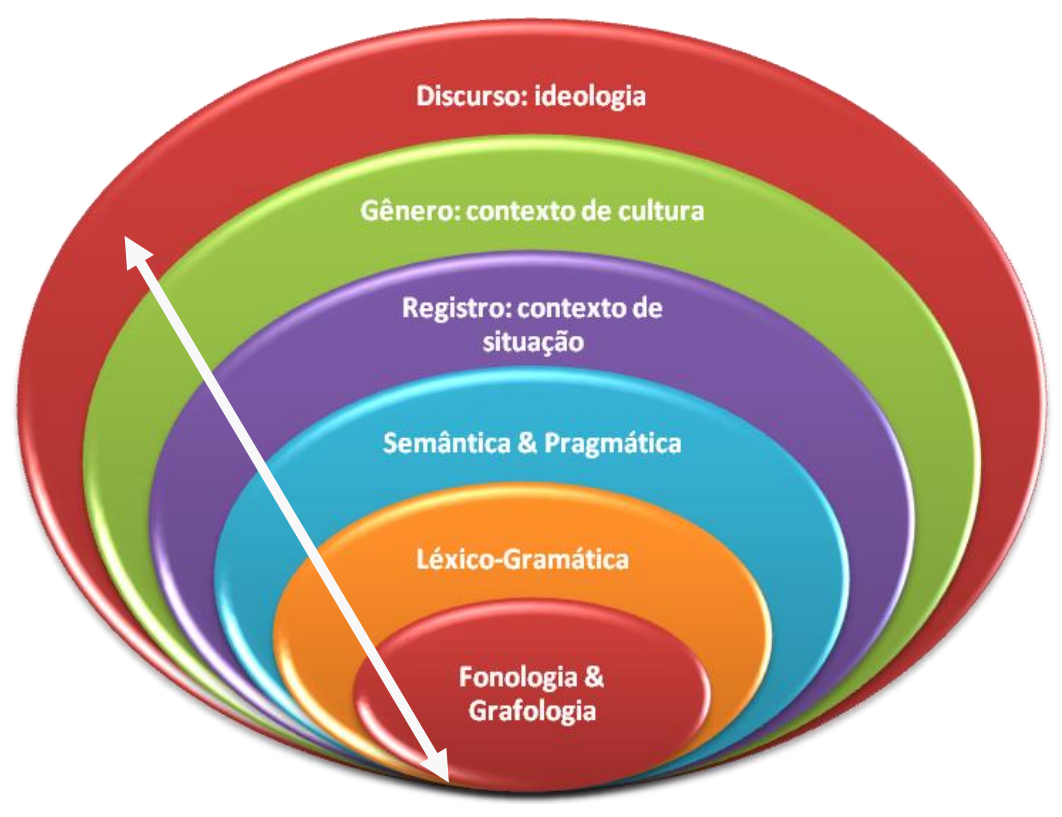

Figura 2.3 - Estratificação dos planos comunicativos linguístico e contextual Adaptada de Halliday e Matthiessen (2004) e Motta-Roth (2006).

A Figura 2.3 aponta a linguagem como um sistema sociosemiótico através do qual os seres humanos produzem suas experiências. A estratificação dos planos comunicativos é tanto linguística quanto contextual devido ao ambiente semiótico das interações humanas e, por isso, a unidade de análise da LSF é o texto atrelado, inseparavelmente, ao contexto. Qualquer uso linguístico que se constitua em um texto está sempre envolvido por um determinado contexto. Esse princípio, teorizado por Malinowski (1923), é fundamental na LSF e na ADC. Nessa perspectiva, os textos, simultaneamente, representam aspectos do mundo (o mundo físico, o social e o mental) e interpretam as relações sociais entre participantes de eventos sociais e as atitudes, os desejos e os valores dos participantes (HALLIDAY, 1978, 1994). Na 
LSF, há interesse na relação entre a língua e outros elementos e aspectos de vida social, de maneira que a análise linguística é sempre orientada para o caráter social dos textos.

Segundo Halliday e Hasan (1989), o contexto é configurado em dois níveis: o entorno mais amplo, cultural do texto e o nível de representação abstrata que se dá em termos das categorias linguísticas relevantes para o texto. Os dois níveis são necessários e complementares para a análise textual, haja vista ser a partir deles que os textos são gerados e negociados. O funcionamento do contexto nesses dois níveis é definido como contexto de situação (registro) e contexto de cultura (gênero).

Por um lado, o contexto de situação é o ambiente imediato de funcionamento do texto. Como bem colocam Cunha e Souza (2011), no contexto de situação, estão as características linguísticas dos textos, que dão substância às palavras e aos padrões gramaticais usados (orais, escritos) e que as pessoas, através delas, identificam e classificam os gêneros discursivos.

Observe-se que as diferenças entre os gêneros podem ser atribuídas a três variáveis constitutivas desse nível de contexto. A LSF denonima, por sua vez, as variáveis do contexto de situação em campo (field), relação (tenor) e modo (mode). O 'campo' diz respeito à natureza da prática social, corresponde ao que é dito ou escrito sobre algo e abrange a questão sobre como as pessoas representam suas experiências de mundo. A 'relação' refere-se ao conjunto de relações sociais, à natureza do envolvimento entre os participantes da situação, abarcando níveis de formalidade como aspecto particular. Já o 'modo' remete ao meio de comunicação escolhido para transmitir as mensagens. Esses aspectos do contexto de situação formam parte das escolhas linguísticas que as pessoas fazem, conforme resume a Figura 2.4.

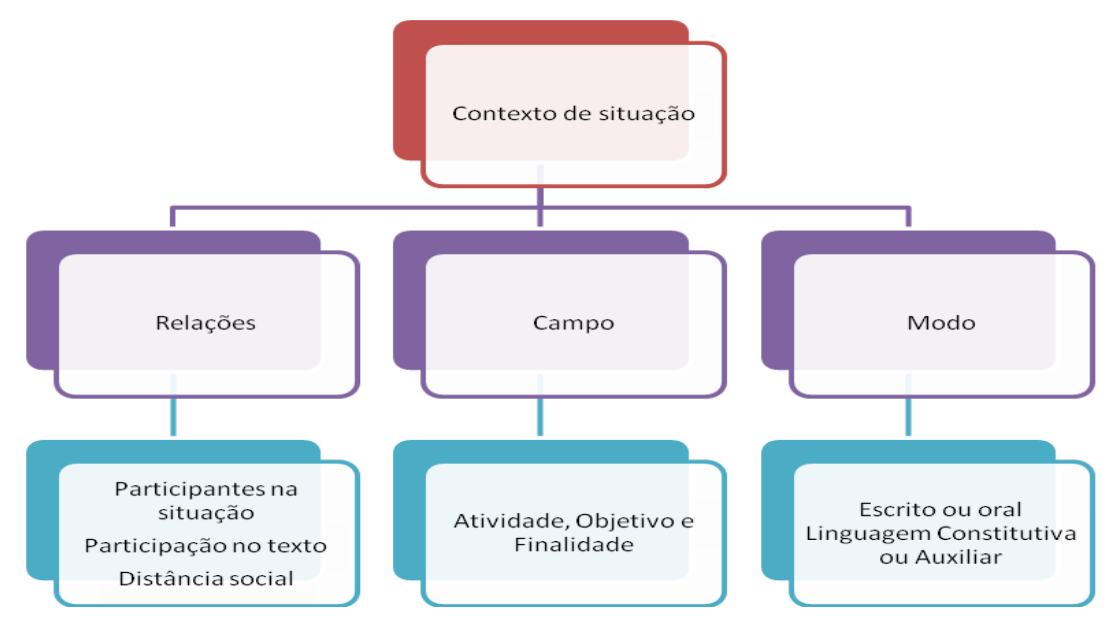

Figura 2.4 - Variáveis do contexto de situação. Adaptada de Halliday \& Matthiessen (2004). 
Para Halliday (1978, p.110), “campo, relação e modo são uma estrutura conceitual para representar o contexto social como o ambiente semiótico em que as pessoas trocam significados".

Por outro lado, o contexto de cultura refere-se às informações acerca da história cultural dos interactantes e dos tipos de práticas em que estão engajados/as, visto que "resulta da soma de todos os significados possíveis de fazerem sentido em uma cultura particular" (CUNHA; SOUZA, 2011, p. 24). Isto é, esse nível do contexto está relacionado ao propósito e ao significado para o qual o texto foi produzido (HALLIDAY \& HASAN, 1989). O contexto de cultura refere-se, assim, ao ambiente sociocultural mais amplo, abrange ideologia, convenções sociais e instituições. Destaque-se a noção de contexto de cultura relacionada à concepção de gêneros discursivos, definidos funcionalmente em termos de seus propósitos sociais. Os gêneros desenvolvem expressões linguísticas através de um número limitado de estruturas esquemáticas ou etapas funcionais e envolvem a maneira como uma cultura institucionaliza maneiras para se alcançar objetivos com o língua.

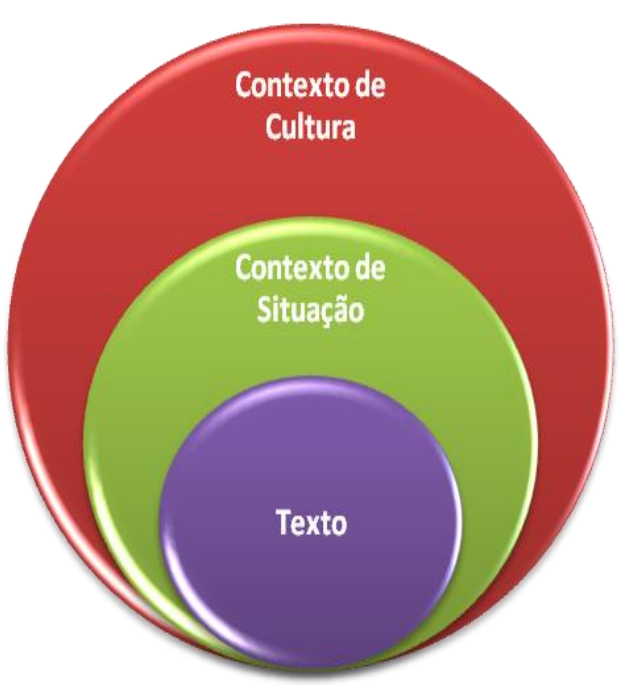

Figura 2.5 - Textos em contextos

A partir da Figura 2.5, observe-se a necessidade de informações acerca do que está acontecendo no momento da produção do texto e também acerca de todos os aspectos culturais, porque envolvem todo tipo de interação linguística. A constituição da interpretação do sentido configura-se no nível do contexto de situação (refere-se ao 'registro') e no nível do contexto de cultura (refere-se ao 'gênero discursivo'). 
Há de se destacar também a relação entre o sistema gramatical e as necessidades sociais e pessoais que a linguagem precisa atender. Segundo Halliday (1994), a linguagem realiza, além da função comunicativa, mais três funções básicas: a ideacional (conteúdo e experiências do mundo), a interpessoal (papeis sociais) e a textual (relações entre as partes do texto). Essas três funções são constituídas simultaneamente, o que está diretamente relacionado ao caráter multidimensional dos textos. Em outras palavras, o significado ideacional corresponde à experiência de mundo na linguagem: fala-se sobre alguma coisa ou alguém, fazendo alguma coisa. O significado interpessoal remete às relações sociais estabelecidas entre os/as participantes da prática comunicativa e às atitudes expressas na linguagem: expressam-se atitudes e desempenham-se papeis ao usar a língua. Já o significado textual corresponde à organização da informação enquanto mensagem: estrutura-se o dizer em forma de textos coerentes. Além disso, a interrelação entre os três significados da linguagem é constituída por meio da léxico-gramática.

Por considerarem as três funções em termos da análise de aspectos da léxicogramática, Halliday \& Matthiessen (2004) concebem o estudo da língua(gem) no nível das orações e classificam as (meta)funções de acordo com tal critério. No sistema linguístico, as metafunções são expressões simultâneas dos propósitos inerentes a todos os usos da língua. Desse modo, na perspectiva da metafunção ideacional, as orações são analisadas como representação em termos de processos; na metafunção interpessoal, as orações são analisadas como troca em termos de atos de fala; e na metafunção textual as orações são analisadas como mensagem (HALLIDAY; MATTHIESSEN, 2004). Cada mensagem é 'sobre algo' (oração como representação), 'dirigida a alguém' (oração como troca) e 'organizada com alguma finalidade' (oração como mensagem) simultaneamente.

As escolhas léxico-gramaticais constitutivas de uma/um mensagem/texto referem-se à composição textual e à maneira como os elementos relacionam-se e integram-se para construir o significado. Essas escolhas são constituídas na estrutura lexical, semântica e sintática dos textos. As práticas comunicativas desempenham essas metafunções e que fazem referência à produção dos significados ideacional, interpessoal e textual da linguagem. Ressalte-se essa postura da LSF (em relação à análise linguística) um recurso importante para a ADC, como pesquisa social e como prática teórica crítica. Para a investigação de um texto, a ADC envolve os significados acional, representacional e identificacional (FAIRCLOUGH, 
2003) e que correspondem às metafunções textual, ideacional e interpessoal respectivamente. $^{17}$

Nesse âmbito, alguns pressupostos teóricos e metodológicos da Linguística SistêmicoFuncional, propostos por Halliday (1994) e ampliados por Halliday e Matthiessen (2004), são instrumentos para a análise da interioridade da linguagem em termos de aspectos léxicogramaticais, o que contribui para parte da análise proposta pela Análise de Discurso Crítica e, por conseguinte, são utilizados neste trabalho. Dentre esses pressupostos, a metafunção interpessoal e a metafunção ideacional remetem, respectivamente, à função de estabelecer/manter relações/papeis sociais e à função de expressar conteúdo e experiências do mundo (subfunções experiencial e lógica) e, por isso, vão ao encontro dos objetivos desta pesquisa - já apresentados anteriormente - e serão detalhados nas próximas subseções. A primeira metafunção será detalhada na subseção 2.5.2 e a segunda será abordada a seguir.

\subsubsection{A oração como representação e a metafunção ideacional}

Na metafunção ideacional, linguagem é tratada como estruturadora da experiência, sinalizando as representações e as realidades sociais do mundo. Isto é, a partir da perspectiva ideacional, a linguagem constroi a experiência humana em relação a seu mundo interior e exterior (HALLIDAY \& MATTHIESSEN, 2004). Para tanto, duas subfunções são envolvidas nesse processo: a experiencial e a lógica. A subfunção experiencial relaciona-se à construção de um modelo de representação do mundo. Sua unidade de análise é a oração e o sistema relevante considerado é o da 'transitividade' da língua. A transitividade é configurada no estabelecimento do mundo da experiência em conjuntos de tipos de processos. Segundo, Halliday e Matthiessen (2004), o Sistema de Transitividade dá conta da construção da experiência em termos de configuração de processos, participantes e eventuais circunstâncias, sinalizando representações. Já a subfunção lógica remete a combinações de grupos lexicais e oracionais e sua unidade de análise é o complexo oracional.

Observe-se que, na ADC, a metafunção ideacional relaciona-se, principalmente, com o significado representacional da linguagem. A estrutura ideacional mantém uma relação dialética com a estrutura social tanto a refletindo quanto a influenciando em termos de

\footnotetext{
${ }^{17}$ Como o foco desta pesquisa está voltado para as discursividades e as representações de práticas sociais constitutivas do PDA do PA Santa Tereza I, a metafunção textual não será detalhada neste estudo. Isto é, como a metafunção textual trata da organização das orações no nível do texto, concebendo a oração como mensagem (analisada em termos de 'Tema' e 'Rema' (BARBARA; MACEDO, 2009), não integra aspectos teóricos e metodológicos que ancoram a pesquisa ora apresentada.
} 
representação. Sendo assim, a língua oferece um conjunto de recursos léxico-gramaticais para se referir à experiência humana, no caso da metafunção ideacional, conforme o Quadro 2.2 abaixo.

\section{Quadro 2.2 - A metafunção ideacional e a realização léxico-gramatical}

\begin{tabular}{|c|c|c|c|}
\hline \multirow{2}{*}{$\begin{array}{c}\text { Metafunção } \\
\text { Ideacional }\end{array}$} & Significado & $\begin{array}{c}\text { Status correspondente } \\
\text { na oração }\end{array}$ & $\begin{array}{c}\text { Realização } \\
\text { léxico-gramatical }\end{array}$ \\
\cline { 2 - 4 } & $\begin{array}{c}\text { Realiza o mundo } \\
\text { da experiência }\end{array}$ & $\begin{array}{c}\text { Oração como } \\
\text { representação }\end{array}$ & $\begin{array}{c}\text { Transitividade } \\
\text { e relações } \\
\text { lógico-semânticas }\end{array}$ \\
\hline
\end{tabular}

Baseado em Halliday \& Matthiessen (2004).

As informações do Quadro 2.2 apontam a vinculação entre a noção de linguagem e a noção de contexto, pois o contexto é constituído como uma representação abstrata através de certas categorias linguísticas relevantes para o texto, bem como em torno de algo mais amplo, cultural. Segundo Thompson (2004, p. 86), "a linguagem reflete nossa visão de mundo, consistindo em eventos (verbos) e envolvendo coisas (substantivos), com atributos ou não (adjetivos), e que acontecem de acordo com detalhes de lugar, tempo, forma e outros (advérbios)". No caso, a oração como representação é configurada no sistema de transitividade, representando o mundo da experiência.

Para Silva (2012), é relevante destacar a intensificação da Análise de Discurso Crítica (ADC) com a Linguística Sistêmico-Funcional (LSF), duas vigas mestras que sustentam a edificação epistemológica da tese ora apresentada. Como ponto de partida, a linguista sugere a consideração do princípio de que a relação linguagem-sociedade não é externa, mas é interna e dialética. Por isso, os processos linguístico-discursivos são, em parte, fenômenos sociais e, em parte, fenômenos cognitivos. Ambos os fenômenos são dispostos em uma espécie de entrada de mão dupla por onde transitam o discurso como prática social (exterioridade) e a gramática (interioridade do sistema linguístico), analogia apontada em Silva (2012). Nessa perspectiva, a autora propõe um construto teórico, baseado na proposta de Halliday (1994), o qual é apresentado na figura a seguir. 


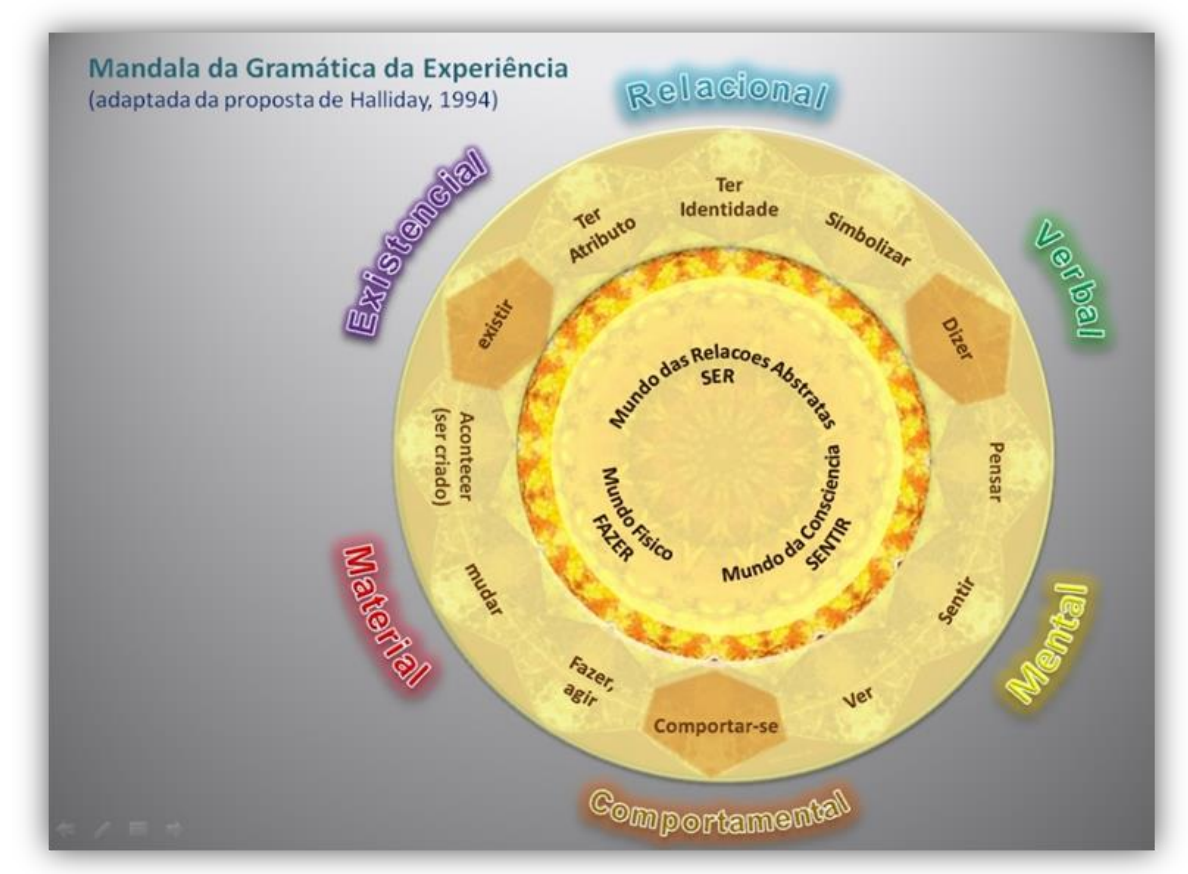

Figura 2.6 - Mandala da Gramática da Experiência (SILVA, 2011)

A Figura 2.6, criada e batizada por Silva (2011) - Mandala da Gramática da Experiência -, configura, de acordo com a autora, uma aproximação metafórica da energia emanada dos centros geradores de nosso mundo conceptual e linguístico, o que é caracterizado, na proposta hallidayana, por seis tipos de processos: material, mental, relacional, comportamental, verbal e existencial. Há, pois, uma continuidade entre um processo e outro, como em uma 'mandala'. Os significados prototípicos, exibidos no interior das formas sextavadas (os processos), “constituem pistas para análise léxico-gramatical bem como para a semântico-discursiva" (SILVA, 2011). Os processos são realizados pelo verbo ou grupo verbal e configuram-se como o elemento central na configuração semântica. Há também outros dois componentes do sistema de transitividade que constituem pistas para as análises léxico-gramatical e semântico-discursiva. Os participantes são inerentes à concretização dos processos, em que suas funções mudam de acordo com o tipo de processo experiencial. Geralmente, configuram-se em nomes ou grupos nominais. Já as circunstâncias podem ou não fazer parte da oração experiencial. São realizadas por grupos adverbiais e sintagmas preposicionados. Observe-se, assim, que o contexto e a semântica dispõem de elementos para que se identifique na oração os diferentes tipos de processos.

Sob essa perspectiva, os processos materiais, mentais e relacionais são concebidos básicos, os outros três - comportamentais, verbais e existenciais - são considerados secundários, uma vez que se encontram mesclados em termos de significado(s), justamente pela proximidade das fronteiras de sentido, intercaladas pelos processos básicos (HALLIDAY 
\& MATTHIESSEN, 2004). Na Gramática Sistêmico-Funcional, ao se investigar a metafunção ideacional pelo Sistema de Transitividade, analisa-se a gramática da oração como representação. Há escolha do processo (verbo da oração), do participante do processo (substantivos e grupos nominais) e, quando ocorre, da circunstância (grupos adverbiais e sintagmas preposicionados) (HALLIDAY \& MATTHIESSEN, 2004). Destaque-se que o processo é o componente principal na configuração semântica e em cada processo há pelo menos um participante.

Para Halliday e Matthiessen (2004), os processos materiais representam ações "físicas", eventos e atividades ocorridas no mundo material. As orações que se configuram em processos materiais são vistas como orações de 'fazer' (materiais transitivos) e de 'acontecer' (materiais intransitivos), uma vez que estabelecem mudanças no fluxo dos eventos, provocadas por algum investimento de energia do participante ator. Nesse tipo de oração, ocorre, pelo menos, um participante principal, responsável pela 'ação' do fazer e do acontecer. Podem ocorrer também o participante meta (entidade para quem ou a que a ação é direcionada) e outros três participantes opcionais: recebedor/a, cliente e escopo. As funções dos participantes 'recebedor/a' e 'cliente' relacionam-se ao 'beneficiário/a' da ação realizada. Por um lado, o 'recebedor/a' aponta para quem alguma coisa é dada; por outro, o 'cliente' é aquele para quem algo é feito. Ainda o 'escopo' figura uma extensão do processo, um verbo lexicalmente vazio, completando seu significado.

Os autores (2004) também apontam que as construções com processos materiais explicitam fatos e ações concretos ou abstratos (HALLIDAY \& MATHIESSEN, 2004). Enquanto os processos materiais concretos são as mudanças no mundo material e que podem ser constatadas como movimentos no espaço ou alterações nos estados físicos dos objetos, os processos materiais abstratos são mudanças onde acontecem fenômenos abstratos. Isto é, os processos materiais podem estar no plano do 'real' ou no plano das abstrações.

Já os processos mentais ocorrem em orações que remetem à experiência do mundo da consciência, a atividades cognitivas (pensamentos, sentimentos, percepções, crenças, desejos). É a expressão da realidade interior. Os participantes desse tipo de processo são o experienciador e o fenômeno (HALLIDAY; MATTHIESSEN, 2004). O 'experienciador' é um participante humano ou com característica humana, pois sente, pensa, percebe ou deseja. Nesse sentido, as orações mentais perceptivas referem-se a percepções do mundo com base na visão, no olfato, na gustação, na audição e no tato. As orações mentais cognitivas remetem ao que é sentido, pensado ou desejado no âmbito da consciência. As orações mentais afetivas (ou emotivas) exprimem graus de afeição. As orações mentais desiderativas referem-se ao desejo, 
interesse por algo. Já o 'fenômeno', outro participante, remete ao que se é sentido, pensado, percebido ou desejado.

Os processos relacionais identificam e classificam entidades no mundo. Ou seja, representam seres no mundo em termos de atribuição de características e identidades e, por isso, são denominados, respectivamente, atributivos e identificativos. O processo relacional atributivo configura como participantes o portador e o atributo. E o processo relacional identificativo apresenta como participantes a característica e o valor (HALLIDAY; MATTHIESSEN, 2004). Nesses processos, há uma configuração de "ser", no sentido de significar. Além disso, podem ser intensivas (caracterizam uma entidade), possessivas (a relação entre as entidades é de posse) e circunstanciais (indicam tempo, lugar, modo, causa, acompanhamento, papel, assunto ou ângulo).

Os processos comportamentais representam a resultante de estados fisiológicos e psicológicos, como olhar, respirar, sonhar e tossir. É sinal físico de percepção ou estado mental. Esses processos estão entre os processos materiais e os mentais. Os seus participantes são o comportante, um ser tipicamente consciente do comportamento; e o fenômeno, o comportamento em si (HALLIDAY; MATTHIESSEN, 2004).

Os processos verbais representam o dizer e situam-se entre os mentais e os relacionais. Os seus participantes são o dizente, que é responsável por aquilo que é dito; o receptor representa a quem o dizer é direcionado; a verbiagem refere-se àquilo que é dito; e o alvo é o participante atingido/a pelo processo (HALLIDAY; MATTHIESSEN, 2004).

Os processos existenciais representam a existência de fenômenos e entidades e situam-se entre os relacionais e os materiais e. Há um único participante denominado existente (HALLIDAY; MATTHIESSEN, 2004). O existente pode remeter a uma pessoa, a uma instituição, a um objeto, a uma abstração.

As escolhas linguísticas possuem, pois, desempenho essencial no modo como os elementos das 'práticas' produzem significados quando são recontextualizados, conforme o Quadro 2.3. 
Quadro 2.3 - Processos, participantes e significados

\begin{tabular}{|c|c|c|c|c|}
\hline Processos & Significados & $\begin{array}{c}\text { Participantes } \\
\text { obrigatórios }\end{array}$ & $\begin{array}{c}\text { Participantes } \\
\text { opcionais }\end{array}$ & $\begin{array}{l}\text { Exemplos } \\
\text { processos }\end{array}$ \\
\hline \begin{tabular}{l}
\multicolumn{1}{c}{ Material } \\
$>$ Transitivo, Intransitivo \\
$>$ Criativo, Transformativo \\
$>$ Concreto, Abstrato
\end{tabular} & $\begin{array}{l}\text { fazer } \\
\text { acontecer }\end{array}$ & Ator & $\begin{array}{l}\text { Meta } \\
\text { Escopo } \\
\text { Beneficiário } \\
\text { Atributo }\end{array}$ & $\begin{array}{l}\text { pintar, } \\
\text { crescer, } \\
\text { reunir, } \\
\text { levar, voar }\end{array}$ \\
\hline $\begin{array}{l}\text { Mental } \\
\text { Perceptivo } \\
\text { Cognitivo } \\
\text { Afetivo } \\
\text { Desiderativo }\end{array}$ & $\begin{array}{l}\text { perceber } \\
\text { pensar } \\
\text { sentir } \\
\text { desejar }\end{array}$ & $\begin{array}{l}\text { Experienciador } \\
\text { Fenômeno }\end{array}$ & ------ & $\begin{array}{l}\text { escutar } \\
\text { acreditar } \\
\text { ofender } \\
\text { desejar }\end{array}$ \\
\hline $\begin{array}{l}\text { Relacional } \\
\text { > Intensivo } \\
>\text { Possessivo } \\
>\text { Circunstancial } \\
\end{array}$ & $\begin{array}{l}\text { ser, } \\
\text { classificar, } \\
\text { definir }\end{array}$ & $\begin{array}{l}\text { Portador } \\
\text { Atributo } \\
\text { Identificado } \\
\text { Identificador }\end{array}$ & ------ & $\begin{array}{l}\text { ser, ter, } \\
\text { ficar, } \\
\text { parecer, }\end{array}$ \\
\hline Verbal & dizer & Dizente & $\begin{array}{l}\text { Receptor } \\
\text { Alvo } \\
\text { Verbiagem }\end{array}$ & $\begin{array}{l}\text { dizer, } \\
\text { conversar, } \\
\text { culpar }\end{array}$ \\
\hline Comportamental & comportar-se & $\begin{array}{l}\text { Comportante } \\
\text { Comportamento }\end{array}$ & $\begin{array}{l}\text { Fenômeno } \\
\text { Behaviour }\end{array}$ & relatar \\
\hline Existencial & existir & Existente & ------ & $\begin{array}{l}\text { existir, } \\
\text { haver }\end{array}$ \\
\hline
\end{tabular}

Baseado em Halliday \& Matthiessen (2004).

O Quadro 2.3 apresenta uma síntese dos processos e de seus participantes, constituintes do Sistema de Transitividade, proposto na GSF (HALLIDAY, 1994; 2004). Sob a perspectiva desse sistema, em que as orações são concebidas como representação, as escolhas no sistema gramatical da língua, como tipo de processo e de participante, corroboram para a investigação da representação das experiências de mundo das pessoas.

Ainda, no que concernem ao terceiro componente que completa o Sistema de Transitividade, as circunstâncias indicam a expansão do processo em uma condição específica, de modo que adicionam significados à oração pela descrição do contexto dentro do qual o processo se realiza. Observe-se que podem ocorrer livremente com todos os tipos de processos. Em relação a aspectos léxico-gramaticais, elas se realizam em grupos adverbiais e sintagmas preposicionados. Sobre isso, Halliday e Matthiessen (2004, p. 263-277) propõem categorias para a classificação dos tipos de circunstâncias, como apresenta o Quadro 2.4 abaixo, 
Quadro 2.4 - Os tipos de circunstâncias

\begin{tabular}{|c|c|c|}
\hline $\begin{array}{c}\text { Tipo de } \\
\text { circunstância }\end{array}$ & Significado & Exemplos \\
\hline Acompanhamento & $\begin{array}{l}\text { Essa circunstância remete a uma forma de } \\
\text { participação conjunta no processo e } \\
\text { apresenta dois tipos: } \\
\text { > Comitativo (Com quem? Com o que?) } \\
\text { > Aditivo (Quem mais? O que mais?) }\end{array}$ & $\begin{array}{l}\text { Contar com a COOPVAG. } \\
\text { [circ. de acomp. comitativo] } \\
\text { Além do solo, há problema com } \\
\text { água. [circ. de acomp. aditivo] }\end{array}$ \\
\hline Ângulo & $\begin{array}{l}\text { Faz referência ao dizente de uma oração } \\
\text { verbal e ao experienciador de uma oração } \\
\text { mental e apresenta dois tipos: } \\
\text { >Recurso } \\
\text { > Ponto de vista }\end{array}$ & $\begin{array}{l}\text { Para a pioneira, o PA é } \\
\text { sobrevivência. } \\
\text { [circ. de ângulo recurso] } \\
\text { Segundo o INCRA, o PA recebeu } \\
\text { muitos recursos. [circ. de ângulo } \\
\text { ponto de vista] }\end{array}$ \\
\hline Assunto & $\begin{array}{l}\text { Remete àquilo que é descrito, narrado, } \\
\text { dito. (Sobre o que?) }\end{array}$ & $\begin{array}{l}\text { Discutir sobre o PDA. } \\
\text { [circ. de assunto] }\end{array}$ \\
\hline Causa & $\begin{array}{l}\text { Apresenta a razão da realização do } \\
\text { processo, o propósito ou o interesse e } \\
\text { apresenta dois tipos: } \\
\text { > Razão (Por que?) } \\
\text { > Propósito (Para que?) } \\
\text { > Interesse/Representação (De quem?) }\end{array}$ & $\begin{array}{l}\text { Ser castigado por lutar pela inclusão } \\
\text { social. [circ. de causa razão] } \\
\text { Lutar para viver melhor. } \\
\text { [circ. de causa propósito] } \\
\text { Lutar pelos pioneiros. } \\
\text { [circ. de causa interesse] }\end{array}$ \\
\hline Contingência & $\begin{array}{l}\text { Aponta um elemento do qual a realização } \\
\text { do processo depende e apresenta três } \\
\text { tipos: } \\
\text { > Condição (Por quê?) } \\
\text { > Concessão } \\
\text { > Falta }\end{array}$ & $\begin{array}{l}\text { Acionar a polícia em caso de confronto. } \\
\text { [circ. de conting. condição] } \\
\text { Omitir-se a despeito das } \\
\text { irregularidades. } \\
\text { [circ. de contingência concessão] } \\
\text { Sem água não há produção. } \\
\text { [circ. de contingência falta] }\end{array}$ \\
\hline Extensão & $\begin{array}{l}\text { Representa a extensão do desdobramento } \\
\text { do processo no tempo e no espaço e } \\
\text { apresenta três tipos: } \\
\text { > Frequência (Quantas vezes?) } \\
\text { > Duração (Há quanto tempo?) } \\
\text { > Distância (A que distância?) }\end{array}$ & $\begin{array}{l}\text { Fui ao INCRA cinco vezes. } \\
\text { [circ. de extensão frequência] } \\
\text { O acampamento durou dois anos. } \\
\text { [circ. de extensão duração] } \\
\text { A cidade fica a 30km do PA. } \\
\text { [circ. de extensão distância] }\end{array}$ \\
\hline Localização & $\begin{array}{l}\text { Representa a localização do } \\
\text { desdobramento do processo no espaço e } \\
\text { no tempo. } \\
\text { > Lugar (Onde?) } \\
\text { > Tempo (Quando?) }\end{array}$ & $\begin{array}{l}\text { Vemos nossa casa na cidade. } \\
\text { [circ. de localização tempo] } \\
\text { O recurso acabou logo. } \\
\text { [circ. de localização lugar] }\end{array}$ \\
\hline Modo & $\begin{array}{l}\text { Representa o modo através do qual o } \\
\text { processo é realizado e apresenta quatro } \\
\text { tipos: } \\
\text { > Comparação (Como é?) } \\
\text { > Grau (Quanto?) } \\
\text { > Meio (Como?) } \\
\text { 'Qualidade (Como?) }\end{array}$ & $\begin{array}{l}\text { Resistir como os outros assentados. } \\
\text { [circ. de modo comparação] } \\
\text { Nossa vida piorou profundamente. } \\
\text { [circ. de modo grau] } \\
\text { Saí do acampamento com ajuda de } \\
\text { vizinhos. [circ. de modo meio] } \\
\text { Os acampados chegaram sem nada. } \\
\text { [circ. de modo qualidade] }\end{array}$ \\
\hline Papel & $\begin{array}{l}\text { Representa os significados "ser" e } \\
\text { "tornar-se" circunstancialmente e } \\
\text { apresenta dois tipos: } \\
\text { > Aparência/Estilo (Ser como o quê?) } \\
\text { > Produto (O quê? Em quê?) }\end{array}$ & $\begin{array}{l}\text { Agir como cidadã. } \\
\text { [circ. de papel aparência] } \\
\text { Garça-Real cortou a madeira em } \\
\text { pedaços. } \\
\text { [circ. de papel produto] }\end{array}$ \\
\hline
\end{tabular}

Baseado em Halliday \& Matthiessen (2004). 
De acordo com o Quadro 2.4, as circunstâncias são classificadas em nove categorias e que, por sua vez, dividem-se em subcategorias/tipos. Além disso, as circunstâncias, em termos de significado, associam-se aos processos, principalmente, com referência à localização no tempo (Quando?) ou espaço (Onde?), ao modo (Onde?) ou à causa (Por quê?).

Como já explicitado neste capítulo, além da metafunção ideacional que configura experiências humanas em termos de representação, há outras duas metafunções da linguagem, sendo que uma delas, a metafunção interpessoal, interessa a esse estudo e será apresentada na subseção 2.5 .2 a seguir.

\subsubsection{A oração como troca e a metafunção interpessoal}

A metafunção interpessoal da linguagem trata das relações entre os participantes de um evento comunicativo em termos de constituição de identidades e de identificações. Essa metafunção configura a interação dos participantes em um evento comunicativo e faz referência à variável contextual 'Relações'. Como bem colocam Resende e Ramalho (2006), essa metafunção tem relação com a construção de significado do ponto de vista de sua função no processo de interação social, da língua como 'ação'. Nesse âmbito, a linguagem além de manifestar a experiência dos falantes, de instituições da sociedade (metafunção ideacional), também representa falantes, suas intenções e relações. Para Bárbara e Macedo,

É através da metafunção interpessoal que se manifesta a interação entre os participantes da situação e deles com a sociedade, como interagem, o grau de distância/proximidade ou de poder/solidariedade existente entre eles, a responsabilidade que assumem quanto à mensagem que transmitem, se o fazem de maneira assertiva/categórica, ou não (BARBARA; MACEDO, 2009, p. 100).

Desse modo, em termos da linguagem como interação/troca entre participantes de um evento comunicativo, a metafunção interpessoal aponta negociações das relações, opiniões e atitudes, produzindo significados em textos. Para isso, a oração é vista como 'troca', já que a gramática disponibiliza recursos para a interação entre as pessoas através da língua, constituindo relações sociais, papeis sociais, identidades e significados (HALLIDAY; MATTHIESSEN, 2004). Os usos da linguagem são instrumentos para que interlocutores alcancem objetivos 'não-linguísticos'. Observe-se, em termos de significados da linguagem, que o significado identificacional (estudado na subseção 2.6.3), nos moldes da ADC (FAIRCLOUGH, 2003), relaciona-se a essa metafunção. 
Na gramática sistêmico-funcional, a metafunção interpessoal representa a interação e os papeis assumidos pelos participantes mediante, o Sistema de Modo e a Modalidade. ${ }^{18}$

Quadro 2.5 - A metafunção interpessoal e sua realização léxico-gramatical

\begin{tabular}{|c|c|c|c|}
\hline \multirow{2}{*}{$\begin{array}{c}\text { Metafunção } \\
\text { Interpessoal }\end{array}$} & Significado & $\begin{array}{c}\text { Status } \\
\text { correspondente na } \\
\text { oração }\end{array}$ & $\begin{array}{c}\text { Realização léxico- } \\
\text { gramatical }\end{array}$ \\
\cline { 2 - 4 } & $\begin{array}{c}\text { Realiza relações } \\
\text { sociais }\end{array}$ & Oração como troca & $\begin{array}{c}\text { Modo, Modalidade, } \\
\text { Atitude/Avaliatividade }\end{array}$ \\
\hline
\end{tabular}

Baseado em Halliday \& Matthiesen (2004).

O Sistema de MODO é o principal recurso para a investigação entre as trocas comunicativas entre os interlocutores, aceitando e atribuindo papeis, como "dar e solicitar bens e serviços ou informações" (através das orações declarativas, interrogativas em perguntas); e solicitar algo ou dar ordem (através das orações imperativas) (SILVA, 2010). Esse recurso léxico-gramatical expressa os movimentos interativos em um evento comunicativo. Na troca de informação, a própria linguagem é trocada; e, na troca de bens e serviços, a linguagem é usada para influenciar comportamento ou atitudes.

Em termos de análise, há possibilidade de informações sobre a modalidade (usualidade, obrigação, probabilidade), a polaridade (positiva ou negativa), o modoltempo (passado, presente e futuro) e os complementos e adjuntos. A análise das trocas linguísticas indica o tipo de proposição, de atitudes e de julgamentos que constituem o ato simbólico interpessoal (HALLIDAY; MATTHIESSEN, 2004). No Sistema de MODO, a oração se organiza em dois componentes básicos: Modo e Resíduo. O componente Modo constitui-se em outros dois elementos e que contribuem de maneiras diferentes na oração: sujeito e finito (HALLIDAY; MATTHIESSEN, 2004). Ambos sinalizam o que está acontecendo no discurso: troca de informações ou bens e serviços - declaração, questão, ordem ou pedido. O sujeito é um elemento conhecido nas orações, tipicamente um 'grupo nominal'. Já o finito é constituinte do 'grupo verbal' que carrega o tempo e/ou a opinião do falante e inclui polaridade positiva ou negativa (THOMPSON, 2004). As funções do finito são o tempo, a modalidade e a polaridade. Em português, o finito geralmente é constituído com a desinência modo-temporal. Enquanto o componente Resíduo do Sistema de MODO é o restante da oração sem o Modo (sujeito + finito). E esse componente é constituído pelos elementos

\footnotetext{
${ }^{18}$ Observe-se que o Sistema de Avaliatividade também representa a metafunção interpessoal, haja vista que a escolha da avaliação reflete e reforça os valores ideológicos da sociedade (MARTIN; WHITE 2005), mas não será utilizado neste trabalho.
} 
predicador, complemento e adjunto(s) (HALLIDAY; MATTHIESSEN, 2004). A maioria das orações possui o predicador, realizado por um grupo verbal. Já o complemento possui característica de sujeito (mas não o é) e é realizado por um grupo nominal ou um grupo adjetivo.

Além dessas realizações léxico-gramaticais, há de se destacar a Polaridade. Segundo Halliday (1989), a polaridade é configurada geralmente por um elemento finito (grupo verbal) e em orações afirmativas ou negativas. A ocorrência da polaridade dá-se em polos extremos das orações, havendo somente referência ao 'polo positivo' e ao 'polo negativo'. Destaque-se também a ocorrência de 'graus intermediários' entre o polo positivo e o polo negativo para situar a interação humana: a Modalidade. Como recurso interpessoal, a modalidade expressa a 'posição' (julgamento, opinião, ponto de vista) dos/as interlocutores/as em graus variados. Quando a modalidade trata de 'proposições' (informações), é conhecida como modalização; e quando trata de 'propostas' (bens e serviços), é conhecida como modulação.

A modalização (ou modalidade epistêmica) ocorre quando há troca de informações ou conhecimentos. Nessa categoria, as informações podem ser expressas em termos de 'probabilidade' ou 'usualidade'. São diversos os recursos léxico-gramaticais que expressam os significados epistêmicos, como adjuntos modais (talvez, possivelmente), adjuntos adverbiais (com certeza, às vezes), expressões (é costume, é possível) e verbos modais (deve, pode) (HALLIDAY; MATTHIESSEN, 2004). Já a modulação (ou modalidade deôntica) ocorre em propostas de ofertas ou de comandos. Na oferta, os graus referem-se à 'inclinação' (inclinado, determinado, disposto). No comando, os graus remetem à 'obrigação' (necessário, permitido, obrigatório). Quanto aos os recursos léxico-gramaticais que expressam os significados deônticos, são os adjuntos modais (alegremente, necessariamente), os verbos modais (deveria, deve) e certas expressões (está inclinado, é esperado, é necessário).

Os papeis dos/as interlocutores/as são determinados por condições particulares (sociais, econômicas, políticas, profissionais), como ilustra a figura abaixo. 


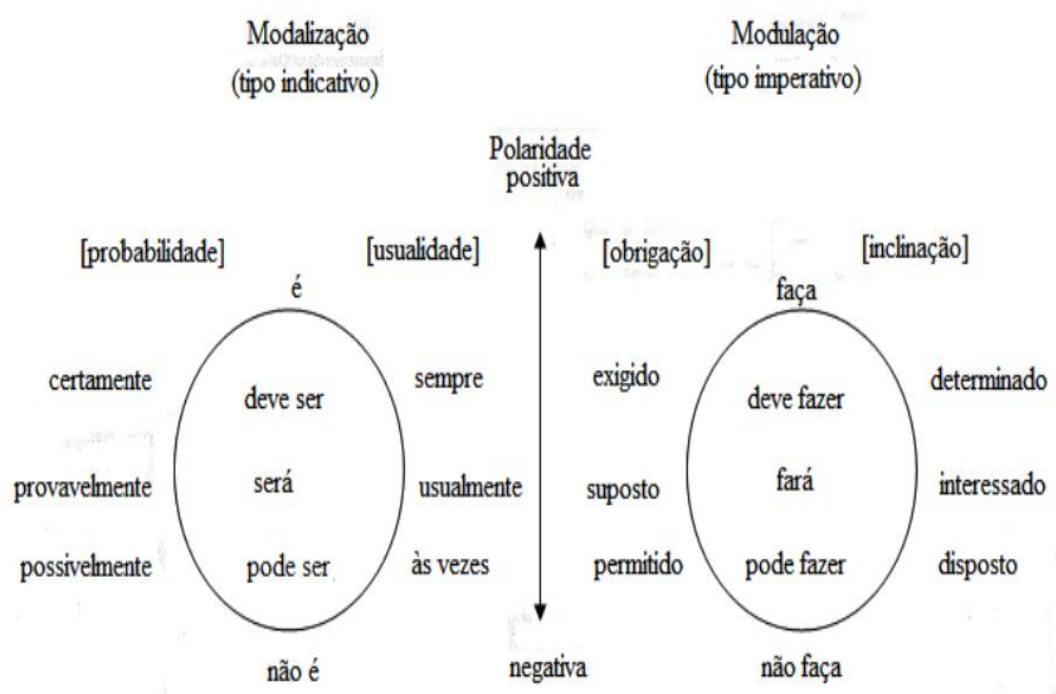

Figura 2.7 - Diagrama da relação de Polaridade, Modalidade e Modo

Traduzido de Halliday e Matthiessen (2004).

De acordo com Halliday e Hasan (1989), a análise das trocas linguísticas indica o tipo de proposição, de atitudes e de julgamentos constituintes do ato simbólico interpessoal. No que concerne a cada metafunção, o foco de análise difere, como resume a Figura 2.8.

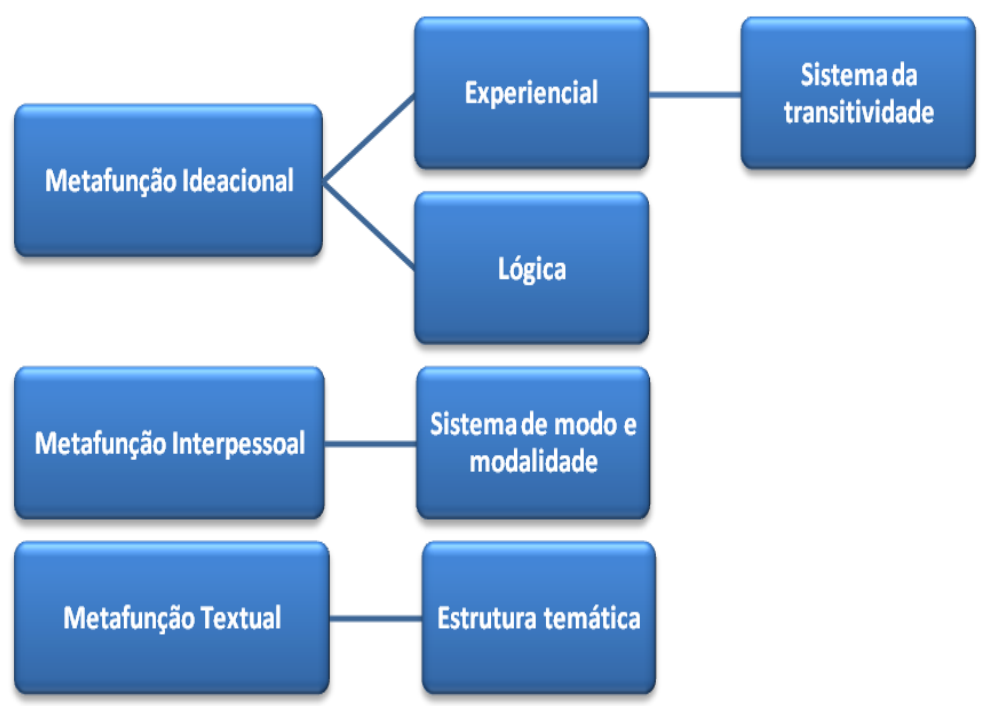

Figura 2.8 - As metafunções e os sistemas léxico-gramaticais

Baseada em Halliday \& Matthiessen (2004). 
O foco de análise das metafunções são diferentes, uma vez que o sistema de realização léxico-gramatical de cada uma é específico: sistema de transitividade (ideacional), sistema de modo e modalidade (interpessoal) e estrutura temática (textual). Além disso, Halliday \& Matthiessen (2004) apontam que a chave para a interpretação funcional da estrutura gramatical remete à multifucionalidade. Simultaneamente, cada componente refere-se a três aspectos e estão sistematicamente relacionados, visto que um mesmo item gramatical os representa.

Como os textos, na ADC, são efeitos de estruturas linguísticas atreladas a ordens de discurso, estruturas sociais e práticas sociais, a seção a seguir propõe alguns apontamentos sobre a investigação linguístico-discursiva no que se refere à perspectiva de gênero discursivo como prática social.

\subsection{A exterioridade da linguagem e(m) ações, representações e identificações}

Para Fairclough (2006), no âmbito dos estudos discursivos críticos, a vida social é cada vez mais mediada por textos e o papel de textos na vida social é expressivo em todos os campos da atividade humana. Sob essa perspectiva da relação indissociável entre os usos da linguagem e a vida social, a Análise de Discurso Crítica (FAIRCLOUGH, 2003; 2010) é proponente de investigações textualmente orientadas ou linguístico-discursivas, devido a tratarem do caráter sócio-ideológico e cultural das manifestações discursivas e, sobretudo, porque se baseiam na premissa de que situações opressoras podem ser mudadas através de contribuições das pesquisas realizadas. As formas de opressão, por sua vez, costumam emergir a partir de decisões de natureza social, o que as torna passíveis de transformações. Considera-se que os usos de linguagem, configurados em textos, podem ter efeitos causais e mudar pessoas, ações, relações sociais e o mundo material.

Nessa perspectiva de Fairclough, há apreciação de uma contribuição importante da LSF, relacionada à noção sócio-semiótica de texto (qualquer instância real de uso da linguagem), constituída na articulação entre fatores linguísticos e, sobretudo, fatores sociais. Essa noção de texto, cunhada por Halliday e Hasan (1989), também é uma herança para a ADC, por localizar o texto em uma dimensão social. Para os teóricos (1989), os textos possuem papeis sociais específicos de acordo com contextos específicos. Desse modo, Fairclough (2003) concebe os textos - escritos, falados, visuais ou multimodais - como integrantes de eventos sociais, em termos de uma dimensão dos discursos. Em outras 
palavras, os textos são produtos e processos que configuram uma mediação no processo discursivo.

Sobre isso, Fairclough (2003) aponta que a análise de texto não é vista como análise linguística, mas como "análise interdiscursiva", os textos como discursos, gêneros e estilos que se articulam. Esse posicionamento da ADC corrobora para a determinação da postura teórica e metodológica do/a analista de discurso frente às investigações linguísticodiscursivas. O/a analista não pode desconsiderar que a prática de produção textual é edificada em (a partir de) uma prática discursiva, a qual dimensiona o texto produzido como parte integrante de um processo mais extenso que é o discurso e em uma relação histórica com outros textos, outros discursos, o que implica reconhecer a interdiscursividade intertextualidade constitutiva - como inerente ao processo de construção de sentido(s).

Também Silva (2012, p. 227) diz que "no âmbito dos estudos críticos do discurso, o trabalho do linguista deve objetivar não só a descrição rigorosa dos fatos linguísticos contextualizados, mas, sobretudo, a intervenção ativa e proposital na realidade social encontrada". Ressalte-se, nesse ponto, a concepção de texto em uma dimensão social, a qual demanda visualizar o envolvimento dos textos em processos de produção de significados.

Além disso, ao relacionar os textos à dimensão social, vale retomar a noção de discurso na ADC, já discutida no início deste capítulo. Os analistas de discurso críticos integram à noção de discurso sua 'natureza social'. Essa concepção, por sua vez, implica na definição de discurso (o uso da linguagem) como prática social (FAIRCLOUGH, 1989), forma parte da sociedade; assim como na visão de discurso como um processo social de produção. Sob esse ponto de vista, Fairclough (2003) aponta que os discursos constituem modos de representar e compreender aspectos do mundo a partir de perspectivas particulares, haja vista esses aspectos do mundo ('realidades') poderem ser tanto (re)produzidos, como também poderem ser transformados. De certa forma, os discursos podem ser diferenciados de acordo com a maneira que significam o mundo.

Há, pois, uma relação dinâmica, ativa entre o discurso e o social. De acordo com esse enquadre, o discurso forma parte das dimensões da estrutura social, que o moldam e o restringem. Consequentemente, o discurso é uma prática social, representante e significadora do mundo, constituindo-o e construindo-o em termos de significado (FAIRCLOUGH, 2001). Desse modo, os textos são efeitos de estruturas linguísticas e de ordens de discurso, bem como são efeitos de outras estruturas sociais e de práticas sociais em todos os seus aspectos, de maneira que esses feitos são interrelacionados. Observe-se, a partir disso, a necessidade do desenvolvimento de abordagens de análise de textos através da transdisciplinaridade 
(FAIRCLOUGH, 2003), com a capacidade de analisar textos como elementos do processo social.

Ademais, todo discurso concebido como prática social configura-se enquanto modo de (inter-) agir, modo de representar e modo de identificar (-se). Fairclough (2003) sugere, então, que o discurso figura três principais maneiras na relação entre textos e eventos sociais nas práticas sociais:

(i) modos de agir, no que concerne às interações entre as pessoas, à ação sobre elas e com o poder: refere-se ao gênero;

(ii) modos de representar, no que concerne ao conhecimento e ao controle sobre as coisas: refere-se ao discurso;

(iii) modos de ser, no que concerne à(s) identificação(ões) das pessoas: refere-se ao estilo.

Considerando o papel do discurso em diversas práticas sociais, Fairclough (2003, p. 67) também diz que esses modos pelo qual o discurso se apresenta em práticas sociais correlacionam-se a três tipos de significados produzidos, também de forma simultânea e dialética, em todo discurso. Esses significados realizados no discurso são denominados "significados acionais e formas do texto, em significados representacionais e discursos e significados identificacionais e estilos" (FAIRCLOUGH, 2003, p. 23). Nas práticas sociais, os três significados configuram três efeitos constitutivos do discurso, pois todo discurso se apresenta como forma de ação e interação social. Conforme bem colocam Ramalho e Resende (2011), esses significados sempre presentes em textos associam-se aos elementos constituintes de ordens do discurso (significado acional a gêneros, o significado representacional a discursos e o significado identificacional a estilos), de modo que os três eixos da obra de Foulcault não são isolados, mas dialeticamente articulados.

Os três eixos da obra de Foulcault não são isolados, mas dialeticamente articulados, ou seja, o controle sobre as coisas (eixo do saber) é mediado pelas relações com/sobre os outros (eixo do poder), assim como as relações com/sobre os outros pressupõem relações consigo mesmo (eixo da ética) e assim por diante (RAMALHO \& RESENDE, 2011, p. 51).

Primeiramente, diferentes gêneros são diferentes modos de (inter)agir discursivamente, como os PDAs enquanto ferramenta institucional (INCRA) para o desenvolvimento de projetos de assentamentos. Além desse efeito, todo discurso figura como 
um modo de representação do mundo, que se realiza em forma de discursos, como o discurso oficial sobre os PDAs. Por último, todo discurso figura como um modo de identificar(-se), como o modo como assentados/as pioneiros/as são identificados/as no texto do PDA do assentamento onde vivem.

Segundo Fairclough (2003), discursos, gêneros e estilos constituem, assim, os elementos de textos e os elementos sociais. São tidos como elementos de ordens de discurso no nível da prática social. A análise das relações dos textos com outros elementos de eventos sociais inclui, pois, as reflexões de como eles figuram em "Ações, Representações e Identificações". As 'ações' remetem à relação com os outros e também à "ação sobre os outros e sobre o poder"; as 'representações' remetem ao conhecimento e, através dele, ao “controle sobre coisas”; e as 'identificações' remetem às relações com a própria pessoa, à ética e a assuntos morais.

De modo a detalhar a proposta de Fairclough (2003) sobre a análise de textos, as três próximas subseções são voltadas à apresentação dos três significados realizados no discurso.

\subsubsection{O texto e(m) ação}

A modernização da vida social envolve sistemas sociais complexos e suas relações sociais, todas realizadas através de usos da linguagem. Para tanto, a interação humana é estratégica e orientada a produzir ação, resultado, efeito. Segundo Moreira (2013), a ação está atrelada à relação com os outros e com a 'ação sobre os outros' e, ainda, com o poder exercido sobre os outros. Desse modo, a perspectiva de texto como modo de (inter)ação em eventos sociais, em termos dessa ação legitimar e/ou questionar as relações sociais, faz-se uma forma de ação, mecanismo de transformação do mundo (FAIRCLOUGH, 2003). Sobre isso, Marcuschi (2006, p. 25) sugere que quando aprendemos a operar com um gênero, aprendemos um modo de atuação sócio-discursiva numa cultura, e não um simples modo de produção textual. Para Miller (1984), o aprendizado com os gêneros não são padrões de formas, ou mesmo métodos para atingirmos nossos próprios fins. O aprendizado está nos fins que se pode alcançar; está na melhor compreensão das situações em que as pessoas se encontram; nas potencialidades para o fracasso e o sucesso da ação praticada; e nos modos em como participar das ações de uma comunidade. Esse é o motivo pelo qual a autora (1984) considera que os gêneros incorporam elementos de racionalidade cultural. Sob a mesma posição, MottaRoth (2006) concebe o gênero como "um fenômeno estruturador da cultura". 
A postura desses linguistas converge no que concerne à relação entre as culturas e as formas de interação (usos de linguagens) e de ação, uma vez que 'as formas de ação' estão relacionadas a práticas sociais mediadas pela linguagem, compartilhadas e reconhecidas como integrantes de uma dada cultura.

Segundo Fairclough, "gêneros são o aspecto especificamente discursivo de modos de agir e interagir no curso dos eventos sociais" (FAIRCLOUGH, 2003, p.65). Nas sociedades, os eventos sociais materializam-se em textos, constituídos em "um conjunto de convenções relativamente estável" (FAIRCLOUGH, 2001), associado com um tipo de atividade socialmente aprovado, e parcialmente representam essa atividade, como os planejamentos de desenvolvimento para os PAs, e dentre eles está o PDA; as reuniões parlamentares, um leilão. O autor (2003) ainda acrescenta que os gêneros implicam não somente tipos particulares de textos, mas também processos particulares de produção, distribuição e consumo de textos.

As formas de ações e interações em eventos sociais são configuradas por práticas sociais e modos pelos quais esses eventos organizam-se em redes de comunicação. Para tanto, a definição do que se entende por gênero é, aqui, fundamental para a identificação dos PDAs como uma forma cultural e cognitiva de ação social, envolta de modo particular na linguagem; como um fenômeno linguístico condicionado a escolhas que não podem ser totalmente livres nem aleatórias, seja sob o ponto de vista lexical, formal ou temático; e como um fenômeno sensível à realidade que representa.

Sendo assim, Fairclough (2003) aponta algumas características/categorias constituintes dos gêneros e que influenciam na 'forma de ação' dos mesmos. Segundo esse autor, essas características são configuradoras do significado acional dos gêneros discursivos. Para isso, define os gêneros em níveis de abstração e um dos níveis de abstração do significado acional refere-se ao conceito de pré-gênero, sugerido por Swales (1990), e que é adotado por Fairclough para as categorias abstratas, que ultrapassam redes particulares de comunicação e que não estão especificamente situadas em termos de práticas sociais. Outro nível remete a categorias concretas, os gêneros situados, para definirem gêneros específicos de uma rede particular. No caso, o que faz um gênero ser situado é as práticas sociais a que ele se vincula. O tipo de documento institucional investigado nesta pesquisa, o PDA do PA Santa Tereza I, encontra-se na categoria dos gêneros situados, haja vista figurar um tipo relativamente estável de texto em termos de cumprir funções normativas a que sua elaboração foi submetida. $\mathrm{Ou}$ seja, os PDAs configuram-se segundo determinações de conteúdo, forma e função social prescritas na Norma de Execução/INCRA/DD/No. 71, de 12 de maio de 2008, e estão situados em práticas sociais. 
Os gêneros de governança também sinalizam outra categoria, pois constituem papel crucial para sustentação da estrutura institucional da sociedade contemporânea, o que será discutido no Capítulo 4 desta tese. ${ }^{19}$ O PDA Santa Tereza I também pode ser considerado formar parte de um gênero de governança na medida em que é constituído como uma ferramenta institucional para o planejamento do desenvolvimento do PA com o mesmo nome e a partir também de uma Norma de Execução da mesma instituição. Isto é, desempenha um papel para sustentação da estrutura institucional responsável tecnicamente pela sua elaboração e que também determina e especifica seu conteúdo através de uma norma de execução.

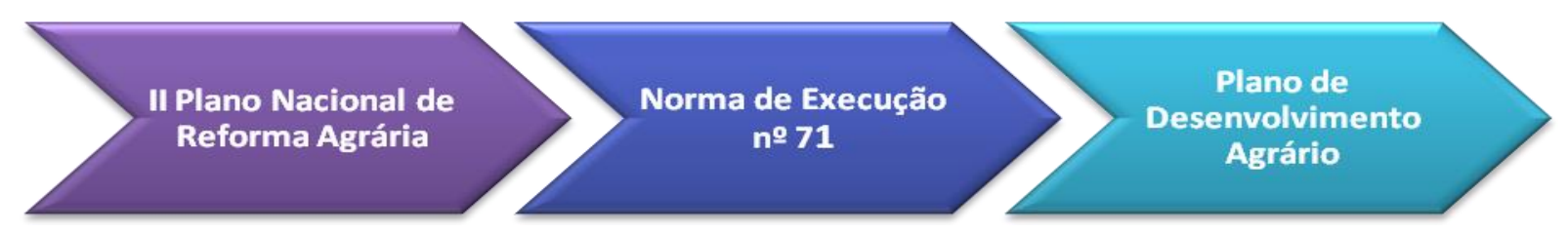

\section{Figura 2.9 - Textos referentes à reforma agrária}

Os gêneros de governança materializados em textos parecem gerenciar a vida social das pessoas que os utilizam e podem ocorrer em cadeia (FAIRCLOUGH, 2003), um pode dar origem a outro. No caso dos PDAs, da Constituição Federal de 1988 até à sua constituição, há a retextualização e a recontextualização de alguns gêneros de governança, pois cada um desempenha um papel, uma função social específica. Segundo Dell'Isola (2007, p. 36), "retextualização é a refacção ou a reescrita de um texto para outro", ou seja, trata-se de um processo de transformação de uma modalidade textual em outra, envolvendo operações específicas de acordo com o funcionamento da linguagem. Já a recontextualização é um conceito desenvolvido na sociologia da educação e pode ser bem operacionalizado dentro do discurso e da análise de texto (FAIRCLOUGH, 2003, p. 38), visto que está relacionada a questões do contexto de cultura em que cada gênero é configurado. A recontextualização trata da constituição dos textos, considerando a função de social de cada um enquanto componente de um gênero discursivo, a partir dos momentos sócio-históricos e culturais específicos de sua elaboração.

Desse modo, as políticas públicas sobre reforma agrária, desenvolvidas nos mandatos do presidente Lula, apresentam como culminância a configuração do II Plano Nacional de Reforma Agrária (II PNRA, de 2004). Já a Norma de Execução no 71 propõe a concretização

\footnotetext{
${ }^{19} \mathrm{O}$ termo 'governança' refere-se a qualquer atividade dentro de uma instituição ou organização direcionada para regular ou gerenciar alguma outra (rede de) prática(s) social(ais) (FAIRCLOUGH, 2003).
} 
de algumas proposições do II PNRA, como determinar o conteúdo e a organização dos textos dos PDAs. Os PDAs, por sua vez, são uma das ferramentas utilizadas pelo INCRA, como dito anteriormente, para o planejamento do desenvolvimento dos PAs.

Outra categoria produtiva na análise do significado acional - e nesta pesquisa - é a intertextualidade. ${ }^{20} \mathrm{~A}$ intertextualidade trata da propriedade dos textos conterem fragmentos de outros textos (FAIRCLOUGH, 2001, p. 114). Ressalte-se a constituição/inserção desses fragmentos nos textos através de várias formas: explícita, mesclada, implícita e assim por diante. De acordo com Fairclough (2001), em termos de produção de textos, essa categoria destaca a historicidade dos textos, considerando o 'acréscimo' de fragmentos de outros textos. Já em termos de distribuição, a perspectiva intertextual contribui na investigação de redes relativamente estáveis em que os textos se transformam em outro ou com característica(s) de outro(s) texto(s). Ainda em termos de consumo de textos, a intertextualidade propicia a perspectiva de que a interpretação do texto é produzida tanto a partir do próprio texto interpretado com seus 'intertextos' (fragmentos de outro texto ou de outros textos que o constituem) quanto a partir de textos que os intérpretes trazem ao processo de interpretação (RESENDE; RAMALHO, 2006).

No PDA Santa Tereza I, a intertextualidade está presente no decorrer de todo o texto, como em: "Segundo informações dos assentados e da própria prefeitura ainda não está funcionando, mas a expectativa da comunidade é que esta faça um atendimento de qualidade, pelo menos duas vezes ao mês para atender as necessidades da comunidade" (COOPVAG, 2007, p. 22). Esse exemplo de intertextualidade trata da inserção das vozes 'dos assentados' e da 'prefeitura de Ponte Alta', informando aspectos dos serviços de saúde sob a responsabilidade da prefeitura de Ponte Alta à zona rural. Nesse sentido, em um estudo de intertextualidade, há necessidade de verificação da inclusão e da exclusão de vozes; bem como da observação da articulação dessas vozes, visto que as escolhas linguísticas realizadas podem evidenciar o grau de engajamento das vozes com os seus ditos. Então, a dialogicidade é múltipla entre os textos, podendo se materializar de várias formas e com vários efeitos.

No que concerne à categoria interdiscursividade (intertextualidade constitutiva), Fairclough (2010) sinaliza sua utilidade no estudo sobre os tipos de gêneros, de discursos e de estilos relacionados aos textos veiculados, e como funciona em termos de suas articulações específicas, em vários níveis, como a ordem de discurso societária, a ordem de discurso institucional, o tipo de discurso, e mesmo aos elementos que constituem os discursos

\footnotetext{
${ }^{20}$ A intertextualidade é um termo baseado no postulado de Bakhtin (1929) de que o texto só ganha vida em contato com outro texto (com contexto) (BAKHTIN, 1979).
} 
(discurso institucional/oficial, o discurso tecnicista, discurso acadêmico). O PDA, em estudo, também apresenta essa categoria no decorrer de todo texto, como sinaliza o exemplo a seguir: "Razão social: Instituto Nacional de Colonização e Reforma Agrária - INCRA; Representante legal: Edvaldo Soares de Oliveira; CNPJ: 00.375.972/0095-40”. Esse fragmento forma parte do título dois do PDA - "Identificação dos responsáveis" - e sugere a configuração dos discursos oficial/institucional e mercadológico (próprio do Agronegócio), como visto no Capítulo 1, através da escolha das palavras utilizadas. Como sugere Moreira (2013), a ordem de discurso institucional tem uma configuração particular de gêneros em relações particulares uns com os outros, constituindo um sistema. Essa configuração de gêneros caracteriza a interdiscursividade. A análise da interdiscursividade faz referência à identificação dos discursos e à forma como são articulados.

Desse modo, o estudo de textos da ordem do discurso institucional no âmbito da reforma agrária, como o PDA do PA Santa Tereza I, pode corroborar para o entendimento de relações sociais em um contexto determinado de reforma agrária no Brasil.

\subsection{2 $\mathrm{O}$ texto $\mathrm{e}(\mathrm{m})$ representações}

Em Análise de Discurso Crítica, o processo da representação, em qualquer texto, remete à decisão de quais escolhas linguísticas efetuar - o que incluir e o que excluir, o que tornar explícito e o que deixar implícito, o que colocar em primeiro/segundo plano, quais tipos de processo e quais categorias usar -, uma vez que, nessa situação única e específica, uma representação particular de algum aspecto do mundo está sendo organizada e construída nas proposições do texto (FAIRCLOUGH, 2003). Ao se representar algo do mundo em textos, constitui-se a necessidade de escolha sobre o tipo de representação desse algo, como um dizer, uma ação, um sentir, uma existência ou um comportamento. Ressaltem-se as escolhas (linguístico-discursivas) motivadas (socialmente, culturalmente, politicamente) e realizadas em detrimento daquelas que poderiam ter sido realizadas, mas que por algum motivo não foram. Assim sendo, a língua é um potencial de significados e o estudo da representação baseia-se tanto no nas ausências do texto quanto no que está presente, e até no que poderia estar no texto, mas não está através de escolhas também léxico-gramaticais.

Sobre isso, Fairclough (2001) aponta que a constituição das escolhas remete, em parte, à questão de vocabulário e, em parte, a uma questão de gramática. Isso se justifica na medida em que a representação está implicada na determinação do tipo de organização representado no vocabulário usado. Da mesma maneira, por meio do uso da gramática, as pessoas podem 
distinguir tipos de processo, participantes e elementos circunstanciais para representarem as experiências de mundo. Em outras palavras, a representação, na língua, de algo ocorrido no mundo implica nas escolhas de representação, como uma ação, um sentir, uma relação, um dizer, um comportamento ou uma existência. Por conseguinte, também há escolha de representação dos atores sociais, como 'dizentes', 'comportantes', 'experienciadores', dentre outros tipos; e ainda há escolha ao se situar a representação em termos de circunstâncias como extensão, causa, localização (tempo, espaço), modo, contingência, acompanhamento.

Nessa perspectiva, Fairclough (2001, 2003, 2010), com o intuito de investigar o(s) modo(s) como os eventos sociais - atividades, pessoas, relações sociais, linguagem, objetos, lugares, tempos - são representados no nível do texto, indica analisar as orações a partir de uma abordagem representacional, com fundamento em alguns pressupostos da Linguística Sistêmico-Funcional (HALLIDAY, 1978, 1994). Assim, para o teórico (2003), as orações em uso funcionam como um recurso que aponta como as pessoas configuram a realidade a sua volta e como a gramática é usada para representar suas experiências de mundo. Também os elementos constituintes dos eventos sociais podem ser escolhidos para representar um aspecto específico da experiência de maneira mais proeminente.

Para tanto, Fairclough (2003) concebe a representação como uma substância discursiva, já que diferentes discursos podem representar a mesma área do mundo de diferentes perspectivas ou posições, podendo até projetar realidades através, principalmente, da interdiscursividade e do significado das palavras. Vale ressaltar, aqui, a concepção de 'discurso' em um sentido mais concreto, como substantivo contável, com o significado de “a formas particulares de representar aspectos do mundo" (FAIRCLOUGH, 2003, p. 124). Portanto, discurso pode ser concebido como modo de representação com certo grau de 'afinidade' e 'estabilidade' e como modo de representação constituinte de pontos essenciais na relação dialética entre linguagem e outros elementos da vida social. Ramalho e Resende relacionam o objeto de estudo da ADC a essa dialética entre a linguagem e os outros elementos do social:

O objeto de estudo da ADC não é a linguagem como estrutura (sistema semiótico), tampouco apenas como evento (texto), mas também como prática social, ou seja, análises discursivas críticas privilegiam o espaço das ordens do discurso como espaço de geração de conhecimento sobre o funcionamento da linguagem. É claro que para tanto investigam as instanciações materializadas em textos concretos, isto é, têm como material analítico as concretizações do potencial do sistema semiótico em eventos discursivos situados (RAMALHO; RESENDE, 2011, p. 41). 
Desse modo, uma análise da interdiscursividade refere-se à identificação de quais discursos são utilizados e da forma como eles são articulados devido às análises da ADC focarem no nível intermediário das ordens do discurso (RESENDE, 2010b). As relações das pessoas e com o mundo, consigo mesmas e com outras pessoas - suas posições no mundo remetem a diferentes discursos. Neste trabalho, o estudo de um PDA, o PDA do PA Santa Tereza I, como um gênero de governança, atua no contexto das ferramentas institucionais para o planejamento do desenvolvimento dos projetos de assentamentos no Brasil, bem como no contexto do assentamento para o qual foi elaborado.

A seguir, apresento a perspectiva proposta por Fairclough (2003) acerca dos significados identificacionais da linguagem.

\subsubsection{O texto e(em) identificações}

A linguagem como discurso, além de configurar um modo de (inter)ação no mundo e um modo de representação nele, também é um modo de identificação de si mesmo e das outras pessoas.Por isso, o significado identificacional está relacionado ao aspecto discursivo das formas de ser (FAIRCLOUGH, 2003), das identidades sociais ou pessoais particulares. Tal aspecto da linguagem dá ênfase à negociação e à construção de identidades no discurso, de modo que os atores sociais atuam no mundo.

De acordo com Ramalho e Resende (2011, p. 68), os atores sociais não são completamente livres e nem completamente constrangidos pela estrutura social. Nos eventos sociais, as pessoas participam, atuam, agem e não são passivas. Ocorre, pois, uma reciprocidade constitutiva entre a ação individual e a estrutura social. Observe-se, sobre isso, como apontado no Capítulo 1, a questão do conceito de pobreza como restrição de liberdade (SEN, 2010), no que concerne ao engendramento entre as relações econômicas, políticas e sociais em várias sociedades, como o Brasil. Apesar de muitas pessoas estarem em meio a identificações com o consumismo de bens materiais e serviços, milhares e milhares de pessoas não podem se identificar com essa sociedade baseada no consumismo, pois suas escolhas são limitadas, suas liberdades são restringidas, mesmo sendo brasileiros e brasileiras, ‘constituindo' a sociedade brasileira. Além disso, Fairclough (2003) destaca a necessidade de a 'diferença' ser concebida entre os aspectos pessoais e sociais da identidade, pois a identificação faz-se um processo complexo em termos de identidade pessoal e identidade social. 
A partir dessas considerações, pode-se refletir sobre as características dos agentes em eventos sociais. A agência, na ADC, está relacionada à capacidade dos agentes sociais (atores sociais) de criarem ou mudarem o que seja. Para isso, Fairclough (2003) considera a consciência de si mesmo/a um condicionante inicial para a (des)construção de processos sociais de identificação no discurso e em textos. Ademais, as pessoas, de certa maneira, atingem identidade social quando desempenham papeis sociais personificados, investidos de sua própria personalidade. Vale ressaltar também o papel dos agentes sociais ao produzirem textos, devido à variedade de recursos linguísticos (léxico-gramaticais) disponíveis a sua escolha. A identificação, em textos, remete tanto à individualidade e quanto à coletividade.

O significado identificacional relaciona-se, assim, ao conceito de'estilo' e sinaliza nos textos as identidades dos atores sociais. O estilo está ligado à identificação, às maneiras como as pessoas se identificam e são identificadas por outras pessoas, constituindo um processo dialético no discurso. Diante desse processo, há envolvimento de efeitos constitutivos do discurso e de aspectos não discursivos. Uma consequência dessa perspectiva dialética está no fato de os sentidos de identificação (assim como os sentidos acionais) poderem ser vistos como sentidos representacionais pressupostos, as suposições nas quais as pessoas identificamse segundo o que elas fazem. O processo de constituição de 'identificação', muitas vezes, está relacionado à avaliação e à modalidade (FAIRCLOUGH, 2003), por estarem diretamente atrelados à constituição das "formas de ser”, citadas acima.

A avaliação remete às 'afirmações avaliativas' e às 'presunções valorativas'. Para Resende e Ramalho (2006), as afirmações avaliativas são aquelas acerca do que é considerado desejável ou indesejável (são juízos de valor) e as presunções valorativas relacionam-se ao que está implícito, ao que é presumido. Conforme Fairclough (2003), a avaliação pode ser configurada por meio de um adjetivo, de um verbo, de um advérbio ou de um sinal de exclamação.

A modalidade faz referência, por sua vez, ao tipo de envolvimento das pessoas quando fazem declarações, perguntas, ofertas ou procuras (FAIRCLOUGH, 2003). Isto é, contribui para a construção discursiva de identidades através de afirmações, perguntas e ofertas que as pessoas fazem. Sobre isso, Halliday (1994) diz que a modalidade é o julgamento do/a falante quanto às probabilidades ou obrigações concernentes ao que ele/a diz. Está relacionada a 'atitudes', 'julgamentos', 'posturas' e, consequentemente, à identificação. É uma relação entre aqueles/as que interagem e as representações. Fairclough (2003) destaca essas escolhas nos textos como parte do processo de estruturação da própria identidade. $\mathrm{O}$ autor ainda acrescenta que as identidades são relacionais, já que se constituem na relação entre uma pessoa e o 
mundo e com outras pessoas. Isso corrobora para a concepção de que as escolhas, na modalidade, são significantes não apenas em termos de identificação, mas também em termos de ações, relações sociais e representações. A modalidade está relacionada, assim, ao modo como os gêneros discursivos são construídos, visto que o grau de comprometimento de quem o produz refere-se ao processo de textualização, parte das auto-identidades (FAIRCLOUGH, 2003). Sobre isso, Resende e Ramalho (2006, p. 76) salientam que "a identificação deve ser compreendida como um processo dialético em que discursos são inculcados em identidades, uma vez que a identificação pressupõe a representação em termos de presunções acerca do que se é".

Desse modo, os sentidos de identificação nos textos (significado identificacional), assim como os de ação (significado acional), podem ser vistos como sentidos representacionais (significado representacional) pressupostos. Além disso, os três significados para a análise de discursos, propostos por Fairclough (2003), relacionam-se de forma dialética, à medida que os gêneros (significado acional) concretizam discursos (significado representacional) e estilos (significado identificacional): ações e identidades são representadas em discursos.

Neste estudo, há foco na análise do texto do PDA do PA Santa Tereza I, no que faz referência a discursos e representações através da discussão teórica com base nos significados acionais, representacionais e identificacionais, abordados acima, de acordo com Fairclough (2003).

\subsection{A representação dos atores sociais}

De acordo com Theo van Leeuwen (2008), todo discurso recontextualiza práticas sociais e todo conhecimento está, em última análise, baseado em práticas sociais. E no que concerne à representação dos atores sociais, o autor $(1997,2008)$ propõe o estudo das diversas maneiras pelas quais os atores sociais são representados discursivamente, bem como das escolhas apresentadas pela língua como alusão às pessoas. Cada "escolha representacional" proposta relaciona-se a realizações linguísticas ou retóricas específicas. Nessa perspectiva, van Leeuwen $(1997,2008)$ propôs um sistema para analisar a representação dos atores sociais no discurso, de acordo com os papeis exercidos nas práticas sociais e os papeis gramaticais atribuídos a eles nos textos. A proposta está baseada na Gramática Sistêmico-Funcional (HALLIDAY, 1994) devido à concepção de articulação entre os atores sociais e o contexto 
sócio-cultural onde estão inseridos, como a LSF propõe. Essa articulação corrobora com o propósito de investigação da inclusão e da exclusão de pessoas ou grupos sociais nos discursos.

Para tanto, o autor lança mão de uma série de sistemas linguísticos distintos, tanto no nível léxico-gramatical como no nível do discurso, da transitividade, da referência, do grupo nominal e das figuras retóricas (VAN LEEUWEN, 1997, p. 216). Essa rede de sistemas oferece categorias com o intuito de apontar como as escolhas linguísticas e retóricas, que constituem as práticas discursivas, são específicas, com efeitos representacionais também específicos em relação aos atores sociais. Observe-se que van Leeuwen (2008) amplia a rede de sistemas e as escolhas de fenômenos linguísticos e retóricos ao enfatizar as categorias sociológicas (agência, nomeação) e não as linguísticas (nomeação, apagamento do agente da passiva), apresentando como elemento principal o conceito de 'ator social'. ${ }^{21}$ A Figura 2.10 apresenta essa rede de sistemas.

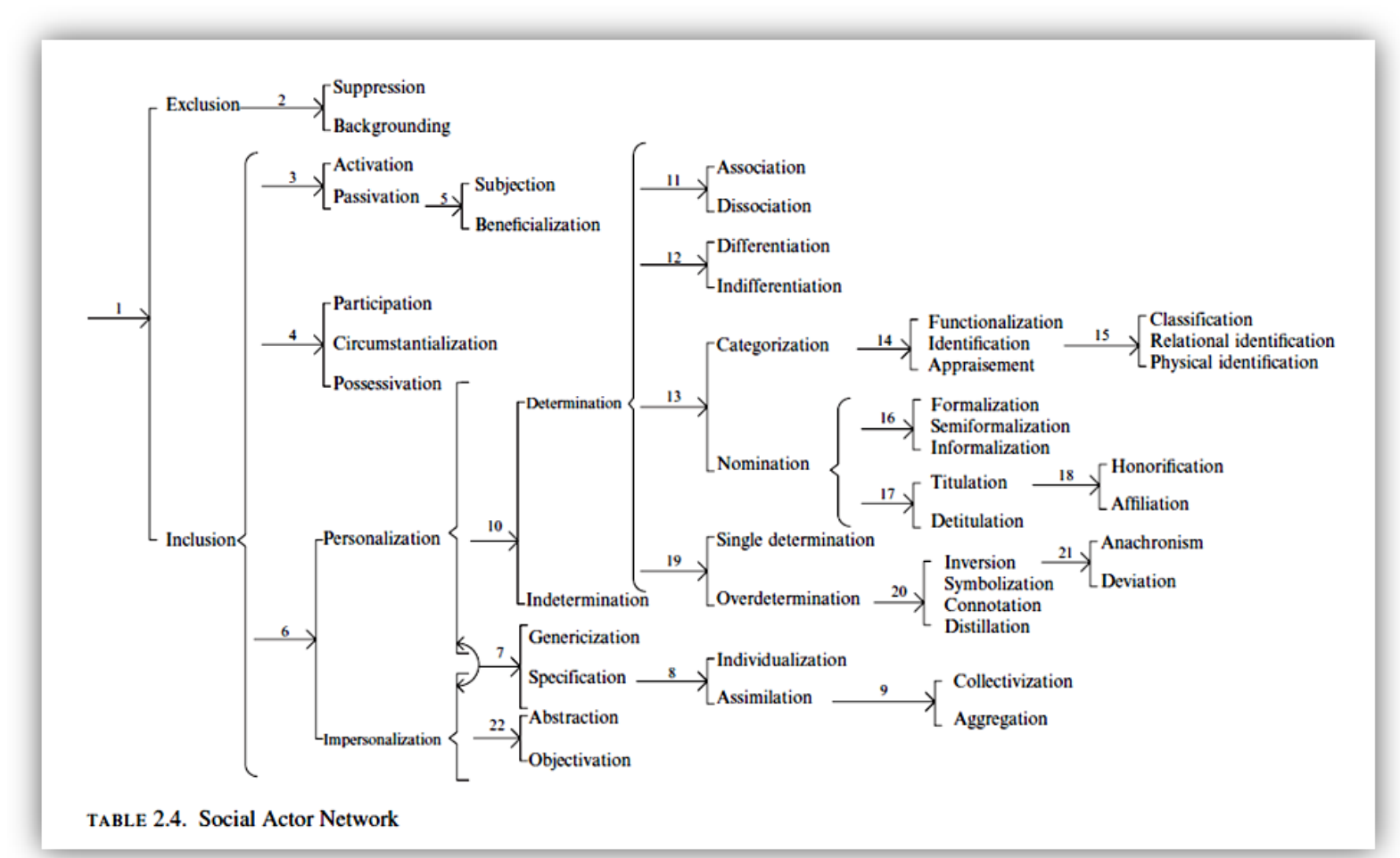

Figura 2.10 - A representação dos atores sociais no discurso Baseada em van Leeuwen (2008).

\footnotetext{
${ }^{21}$ Não há uma co-referência exata entre as categorias sociológicas e linguísticas, e se a análise crítica do discurso se restringir demasiado a operações ou categorias linguísticas específicas, poderá ignorar muitos exemplos relevantes de 'agência' (VAN LEEUWEN, 1997, p. 170).
} 
A Figura 2.10 delineia a estrutura proposta por van Leeuwen (1997; 2008) para apresentar a rede de sistema de representação dos atores sociais no discurso. Destaque-se, primeiramente, a utilização de "chaves" para relacionar os elementos da rede de sistema em termos de 'inclusão' e 'exclusão' de atores sociais. Segundo o teórico (2008), os atores sociais são incluídos ou excluídos das representações devido aos interesses de quem elaborou o texto.

No sistema de chaves, a exclusão é a primeira categoria apresentada (da esquerda para direita e de cima para baixo) e aparece sob dois modos: supressão e encobrimento (ou colocar em segundo plano). Enquanto na supressão (apagamento do agente da passiva, orações infinitivas, nominalizações, processos) não há qualquer referência ao/s ator/es em questão; no encobrimento (elipses), a exclusão é menos radical, há alguma referência no texto ao/s ator/es, mas em segundo plano.

A outra categoria de representação, proposta van Leeuwen, é a inclusão, podendo ser constituída de duas maneiras: ativação ou passivação. O fator determinante do tipo de inclusão remete aos papeis atribuídos ao ator na representação do discurso. A ativação ocorre quando os atores sociais são representados de forma ativa e dinâmica no discurso (VAN LEEUWEN, 2008), através de papeis gramaticais dos participantes de processos verbais claros, preposições. Já a inclusão por passivação ocorre quando os atores sociais são representados como "submetendo-se à atividade ou como receptores dela", ou seja, passivação por sujeição ou por beneficiação. A sujeição pode ser realizada por 'participação', ‘circunstancialização' e ‘possessivação'. Em caso de o ator passivado comportar-se como finalidade (Meta) em um processo material, como fenômeno em um processo mental ou com um portador em um processo atributivo intensivo, há passivação por participação. Já em caso do uso de um sintagma preposicional, há passivação por circunstancialização. Por último, em caso de ocorrer o uso de um sintagma preposicional iniciado pela preposição 'de', com mudança em uma nominalização ou em um substantivo processual, há passivação por possessivação (VAN LEEUWEN, 2008). Van Leeuwen (2008) propõe que a sujeição por beneficiação realiza-se quando o participante beneficiado é receptor ou cliente em relação a um processo material ou quando o participante é destinatário em relação a um processo verbal.

Destaque-se também, na representação dos atores sociais, a escolha entre referência genérica - generalização - e referência específica - especificação (VAN LEEUWEN, 2008). Os atores sociais também podem ser referidos em termos de individualização e de associação. $\mathrm{Na}$ realização da primeira referência, os atores sociais são representados nas suas 
singularidades. Há tentativa de individualizar, singularizar os atores. Na realização da assimilação, os atores sociais são representados em grupos, na pluralidade e ocorrem por meio de dois tipos: coletivização e agregação. Enquanto na agregação a representação quantifica grupos de participantes em dados estatísticos; na coletivização, a representação constitui uma imagem de coletividade para tratar os atores sociais (VAN LEEUWEN, 2008).

Outro modo de representação dos atores sociais é a associação e, quando ela se desfaz, ocorre a dissociação. A associação consiste em grupos formados por atores sociais e grupos sociais que nunca são classificados no texto e sua realização mais comum é a parataxe (VAN LEEUWEN, 2008). Ela também pode ser realizada através de circunstâncias de acompanhamento, de pronomes possessivos e de orações possessivas atributivas.

Também na categoria inclusão está a diferenciação e a indeterminação. A determinação ocorre quando a identidade do ator social é especificada. E a 'indeterminação' ocorre quando os atores sociais são representados como indivíduos ou grupos não específicos e "anônimos", sendo realizada tipicamente pelo uso de pronomes indefinidos em função nominal, mas podendo ser realizada através de uma "referência exofórica generalizada".

A nomeação e a categorização também podem representar os atores sociais. A primeira faz referência à constituição de uma identidade única através do uso de nomes próprios. A segunda remete a identidades e funções que compartilham com outros, ou seja, são categorizados. Além disso, a afiliação (uso de um termo de relação pessoal ou de parentesco) e a honorificação (uso de títulos-padrão, cargos) são duas maneiras de realização da nomeação (VAN LEEUWEN, 2008).

Segundo van Leeuwen (2008), a categorização ocorre por funcionalização e identificação. Quando os atores sociais são representados por meio da função desempenhada ou do cargo ocupado em determinada atividade, há a funcionalização e se concretiza linguisticamente pelo uso de um substantivo indicador de profissão; pelo uso de um substantivo formado a partir de outro substantivo indicador do local ou do instrumento, diretamente associado a uma determinada atividade ou associado diretamente a atividades e categorizações generalizadas. Quando os atores sociais são definidos a partir do que está mais ou menos permanente ou inevitavelmente é, ocorre a identificação, distinta em identificação física (identificação dos atores por meio das características físicas peculiares que os identificam em determinados contextos), identificação relacional (a representação dos atores constitui-se em termos da relação pessoal, de parentesco ou de trabalho que têm entre si) e classificação (atores sociais identificados através de categorias pelas quais a sociedade ou uma instituição diferencia as classes de pessoas) (VAN LEEUWEN, 2008). 
O teórico (2008) também aponta a personalização e a impersonalização como modos de representação. A representação dos atores sociais como seres humanos é a personalização e ocorre através do uso de nomes próprios ou substantivos, pronomes pessoais ou possessivos ou do uso de adjetivos, cujos significados incluem características humanas. Já a representação através do uso de substantivos abstratos ou concretos, sem características semânticas humanas, é a impersonalização por abstração ou por objetivação. A impersonalização por abstração representa o ator através de uma qualidade que lhe é atribuída. A impersonalização por objetivação faz referência ao local ou à coisa diretamente associados à pessoa ou à atividade ligada a ela através de 'referência metonímica' por autonomização do enunciado, espacialização, instrumentalização ou somatização.

Ainda, na categoria inclusão, van Leeuwen (2008) aponta como representação a sobredeterminação. Nela, os atores sociais participam simultaneamente de mais de uma prática social e está dividida em conotação (atores sociais representados quando uma nomeação ou uma identificação física corresponde a uma classificação ou funcionalização), destilação (atores sociais representados com relação em várias práticas sociais, de modo a abstraírem a mesma característica dos atores sociais envolvidos nestas práticas), inversão (atores sociais representados através da relação entre duas práticas que se opõem uma à outra) e simbolização (atores sociais ou grupos de atores sociais "ficcionais" representam atores ou grupos em práticas sociais "não-ficcionais").

O estudo da representação de atores sociais pode contribuir, assim, para a configuração de funções que cada ator social exerce e isso interessa a este trabalho, em termos das representações de atores sociais no texto de um plano de desenvolvimento agrário e que forma parte das questões de pesquisa. Para van Leeuwen (1997, p. 187), cabe ao analista "investigar as opções feitas em contextos institucionais e sociais: o motivo pelo qual as escolhas são feitas, que interesses é que as servem e que propósitos são alcançados”. Sendo assim, busco investigar os modos pelos quais os atores sociais são representados, sobretudo, nos discursos do PDA do PA Santa Tereza I.

\subsection{A interface entre a ADC e a LSF para a análise crítica}

A Análise de Discurso Crítica (ADC), sob a égide da investigação linguística e social, é constituída como um arcabouço teórico e metodológico para a análise de 'sentidos' a serviço de projetos particulares de dominação e exploração, seja para sustentar ou modificar conhecimentos, crenças, atitudes ou valores (CHOULIARAKI \& FAIRCLOUGH, 1999). 
Para tanto, a ADC propõe recursos de diferentes disciplinas, com sustentação científica, para a investigação dos efeitos ideológicos, configurados nos textos e atuantes na interação das sociedades e sobre as sociedades, seja nas representações constituídas nelas, como meio para a análise de fenômenos sociais. Por essa razão, o trabalho de Fairclough para uma ADC destaca-se, segundo Magalhães (2005, p.3), pela “criação de um método para o estudo do discurso e seu esforço extraordinário para explicar por que cientistas sociais e estudiosos da mídia precisam dos linguistas".

Segundo Silva (2010), a ADC faz-se um instrumento teórico e metodológico para pesquisas científicas acerca do uso da linguagem nas instituições sociais e das relações entre a linguagem, o poder e a ideologia. Enquanto uma teoria social crítica, propositiva de uma investigação linguístico-discursiva dos mais variados textos, busca desenvolver seu modelo de análise balizado na relação entre aspectos da interioridade e da exterioridade da linguagem, os quais constituem textos orais e escritos, nos moldes de Fairclough (1999, 2003, 2010). Para isso, esse arcabouço requer uma teoria gramatical que conceba a relação entre linguagem e contexto social para levar a cabo estudos sobre as diferenças entre os textos e relacioná-los aos contextos de cultura e de situação.

A articulação proposta com a LSF é configurada, aqui, na medida em que os pressupostos teórico-metodológicos das duas teorias fundamentam o desenvolvimento de uma análise crítica da linguagem, configurando a combinação entre as relações internas e externas de um gênero discursivo. Ademais, a ADC é configurada como um aprofundamento teórico posterior à LSF. Em relação a esse aprofundamento teórico, a ADC lança mão das metafunções da linguagem desenvolvidas na LSF, o que propiciou o desenvolvimento da GSF, já dito anteriormente, para formular a teoria do funcionamento social da linguagem.

Com o propósito de interação nas diversas práticas sociais, Fairclough (2003) apresenta três principais significados de um texto, articulando-os com as metafunções (ideacional, interpessoal, textual) de Halliday (1994). Para essa proposição, Fairclough baseia-se nos pressupostos teóricos de Halliday, incorporando a macrofunção textual ao significado acional. Com isso, a ADC, nesta tese, faz uso LSF como ferramenta para a análise das relações internas dos textos. Como sinaliza Barros, ${ }^{22}$

é relevante para o analista de discurso crítico se utilizar da GSF, a fim de se investigar melhor a linguagem do ponto de vista micro e macrossociais. A

\footnotetext{
${ }^{22}$ Disponível em: www.letras.ufscar.br/linguasagem. Acesso em: 02 jan. 2014.
} 
ACD, em conjugação com a GSF, pode proporcionar ao analista uma visão mais holística do contexto social investigado, estreitando cada vez mais o elo entre o texto e o contexto, entre o social e o linguístico. A convergência dessas duas concepções teórico-analíticas é uma forma dialética de olhar a linguagem sob vários prismas (BARROS, 2011, p. 3-4).

Para Barros (2011), a conjugação da ADC com a LSF, em termos de GSF, propicia diferentes modos de enxergar e sentir a realidade, facilitando uma melhor compreensão dos mecanismos sociais de dominação e resistência ou de emancipação e transformação social.

Para tanto, a ADC lança mão de categorias analíticas propostas pela Gramática Sistêmico-Funcional (GSF) (HALLIDAY, 1994), visto que a análise (inter)discursiva de textos se constitui na integração indissociável da análise linguística e da análise social. Segundo Barros (2011), a ênfase na 'analise interdiscursiva' de textos no que remete a gêneros, discursos e estilos se faz uma tentativa de a ADC tecer mais adequadamente sobre a relação entre texto e contexto social. A investigação proposta pela ADC pode potencializar, assim, o desvelamento de aspectos da vida social das sociedades a partir de discursos e representações para a 'mudança social'.

A Linguística Sistêmico-Funcional (LSF), nos moldes de Halliday (1978, 1994), apresenta duas concepções que sustentam a proposta teórico-metodológica. Uma diz respeito à concepção de linguagem como um sistema semiótico de escolhas e, com isso, a língua desempenha funções externas ao sistema linguístico. A segunda concepção diz respeito à proposição de estudos envolverem as formas linguísticas e as funções convenientes nas práticas sociais, a partir da perspectiva de que o funcionamento das sociedades está atrelado (a escolhas específicas de) a elementos gramaticais constituintes dos textos e que produzem significados sociais. Por isso, essa teoria propõe a GSF que emprega uma linguagem especializada para descrever e analisar os significados contextuais dos diversos textos (SILVA, 2010).

Nesse âmbito, as premissas da LSF alinham-se às da ADC no que concerne ao engendramento entre usos da linguagem e as práticas sociais a partir de seus contextos de cultura e de situação. Para isso, em ambas as abordagens, a unidade básica de análise é o texto e(m) os seus contextos e que é a realização de três significados: uma representação (significado como conteúdo), uma troca (significado como forma de ação) e uma mensagem (significado como relevância para o contexto), como sugere a Figura 2.11. 


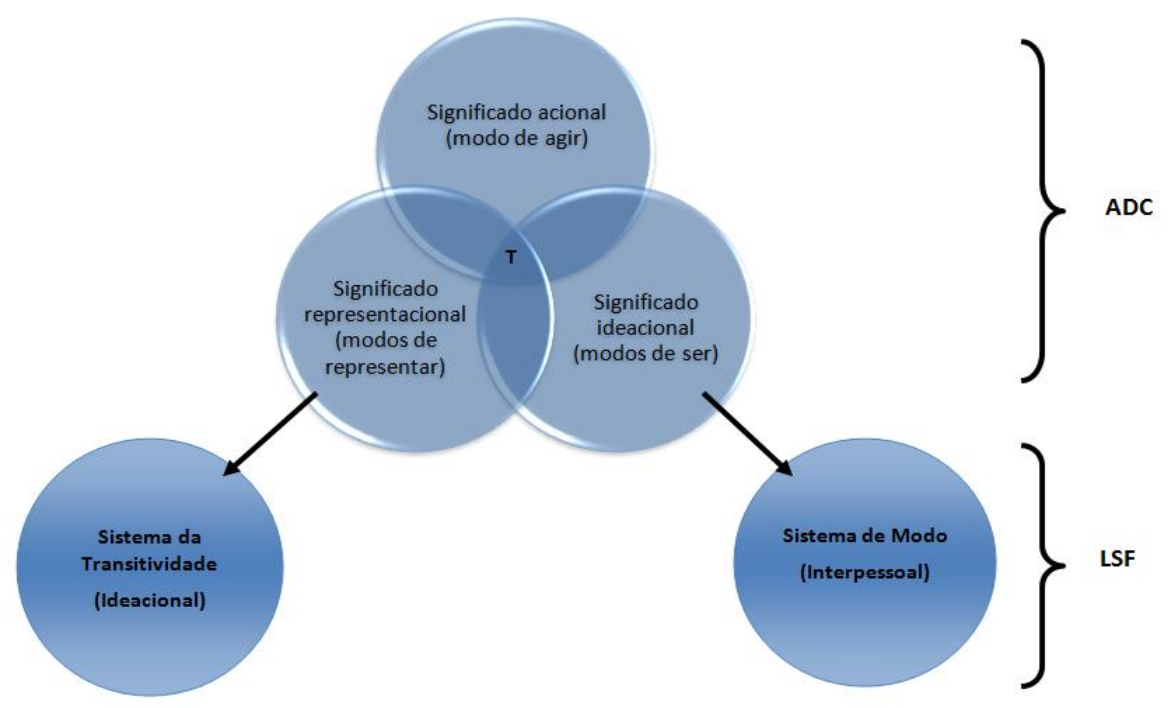

Figura 2.11 - Triangulação dos pressupostos teórico-metodológicos da pesquisa Adaptada de Câmpelo (2015).

A partir disso, Silva (2010, p. 63) sinaliza que a ADC e a LSF adotam uma concepção dialética de linguagem, em que os significados construídos nos gêneros de discurso influenciam os contextos culturais e situacionais e que também influenciam nos gêneros discursivos. Ambas as propostas reconhecem a semiose (e, em especial, o sistema de linguagem verbal, a língua) como um elemento que se (re)constroi unicamente por meio de seus laços com outros elementos não-semióticos da prática social, isto é, entendem que a relação entre os textos em si e as redes de práticas sociais está amparada por uma imbricação dialética e transformacional (BARBARA \& MACÊDO, 2009). Sobre isso, a linguista Edna Muniz da Silva também aponta:

Por um lado, o uso da gramática sistêmico-funcional para o estudo e a análise de textos envolve uma descrição gramatical que privilegia a relação de textos aos seus contextos de cultura e situação ao mesmo tempo em que propicia a consciência de que a estrutura dos gêneros relaciona-se a seus propósitos nas práticas sociais. Por outro lado, ao examinar questões sociais que se manifestam discursivamente através dos gêneros nos diferentes domínios sociais, a ADC enfatiza a relação entre língua, poder e ideologia, sobretudo, ao desvelar as estruturas linguísticas que revelam as relações de dominação e desigualdade (SILVA, 2010, p. 77).

Como os estudos da ADC refletem acerca do papel da linguagem na dinâmica da vida social pública contemporânea, investigando a realização de discursos e propondo um olhar 
crítico sobre eles e seus impactos na mudança social; as categorias de análise da LSF, constituídas a partir da concepção da inerente relação entre linguagem e os contextos de situação e de cultura, contribuem para as análises baseadas nos pressupostos teóricos e metodológicos da ADC por buscarem explicar as diferenças entre os textos e relacioná-los aos seus contextos.

\section{Algumas considerações}

Com base na abordagem teórico e metodológica da ADC e na abordagem da LSF, no proponho uma investigação de aspectos sociais e discursivos constitutivos do texto do Plano de Desenvolvimento Agrário do PA Santa Tereza I, em termos de representações dos atores sociais envolvidos na elaboração do PDA. Para tanto, a proposição da triangulação entre aspectos coincidentes dessas teorias subsidia a busca pela compreensão da constituição, bem como de "ações sobre o mundo (sobre o assentamento)" de práticas sociais constituídas no texto do PDA investigado, considerando que esse documento surgiu como uma ferramenta institucional (MDA/INCRA), concretizada linguisticamente, para colocar em prática proposições (prescrições) do II PNRA, de 2004, e para contribuir com o desenvolvimento do PA Santa Tereza I.

A análise proposta, neste estudo, é constituída, sobretudo, na complementação e na interação entre os significados dos discursos, de acordo com Fairclough (2003). As categorias de análise das metafunções ideacional e interpessoal, nos moldes de Halliday (1978, 1994, 2004) e ampliação de Halliday \& Matthiessen (2004), estão voltadas para a análise das discursividades e das representações constituintes do PDA. Essa conjugação dá-se devido a algumas diretrizes teóricas e ferramentas metodológicas dialogarem e se complementarem de acordo com uma perspectiva de análise textualmente orientada, considerando a interioridade e a exterioridade da linguagem.

$\mathrm{Na}$ investigação ora proposta, o uso de categorias de análise da gramática sistêmicofuncional e a análise do PDA Santa Tereza I envolvem uma descrição gramatical que privilegia sua relação aos seus contextos de cultura e situação ao mesmo tempo em que propicia a perspectiva de que a sua estrutura em termos de gênero relaciona-se a seus propósitos nas práticas sociais. Além disso, como a ADC enfatiza a relação entre língua, poder e ideologia, sobretudo, ao desvelar estruturas linguísticas que apontam relações de dominação e desigualdade através da proposição de análises linguisticamente orientadas, seus pressupostos podem propiciar e subsidiar a investigação de questões sociais manifestas 
discursivamente no texto do PDA Santa Tereza I, principalmente, no que concerne às representações dos atores sociais envolvidos na sua elaboração. 


\section{CAPÍTULO 3}

\section{A CONSTRUÇÃO DA REVOADA: ESTRATÉGIAS DE PESQUISA}

A visão é sempre uma questão do poder de ver - e talvez da violência implícita em nossas práticas de visualização; determinar a quem é permitido esse poder de ver e falar a respeito do que se vê é uma questão que está no cerne de nossas responsabilidades sociais de escrever ou de representar (DENZIN; LINCOLN, 2006).

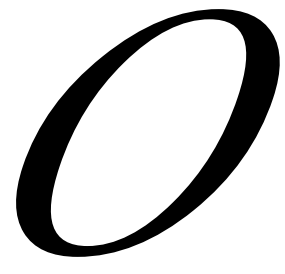

foco deste capítulo envolve a apresentação e a discussão dos procedimentos teórico-metodológicos constituintes desta pesquisa. O capítulo está dividido em sete seções. A primeira seção trata da perspectiva da pesquisa qualitativa e apresenta algumas considerações sobre ética vinculadas a ela. A segunda apresenta as estratégias de investigação da pesquisa. É dedicada à relação entre os objetivos e as questões de pesquisa. A terceira seção envolve a coleta e a seleção de dados de natureza documental, referentes ao PDA Santa Tereza I. A quarta apresenta a geração e a seleção de dados de natureza etnográfica. A quinta seção é dedicada aos métodos de análise dos dados: os pressupostos teórico-metodológicos da ADC e os pressupostos teórico-metodológicos da LSF. Já a sexta trata da abordagem articulatória entre as análises. Por último, há algumas considerações. 


\subsection{A pesquisa qualitativa}

A pesquisa qualitativa propõe abranger construções variadas de mundo, entendendo, descrevendo e explicando processos sociais específicos dessas construções (ANGROSINO, 2009). Os/as pesquisadores/as qualitativos/as estão interessados/as em ter acesso a experiências, interações, documentos em seu contexto natural. Nesse sentido, a pesquisa qualitativa "visa a abordar o mundo 'lá fora' (e não laboratórios) e entender, descrever e, às vezes, explicar os fenômenos sociais 'de dentro' de diversas maneiras diferentes” (GIBBS, 2009, p. 8). A sua perspectiva de análise envolve experiências de indivíduos e grupos, examinando as interações.

Além disso, a palavra "qualitativa" implica uma ênfase sobre as qualidades das entidades, sobre os processos e sobre os significados não examinados ou medidos experimentalmente em termos de "quantidade". Desse modo, esse tipo de pesquisa não é uma 'pesquisa não quantitativa', apresenta identidade própria e abstém-se do estabelecimento de um conceito rígido do objeto de pesquisa que estuda. Os conceitos são desenvolvidos e refinados ao longo da pesquisa (FLICK, 2009). Os métodos e a teoria devem ser adequados àquilo que se estuda.

A pesquisa qualitativa propõe, assim, a busca do entendimento, da descrição e da explicação de fenômenos sociais através de diversas maneiras, mediante análise de experiências de indivíduos ou grupos, de exame das interações e comunicações que estejam se desenvolvendo, bem como mediante investigação de documentos. Essas abordagens buscam detalhar a forma como as pessoas constroem o mundo à sua volta (FLICK, 2009). As interações e os documentos são maneiras de configuração, de forma conjunta (ou conflituosa), de processos e artefatos sociais.

Assim, esta pesquisa de natureza qualitativa (descritiva e interpretativa) se desenvolve com interpretações de realidades sociais, no caso, de um texto institucional: o PDA do PA Santa Tereza I. O interesse é investigar discursividades e representações constituídas no texto desse PDA. No caso, na época de elaboração do PDA Santa Tereza I (em 2007), cada projeto de assentamento (PA) deveria possuir um planejamento de desenvolvimento agrário para que os lotes fossem sorteados e o direito de uso aos/às candidatos/as fosse concedido. Além do corpus com dados de natureza documental, coletados e selecionados no texto do PDA do PA Santa Tereza I; compõe a pesquisa o corpus com dados de natureza etnográfica, gerados e selecionados a partir, principalmente, de entrevistas semiestruturadas com colaboradores/as, que de alguma forma, estavam envolvidos/as com a elaboração do PDA estudado, com o 
propósito de acercamento do objeto de pesquisa. Nesse sentido, pesquisadores/as fazem uso de ampla variedade de práticas interpretativas interligadas, com o intuito de compreender melhor o assunto que está ao seu alcance (DENZIN; LINCOLN, 2006). Para tanto, é proposta a triangulação de métodos de pesquisa: documental e etnográfica.

Vale ressaltar que a tentativa de acercamento do corpus do PDA em estudo, através do uso de diversos métodos ou da triangulação, reflete uma tentativa de assegurar uma compreensão em profundidade do objeto de estudo, ou seja, está relacionada à questão da 'qualidade' da pesquisa. ${ }^{23}$ Para Flick (2009), o principal vínculo entre a triangulação e a qualidade da pesquisa é que a primeira significa ampliar as atividades do/a pesquisador/a no processo, usando, por exemplo, mais de um método, mais de uma teoria. Essa combinação de métodos ou teorias não tem o propósito de buscar a verdade "objetiva", mas de aumentar a profundidade da análise, podendo embasar mais os dados e a interpretação do objeto de pesquisa.

Além disso, pesquisadores/as qualitativos/as "ressaltam a natureza socialmente construída da realidade, a estreita relação entre o/a pesquisador/a e o que é estudado e as limitações situacionais que influenciam a investigação" (DENZIN; LINCOLN, 2006, p. 23). Por isso, um objetivo importante do/a pesquisador/a social é compreender as interpretações que os atores sociais possuem do mundo, já que motivam o comportamento que cria o próprio mundo social (BAUER; GASKELL; ALLUM, 2008).

Nessa perspectiva, questões éticas também devem ser consideradas nas pesquisas qualitativas, sobretudo, quando apresentam a participação de colaboradores/as. De acordo com Resende (2008), os princípios éticos orientadores das relações interpessoais devem ser conhecidos e seguidos por todos/as que fazem pesquisa qualitativa, pois esse tipo de pesquisa envolve vidas de pessoas. A qualidade pode ser vista, pois, como um pré-requisito para a pesquisa eticamente adequada.

Para Flick (2009), a relação entre ética e qualidade na pesquisa qualitativa pode ser discutida a partir de diferentes pontos. O primeiro refere-se à qualidade, considerada précondição para a pesquisa eticamente sólida. O segundo ponto refere-se à reflexão sobre questões éticas. Faz-se característica de qualidade da pesquisa (qualitativa) proteger os dados, evitar danos a participantes e respeitar perspectivas e privacidades. Já o terceiro remete à dimensão dos padrões de qualidade que podem afetar as questões éticas. Do ponto de vista metodológico, por exemplo, quanto mais detalhadamente uma narrativa do/a participante for

\footnotetext{
${ }^{23}$ A triangulação é a exposição simultânea de realidades múltiplas, refratadas (DENZIN; LINCOLN, 2006).
} 
desenvolvida no estudo, melhor será a qualidade dos dados produzidos. No entanto, o detalhamento pode causar vulnerabilidade ao/à participante e isso pode gerar conflito entre padrões metodológicos (ou expectativas de qualidade) e preocupações éticas em relação ao participante. Sendo assim, a proteção de colaboradores/as da pesquisa diz respeito a protegêlos/as de danos físicos e psicológicos, assim como se refere à proteção de sua privacidade e à manutenção do sigilo de todos os dados de pesquisa que possam identificá-los/as (ANGROSINO, 2009).

A pesquisa que utiliza alguma ferramenta etnográfica, como a observação participante, relaciona-se, necessariamente, à interação direta dos/as pesquisadores/as com as pessoas participantes e, por essa razão, pesquisadores/as contemporâneos/as preocupam-se muito com a conduta ética correta na pesquisa. Segundo Flick (2009), deve haver uma relação entre a relevância da pesquisa e a solidez ética, baseada em questões de adequação e uma relação custo/benefício para os/as colaboradores/as da pesquisa.

Também é necessário pontuar a questão da 'validade' da pesquisa qualitativa. Mishler (1990) define a validade da pesquisa qualitativa como uma construção social do conhecimento, pela qual se avalia a veracidade de observações, interpretações e generalizações relatadas. A 'validade' não está mais em definir um critério abstrato e ajustar resultados e procedimentos a ele, mas sim em refletir em vários níveis, enquanto válido é aquilo que encontra consenso dos membros e funciona em campo (FLICK, 2009).

Portanto, o comprometimento, neste estudo, como propõem Denzin e Lincoln (2006), é insistir em um Estado com responsabilidade para com seus cidadãos e suas cidadãs. Para tanto, parto do pressuposto de que a "finalidade da investigação social trata da geração de conhecimento, bem como trata de reformar o 'senso comum' e presta informações críticas às políticas" públicas, aos movimentos sociais existentes e ao dia a dia da comunidade (DENZIN; LINCOLN, 2006, p. 133). A questão não é apenas tomar o poder, mas reinventá-lo em termos de possibilidade de mudança social, inclusão social. A ética de escrever, de analisar textos (orais, escritos, multimodais) faz-se necessária para o interesse da justiça social.

\subsection{Estratégias de investigação}

Em termos de pesquisa qualitativa, o trabalho de investigação do/a pesquisador/a está diretamente suscetível ao valor da abordagem de múltiplos métodos e, por isso, deve ter um compromisso com a compreensão interpretativa da experiência humana, apresentando tensões 
e contradições (DENZIN; LINCOLN, 2006, p. 389). Essas tensões estão relacionadas aos pontos de o/a pesquisador/a qualitativo/a não ser observador/a objetivo/a (politicamente neutro/a) e possuir uma posição histórica diante do objeto estudado. Além disso, a política perpassa todo relato, sendo o significado plural.

A investigação qualitativa é um projeto colaborativo - um diálogo moral contínuo entre participantes, inclusive o/a pesquisador/a. Com isso, o uso de diferentes estratégias de pesquisa - diferentes métodos qualitativos - é uma tentativa de aperfeiçoar o acercamento do objeto de pesquisa, no caso, a constituição e as consequências das discursividades de um Plano de Desenvolvimento Agrário. Nesse sentido, Fairclough (2003) enfatiza a necessidade de relacionar a 'microanálise' de textos à 'macroanálise' de maneiras como relações de poder atuam através de redes, de práticas e de estruturas com o objetivo de acessar os efeitos ideológicos de textos.

A partir da consideração de que o objeto de estudo desta pesquisa diz respeito às discursividades e representações em um PDA, primeiramente, há interesse nos conhecimentos gerados na pesquisa, através de uma análise linguístico-discursiva, com o intuito de compartilhar conhecimentos acerca do PDA Santa Tereza I enquanto ferramenta institucional para o planejamento do desenvolvimento de projetos de assentamentos. Nesse âmbito, a pesquisa busca o acesso a esse conhecimento para poder corroborar com reflexões sobre a luta na terra no Brasil, principalmente, sobre as ferramentas institucionais utilizadas para o desenvolvimento dos assentamentos. Esse foi o principal motivo que impulsionou o interesse pelo objeto de estudo e que impulsiona o desenvolvimento da pesquisa. Faz-se necessária a análise da conjuntura que envolve a elaboração do PDA Santa Tereza I em relação tanto às políticas públicas para o desenvolvimento dos assentamentos já criados, quanto à organização' social de luta na terra, ambas relacionadas ao tipo de reforma agrária implantado no país ao longo dos anos e, sobretudo, nas últimas três décadas.

Além dessa preocupação, o/a pesquisador/a deve se cuidar da análise da prática particular e da análise de discurso (RAMALHO; RESENDE, 2011, p. 106). Desse modo, há de se destacar o desenvolvimento da pesquisa documental, ancorado na necessidade de descrever e interpretar as discursividades e representações no PDA. Toda a pesquisa foi fundamentada teórica e metologicamente de acordo com o os pressupostos da Análise de Discurso Crítica (FAIRCLOUGH, 2003; 2010), como proponente de uma investigação textualmente orientada de problemas sociais, concretizados em textos.

Ademais, a Linguística Sistêmico-Funcional (LSF), como teoria precursora da ADC e como teoria que dialoga em vários aspectos sobre a relação entre linguagem e o social, foi 
uma ferramenta para o desenvolvimento da análise da interioridade da linguagem (microanálise), a qual integra a análise proposta, com o objetivo de identificação de elementos linguísticos que apontem as discursividades e as representações no PDA. Também observe-se a utilização do programa computacional Wordsmith Tools (SCOTT, 2012) diante a extensão do texto do PDA e, consequentemente, a quantidade de dados constituinte do corpus de natureza documental. O uso dessa ferramenta contribui para a visualização de dados em um corpus extenso, no caso, a descrição e a interpretação de dados do PDA. Os dados selecionados a partir do uso dessa ferramenta também foram analisados à luz da ADC e da LSF. Em se tratando de discursividades, há consideração também da representação dos atores sociais. Para isso, foi feita a opção pelos pressupostos de van Leeuwen (1997; 2008), por tratarem da representação dos atores sociais em termos de rede de sistemas, como já discutido no Capítulo 2. Para a análise dos dados documentais, ocorre, pois, uma triangulação teóricometodológica.

Além da investigação com dados documentais, a investigação com dados de natureza etnográfica, gerados, sobretudo, a partir de entrevistas realizadas com assentados/as pioneiros/as do PA Santa Tereza I (participaram das reuniões com a COOPVAG para elaboração do referido PA por estarem acampados/as onde está situado o assentamento) e com funcionários do INCRA (responsáveis técnicos pela elaboração do PDA) integra pesquisa proposta em termos de representações e identificações constituídas no PDA. Ressalte-se o desenvolvimento de ambas as investigações, o que propicia outra triangulação, a triangulação de dados, para um maior acercamento do objeto de pesquisa. Nesse ponto, há de se observar ainda a ocorrência de uma triangulação de ferramentas de investigação, utilizadas para a configuração da análise proposta.

Com isso, torna-se pertinente a investigação das discursividades e das representações no PDA do PA Santa Tereza I com o objetivo de desvelar representações frente aos diferentes discursos que circulam no contexto de constituição e uso de um PDA. Questiona-se quem prescreveu ações concretizadas linguisticamente no PDA, como prescreveu, para quem prescreveu a realização das ações. Esses questionamentos são orientados devido ao propósito para o qual o PDA foi elaborado.

Sobre a relevância social da pesquisa, ela está pautada na partilha de saberes gerados a partir da investigação realizada com as pessoas envolvidas na elaboração do PDA do PA Santa Tereza I e colaboradores deste estudo (assentados/as pioneiros/as e funcionários do INCRA-SR26), através da apresentação dos resultados da pesquisa, bem como através da doação de uma cópia da tese para cada tipo de participante. 


\subsection{Coleta e seleção de dados de natureza documental}

No Brasil, desde a época da colonização, questões agrárias referentes à posse de terras, à Reforma Agrária, sempre estão em voga, seja no âmbito governamental, devido a mobilizações populares, seja no âmbito midiático. Muitas questões referentes ao uso da terra por assentados/as e concretizadas em textos institucionais, como o PDA, não estão, porém, ainda em voga nas instâncias citadas e nem na instância acadêmica da Linguística e, especificamente, da Análise de Discurso Crítica. Sendo assim, a principal abordagem metodológica para a elaboração deste trabalho é a pesquisa documental, utilizando métodos e técnicas para sua apreensão, compreensão e análise de documentos dos mais variados tipos (SÁ-SILVA et al., 2009).

\subsubsection{O corpus de natureza documental}

A pesquisa proposta é constituída, sobretudo, de um documento institucional escrito, no âmbito do INCRA, referente a instrumentos concretizados linguisticamente em textos escritos, elaborados para prover a Reforma Agrária no Brasil e, especificamente, o planejamento do desenvolvimento de projetos de assentamentos a partir de um recorte temporal.

Ao considerar o foco do objeto de pesquisa ora proposto - investigação de discursos (re)contextualizados em um Plano de Desenvolvimento Agrário -, o principal texto documental/institucional constituinte do corpus deste estudo é o PDA do PA Santa Tereza I. O II PNRA, de 2004, e a Norma de Execução/INCRA/DD/No. 71, de 12 de maio de 2008, formam parte do corpus de natureza documental como forma de acercamento do corpus básico, em termos de recorte temporal para sustentação da análise linguístico-discursiva. Esses textos compõem a triangulação dos dados, em relação ao recorte temporal de hierarquia de textos institucionais, na instância federal de planejamento, regulamentação e execução de políticas públicas, referentes à reforma agrária durante os governos do presidente Lula. Ambos os textos institucionais materializam uma perspectiva sobre o uso de terras no Brasil.

A política de reforma agrária concernente à ampliação de projetos de assentamentos no Brasil é relativamente nova, com intensificação a partir da elaboração do II Plano Nacional de Reforma Agrária (2004). Ainda há mais interesse midiático e político sobre mobilizações populares com objetivo da luta pela terra - 'desapropriações' de grandes latifúndios quando ocorrem, ampliação do número de PAs e aumento do número de assentados/as em contraste 
aos interesses do agronegócio, legislação sobre distribuição de terras - do que há interesse sobre a luta na terra. Mesmo no meio acadêmico-científico, o que interessa aqui, muitas pesquisas desenvolvidas em várias áreas do conhecimento e, principalmente, nos ramos da Linguística, sobre o tema Reforma Agrária no Brasil ainda estão muito voltadas para análise sobre a luta na terra. No caso da $\mathrm{ADC}$, há pesquisas cujos corpora se referem à luta pela terra em textos oficiais, midiáticos, de movimentos sociais, mas ainda há de se desenvolver muitas pesquisas sobre a luta na terra, sejam relacionadas à regulamentação da manutenção da concessão de uso da terra, sejam relacionadas aos modos de vida nos assentamentos, como é o caso da presente pesquisa.

No entanto, especificamente nas últimas duas décadas, como houve uma considerável ampliação dos projetos de assentamentos por todo o país em comparação com qualquer outro momento histórico, políticas públicas referentes à organização dos PAs foram criadas e implementadas, com regulamentações e normatizações na instância federal. Nessa perspectiva, há interesse de pesquisa em um PDA, uma vez que se refere a um planejamento de funcionamento de um assentamento. O PDA, considerado como fenômeno social, um gênero discursivo (FAIRCLOUGH, 2003), configurado através do uso da linguagem escrita, constitui representações sociais em um contexto sócio-histórico determinado. Cada gênero discursivo articula discursos em determinados contextos sócio-históricos e culturais, sendo definido pelas práticas sociais que o compõem e o articulam.

\subsubsection{Procedimentos de saturação do corpus documental}

A situação agrária no Brasil é resultado de questões referentes à propriedade da terra, presentes desde a primeira fase de ocupação europeia, em 1500. Até os dias de hoje essa problemática faz com que a questão agrária continue como tema importante em discussões de políticas públicas para o campo, concomitante a discussões a respeito da modernização da agricultura. Durante esse período, textos institucionais foram criados para "organizar" essa situação, de acordo principalmente com os contextos sócio-políticos existentes no país, com o poder político vigente em cada época. Para esta pesquisa, cujo objetivo principal é refletir sobre as discursividades de um PDA, foi necessário fazer um recorte temporal em relação aos textos que originaram a constituição de PDAs. 
Quadro 3.1 - Corpus ampliado para suporte à análise discursiva

\begin{tabular}{|c|l|c|}
\hline Data & \multicolumn{1}{|c|}{ Dispositivos legais } & Total de páginas \\
\hline 2008 & Norma de Execução no. 71 & 47 \\
\hline 2004 & II PNRA & 40 \\
\hline 2007 & PDA do PA Santa Tereza I & 236 \\
\hline
\end{tabular}

O II Plano Nacional de Reforma Agrária (II PNRA), de 2004, foi elaborado em meio à intensificação de discussões sobre formas de fazer a reforma agrária no Brasil. Muitas mobilizações populares ocorreram, principalmente, a partir da criação do MST na década de 1980. Sendo assim, o II PNRA forma parte das políticas públicas sobre reforma agrária. O PDA, no caso, configura-se como um instrumento do MDA e executado pelo INCRA com o intuito de colocar em prática ações propostas no II PNRA no que se refere ao desenvolvimento de PAs.

Já a Norma de Execução/INCRA/DD/No. 71, de 12 de maio de 2008, "Estabelece critérios e procedimentos referentes à Assessoria Técnica, Social e Ambiental a Reforma Agrária - ATES", como a constituição de PDAs, apesar de o PDA do PA Santa Tereza I ser de 2007. De acordo com uma nota de campo, foi registrado um questionamento a um funcionário do INCRA sobre o documento que instruiu a elaboração de PDAs.

(1) O funcionário do INCRA me relatou que o PDA é uma das ferramentas utilizadas pelo órgão para subsidiar o planejamento de demandas de organização dos PAs, com o componente participativo de candidatos/as a um lote e, por isso, o PDA somente aparece em normativas internas. Além disso, informou que a Norma de Execução/INCRA/DD/No. 71 é a norma interna que orienta o conteúdo dos PDAs. No instante, questionei sobre a data de publicação da Norma. Ele apontou essa norma de execução como o texto institucional que especifica a elaboração do PDA, apesar de sua publicação ser de 2008 e o PDA Santa Tereza I ser de 2007.

(Nota 11 INCRA, 16 de julho de 2014)

O II PNRA e a Norma de Execução no. 71 são meios de perpassar os caminhos da legislação brasileira até a constituição dos PDAs e, por isso, interessam a esta pesquisa. 


\subsubsection{A ferramenta computacional Wordsmith Tools e os dados documentais}

O programa Wordsmith Tools (SCOTT, 2012) é uma ferramenta computacional utilizada pela Linguística de Corpus, uma ciência que faz uso de ferramentas computacionais para o armazenamento, tratamento e análise de dados linguísticos. No caso da pesquisa proposta, há uso dessa ferramenta computacional para a análise da "interioridade da linguagem" em dados documentais. O programa é composto dos seguintes instrumentos de análise: lista de palavras (wordlist), concordância (concord) e palavras-chave (keywords).

O instrumento 'lista de palavras' fez um levantamento do número de palavras do PDA analisado (parte do corpus da pesquisa), disponibilizando-o em ordem de frequência e em ordem alfabética. Já o 'concordância' possibilitou a criação de concordâncias entre palavras da 'lista de palavras'; criação de listas de palavras à esquerda e à direita da palavra selecionada, em ordem de frequência; criação de listas de frases comuns; e criação de listas de grupamentos lexicais (SCOTT, 2012).

O analista, que utiliza o Wordsmith, dispõe de recursos para investigação de aspectos da linguagem como, no caso, a organização composicional de gêneros discursivos e a composição lexical de textos institucionais, principalmente quando esses textos para a análise são extensos e muitos. O Wordsmith Tools pode ser utilizado, então, como ferramenta para análise e interpretação tanto de corpus com poucos dados e com muitos dados, uma vez que auxilia na localização e na frequência de palavras nos textos em um tempo menor e em detalhes.

\subsection{Geração de dados de natureza etnográfica}

Alguns instrumentos de coletas de dados requisitados por esta pesquisa são de natureza etnográfica - observação participante, nota de campo e entrevista semiestruturada. Eles apresentam, principalmente, a finalidade de acercamento do fenômeno estudado, corroborando também para a proposição da triangulação de ferramentas de origem etnográfica. Etnografia, aqui, é definida como "a arte e a ciência de descrever um grupo humano - suas instituições, seus comportamentos interpessoais, suas produções materiais e suas crenças" (ANGROSINO, 2009, p. 30). Essa definição implica a concepção de que a etnografia é feita in loco e o/a pesquisador/a, que se propõe a desenvolver alguma de suas ferramentas, é alguém participante, de certa forma, subjetivamente das vidas daqueles/as que estão sendo estudados/as, assim como um/uma observador/a daquelas vidas. 
Sendo assim, a pesquisa ora apresentada não é etnográfica, mas utiliza ferramentas da pesquisa etnográfica para geração e coleta de dados a partir da colaboração dos/as envolvidos/as com a elaboração do PDA Santa Tereza I. A pesquisadora esteve em campo com assentados/as e funcionários do INCRA, mas não houve um período de permanência para que se que possa denominar a pesquisa proposta como 'pesquisa etnográfica'.

Para validação desta pesquisa através da geração de dados de natureza etnográfica, propôs-se a constituição da triangulação de fontes de dados, o que envolve certa comparação de dados relacionados ao mesmo fenômeno no trabalho de campo (HAMMERSLEY; ATKINSON, 1983). No caso, há três triangulações: a triangulação de fontes de dados de natureza documental e dados de natureza etnográfica; a de ferramentas etnográficas, como notas de campo e entrevistas semiestruturadas; e a triangulação de teorias, como a Análise de Discurso Crítica e Linguística Sistêmico-Funcional. Com as triangulações, há uma tentativa de relação entre diferentes tipos de dados para a validação da pesquisa, com adaptação do uso de métodos à situação e com adaptação dos próprios métodos.

A partir da utilização dessas ferramentas, o/a pesquisador/a estabelece conversações recíprocas com as pessoas da comunidade (ANGROSINO, 2009) e o uso flexível e híbrido de diferentes formas de coletar dados - triangulação de ferramentas etnográficas - pode levar a maiores potenciais de conhecimento, com suas convergências e divergências. Isso pode desvelar diferentes perspectivas sobre uma questão em pesquisa e essa postura pode ampliar a qualidade para a pesquisa qualitativa. Ainda, para o teórico (2009), os métodos etnográficos são especialmente úteis para as situações de campo, como questões sociais, comportamentos não são claramente entendidos; ou para obter o ponto de vista das pessoas participantes da pesquisa.

\subsubsection{O PA Santa Tereza I}

Como dito no início deste estudo, o estado do Tocantins possui aproximadamente 46.000 famílias morando no campo, tentando sobreviver do trabalho com a terra, e mais da metade vive em projetos de assentamentos. No Estado mais novo do Brasil, segundo dados do Sistema de Informações de Projetos de Reforma Agrária (SIPRA), em 06 de setembro de 2010, havia 366 projetos de assentamento, com capacidade para 24.275 unidades agrícolas familiares, com 23.110 famílias assentadas. Observa-se, sobre isso, a exclusão social daqueles/as que necessitam do trabalho com o uso da terra, apesar do problema parecer ser resolvido através da criação de projetos de assentamentos e seus PDAs. O/a assentado/a, por 
sua vez, pode ter a vida, de certa forma, determinada pelo PDA do assentamento, haja vista o INCRA ter exigido a participação dele/a nas reuniões para sua elaboração, como condição para que os lotes do PA, onde era candidato/a, fossem sorteados.

Nesse contexto, o projeto de assentamento Santa Tereza I (PA Santa Tereza I) foi instituído em fevereiro de 2006, a partir de desapropriação da fazenda Santa Tereza (em 2005), localizada no município de Ponte Alta, no estado do Tocantins. O PA possui capacidade para 47 famílias e o mesmo número de famílias foi assentado. A área do PA está localizada a uma distância de 49,5 $\mathrm{km}$ da sede do seu município ao qual forma parte. No entanto, o PA Santa Tereza I situa-se a uma distância aproximada de $25 \mathrm{~km}$ da sede do município de Santa Tereza do Tocantins, o que faz com que a comunidade inserida no PA dependa em diversos aspectos deste município.

Além disso, a entidade representativa dos/as assentados/as é a Associação dos Pequenos Produtores Rurais do PA Santa Tereza I, cujo CNPJ é 08150356/0001-13.

\subsubsection{Observação participante}

Um dos principais instrumentos para geração e coleta de dados de natureza etnográfica, em termos de pesquisa qualitativa, é a observação participante. A observação participante consiste em um modo de permitir que o/a pesquisador/a seja inserido/a no contexto de campo de pesquisa, corroborando para a análise do "todo" estudado. Esse tipo de observação forma parte de uma postura de pesquisa denominada 'participante' devido ao princípio de que o/a pesquisador/a tem sempre um grau de interação com a situação estudada, afetando-a ou sendo afetado por ela (ANDRE, 1995, p. 28). O/a pesquisador/a com essa observação participa, de certa forma, do cotidiano da comunidade vivente do problema estudado.

A ‘interação’ do/a pesquisador/a, para Ludke \& André (1986), sugere uma escala de continuum de observação: participação total, participação-como-observador, observadorcomo-participante e observador total, como destaca Silva (1991, p. 51). O observador denominado participante total coleta informações do seu interesse no grupo, de forma espontânea, sem revelar sua identidade e seus objetivos. O participante-como-observador revela sua identidade e parte de seus interesses de pesquisa. Esse tipo de observação facilita as relações sociais durante a pesquisa. O observador-como-participante revela tanto sua identidade quanto os objetivos de pesquisa ao grupo. Já o observador total não interage com o grupo e sua pesquisa é desenvolvida sem que o grupo perceba. 
Neste estudo, para geração de dados de natureza etnográfica, adotou-se a posição de observador-como-participante. O motivo dessa escolha deveu-se ao fato de tanto os funcionários do INCRA quanto os/as assentados/as terem conhecimento da identidade da pesquisadora e dos objetivos de pesquisa. Ademais, o grupo de colaboradores/as forneceu uma série de informações para obtenção de dados a partir de tais conhecimentos.

Também, de acordo com Angrosino (2009), a observação participante não é propriamente uma técnica de coletar dados e sim um papel adotado pelo/a pesquisador/a para facilitar sua coleta de dados. Faz-se uma estratégia de pesquisa para analisar contextos concretos e estruturas sociais.

Além disso, segundo Denzin (1989), a observação participante é uma estratégia de campo que combina, simultaneamente, análise de documentos, entrevistas, participação e observação diretas e introspecção, como aponta a fotografia abaixo.

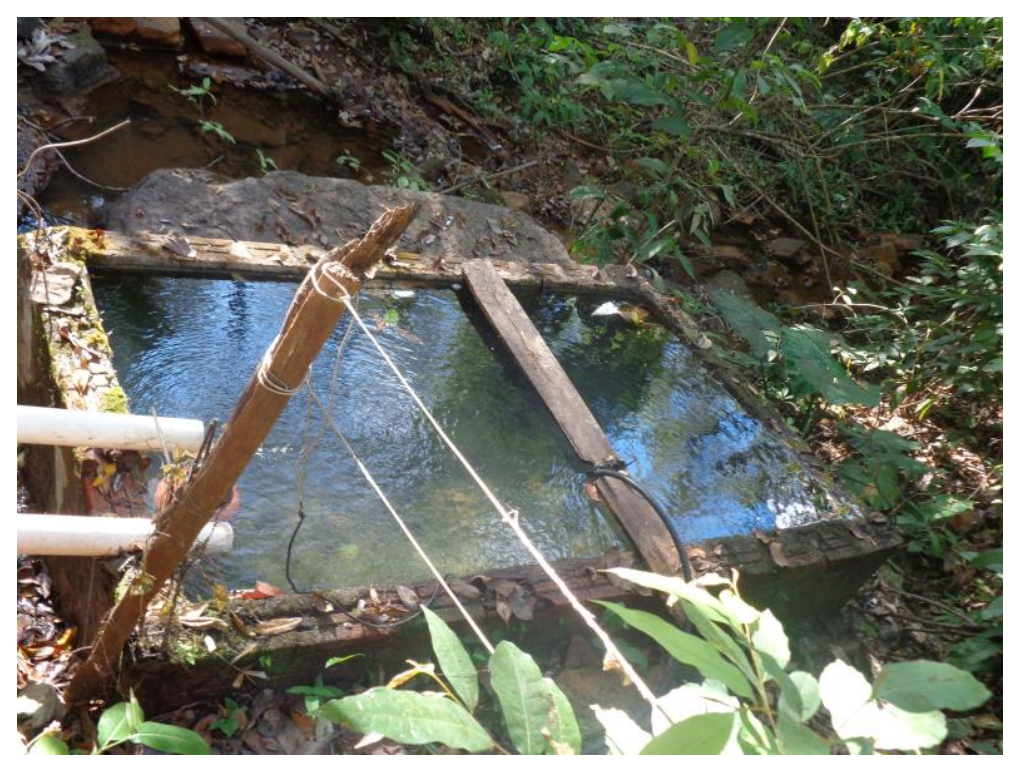

Fotografia 3.1 - Água disponibilizada à escola do PA

A Fotografia 3.1 forma parte das observações da pesquisadora dos espaços comuns utilizados pela comunidade assentada. No caso, essa fotografia sinaliza a qualidade ruim da água enviada à escola do assentamento e, consequentemente, consumida por alunos/as e professora.

A principal característica da observação participante é, então, descrever detalhes do modo mais objetivo possível, pondo de lado os próprios preconceitos (ANGROSINO, 2009). A partir da observação participante é que os métodos etnográficos podem ocorrer com qualidade. 


\subsubsection{Notas de campo}

Nesta pesquisa, as observações foram registradas em notas de campo. As notas de campo formam parte do trabalho de campo como uma ferramenta etnográfica, articulando percepções e interpretações de momentos diversos da pesquisa.

A propósito, as notas de campo são consideradas em três tipos: inscrição, transcrição e descrição (CLIFFORD, 1993). Na inscrição, o/a pesquisador/a faz notas durante as interações com colaboradores/as da pesquisa, a partir de anotações de palavras-chave que auxiliam no desenvolvimento posterior de notas mais acuradas. Já na transcrição, o/a pesquisador/a anota as respostas dos/as colaboradores/as durante a entrevista. Na descrição, o/a pesquisador/a reflete acerca da realidade cultural analisada através de interpretações e análises das representações observadas. No caso das notas registradas no assentamento e no INCRA, o tipo descrição foi privilegiado nas situações observadas, por opção pelas anotações após as observações, conversas e entrevistas, principalmente, para não prejudicar o desenvolvimento das interações.

A nota de campo, a seguir, faz-se um exemplo de como esse tipo de ferramenta etnográfica pode integrar e favorecer a análise dos dados.

O pioneiro Xexéu relatou-me e eu pude contatar a dificuldade que possui para conseguir água para o consumo próprio no assentamento. Para beber água, esse senhor de 67 anos necessita contar com a permissão do pioneiro vizinho para usar uma nascente, pois no seu lote não há disponibilidade de água. Além disso, para acessar a nascente, o pioneiro necessita caminhar 1.200 metros por um terreno íngreme, guiando um carrinho de mão com alguns vasilhames para armazenar água. Devido à idade avançada, adquiriu problemas de locomoção e passa por dificuldades para condução do carrinho morro acima.

(Nota 19 PA, 24 de julho de 2014)

Trata-se de uma nota registrada após entrevista com um assentado. Nesse dia, a pesquisadora se deparou com uma situação inesperada em relação ao tamanho da dificuldade enfrentada pelo pioneiro para sobreviver no lote concedido a ele, já que não há disponibilidade de água no mesmo.

Para Angrosino (2009), quanto mais registros de observações "em campo" contiverem a mesma informação, mais consistente será o processo de recuperar e comparar dados. As notas de campo fazem parte da rotina de uma boa observação participante. As notas de campo, aqui, fazem referência tanto ao ambiente institucional (INCRA) quanto ao ambiente do assentamento (assentados/as). 


\subsubsection{Entrevistas semiestruturadas}

As entrevistas são uma extensão lógica da observação participante. "Entrevistar é um processo que consiste em dirigir a conversação de forma a colher informações relevantes" (ANGROSINO, 2009, p. 61). Quando se fala em entrevista semiestruturada, considera-se que flui interativamente a partir de tópicos predeterminados e campos de interesse pelo/a pesquisador/a. Segundo Angrosino (2009, p. 67), “a entrevista semiestruturada segue de perto o tópico escolhido de antemão e apresenta questões destinadas a extrair informações específicas sobre aquele tópico". Há uma parceria entre o/a pesquisador/a e as pessoas entrevistadas de um grupo específico, já que aquele/a, de certa forma, conhece o grupo e este conhece o/a pesquisador/a.

Nesse sentido, em pesquisa qualitativa, a verdade pode ser considerada relativa ao se reconhecer a existência de 'múltiplas vozes' e, muitas vezes, busca-se essas vozes em vez de uma 'visão definitiva'. Essa abordagem pode iluminar as preocupações daqueles/as cujas vozes estariam de outra forma, emudecidas (BARBOUR, 2009).

Esse tipo de entrevista possui um/a único/a respondente (entrevista em profundidade) com "o objetivo de uma compreensão detalhada das crenças, atitudes, valores e motivações, em relação aos comportamentos das pessoas em contextos sociais específicos" (GASKELL, 2008, p. 65). Com isso, é iniciada a partir de um tópico guia, apresenta foco em pontos específicos de interesse, mas permite uma interação mais livre, flexível. Esse método visa permitir aos/às participantes liberdades para relatarem o que consideram importante sobre o tema abordado.

$\mathrm{Na}$ pesquisa ora apresentada, funcionários da Superintendência Regional do INCRA no Tocantins (INCRA-SR26), responsáveis técnicos pela elaboração do PDA estudado, e assentados/as pioneiros/as do PA Santa Tereza I foram entrevistados/as. ${ }^{24}$ Com ambos os tipos de entrevistados/as, o tópico guia fez referência à constituição do PDA do PA Santa Tereza I em termos de representações dos/as envolvidos/as nesse processo. Como se trata de uma técnica, as entrevistas semiestruturadas foram procedidas de acordo com os objetivos da pesquisa.

\footnotetext{
${ }^{24}$ Esta pesquisa apresenta como escopo principal analisar discursos (re)contextualizados no Plano de Desenvolvimento Agrário Santa Tereza I e que institucionalizam e tentam organizar o PA Santa Tereza I, no município de Ponte Alta-TO. A partir disso, identificar e analisar representações linguístico-discursivas constituídas no PDA. Para tanto, tem-se os seguintes objetivos específicos: Investigar as representações constituintes do PDA Santa Tereza I; Verificar as práticas sociais estabelecidas entre os/as assentados/as e o PDA; Investigar as representações envolvidas entre representantes do governo e os/as assentados/as no que concerne tanto à constituição do PDA Santa Tereza I quanto à sua execução; Estabelecer, por meio de análise discursiva linguisticamente orientada, a constituição de identificações dos sujeitos constitutivos do PDA.
} 
Para que isso ocorresse, o projeto dessa pesquisa foi submetido à apreciação do Comitê de Ética da Universidade de Brasília (CEP-UnB) devido a questões éticas, visto que a colaboração de seres humanos integra a pesquisa, o que exige princípios éticos para resguardar as pessoas de qualquer risco ou dano. Na submissão, o projeto foi aprovado pelo referido comitê e o parecer de aprovação encontra-se nos Anexos desta tese. Depois da aprovação do CEP-UnB, iniciei as visitas ao PA e ao INCRA.

No caso do PA, no primeiro momento, os espaços de convivência mútua foram visitados, como uma pequena mercearia em um dos lotes, onde ocorrem os eventos da comunidade. Devido ao número expressivo de pessoas assentadas encontrado ao mesmo tempo, a pesquisadora pôde conhecê-las e suas famílias. A opção por esse tipo de contato deuse por o PA possuir uma extensão de terras muito grande, sem estradas e sem sinalização com indicação dos lotes. Nesses encontros, como a festa anual da colheita da mandioca, houve contato, conversas com a maioria das pessoas de interesse da pesquisa. Nessas conversas, o assunto predominante foi acerca das condições de sobrevivência nos lotes do assentamento; além disso, houve apresentação da pesquisadora e da pesquisa em desenvolvimento. Em outro momento específico, as entrevistas com os/as assentados/as foram realizadas nos lotes, pois durante as conversas iniciais a maioria convidou a pesquisadora para visitar os lotes com o intuito de observar mais detalhadamente as condições de sobrevivência a que estavam submetidos/as.

Enquanto para a realização dessas entrevistas, a pesquisadora e suas colaboradoras foram conduzidas a cada lote pelo presidente da associação de moradores do PA Santa Tereza I devido à dificuldade de acesso aos lotes. Nos lotes, cada o/a assentado/a era convidado/a a participar da pesquisa, após uma breve apresentação da mesma. Destaque-se que dos 23 lotes com assentados/as pioneiros/as, 21 moradores/as foram encontrados/as e todos/as aceitaram participar da pesquisa por meio de concessão de uma entrevista. Depois de cada participante aceitar conceder a entrevista, a pesquisadora leu para cada um/a o Termo de Consentimento Livre e Esclarecido (TCLE), cujo conteúdo faz referência à explicação pormenorizada dos objetivos da pesquisa, dos dados pessoais e profissionais da pesquisadora relacionados ao estudo, da participação voluntária do/a entrevistado/a, do desenvolvimento da entrevista e da preservação da identidade do/a participante. ${ }^{25}$ Por conseguinte à leitura, o/a participante e a pesquisadora assinaram duas vias do TCLE, sendo uma das vias entregue a ele/ela. Além

\footnotetext{
${ }^{25}$ Para a realização das entrevistas, foram elaborados dois Termos de Consentimento Livre e Esclarecido (TCLEs) - um para as entrevistas com os/as assentados/as pioneiro/as e outro para as entrevistas com os funcionários do INCRA-SR26. Ambos se encontram na íntegra nos Anexos dessa tese.
} 
desse termo, para identificar os/as entrevistados/as, documentar o contexto e a situação da geração de dados, o modelo de ficha de documentação proposto por Flick (2004, p. 185) e adaptado no Quadro 3.2, abaixo, foi preenchido.

\section{Quadro 3.2 - Ficha de documentação de assentado/a participante da pesquisa}

\begin{tabular}{|l|l|}
\hline \multicolumn{2}{|c|}{ Ficha de documentação } \\
\hline \multicolumn{2}{|c|}{ Informações sobre a entrevista e o entrevistado: } \\
\hline Pseudônimo para o entrevistado & \\
\hline Data da entrevista & \\
\hline Local da entrevista & \\
\hline Cidade do entrevistado & \\
\hline Sexo do entrevistado & \\
\hline Idade do entrevistado & \\
\hline Nível de escolaridade & \\
\hline Estado Civil & \\
\hline Filhos & \\
\hline Tempo no assentamento & \\
\hline Produção do lote & \\
\hline Local de trabalho & \\
\hline Auxílio do governo & \\
\hline Duração da entrevista & \\
\hline Observações &
\end{tabular}

Baseado e adaptado em Flick (2004).

A organização das informações pessoais de cada participante tem o objetivo principal de documentar cada entrevista em sua especificidade, o que permite à pesquisadora uma maior aproximação e compreensão dos relatos dos/as entrevistados/as. Ademais, a 'Ficha de documentação' configura um perfil de cada entrevistado/a, com informações pessoais e profissionais, o que contribuiu tanto para a análise dos dados de natureza documental quanto dos dados de natureza etnográfica.

$\mathrm{Na}$ fase de iniciação da entrevista, a gravação começou a partir da introdução do tópico guia, com a finalidade de obter relatos de assentados/as pioneiros/as acerca do objeto de estudo dessa pesquisa e com o mínimo de interferência em suas falas. O tópico guia foi configurado em: Gostaria que você me contasse como o PDA Santa Tereza I foi elaborado. A proposta foi não interromper os relatos, fazendo apenas sinais de encorajamento para que continuassem falando. Em se tratando dos/as participantes assentados/as, houve necessidade de interferir, porém, em alguns momentos da entrevista através de 'comentários explicativos', principalmente, quando não se lembravam de acontecimentos, fatos das reuniões com a COOPVAG, com o objetivo de dar continuidade aos relatos. 
Já a fase central da entrevista teve como propósito o relato dos/as participantes sobre as participações das pessoas envolvidas - da COOPVAG, do INCRA, assentado/a - na elaboração do PDA do PA Santa Tereza I.

Depois, na fase de perguntas a partir do tópico guia, houve inserção de perguntas com o propósito de obter mais esclarecimentos, detalhes, sobre a elaboração do PDA e o tipo de participação dos/as envolvido/as na elaboração do mesmo. Essas fases justificam a especificação 'semiestruturada' para esse tipo de entrevista, pois prima pela 'fluidez interativa' (ANGROSINO, 2009). A seguir, no Quadro 3.3, há o esboço das perguntas planejadas e elaboradas aos/às assentados/as com o objetivo de melhor elucidar os relatos sobre o tópico guia e, consequentemente, contribuindo para responder os objetivos da pesquisa.

Quadro 3.3 - Questões das entrevistas dos/as assentados/as ${ }^{26}$

\begin{tabular}{|l|l|}
\hline Tópico: & A elaboração do PDA do PA Santa Tereza I \\
\hline Questão 'a': & Quem elaborou o PDA Santa Tereza I? \\
\hline Questão 'b': & Qual foi sua participação na elaboração do PDA Santa Tereza I? \\
\hline Questão 'c': & Você possui cópia do PDA? \\
\hline Questão 'd': & Você tem conhecimento sobre conteúdo final do PDA? \\
\hline Questão 'e': & Você se sente representado no PDA Santa Tereza I? \\
\hline Questão 'f': & O PDA está sendo executado no PA Santa Tereza I? \\
\hline Questão 'g': & O INCRA faz cumprir o PDA? \\
\hline Questão ' $h$ ': & O PDA ajuda a melhorar a vida do assentado/a? \\
\hline
\end{tabular}

Observe-se que, no decorrer das entrevistas, nem todas as questões propostas acima foram feitas devido a especificidades próprias de cada participante, relato, e que serão apresentadas, posteriormente, no Capítulo 5. Desse modo, algumas questões planejadas não foram feitas e outras questões relacionadas ao tópico guia surgiram durante as entrevistas. No entanto, todas as respostas foram registradas, analisadas e estão transcritas nos Anexos deste estudo.

Em se tratando das entrevistas com os funcionários do INCRA SR26 (INCRATocantins), os mesmos passos seguidos nas entrevistas com os/as assentados/as pioneiros/as foram seguidos nas entrevistas com os 02 funcionários do INCRA entrevistados, inclusive com a utilização do mesmo tópico guia. Observe-se que o número de entrevistados no INCRA foi determinado pela atribuição de responsabilidade técnica para elaboração do PDA em estudo a apenas dois funcionários diretamente. O processo de desenvolvimento das entrevistas

\footnotetext{
${ }^{26}$ As 'questões complementares' foram elaboradas como uma exigência do Comitê de Ética da Universidade de Brasília, ao qual o projeto de pesquisa desta tese foi submetido e aprovado.
} 
só se diferenciou no conteúdo do TCLE, da ficha de documentação e das questões das entrevistas, como seguem os modelos com esses formulários nos Quadros 3.4 e Quadro 3.5, exceto o TCLE disponibilizado nos Anexos.

\section{Quadro 3.4 - Ficha de documentação de}

funcionário do INCRA participante da pesquisa

\begin{tabular}{|l|l|}
\hline \multicolumn{2}{|c|}{ Ficha de documentação } \\
\hline \multicolumn{2}{|c|}{ Informações sobre a entrevista e o entrevistado: } \\
\hline Pseudônimo para o entrevistado & \\
\hline Data da entrevista & \\
\hline Local da entrevista & \\
\hline Cidade do entrevistado & \\
\hline Sexo do entrevistado & \\
\hline Idade do entrevistado & \\
\hline Nível de escolaridade & \\
\hline Estado Civil & \\
\hline Função no INCRA & \\
\hline Tempo de trabalho no INCRA & \\
\hline $\begin{array}{l}\text { Tipo de participação na elaboração do } \\
\text { PDA Santa Tereza I }\end{array}$ & \\
\hline Duração da entrevista & \\
\hline Observações &
\end{tabular}

Baseado e adaptado em Flick (2004).

\section{Quadro 3.5 - Questões das entrevistas dos responsáveis técnicos pelo PDA}

\begin{tabular}{|l|l|}
\hline Tópico: & A elaboração do PDA do PA Santa Tereza I \\
\hline Questão 'a': & Quem elaborou o PDA Santa Tereza I? \\
\hline Questão 'b': & Qual é a participação dos assentados na elaboração do PDA? \\
\hline Questão 'c': & Qual foi sua participação na elaboração do PDA Santa Tereza I? \\
\hline Questão 'd': & Você tem conhecimento sobre conteúdo final do PDA? \\
\hline Questão 'e': & $\begin{array}{l}\text { Em qual parte do processo do PDA Santa Tereza I a COOPVAG deixou } \\
\text { de prestar assistência técnica ao PA Santa Tereza I uma vez que o PDA } \\
\text { diz que ela participaria tanto da elaboração quanto da execução do } \\
\text { mesmo? }\end{array}$ \\
\hline Questão 'f': & O PDA está sendo executado no PA Santa Tereza I? \\
\hline Questão 'g': & O INCRA faz cumprir o PDA? \\
\hline Questão 'h': & O PDA ajuda a melhorar a vida do assentado/a? \\
\hline
\end{tabular}

\subsubsection{Os/as participantes das entrevistas}

Ao se referir a um PDA, em termos de seu entendimento e sua interpretação, faz-se importante relacioná-lo ao contexto de situação e ao seu contexto de cultura que o constituem. 
Há, pois, atores sociais que o produziram; há políticas públicas que permitem sua elaboração; e também há outros textos (institucionais) que o sustentam legalmente. Nesse sentido, os PDAs concretizam discursividades, representações específicas e, para a investigação delas, a análise constituiu-se a partir de dois corpora: o corpus de natureza documental escrita - o PDA do PA Santa Tereza I - e o corpus de natureza etnográfica ou documental oral.

No que se refere ao corpus de natureza documental oral, configura-se a estratégia de triangulação de dados que se complementam. Apesar de serem de naturezas diferentes, os dois tipos de dados propiciam análises que estabelecem o acercamento mais detalhado do objeto de pesquisa, uma vez que os dados etnográficos foram gerados, principalmente, a partir de entrevistas semiestruturadas realizadas com pessoas envolvidas, de alguma forma, na elaboração do texto do PDA pesquisado, que forma parte do corpus documental. Sendo assim, a partir da observação participante, foram entrevistados/as tanto assentados/as pioneiros/as do PA Santa Tereza I quanto funcionários do INCRA-SR 26/Tocantins.

Em se tratando das entrevistas, foram entrevistados/as assentados/as pioneiros/as do PA Santa Tereza I. A denominação 'pioneiro/a' atribuída a alguns/mas assentados/as, tanto pelo INCRA quanto por outros/as assentados/as, é motivada pelo fato de essas pessoas permanecerem sob a lona preta (acampadas) em terras da propriedade onde seria o assentamento Santa Tereza I por dois anos. O acampamento foi constituído por motivo de mobilização para obtenção de um lote no assentamento que estava sendo criado no local. Como estavam mobilizadas em um acampamento, todas as pessoas acampadas eram candidatas a um lote no futuro PA.

Na época, entre 2006 e 2007, a elaboração do PDA era uma das exigências do INCRA para que os lotes de novos assentamentos fossem 'sorteados' e, consequentemente, as pessoas sorteadas - selecionadas a participarem do PA - pudessem mudar do acampamento para os lotes. O INCRA exigia a presença de, pelo menos, um membro de cada família (homem ou mulher) nas reuniões, cujo objetivo consistia no planejamento do desenvolvimento do 'futuro' PA, planejamento materializado linguisticamente no PDA do assentamento. Por esse motivo, 21 das 23 famílias pioneiras, ainda residentes no assentamento Santa Tereza I no decorrer da pesquisa, foram entrevistadas. Pessoas de duas famílias não foram entrevistadas devido ao motivo de não se encontrarem no lote durante o período de realização das entrevistas. Por causa da grande distância entre os lotes e da dificuldade de mobilidade (sem estradas) entre eles, não foi possível retornar a dois lotes na tentativa de e realizar as entrevistas novamente.

Ressalte-se que a pesquisadora percorreu os 23 lotes de pioneiros/as para que a observação participante pudesse ocorrer também neste locus (e não somente na sede da 
associação do PA), para que as entrevistas pudessem acontecer de forma individual e respeitar a solicitação de alguns/mas pioneiros/as com referência à visita aos lotes. Durante algumas visitas à associação de moradores/as e a um evento comemorativo do PA em um dos lotes, ao conversar com pioneiros/as sobre a vida no PA, as condições de sobrevivência, a pesquisadora foi convidada a visitar vários lotes para observar a 'realidade' de cada um. Uma das visitas foi durante a festa da mandioca do PA Santa Tereza I, em julho de 2014, um evento em comemoração à colheita anual da mandioca, como sinaliza o cartaz abaixo.

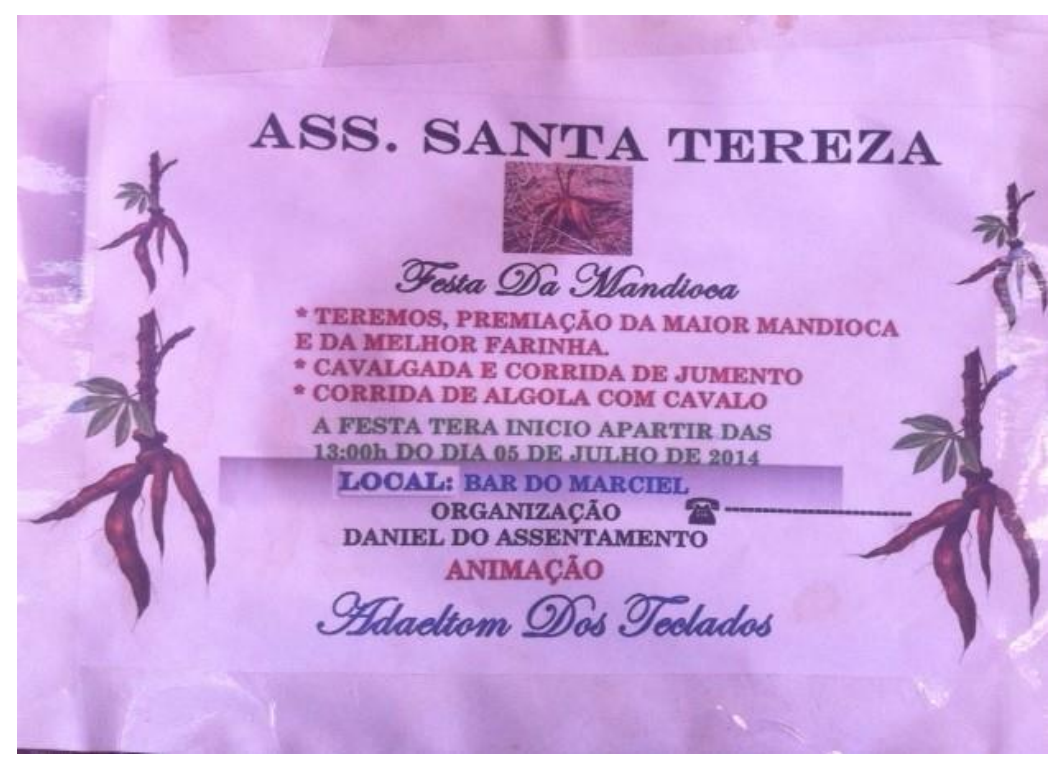

Fotografia 3.2 - Cartaz da festa da mandioca de 2014

Nestes momentos, a pesquisadora constatou a importância de realizar as entrevistas a partir dessas visitas. Além disso, ao relatar essa solicitação de alguns/mas pioneiros/as ao presidente da associação (assentado 'não pioneiro'), obteve a informação de que havia a necessidade dele conduzi-la nas visitas aos lotes, como também procedia ao encontrá-la, na entrada do PA (quando a pavimentação asfáltica terminava), para se locomover no assentamento e a observação participante pudesse ocorrer.

O presidente da associação conduziu a pesquisadora pelo PA durante todas as idas ao local por causa do difícil acesso, inclusive acompanhando-a em todas as visitas aos lotes. No PA Santa Tereza I, há mais trilhas entre os lotes do que estradas e em muitas delas não há possibilidade de automóvel trafegar. Sendo assim, as vinte e uma entrevistas ocorreram nos lotes de cada pioneiro/a porque o presidente da associação de moradores guiou a pesquisadora por entre estradas e trilhas de todo PA. Ora foi possível prosseguir de automóvel entre um lote e outro, ora foi necessário prosseguir a pé para chegar a alguns lotes. 
Já no caso das entrevistas na Superintendência do INCRA no estado do Tocantins (INCRA-SR26/Tocantins), foram entrevistados dois funcionários responsáveis técnicos pela elaboração do PDA Santa Tereza I. Por exigência do Ministério de Desenvolvimento Agrário (MDA) e execução do INCRA para o cumprimento do II PNRA, os lotes de um PA somente poderiam ser 'sorteados' entre candidatos/as, caso o PDA do assentamento estivesse elaborado. Para fazer cumprir essas determinações, o INCRA estabeleceu convênios com instituições para execução dessas ações.

No que concerne ao PDA do PA Santa Tereza I, a Cooperativa de Profissionais Liberais do Vale Araguaia (COOPVAG) prestou esse serviço ao INCRA-SR26. A COOPVAG foi contratada para elaborar o PDA Santa Tereza I, sob a orientação e fiscalização de funcionários do INCRA, com responsabilidade técnica para desempenhar essa função. Apesar dos/as técnicos/as da COOPVAG organizarem, realizarem reuniões ao longo do primeiro semestre de 2007 com os/as candidatos/as a um lote acampados/as, e terem elaborado o referido PDA, os funcionários do INCRA também participavam dessas reuniões assim como fiscalizavam as ações da COOPVAG para fazerem cumprir a legislação. Ademais, o número de funcionários do INCRA com responsabilidade técnica para tal função faz-se reduzido, havendo necessidade de 'terceirização' desse tipo de serviço.

Em relação às notas de campo, foram registradas durante a observação participante no PA Santa Tereza I e no INCRA-SR26. Essas notas tiveram importante contribuição para a análise dos corpora - texto do PDA e as entrevistas realizadas.

\subsubsection{Sistematização dos dados de natureza etnográfica}

Nesta subseção, apresento a sistematização dos dados de natureza etnográfica gerados durante esta pesquisa, especificamente, dados das entrevistas semiestruturadas. A seguir, são apresentados dois quadros que sumarizam o levantamento de dados sobre os/as participantes das entrevistas. Enquanto o Quadro 3.6 configura os perfis dos/as assentados/as pioneiros/as entrevistados/as, o Quadro 3.7 configura os perfis dos funcionários do INCRA-SR26 entrevistados. 
Quadro 3.6 - Perfil dos/as assentados/as pioneiros/as entrevistados/as ${ }^{27}$

\begin{tabular}{|l|c|c|c|c|}
\hline \multicolumn{1}{|c|}{ Nome } & Sexo & Idade & $\begin{array}{c}\text { Data da } \\
\text { entrevista }\end{array}$ & $\begin{array}{c}\text { Duração em } \\
\text { minutos }\end{array}$ \\
\hline Arara-Canindé & $\mathrm{M}$ & 63 & $18 / 07 / 14$ & $10 \mathrm{~min} 51$ \\
\hline Mãe-da-Lua & $\mathrm{M}$ & 65 & $18 / 07 / 14$ & $8 \mathrm{~min} 33$ \\
\hline Gavião-Vaqueiro & $\mathrm{M}$ & 39 & $18 / 07 / 14$ & $10 \mathrm{~min} 03$ \\
\hline Xexéu & $\mathrm{M}$ & 67 & $19 / 07 / 14$ & $18 \mathrm{~min} 29$ \\
\hline Cigana & $\mathrm{F}$ & 29 & $19 / 07 / 14$ & $7 \mathrm{~min} 52$ \\
\hline Garça-Real & $\mathrm{M}$ & 74 & $18 / 07 / 14$ & $10 \mathrm{~min} 28$ \\
\hline João-Bobo & $\mathrm{M}$ & 56 & $19 / 07 / 14$ & $13 \mathrm{~min} 35$ \\
\hline Irerê & $\mathrm{F}$ & 62 & $18 / 07 / 14$ & $6 \mathrm{~min} 16$ \\
\hline Periquito-Rei & $\mathrm{M}$ & 48 & $18 / 07 / 14$ & $6 \mathrm{~min} 12$ \\
\hline Gavião-Carijó & $\mathrm{F}$ & 42 & $18 / 07 / 14$ & $8 \mathrm{~min} 45$ \\
\hline Carão & $\mathrm{F}$ & 50 & $18 / 07 / 14$ & $10 \mathrm{~min} 03$ \\
\hline Quero-Quero & $\mathrm{F}$ & 59 & $18 / 07 / 14$ & $12 \mathrm{~min} 56$ \\
\hline Tuiuiu & $\mathrm{M}$ & 63 & $18 / 07 / 14$ & $7 \mathrm{~min} 32$ \\
\hline Savacu & $\mathrm{M}$ & 51 & $19 / 07 / 14$ & $11 \mathrm{~min} 42$ \\
\hline Sanhaçu-do-Coqueiro & $\mathrm{M}$ & 46 & $18 / 07 / 14$ & $6 \mathrm{~min} 09$ \\
\hline Suiriri & $\mathrm{M}$ & 41 & $18 / 07 / 14$ & $7 \mathrm{~min} 44$ \\
\hline Tico-Tico & $\mathrm{M}$ & 52 & $18 / 07 / 14$ & $7 \mathrm{~min} 20$ \\
\hline Bem-Te-Vi & $\mathrm{M}$ & 67 & $18 / 07 / 14$ & $13 \mathrm{~min} 11$ \\
\hline Rolinha-Vaqueira & $\mathrm{F}$ & 60 & $18 / 07 / 14$ & $7 \mathrm{~min} 55$ \\
\hline Andorinha-Azul & $\mathrm{F}$ & 30 & $18 / 07 / 14$ & $4 \mathrm{~min} 12$ \\
\hline Gralha-do-Campo & $\mathrm{F}$ & 54 & $19 / 07 / 14$ & $10 \mathrm{~min} 50$ \\
\hline
\end{tabular}

Quadro 3.7 - Perfil dos funcionários do INCRA entrevistados

\begin{tabular}{|l|c|c|c|c|}
\hline \multicolumn{1}{|c|}{ Nome } & Sexo & Idade & $\begin{array}{c}\text { Data da } \\
\text { entrevista }\end{array}$ & Duração em minutos \\
\hline Capim Dourado & $\mathrm{M}$ & 43 & $16 / 07 / 14$ & $10 \mathrm{~min} 43$ \\
\hline Babaçu & $\mathrm{M}$ & 36 & $16 / 07 / 14$ & $27 \mathrm{~min} 19$ \\
\hline
\end{tabular}

\subsection{Métodos de análise dos dados}

Esta seção apresenta as abordagens teórico-metodológicas da Análise de Discurso Crítica, nos moldes de Fairclough (2003, 2010), e da Linguística Sistêmico-Funcional, de acordo com Halliday \& Matthiessen (2004), pois são basilares para esta tese.

\footnotetext{
${ }^{27}$ Os/as colaboradores/as da pesquisa são apresentados/as com pseudônimos por questão ética na pesquisa. No caso dos/as participantes assentados/as, os pseudônimos referem-se à fauna do Tocantins, especificamente, aos pássaros. Enquanto que os pseudônimos dos funcionários do INCRA-SR26 entrevistados são assinalados com referência à flora tocantinense.
} 


\subsubsection{Abordagem teórico-metodológica da ADC}

Como pontua Angrosino (2009), as teorias críticas compreendem uma variedade de abordagens no estudo da sociedade e da cultura contemporâneas com a perspectiva de desafiar os pressupostos das instituições dominantes das sociedades, como a ADC propõe-se a fazer. Sobre isso, explicita Silva:

$\mathrm{Na}$ vertente crítica, enquanto analistas de discurso, cientes da variabilidade entre práticas e heterogeneidade, bem como entre processos de mudança histórica, conduzimos pesquisas linguísticas em torno de temas que vão desde práticas discursivas de natureza educacional, política, jurídica, como também midiática, passando pelas implicações de poder, ideologia e identidades sociais do mundo pós-moderno até questões de luta e conflito social (SILVA, 2012, p. 227).

Na perspectiva da Análise de Discurso Crítica, como dito anteriormente, os usos da linguagem, em várias perspectivas de análise, têm sido concebidos como responsáveis pela interação entre o homem e a sociedade. Os textos orais e escritos podem promover a constituição, propagação, transformação de crenças e valores nas sociedades, haja vista serem constituídos em práticas sociais. Em vista disso, a ADC compromete-se com o exame dos aspectos discursivos da mudança social e objetiva investigar, de forma crítica, como as relações de poder são expressas e legitimadas através da linguagem.

Fairclough (1989, 2001, 2003, 2006, 2010) concebe, assim, os textos como um processo constituído por um contexto sócio-histórico e cultural e fazem circular informações e conteúdo simbólico nas sociedades. A partir dessa concepção de texto, especificamente, Chouliaraki e Fairclough (1999); Fairclough (2003, 2010) propõem um arcabouço teóricometodológico, balizado no modelo da crítica explanatória, sugerido por Bhaskar (1986), como uma maneira de desenvolvimento de uma análise textualmente orientada, visando à emancipação social. Para tanto, Norman Fairclough ao longo de sua obra foi desenvolvendo aspectos de uma metodologia, como ele mesmo expõe: ${ }^{28}$

\footnotetext{
${ }^{28}$ The first paper ('A dialectical-relational approach to critical discourse analysis in social research') presents a metodology which is a form what Bhaskar (1986) calls "explanatory critique". The same methodology in essence was proposed in the book I co-authored with Lilie Chouliaraki, Discourse in Late modernity (1999), though I have modified it here (FAIRCLOUGH, 2010, p. 226).
} 
O primeiro artigo ("A abordagem dialética-relacional para Análise de Discurso Crítica na pesquisa social') apresenta uma metodologia nos termos do que Baskar (1986) chama de "crítica explanatória". A mesma metodologia, em essência, foi proposta no meu livro com co-autoria de Lilie Chouliaraki, Discourse in Late modernity (1999), apesar de eu tê-la modificado aqui (no livro Critical Discourse Analysis: the critical study of language (FAIRCLOUGH, 2010, p. 226).

De acordo com o próprio autor, a metodologia de pesquisa é desenvolvida ao longo de sua obra a partir dos objetos de pesquisa, com destaque para a crítica explanatória, proposta por Baskar (1986). Sob a perspectiva da crítica explanatória, as análises são baseadas na consideração de que os significados são construídos na vida social prática (BHASKAR, 1986, 1998). Conforme Bhaskar (1986), Fairclough ressalta a relação dialética entre o discurso e outros elementos práticos de práticas sociais, situados no cerne da análise de discurso proposta por ele. Sobre isso, a linguista brasileira Solange Barros (2011) também sinaliza que o modelo de análise da ADC, nos moldes de Fairclough, está em conformidade com a crítica explanatória de Bhaskar (1998; 2002), uma vez que ambos entendem as pesquisas em ADC com foco em problemas práticos da vida social, vislumbrando uma crítica explanatória construída com base nas descobertas dos problemas sociais oriundos das práticas sociais e a partir delas buscar soluções para a sua superação.

Ressalte-se a dificuldade de separar e opor teoria e método neste viés de análise, haja vista haver uma proposição de um processo teórico que constroi um objeto de pesquisa (um objeto pesquisável, com questões pesquisáveis) para um tema de investigação, trazendo sobre ele perspectivas e enquadramentos teóricos relevantes. Essa complexidade dos objetos de pesquisa configura métodos (dados coletados e análises) selecionados de acordo com o modo como o objeto de pesquisa é construído (FAIRCLOUGH, 2010, p. 225).

Isso posto, Fairclough (2010) aponta que a metodologia pode ser elaborada com um número de passos a depender dos objetivos do/a analista, do objeto de pesquisa, podendo ser formulada em quatro etapas, conforme o Quadro 3.8. 


\section{Quadro 3.8 - Arcabouço teórico-metodológico da ADC}

\begin{tabular}{|l|}
\hline \multicolumn{1}{|c|}{ (Focar em um problema social, considerando } \\
seu aspecto semiótico.)
\end{tabular}

Baseado em Fairclough (2010, p. 226-229).

O arcabouço da ADC, proposto por Fairclough (2010) e apresentado no quadro acima, apresenta uma metodologia formulada em quatro etapas, podendo ser mais detalhada em número de passos.

A primeira etapa remete à apreensão de um problema social, produtivamente pesquisado em termos das relações entre elementos semióticos e 'não semióticos, entre a interioridade e a exterioridade da linguagem. É a percepção de um problema relacionado a alguma parte da vida social. O autor (2010, p. 226) sugere que um passo para essa etapa é a construção do objeto de pesquisa com o intuito de investigação de um problema de pesquisa sob um viés transdisciplinar.

A segunda etapa aponta para questões sobre a origem e a natureza da ordem social onde o problema existe em termos de dificuldades para a sua superação. Isto é, se o ponto de partida na ADC é a investigação semiótica, é necessário considerar, particularmente, aspectos semióticos dos obstáculos para a mudança social, assim como é necessário analisar dialeticamente relações entre elementos semióticos e não semióticos em instituições, práticas, e eventos relevantes, o que implica escolha e análise adequadas. Segundo Fairclough (2010), em ADC, é basilar o entendimento da conjuntura, dos obstáculos estruturais para a mudança e da relação entre discursos e outros momentos da prática social.

A terceira sugere a investigação da ordem social do problema em termos da avaliação do seu papel na prática. Questiona-se a inerência do problema frente à ordem social de modo que não possa corrigi-lo sem alterar essa ordem. 
Já a quarta etapa remete às possíveis superações dos obstáculos identificados na segunda etapa ao considerar, em parte, seu caráter semiótico e isso incide em como as pessoas realmente lidam ou poderiam lidar com eles, em parte, contestando e mudando o discurso. A proposição dessa etapa está voltada para a distinção de recursos para uma mudança social, levando em conta as deficiências das estruturas e as especificidades de cada conjuntura no que concerne a lacunas e contradições.

Os quatro estágios, propostos por Fairclough (2010), são apresentados e adaptados a esta pesquisa, de acordo com o Quadro 3.9.

Quadro 3.9 - Arcabouço teórico-metodológico da ADC adaptado à tese

\begin{tabular}{|c|c|c|}
\hline $\mathrm{N}$ & Etapas da metodologia & Proposição para a tese \\
\hline 1 & Um problema social & $\begin{array}{l}\text { Como discursividades e representações linguístico- } \\
\text { discursivas configuradas no PDA do PA Santa Tereza I } \\
\text { contribuem como ferramenta para o desenvolvimento de } \\
\text { projetos de assentamentos em termos de inclusão social de } \\
\text { assentados/as. }\end{array}$ \\
\hline 2 & $\begin{array}{l}\text { Identificar obstáculos para } \\
\text { superar o problema social } \\
\text { (a) Análise da conjuntura } \\
\text { (b) Análise da prática particular } \\
\text { (i) práticas relevantes } \\
\text { (ii) relações do discurso com } \\
\text { outros momentos da prática: } \\
\text { >discurso como parte da atividade, } \\
\text { >discurso e reflexividade. } \\
\text { (c) análise do discurso } \\
\text { (i) análise estrutural: a ordem do } \\
\text { discurso } \\
\text { (ii) análise interacional } \\
\text { >análise interdiscursiva } \\
\text { > análise linguística e semiótica }\end{array}$ & $\begin{array}{l}\text { (a) Analisar a conjuntura envolvida no PDA do PA Santa } \\
\text { Tereza I no que remete à reforma agrária no Brasil. } \\
\text { (b) Analisar o PDA do PA Santa Tereza I no que se refere } \\
\text { às discursividades (re)contextualizadas no texto bem } \\
\text { como representações de agentes sociais envolvidos na } \\
\text { elaboração desse documento institucional. } \\
\text { (i) Relacionar os discursos do PDA aos discursos dos/as } \\
\text { assentados/as pioneiros/as do PA e dos funcionários do } \\
\text { INCRA-SR26, no que concerne à elaboração do PDA } \\
\text { Santa Tereza I. } \\
\text { (ii) Analisar representações linguístico-discursivas } \\
\text { constituídas no texto do PDA estudado com vistas a } \\
\text { desvelar facetas de práticas sociais (re)produzidas. } \\
\text { (c) Analisar o discurso institucional. } \\
\text { (i) Ordem do discurso institucional } \\
\text { (ii) Análise de representações e identificações de agentes } \\
\text { sociais no processo de elaboração do PDA Santa Tereza I, } \\
\text { embasada em categorias da ADC e da GSF. }\end{array}$ \\
\hline 3 & $\begin{array}{l}\text { Função do problema social na } \\
\text { prática }\end{array}$ & $\begin{array}{l}\text { Investigar em que medida representações linguístico- } \\
\text { discursivas, configuradas no PDA Santa Tereza I, podem } \\
\text { contribuir ou não como parte prática de políticas públicas } \\
\text { no Brasil acerca da reforma agrária. }\end{array}$ \\
\hline 4 & $\begin{array}{l}\text { Identificar possíveis maneiras } \\
\text { para superar os obstáculos }\end{array}$ & $\begin{array}{l}\text { Apontar caminhos norteadores, através de usos da } \\
\text { linguagem como prática social (discurso), que possam } \\
\text { favorecer, em condições propícias, o desvelamento de } \\
\text { práticas discursivas que amenizem ou revertam a situação } \\
\text { de risco a que estão submetidos/as muitos/as assentados/as } \\
\text { tocantinenses e brasileiros/as. }\end{array}$ \\
\hline 5 & $\begin{array}{l}\text { Reflexão sobre a análise em } \\
\text { termos da crítica explanatória }\end{array}$ & 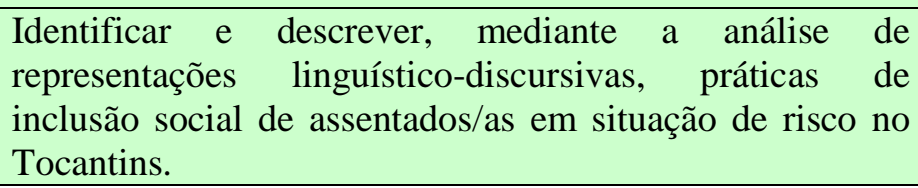 \\
\hline
\end{tabular}


No âmbito dos estudos discursivos críticos, o papel do uso dos mais diversos tipos de textos na vida social é cada vez mais expressivo em todos os campos da atividade humana (FAIRCLOUGH, 2006) e, por isso, a ADC busca desenvolver aspectos da sua metodologia no que concerne aos níveis da interioridade e da exterioridade da linguagem que constituem os textos. Sobre isso, Fairclough (2003) aponta que os gêneros discursivos são diferentes maneiras de (inter)agir discursivamente (formas de ação), relacionadas a "discursos", os quais são definidos como significados e formas de representação. Nessa perspectiva, os gêneros são importantes para a sustentação das estruturas institucionais das sociedades contemporâneas. Ao se analisar uma interação em termos de gênero, há indagação sobre como é configurado em termos de ações sociais e como contribui para a ação social e para a interação em eventos sociais - especificamente nas transformações associadas ao novo capitalismo.

Para tanto, sob a perspectiva de gênero discursivo como ação social no decorrer de eventos sociais, os significados da linguagem são realizados em significados acionais e formas do texto, em significados representacionais e discursos e em significados identificacionais e estilos (FAIRCLOUGH, 2003, p. 67). O significado acional faz referência ao texto como modo de (inter)ação em eventos sociais, já que a ação legitima e/ou questiona as relações sociais. O significado representacional remete aos aspectos representacionais dos textos. Já o significado identificacional enfatiza a negociação e a construção de identidades no discurso. Fairclough (2003) ressalta uma correspondência entre gênero e modos de agir, discursos e modos de representar e estilos e modos de identificar. Gêneros, discursos e estilos relacionam o texto a outros elementos da vida social, como as relações internas do texto com suas relações externas. Enquanto uma teoria crítica, a ADC, como método, considera a macroanálise e a microanálise de dados como constituintes da análise de discursos (FAIRCLOUGH, 2003). A LSF, por sua vez, como teoria basilar da ADC, interessa, aqui, como instrumento para a exploração da interioridade da linguagem, isto é, para a microanálise de acordo com a proposta de Halliday (1994) e Halliday e Matthiessen (2004).

Van Leeuwen (2008) também apresenta, na perspectiva da ADC, a teoria da representação dos atores sociais com o objetivo de identificação de funções que cada ator social exerce por meio da utilização dos mais variados usos de linguagem (oral, escrita, visual, multimodal). Sendo assim, essa abordagem interessa a este trabalho em termos das representações de atores sociais em textos. Segundo van Leeuwen (1997, p. 187), cabe ao/à analista "investigar que opções são feitas em que contextos institucionais e sociais, e por que essas escolhas são feitas, a que interesses servem e que propósitos são alcançados”. Através 
dessa teoria, busco investigar modos pelos quais os atores sociais são representados, sobretudo, nos discursos do PDA do PA Santa Tereza I.

\subsubsection{Abordagem teórico-metodológica da LSF}

Os pressupostos teórico-metodológicos da Análise de Discurso Crítica (ADC) coadunam com os da Linguística Sistêmico-Funcional (LSF) e dão suporte para o desenvolvimento de uma análise crítica da linguagem. A articulação proposta entre a ADC e a LSF se refere à necessidade de a ADC utilizar uma teoria gramatical que relacione cada uso de linguagem aos seus contextos de cultura e de situação.

A LSF, por sua vez, é uma teoria gramatical que conecta usos da linguagem aos seus contextos de cultura e de situação e a ADC utiliza suas categorias analíticas. A abordagem sistêmico-funcional concebe a língua como uma rede de sistemas interligados de que o/a falante faz uso (base funcional) para produzir significados (base semântica) em situações de comunicação (base contextual). Propõe uma abordagem ao estudo da linguagem centrada na noção de função, já que se preocupa em explicar como a linguagem é estruturada e utilizada em contextos diversos de uso. Isto é, considera a gramática de uma língua como um sistema que (re)produz significados.

Segundo Halliday e Matthissen (2004, p. 21), a gramática é considerada "a unidade central de processamento da linguagem, a base onde significados são criados". É um sistema de opções disponíveis na língua. Com isso, as práticas comunicativas, através da linguagem, desempenham simultaneamente três metafunções básicas: produção de significados ideacionais (oração como processo), interpessoais (orações como ato de fala) e textuais (oração como mensagem) (HALLIDAY; MATTHIESSEN, 2004). Como o foco principal neste estudo está nas discursividades e representações do PDA Santa Tereza I, o interesse maior está no estudo das metafunções ideacional e da interpessoal, explicado a seguir.

A metafunção ideacional da linguagem expressa representações, realidades sociais do mundo. Isto é, expressa o conteúdo da experiência do falante em relação a seu mundo interior e exterior. Nessa perspectiva, a língua oferece um conjunto de recursos para se referir ao mundo. Pelo Sistema de Transitividade, ao se analisar a metafunção ideacional, analisa-se a gramática da oração como representação, ou seja, há escolha de processo, participante $e$ circunstância quando se representa linguisticamente a experiência de mundo do/a falante. As escolhas são, pois, materializadas na estrutura lexical, semântica e sintática dos textos. 
Já ao se considerar a oração como troca - metafunção interpessoal -, constata-se que a gramática disponibiliza recursos para a interação entre as pessoas através da língua. Nesse sentido, a linguagem humana constitui relações sociais, papeis sociais e identidades. Assim, a parte da oração que desempenha a metafunção interpessoal é chamada Sistema de MODO, que consiste em um recurso gramatical para se realizarem movimentos interativos no diálogo. No sistema de MODO, a oração se organiza em dois componentes básicos: modo e resíduo. O Modo, por sua vez, se constitui de dois elementos: sujeito e o finito. O sujeito e o finito tornam-se o sinal do que está acontecendo no discurso: troca de informações ou bens e serviços - declaração, questão, ordem ou pedido. De acordo com Halliday (1989), a análise das trocas linguísticas indica o tipo de proposição que está ocorrendo, de atitudes e de julgamentos que constituem o ato simbólico interpessoal.

\subsection{Abordagem articulatória das análises}

Sob a perspectiva da Análise de Discurso Crítica, a Línguística Sistêmico-Funcional possui interesse na relação entre a linguagem e outros elementos, aspectos da vida social e sua abordagem para a análise linguística de textos, estando sempre orientada para o caráter social dos textos (FAIRCLOUGH, 2003). Esses aspectos coincidentes entre as duas teorias fazem, principalmente, da Gramática Sistêmico-Funcional (HALLIDAY, 2004) um recurso importante para parte da análise proposta pela ADC. Por isso, Chouliaraki e Fairclough (1999), indicam a LSF como a teoria linguística que mais tem em comum com a ADC em termos de favorecer a constituição da análise.

Entre as semelhanças das duas abordagens, Young e Harrison (2004) apontam algumas. Uma delas diz respeito à concepção de linguagem como construto social, com ênfase no papel da linguagem na sociedade e as formas pela qual a sociedade molda a linguagem. Outra semelhança, segundo os autores, faz referência à postura de ambas destacarem aspectos culturais e históricos na constituição dos significados da linguagem. Ainda, a semelhança entre a LSF e a ADC ocorre em relação à visão dialética da linguagem, visto que eventos discursivos particulares influenciam seus contextos de ação e são, ao mesmo tempo, influenciados por esses mesmos contextos (a linguagem constitui o social e é, ao mesmo tempo, influenciada por ele). Em contribuição para este trabalho, essas semelhanças garantem uma interface construtiva para o desenvolvimento da pesquisa. Vale ressaltar que, apesar dessas semelhanças para com a linguagem, as duas teorias também 
apresentam algumas perspectivas teóricas e metodológicas que as diferenciam e não 'dialogam', o que não necessita ser elucidado, aqui, por não interferir na investigação.

Segundo Silva (2009), reforçar o diálogo entre a LSF e a ADC é fundamental para a compreensão das relações de poder, pois o texto, além de envolver simultaneamente as funções ideacional, interpessoal e textual deve ser visto como ação (gênero), representação (discurso) e identificação (estilo), que são os três elementos de ordem do discurso. Enquanto a LSF propicia a explicitação de como a linguagem é estruturada em seus diferentes usos na produção de significados construídos socialmente, mediante as escolhas léxico-gramaticais (registro) das pessoas para agirem e interagirem em contextos de cultura (gênero), a ADC prioriza os elementos concernentes às ordens do discurso (ação, representação e estilo) e, de modo especial, com as relações de poder que determinam essas escolhas linguísticas.

\section{Algumas considerações}

O conhecimento de um tipo de texto institucional sobre reforma agráriaé um meio que pode corroborar para o desvelamento de práticas sociais excludentes, para o entendimento de aspectos de uma cultura em um determinado contexto. Além de descrever formas culturais, pode desvelar também como as formas de vida agem na sociedade, quais são seus efeitos. Com isso, a reflexão sobre os mais variados tipos de textos é importante em relação à desnaturalização daquilo que é considerado senso comum em uma determinada cultura, em determinado momento histórico.

Nessa perspectiva, tanto os discursos quanto os gêneros discursivos constroem representações sociais que emergem dos significados de determinada cultura e das relações sociais. Acreditamos, com isso, que o estudo do PDA Santa Tereza I, concebido como prática social, é mecanismo para se descrever e analisar certos meios de vida de parte da sociedade brasileira e, consequentemente, suas ações sobre o mundo. Por isso, houve a opção, neste trabalho, pelos apontamentos, sobretudo, da Análise de Discurso Crítica, propostos por Fairclough (2003) e descritos anteriormente.

Assim, o presente estudo pode contribuir para a compreensão de questões sociais configuradas em um Plano de Desenvolvimento Agrário (PDA) e que se materializam através da linguagem e que disponibilizam instrumentos a fim de que se proponham soluções para problemas sociais.

A opção pelo estudo de um gênero discursivo específico (um PDA) faz parte de uma escolha. Em um primeiro momento, essa escolha diz respeito a uma questão de valoração de 
elementos linguísticos, mas também pode construir algumas representações, tanto de quem produziu como de quem pode e deve "consumir" o texto. Além disso, a formação dos gêneros se dá através da interação das vivências, dos usos das linguagens em situações diversas. É um meio de modular um discurso e pode revelar escolhas linguísticas, discursivas e sociais na sociedade brasileira em um contexto sócio-histórico e cultural específico. As palavras, desse modo, quando "utilizadas", são dotadas de tudo que é próprio da cultura. Cada sociedade, cada momento sócio-histórico e cultural, por exemplo, pode materializar gêneros discursivos com características particulares, representando possíveis realidades.

Isso posto, o desenvolvimento da Tese, proposto e especificado neste capítulo, foi sistematizado no esquema abaixo.

\section{Quadro 3.10 - Quadro sinóptico da pesquisa}

\section{Discursividades em um Plano de Desenvolvimento Agrário: facetas de práticas sociais (re)produzidas}

O problema de pesquisa, destacado nesta tese, faz referência ao estudo de discursividades e representações linguístico-discursivas configuradas no Plano de Desenvolvimento Agrário do Projeto de Assentamento Santa Tereza I, em Ponte Alta-Tocantins, em termos de discussões sobre justiça social no contexto brasileiro, a partir de políticas públicas voltadas para a reforma agrária, como os PDAs, considerando a inclusão social de assentados/as, historicamente, à margem da sociedade brasileira.

O objetivo geral é investigar as discursividades e as representações configuradas no texto do PDA Santa Tereza I, com o propósito de favorecer a reflexão sobre práticas discursivas transformadoras e que beneficiem parte da sociedade sedenta por mais justiça social no que remete à questão agrária no Brasil.

Para tanto, a pesquisa foi constituída de acordo com o aporte teórico-metodológico da Análise de Discurso Crítica (FAIRCLOUGH, 2003, 2010) e da Gramática Sistêmico-Funcional (HALLIDAY \& MATTHIESSEN, 2004) como ferramenta para a microanálise da linguagem, que forma parte da análise proposta pela primeira.

Há também aspectos da abordagem acerca da representação dos atores sociais, sugerida por van Leuween $(1997,2008)$, de interesse aqui.

Análise dos dados de natureza documental:

o PDA Santa Tereza I

Análise dos dados de natureza etnográfica: entrevistas com assentados/as e funcionários do INCRA, ambos os tipos de participantes envolvidos na elaboração do PDA

Questões de pesquisa:

Questões de pesquisa:

Que representações de atores sociais são constituídas na configuração linguística do PDA Santa Tereza I?

Como os/as assentados/as são representados/as em seu PDA?

Categorias de análise:

aspectos das metafunções ideacional e interpessoal
$\mathrm{O} / \mathrm{a}$ assentado/a entrevistado/a se identifica com as representações expressas no PDA?

Que representações são constituídas quando funcionários do INCRA-SR26 relatam sobre a constituição do mesmo?

\section{Categorias de análise:}

aspectos das metafunções ideacional e interpessoal 


\section{CAPÍTULO 4}

\section{EM BUSCA DO NINHO: O PDA DO PA SANTA TEREZA I E(M) REPRESENTAÇÃO DE ASSENTADOS/AS}

Cada palavra se apresenta como uma arena em miniatura onde se cruzam e lutam valores sociais $e$ revela-se, no momento de sua expressão, como o produto da interação viva das forças sociais (BAKHTIN, 1979).

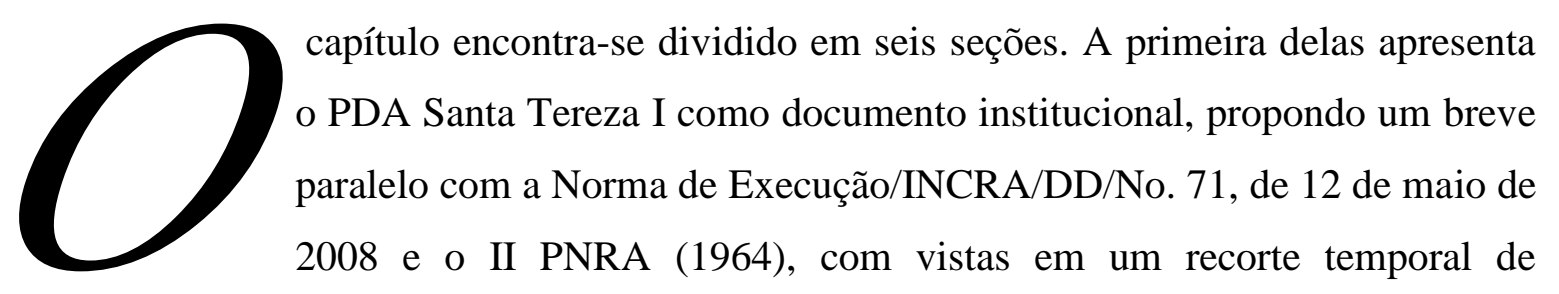
investigação. Ambos os textos institucionais orientam a produção de PDAs. A segunda seção tece a análise linguístico-discursiva da estrutura composicional ou alguns modos de agir no texto do PDA Santa Tereza I. A terceira seção analisa o PDA Santa Tereza I em termos de modos de representar a partir do significado representacional da linguagem (FAIRCLOUGH, 2003). A quarta também trata dos modos de representar, mas no que se refere à representação dos atores sociais (VAN LEEUWEN, 2008). A quinta seção trata de aspectos do significado identificacional da linguagem no PDA, remetendo aos modos de ser constituídos no PDA. A análise proposta é constituída a partir da concepção de que o PDA Santa Tereza I é configurado em modo(s) de agir sobre o mundo (significado acional), modo(s) de representar o mundo (significado representacional) e modo(s) de ser no mundo (significado identificacional) (FAIRCLOUGH, 2003). A última seção apresenta algumas considerações.

\subsection{O PDA como documento institucional}

Com a implementação de várias políticas públicas sobre reforma agrária no Brasil nas duas últimas décadas, observa-se que a ampliação da criação de projetos de assentamentos 
faz-se uma realidade no país. Desse modo, tanto a constituição quanto o desenvolvimento de assentamentos fazem parte de políticas públicas recentes. Dentre as políticas referentes ao desenvolvimento de projetos de assentamentos, parte de uma é concretizada através do Plano de Desenvolvimento Agrário (PDA) de cada assentamento.

No percurso de constituição e funcionamento de cada assentamento, uma das formas de tentativas para fazer cumprir a legislação sobre reforma agrária e dizer que o/a assentado/a participa da organização do modo de vida no assentamento é a produção e a execução do PDA. Cada assentamento, de acordo com políticas implementadas durante os governos do presidente Lula, deveria possuir um PDA, produzido sob o "auxílio técnico" do INCRA (ou por serviço técnico "terceirizado") e por pessoas candidatas ao PA. Pode-se dizer, assim, que os/as assentados/as podem ter suas vidas nos assentamentos, de certa forma, guiadas pelo PDA quando executado. Em poucas palavras, os modos de vida nos assentamentos podem ser determinados por práticas sociais materializadas em textos e que passam a ser impostas a assentados/as. Cabe, aqui, observar no texto de Apresentação do PDA Santa Tereza I a ocorrência de uma divergência ao apontar as funções do PA. No início desse texto, tem-se o seguinte:

(1) deverá se constituir em um importante instrumento de desenvolvimento para os Projetos de Assentamentos de Reforma Agrária. A sua construção é parte integrante da Política de Reforma Agrária, que visa garantir a permanência do homem no campo, com todas as condições necessárias para o desenvolvimento sustentável e melhoria da qualidade de vida de toda a comunidade.

(COOPVAG, 2007, p. 1)

O documento PDA funciona como uma estratégia para o desenvolvimento de PAs, pois 'visa garantir a permanência das pessoas no campo', justamente através da produtividade com o uso da terra. Já, no último parágrafo desse mesmo texto, há identificação de outra função para o PDA:

(2) O PDA constitui-se em uma ferramenta de trabalho para a Assessoria Técnica, que tem responsabilidades no acompanhamento e monitoramento de sua execução, sendo dinâmico, visto que deve estar sempre em consonância com a realidade e acompanhar os estágios de desenvolvimento da comunidade podendo, dessa forma, ser atualizado periodicamente.

(COOPVAG, 2007, p. 1) 
O excerto (2) destacado faz referência ao PDA como um instrumento para a assessoria técnica do assentamento, mediante os termos "O PDA constitui-se em uma ferramenta de trabalho para a Assessoria Técnica, que tem responsabilidades no acompanhamento e monitoramento de sua execução". Afirma-se ser necessário "monitorar" as ações previstas no PDA. O INCRA aponta, porém, que o PDA é feito por assentados/as e que o seu papel é somente auxiliar tecnicamente em sua elaboração. Observa-se no texto de Apresentação funções que parecem, em princípio, caminhos divergentes em relação ao uso do PDA. Na apresentação do PDA Santa Tereza I, parece haver um contra-senso. Faz-se importante, assim, averiguar como se dá a constituição linguístico-discursiva dessa parte do documento.

Na perspectiva, de investigar as materializações discursivas constituintes de um PDA e sua ação através de suas representações e identificações, o ponto de partida dessa discussão é configurada a partir da premissa de que gêneros e discursos constituem identidades, relações sociais e conhecimentos. É necessário analisar como o PDA representa ou não as condições de vida nos assentamentos. A constituição linguística-discursiva dos planos de desenvolvimento pode ser, por sua vez, uma forma de estudo de um modo de vida proposto para os/as assentados/as. Além disso, a concepção do documento como ação social, uma forma de ação sobre o mundo, possibilita a oportunidade de reflexão sobre "ações" do PDA investigado.

\subsection{Modos de agir: a estrutura composicional do PDA}

O PDA Santa Tereza I, neste estudo, é considerado uma ‘interação’ entre, pelo menos, assentados/as e INCRA e, como tal, é estratégico e orientado a produzir resultado. Esse PDA, enquanto componente de um gênero discursivo, é constituído como uma maneira de ação e interação no decorrer de eventos sociais (FAIRCLOUGH, 2003). Sendo assim, interessa, aqui, estudar a constituição do PDA para desvelar suas facetas enquanto estratégia e resultado de interação. O significado acional, por sua vez, com foco no texto como modo de (inter)ação em eventos sociais, já que a ação legitima e/ou questiona as relações sociais (FAIRCLOUGH, 2003), como visto no Capítulo 3, faz-se uma forma de ação e pode ser tido como um mecanismo de transformação do mundo e por isso merece ser investigado. 


\subsubsection{Textos articulados e a reforma agrária no Brasil}

O texto do PDA enquanto uma das ferramentas utilizadas pelo INCRA para o desenvolvimento de projetos de assentamentos é elaborado a partir da legislação federal brasileira, especificamente, sobre reforma agrária. Para isso, ocorre uma triangulação de documentos na constituição do PDA. Por uma necessidade de delimitação dos corpora para a investigação, neste trabalho, há um recorte temporal da triangulação de textos para a análise do PDA Santa Tereza I:

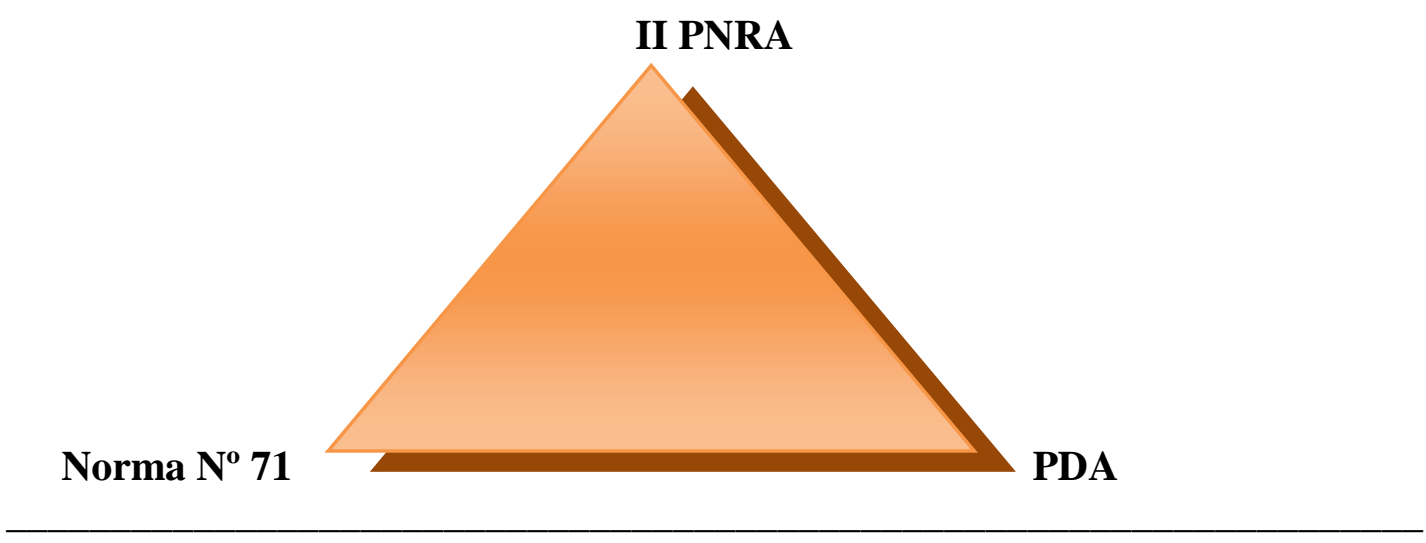

Figura 4.1. Triangulação documental

O II Plano Nacional de Reforma Agrária - II PNRA (MDA; INCRA, 2004) - surge de acordo com a tentativa de ampliar e/ou criar políticas públicas sobre reforma agrária no Brasil. A partir do que foi configurado nele, referente ao desenvolvimento dos projetos de assentamentos, o Ministério de Desenvolvimento Agrário (MDA) e o Instituto Nacional de Colonização e Reforma Agrária (INCRA) propuseram a criação de planejamentos de desenvolvimentos para os projetos de assentamentos.

O II PNRA, de 2004, foi elaborado no âmbito de uma solicitação do Governo Federal, na tentativa de materializar uma visão para a reforma agrária no Brasil em relação à distribuição, à ocupação e à produtividade de terras, regulamentando-a e normatizando-a. Esse planejamento nacional é um texto abrangente no que concerne à reforma agrária no país. Além disso, há de se considerar que sua elaboração foi concretizada depois de muitas mobilizações populares sobre a questão da terra no país. Observa-se ainda que o II PNRA foi elaborado de acordo com as políticas públicas dos governos do presidente Lula, política 'orientadora' da produção dos PDAs. 
A vigência do II PNRA levou à necessidade de que outros textos institucionais fossem elaborados para colocá-lo em execução no que se refere à ampliação da reforma agrária, à criação de novos assentamentos, bem como ao planejamento social (como oferta de cultura, educação, saúde), à infraestrutura (energia elétrica, água, estradas) e ao uso da terra (produção agropecuária) dos assentamentos. Os textos institucionais elaborados a partir do II PNRA possuem o papel, principalmente, de normatizar, regulamentar e executar ações propostas nele. Dentre eles, há os textos normativos do MDA/INCRA com o objetivo de criação de instrumentos para o desenvolvimento dos PAs, e há os textos que prescrevem o conteúdo desses textos normativos. O PDA, no caso, configura-se como um instrumento criado e utilizado pelo INCRA com o intuito de colocar em prática ações propostas no II PNRA relacionadas ao desenvolvimento de assentamentos.

Como consequência da ampliação da criação dos projetos de assentamentos, o governo federal, no âmbito do INCRA, teve que se preocupar também com questões pautadas nos meios de vida dos assentamentos e não mais somente com questões voltadas para a 'posse da terra', pois também os meios de vida formam parte do processo de concretização da reforma agrária no Brasil. Para isso, em consonância com II PNRA e o MDA, o INCRA, no ato de suas atribuições, criou e pôs em execução uma normativa para orientar a elaboração de algumas ferramentas utilizadas para o desenvolvimento dos projetos de assentamentos, como a Norma de Execução/INCRA/No. 71, de 12 de maio de 2008.

A proposição da Norma de Execução no. 71 está voltada para a normatização de instrumentos, utilizados pelo INCRA, para o planejamento de desenvolvimento dos assentamentos, como os PDAs. Essa Norma de Execução foi fundamentada na legislação brasileira no que concerne a convênios entre o governo federal e outras instituições, visto que o INCRA terceirizou a atividade de elaboração de algumas ferramentas para o desenvolvimento de PAs. Com a terceirização desse serviço, houve a necessidade de normatizar a elaboração das ferramentas de desenvolvimento dos assentamentos em termos de forma e de conteúdo. Essa normatização foi baseada, por sua vez, de acordo com o que é permitido na legislação brasileira.

Os atos oficiais basilares da Norma de Execução no. 71 são a Lei no. 8.666, de 21 de junho de 1993 e alterações; a IN/STN/01, de 15 de janeiro de 1997 e alterações; e o Decreto $\mathrm{n}^{\circ}$ 6170/2007 e alterações. A Lei no. 8.666, de 21 de junho de 1993 e alterações "Regulamenta o art. 37, inciso XXI, da Constituição Federal, institui normas para licitações e contratos da Administração Pública e dá outras providências” (BRASIL, 2014a). Já a Instrução Normativa 01, de 15 de janeiro de 1997 e alterações (IN/STN/01) "Disciplina a 
celebração de convênios de natureza financeira que tenham por objeto a execução de projetos ou realização de eventos e dá outras providências" (BRASIL, 2014b). A Secretaria do Tesouro Nacional faz uso dessa instrução normativa para disciplinar a assinatura de termo de convênio e a execução de convênio de natureza financeira, para fins de execução descentralizada de Programa de Trabalho de responsabilidade de órgão ou entidade da Administração Pública Federal, direta ou indireta. Ainda o Decreto $n^{\circ}$ 6170/2007 e alterações "Dispõe sobre as normas relativas às transferências de recursos da União mediante convênios e contratos de repasse, e dá outras providências." (BRASIL, 2014c). Com esse Decreto, a Presidência da República estabelece instruções sobre os convênios firmados, entre outros por suas autarquias como o INCRA:

(3) Art. 1o Este Decreto regulamenta os convênios, contratos de repasse e termos de execução descentralizada celebrados pelos órgãos e entidades da administração pública federal com órgãos ou entidades públicas ou privadas sem fins lucrativos, para a execução de programas, projetos e atividades que envolvam a transferência de recursos ou a descentralização de créditos oriundos dos Orçamentos Fiscal e da Seguridade Social da União.

(BRASIL, 2014c)

Esses três últimos textos institucionais determinam o que são e como devem ser feitos os convênios no âmbito federal. Já a Norma de Execução/INCRA/No. 71, de 2008, a partir dos documentos acima citados, "estabelece critérios e procedimentos referentes à Assessoria Técnica, Social e Ambiental à Reforma Agrária - ATES”, como as normas para o estabelecimento de convênios para a elaboração de PDAs e um roteiro básico para a elaboração do PDA (com itens de formatação e de conteúdo para os PDAs), apresentado no Anexo II (p.14).

\subsubsection{A interface entre os textos institucionais}

Os Planos de Desenvolvimento Agrários construídos em instância de convênio do Governo Federal (INCRA), a priori, constituem-se de acordo com a legislação máxima brasileira, a Constituição da República Federativa do Brasil, de 5 de outubro de 1988. Além disso, os PDAs foram instituídos a partir dos anos 2000, ou seja, posteriormente à promulgação da Carta Magna. 
O Título VII - Da Ordem Econômica e Financeira - da Constituição Federal, em seu Capítulo III, trata Da Política Agrícola e Fundiária e da Reforma Agrária. O Artigo 186 determina a função social da propriedade rural. Vejamos.

(4) Art. 186. A função social é cumprida quando a propriedade rural atende, simultaneamente, segundo critérios e graus de exigência estabelecidos em lei, aos seguintes requisitos:

I - aproveitamento racional e adequado;

II - utilização adequada dos recursos naturais disponíveis e preservação do meio ambiente;

III - observância das disposições que regulam as relações de trabalho;

IV - exploração que favoreça o bem-estar dos proprietários e dos trabalhadores.

(BRASIL, 2008, p. 126)

Como se pode observar, o Artigo em destaque no excerto (4) implica que as pessoas devem cumprir a função social do uso da terra. Aqueles/as que possuem o direito de uso de alguma propriedade rural - proprietários/as ou não - devem fazer uso dela de modo que preservem o meio ambiente e respeitem as relações de trabalho. Isto é, quem tem a concessão de uso de uma propriedade rural ou parte dela, como um lote de um assentamento, necessita fazer uso de acordo também com a legislação. Ao considerar o uso da terra, vale ressaltar que a pessoa com concessão de uso de uma parcela de terra ou lote em um projeto de assentamento - o/a assentado/a -, de acordo com a própria Constituição Federal, recebe somente um título de domínio de uso da terra. Vejamos.

(5) Art. 189. Os beneficiários da distribuição de imóveis rurais pela reforma agrária receberão títulos de domínio ou de concessão de uso, inegociáveis pelo prazo de dez anos.

Parágrafo único. O título de domínio e a concessão de uso serão conferidos ao homem ou à mulher, ou a ambos, independentemente do estado civil, nos termos e condições previstos em lei.

(BRASIL, 2008, p. 127)

O/a assentado/a tem o direito de uso da terra do lote concedido a ele/a, desde que caso cumpra as exigências determinadas pela legislação brasileira, é um uso com normas. Essa pessoa não é o proprietário da mesma, ou seja, não tem direito de comercializá-la.

Também a perspectiva de que o PDA seja elaborado com consulta aos assentados/as vem do Artigo 187, exposto a seguir. 
(6) Art. 187. A política agrícola será planejada e executada na forma da lei, com a participação efetiva do setor de produção, envolvendo produtores e trabalhadores rurais, bem como dos setores de comercialização, de armazenamento e de transportes, levando em conta, especialmente:

I - os instrumentos creditícios e fiscais;

II - os preços compatíveis com os custos de produção e a garantia de comercialização;

III - o incentivo à pesquisa e à tecnologia;

IV - a assistência técnica e extensão rural;

V - o seguro agrícola;

VI - o cooperativismo;

VII - a eletrificação rural e irrigação;

VIII - a habitação para o trabalhador rural.

$\S 1^{\circ}$ - Incluem-se no planejamento agrícola as atividades agroindustriais, agropecuárias, pesqueiras e florestais.

$\S 2^{\circ}$ - Serão compatibilizadas as ações de política agrícola e de reforma agrária.

(BRASIL, 2008, p. 126)

Como a função social da terra passa pela responsabilidade de quem faz uso dela, no caso, é exigida do/a assentado/a a participação na elaboração do planejamento de desenvolvimento (PDA) do assentamento onde é candidato/a a um lote através da presença em reuniões com esse objetivo.

Desse modo, a Constituição Federal de 1988, como lei máxima do país, orienta as políticas públicas sobre reforma agrária. A partir dela, algumas políticas públicas referentes a esse assunto foram criadas e implantadas, como se pode constatar no fragmento (7).

(7) Art. 188. A destinação de terras públicas e devolutas será compatibilizada com a política agrícola e com o plano nacional de reforma agrária.

$\S 1^{\circ}$ - A alienação ou a concessão, a qualquer título, de terras públicas com área superior a dois mil e quinhentos hectares a pessoa física ou jurídica, ainda que por interposta pessoa, dependerá de prévia aprovação do Congresso Nacional.

$\S 2^{\circ}$ - Excetuam-se do disposto no parágrafo anterior as alienações ou as concessões de terras públicas para fins de reforma agrária.

(BRASIL, 2008, p. 127)

Nesse ponto, vale destacar a elaboração de políticas públicas agrícolas, como a elaboração do II Plano Nacional de Reforma Agrária em cumprimento à Lei Maior. No caso, o PDA Santa Tereza I é constituído a partir da política agrícola de oito anos do governo Lula, sobretudo, da constituição do II PNRA, como sinaliza o excerto abaixo. 
(8) Plano Nacional de Reforma Agrária representa uma inovação em relação ao modelo de implementado nos últimos anos ao se orientar para fazer dos assentamentos espaços de produção e qualidade de vida integrados o desenvolvimento territorial.

(MDA e INCRA, 2004, p. 15)

A consideração do assentamento como um espaço de produção e qualidade de vida no II PNRA faz referência à Constituição Federal de 1988, no que concerne à função social da terra, conforme discutida anteriormente. Além disso, há a configuração de uma política pública específica em termos de modelo de reforma agrária para o Brasil. O II PNRA também reitera a Constituição Federal em termos de participação da 'parte produtiva' nas decisões sobre a produção:

(9) Não se trata de impor um modelo, mas apresentar e discutir alternativas com os beneficiários da Reforma Agrária, que possam garantir a sustentabilidade econômica, social e ambiental, amparadas em mecanismos de indução e fomento.

(MDA e INCRA, 2004, p. 16)

Conforme o excerto (9), parte do II PNRA, fica subtendida a participação do/a assentado/a nas discussões sobre a produção agrícola, de forma que não seja imposta àquele/a um padrão de produção. Dessa forma, se há discussão, há que se discutir com alguém: o governo federal, pelo menos através do INCRA, compromete-se a promover assistência técnica, sustentabilidade econômica, bem como social e ambiental do assentamento.

Por outro lado, com referência à ação governamental planejada no II PNRA, ocorre uma espécie de avaliação quanto à política agrícola anterior. Observemos o fragmento (10):

(10) Recuperar essa capacidade de ação governamental planejada, combinada com a prática democrática do diálogo social, representa um passo importante - e não menos inovador - para reforçar o caráter dinâmico da Reforma Agrária e acelerar seu papel na constituição de um novo tecido social em âmbito regional e nacional.

(MDA e INCRA, 2004, p. 16)

Avalia-se a ação governamental anterior no que se refere à Reforma Agrária, já que seria necessário reaver uma capacidade de ação governamental e, além disso, uma prática do diálogo social como algo inovador. Fica implícita, ao que parece, uma avaliação pejorativa da ação governamental anterior, tanto em termos de planejamento quanto de diálogo com os 
beneficiários. Também, com essa 'ação governamental planejada', certas políticas de execução para a 'ação' aparecem enfatizadas, sobretudo, com relação ao binômio renda/beneficiário.

(11) Daí a necessidade de fixar metas e de estabelecer políticas de execução da Reforma que harmonizem os objetivos de massividade e qualidade, que se expressem na fixação de metas de renda e de número de beneficiários, na adoção de um novo modelo de assentamento e no compromisso com a recuperação dos atuais assentamentos.

(MDA e INCRA, 2004, p. 19)

Os planos de desenvolvimento dos assentamentos, como os PDAs, são propostos no II PNRA como uma política de execução de um modelo de reforma agrária e de assentamento, uma vez que os mesmos pretendem fixar metas de renda, conforme se pode observar abaixo:

(12) A partir do II PNRA a criação e o desenvolvimento dos novos assentamentos passarão a se orientar por um projeto regional produtivo associado a um plano de desenvolvimento territorial, definido conjuntamente com os beneficiários e acompanhado pela assistência técnica.

(MDA e INCRA, 2004, p. 21)

Com o II PNRA, ocorre - pelo menos na sua concretização linguística - a consideração da necessidade de cada assentamento ser constituído a partir de orientações de um projeto regional produtivo, configurado em planos de desenvolvimento. Desse modo, surge a necessidade da constituição de planos de desenvolvimento para cada projeto de assentamento, ora designado como Plano de Desenvolvimento Territorial, ora como Plano de Desenvolvimento Agrário e ora como Plano de Desenvolvimento do Projeto de Assentamento.

Para tanto, no Brasil, cabe ao Ministério de Desenvolvimento Agrário (MDA) e ao Instituto Nacional de Colonização e Reforma Agrária (INCRA) a normatização, a operacionalização e o cumprimento do II PNRA em vigência atualmente.

No caso, o PDA resulta da retextualização e da recontextualização de uma Norma de Execução no. 71 e que, por sua vez, tenta colocar em prática as determinações do II PNRA, como já visto anteriormente. 
Observe-se, aqui, 'norma' como "Regra, modelo, paradigma, forma ou tudo que se estabelece em lei ou regulamento para servir de padrão na maneira de agir" (BRASIL/MPF, 2014d). ${ }^{29}$ Nas normas, são gravados preceitos e valores que vão compor a ordem jurídica. É responsável por regular a conduta do indivíduo e fixar enunciados sobre a organização da sociedade e do Estado, impondo as penalidades previstas aos que a ela infringem. E isso se dá em prol da busca do bem maior do Direito, que é a Justiça. A norma que determina o tipo de texto que é o PDA, o que deve apresentar em termos de conteúdo, é a Norma de Execução no. 71, INCRA/DD, 12 de maio de 2008, cujos Artigos 23 e 24 do Capítulo IV (Disposições Gerais) afirma-se que:

(13) Art. 23. Todos os dados e informações pertinentes as atividades realizadas e produtos pertinentes ao Programa de ATES e aos Planos (PEA - Anexo I, PDA - Anexo II, PRA - Anexo III e RAS - Anexo IV) deverão ser agregados aos Sistemas Corporativos do INCRA, quando for o caso.

Art. 24. As atividades de ATES terão seus procedimentos técnicos e administrativos regulados por esta Norma de Execução, em se tratando dos Projetos de Assentamento de Reforma Agrária e Projetos de Assentamento reconhecidos pelo INCRA.

Desse modo, a Norma de Execução tem por função regular os procedimentos técnicos e administrativos, dentre outros, do PDA de cada projeto de assentamento. Por ser agregado ao sistema corporativo do INCRA, é um texto institucional. O PDA resulta da retextualização e da recontextualização (conceitos já explicitados na subseção 2.6.1) da Norma de Execução, no. 71, uma Norma do INCRA que "estabelece critérios e procedimentos referentes à Assessoria Técnica, Social e Ambiental à Reforma Agrária - ATES”.

\subsubsection{A estrutura composicional do PDA}

Em relação à constituição do significado acional, destaca-se a "estrutura genérica" e a “intertextualidade" (FAIRCLOUGH, 2003) em termos de "ação" do gênero. Há escolhas linguístico-discursivas para que o PDA Santa Tereza I seja materializado no que se refere à forma, ao conteúdo e à ação dele, podendo-se investigar o efeito social de tais escolhas. Isso é possível devido ao alcance desses textos e discursos, haja vista ser exposto e "consumido", no

\footnotetext{
${ }^{29}$ Lei $\mathrm{N}^{\mathrm{o}}$ 10.550, de 13 de novembro de 2002. Brasília: Presidência da República, Casa Civil, Subchefia para Assuntos Jurídicos. Disponível em: <http://www.planalto.gov.br/ccivil_03/Leis/2002/L10550.htm>. Acesso em: 10 dez. 2014.
} 
mínimo, pela comunidade do assentamento para a qual é elaborado e por funcionários/as do INCRA com função, teoricamente, de fazê-lo cumprir.

Assim, a estrutura genérica do PDA Santa Tereza I é configurada em muitas partes, aqui, denominadas 'títulos' e 'subtítulos'. Em princípio, esses tópicos tendem a descrever o caminho entre a legislação brasileira sobre reforma agrária, visto que é um texto institucional tanto do assentamento quanto do governo federal. Além disso, o texto de Apresentação do PDA observa que os/as assentados/as participaram da produção do PDA:

(14) Este foi o trabalho realizado com as famílias do Projeto de Assentamento Santa Tereza I, que participaram ativamente de todo o processo e contribuíram com o conhecimento da realidade, elencando prioridades, intenções e expectativas ora apresentadas na forma desse documento.

(COOPVAG, 2007, p.1)

De acordo com o excerto acima, os desejos e as vontades dos/as assentados/as, de certa forma, também foram considerados no "caminho" para construção do PDA e estão em conformidade com a legislação sobre reforma agrária. Ainda, a COOPVAG construiu o PDA segundo a supervisão do INCRA. Parece que muitos interesses devem ser materializados, pois, linguisticamente em um PDA.

Nessa perspectiva, o Quadro 4.1, a seguir, apresenta a estrutura textual/composicional do PDA Santa Tereza I em termos de "títulos" e "subtítulos" que o constituem.

\section{Quadro 4.1 - Estrutura composicional geral do PDA do PA Santa Tereza I}

\begin{tabular}{|c|c|c|}
\hline Títulos & Subtítulos & Páginas \\
\hline Capa & & 01 \\
\hline Agradecimentos & & 01 \\
\hline 1. Apresentação & & 01 \\
\hline $\begin{array}{l}\text { 2. Identificação dos } \\
\text { responsáveis }\end{array}$ & $\begin{array}{l}\text { 2.1 Identificação do empreendedor } \\
\text { 2.2 Identificação da entidade responsável pela elaboração do PDA }\end{array}$ & 02 \\
\hline 3. Metodologia & $\begin{array}{l}\text { 3.1 Elaboração do plano } \\
\text { 3.2 Assessoria técnica, social e ambiental }\end{array}$ & 03 a 08 \\
\hline $\begin{array}{l}\text { 4. Contexto } \\
\text { socioeconômico e } \\
\text { ambiental da área de } \\
\text { influência do projeto de } \\
\text { assentamento }\end{array}$ & $\begin{array}{l}\text { 4.1 Território } \\
\text { 4.2 Caracterização do meio físico } \\
\text { 4.3 Caracterização do meio biótico } \\
\text { 4.4 Condições de conservação-degradação ambiental da área de } \\
\text { influência } \\
\text { 4.5 Caracterização do meio socioeconômico e cultural }\end{array}$ & 09 a 31 \\
\hline & $\begin{array}{l}\text { 5.1 Informações gerais do assentamento } \\
\text { 5.2 Localização geográfica do assentamento }\end{array}$ & \\
\hline
\end{tabular}




\begin{tabular}{|c|c|c|}
\hline Títulos & Subtítulos & Páginas \\
\hline $\begin{array}{l}\text { 5. Diagnóstico do projeto } \\
\text { de assentamento }\end{array}$ & $\begin{array}{l}\text { 5.3 Diagnóstico do meio físico } \\
\text { 5.4 Diagnóstico do meio biótico } \\
\text { 5.5 Organização territorial atual } \\
\text { 5.6 Diagnóstico do meio socioeconômico e cultural } \\
\text { 5.7 Análise das potencialidades e limitações do PA Santa Tereza I }\end{array}$ & 32 a 66 \\
\hline $\begin{array}{l}\text { 6. Plano de ação para o } \\
\text { desenvolvimento } \\
\text { sustentável }\end{array}$ & $\begin{array}{l}\text { 6.1 Apresentação } \\
\text { 6.2 Justificativa } \\
6.3 \text { Objetivos } \\
6.4 \text { Programas de desenvolvimento } \\
6.5 \text { Avaliação e monitoramento do plano } \\
\text { 6.6 Investimentos totais e usos-fontes de financiamento }\end{array}$ & 67 a 200 \\
\hline $\begin{array}{l}\text { 7. Prognóstico de } \\
\text { impactos ambientais e } \\
\text { medidas propostas }\end{array}$ & $\begin{array}{l}\text { 7.1 Considerações iniciais } \\
\text { 7.2 Impactos ambientais do projeto de assentamento } \\
\text { 7.3 Principais impactos ambientais gerados na execução dos programas }\end{array}$ & 201 a 210 \\
\hline 8. Considerações finais & & 211 \\
\hline Referências bibliográficas & & 212 \\
\hline Anexos & & \\
\hline
\end{tabular}

Observe-se que o PDA Santa Tereza I possui oito títulos numerados, além de Capa, Agradecimentos e Referências bibliográficas, com um total de 236 páginas, incluindo Anexos. A partir dos títulos, o PDA configura uma estrutura híbrida de texto tecnicista-instrucional e acadêmico. Há itens típicos de textos acadêmicos: Capa, Agradecimentos, Apresentação, Metodologia, Considerações finais e Referências bibliográficas. Em textos tecnicistas, também é comum tais itens, exceto Metodologia. Nesse tipo, também é comum aparecer Identificação dos responsáveis, Diagnóstico, Plano de ação e Prognóstico.

Além disso, dos oito títulos, o sexto - Plano de ação para o desenvolvimento sustentável - apresenta cento e trinta e três páginas, o que forma parte de mais da metade do total de páginas do PDA. Todos os outros títulos apresentam juntos somente oitenta páginas. Sendo assim, o título seis, com a consideração do número de páginas, é o que se destaca em termos de quantidade de conteúdo, o que justificado pelo tipo de texto proposto, haja vista constituir-se no espaço destinado para apresentação do 'plano de ação' para o assentamento.

A seguir, o Quadro 4.2 apresenta a estrutura detalhada dos títulos com soma de 80 páginas juntos: identificação dos responsáveis; metodologia; contexto socioeconômico e 
ambiental da área de influência do projeto de assentamento; diagnóstico do projeto de assentamento; prognóstico de impactos ambientais e medidas propostas; e considerações finais.

Quadro 4.2- Estrutura composicional detalhada dos títulos do PDA ${ }^{30}$

\begin{tabular}{|c|c|c|c|}
\hline $\mathbf{N}^{\mathbf{o}}$ & Subtítulos & Itens & Divisão \\
\hline 2 & $\begin{array}{l}\text { 2.1 Identificação do empreendedor } \\
2.2 \text { Identificação da entidade } \\
\text { responsável pela elaboração do PDA }\end{array}$ & & \\
\hline 3 & $\begin{array}{l}\text { 3.1 Elaboração do plano } \\
\text { 3.2 Assessoria técnica, social e } \\
\text { ambiental }\end{array}$ & $\begin{array}{l}\text { 3.1.1Motivação } \\
\text { 3.1.2Diagnóstico } \\
\text { 3.1.3Restituição } \\
\text { 3.1.4Conclusão e apresentação do } \\
\text { PDA }\end{array}$ & $\begin{array}{l}\text { 3.1.2.1Diag. interno } \\
\text { 3.1.2.2Diag. externo }\end{array}$ \\
\hline 4 & $\begin{array}{l}\text { 4.1 Território } \\
\text { 4.2 Caracterização do meio físico } \\
\text { 4.3 Caracterização do meio biótico } \\
\text { 4.4 Condições de conservação- } \\
\text { degradação ambiental da área de } \\
\text { influência } \\
\text { 4.5 Caracterização do meio } \\
\text { socioeconômico e cultural }\end{array}$ & $\begin{array}{l}\text { 4.2.1Geologia-Geomorfologia } \\
\text { 4.2.2 Pedologia } \\
\text { 4.2.3 Hidrografia } \\
\text { 4.2.4 Climatologia } \\
\text { 4.2.5 Uso da terra } \\
\text { 4.3.1 Flora } \\
\text { 4.3.2 Fauna } \\
\text { 4.5.1Histórico dos municípios } \\
\text { 4.5.2Espaço geográfico } \\
\text { 4.5.3 Situação demográfica } \\
\text { 4.5.4 Situação fundiária } \\
\text { 4.5.5 Cultura e lazer } \\
\text { 4.5.6 Promoção social } \\
\text { 4.5.7 Educação } \\
\text { 4.5.8 Saúde } \\
\text { 4.5.9 Organização social } \\
\text { 4.5.10 Transporte } \\
\text { 4.5.11 Comunicação } \\
\text { 4.5.12 Energia elétrica e iluminação } \\
\text { pública } \\
\text { 4.5.13Abastecimento de água e } \\
\text { saneamento básico } \\
\text { 4.5.14 Estrutura de produção, } \\
\text { armazenamento e beneficiamento } \\
\text { 4.5.15 Produção } \\
\text { 4.5.16 Comércio, indústrias e serviços } \\
\text { 4.5.17Potencial turístico da região } \\
\text { 4.5.18 Instituições de apoio e } \\
\text { assessoria técnica }\end{array}$ & \\
\hline & $\begin{array}{l}\text { 5.1 Informações gerais do assentamento } \\
\text { 5.2 Localização geográfica do } \\
\text { assentamento } \\
\text { 5.3 Diagnóstico do meio físico }\end{array}$ & $\begin{array}{l}\text { 5.3.1 Solos } \\
\text { 5.3.2 Relevo } \\
\text { 5.3.3 Recursos hídricos } \\
\text { 5.3.4 Uso e cobertura da terra } \\
\text { 5.3.5 Capacidade de uso da terra } \\
\text { 5.3.6 Estratificação ambiental dos }\end{array}$ & $\begin{array}{l}\text { 5.3.3.1 Disp. águas } \\
\text { superficiais } \\
\text { 5.3.3.2 Disp. de águas } \\
\text { subterrâneas }\end{array}$ \\
\hline
\end{tabular}

\footnotetext{
${ }^{30}$ Exceto o título seis.
} 


\begin{tabular}{|c|c|c|c|}
\hline $\mathbf{N}^{\mathbf{0}}$ & Subtítulos & Itens & Divisão \\
\hline 5 & $\begin{array}{l}\text { 5.4 Diagnóstico do meio biótico } \\
\text { 5.5 Organização territorial atual } \\
\text { 5.6 Diagnóstico do meio } \\
\text { socioeconômico e cultural } \\
\end{array}$ & $\begin{array}{l}\text { agroecossistemas } \\
\text { 5.4.1 Flora } \\
\text { 5.4.2 Reserva legal e área de } \\
\text { preservação permanente } \\
\text { 5.4.3 Fauna } \\
\text { 5.6.1 Histórico do projeto de } \\
\text { assentamento Santa Tereza I } \\
\text { 5.6.2 Aspectos demográficos } \\
\text { 5.6.3 Organização social } \\
\text { 5.6.4 Composição da associação } \\
\text { 5.6. } 5 \text { Forma e nível de articulação } \\
\text { com outras instituições } \\
\text { 5.6.6 Infraestrutura física, social e } \\
\text { econômica } \\
\text { 5.6.7. Infraestrutura produtiva } \\
\text { 5.6.8 Sistema produtivo } \\
\text { 5.6.9 Serviços de apoio à produção } \\
\text { 5.6.10 Serviços sociais básicos }\end{array}$ & $\begin{array}{l} \\
\\
\\
\\
\text { técnica e pesquisa } \\
\text { 5.6.9.2 Crédito } \\
\text { 5.6.9.3 Capacitação } \\
\text { profissional } \\
\text { 5.6.10.1 Educação } \\
\text { 5.6.10.2 Saúde e } \\
\text { saneamento } \\
\text { 5.6.10.3 Cultura e lazer } \\
\text { 5.6.10.4 Habitação } \\
\text { 5.6.10.5 Outros } \\
\text { programas } \\
\text { governamentais e não- } \\
\text { governamentais }\end{array}$ \\
\hline 7 & $\begin{array}{l}\text { 7.1 Considerações iniciais } \\
\text { 7.2 Impactos ambientais do projeto de } \\
\text { assentamento } \\
\text { 7.3 Principais impactos ambientais } \\
\text { gerados na execução dos programas }\end{array}$ & & \\
\hline
\end{tabular}

A partir do Quadro 4.2, é observada a apresentação de uma estrutura de texto técnico no PDA, principalmente, nos títulos Identificação dos responsáveis e Metodologia, bem como nos subtítulos Identificação do empreendedor e Identificação da entidade responsável pela elaboração do PDA. Em princípio, um texto acadêmico não é tido como um empreendimento para gerar lucro, pois não é comum o responsável por um texto acadêmico ser designado no próprio texto como um 'empreendedor'.

Já o Quadro 4.3, em termos da estrutura composicional de texto, trata do detalhamento do título Plano de ação para o desenvolvimento sustentável, o mais extenso do PDA, com maior conteúdo, o que pode ser visualizado a seguir. 
Quadro 4.3 - Estrutura composicional do Plano de ação para o desenvolvimento

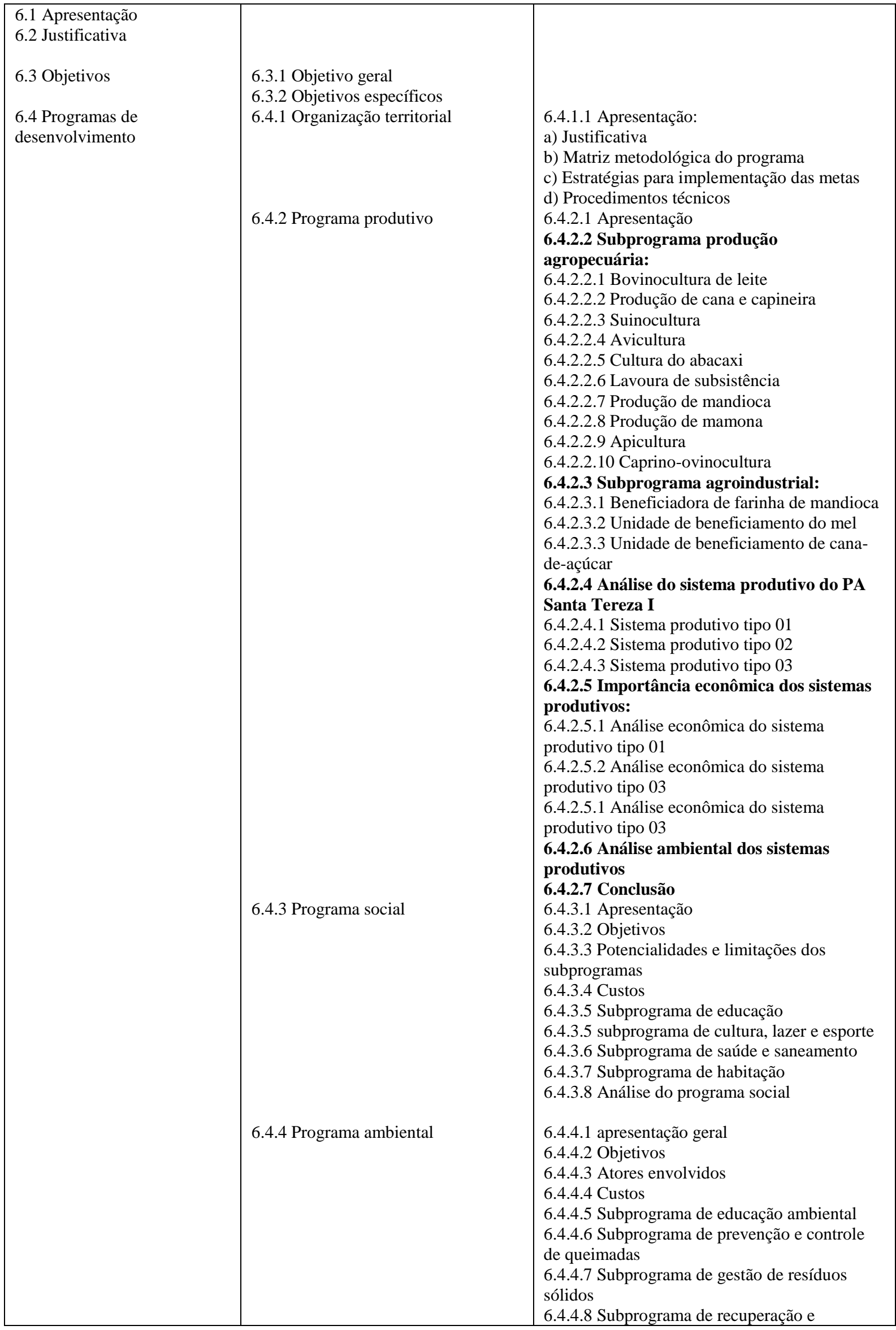


6.5 Avaliação e

monitoramento do plano

6.6 Investimentos totais e

usos-fontes de financiamento

6.4.5 Programa de desenvolvimento organizacional e de gestão do plano 6.4.6 Capacitação e assessoria técnica preservação de áreas de preservação permanente

6.4.4.9 Subprograma de uso e conservação da reserva legal

6.4.4.10 Subprograma de uso e conservação do solo

6.4.4.11 Subprograma de manejo e

racionalização do uso de agroquímicos

6.4.6.1 Resumo dos temas transversais 6.4.6.2 Assessoria técnica, social e ambiental ATES

6.4.6.3 Capacitação

O Quadro 4.3 reitera não só a estrutura de formato acadêmico do PDA com objetivos, justificativas, mas também a composição de texto instrucional - cartilha, um texto técnico. Há de se destacar a estrutura híbrida - 'técnico-acadêmica' - com “apresentação, justificativa e objetivos", e com programas de desenvolvimento a partir do "diagnóstico, das análises dos programas e avaliação e do monitoramento do plano". Há programas de produção agropecuária, contendo prescrições de ações, principalmente para os/as assentados/as.

Por conseguinte, os três quadros apresentados descrevem a estrutura constituinte do PDA Santa Tereza I, sua composição, seu tipo de recorrência. Essa estrutura é apresentada de forma particular, de modo que são concebidas como forma de ação social.

Em relação ao grau de estabilização/ritualização (padrão composicional) do texto do PDA Santa Tereza I, observa-se um padrão composicional com certa estabilidade. Em princípio, o INCRA normatiza o conteúdo de qualquer PDA através da Norma de Execução no. 71, de 2008. A concretização linguística do conteúdo dos títulos e dos subtítulos possui um grau de estabilização. Essa padronização na composição vai ao encontro do objetivo para o qual os PDAs são propostos: funcionar como uma ferramenta utilizada pelo INCRA para o planejamento de desenvolvimento de assentamentos.

Além disso, a padronização da estrutura e do conteúdo dos PDAs, exigida pelo INCRA, atribui a eles uma ação em escala global, visto que há um grande número de PDAs e um grande número a ser produzido, levando-se em conta que todo projeto de assentamento (PA) deveria possuir um PDA. Somente, no estado do Tocantins, são mais de trezentos e cinquenta PAs, o que soma a elaboração de mais de trezentos e cinquenta PDAs. Com isso, os textos dos PDAs tendem a ser 'consumidos', pelo menos, pelo INCRA e por todas as 
comunidades assentadas em escala global. Ademais, por ser um texto institucional, mas de interesse social, é um texto de domínio público.

Em termos da estrutura composicional, há também consideração do grau de abstração. De acordo com Fairclough (2003), uma referência a essa estrutura faz-se através dos pré-gêneros. Referem-se às formas de organização do discurso, como a narração, a argumentação, a descrição, a injunção e a conversação. Por isso, tendem apresentar alto grau de abstração. No caso do PDA Santa Tereza I, o texto é constituído com traços de 'descrição' nos títulos que elencam as características do PA Santa Tereza I, como na sua Ficha de Apresentação: "equipe responsável; identificação do empreendedor; identificação da entidade responsável pela elaboração do PDA; elaboração do plano; assessoria técnica, social e ambiental; o território; caracterização do meio físico; caracterização do meio biótico; condições de conservação/degradação ambiental da área de influência”. A descrição, no texto do PDA, faz referência, sobretudo, às características físicas e humanas do assentamento, seguidas das características potenciais de produção dele.

Nesse sentido, as partes constituintes doo PDA Santa Tereza I estão relacionadas a informações variadas acerca de um planejamento de ações para o desenvolvimento do assentamento, com o objetivo de um "pretendido funcionamento adequado" dele. ${ }^{31} \mathrm{~A}$ estrutura composicional do texto do PDA estudado também é constituída por traços da ‘injunção', principalmente, no título "Plano de ação para o desenvolvimento sustentável" (título 6), em que são prescritas ações a serem desenvolvidas no assentamento. Essas prescrições são direcionadas, por sua vez, sobretudo aos/às assentados/as. Observe-se ainda além de traços da 'descrição' e da 'injunção' constituírem o texto do PDA, traços da 'argumentação' também constituintes do PDA, principalmente, nos títulos: "Plano de ação para o desenvolvimento sustentável, Prognóstico de impactos ambientais e medidas propostas e Considerações finais".

A escolha da concretização dessa estrutura composicional (e não outra) para o texto do PDA Santa Tereza I implica certa ênfase às características, às potencialidades não somente físicas do assentamento. Além do mais, essa 'ritualização' textual faz o PDA parecer um texto basicamente 'descritivo-informativo', o que parece fazer cumprir, em princípio, a Norma de Execução no, 71 do INCRA, que o institui enquanto texto institucional e lhe prescreve um tipo de forma e um determinado conteúdo. O texto do PDA, no entanto, também é constituído com características composicionais típicas da 'argumentação' em meio ao próprio “jogo

\footnotetext{
${ }^{31} \mathrm{O}$ funcionamento do PA será discutido, nesse trabalho, posteriormente.
} 
informação-identificação-execução", enfatizando a orientação ao cumprimento das ações prescritas nele e que, de certa forma, o determina.

Por conseguinte, o texto do PDA Santa Tereza I também pode ser considerado em termos de um gênero situado, devido a um "conjunto de práticas particulares" lhe ser inerente, constitutivo (FAIRCLOUGH, 2003). Em um contexto sócio-histórico específico, o PDA enquanto uma ferramenta institucional (utilizada pelo INCRA) para o planejamento do desenvolvimento de PAs é configurado com características próprias, não somente relacionadas à forma e ao conteúdo, mas também a 'ações' sobre o mundo, no caso, sobre o PA Santa Tereza I.

Nesse sentido, até a 'não ação' ou não execução' do referido PDA faz-se uma forma de ação sobre o PA, visto que esse PDA foi instituído com uma função social a ser cumprida. Ocorre, pois, uma dialética entre a estrutura COOPVAG-INCRA que o produz e a ação 'descrever-instruir/prescrever-informar', que pode ser considerada uma faceta regulatória do discurso.

Além disso, o PDA Santa Tereza I também pode ser considerado em termos de gênero de governança na medida em que é constituído a partir de uma norma institucional do INCRA, a Norma de Execução/INCRA/DD/No. 71, de 12 de maio de 2008, como uma ferramenta institucional para o planejamento do desenvolvimento de assentamentos. Essa norma, por sua vez, foi constituída para fazer cumprir o II PNRA, de acordo com a legislação brasileira sobre a reforma agrária. O PDA é uma retextualização e uma recontextualização de outros textos institucionais do INCRA, do MDA e da Constituição Federal em um recorte temporal, como apontado no Capítulo 2, na subseção 2.6.1.

Desse modo, os PDAs desempenham um papel para sustentação da estrutura institucional, responsável tecnicamente pela sua elaboração e que também determina e especifica seu conteúdo através de uma norma de execução. Em outras palavras, o PDA é constituído a partir da égide de uma legislação vigente no país acerca do "funcionamento", do desenvolvimento, de projetos de assentamentos. Essa legislação foi recontextualizada e retextualizada no II PNRA, de 2004. Para tentar fazer cumprir o II PNRA, o Ministério de Desenvolvimento Agrário (MDA) instituiu regulamentos e normas - concretizados em textos escritos -, sendo muitos desses textos levados a cabo pelo INCRA. O INCRA, para realizar esse papel, elabora textos oficiais, recontextualizando e retextualizando algumas determinações do MDA para o cumprimento da legislação sobre reforma agrária, como é o caso da Norma de Execução/INCRA/DD/No. 71, de 12 de maio de 2008. Essa norma de 
execução trata das normas para a elaboração dos PDAs quanto à forma, ao conteúdo e à função social a cumprir enquanto documento institucional.

Desse modo, para que o processo de retextualização ocorra, o processo de recontextualização também ocorre. Em se tratando do PDA, a legislação federal é retextualizada, à medida que essa legislação sobre reforma agrária é instituída no âmbito do governo federal e o PDA Santa Tereza I é constituído em um contexto sócio-histórico específico do país; em um dos estados brasileiros (o Tocantins), com características físicas e humanas específicas; e em uma região do estado com características também específicas. $\mathrm{O}$ texto de 'Apresentação' do PDA já diz isso:

(15) Este documento contém informações que caracterizam tanto o perfil da comunidade, quanto da região, na qual está inserida e apresenta os programas, que são a materialização de suas demandas de desenvolvimento.

(COOPVAG, 2007, p. 1)

A COOPVAG foi contratada pelo INCRA para elaborar o PDA Santa Tereza I a partir da Norma de Execução no. 71, retextualizando-a, de acordo, em princípio, com a "realidade" do Estado do Tocantins e do próprio assentamento a que se destina. Essa atualização também é construída em termos de recontextualização, à medida que as "informações primárias", citadas anteriormente, instituem o PDA de acordo com sua padronização, ou seja, há adequações para um determinado contexto sócio-histórico da época de elaboração. Tanto os técnicos designados pelo INCRA (representantes do governo) quanto o/a assentado/a que “consomem" esse PDA apresentam formas de vida em um contexto sócio-histórico e cultural determinado, há exigências especificas de seu tempo, pois a sociedade é dinâmica. Ainda, os técnicos da COOPVAG, mesmo tentando seguir as instruções do INCRA - representante do governo federal -, também representam, de alguma forma, a empresa que trabalham quando desempenham as funções que lhes são designadas como a construção de um PDA.

Já as relações intertextuais do PDA Santa Tereza I podem ser consideradas em um sentido bem amplo, já que abrangem possibilidades entre a voz de quem enuncia COOPVAG - e as outras vozes articuladas a ela. O PDA é constituído, sobretudo, com o uso da "descrição" e da "injunção", que materializam a voz do institucional (voz regulamentadora da reforma agrária) e outras vozes como a voz do INCRA, que representa o governo federal; e a do/a assentado/a. Sobre isso, Fairclough (2003), aponta que a intertextualidade faz referência a maneiras de agir discursivamente em práticas sociais. 
De acordo com o texto de Apresentação do PDA, entrevistas de assentados/as foram retextualizadas e recontextualizadas por técnicos/as da COOPVAG e foram utilizadas em textos do PDA. Parece haver, de certa forma, a voz do/a assentado/a e também a voz de técnicos/as (representantes do governo). O uso de 'injunções' materializam a voz institucional (governo federal) com determinações de ações de assentados/as em relação aos seus modos de vida no assentamento.

Posteriormente, será apresentado um estudo sobre a representação dessas 'vozes' no PDA Santa Tereza I.

\subsection{A inclusão do/a assentado/a: o PDA e(m) representações}

Esta seção trata da análise da representação da inclusão do/a assentado/a no Plano de Desenvolvimento do Projeto de Assentamento Santa Tereza I. A partir do significado acional do PDA, há materialização da representação da realidade através da combinação de títulos desse documento, elementos recorrentes na estrutura genérica. A relação desses elementos estrutura genérica e intertextualidade - faz significar aspectos do mundo, pois quando se analisa um texto em termos de gênero, tem-se o objetivo examiná-lo na configuração da interação social. De acordo com Resende e Ramalho (2006, p. 62), “cada prática social produz e utiliza gêneros discursivos particulares que articulam estilos e discursos de maneira relativamente estável, num determinado contexto sócio-histórico e cultural”.

Como o PDA Santa Tereza I é constituído de forma social, o conteúdo de seus itens é perpassado também por um aspecto especificamente discursivo. Esse aspecto discursivo pode ser estudado através do significado representacional, diretamente relacionado com os modos de representar. Para tanto, foi utilizado o programa computacional Wordsmith Tools v. 6.0 (SCOTT, 2012) para seleção e visualização de dados, o que contribui para análise aqui proposta.

A análise linguístico-discursiva proposta configura-se a partir de quatro subseções. A primeira subseção envolve o percurso analítico no texto do PDA do PA Santa Tereza I, constituído através do uso do WordSmith Tools v. 6.0 (SCOTT, 2012). A subseção seguinte propõe a análise da representação de ações no PDA através do estudo do Sistema de Transitividade (HALLIDAY \& MATTHIESSEN, 2004). A terceira subseção discute a representação em sete títulos do PDA de forma detalhada. Já a última subseção, analisa o título mais extenso do PDA (título seis) a partir também do Sistema de Transitividade. 


\subsubsection{Percurso no PDA Santa Tereza I pelo WordSmith Tools}

Para a análise PDA Santa Tereza I, a ferramenta do programa computacional WordSmith Tools v. 6.0 (SCOTT, 2012) é utilizada com vistas a levar a cabo uma descrição detalhada de não somente aspectos da composição lexical como também da temática do texto e da sua organização retórica e composicional em termos de gênero discursivo. De acordo com Sardinha, o programa WordSmith, enquanto ferramenta computacional,

coloca à disposição do analista uma serie de recursos que, bem usados, são extremamente úteis e poderosos na análise de vários aspectos da linguagem, como a composição lexical, a temática de textos selecionados e a organização retórica e composicional de gêneros discursivos (SARDINHA, 2004, p. 85).

Para análise do PDA Santa Tereza I, foram utilizadas duas ferramentas do WordSmith Tools: wordlist (lista de palavras) e concordance (concordâncias). A ferramenta wordlist possibilita uma microanálise do texto quanto ao tamanho do arquivo, quantidade de palavras diferentes e repetidas e com a respectiva frequência. Depois do texto formatado em arquivo txt, a ferramenta wordlist é acessada para selecionar o arquivo e fazer a lista de dimensões e densidade lexical (statistics) do PDA Santa Tereza I, como ilustra a Tabela 4.1:

Tabela 4.1 - Dimensões e densidade lexical (statistics) do PDA Santa Tereza I

\begin{tabular}{c|c|c}
\hline $\mathbf{N}$ & Overall & $\mathbf{1}$ \\
\hline text file & Overall & PDA Santa Tereza I.txt \\
\hline file size & 493.735 & 493.735 \\
\hline $\begin{array}{c}\text { tokens (running words) } \\
\text { in text }\end{array}$ & 74.512 & 74.512 \\
\hline tokens used for word list & 70.077 & 70.077 \\
\hline types (distinct words) & 7.852 & 7.852 \\
\hline
\end{tabular}

De acordo com a tabela, o WordSmith Tools por meio da ferramenta wordlist identificou no PDA Santa Tereza I o número total de palavras (tokens in text), que é 74.512; o número de palavras usado para se fazer o wordlist (tokens used for word list), que é 70.077; e o número de palavras diferentes (distinct words), que é 7.852. A tessitura do texto exige repetição de vocábulos para a manutenção do assunto proposto e também utilização de elementos dêiticos responsáveis pela coesão textual, como advérbios, artigos e pronomes. 
Em seguida, o wordlist foi utilizado novamente para fazer a lista de palavras mais frequentes no PDA e é apresentada na Tabela 4.2.

Tabela 4.2 - Palavras/Substantivos mais frequentes no PDA Santa Tereza I

\begin{tabular}{c|c|c|l}
\hline $\mathbf{N}$ & Word & Frequence & \multicolumn{1}{c}{ \% Ocorrences } \\
\hline 1 & SANTA & 468 & 0,63 \\
\hline 2 & TEREZA & 465 & 0,62 \\
\hline 3 & DESENVOLVIMENTO & 391 & 0,52 \\
\hline 4 & ASSENTAMENTO & 367 & 0,49 \\
\hline 5 & COMUNIDADE & 359 & 0,48 \\
\hline 6 & PLANO & 323 & 0,43 \\
\hline 7 & PROJETO & 305 & 0,41 eto[176] proj[176] projeto [129] \\
\hline 8 & ATIVIDADE & 301 & 0,40 atividades [165] atividade [136] \\
\hline 9 & PROGRAMA & 231 & 0,18 programa [137] programas [ 94] \\
\hline 10 & PRODUÇÃO & 207 & 0,28 \\
\hline 11 & AREA & 199 & 0,27 \\
\hline 12 & AÇÕES & 193 & 0,26 \\
\hline 13 & TOCANTINS & 187 & 0,25 \\
\hline 14 & FAMÍLIAS & 177 & 0,24 \\
\hline 15 & ATIVIDADES & 165 & 0,22 \\
\hline 16 & SISTEMA & 150 & 0,20 \\
\hline 17 & PROCESSO & 134 & 0,18 \\
\hline 18 & FONTE & 127 & 0,17 \\
\hline 19 & TÉCNICA & 126 & 0,17 \\
\hline 20 & SOCIAL & 124 & 0,17 \\
\hline
\end{tabular}

Através da lista de palavras (wordlist) do PDA Santa Tereza I, também foi constituída uma seleção de itens lexicais - substantivos - mais frequentes no que concerne a temática do documento. Sendo assim, o substantivo mais frequente no PDA é 'Santa' (com 468 ocorrências), seguido de 'Tereza' (com 465 ocorrências), os quais, pelos contextos de uso, e com base na ferramenta Concordance, nomeiam o assentamento: Santa Tereza I. No contexto de uso, há junção das duas para se formar um nome.

(16) Este foi o trabalho realizado com as famílias do Projeto de Assentamento Santa Tereza I, que participaram ativamente de todo o processo e contribuíram com o conhecimento da realidade, elencando prioridades, intenções e expectativas ora apresentadas na forma desse documento.

(COOPVAG, 2007, p. 3)

Também há de se destacar, na lista das 20 palavras mais frequentes, o uso da palavra ‘comunidade', com 359 aparições; e a palavra 'famílias', com 177 aparições. 
(17) Desse modo, este documento contém informações que caracterizam tanto o perfil da comunidade, quanto da região, na qual está inserida e apresenta os programas, que são a materialização de suas demandas de desenvolvimento.

(COOPVAG, 2007, p. 3)

(18) Nesse Assentamento, aplicou-se o questionário a aproximadamente 94\% das famílias. Procurou-se também identificar as expectativas das famílias com relação ao futuro, aptidões e expectativas de produção, sendo construídos mapas da propriedade de cada um, expressando como querem o assentamento, futuramente.

(COOPVAG, 2007, p. 7)

Os excertos (17) e (18) ilustram usos das palavras 'comunidade' e 'famílias' respectivamente. A palavra 'comunidade' é a quinta mais usada no PDA e é a primeira a fazer referência ao/à assentado/a. Além disso, 'famílias' é a outra palavra da lista que se refere ao/à futuro/a assentado/a. Nessa lista, não aparece 'assentado/a', somente aparece 'comunidade' (359) e 'famílias' (177). Para denominar o indivíduo que recebeu o direito de uso da terra no PA Santa Tereza I, há preferência por palavras que remetem a modos de vida em coletividade. Em termos de frequência de palavras, não há escolha por uma que faça referência ao indivíduo, ator social e futuro/a assentado/a. Destaque-se, em (18), o uso da palavra 'famílias' relacionado à 'expectativas de produção'. Ocorre um foco no PDA apenas para a produção.

Depois, na Tabela 4.3, é apresentada a lista dos 20 processos verbais mais recorrentes no PDA Santa Tereza I. Essa lista foi elaborada também por meio do uso do wordlist para a análise dos elementos do sistema de transitividade, apontados no Capítulo 2. A tabela é organizada em quatro colunas: a primeira coluna apresenta a numeração dos processos em ordem crescente; a segunda contém os processos ordenados da maior frequência para a menor; a terceira coluna apresenta o número de vezes de aparecimento no PDA e a quarta mostra as formas como os processos se materializaram no texto. ${ }^{32}$

Tabela 4.3 - Processos verbais mais recorrentes no PDA Santa Tereza I

\begin{tabular}{c|l|l|ll}
\hline N & Word & Freq. & \multicolumn{4}{|c}{ Lemmas } \\
\hline 1 & SER & 1447 & $\begin{array}{l}\text { é[373] ser[263] são[169] sendo[139] foi[121] será[114] } \\
\text { serão[98] foram[62] seja[36] serem[34] sejam[13] seria[11] } \\
\text { sido[9] era[4] forem[1] }\end{array}$ \\
\hline 2 & TER & 204 & $\begin{array}{l}\text { tem[54] ter[36] têm[28] tendo[20] tenham[13] terá[11] } \\
\text { tinha[10] teve[10] terão[9] tinham[5] tiveram[3] tem-se[1] } \\
\text { tendo-se[1] terem[1] tinha[1] tiverem[1] }\end{array}$ \\
\hline
\end{tabular}

32 A razão da escolha de vinte processos mais recorrentes foi a carga semântica de cada um em termos de representação social. 


\begin{tabular}{|c|c|c|c|}
\hline $\mathrm{N}$ & Word & Freq. & Lemmas \\
\hline 3 & ESTAR & 202 & $\begin{array}{l}\text { está[93] estão[59] estar[14] estarão[7] esteja[6] estará[5] } \\
\text { estejam [4] estarem[3] estavam[3] estando[2] esteve[2] } \\
\text { estiver[2] estiverem[1] estivessem[1] }\end{array}$ \\
\hline 4 & PODER & 194 & $\begin{array}{l}\text { pode[54] podem[44] poderá[23] possam[18] poderão[14] } \\
\text { podendo [12] possa[10] pode-se[9] podemos[4] poderá[2] } \\
\text { poderem[2] poderia[1] podiam[1] }\end{array}$ \\
\hline 5 & DEVER & 178 & $\begin{array}{lllll}\text { deverá[65] deve[50] } & \text { deverão[29] } & \text { devem[21] } & \text { deve-se[8] } \\
\text { devendo [2] deveria[2] devemos[1] } & & \\
\end{array}$ \\
\hline 6 & FAZER & 137 & $\begin{array}{l}\text { fazer[31] feita[23] feito[23] fazem[11] feitas[10] fez[10] } \\
\text { faz[9] faça[4] fazendo[4] feitos[4] faz-se[3] façam[2] } \\
\text { fazia[1] fez-se[1] fizeram[1] }\end{array}$ \\
\hline 7 & PROMOVER & 108 & $\begin{array}{l}\text { promover[91] promovam[7] promova[3] promovendo[3] } \\
\text { promove [1] promovem[1] promoverá[1] promoverão[1] }\end{array}$ \\
\hline 8 & APRESENTAR & 79 & $\begin{array}{l}\text { apresenta[42] apresentam[14] apresentar[8] apresentados[3] } \\
\text { apresentaram[3] apresente[3] apresentado[2] apresentadas[1] } \\
\text { apresentam-se[1] apresentarem[1] apresenta-se[1] }\end{array}$ \\
\hline 9 & HAVER & 77 & $\begin{array}{l}\text { há[47] haja[7] houve[7] haverá[6] houver[4] haver[3] } \\
\text { havendo[2] havia[1] }\end{array}$ \\
\hline 10 & REALIZAR & 65 & $\begin{array}{l}\text { realizar[15] realizada [14] realizadas [12] } \\
\text { realizados[4] realizado [11] } \\
\text { realizarão[1] realizasse[1] realizavam[1] }\end{array}$ \\
\hline 11 & IDENTIFICAR & 50 & $\begin{array}{l}\text { identificar[30] identificou[7] identificada[4] identificou-se[3] } \\
\text { identificaram[2] identifica[1] identificando[1] identificaram- } \\
\text { se[1] identificarão[1] }\end{array}$ \\
\hline 12 & POSSUIR & 45 & $\begin{array}{l}\text { possui[32] possuir[4] possuíam[3] possuindo[2] possuirá[2] } \\
\text { possuírem[2] }\end{array}$ \\
\hline 13 & CONTRIBUIR & 43 & $\begin{array}{l}\text { contribuir[21] contribuindo[9] contribui[7] contribuirá[2] } \\
\text { contribuíram[2] contribui[2] }\end{array}$ \\
\hline 14 & AUMENTAR & 41 & $\begin{array}{l}\text { aumentar[26] aumentando[4] aumenta[3] aumentado[3] } \\
\text { aumentam [2] aumente[1] aumentem[1] aumentou[1] }\end{array}$ \\
\hline 15 & EXISTIR & 40 & existe[21] existem[17] existia[1] existirá[1] \\
\hline 16 & DEFINIR & 35 & $\begin{array}{llll}\text { definir[21] } & \text { definidos[4] definida[2] } & \text { defina[1] } & \text { define[1] } \\
\text { definindo [1] definiram[1] definidas[1] } & \text { definido[1] } \\
\text { definirem[1] definissem [1] } & & \\
\end{array}$ \\
\hline 17 & GARANTIR & 35 & $\begin{array}{l}\text { garantir[23] } \quad \text { garantam[3] } \\
\text { garantida[2] garantem[1] garantirá[1] }\end{array}$ \\
\hline 18 & MELHORAR & 35 & $\begin{array}{l}\text { melhorar[27] melhorando[3] melhora[2] melhorados [1] } \\
\text { melhorem [1] melhorada[1] }\end{array}$ \\
\hline 19 & DESENVOLVER & 33 & 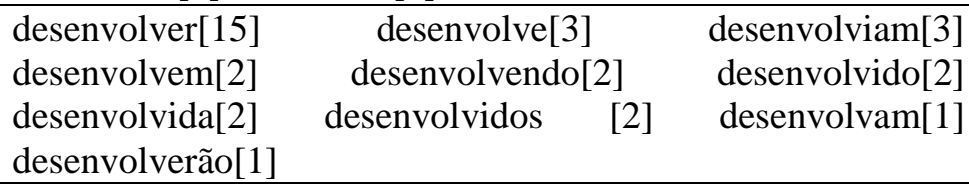 \\
\hline 20 & FOMENTAR & 27 & fomentar[23] fomentando[2] fomentado[1] fomentou[1] \\
\hline
\end{tabular}

A leitura da wordlist, apresentada na Tabela 4.3, remete a processos mais recorrentes no texto do PDA Santa Tereza I: ser (1447), ter (204), estar (202), poder (194) e dever (178). Observa-se tal recorrência também no Gráfico 4.1. Esse gráfico apresenta somente os dez processos mais frequentes, uma vez que o décimo processo apresenta um por cento de 
frequência e os demais processos apresentam menos de um por cento de frequência considerando o total de palavras do PDA e por isso não foram inseridos no gráfico.

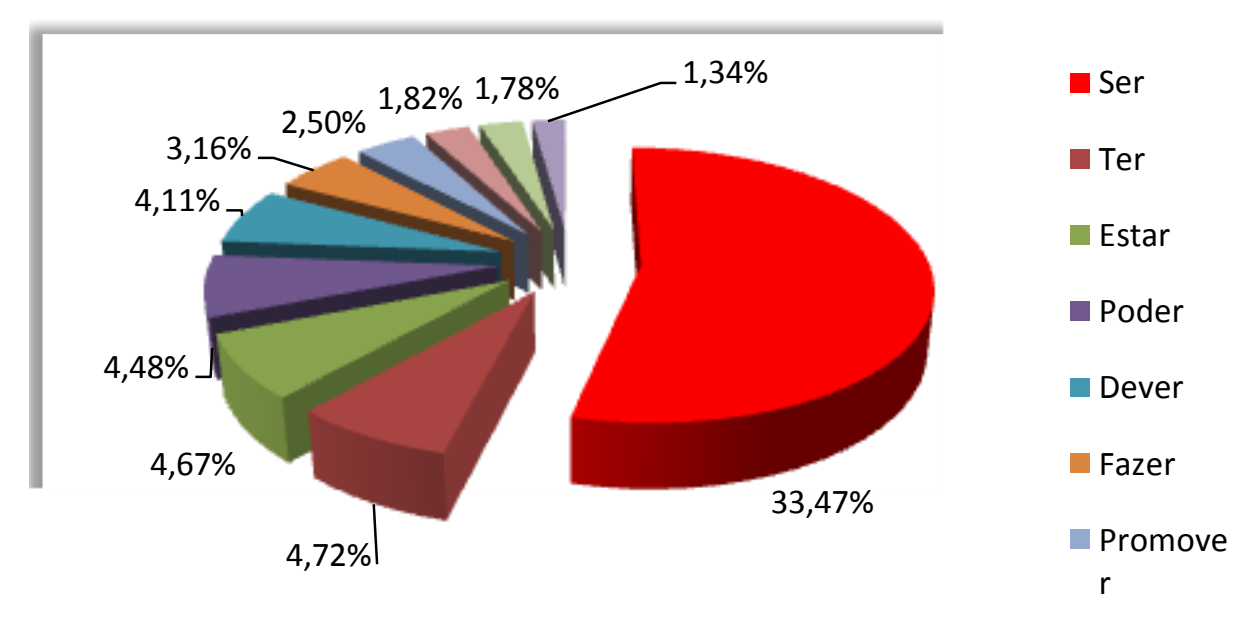

\section{Gráfico 4.1 - Processos mais frequentes no texto do PDA Santa Tereza I}

O processo verbal 'ser' apresenta maior ocorrência e indica que a estrutura textual do PDA pode possuir voz passiva ou processo relacional, o que será discutido adiante. Já a alta ocorrência dos processos 'poder', 'ter' e 'dever' fornece um direcionamento para uma análise da metafunção interpessoal, no que concerne às categorias de modalidade e modulação, as quais serão discutidas posteriormente, na seção que se propõe investigar o significado ideacional da linguagem. Para a investigação linguístico-discursiva, interessa, aqui, as ações de inclusão/exclusão representadas no PDA Santa Tereza I, através da análise dos componentes do sistema de transitividade.

\subsubsection{Representação de ações no PDA e o sistema de transitividade}

Nesta subseção, será analisada a representação de ações no texto do PDA Santa Tereza I como um todo, sem detalhes de cada parte que o constitui devido à sua extensão. Com isso, analiso a representação de ações por meio do estudo do Sistema de Transitividade (HALLIDAY \& MATTHIESSEN, 2004). Para Halliday (1994), a metafunção ideacional é o componente principal do significado no sistema linguístico, pois envolve todo o sistema de transitividade na língua. A transitividade constitui-se na construção do mundo da experiência em conjuntos de tipos de processos, participantes e circunstâncias. A classificação dos processos verbais segue as orientações metodológicas da Gramática Sistêmico-Funcional. 
Trata-se de elementos que envolvem representações, bem como significados, de realidades sociais do mundo. Isto é, expressa o conteúdo da experiência do falante em relação a seu mundo interior e exterior.

Assim, serão analisados os componentes do sistema de transitividade, apresentados no capítulo teórico, presentes no texto do PDA do PA Santa Tereza I. O levantamento de processos presentes no referido PDA foi apresentado após a exclusão dos vocábulos que não são processos verbais, o que admitiu constatar o resultado consequente: de 4.312 processos, 49,42 \% de ocorrências são processos materiais (2.136); acompanhados por 29,50\% de ocorrências de processos relacionais (1.275); 11,57\% de processos mentais (499); 4,49\% de processos existenciais (194), 4,35\% de processos verbais (188) e 0,46\% de processos comportamentais (20). A distribuição dos processos no PDA Santas Tereza I está compendiada no Gráfico 4.2 .

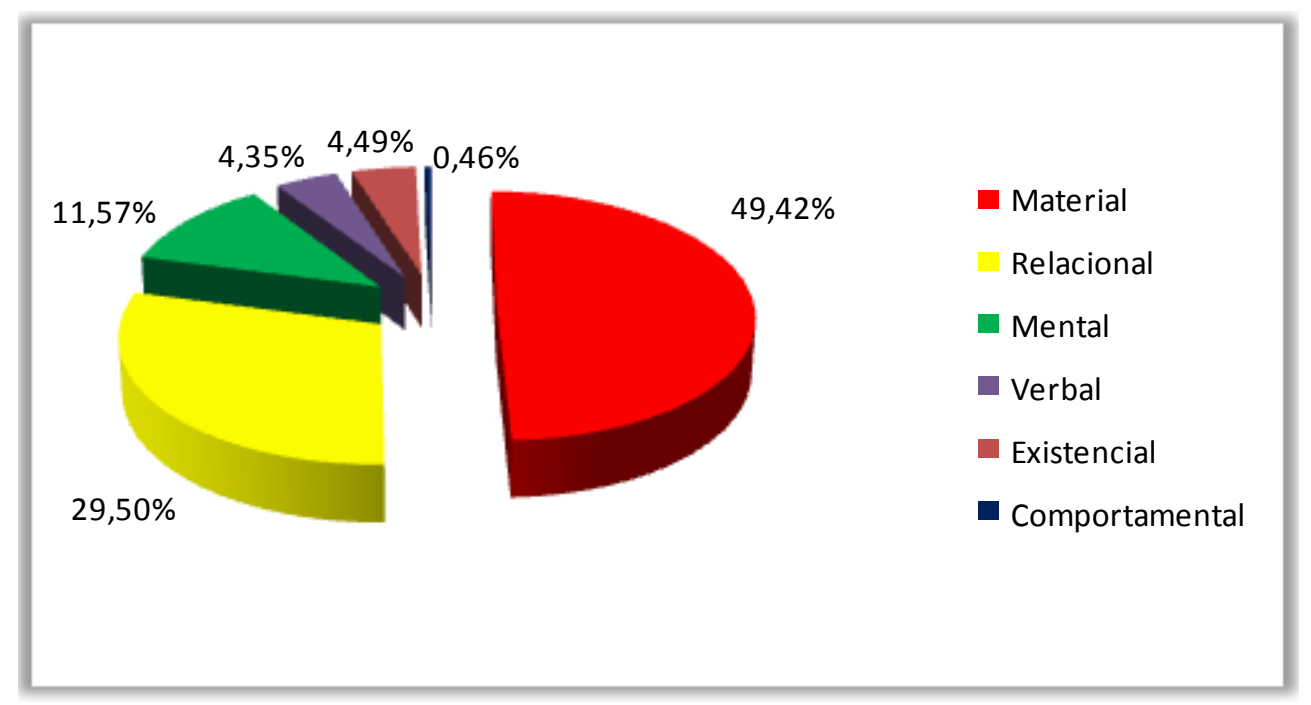

Gráfico 4.2 - Distribuição de processos no PDA Santa Tereza I

Constata-se, no Gráfico 4.2, a ocorrência de processos materiais sendo mais da metade do total de processos do PDA Santa Tereza I. Isso representa mais do que o dobro da ocorrência do segundo tipo de processo. $\mathrm{O}$ índice de ocorrências pode ser justificado devido à própria natureza constitutiva do texto do PDA. No “jogo de informar-descrever-prescrever", o texto envolve tanto descrições de características físicas do assentamento quanto prescrições de ações para o desenvolvimento do mesmo. O documento inclui, ainda, o perfil sócioeconômico esperado para a seleção das pessoas que pleiteiam o direito ao uso da terra. Ações próprias do mundo físico do fazer e do acontecer - típicas de processos materiais - ocorrem nesse gênero textual. As "ações" prescritas devem ser colocadas em prática por atores sociais 
responsáveis pela implementação do PDA. Os dois excertos abaixo, retirados do tópico Plano de ação para o desenvolvimento sustentável, ilustram isso.

(19) Os animais [beneficiário] receberão [processo material] suplementação mineral periodicamente [meta]. Serão feitos [processo material] exames de brucelose uma vez por ano em todos os reprodutores e em vacas não vacinadas [meta]. Ainda serão vacinados [processo material] contra aftosa, raiva e outras zoonoses [meta] conforme o calendário regional de vacinação [circunstância].

(COOPVAG, 2007, p. 81)

(20) A capacitação [meta] será ministrada [processo material] periodicamente [circunstância] pela equipe de Assessoria Técnica conveniada para prestar Assessoria Técnica, Social e Ambiental à Reforma Agrária - ATES [ator], no Projeto de Assentamento Santa Tereza I [circunstância]. Além da capacitação técnica, todo o processo produtivo inicial [meta] no PA [circunstância] também será acompanhado [processo material] pelos técnicos da prestadora [ator].

(COOPVAG, 2007, p. 91)

No excerto (19), ressalte-se a presença, primeiramente, dos processos materiais 'receberão' e 'serão vacinados'. Esses processos materiais apresentam ações propostas aos/às assentados/as a partir da implementação do PDA. Elas reforçam a obrigação de o/a assentado/a cumprir as propostas do PDA. Além disso, esses dois processos não apresentam o ator explícito, apensas apresentam o beneficiário 'os animais'. Já o processo material 'serão feitos' não apresenta ator e nem beneficiário. Este tipo de construção com omissão de ator faz-se recorrente em todo o texto do PDA Santa Tereza I.

Observe-se, no excerto (20), o componente verbal propriamente dito - 'será ministrada' e 'será acompanhada' - também com evidência nas ações propostas pelo PDA, mas apresentando, no caso, o ator social 'equipe de Assessoria Técnica conveniada para prestar Assessoria Técnica, Social e Ambiental à Reforma Agrária - ATES'. Aqui, o ator está explícito, o que sugere a necessidade de uma equipe técnica tanto para auxiliar na implementação e na execução do PDA, quanto na fiscalização de ações desenvolvidas por assentados/as do PA Santa Tereza I. Uma observação a mais se faz, aqui, necessária. Enquanto em (19) o ator que executa o PDA está implícito; no fragmento (20), o ator fiscalizador da implantação do PDA está explícito. Há uma diferença na representação de atores sociais no texto do PDA, o que será retomada na seção dedicada ao estudo da representação dos atores sociais (VAN LEEUWEN, 1997; 2008) deste capítulo. Além disso, o participante meta 'a capacitação' é constituída por uma nominalização do processo 
'capacitar', do mundo físico do fazer, sinalizando o apagamento dessa ação e do agente que poderia executá-la.

O texto do PDA como um todo, conforme os excertos acima, pressupõe que a implantação e a execução de todas as ações propostas no PDA seriam desenvolvidas com o subsídio de uma equipe técnica que seria contratada pelo INCRA para auxiliar o projeto de assentamento. Vale destacar, ainda, que o convênio de prestação de serviços da COOPVAG contratada pelo INCRA -, responsável pelo assessoramento ao PA Santa Tereza I, foi finalizado antes da implementação de grande parte das ações de desenvolvimento proposta no PDA, sendo que outro convênio com qualquer prestadora de assistência técnica não foi feito. Consequentemente, desde então até os dias de hoje, não há assistência técnica contratada pelo INCRA, seja para dar suporte técnico seja para fiscalizar a implementação do PDA no PA Santa Tereza I.

Ademais, considerando que os processos materiais foram mais recorrentes no PDA $(49,42 \%)$, quase duas vezes a recorrência do segundo, buscou-se desenvolver um estudo mais acurado acerca deles. Os 14 processos materiais mais recorrentes são: 'fazer', 'promover', 'realizar, 'contribuir', 'aumentar', 'definir', 'garantir', 'melhorar', desenvolver', 'fomentar', 'implantar', visar', 'atender', 'elaborar'. Essa recorrência é enfatizada no Gráfico 4.3. ${ }^{33}$

${ }^{33}$ Foram elencados 14 processos materiais considerando o aparecimento até $1 \%$ de frequência. Os demais processos materiais apresentaram menos de $1 \%$. 


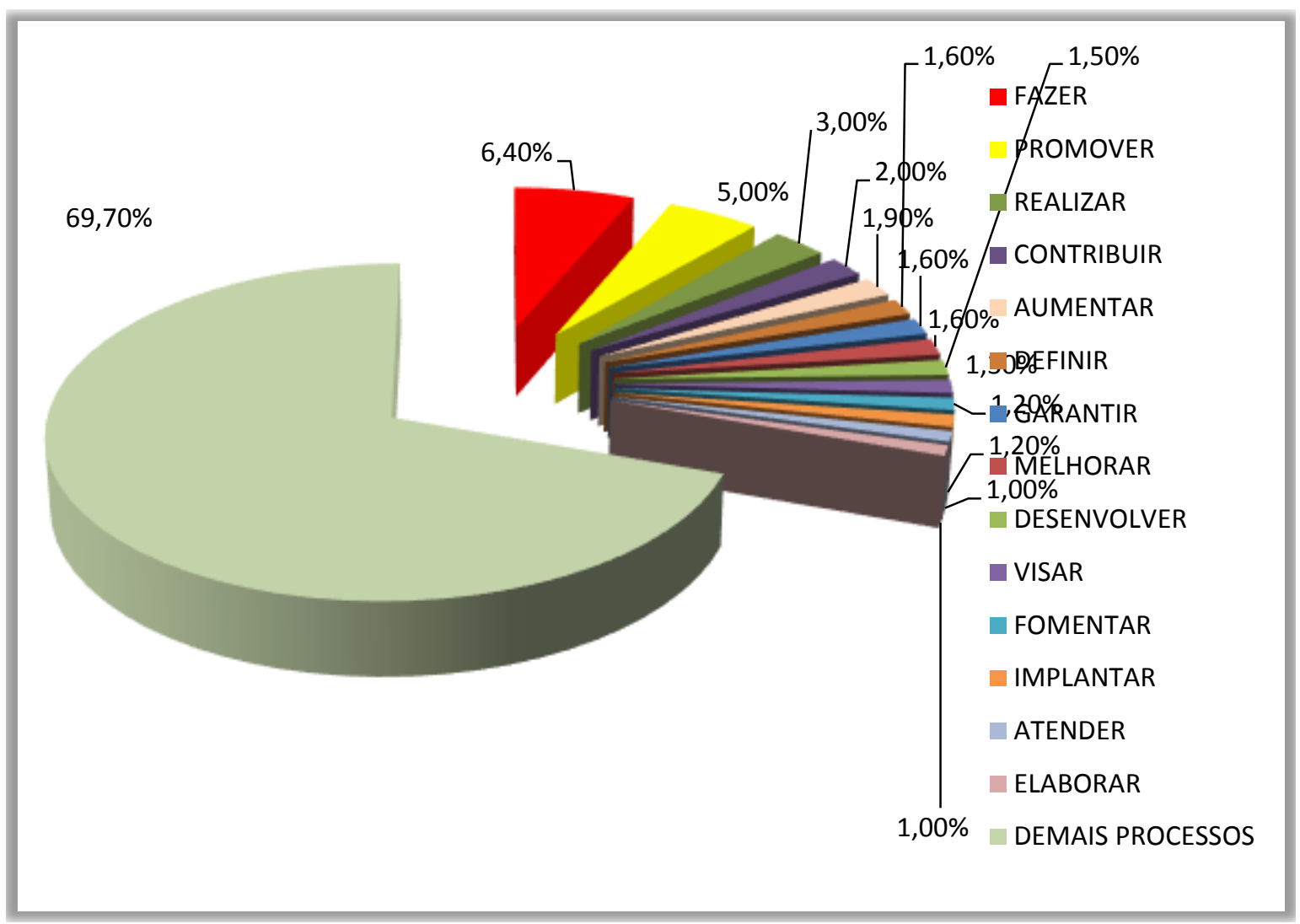

\section{Gráfico 4.3 - Processos materiais mais frequentes no PDA Santa Tereza I}

Desses processos do mundo físico, o mais recorrente é 'fazer' com '137' ocorrências; seguido do processo 'promover' com '108' ocorrências. Essas ações do mundo físico indicam o que deve ser feito e promovido no projeto de assentamento Santa Tereza I, referem-se ao 'mundo do fazer'. Os excertos a seguir elucidam como essas ações são representadas no PDA Santa Tereza I.

(21) De acordo com as últimas informações está sendo realizada a topografia e, logo, será feito [processo material] o encaminhamento das famílias [meta] para seus lotes [circunstância], sendo assim, o próximo passo é aguardar a liberação do crédito habitação para construírem suas casas de acordo com seus sonhos e suas necessidades.

(COOPVAG, 2007, p. 153)

O excerto (21) exibe uma escolha do processo 'fazer' no PDA na voz passiva. Pode-se observar que esse processo aparece com frequência na voz passiva no PDA, ocultando o ator da ação. Aqui, o processo será feito deixa explícito que o PDA foi construído durante o tempo que o/as candidato/as a terem o direito de uso da terra do PA Santa Tereza I estavam acampado/as em terras da propriedade onde seria o PA. Isso é confirmado pelas escolhas da meta 'encaminhamento das famílias' e da circunstância 'para seus lotes'. Essas pessoas 
permaneceram dois anos acampadas com o objetivo de reivindicação de um lote. Isto é, cerca de 47 famílias, em péssimas condições de sobrevivência, que desejavam, de qualquer forma, sair daquela situação, sabiam que se o PDA não fosse concluído, não haveria o sorteio dos lotes e, consequentemente, não poderiam sair daquela situação. Sobre isso, registrei em minhas notas de campo uma reflexão de uma assentada sobre a época do acampamento:

(22) Ao conversar com a assentada Quero-Quero sobre a época de construção do PDA, ela falou sobre a vida durante o tempo de acampamento. Ela disse que as pessoas que queriam um lote no PA Santa Tereza I eram obrigadas a ficarem acampadas na mesma propriedade, pois um funcionário do INCRA fiscalizava sempre o acampamento para ver quem realmente estava acampado. O funcionário dizia que se alguém saísse do acampamento, perderia o direito de concorrer a um lote no PA.

(Nota 1 PA, 7 de outubro de 2013)

Ao que parece, para se tornar assentado/a, é necessário passar um longo tempo por situações degradantes de sobrevivência. Quaisquer ações para o desenvolvimento do PA, que fossem apresentadas pela COOPVAG, naquele momento de sofrimento, seriam aprovadas por essas pessoas em condições de risco, haja vista não conhecerem sequer as características físicas da propriedade. Não sabiam se todos os lotes teriam água, terra fértil, por exemplo. Elas confiavam no que os técnicos da COOPVAG diziam.

Já os fragmentos (23) e (24) explicitam usos do processo 'promover' no PDA.

(23) Promover [processo material abstrato] o desenvolvimento do capital humano, através de ações educativas de caráter pessoal e profissional [meta], aumentando a capacidade de intervenção dos atores sociais do PA Santa Tereza I;

Promover [processo material abstrato] a integração e organização das famílias [meta], respeitando seu grau de consciência, apropriação da realidade e opções de desenvolvimento

(COOPVAG, 2007, p. 69)

(24) Promover [processo material abstrato] o desenvolvimento humano dos moradores do PA Santa Tereza I [meta], a partir da apropriação de conhecimentos necessários para o crescimento e empoderamento da comunidade.

(COOPVAG, 2007, p. 196)

Os fragmentos (23) e (24) encerram escolhas do processo 'promover' no texto do PDA. O fragmento (23) está no item 'objetivos específicos' do Plano de ação do PDA. O processo material 'promover' apresenta a meta 'o desenvolvimento do capital humano, através de ações educativas de caráter pessoal e profissional' e omite o ator. Já o fragmento 
(24) está no 'objetivo' da subseção Capacitação e assessoria técnica da seção Programas de desenvolvimento. Da mesma forma, o processo 'promover' apresenta a meta 'o desenvolvimento humano dos moradores do PA Santa Tereza I' e omite o ator.

Além do mais, no decorrer do texto, há alta ocorrência do processo 'promover' no modo infinitivo, não somente nos 'objetivos', mas também nas 'matrizes'. Esses usos apontam ações propostas com a execução do PDA, como desenvolvimento do capital humano, integração e organização das famílias, desenvolvimento humano. São propostas feitas no decorrer do corpo do texto do PDA, e principalmente no título Plano de ação, onde ocorrem muitas matrizes que expõem ações a serem desenvolvidas no PA através do PDA. Há de se destacar que a maior ocorrência desses processos materiais, elencados acima no gráfico, está diretamente ligada às 'matrizes', onde esses processos aparecem no infinitivo.

O terceiro, o quarto e o quinto processos materiais com maior ocorrência são, respectivamente, 'realizar' (65), 'contribuir' (43) e 'aumentar' (41) como mostram os fragmentos (25) a (30).

(25) As reuniões [meta] devem ser realizadas [processo material], segundo o estatuto, uma vez por mês (segundo domingo de cada mês). No entanto, estas [meta] são realizadas [processo material concreto] de acordo com a necessidade. A frequiência é variada, dependendo do tema em questão.

(COOPVAG, 2007, p.54)

(26) Para implementar a execução dos programas propostos serão realizados [processo material] eventos de organização das atividades [meta], tais como, reuniões de sensibilização, cursos, oficinas, treinamentos, palestras, dias de campo, visitas nos estabelecimentos familiares e intercâmbio com outras comunidades.

(COOPVAG, 2007, p.195)

Os fragmentos (25) e (26) ilustram o uso do processo 'realizar', um processo do mundo do "acontecer", designando ações. O (25) encontra-se na subseção Diagnóstico do meio socioeconômico e cultural, no item Composição da associação. No fragmento, há a determinação de como a associação de moradores PA Santa Tereza I e a periodicidade de tempo que ela deve se reunir. Isto é, o processo material aparece na voz passiva, apresenta a meta 'reuniões', mas omite o ator. O (26) está na subseção Capacitação e assessoria técnica no item Assessoria técnica, social e ambiental - ATES. Também há determinação do tipo de atividade que deve ocorrer para que os programas de desenvolvimento propostos no PDA se materializem. O PDA determina tais atividades, mas na prática não ocorreu uma vez que o 
convênio com a COOPVAG foi desfeito e outra organização não foi contratada para desenvolver tais atividades. No fragmento, o processo material aparece na voz passiva, apresenta a meta 'eventos de organização das atividades' e também omite o ator das ações.

Já excertos (27) e (28) ilustram o uso do processo 'contribuir'.

(27) Visando analisar o plano de forma globalizada, neste item descreve -se como o sistema produtivo planejado para o PA Santa Tereza I irá contribuir [processo material] com a transformação da realidade das famílias envolvidas [meta].

(COOPVAG, 2007, p.124)

(28) Contribuir [processo material] na promoção do desenvolvimento humano e social da comunidade [meta] para que através do processo de ensino-aprendizagem tenha condições de analisar sua realidade, conhecer o espaço social para a sua participação política na sociedade, exercendo plenamente a sua cidadania e promovendo o desenvolvimento e melhoria da qualidade de vida de suas famílias.

(COOPVAG, 2007, p.141)

O excerto (27) encontra-se na subseção Análise do Sistema Produtivo do PA Santa Tereza I, no item Importância econômica dos sistemas produtivos. Nesse excerto, o processo material 'contribuir' relaciona o 'sistema produtivo planejado' do PA como uma provável causa da 'transformação da realidade' das famílias assentadas, ou seja, da melhoria de vida. Considera-se que o sistema produtivo por si só será responsável pela dita transformação. O processo 'contribuir' apresenta a meta 'com a transformação da realidade das famílias envolvidas' e omite, porém, o ator, aquele que seria responsável por executar e/ou planejar o sistema produtivo do PA. No trecho, os papeis sociais não ficam explícitos. Já o excerto (28) encontra-se no Objetivo geral da Matriz metodológica do subprograma de Educação fundamentado nas demandas do PA Santa Tereza I. O processo material apresenta a meta e omite o ator. Ocorre omissão da responsabilidade sobre o ‘subprograma de educação'. Cabe a tal subprograma melhorar o desenvolvimento humano e social da comunidade. Observa-se o encobrimento dos responsáveis pelas ações. Similarmente, o processo 'aumentar' comporta-se como 'material', de acordo com os fragmentos a seguir.

(29) Promover o desenvolvimento do capital humano, através de ações educativas de caráter pessoal e profissional, aumentando [processo material] a capacidade de intervenção dos atores sociais do PA Santa Tereza I [meta].

(COOPVAG, 2007, p. 69)

(30) - Aumentar [processo material] o grau de segurança e conforto no deslocamento das crianças e jovens que estudam fora do PA [meta]; 
- Aumentar [processo material] o índice de satisfação da população [meta].

(COOPVAG, 2007, p. 76)

No fragmento (29), o processo 'aumentar' está nos Objetivos específicos do Plano de ação. No fragmento, os atores sociais do PA parecem possuir capacidade de intervenção no mesmo e que, com o referido plano de ação, a intervenção só melhoria, mesmo que no fragmento não esteja explícito o ator responsável por essa ação. No fragmento (30), o processo 'aumentar' encontra-se no quadro com a Matriz de planejamento das ações de infraestrutura PA Santa Tereza I, na parte Resultados esperados. Ao haver uma proposição de que um resultado esperado das ações de infraestrutura do PA Santa Tereza I seja 'aumentar' a segurança e conforto de estudantes, pressupõe-se que já ocorrem essas ações no PA. Em ambos, os atores das ações são encobertos.

Além disso, o Gráfico 4.4 apresenta a distribuição dos processos materiais na voz ativa e passiva ao longo do texto do PDA Santa Tereza I.

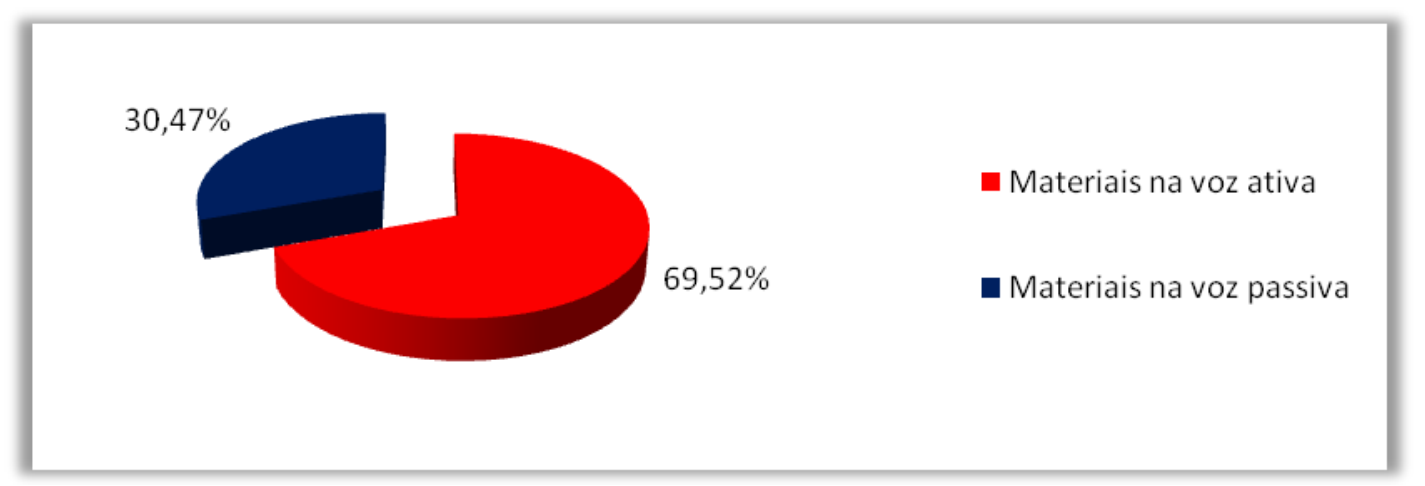

\section{Gráfico 4.4 - Distribuição de processos materiais na voz ativa e na voz passiva no PDA}

O Gráfico 4.4 evidencia que 69,52\% dos processos materiais do PDA Santa Tereza I se apresentam na voz ativa, com 1.485 ocorrências; enquanto que 30,47\% dos processos se apresentam na voz passiva, com 651 ocorrências. Das ocorrências na passiva, 572 aparecem como 'ser + particípio' e 79\% aparecem com a partícula 'se'. Esse tipo de construção, comumente, topicaliza, destaca, no texto, a 'meta' e omite ou anula a identidade do ator da ação. Configura-se, de certa forma, em "impessoalidade" da linguagem. No caso, em um PDA, cujo propósito é propor ações para o desenvolvimento de um projeto de assentamento, o uso da voz passiva pode propiciar a omissão de responsabilidade do desenvolvimento de muitas ações propostas à medida que seus atores são omitidos, como revelam os três próximos excertos. 
(31) De um modo geral, tanto em áreas urbanas, como no meio rural [circunstância], as águas subterrâneas [meta] são obtidas [processo material] a partir de poços tubulares, escavados (cisternas) e nascentes [circunstância], sendo o seu gerenciamento realizado pela Companhia de Saneamento do Estado do Tocantins (SANEATINS) e em algumas cidades e comunidades pelas prefeituras.

(COOPVAG, 2007. p.12)

(32) A sede da Associação [meta] será construída [processo material] em alvenaria, com telha de barro e piso de cimento ou cerâmica [circunstância]. Terá uma sala para reuniões e um pequeno auditório para promover os eventos de capacitação da comunidade, escritório e banheiro. A obra [meta] será implantada [processo material] na área comunitária [circunstância], na divisa com o PA Santo Onofre [circunstância].

(COOPVAG, 2007.p.78)

(33) A maior parte das demandas levantadas na Educação, desde a infraestrutura até os programas a serem implementados [processo material] são responsabilidades da Secretaria Municipal de Educação que, juntamente com a Assessoria Técnica e a comunidade irão acessar Programas de Governo para a realização de todas as ações, tais como: Programa Nacional de Apoio Escolar - PNATE, Programa Nacional Biblioteca Escola - PNBE, Programa Nacional de Livros Didáticos PNLD, Programa Nacional de Informática na Educação - Proinfo, Secretaria Executiva de Esporte e Lazer - SEEL, entre outros. Para tanto serão elaborados [processo material] projetos [meta] que servirão como instrumentos de negociação com os diversos parceiros que serão articulados [processo material] pela Assessoria Técnica, comunidade e a própria Secretaria de Educação [ator].

(COOPVAG, 2007, p.144)

Nos excertos (31), (32) e (33), identifica-se construções com processos materiais na voz passiva, de modo que os atores das ações propostas pelos referidos processos estão encobertos, impessoalizando as ações. No excerto (31), há escolha do uso da voz passiva com o processo 'obter' para se descrever a aquisição de água na região do PA. Por isso, encontrase no tópico Contexto, no subtítulo Caracterização do meio físico, item Hidrografia. Materializa-se linguisticamente a meta 'águas subterrâneas' e a circunstância 'poços tubulares', mas se omite os atores responsáveis para disponibilizar recursos, efetuar a construção. Somente estão explícitos os atores que gerenciam a implantação de modo geral no estado, mas não especifica, no caso do município de Ponte Alta, onde se localiza o PA Santa Tereza I, nem de quem é a responsabilidade da construção.

O fragmento (32), está no subtítulo Organização territorial, item Estratégias para implementação das metas e faz referência à construção da sede da associação do PA. As escolhas dos processos materiais 'construir' e 'implantar' também aparecem na voz passiva, 
com as metas e sem o ator explícito. Igualmente, não se atribui a um ator a responsabilidade pela ação, no caso, a construção.

Já o excerto (33) está no Subprograma de Educação - tópico Plano de ação -, no item Procedimento técnico, ou seja, trata do planejamento da implantação da educação no PA. Quando trata da do mundo físico do fazer, no caso, 'elaborar projetos' há escolha do processo ‘elaborar' na voz passiva, omitindo o ator responsável por essa ação. Também se utiliza a voz passiva para tratar da articulação que os projetos "elaborados" proveriam, através do uso do processo 'articular'. Com esse processo, os atores são explícitos no texto, reforçando a ideia da função de articuladores que 'Assessoria técnica, comunidade e Secretaria de Educação' apresentam diante dos projetos de educação e não de autores.

Ainda, além dos processos materiais, o Gráfico 4.5 apresenta alguns processos relacionais, entre os mais frequentes no PDA Santa Tereza I. Esses processos, como explicitado no Capítulo 2, identificam e classificam entidades no mundo e referem-se ao mundo das relações abstratas (HALLIDAY \& MATHIESSEN, 2004). Além disso, os processos relacionais aparecem como segundo tipo mais recorrente no PDA. Por estes dois motivos serão detalhados aqui.
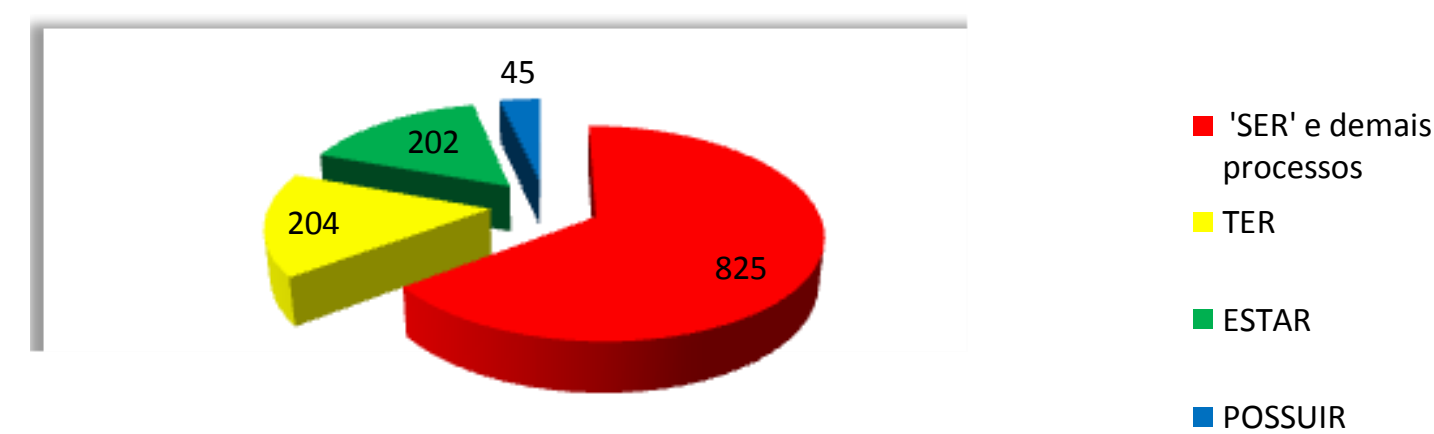

\section{Gráfico 4.5 - Processos relacionais mais frequentes no PDA Santa Tereza I}

Os processos relacionais representam 29,50\% de ocorrências de processos no PDA Santa Tereza I, aparecem 1.275 vezes. Dessas ocorrências, os processos relacionais mais recorrentes no PDA são 'ser', 'ter', 'estar' e 'possuir' 'apresentar' (79). Há 15,98 \% de ocorrências do processo 'ter' (204), 15,83\% de ocorrências do processo 'estar' (202) e 3,52\% de ocorrência do processo 'possuir' (45). Já a ocorrência do processo 'ser' no PDA é de 1.447 vezes, ou seja, é maior ocorrência entre os processos relacionais. No entanto, deve-se destacar que, nessa ocorrência está inclusa a voz passiva com o 'ser' em todos os tipos de 
processos. De qualquer forma, a ocorrência do processo relacional 'ser' é a maior entre os outros.

(34) Todos os Programas [portador] aqui [circunstância] abordados são [processo relacional atributivo] essenciais [atributo] para o processo de desenvolvimento [circunstância], desde que sejam considerados como dependentes. A não execução de um desses programas certamente inviabilizará o Plano ora concebido.

(COOPVAG, 2007, p. 71)

(35) A cultura do feijão caupi [portador] tem [processo relacional atributivo] grande importância [atributo] dentro da manutenção da segurança alimentar dos pequenos agricultores [circunstância]. Em algumas regiões como o nordeste brasileiro [circunstância] é [processo relacional identificativo] o alimento básico das populações de baixa renda [identificador]. Essa espécie [portador] apresenta [processo relacional atributivo] grande rusticidade [atributo] para se desenvolver em solos de baixa fertilidade [circunstância]. A variedade escolhida para o plantio [portador] tem [processo relacional atributivo] um ciclo que gira em torno de 71-80 dias (média precocidade) [atributo] o que permite ao agricultor cultive duas roças ao ano.

(COOPVAG, 2007, p. 96)

Os excertos (34) e (35) apresentam processos relacionais atributivos cujos participantes 'portadores' não são portadores humanos, respectivamente 'Todos os programas'; 'A cultura do feijão caupi', 'Essa espécie' e 'A variedade escolhida para o plantio'. Esses portadores representam características, atributos do PDA e de culturas propostas pelo PDA. Os dois excertos fazem parte do título Plano de ação, que apresenta mais especificamente as ações prescritas para o desenvolvimento do PA e, nele, faz-se frequente o uso de processos que representam o 'mundo das relações abstratas', caracterizando e identificando ações, como argumentação para se justificar e estimular as ações prescritas. Já o excerto (36) apresenta o participante portador 'humano'.

(36) Os dados e a observação participativa com as famílias permitiram constatar que a situação social e econômica dos Assentados é extremamente precária. As famílias [portador] estão [processo relacional atributivo] acampadas [atributo] desde a criação do PA e não foi possível, nesse período, executar nenhuma atividade produtiva, uma vez que não estão [processo relacional atributivo circunstancial] em seus lotes. Durante todo esse período, contou com o auxílio do INCRA, com o benefício da cesta básica primeiramente, seguido do crédito APOIO.

(COOPVAG, 2007, p. 49-50) 
O portador humano é 'As famílias', mas não está no título Plano de ação e, sim, no título Diagnóstico do projeto de assentamento. Nesse título, o uso dos processos relacionais, dentre outros, caracteriza e identifica a vida das pessoas que pleiteavam um lote, nomeadas 'famílias'. No caso, explica-se o tipo de vida das pessoas acampadas onde seria o PA Santa Tereza I. De acordo com o excerto, o atributo 'acampadas' aponta para precarização social e econômica, não possibilidade de produção agrícola, necessidade de auxílio governamental para sobrevivência. Estes são os requisitos exigidos pelo governo federal para uma pessoa pleitear um lote em um PA.

\subsubsection{Sete títulos do PDA em representações}

A partir da análise geral de um aspecto da representação social no PDA do PA Santa Tereza I elaborada anteriormente, proponho aqui uma análise mais acurada de oito títulos do PDA - Agradecimentos, 1.Apresentação, 2.Identificação dos responsáveis, 3. Metodologia, 4.Contexto socioeconômico e ambiental da área de influência do PA, 5.Diagnóstico do PA, 7.Prognóstico de impactos ambientais e medidas propostas, Considerações finais - em termos de representação, considerando que o título seis - Plano de ação - será analisado na próxima subseção haja vista possuir o conteúdo mais extenso do PDA, mais da metade do número de páginas de todo o documento (133).

Como a análise será detalhada, aqui, faz-se necessário também destacar uma característica dos processos materiais - com maior recorrência nas partes do PDA -, discutida no capítulo teórico. As construções com processos materiais explicitam fatos e ações concretos ou abstratos (HALLIDAY \& MATHIESSEN, 2004). Enquanto os processos materiais concretos são as mudanças no mundo material e que podem ser constatadas como movimentos no espaço ou alterações nos estados físicos dos objetos, os processos materiais abstratos são mudanças onde acontecem fenômenos abstratos. Isto é, os processos materiais podem estar no plano do 'real' ou no plano das abstrações. Essa característica dos processos materiais pode contribuir para a interpretação das ações propostas pelo PDA Santa Tereza I, uma vez que podem estar mais no plano da abstração, só plano ou mais no plano do concreto, do realizado.

A investigação linguístico-discursiva, aqui, pretende responder a seguinte questão de pesquisa: Que representações de atores sociais são constituídas na materialização linguística do PDA Santa Tereza I?. 
Ademais, durante a observação participante, em minhas notas de campo, depois de entrevistar vários/as assentados/as, tive a necessidade de lhes fornecer algum esclarecimento sobre o que era o PDA, já que não sabiam do que se tratava. Ao explicar que se constituía uma ferramenta para o planejamento do desenvolvimento do PA, registrei várias vezes a solicitação de esclarecimentos sobre alguns itens de infraestrutura para o PA: água, saúde, educação, energia elétrica e estradas. Sendo assim, comprometi-me a voltar ao assentamento e fazer oficinas sobre as partes do PDA Santa Tereza I que se referem a esses itens. Por isso, aqui, ao analisar, o PDA mais detalhadamente, procuro usar excertos que façam referência ao interesse demonstrado por ele/as.

Dentre as partes do PDA Santa Tereza I, a primeira apresenta o título Agradecimentos. Possui a extensão de 01 página e não é numerada. Faz-se semelhante ao mesmo título em textos acadêmicos: geralmente também possui extensão de uma página, não é numerada e é o espaço do texto onde se agradece às pessoas que colaboraram com o pesquisador para a elaboração da pesquisa, dizendo qual foi a contribuição de cada uma. O PDA, tratando-se de um texto com característica de textos acadêmicos e técnicos, tem esse item e apresenta atores que parecem, a princípio, terem colaborado com a constituição do texto. Esses atores são acompanhados por processos e o Gráfico 4.6 demonstra o uso desses processos em tal título.

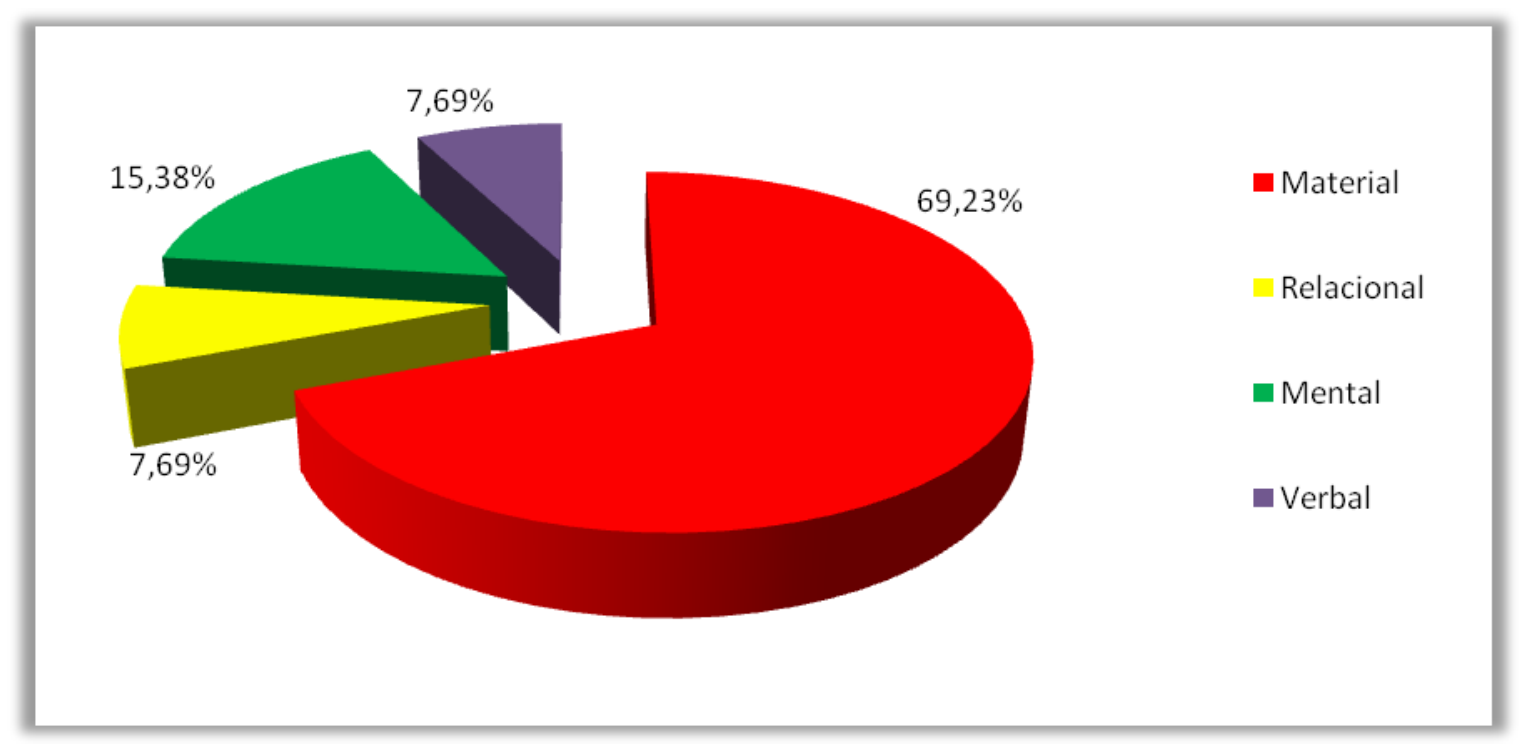

Gráfico 4.6 - Distribuição de processos nos Agradecimentos do PDA

O título Agradecimentos apresenta 13 processos, dos quais 69,23\% de processos matérias (9) - 6 materiais abstratos e 3 materiais concretos; $15,38 \%$ de processos mentais (2); $7,69 \%$ de processos relacionais (1) e 7,69\% de processos verbais (1). Não há ocorrência de 
processos comportamentais e existenciais. Observa-se que processos materiais aparecem quatro vezes mais que o segundo tipo em recorrência: os mentais. A ocorrência de processos materiais está relacionada à atribuição de papeis - ações do mundo do fazer - aos colaboradores do PDA. O ator que assina os Agradecimentos é a equipe responsável, ou seja, a equipe técnica da COOPVAG. A COOPVAG, já no início do PDA, não só aponta os atores colaboradores para a elaboração do plano de desenvolvimento, mas também atribui papeis a eles através do uso de processos verbais. Há uma espécie de caracterização explícita da participação direta de dois atores na elaboração do PDA. Por isso não há uso da voz passiva, que geralmente omite o 'participante' da ação. Vejamos.

(37) Nossos agradecimentos em especial aos assentados, que participaram [processos material concreto] das oficinas, das reuniões, das entrevistas, do grupo que fez [processos material concreto] o levantamento do meio físico [meta], e que são os reais autores desse plano.

(COOPVAG, 2007, s/p)

No excerto acima, os processos materiais 'participaram' e 'fez' propõem 'ações concretas do mundo do fazer', são processos materiais concretos. Essas ações concretas são atribuídas ao/à participante 'assentados/as'. O/a assentado/a aparece como ator/atriz que 'participou' de, colaborou com atividades para geração de dados para a constituição do PDA. As metas 'oficinas, reuniões e levantamento do meio físico' demonstram as ações atribuídas ao participante. Além disso, no final do mesmo excerto, por essa atribuição de papeis ao participante 'assentados/as', foi-lhe designada a autoria do PDA: 'são os/as reais autores/as desse plano'. No entanto, 'participar de atividades' e 'fazer parte de um grupo' não significa ser o/a autor/a do texto, mesmo que nessas atividades tenham sido consideradas algumas 'escolhas' desse participante e que integraram o plano de desenvolvimento. Depois, nos Agradecimentos, aparece o segundo participante com participação direta.

(38) Ao INCRA, que através de seus técnicos, acompanharam [processo material abstrato] nosso trabalho [meta] e sempre disponibilizaram [processos material abstrato] as informações necessárias [meta] ao Plano. E também, a os técnicos que participaram da pesquisa (entrevistas) e aos parceiros (representantes do INCRA, NATURATINS, SEAGRO, ADAPEC), grandes colaboradores no processo de restituição, contribuindo [processos material abstrato] bastante para o bom resultado dos trabalhos.

(COOPVAG, 2007, s/p) 
O excerto (38) está nos Agradecimentos e se refere ao agradecimento à participação do INCRA na elaboração do PDA. Os processos 'acompanharam' e 'disponibilizaram', no contexto de uso, são "ações abstratas do mundo do fazer", são processos materiais abstratos. Esses processos apresentam como ator o 'INCRA'. A participação do INCRA na elaboração do PDA se dá por "ações abstratas” de modo que a meta do processo 'acompanharam' é 'nosso trabalho' e do processo 'disponibilizaram' é 'informações necessárias'. O papel atribuído ao INCRA, nessa parte do texto, parece ser, pela sua abstração, de fiscalização do trabalho dos técnicos da COOPVAG na elaboração do PDA e de fornecimento de informações referentes ao PA. Ao que parece, pelas análises, enquanto as 'ações' do/a ator/atriz 'assentados/as' são mais concretas, as do 'INCRA' são mais abstratas.

Sobre as informações disponibilizadas pelo INCRA à COOPVAG no que concerne à elaboração do PDA Santa Tereza I, registrei uma nota durante uma visita ao INCRA. Um funcionário do órgão que estava como um dos responsáveis por esse PDA, falou-me sobre as informações fornecidas à COOPVAG:

(39) O funcionário do INCRA me disse que o órgão disponibilizou aos técnicos da COOPVAG documentos com características físicas do PA Santa Tereza I, como os mapas de onde seria o PA, o levantamento topográfico da propriedade, alguns estudos sobre os tipos de solo, vegetação.

(Nota 12 INCRA, 16 de julho de 2014)

Considerando que nos Agradecimentos e nem em outra parte do PDA se especifica que tipo de informação o INCRA disponibilizou à COOPVAG, a nota de campo parece esclarecer esse tipo de informação. O INCRA forneceu o estudo com os dados físicos do PA já elaborado para a COOPVAG. Em relação às características físicas da propriedade, os técnicos responsáveis pela elaboração do PDA tiveram somente que transcrevê-las para o PDA. Além do mais, no texto no PDA não há referência detalhada sobre o tipo de informação sobre o PA fornecida pelo INCRA.

Ainda há de se considerar, que não existe, nesta parte do texto (Agradecimentos), a caracterização explícita da atribuição de papeis aos técnicos da COOPVAG para a elaboração do PDA Santa Tereza I. O uso do pronome possessivo 'nossos', como visto no excerto (37), e no excerto (40) abaixo, ilustra, de alguma forma, a 'equipe responsável', a COOPVAG, como 'participante', mesmo não especificando seu tipo de participação. 
(40) Aos nossos familiares, que souberam compreender nossas ausências e nos apoiar durante todo o processo de elaboração do PDA.

(COOPVAG, 2007, s/p)

A COOPVAG, através de sua equipe técnica, elaborou o PDA Santa Tereza I e não foi uma ação individual, exclusiva, dos/as assentados/as. Em visita ao PA Santa Tereza I, durante uma comemoração da associação de moradores - Festa da Mandioca -, um assentado me descreveu a participação da COOPVAG na elaboração do PDA e a seguinte nota de campo foi registrada:

(41) Conversando com um assentado sobre o período que morava no acampamento onde seria o PA Santa Tereza I, ele me relatou as ações dos técnicos da COOPVAG no acampamento. Segundo o assentado, os técnicos da COOPVAG reuniam as pessoas acampadas, apresentavam propostas para o desenvolvimento do projeto de assentamento, depois as dividiam em grupos para discutir as propostas e a seguir todos votavam quais ações deveriam ser desenvolvimento no PA.

(Nota 2 PA, 5 de julho de 2014)

Os técnicos não levaram em conta que as pessoas acampadas podiam não ter conhecimento prévio sobre as propostas em termos de concretas possibilidades para serem implantadas no PA, sejam por características físicas do terreno, sejam por disponibilidade de recursos hídricos, sejam por disponibilidade de recursos financeiros, por exemplo. As pessoas acampadas acreditavam nas propostas, já prontas, apresentadas pela COOPVAG. Como a elaboração do PDA era requisito para que os lotes do PA fossem sorteados, as pessoas acampadas necessitavam que o texto ficasse pronto o mais rápido possível.

O PDA do PA Santa Tereza I, como os textos acadêmicos, também tem Apresentação e essa possui uma página. Em termos de processos, há ocorrência de três tipos como pode se observar no Gráfico 4.7. 


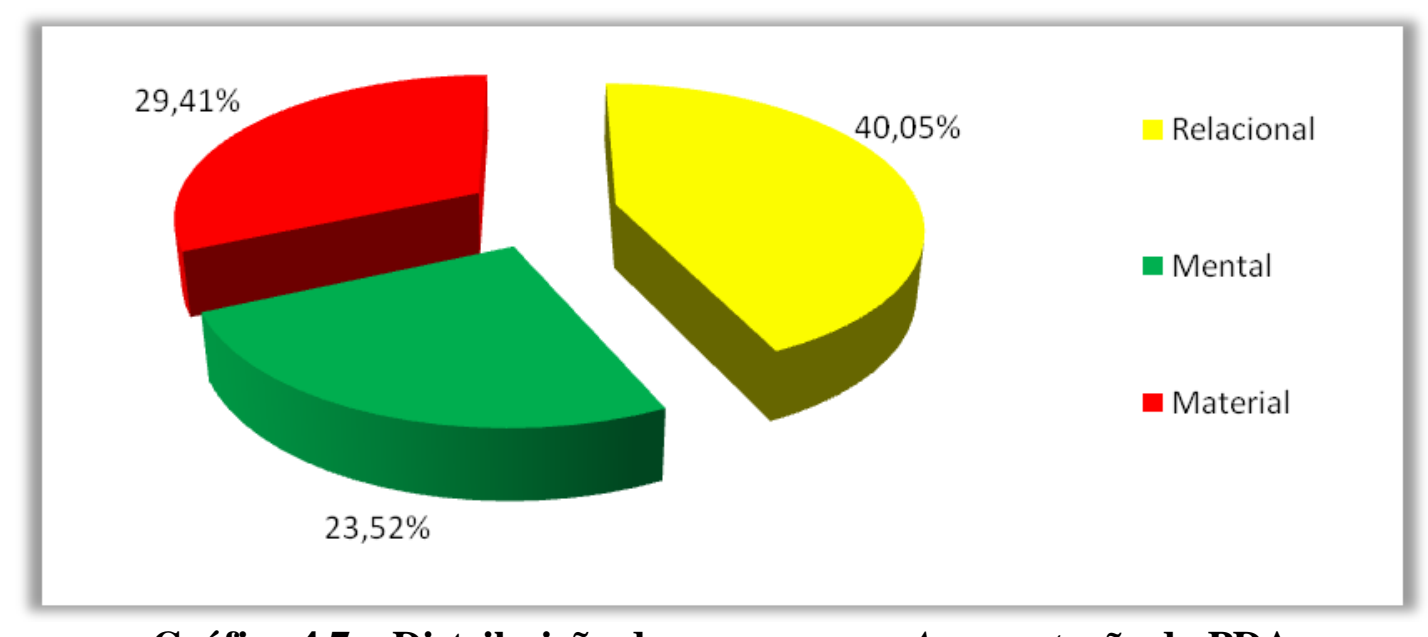

\section{Gráfico 4.7 - Distribuição de processos na Apresentação do PDA}

De acordo com o Gráfico 4.7, a Apresentação possui 40,05\% de processos relacionais (16), 11 atributivos e 5 identificativos; $29,41 \%$ de processos materiais (10), 8 abstratos e 2 concretos; e 23,52\% de processos mentais (8). Os processos verbais, comportamentais e existenciais não ocorrem. Considerando que essa é a parte do plano de desenvolvimento que se propõe a apresentar as proposições do texto, esperava-se que ocorressem mais processos do 'mundo físico do fazer, acontecer' e não processos do 'mundo das relações abstratas e atributos'.

(42) O Plano de Desenvolvimento do Assentamento - PDA [portador] deverá se constituir [processo relacional atributivo] em um importante instrumento de desenvolvimento [atributo] para os Projetos de Assentamentos de Reforma Agrária. A sua construção é [processo relacional atributivo] parte integrante da Política de Reforma Agrária [atributo], que visa garantir a permanência do homem no campo, com todas as condições necessárias para o desenvolvimento sustentável e melhoria da qualidade de vida de toda a comunidade.

(COOPVAG, 2007, p.1)

O excerto (42) configura processos relacionais, do mundo das relações abstratas. O participante que mais aparece é o 'portador' de 'atributos', elemento dos processos relacionais, no caso, é o PDA. Além disso, ter atributos ou identidade, simbolizar implica relações abstratas entre os participantes, implicando uso de atributos e identidades que são subjetivas. Por haver mais processos relacionais, não ocorre no texto de Apresentação do PDA o participante 'ator', elemento dos processos materiais. O PDA ou palavras que se referem a ele são os portadores de atributos e identidades, não ocorrendo explicitamente o apontamento de ator que escolheram esses atributos e identidades. 
(43) O PDA constitui-se [processo relacional atributivo] em uma ferramenta de trabalho [atributo] para a Assessoria Técnica, que tem [processo relacional atributivo] responsabilidades [atributo] no acompanhamento e monitoramento de sua execução [circunstância], sendo [processo relacional atributivo] dinâmico [atributo], visto que deve estar [processo relacional atributivo] sempre em consonância com a realidade [atributo] e acompanhar os estágios de desenvolvimento da comunidade podendo, dessa forma, ser atualizado periodicamente.

(COOPVAG, 2007, p.1)

O excerto (43), da mesma forma, também apresenta processos relacionais, com o portador 'PDA' e seus atributos. Mas o que destaco, aqui, é o atributo 'ferramenta de trabalho' do portador 'PDA', uma vez que, diferente do excerto anterior, aponta um agente Assessoria Técnica. O PDA é concebido, no trecho, como uma ferramenta usada pela assessoria técnica para fiscalizar a execução de ações prescritas no texto do PDA. A esse agente é designada uma função diante o portador PDA e seus atributos quando for implantado. No entanto, uma nota de campo sobre ações da COOPVAG quando o PDA foi concluído foi registrada:

(44) A pioneira Gavião-Carijó também me relatou as ações da COOPVAG quando as pessoas acampadas tinham acabado de mudar para os lotes do PA. Ela disse que, quando os pioneiros/as mudaram para os lotes, a COOPVAG teve a responsabilidade técnica de dar assistência ao PA por mais ou menos um ano. No entanto, os técnicos começaram a passar em cada lote uma vez por mês, buzinavam na entrada do lote, não desciam da moto, pediam assinatura de uma pessoa do lote em um papel e logo depois do papel assinado se despediam. Para essa assentada, os técnicos da COOPVAG, na realidade, não davam assistência alguma, mas os/as assentados/as assinavam o papel como se tivessem dado.

(Nota 3 PA, 5 de julho de 2014)

De acordo com a nota de campo acima, há uma discrepância entre o dito da COOPVAG e o dito da assentada. A COOPVAG diz no excerto (44) que 'monitorará a execução do PDA', já a assentada diz que os técnicos somente 'colhiam assinaturas'. Essa nota de campo foi registrada devido à consideração de que o depoimento de uma pessoa pioneira do PA sobre as ações da COOPVAG no PA Santa Tereza I é de relevância e também devido a outros relatos com a mesma postura atribuída à COOPVAG em relação à 'não assistência' técnica prestada.

Depois do título Apresentação, inicia o título Identificação dos responsáveis. Como o conteúdo desse título não se constitui a partir de processos verbais, sua análise será apresentada posteriormente, na subseção 4.4.1. Em seguida, há a Metodologia, um comum em 
de textos acadêmicos, onde se costuma configurar, dentre outros conteúdos, os passos metodológicos da pesquisa, o tipo de pesquisa e o método. No caso do PDA, a Metodologia apresenta as etapas de elaboração do plano em cinco páginas: Elaboração do plano (Motivação, Diagnóstico, Restituição, Conclusão e apresentação) e Assessoria técnica, social e ambiental. Para esse estudo, faz-se necessária uma análise detalhada dessa pelo que se propõe a fazer, principalmente por tentar descrever a participação dos atores sociais na elaboração do PDA. Quanto aos processos, há cinco tipos de processos, exceto os existenciais, como se observa no Gráfico 4.8.

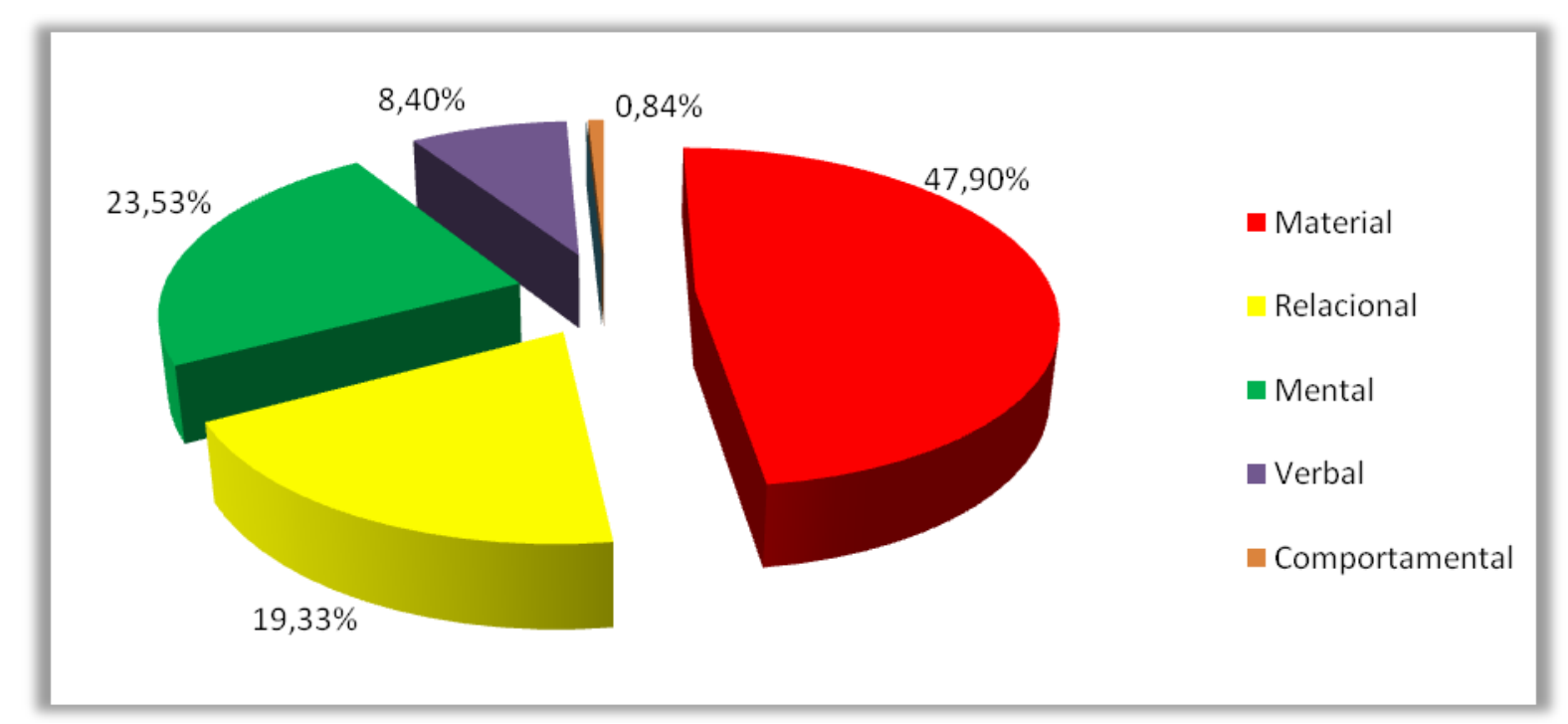

\section{Gráfico 4.8 - Distribuição de processos na Metodologia do PDA}

Já que esse título propõe apresentar as etapas de elaboração do PDA, isto é, apresentar as ações desenvolvidas para a elaboração do texto, espera-se que ocorram mais processos materiais e é o que se concretiza. Os processos materiais aparecem duas vezes mais que os processos relacionais e mentais. O Gráfico 4.8 demonstra que há 47,90\% de processos materiais (57); 23,53\% de processos mentais (28); 19,33\% de processos relacionais (23); $8,40 \%$ de processos verbais (10); e 0,84 de processos comportamentais (1). Dentre os processos materiais, com maior frequência, 25 são abstratos e 32 são concretos; 34 estão na voz ativa e 23 na voz passiva. A seguir, seguem excertos da Metodologia.

(45) É um método [ator] que rejeita a pretensa "neutralidade" e "superioridade" do pesquisador externo e busca socializar [processo material abstrato] o conhecimento [meta], democratizar [processo material abstrato] os processos de investigação e educação [meta], basear-se [processo material abstrato] nas necessidades fundamentais da população, propiciar [processo material abstrato] a participação ativa 
dos seus vários segmentos [meta] e buscar respostas coerentes aos seus problemas [meta] visando ações concretas e transformadoras dessa realidade.

(COOPVAG, 2007, p.3)

No fragmento (45), os processos materiais abstratos apresentam como participante ator 'um método'. Como o fragmento faz parte da na introdução do título Metodologia, 'um método' é dito o método utilizado para elaboração do PDA. Tenta-se elencar ações abstratas realizadas por um ator que não é humano, o 'método' por si só desenvolve as ações propostas. O fragmento (46) também está na Metodologia, no item itens Diagnóstico.

(46) $1^{\circ}$. Passo - Após o levantamento de dados [circunstância], fez -se [processo material concreto] o processo de análise e sistematização [meta], resultando [processo material concreto] na primeira parte do PDA [meta], que é o Diagnóstico. Assim, o terceiro momento consistiu na continuidade desse processo, onde se tratou da restituição dos dados, após a elaboração da primeira parte do documento. A equipe técnica e parceiros [ator] voltaram a se reunir [processo material concreto] com a comunidade [meta], onde apresentaram [processo material concreto] o resultado do trabalho [meta] e, juntamente com os agricultores, fizeram [processo material concreto] as alterações [meta] que julgaram necessárias. Em seguida, com a discussão e aprovação da primeira parte, deu-se início [processo material concreto] a Oficina de Planejamento [meta].

(COOPVAG, 2007, p.5-6)

No fragmento (46), o processo material concreto 'fez-se' é utilizado na voz passiva, apresenta a meta 'o processo de análise e sistematização' e omite o ator da ação. Assim, no primeiro passo da metodologia indicada como a usada para a elaboração do PDA Santa Tereza I, o ator responsável pela ação do mundo físico do fazer é apagado, uma vez que já havia sido atribuída a autoria do PDA os/as assentados/as, e nesse trecho, a meta 'o processo de análise e sistematização’ indicia autoria do PDA aos técnicos da COOPVAG.

Em relação aos participantes desse fragmento, 'comunidade' é a meta do processo 'voltaram a se reunir', e 'agricultores' é um dos 'atores' do processo 'fizeram'. Nos dois casos, há referência às pessoas acampadas, vivendo em comunidade, de certa forma, obrigadas a acamparem na propriedade onde estava sendo criado um projeto de assentamento por um período de dois anos. Estar acampado/a, no caso, sinaliza tornar-se candidato/a a um lote do PA, desde que faça a inscrição no INCRA. Vale destacar que as pessoas acampadas sobreviviam devido à distribuição de cestas básicas distribuídas pelo INCRA, visto que o 
acampamento não oferecia condições de trabalho. Além disso, caso saíssem do acampamento, eram mais consideradas candidatas a um lote do assentamento pelo INCRA. Ainda, muitas pessoas vieram de áreas urbanas, cidades próximas como Palmas, Ponte Alta e Santa Tereza, ou seja, até então não tinham exercido a função de agricultores/as. Sobre isso, durante a observação participante, uma nota de campo registrou um desabafo de uma assentada.

(47) A COOPVAG, em suas palestras, vendia um sonho de um paraíso para as pessoas acampadas e isso as mantinha no acampamento. Os técnicos diziam que quando fossem para os lotes teriam assistência técnica, incentivos financeiros para construírem as casas, para plantarem e criarem seus animais. Além disso, a assentada me disse que, se soubesse que passaria por tanta dificuldade financeira e de sobrevivência no lote, teria desistido do acampamento e, consequentemente, do lote do PA.

(Nota 7 PA, 18 de julho de 2014)

A assentada relatou que todas as propostas da COOPVAG eram aceitas pelas pessoas acampadas. Primeiramente, essas pessoas tinham a convicção de que, nos lotes, teriam assistência técnica para desenvolverem todas as ações votadas durante as reuniões. Além do mais, queriam sair logo do acampamento e a única maneira era votarem de imediato nas ações propostas pela COOPVAG e que seriam desenvolvidas no PA. Sendo assim, a nota de campo acima implica em um contraponto entre o primeiro passo descrito na Metodologia e o ponto de vista da assentada, pois a COOPVAG sinaliza que as pessoas acampadas não só propuseram ações para o desenvolvimento do PA como também escolheram as ações.

Já o excerto (48) está no item Restituição e faz referência ao segundo passo da Metodologia.

(48) $2^{\circ}$ Passo - A oficina teve como objetivo fazer com que a comunidade [ator] realizasse [processo material concreto] o planejamento de suas ações [meta], a partir da realidade diagnosticada [circunstância]. Foi utilizada a metodologia do Planejamento Orientado por Objetivos de Trabalho [meta]. A comunidade [meta] foi dividida [processo material concreto] em grupos temáticos [circunstância], que após analisarem [processo mental cognitivo] potencialidades e limitações [fenômeno], propuseram [processo material concreto] ações-soluções para os problemas diagnosticados no PA [meta]. Posteriormente, os grupos [ator] apresentaram [processo material abstrato] os resultados das discussões [meta], sistematizados em cartazes e, através do debate em plenária [circunstância], estabeleceram [processo material abstrato] consensos sobre os objetivos das ações propostas [meta].

(COOPVAG, 2007, p. 6) 
O excerto acima remete às oficinas realizadas pela COOPVAG com as pessoas acampadas acerca das ações para o desenvolvimento do PA, que deveriam compor o PDA. Por um lado, o processo material 'realizasse' é concreto e está na voz ativa, atrelado ao ator 'comunidade', à meta 'planejamento de suas ações' e à circunstância ' a partir da realidade diagnosticada'. Como a ação proposta é desenvolvida pelo ator comunidade, esse aparece explícito, apesar da circunstância indiciar autoria da ação da COOPVAG, haja vista ter realizado o diagnóstico. Por outro lado, o processo material 'foi dividida' é concreto e está na voz passiva, atrelado à meta 'comunidade', e à circunstância 'em grupos'. O ator desse processo foi apagado. Com isso, o uso do processo material 'foi dividida' na voz passiva indicia a escolha pelo ator apagado, implícito, pois quem divide a meta 'comunidade' é a COOPVAG, que não aparece neste trecho.

Ademais, a partir da observação participante, pode-se refletir sobre a organização das oficinas desenvolvidas pela COOPVAG com as pessoas acampadas em termos de atribuir a autoria do PDA às mesmas no título Agradecimentos.

(49) Um assentado narrou-me sobre as condições e as circunstâncias da vida no acampamento. De acordo com ele, as pessoas que participaram das oficinas estavam acampadas já há dois anos na propriedade onde seria o PA. Também tinham sido informadas pelo INCRA que participar das oficinas promovidas pela COOPVAG era um requisito para que os lotes do PA fossem sorteados. Por isso participavam das oficinas e concordavam de imediato com "o sonho vendido pela COOPVAG". Isto é, segundo elas, não houve tempo para refletir se as propostas da COOPVAG eram adequadas para o PA. Desejavam que aquele planejamento ficasse pronto logo, para poderem ir para seus lotes.

(Nota 8 PA, 18 de julho de 2014)

$\mathrm{O}$ ato de votar a favor ou contra as propostas apresentadas e escolhidas pela COOPVAG em relação às ações inseridas no PDA não garante autoria exclusiva das pessoas acampadas no texto do PDA. Também em consideração a algumas informações observadas durante a leitura e o preenchimento do Termo de Livre Esclarecido, no momento precedente das entrevistas semiestruturadas com assentados/as pioneiros/as, uma nota de campo foi registrada.

(50) Antes de cada entrevista semiestruturada, entregava para cada, possível, participante uma cópia do Termo de Livre Esclarecido, que apresentava as condições das entrevistas, e outra ficava comigo. Em seguida, eu lia em voz alta o conteúdo do termo para o possível participante para perguntar se ele concordava ou não a dar a entrevista. Quando começava a ler o termo, percebi durante muitas leituras que vários 
ouvintes não liam junto comigo o termo. Depois, se concordavam em dar a entrevista, eu solicitava que assinassem o termo, e o constatei a dificuldade da maioria para assinar o nome no termo. Ainda, depois da assinatura do termo, necessitava que cada participante me fornecesse algumas informações sobre informações sobre perfil socioeconômico e nele havia um item sobre nível de escolaridade. Constatei aí também que o nível de escolaridade da maioria era quase nenhum. Quando algum tinha frequentado a escola era, no máximo, por dois anos.

(Nota 11 PA, 19 de julho de 2014)

De acordo com a nota de campo acima, se a pessoa acampada não sabe ler ou se quase não sabe ler, fica inviável colocar essas pessoas em grupos para discutirem propostas escritas e depois apresentarem essas discussões também através de cartazes. Ainda, há uma nota de campo com a descrição de como a COOPVAG apresentava as propostas.

(51) Os recursos audiovisuais utilizados pelos técnicos da COOPVAG durante as oficinas com as pessoas acampadas eram data show, textos escritos, muitas apostilas. Eles projetavam os slides que apresentavam os programas de produção para PA Santa Tereza I às pessoas acampadas e também distribuíam apostilas com os programas de produção.

(Nota 6 PA, 18 de julho de 2014)

Considerando que as pessoas oficinistas eram analfabetas ou quase analfabetas, os recursos descritos no excerto (51) são inadequados, ineficientes para este público. Como acréscimo a essa inadequação, há a situação de vulnerabilidade social e econômica, já descrita anteriormente, das pessoas acampadas, que juntas podem ter propiciado uma não reflexão sobre as escolhas feitas e que estão no PDA. Essas pessoas tiveram que decidir em poucos dias o planejamento do PA para que tivessem chance de "sair" daquela condição de acampadas. Ainda sobre as escolhas das pessoas acampadas, os itens Conclusão e Apresentação tentam relatar a etapa posterior às oficinas e como a versão final foi escrita.

(52) Após a oficina [circunstância], na qual foram abordados os principais pontos e demandas a serem trabalhados no Planejamento, a equipe [ator] sistematizou [processo material abstrato] as propostas da comunidade [meta] dando [processo material abstrato] continuidade [meta] ao processo de construção do Plano de Desenvolvimento do Assentamento, sua redação e a análise de viabilidade. Foram feitas [processo material concreto] as propostas de intervenção [meta] que resultaram nos seguintes Programas: Organização Territorial, Produtivo, Social (subprogramas de educação; saúde e saneamento; cultura, lazer e esporte; e habitação), Ambiental, Desenvolvimento Organizacional e de Gestão do Plano e Assessoria Técnica, Social e 
Ambiental. E depois de concluído, o documento [meta] foi apresentado [processo material concreto] à comunidade e parceiros [meta], para ser avaliado e aprovado.

(COOPVAG, 2007, p. 7)

O processo material 'sistematizou' apresenta o ator 'a equipe', mas sua ação se faz abstrata à medida que é vaga no que se refere que tipo de sistematização feita pela COOPVAG. A meta 'propostas da comunidade' também enfatiza que as pessoas acampadas escolheram as propostas do PDA e não leva em conta o contexto em que tais escolhas foram feitas. No entanto, o processo material 'foram feitas' aponta uma ação concreta da COOPVAG em relação à elaboração do PDA, de acordo com o excerto, apesar de o ator estar apagado. A meta 'propostas de intervenção' indicia não somente autoria da COOPVAG, mas também escolhas feitas em termos de conteúdo do PDA. Além do mais, o processo material 'foi apresentado' está na voz passiva, omitindo o ator, mas a meta 'comunidade e parceiros' indicia que a COOPVAG apresentou a outra meta 'documento' a este público. Nesse ponto, vale destacar uma nota de campo elaborada após as entrevistas no PA.

(53) Quando chegava a um lote para realizar a entrevista semiestruturada com os/as pioneiros/as do PA, e introduzia o tópico "Gostaria que o senhor/a me contasse como o PDA Santa Tereza I foi elaborado", fiquei muito surpreendida com quantidade de assentados/as que disseram não saber o que era o PDA. Também disseram não saberem qual tinha sido o resultado das oficinas realizadas com a COOPVAG.

(Nota 12 PA, 19 de julho de 2014)

Com a nota de campo acima, há que se questionar a apresentação do 'documento PDA Santa Tereza I - descrita no excerto (53). Se vários/as assentados/as me disseram que nunca ouviram falar em PDA, algum problema, no mínimo, ocorreu com o tipo de apresentação do referido documento. Caso realmente tenha acontecido a apresentação do PDA Santa Tereza I à comunidade assentada, parece que a comunidade pioneira por algum motivo não se lembra dela.

Depois da Metodologia, aparece o título Contexto socioeconômico e ambiental da área de influência do projeto de assentamento. Esse título propõe descrever a área que influencia o PA Santa Tereza I. Os itens apresentados nessa parte do PDA são território, caracterização do meio físico, caracterização do meio biótico, condições de conservação ambiental e caracterização do meio socioeconômico e cultural. O gráfico abaixo identifica os processos desse título. 


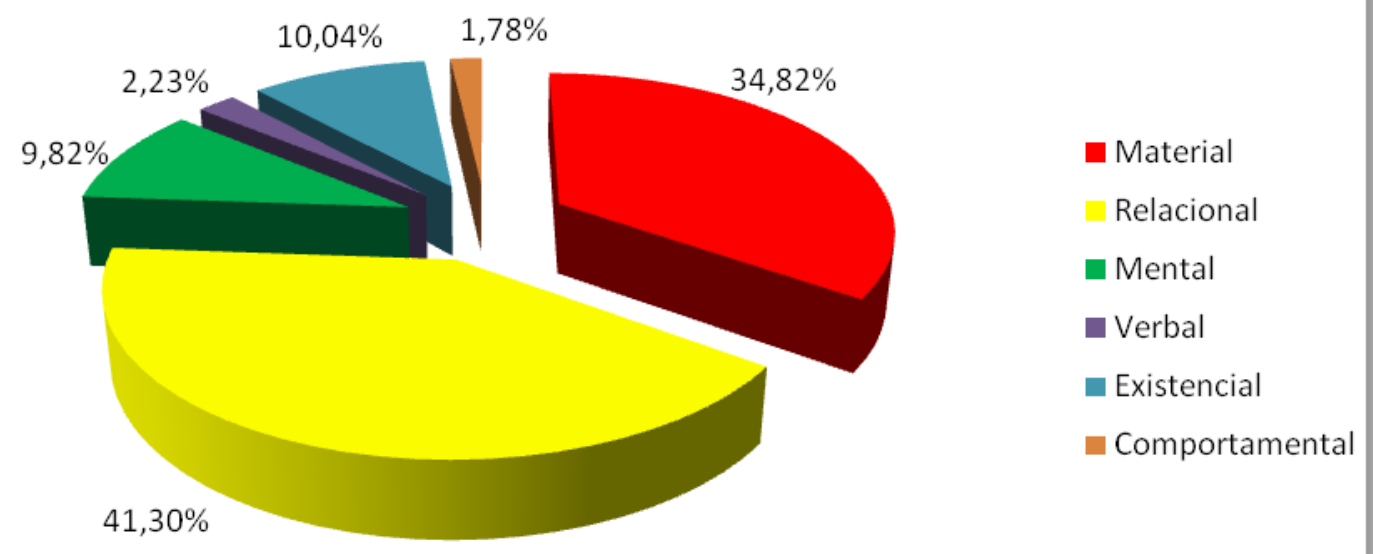

\section{Gráfico 4.9 - Distribuição de processos no Contexto socioeconômico e ambiental do PA}

O Gráfico 4.9 demonstra que no título Contexto há todos os tipos de processos. Há $41,30 \%$ de processos relacionais (185), 34,82\% de processos materiais (156), 10,04\% de processos existenciais (45), 9,82\% de processos mentais (44), 2,23\% de processos verbais (10) e $1,78 \%$ de processos comportamentais (8). Ocorre, pois, uma diferença dos outros títulos: o tipo de processo que mais se apresenta são os processos relacionais e não os materiais. Há mais ações do mundo abstrato, que atribuem características ou identificam. Essa configuração de processos no Contexto parece ser devido ao seu conteúdo: descrever, no caso, a área de influência do PA. Entre os relacionais, 154 são relacionais atributivos e 31 são identificativos. No item Hidrografia, como em todo o título, há essa caracterização.

(54) A hidrografia dos municípios de influência (Ponte Alta do Tocantins e Santa Tereza do Tocantins) [portador] está [processo relacional atributivo] inserida [atributo] na sub-bacia do rio das Balsas, onde esta [portador] possui [processo relacional atributivo] uma área de 12.386,7 $\mathrm{km}^{2}$ [atributo], e que por sua vez está [processo relacional atributivo] inserido [atributo] no sistema hidrográfico do rio Tocantins.

(COOPVAG, 2007, p.11)

O fragmento (54) possui processos relacionais, o mais frequente desse título. Esses processos se configuram como relacionais atributivos 'está' e 'possui', com portadores e atributos, caracterizando a hidrografia dos municípios de Ponte Alta e Santa Tereza do Tocantins que circundam o PA. No mesmo item, depois de caracterizar, teoricamente, a área hidrográfica de influência do PA, relata-se outra realidade através do uso do processo material, segundo tipo com maior ocorrência. Há 126 processos materiais concretos e 30 abstratos; 99 na voz ativa e 57 na voz passiva. 
(55) De um modo geral, tanto em áreas urbanas, como no meio rural, as águas subterrâneas [meta] são obtidas [processo material concreto] a partir de poços tubulares, escavados (cisternas) e nascentes [circunstância], sendo o seu gerenciamento realizado pela Companhia de Saneamento do Estado do Tocantins (SANEATINS) e em algumas cidades e comunidades pelas prefeituras.

(COOPVAG, 2007, p.12)

O excerto (55) também está no item Hidrografia e apresenta processo material concreto 'são obtidas' e a meta 'as águas subterrâneas'. No entanto, mesmo apresentando um processo do mundo do fazer, uma ação concreta, há o apagamento do ator, agente desta ação. Somente está explícito o ator fiscalizador das construções dos 'poços tubulares': a 'SANEATINS'. Isto é, o texto só aponta um modo de obtenção de água na área de influência do PA, sem explicitar quem constrói, quem financia.

No item Uso da terra, descreve-se o tipo de solo da região onde está inserido o PA, como está no excerto (56).

(56) O município de Ponte Alta do Tocantins e entorno [portador] apresenta [processo relacional atributivo] uma potencialidade de uso das terras bastante heterogênea [atributo], onde se classificam entre áreas para pecuária extensiva, áreas para silvicultura e/ou pecuária intensiva e áreas de conservação ou com alta limitação natural para uso. Esta última está presente no entorno imediato à sede do município de Ponte Alta do Tocantins, onde existe [processo existencial] a presença de solos litólicos, bastante íngremes, com alto grau de erodibilidade potencial [existente]. Também é [processo relacional atributivo] relevante [atributo] a aptidão do município para a pecuária extensiva [portador], devendo-se levar em consideração que nas áreas de areias quartzosas a retirada da cobertura vegetal propicia o aparecimento de processos de desertificação.

(COOPVAG, 2007, p.13)

No excerto (56), ocorre o processo relacional atributivo 'apresenta' que caracteriza o solo do PA com um atributo 'uma potencialidade de uso de terra bastante heterogênea'. Esse atributo 'heterogênea', foi exposto como 'áreas para pecuária extensiva, áreas para silvicultura e/ou pecuária intensiva e áreas de conservação ou com alta limitação natural para o uso', apresentando somente duas possibilidades de uso do solo em termos de subsistência das pessoas assentadas. $\mathrm{O}$ tipo de solo apresentado restringe às possibilidades de programas de produção. Assim, há de se questionar a criação de um projeto de assentamento em uma região com 'alta limitação natural para o uso', podendo ocorrer 'processos de desertificação'. Também há de se questionar os diversos programas de produção propostos pelo PDA uma vez 
que na descrição do uso do solo que dito próprio para a produção afirma-se que é próprio para um único programa: a pecuária.

Já o título Diagnóstico apresenta informações gerais sobre o PA Santa Tereza I, no que concerne, entre outros aspectos, à caracterização da localização geográfica, do meio físico, da organização territorial. Em seu conteúdo, também ocorrem todos os tipos de processos, como se pode observar no Gráfico 4.10.

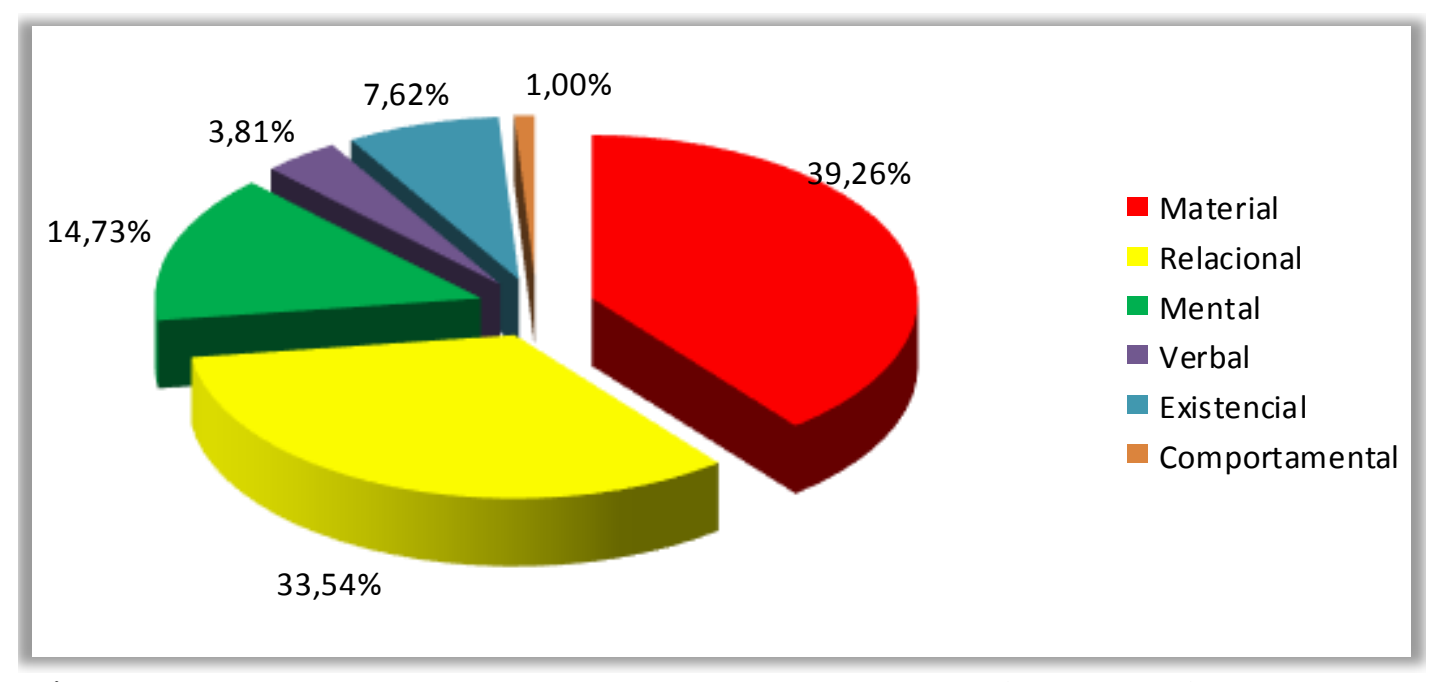

Gráfico 4.10 - Distribuição de processos no Diagnóstico do projeto de assentamento

O Gráfico acima demonstra que ocorrem 39,26\% de processo materiais (309), 33,54\% de processos relacionais (264), 14,73\% de processos mentais (116), 7,62\% de processos existenciais (60), $3,81 \%$ de processos verbais (30) e $1 \%$ de processos comportamentais (8). Desses processos matérias, 248 são concretos e 30 abstratos; 207 na voz ativa e 102 na voz passiva. Os excertos (57) e (58) descrevem um tipo de solo do PA.

(57) Os Latossolos são caracterizados como preferenciais para atividades agropecuárias dentre os solos citados. São [relacional atributivo] solos profundos [atributo], de fácil drenagem [atributo] e bem estruturados fisicamente [atributo]. Apresentam Horizonte B espesso. São [processo relacional atributo] solos muito intemperizados [atributo], com pequena reserva de nutrientes para as plantas [atributo] sendo [processo relacional atributivo] um fator importante [atributo] para agricultura. $\mathrm{O}$ $\mathrm{pH}$ varia em torno de 4,0 a 4,5 apresentando [processo relacional atributivo] baixa capacidade de troca de cátions $\left(C T C=3,02 \mathrm{cmol} / \mathrm{dm}^{3}\right.$ ) [atributo], sendo uma das justificativas de sua baixa fertilidade. São solos que precisam ter sua acidez e teor de alumínio trocável e/ou corrigidos através da utilização de calcário, uma vez que muitas culturas [ator] não se desenvolvem [processo material abstrato] nessas áreas.

(COOPVAG, 2007, p.34) 
(58) De maneira geral, os solos [portador] apresentam [processo relacional atributivo] fertilidade baixa [atributo], característica de solos do Cerrado, que devem ser manejadas de modo que se mantenham conservados e propícios para atividades agropecuárias.

(COOPVAG, 2007, p.36)

O excerto (57) configura os processos relacionais atributivos 'ser' e 'apresentar', os portadores 'solos' e 'PH', respectivamente, e seus atributos. Vale destacar que esses atributos são pejorativos no que se refere à qualidade do solo para a agricultura: 'muito intemperizados', 'com pequena reserva de nutrientes para as plantas'. 'baixa capacidade de troca de cátions $\left(\mathrm{CTC}=3,02 \mathrm{cmol} / \mathrm{dm}^{3}\right)^{\prime}$. Esses atributos tentam justificar os ditos posteriores: 'baixa fertilidade, 'precisam ter sua acidez e teor de alumínio trocável e/ou corrigidos'. Os atributos sugerem que o solo do PA não é adequado para a agricultura devido à sua composição. É dito que, para produzir nele, é necessário tratá-lo e isto, no mínimo, exige investimento financeiro. No final, há o processo material abstrato 'desenvolvem' com o ator 'muitas culturas', afirmando que certos tipos de plantações não são adequados para o tipo de solo existente. O excerto (58) reitera o dito do (57) através também do uso de processo relacional atributivo 'apresentam', o portador 'os solos' e o atributo 'baixa fertilidade'. Esse atributo também caracteriza pejorativamente o solo do PA. Questiona-se, neste ponto, a escolha da propriedade para se construir o PA haja vista a qualidade do solo dela, considerando que as pessoas assentadas precisam, pelo menos, produzirem alimentos para sua subsistência. Já os fragmentos (59) e (60) versam sobre a disponibilidade de recursos hídricos do PA.

(59) Cabe ressaltar que nos períodos longos de estiagem [circunstância], boa parte dos córregos do PA [ator] não consegue manter [processo material concreto] sua vazão [meta] tendo seu curso interrompido ou significantemente reduzido; restando água apenas nos córregos de maior volume.

(COOPVAG, 2007, p.37)

(60) Segundo estudos de Frasca e Araújo (2001) através da Companhia de Pesquisa de Recursos Minerais/Ministério de Minas e Energia (CPRM/MME), o interesse pelo estudo de águas subterrâneas na região vem sendo desenvolvido desde a década de 80 e se intensificou nos últimos anos, motivado pelo aumento da atividade de perfuração de poços tubulares que está diretamente associado ao desenvolvimento da região, entretanto, pouco se conhece [processo mental] sobre os poços existentes [fenômeno], sua produção, qualidade da água e perfil geológico, por isso, há a necessidade de otimizar o aproveitamento das águas subterrâneas para solucionar problemas de pequenas e médias demandas. 
O fragmento (59) possui um processo material concreto 'manter', um ator 'boa parte dos córregos do PA' e a meta 'sua vazão', apontando para os problemas hídricos do PA durante meses do ano em relação aos córregos, problemas que é reforçado por meio do uso do advérbio modalizador 'apenas'. O uso do 'apenas' remete, no caso, à restrição de água nas terras onde está situado o PA Santa Tereza I. Além do mais, o fragmento (60) apresenta o processo mental 'se conhece' e o fenômeno 'os poços existentes' com apontamento para problemas em relação à obtenção de poços artesianos no PA. As características do fenômeno são pejorativas ainda em relação à obtenção de água no PA: 'sua produção', 'qualidade da água' e 'perfil geológico'. Ao conversar com vários/as assentados/as, uma nota de campo foi registrada a partir de um relato de um assentado sobre a disponibilidade de águas subterrâneas. A nota segue abaixo.

(61) O assentado disse que recebeu o dinheiro do PRONAF para perfurar um poço artesiano, mas duas tentativas foram feitas e não conseguiu achar água. Ele falou que terá que começar pagar as prestações do PRONAF, mas não terá condições, pois não poderá plantar já que o lote não tem água. Para todo o consumo de água, ele percorre $1,2 \mathrm{~km}$ para buscar água em um carrinho de mão.

(Nota 4 PA, 5 de julho de 2014)

A nota de campo, excerto (61), descreve um relato sobre um lote que não possui água para o consumo da família e nem para o plantio ou consumo de animais. Além disso, as tentativas de perfuração de poço artesiano no local não tiveram hesito. Na visita a esse lote, a falta total de água foi constatada, o que foi registrado em uma foto retratando o modo como o assentado obtém água para todo o consumo do lote. A fotografia segue abaixo.

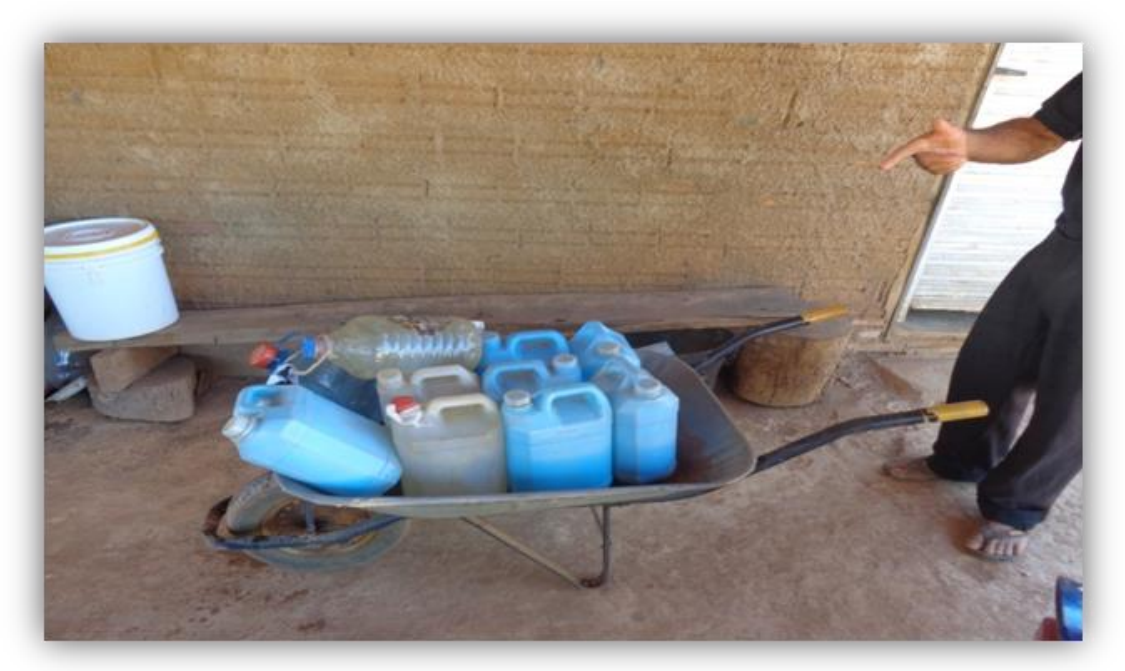

Fotografia 4.1 - Obtenção de água em um dos lotes do PA 
A imagem acima apresenta o modo como um assentado obtém água no PA Santa Tereza I. O assentado é um senhor idoso e é obrigado empurrar um carrinho de mão por 1,2 $\mathrm{km}$ em um caminho íngreme até a nascente mais próxima de seu lote.

Quanto ao diagnóstico do uso e cobertura da terra do PA, os excertos (66) e (67) apontam a sua construção.

(62) O mapa de uso e cobertura da terra (Mapa A2) [meta], apresentado neste Plano, foi disponibilizado [processo material concreto] pelo INCRA [ator], bem como uma série de informações coletadas através do Sistema de Informações dos Projetos de Assentamento - SIPRA [meta], que permitiram a classificação e representação das diferentes fitofisionomias e os prováveis usos da área, indicando características peculiares do modo de ocupação. As categorias delineadas abrangem os grupos tipológicos existentes na área o que resultou em 06 classes temáticas.

(COOPVAG, 2007, p.39)

(63) Destacam-se, ainda, as áreas formadas por Neossolos Litólicos, essas áreas [portador] são [processo relacional atributivo] praticamente impróprias [atributo] ou de utilização restrita [atributo] para lavouras e pastagens, sendo sua maioria [meta] utilizada [processo material concreto] para áreas de Preservação Permanente [circunstância].

(COOPVAG, 2007, p.42)

No fragmento (62), o processo material concreto 'foi disponibilizado' está na voz passiva, mas possui o ator explícito - 'INCRA' -, pois descreve uma ação do referido representante do governo federal. A meta desse processo é 'o mapa de uso e cobertura da terra'. Em relação a essa meta, a COOPVAG, empresa contratada para fazer o PDA, teve parte do serviço contratado "poupado" com a ajuda do INCRA. O fragmento (63) reforça o dado de que os solos do PA são impróprios para a agricultura e a agropecuária. O processo relacional atributivo 'são' vem acompanhado do portador 'essas áreas' e dos atributos 'impróprias' 'utilização restrita'. Esses atributos avaliam pejorativamente o solo do PA Santa Tereza I. Sendo assim, o INCRA já dispunha de informações sobre o solo do PA antes do diagnóstico elaborado pela COOPVAG e mesmo assim decidiu que haveria um projeto de assentamento naquela propriedade.

O item Organização territorial atual abrange as condições da propriedade onde as pessoas estavam acampadas e que seria o PA, como mostram os dois fragmentos abaixo.

(64) A área ocupada pelo Projeto de Assentamento [identificado] não possui [processo relacional identificativo] ainda o parcelamento dos lotes 
[identificador], portanto a sua organização territorial [portador] atual está [processo relacional atributivo] baseada [atributo] apenas na infraestrutura que já existia, antes da desapropriação da fazenda: uma estrada não-pavimentada e em péssimas condições de conservação e, as poucas infra-estrutura instaladas, após a ocupação pela comunidade.

(COOPVAG, 2007, p.47)

(65) Os dados e a observação participativa com as famílias permitiram constatar que a situação social e econômica dos Assentados [portador] é [processo relacional atributivo] extremamente precária [atributo]. As famílias estão [processo relacional atributivo] acampadas [atributo] desde a criação do PA e não foi possível, nesse período, executar nenhuma atividade produtiva, uma vez que não estão em seus lotes.

(COOPVAG, 2007, p.49-50)

O fragmento (64) diagnostica a ocupação territorial onde seria o PA quando a propriedade foi desapropriada. Nele, há um processo relacional identificativo 'possui', um identificador 'o parcelamento dos lotes' e o identificado 'A área ocupada pelo Projeto de Assentamento'. Isto é, a propriedade onde seria o PA não tinha sido dividida em lotes ainda e as pessoas que pleiteavam um lote lá estavam acampadas. Ocorre, no mesmo fragmento, a caracterização pejorativa da infra-estrutura do PA durante o período de acampamento: 'uma estrada não-pavimentada e em péssimas condições de conservação' e 'as poucas infraestrutura instaladas, após a ocupação pela comunidade'. O fragmento (65) avalia, igualmente, as condições de sobrevivência das pessoas acampadas através do uso do processo relacional atributivo 'é' e seus participantes. O portador a 'situação social e econômica dos Assentados' tem como atributo 'extremamente precária'. A COOPVAG, ao utilizar esse atributo, avalia negativamente o meio de sobrevivência durante o período do acampamento. Vale destacar ainda que pessoas acampadas são denominadas de 'assentados', sendo que ainda não eram.

Além disso, o excerto (66) traz o diagnóstico sobre saúde no PA Santa Tereza I.

(66) Não existe [processo existencial] posto de Saúde [existente] no Projeto de Assentamento Santa Tereza I [circunstância] e quando precisam recorrem à cidade vizinha Santa Tereza do Tocantins. Na realidade, devido à flagrante situação de carência da comunidade, é no município de Santa Tereza do Tocantins, por ser próximo ao PA, que recorrem quando precisam utilizar as estruturas como, posto médico, escola, telefone público, comércio entre outros serviços.

(COOPVAG, 2007, p.57)

Em relação ao acesso à saúde onde seria o PA Santa Tereza I, o excerto (66) configura também falta de assistência: 'flagrante situação de carência da comunidade'. O excerto apresenta o processo existencial 'existe', o existente 'posto de saúde, sendo que o processo 
existencial está precedido pelo adjunto modal 'não'. Esse adjunto modal, por sua vez, possui um valor de julgamento com polaridade negativa. Assim, o excerto aponta para um diagnóstico negativo, para a ausência de assistência à saúde onde as pessoas estavam acampadas.

Já o título 7 - Prognóstico de impactos ambientais e medidas propostas - possui 10 páginas e propõe a identificação dos impactos ambientais do projeto de assentamento, a partir da Política Nacional do Meio Ambiente, de 1981. De acordo com a COOPVAG (2007, p. 201), a avaliação de impactos ambientais de um PA é definida como "um conjunto de ações planejadas e desenvolvidas em áreas destinadas à Reforma Agrária, de natureza interdisciplinar e multissetorial, integradas ao desenvolvimento territorial e regional". A partir disso, pelas características do seu conteúdo, o título apresenta todos os tipos de processos.

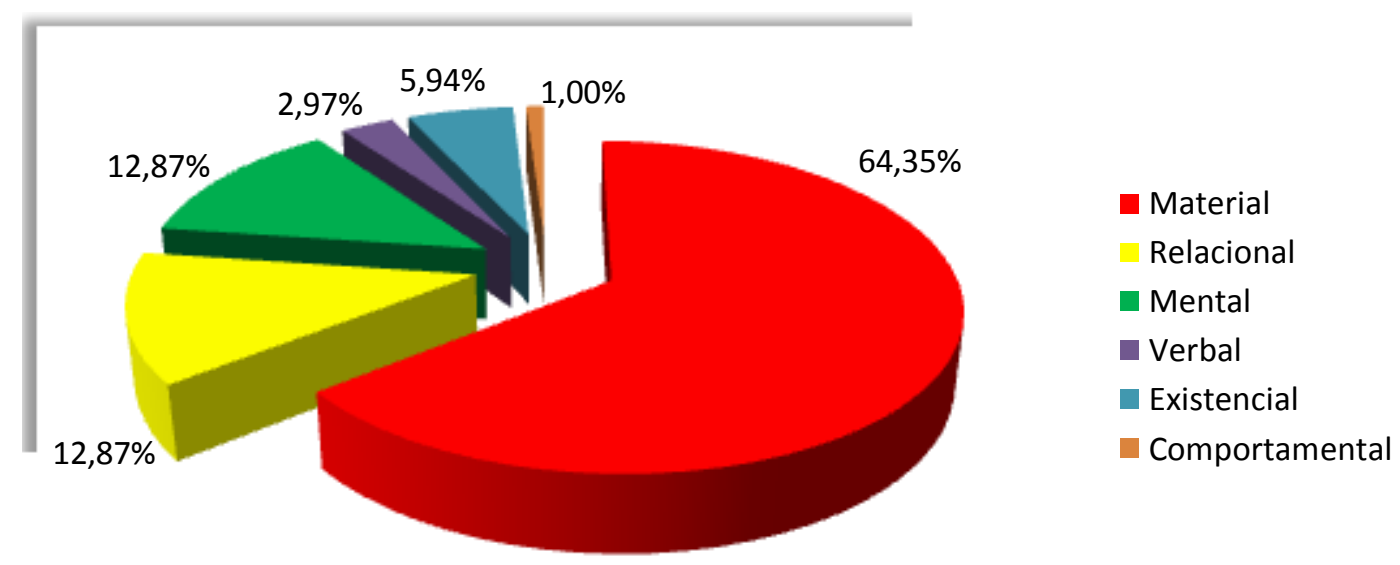

Gráfico 4.11 - Distribuição de processos no Prognóstico
de impactos ambientais e medidas propostas para o PDA

O Gráfico 4.11 demonstra que, no Prognóstico, ocorrem 64,35\% de processos materiais (65), 12,87\% de processos relacionais (13), 12,87\% de processos mentais (13), $5,94 \%$ de processos existenciais (6), 2, 97\% de processos verbais (3) e $1 \%$ de processos comportamentais (1). Há cinco vezes mais processos materiais do que o segundo: verbal. Vale salientar também que, dos materiais, há 43 abstratos e 22 concretos. Além disso, 36 estão na voz ativa e 29 na voz passiva. Os fragmentos (67) e (68) destacam o comportamento de tais processos.

(67) $\mathrm{Na}$ apresentação dos impactos [circunstância] utilizou-se [processo material concreto] o método da listagem de controle ( check list) [meta], que reúne as ações, impactos (positivos ou negativos) e medidas a 
serem adotada como forma de facilitar a visualização. Posteriormente, as análises se limitam a identificar as origens dos impactos e a descrever suas relações com o meio ambiente.

(COOPVAG, 2007, p. 202)

No fragmento (67), o processo material concreto 'utilizou-se' apresenta a meta 'o método da listagem de controle (check list)' e suprime o ator. Há um apagamento do ator da ação concreta. Esse apagamento sugere uma tentativa de manter os/as assentados/as como os atores das ações propostas no PDA assim o ator autor do PDA. Pelo contexto do fragmento, ocorre constatação, porém, de que o ator suprimido é a COOPVAG. No fragmento (68), da mesma forma, os atores dos processos materiais estão omitidos.

(68) Sendo assim, quando se retirou [processo material concreto] a vegetação natural dessa área [meta], mesmo que tenha sido apenas pequenas áreas para construção dos barracos e adequação das famílias (construção da escola, local de acesso à água, etc), houve toda uma alteração física, biológica e social do local. Até mesmo espécies vegetais [meta] foram suprimidas [processo material concreto] para estruturar as moradias [circunstância] e parte da fauna local [meta] foi afugentada [processo material concreto], devido à presença humana [circunstância] ou pela ação da caçar como fonte de alimento para algumas famílias [circunstância].

(COOPVAG, 2007, p. 204)

O processo material concreto 'se retirou', no fragmento (68), apresenta a meta 'a vegetação natural dessa área' e oculta o ator. Não está explícita a responsabilidade de qual ator na retirada da vegetação da área do acampamento. Também ocorre o processo material concreto 'foram suprimidas' na voz passiva, a meta 'espécies vegetais' e a circunstância 'para estruturar as moradias', mas o ator dessa ação não está explícito. Ainda o processo material concreto 'foi afugentadas' também está na voz passiva, apresenta a meta 'parte da fauna local' e as circunstâncias 'devido à presença humana' e 'pela ação da caçar como fonte de alimento para algumas famílias'. Não há, porém, o ator responsável por essa ação. Dessa forma, como as metas desses processos materiais do mundo do fazer referem-se, de alguma maneira, à degradação da flora ou da fauna do PA, ocorre o apagamento dos atores desses processos. No fragmento (69), também acontece o apagamento de um participante. 
(69) Para a implantação da área de cultivo [circunstância] não se levou em consideração [processo mental cognitivo] à topografia do terreno [fenômeno] ou as condições de aptidão do solo [fenômeno] classificada no laudo de vistoria de desapropriação do imóvel ou até mesmo a indicação técnica para utilização de outra área [fenômeno].

(COOPVAG, 2007, p. 204)

No fragmento acima, o processo 'se levou em consideração' comporta-se como mental cognitivo e, por isso, apresenta fenômenos 'à topografia do terreno', 'as condições de aptidão do solo' e 'a indicação técnica para utilização de outra área', mas não apresenta o experienciador. Há o apagamento do desse participante. Os fenômenos sugerem a falta de observância por parte do experienciador das características do solo do PA para um possível cultivo.

Ainda o título Considerações finais possui 01 página e elenca algumas considerações sobre as ações projetadas no PDA Santa Tereza I. Em relação aos processos, não aparecem os processos existenciais e os comportamentais, como mostra o Gráfico 4.12.

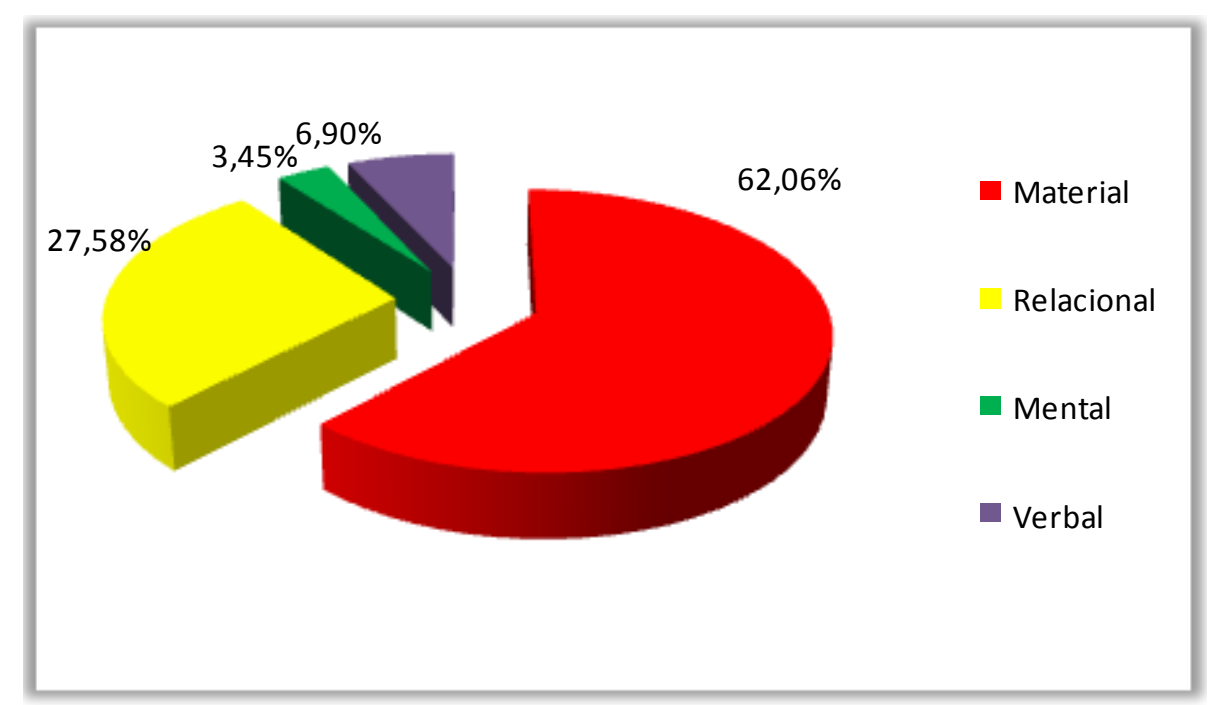

\section{Gráfico 4.12 - Distribuição de processos nas Considerações finais}

Nas Considerações finais, há 62,06\% de processo materiais (18), 27,58\% de processos relacionais (8), 6,90\% de processos verbais (2) e 3,45\% de processos mentais (1). Dos processos materiais, 16 são abstratos enquanto que somente 2 são concretos. Além disso, 17 processos materiais estão na voz ativa enquanto que 1 está na voz passiva. A presença de mais processos materiais vai ao encontro com o objetivo de se elaborar um PDA: propor ações do mundo do fazer e acontecer. No entanto, a COOPVAG utiliza processos mentais, do mundo da consciência, quando se refere às pessoas acampadas como participante do processo. 
(70) A comunidade [experienciador] espera [processo mental desiderativo] com a implementação do Plano de Desenvolvimento do Assentamento PDA, que as ações propostas possam se consolidar [fenômeno]. A permanência dos agricultores familiares assentados depende de sua sustentabilidade, resultado de um sistema de produção plenamente desenvolvido, da sua inclusão no circuito comercial e do equilíbrio ecológico e social.

(COOPVAG, 2007, p. 211)

(71) Os agricultores familiares [experienciador] apostam [processo mental cognitivo] na projeção da melhoria do manejo produtivo e de ações racionais de utilização dos recursos naturais existentes [fenômeno] para balizar a situação econômica, social e ambiental [circunstância] e, conseqüentemente, elevar a qualidade de vida das famílias aproximando-as do sonho de um "Projeto de Assentamento com Desenvolvimento Sustentável" [circunstância].

(COOPVAG, 2007, p. 211)

Os excertos (70) e (71) trazem processos mentais no âmbito do mundo das ideias. Não estão no mundo físico do fazer e do acontecer. No primeiro, o processo mental desiderativo 'espera' possui o experienciador 'a comunidade' e o fenômeno projetado 'que as ações propostas possam se consolidar'. Esse processo aponta o desejo das pessoas acampadas de que as ações propostas no PDA se concretizem para que consigam permanecer nos lotes determinados a elas. No segundo, o processo mental cognitivo 'apostam' apresenta o experienciador 'os agricultores familiares' e o fenômeno 'na projeção da melhoria do manejo produtivo e de ações racionais de utilização dos recursos naturais existentes'. São processos que sugerem subjetividade do experienciador, no caso, o mesmo - as pessoas acampadas - no que concerne às ações propostas no PDA. Os fenômenos concretizados estão no mundo do pensamento e não no da realidade concreta.

\subsubsection{O título de vôo mais extenso: Plano de ação para o desenvolvimento sustentável}

O Plano de ação é o tópico mais extenso do PDA Santa Tereza I, com 133 das 236 páginas do documento. Suas páginas são mais que duas vezes a soma dos outros títulos e, por isso, é apresentado de forma mais acurada aqui. O título propõe um planejamento de ações para o desenvolvimento do PA, ou seja, apresenta programas de desenvolvimento, a partir de dados do título Diagnóstico. No que se refere ao Sistema de Transitividade, o Plano de ação tem 2.781 processos, apresentados no Gráfico 4.13. 


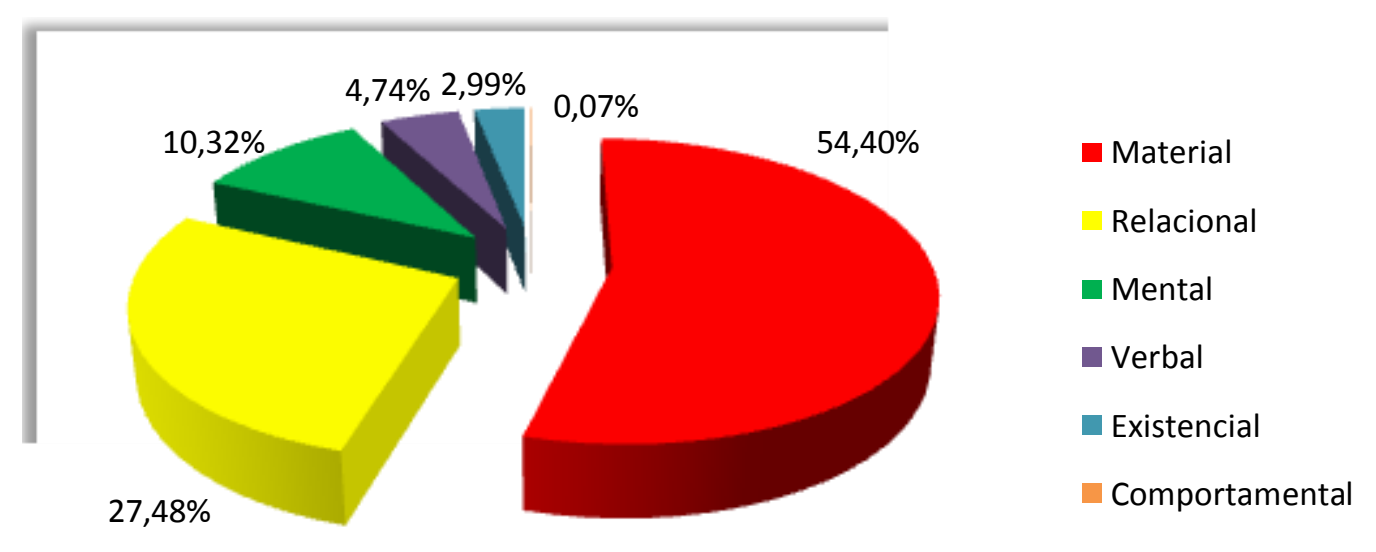

Gráfico 4.13 - Distribuição de processos no título Plano de ação

De acordo com o Gráfico 4.13, o Plano de ação possui os seis processos verbais. A frequência dos processos é 54,40\% de processos materiais (1.512), 27,48\% de processos relacionais (765), 10,32\% de processos mentais (287), 4,74\% de processos verbais (132), $2,99 \%$ processos existenciais (83) e $0,07 \%$ de processos comportamentais (2), como configuram os excertos a seguir. Vale destacar que, durante as entrevistas, os/as assentados/as solicitaram que, na oficina de leitura proposta por mim sobre algumas partes do PDA para ele/as, os temas tratados fossem: água, saúde, educação e energia elétrica. Sendo assim, como esse é o título que propõe apresentar as ações para o desenvolvimento do projeto de assentamento, os excertos a seguir abordarão tais 'ações' entre outras.

(72) Plano de Ação do PA Santa Tereza I [meta] foi construído [processo material concreto] a partir do olhar coletivo [circunstância], onde o resultado desse trabalho [portador] é [processo relacional atributivo] fruto do planejamento da comunidade [atributo], que se reuniu, discutiu e decidiu o que fazer para sair da situação em que se encontram e chegar onde querem.

(COOPVAG, 2007, p. 67)

O excerto (72) se encontra no item Apresentação do Plano de Ação. O processo material concreto 'foi construído' apresenta uma meta 'Plano de Ação do PA Santa Tereza I' e uma circunstância 'a partir do olhar coletivo'. O ator, agente da ação de construção do plano é apagado. A circunstância relacionada a esse processo que tenta, de certa forma, especificar o modo como a construção foi feita, também generaliza o ator, uma vez que o 'olhar coletivo' pode sugerir a visão de vários/as atores/atrizes como assentado/a, COOPVAG, INCRA, parceiros. O processo seguinte, apesar de não ser do mundo físico do fazer e do acontecer, 
tenta atribuir a materialização do plano à 'comunidade', que em todo texto do PDA, refere-se ao/à assentado/a. Esse processo relacional ‘é' possui o portador 'o resultado desse trabalho' e o atributo 'fruto do planejamento da comunidade'. Isto é, o plano é tido, no texto, como um atributo do planejamento da comunidade. Em ambos, como em outros títulos do PDA, há o apontamento de que a COOPVAG elaborou o Plano de ação de acordo com as escolhas, as vontades dos/as assentados/as.

Os processos materiais além se materializarem muito mais que os outros nesse título, diferentemente do que ocorre nos outros títulos, há mais processos materiais abstratos do que concretos: 1.069 abstratos e 443 concretos. Em princípio, espera-se que um título que propõe ações a serem desenvolvidas apresente processos materiais, do mundo físico. Os excertos apresentados a seguir demonstram esta característica materializada no Plano de ação. Para tanto, os Programas de desenvolvimento (item 6.4) apresentados nesse plano são: Programa de Organização Territorial, Programa Produtivo, Programa Ambiental e Programa Social, como mostra o excerto a seguir.

(73) A recuperação e construção de estradas, bem como a construção de bueiros [ator], deverão obedecer [processo material abstrato] às normas do INCRA (Norma de execução $n^{\circ}$. 36 de 30/03/04, Instrução Normativa $n^{\circ} .37$ de 08/12/06 e Norma do Incra $n^{\circ} .53$ de 20/12/06).

O convênio [meta] deverá ser efetuado [processo material abstrato] entre Prefeitura e o INCRA [ator], no qual ficará estabelecido à responsabilidade da prefeitura pela recuperação e construção das estradas e o grupo gestor do Programa de Organização Territorial [ator] deverá fiscalizar [processo material abstrato] e acompanhar [processo material abstrato] a execução das ações/obras [meta] (...).

O poço artesiano [meta] será perfurado [processo material abstrato] na área comunitária [circunstância] e deverá medir [processo material abstrato] 50 metros de profundidade equipado com bomba e uma caixa d'agua com capacidade para 10.000 litros e encanações diversas [meta]. A construção deverá_obedecer às exigências do INCRA e será efetuado [processo material abstrato] o convênio entre INCRA e Prefeitura [meta] que deverá se responsabilizar pela execução, sendo o grupo gestor responsável pela fiscalização e acompanhamento da obra.

(COOPVAG, 2007, p. 79)

O excerto (73) faz parte do Programa de Organização Territorial, no subitem Procedimentos técnicos, e aponta para os temas como estrada e água solicitados pelos/as asssentados/as no decorrer da observação participante e notas de campo. No que concerne às estradas, o processo material abstrato 'deverá ser efetuado' está na voz passiva com os atores Prefeitura e INCRA explícitos e a meta 'o convênio', cabendo ao ator prefeitura de Ponte Alta a responsabilidade de execução das estradas e ao ator INCRA e assentados/as a 
responsabilidade de fiscalização das estradas. Além da ocorrência da voz passiva com a omissão do ator/agente da ação, há também o apagamento de várias "ações" por meio da nominalização de processos verbais. Ocorre, assim, o uso de muitas nominalizações, como recuperação, construção, responsabilidade, execução e fiscalização. Essas nominalizações distanciam a proposição de ações e a sua execução.

Sobre isso, no entanto, durante a observação participante nas casas dos/as pioneiros/as do PA Santa Tereza I, uma nota de campo foi registrada acerca do acesso aos lotes.

(74) Ao percorrer os lotes do PA, tive grande dificuldade para acessar alguns, pois além de não ter acesso de carro também há algumas trilhas muito íngremes, pedregosas e estreitas. Do ponto até onde era possível ir de carro até alguns lotes o percurso era longo e feito em trilhas sem infraestrutura alguma. Quando chegava nestes lotes, os moradores viam meu cansaço e reclamavam do difícil acesso aos lotes. Disseram que a prefeitura tinha recebido recurso financeiro para executar as estradas e que não tinham feito. Também uma moradora disse que tinha que acordar às 4 horas da manhã para poder levar seus filhos pequenos a pé até o acesso ao ônibus escolar porque o ônibus escolar só ia onde tinha estrada.

(Nota 15 PA, 19 de julho de 2014)

Com essa nota, constata-se uma contradição entre o dito do PDA e a realidade vivida por assentados/as. Abaixo há uma fotografia que aponta a dificuldade de acesso ao lote para a assentada que leva o filho e a filha pequenos ao ponto até onde o ônibus escolar passa.

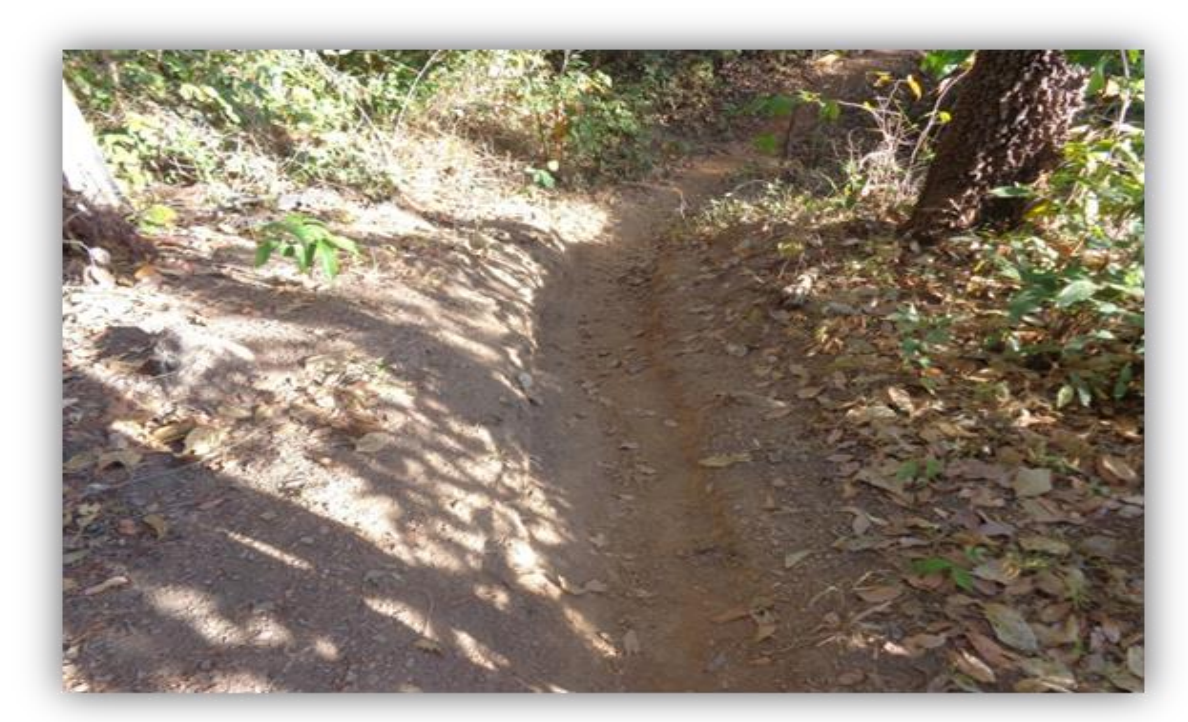

Fotografia 4.2 - Único caminho para um dos lotes do PA

Os atores - prefeitura e INCRA - não cumpriram as funções designadas a eles em relação às estradas do PA propostas no PDA de acordo com a nota de campo e a fotografia 
acima. Em relação à obtenção de água através de poços artesianos, o excerto (77) também apresenta um processo material abstrato - 'será perfurado' -, a meta 'poço artesiano', a circunstância 'na área comunitária'. Há, assim, o apagamento do ator responsável pela execução da obra. Ademais, a circunstância de lugar determina onde o poço deve ser feito 'na área comunitária' - e não especifica a construção de poços nos lotes, considerando que alguns lotes não possuem nascentes disponíveis. Sobre isso, também registrei a nota abaixo.

(75) Alguns moradores solicitaram o recurso do PRONAF para perfuração de poço, pois não há nascente disponível em seus lotes. A carência para o pagamento da primeira parcela do empréstimo são 3 anos, no entanto ao perfurarem até 80 metros não encontraram água.

(Nota 4 PA, 5 de julho de 2014)

Há discrepância entre o que o PDA aponta e o que alguns moradores dizem. Se não conseguirem água, não produzirão e, consequentemente, não terão condições financeiras para pagarem o empréstimo financeiro feito para a construção de poços artesianos. Ainda ocorre outra contradição, pois o excerto (73) determina a profundidade do poço a ser feito através do processo material abstrato 'deverá medir' e especifica a profundidade a ser perfurada para a obtenção de água através da meta '50 metros de profundidade equipado com bomba e uma caixa d'água com capacidade para 10.000 litros e encanações diversas'. Já na nota de campo (75), foi registrado que o assentado perfurou 80 metros, ou seja, uma profundidade 30 metros maior do que o excerto (73) propõe e que um assentado não conseguiu obtenção de água.

Além disso, há de se destacar a alta ocorrência de processos materiais abstratos, no excerto (73), como também em outros no decorrer do Plano de ação. Ocorrem tanto devido à utilização de processos materiais com uma natureza de 'ação abstrata' como também devido à utilização de processos materiais no tempo futuro, o que faz da 'ação' proposta por eles se apresentarem como abstratas, mesmo que sua natureza seja concreta, o contexto de uso a torna abstrata. Há processos materiais, que no contexto de uso do tempo presente, seriam concretos, por apresentarem ações concretas, mas que devido ao uso no tempo futuro, passam a se comportarem como 'abstratos'. As ações propostas no tempo futuro podem vir a ocorrer, incidem na ausência de ações concretas.

A seguir, o Plano de ação propõe dentro dos Programas de Desenvolvimento (subitem 6.4) vários Programas Produtivos (6.4.2) - Bovinocultura de leite, Cana e Capineira, Suinocultura, Avicultura, Abacaxi, Lavora de subsistência, entre outros -, como mostra o fragmento a seguir. 
(76) A discussão do programa produtivo [meta], a exemplo dos demais, foi desenhado/criado [processo material abstrato] pela comunidade [ator]. O grupo temático [ator], com base na análise do diagnóstico e no interesse dos agricultores [circunstâncias] construiu [processo material concreto] sistemas produtivos [meta] e identificou as diversas atividades que pretendem desenvolver visando promover a sua sustentabilidade.

(COOPVAG, 2007, p. 79)

O fragmento (76) apresenta o processo material abstrato na voz passiva 'foi desenhado/criado', o ator 'comunidade' e a meta 'a discussão do programa produtivo'. O ator ligado a um processo do mundo do fazer, ao se referir ao/à assentado/a, está explícito. O mesmo ocorre com o processo material concreto ‘construiu', cujo ator 'grupo temático' está explícito e se refere ao/à assentado/a. No decorrer do texto do Plano de ação, faz-se recorrente configuração de processos materiais com ator explícito quando se refere ao/à assentado/a e ator implícito quando se refere a outros atores.

Nesse plano, os programas produtivos são apresentados no PDA da seguinte forma: a)justificativa, b)descrição da atividade, c)procedimento técnico $e$ d)mercado $e$ comercialização. Os excertos de (77) e (78) tratam de um dos programas produtivos (a suinocultura), já que todos os outros são apresentados da mesma forma. O excerto (77) está no item Procedimento técnico do programa produtivo.

(77) Serão adquiridas [processo material abstrato] através do PRONAF A [circunstância], 03 matrizes da raça Sorocaba [meta] e 01 reprodutor da raça Landrace [meta], aproveitando rusticidade e a boa adaptação desses animais ao sistema de criação SISCAL. O cruzamento dessas raças resultará em animais com rápido crescimento (característica da raça Landrace) e com bom rendimento de carcaça e carne com menos gordura (característica da raça Sorocaba).

Os agricultores poderão aumentar o rendimento, uma vez que os leitões serão precoces. A Assistência Técnica [ator] auxiliará [processo material abstrato] os agricultores familiares [meta] no controle reprodutivo dos animais [circunstância], para que os criadores mantenham uma freqüência na reprodução, de modo que tenham leitão para comercialização maior parte do ano.

(COOPVAG, 2007, p. 86)

O processo material 'serão adquiridas', no excerto 81, é abstrato, pois está no tempo futuro. $\mathrm{O}$ ator está apagado, mas há uma circunstância 'através do PRONAF A', que indica de onde será o financiamento. Há duas metas '03 matrizes da raça Sorocaba' e '01 reprodutor da raça Landrace' que especifica a aquisição. Não há, assim, a especificação de que o PRONAF é um subsídio do governo para a agricultura familiar, ou seja, é um programa do governo 
federal de empréstimo para os agricultores familiares, no caso, assentados/as. Além do mais, nesse excerto, há também um processo material abstrato 'auxiliará', relacionado, porém, ao ator explícito 'A Assistência Técnica', à meta 'os agricultores familiares' e à circunstância 'no controle reprodutivo dos animais'. Faz-se recorrente, no plano de ação, o ator 'assistência técnica' de forma explícita, com processos materiais que apontam ações desse ator para a execução das propostas do PDA. Também as metas especificam os papeis que esse ator deve desempenhar para que as propostas do PDA tenham êxito.

O excerto (78) do item Mercado e comercialização do programa produtivo suinocultura possui também a mesma estrutura dos processos dos anteriores.

(78) Os animais [meta] serão comercializados [processo material abstrato] vivos [circunstância] a um preço de $\mathrm{R} \$ 45,00 /$ arroba (quarenta e cinco reais), pesando em torno de 02 (duas) arrobas. As vendas [meta] se realizarão [processo material abstrato] no próprio PA e na micro-região de Porto Nacional, Ponte Alta do Tocantins, Santa Tereza do Tocantins e Palmas [circunstâncias].

(COOPVAG, 2007, p. 87)

O processo material 'serão comercializados', acima, também é abstrato por estar no tempo futuro e está na voz passiva, com omissão do ator. A meta indica o objeto comercializado e circunstância 'vivos' indica de que modo os animais serão vendidos. Além disso, cada programa produtivo apresentado no PDA possui uma Matriz metodológica, com o resumo das ações propostas. Com isso, nessas matrizes, ocorrem muitos processos materiais, como demonstra a figura a seguir.

\begin{tabular}{|l|c|c|c|c|}
\hline \multicolumn{3}{|l|}{ Objetivo geral: Diversificar a produção do estabelecimento familiar, para garantir a segurança alimentar dos assentados e geração } \\
de renda.
\end{tabular}

*Fonte: Pesquisa de mercado realizada por Coopvag, 2007.

Figura 4.2 - Matriz metodológica da suinocultura do PDA

A matriz apresentada, na Figura 4.2, encontra-se no sistema produtivo Suinocultura (COOPVAG, 2007, p. 87). A utilização dela, como de outras Matrizes, no decorrer do texto 
do PDA Santa Tereza I, se relaciona a um projeto político, a uma corrente ideológica. Os processos constituem uma matriz política no que se refere à Reforma Agrária no Brasil. Espera-se, inclusive, a presença deles em uma matriz política, um plano de governo. Apesar da configuração dos programas produtivos e de suas matrizes metodológicas no texto do PDA, essa configuração não se tornou concreta até então no PA Santa Tereza I de acordo com a observação participante e a nota de campo a seguir.

(79) O pioneiro Suiriri do PA me relatou que os programas produtivos propostos nas reuniões com a COOPVAG não se materializaram. Segundo ele, não há recurso financeiro para a implantação e execução dos programas, não há assistência técnica e muitos lotes não possuem características físicas para o desenvolvimento desses programas.

(Nota 16 PA, 19 de julho de 2014)

De acordo com a nota de campo acima, os programas produtivos sugeridos no PDA e resumidos em suas matrizes não se concretizaram, seja por falta de recursos financeiros seja por falta de assistência técnica. Há, assim, oposição entre o dito da nota de campo e o dito das matrizes uma vez que as matrizes definem recursos financeiros e prazos de execução dos programas produtivos.

Depois de o Plano de ação propor vários programas produtivos, configura a Análise do Sistema Produtivo do PA Santa Tereza I (item 6.4.2.4). Considerando que esse item implica a constituição de uma análise, ao se analisar, caracteriza-se e identifica-se algo, ocorrem vários processos relacionais em sua constituição.

(80) A bovinocultura [identificado] é [processo relacional identificativo] a principal atividade econômica da parcela [identificador], seguida da produção de mamona e da produção de mandioca que terá parte de suas raízes destinadas à produção de mamona e da produção de mandioca que será parte de suas raízes destinadas à produção de farinha.

(COOPVAG, 2007, p. 119-120)

O excerto (80) apresenta o processo relacional identificativo 'é', acompanhado do identificado 'A bovinocultura' e do identificador 'a principal atividade econômica da parcela'. O programa produtivo bovinocultura aparece como identificado por si só, sem se atrelar, no texto explicitamente, a um ser humano, como se a identificação ocorresse por si só. O identificador também se constitui, no texto, por si só. No excerto (81), ocorre configuração similar.

(81) A mamona [portador] apresenta [processo relacional atributivo] uma receita considerável [atributo] no sistema [circunstância], porém cabe 
destacar que a rentabilidade da atividade é muito baixa. Não deixa de ser uma atividade geradora de renda sazonal, que conforme as expectativas tende a melhorar com o desenvolvimento das condições de mercado e comercialização.

(COOPVAG, 2007, p. 125-126)

O excerto (80) apresenta, do mesmo modo, o processo relacional atributivo 'é', acompanhado do portador 'A mamona' e do atributo 'uma receita considerável. O excerto (82) não apresenta, porém, processo relacional e sim processos materiais, como aparece em grande parte do PDA.

(82) Analisando o aspecto econômico todos os sistemas estabelecidos [ator] na discussão da oficina [circunstância], realizada no PA Santa Tereza I [circunstância], oferecem [processo material abstrato] estabilidade e sustentabilidade [meta] aos assentados [beneficiário], gerando [processo material abstrato] uma renda substancial [meta] e capitalizando [processo material abstrato] os estabelecimentos [meta] para o investimento na qualidade de vida da família e no modelo produtivo escolhido [circunstância].

(COOPVAG, 2007, p. 136-137)

O excerto (82) apresenta os processos materiais 'oferecem', 'gerando' e 'capitalizando', todos abstratos, isto é, não estão no mundo das concretizações reais. Além disso, também ocorre o apagamento de seres humanos como agentes das ações. Desse modo, os excertos (81) a (82) configuram parte da análise dos processos produtivos do PDA e neles não é recorrente a materialização de atores que desenvolvem ações no mundo do fazer e acontecer. Há análise dos programas por si só, sem comprometimento de participantes humanos para a realização de ações de desenvolvimento. Nessa perspectiva, a nota de campo abaixo, registrada durante uma observação participante no INCRA, parece evidenciar, igualmente, o descomprometimento no que concernem atribuições de funções, papeis para que todas as ações de desenvolvimento para o PA, através do PDA, sejam implantadas.

(83)Em uma observação participante no INCRA, procurei saber sobre a infraestrutura dos lotes em relação a estradas, ao tipo de terreno existente e às condições técnicas para o desenvolvimento dos programas produtivos no PA Santa Tereza I. Um funcionário me relatou que o INCRA já fez a parte que cabia a ele no assentamento Santa Tereza I. Daqui para frente, os/as assentados/as devem andar com as próprias pernas, pois vários itens do PDA já foram cumpridos. Neste momento, eu indaguei quais e ele respondeu que há estradas e luz elétrica no PA. E eu retruquei que, no PDA, a implementação destas ações cabe à prefeitura de Ponte Alta e que eu gostaria de saber quais eram as ações desenvolvidas pelo INCRA. Neste ponto, não obtive resposta. 
Segundo o excerto (83), o papel do INCRA se encerra ao intermediar obras de infraestrutura - estradas e energia elétrica - junto ao município de Ponte Alta para o PA Santa Tereza I. Parece que todas as outras propostas do PDA são de responsabilidade das pessoas que estão com o direito de uso dos lotes desse PA.

Já o Programa Social (item 6.4.3) proposto baseia-se na educação, saúde, saneamento, esporte/cultura e lazer e habitação, de acordo com o excerto (84).

(84) Para tanto, o resultado das discussões de cunho social [meta] foi sistematizado [processo material concreto] em 04 subprogramas distintos: Educação; Saúde e Saneamento; Esporte/Cultura e Lazer; e Habitação. As prioridades [meta] foram definidas [processo material abstrato] pela comunidade [ator] através de discussões em grupos temáticos e depois socializadas [processo material abstrato] e rediscutidas em plenária, onde estabeleceram um consenso sobre as ações necessárias e indispensáveis ao processo de desenvolvimento da comunidade.

(COOPVAG, 2007, p. 137)

No excerto (84), ocorrem processos materiais concretos e abstratos. No entanto, quando esses processos apresentam como ator as pessoas acampadas, esse está explícito: 'pela comunidade'. Quando esses processos apresentam como ator a COOPVAG, esse é apagado, aparecendo somente a meta: 'o resultado das discussões de cunho social'. Já os excertos (85) e (86) tratam do Subprograma de Educação (item 6.4.3.5).

(85) A maior parte das demandas levantadas na Educação, desde a infraestrutura até os programas a serem implementados são responsabilidades da Secretaria Municipal de Educação que, juntamente com a Assessoria Técnica e a comunidade [ator] irão acessar [processo material abstrato] Programas de Governo para a realização de todas as ações, tais como: Programa Nacional de Apoio Escolar - PNATE, Programa Nacional Biblioteca Escola - PNBE, Programa Nacional de Livros Didáticos - PNLD, Programa Nacional de Informática na Educação - Proinfo, Secretaria Executiva de Esporte e Lazer - SEEL, entre outros [meta]. Para tanto serão elaborados [processo material abstrato] projetos [meta] que servirão como instrumentos de negociação com os diversos parceiros que serão articulados pela Assessoria Técnica, comunidade e a própria Secretaria de Educação.

(COOPVAG, 2007, p. 144)

(86) No ato da restituição dos dados e no levantamento de demandas pela comunidade, o prefeito municipal [dizente] afirmou [processo verbal] que está buscando a implantação de uma Escola de Educação Rural para o município [verbiagem] e a proposta do mesmo é que esta seja implantada na divisa entre o PA Santa Tereza I e PA Santo Onofre com $\mathrm{o}$ intuito de atender toda a região.

(COOPVAG, 2007, p. 144-145) 
O fragmento (85) apresenta dois processos materiais 'irão acessar' e 'serão elaborados' que são abstratos por se referirem a ações propostas para ocorrerem no tempo futuro. Também os atores desses processos estão explícitos - 'Secretaria Municipal de Educação que, juntamente com a Assessoria Técnica e a comunidade' -, eximindo o INCRA da responsabilidade dessa ação, mesmo a assessoria técnica sendo a representante dele, uma vez que não há mais assistência técnica contratada para o PA e, mesmo assim, como visto na nota de campo anterior, o INCRA sustenta que já fez o que cabia a ele no PA. Enquanto as metas - 'Programas de Governo para a realização de todas as ações, tais como: Programa Nacional de Apoio Escolar - PNATE, Programa Nacional Biblioteca Escola - PNBE, Programa Nacional de Livros Didáticos - PNLD, Programa Nacional de Informática na Educação - Proinfo, Secretaria Executiva de Esporte e Lazer - SEEL, entre outros' especificam as ações relacionadas à educação a serem executadas pelos atores. $\mathrm{O}$ fragmento (86) também sustenta a 'desobrigação' do INCRA em relação à implantação da educação no PA ao introduzir o dito do prefeito de Ponte Alta sobre a implantação de escola no PA. O que eu constatei, porém, durante a observação participante, é uma situação oposta aos ditos da COOPVAG e do prefeito de Ponte Alta. As imagens abaixo, registradas durante o período de observação participante, relatam tal realidade.

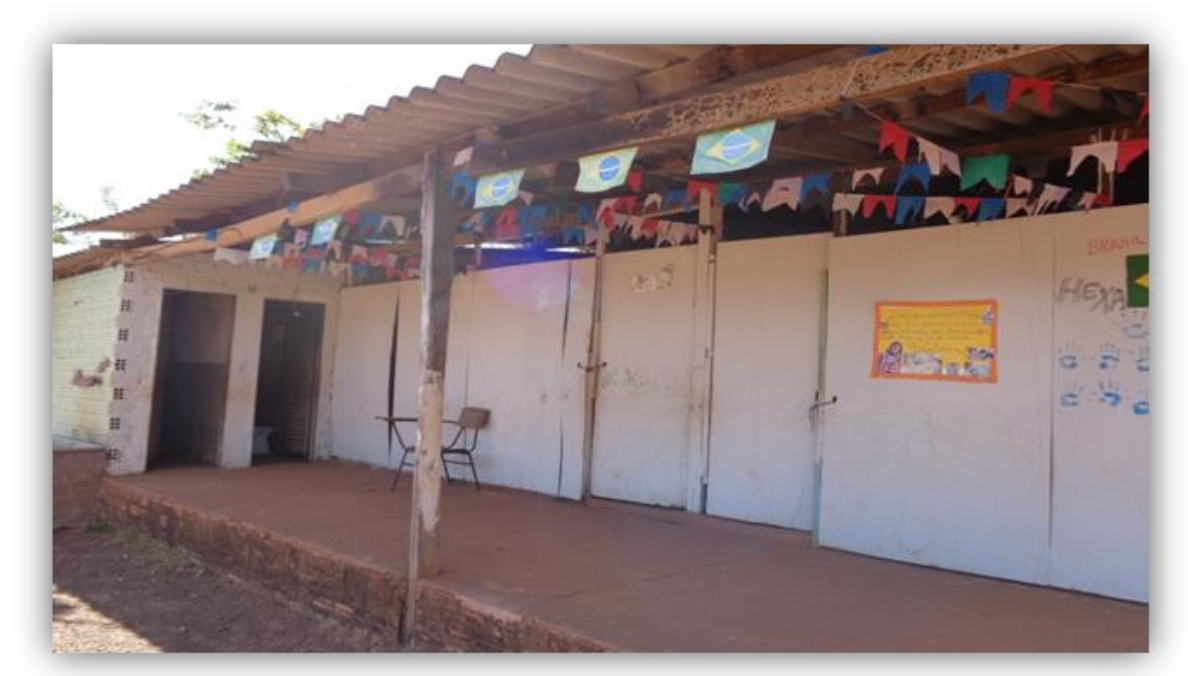

Fotografia 4.3 - Frente do prédio da escola do PA Santa Tereza I 


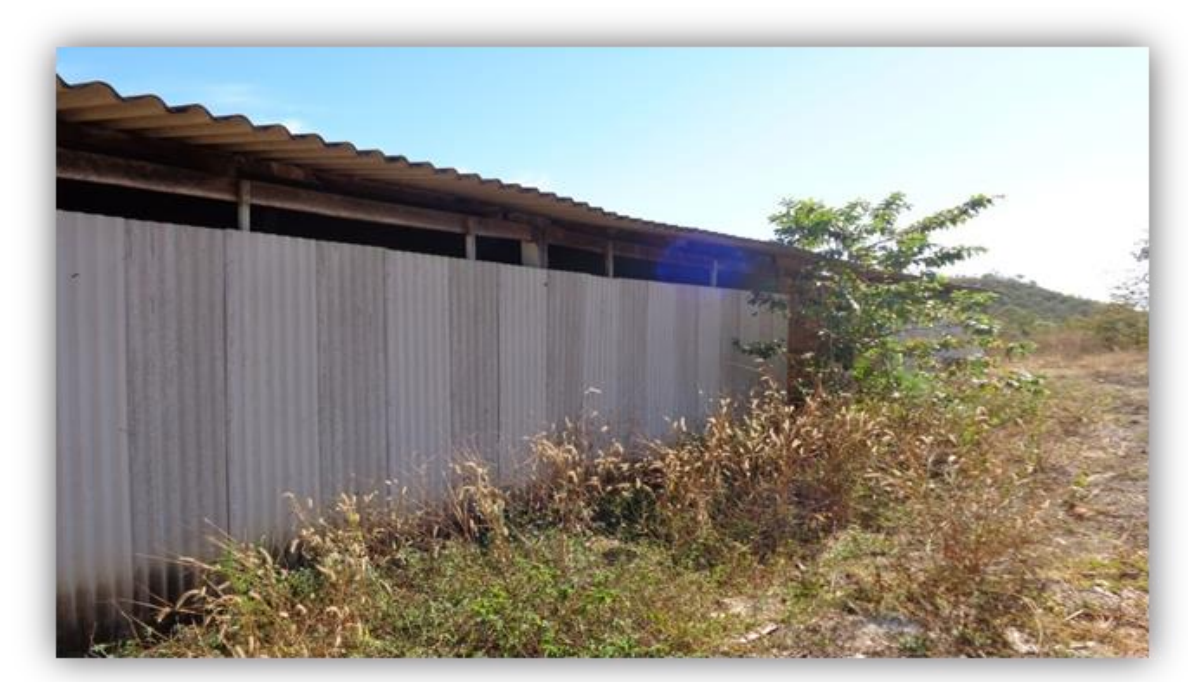

Fotografia 4.4 - Fundos do prédio da escola do PA Santa Tereza I

As fotografias 4.3 e 4.4 configuram a situação calamitosa do prédio da escola do PA até os dias de hoje e, por isso, segue a nota de campo abaixo, que registra essa instalação:

(87) No caminho para os lotes dos/as pioneiros/as, deparei-me com uma instalação com algumas paredes de madeira, outras com telhas de amianto; o telhado é de telha amianto e não há janelas. Nos fundos, há muito mato e no banheiro não há instalação de água, sendo assim, não se pode usá-lo. Nas paredes havia desenhos que pareciam de crianças nas paredes de madeira e perguntei ao assentado que me acompanhava do que se tratava. Ele imediatamente me disse que era o prédio escola do PA, feito por assentados/as quando os lotes foram distribuídos e que assim funciona até os dias de hoje.

(Nota 9 PA, 18 de julho de 2014)

De acordo com a nota de campo, apesar de o PDA propor que a prefeitura de Ponte Alta seja a responsável pela implantação de uma escola rural no PA, escola alguma foi construída até os dias de hoje. E se há, pelo menos, uma instalação precária para o funcionamento de séries iniciais da escola, é porque assentados/as construíram. Ademais, o PDA também propõe que a prefeitura, a assistência técnica e os/as assentados/as a busquem programas de educação junto ao governo federal. Sobre isso, já foi dito que o agente assistência técnica não é disponibilizado ao PA e que muito menos programas educacionais foram pleiteados se nem prédio adequado para a escola há. Enquanto que os excertos (88) e (89) tratam do Subprograma de Saúde e Saneamento (item 6.4.3.6).

(88) Como se observa, a comunidade [ator] não propôs [processo material abstrato] nenhuma ação [meta] esdrúxula e inalcançável [atributo]. Todas as ações [portador] são [processo relacional atributivo] coerentes [atributo] com a necessidade básica, bem como com os direitos de todo 
cidadão. Para realização desse programa, alguns acordos foram estabelecidos. Segundo a prefeitura, foi adquirida [processo material concreto] recentemente [circunstância] uma unidade móvel [meta] para prestar atendimento do PSF nas comunidades rurais.

(COOPVAG, 2007, p. 152)

(89) A prefeitura [ator] também já disponibilizou [processo material concreto] 01 agente de saúde [meta] para atender o PA Santa Tereza I. A idéia é regularizar e melhorar o atendimento do agente às famílias assentadas.

(COOPVAG, 2007, p. 152)

Os fragmentos (88) e (89) também apresentam processos materiais que explicitam os atores 'comunidade' e 'prefeitura'; e 'prefeitura' respectivamente. No (88), a meta - 'ação' do ator comunidade - se materializa com uma avaliação sobre o ator: 'esdrúxula e inalcançável'. A COOPVAG tenta avaliar positivamente a ação da comunidade em relação à saúde, mas utiliza adjetivos pejorativos para isso. Parece que o esperado pela COOPVAG, o comum, é que a comunidade tivesse ações descritas pelos adjetivos e não o contrário. Da mesma forma, são atribuídas ao ator 'prefeitura' as metas 'uma unidade móvel' e '01 agente de saúde'. Sobre isso, segue uma nota de campo.

(90) Quando cheguei à casa de um pioneiro para a entrevista, deparei-me um pioneiro ensanguentado e sem conseguir colocar um dos pés no chão, pois tinha acabado de sofrer um acidente de bicicleta. Indaguei sobre o socorro e sua esposa respondeu que estava aguardando a ajuda de um assentado, pois era um dos poucos que tinha carro no PA. Ela acrescentou dizendo que a prefeitura de Ponte Alta não presta assistência nem com agente de saúde e nem com ambulância ao PA.

(Nota PA19, 19 de julho de 2014)

Como registrado na nota acima destacada, no PA Santa Tereza I não há agente de saúde e nem unidade móvel que preste assistência a essa comunidade. Ocorre mais uma contradição entre as proposições do PDA e a realidade do PA no que se refere à saúde. O item que trata do Subprograma de Habitação (item 6.4.3.7) ocorre, porém, contradição entre a proposição do PDA e a realidade em parte, como aponta o excerto (91).

(91) O recurso do crédito habitação a ser liberado pelo INCRA [identificado] será [processo relacional identificativo] no valor de $\mathrm{R} \$ 7.000,00$ (sete mil reais) [identificador], por família. O restante será complementado através de um convênio estabelecido com a Caixa Econômica Federal $\mathrm{CEF}$, no valor de $\mathrm{R} \$ 6.000,00$ (seis mil reais), totalizando um crédito de $\mathrm{R} \$ 13.000,00$ (treze mil reais) para a construção de cada casa.

(COOPVAG, 2007, p. 153) 
O excerto (91) possui um processo relacional que identifica o recurso financeiro federal para a construção de casas nos lotes do PA e esse recurso foi liberado aos/às assentados/as. A imagem a seguir configura a utilização desse recurso.

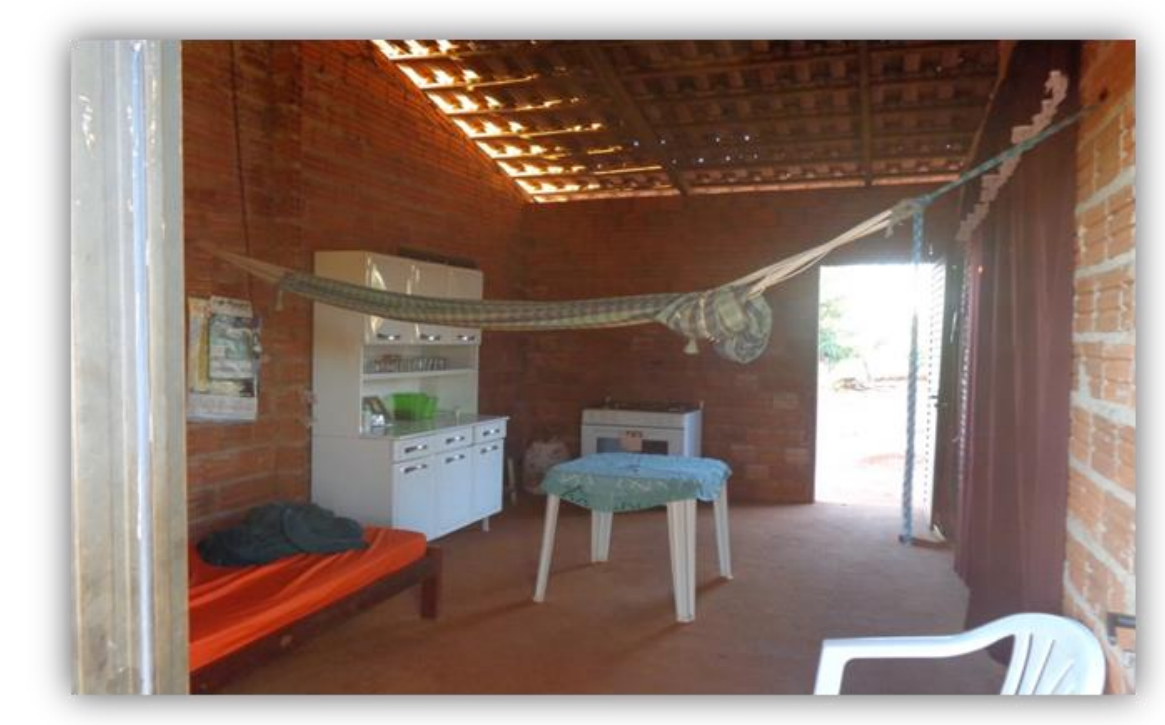

\section{Fotografia 4.5 - Sala de uma casa construída com recurso público}

A partir do recurso financeiro disponibilizado, o INCRA contratou uma empresa responsável pela construção de todas as casas do PA. Como prevê o excerto (95), as casas foram construídas e de forma similar: sala, cozinha, quarto e banheiro. A utilização desse recurso, no entanto, não foi adequada de acordo com uma nota de campo.

(92) Para realizar as entrevistas com as pessoas pioneiras do PA, isto é, que já estavam acampadas onde seria o PA e participaram das reuniões com a COOPVAG para a elaboração do PDA, conheci muitas casas do assentamento, construídas com recurso financeiro federal - descrito no excerto (95). Ao observá-las, constatei que nenhuma teve acabamento nas paredes; todas possuem somente o contrapiso (cimento "grosso" no chão); algumas possuem banheiro, mas não há água para que ele seja usado; outras estão rachando. Sobre isso, alguns/mas assentados/as me relataram que já reclamaram com o INCRA no que concernem os problemas com as casas, todavia não obtiveram resposta sobre o término das obras e os reparos.

(Nota 9 PA, 18 de julho de 2014)

Segundo é observado na imagem e na nota de campo, o recurso disponibilizado pelo governo federal para a construção das casas do PA foi, no mínimo, mal administrado para que as casas em tão pouco tempo de construção apresentem problemas ou mesmo nem terem sido 
terminadas adequadamente. Ainda há de se destacar a quantidade de cômodos das casas todas iguais, sem levar em consideração o número de pessoas que ali necessitam viver. Além desses, há no plano de ação o Programa de Desenvolvimento Organizacional e de Gestão do Plano (6.4.5).

(93) Deverá ser criado [processo material abstrato] um grupo gestor [meta] para discutir, planejar e implementar o Programa Social, sendo que este grupo se dividirá em comissões para trabalhar os subprogramas de educação, esporte, cultura e lazer, a qual deverá ter em sua composição os jovens como garantia de promover a participação destes, de uma forma mais efetiva no processo de desenvolvimento do PA. Serão criados [processo material abstrato] grupos gestores [meta] também para trabalhar o subprograma da saúde e os programas de Organização Territorial e Programa de Meio Ambiente, além de grupos gestores para os subprogramas de agropecuária e agroindústria do Programa Produtivo.

(COOPVAG, 2007, p. 192)

(94) No caso do Programa Produtivo, os grupos gestores deverão se dividir [processo material abstrato] ainda em comissões por atividades produtivas [meta] que acompanharão a implementação da atividade, desde sua implantação. A idéia é que esses grupos, juntamente com a Assessoria Técnica, comecem a administrar [processo material abstrato] a atividade [meta] desde o início de sua implantação [circunstância] e sejam responsáveis por identificar e solucionar problemas eventuais.

(COOPVAG, 2007, p. 192)

No excerto (93), ocorrem processos materiais na voz passiva, omitindo o ator com a função de executar a ação configurada nos processos verbais - 'deverá ser criado' e 'serão criados'. As metas de ambos estão explícitas e são as mesmas - 'grupos gestores'. Isto é, há o apagamento do agente responsável pela criação do grupo. Também, por estarem no tempo futuro, os processos são abstratos em termos de concretização da ação de criar o grupo gestor. Similarmente, o excerto (94) possui processos materiais abstratos, mas na voz ativa, com atores - 'grupos gestores' e 'esses grupos' e metas explícitos já que especificam tanto a organização deles - 'comissões por atividades produtivas' - quanto a sua função - 'atividade'. Enquanto, no (93), há o apagamento do ator responsável pela criação dos grupos gestores, sendo 'grupos gestores' a meta; no (94), 'grupos gestores' deixa de ser meta e passa a ser ator e está explícito.

Além de todos os itens interpretados anteriormente, ocorre ainda o item Avaliação $e$ Monitoramento do Plano (item 6.5) no Plano de ação. 
(95) O Plano ora elaborado [portador] não é uma camisa de força, estático. Ao contrário, é [processo relacional atributivo] flexível [atributo] na medida em que, no processo de monitoramento [circunstância], se indique [processo material abstrato] a necessidade de alterá-lo [meta], no sentido de melhorar o processo de desenvolvimento da comunidade. Para que isso ocorra de forma organizada, prevê-se que representantes de cada grupo gestor, juntamente com a Assessoria Técnica [ator] se reúnam semestralmente [circunstância] para avaliar a execução do Plano. Essa avaliação parcial deverá estar subsidiada da análise do monitoramento de cada Programa e subprograma que será de responsabilidade de cada grupo gestor. Os resultados serão avaliados a partir da análise dos indicadores circunstância que estarão subsidiados por vários instrumentos de controle como, listas de presença, registros de atividades, etc.

(COOPVAG, 2007, p. 198)

No fragmento (95), primeiramente ocorre um processo do mundo das relações abstratas 'é', processo relacional, que confere um atributo ao portador 'Plano': 'flexível'. Esse atributo tenta justificar alterações do PDA propostas a partir do monitoramento de atividades propostas no PDA e que venham ser desenvolvidas. Para tanto, explicita-se a meta 'necessidade de alterá-lo' do processo material abstrato ' se indique' e omite o ator responsável pela execução da ação proposta no processo verbal, no caso, o monitoramento da execução de propostas do PDA. Depois, o processo material 'se reúnam' especifica o ator da ação de monitoramento do PDA: 'representantes de cada grupo gestor, juntamente com a Assessoria Técnica'. Ao se dizer que cada grupo gestor se reunirá com a assessoria técnica, implica que, em princípio, o monitoramento da implementação e execução do PDA no PA cabe ao INCRA, uma vez que a assistência técnica representa o INCRA no assentamento. Apesar do funcionário do INCRA considerar que os papeis atribuídos a ele no PA Santa Tereza I terem sido executados, o próprio texto do PDA contradiz essa consideração. O texto do PDA propõe papeis para a assistência técnica no que se refere à implementação e execução do PDA, mesmo que a instituição INCRA - agente - esteja omitida do texto.

Assim, a investigação linguístico-discursiva das partes do Plano de ação do PDA sugere que a escolha pelo uso de processos materiais abstratos aponta para uma preferência por mudanças em que ocorrem fenômenos abstratos, que podem ou não se concretizar. Ademais, a escolha pelo aparecimento da meta e pelo apagamento do ator das ações 'a serem feitas' sugere uma preferência pela meta em detrimento do ator. Isto é, parece haver uma valorização das 'ações' propostas pelo PDA Santa Tereza I e uma desvalorização do ator dos processos materiais que se referem a ações do mundo físico do fazer e acontecer. 


\subsection{A representação de atores sociais no PDA Santa Tereza I}

Esta seção é dedicada à análise da representação dos atores sociais mais recorrentes no PDA Santa Tereza I. Busca-se discutir as seguintes questões: Quais são os atores de proeminência no processo de elaboração do PDA Santa Tereza I? Quais são os modos pelos quais os atores sociais são representados no discurso do PDA? O texto do PDA apresenta que escolhas em relação aos/às assentados/as e aos demais atores do PDA em termos de sua elaboração, implementação e execução? Ademais, abordarei uma questão mais específica de como os atores sociais de proeminência estão representados no PDA Santa Tereza I.

Para tanto, na subseção 4.4.1, para analisar o significado representacional do PDA Santa Tereza I, faz-se importante também interpretar o tipo de apresentação dos responsáveis pelo PDA e sua consequente representação em termos de (inter)discursividades materializadas no decorrer do texto. A interdiscursividade é uma das categorias de análise do significado representacional (FAIRCLOUGH, 2003). Ademais, com o intuito de analisar a posição dos atores sociais, em termos de sua inclusão e exclusão no PDA Santa Tereza I, na subseção 4.4.2, são utilizadas duas ferramentas do WordSmitht Tools 6.0 (SCOOT, 2012): a lista de palavras (wordlist) e o concordanciador (concordancer) para tratar da representação dos atores sociais, conforme a perspectiva da 'interdiscursividade', proposta por Fairclough (2003), e a rede de sistemas, sugerida por van Leeuwen (1997).

\subsubsection{A interdiscursividade no PDA}

O significado representacional traz os aspectos do mundo através de discursos (FAIRCLOUGH, 2003) materializados tanto na estrutura genérica quanto no conteúdo do PDA analisado ao se considerar o significado acional desse gênero. Os discursos representam o mundo e projetam possibilidades de realidade sobre ele. Segundo Fairclough (2003), a interdiscursividade é constituída pela articulação de diferentes vozes com diferentes discursos, uma heterogeneidade textual. Sendo assim, destaco, nessa subseção, a interdiscursividade em partes do PDA Santa Tereza I que mais materializam tanto explicitamente quanto implicitamente vários discursos: Capa, Agradecimentos, Identificação dos responsáveis e Plano de ação.

O PDA Santa Tereza I articula, principalmente, uma interdiscursividade 'técnicocientífica' no formato da estruturação do conteúdo do texto do PDA sob a responsabilidade de 
técnicos/as da COOPVAG, assim como a interdiscursividade ora o texto tentando parecer 'fazer cumprir' a legislação sobre reforma agrária sob responsabilidade do governo federal via INCRA e ora o texto tentando parecer configurar ações propostas pelos/as assentados/as para o assentamento. Vale ressaltar que a interdiscursividade relacionada ao/à assentado/a, se aparece, é configurada sob o olhar dos/as técnicos/as da COOPVAG, já que a COOPVAG ao menos materializou linguisticamente o texto do PDA, sinalizando a materialização de vários discursos na imbricação "informar-descrever/prescrever".

Esses discursos já se materializam na primeira página do PDA - Capa -, há a presença do pré-gênero descrição, apresentando os nomes e funções de pessoas que se responsabilizam pela política desenvolvida nos assentamentos, como a elaboração do PDA. Os primeiros nomes que aparecem são do "presidente e do coordenador do núcleo operacional do Tocantins da COOPVAG". A seguir, são apresentados os nomes da "equipe técnica - engenheiros agrônomos, engenheiros ambientais, socióloga, assistente social, técnicos em agropecuária, estagiário". Materializa-se, portanto, a presença de discursos que aqui nomeio de técnico, científico e oficial, uma vez que a COOPVAG foi contratada pelo INCRA/Governo Federal para desenvolver um trabalho - elaboração de PDA.

A configuração linguística do PDA é institucionalizada, ou seja, técnicos da empresa contratada elaboram o PDA para o INCRA e para assentados/as, sendo também um meio de monitoramento de ações de assentados/as, pois os técnicos representam o poder público. Haja vista o "conhecimento" sobre o uso da terra ser materializado no PDA por "técnicos" e não se materializa um único nome de assentado/a no corpo do texto do PDA Santa Tereza I.

Além do mais, na mesma página, há a apresentação da equipe de elaboradores do PDA, designados pelo INCRA, ou seja, pelo governo federal, sendo usado também o prégênero descrição. Os nomes que aparecem como elaboradores são nomes de técnicos da COOPVAG, que também são da equipe técnica. Também não há nome de assentado/a nessa equipe. Notadamente, na próxima página do PDA - Agradecimentos -, os/as assentados/as são citados:

(96) Nossos agradecimentos em especial aos assentados, que participaram das oficinas, das reuniões, das entrevistas, do grupo que fez o levantamento do meio físico, e que são os reais autores desse plano.

(COOPVAG, 2007, s/p)

No título Agradecimentos, os/as assentados/as são apresentados/as como "reais autores" do PDA. Por um lado, institucionaliza-o/as como responsáveis pelas escolhas das 
ações prescritas no texto, já que se faz um texto institucional. Além de o texto designá-los/as como 'autores', também faz uso do adjetivo 'reais', avaliando essa autoria de modo a reforçála. Por outro lado, não aparece no decorrer de todo o texto do PDA sequer o nome da associação de moradores do PA Santa Tereza I ou de qualquer assentados/a, como aparece de funcionários do INCRA assim como da COOPVAG.

Depois, no título Identificação dos responsáveis (COOPVAG, 2007, p. 2), há, todavia, o apontamento das instituições responsáveis pela elaboração do PDA Santa Tereza I. O primeiro subtítulo dessa parte é Identificação do empreendedor. Vale destacar o uso da palavra 'empreendedor' em um texto que é dito uma das ferramentas utilizadas pelo INCRA para o desenvolvimento do PA. No dicionário, empreendedor apresenta os seguintes sentidos: “1 Tentar realizar algo difícil. 2 Pôr em execução" (EDIÇÕES POLIGLOTAS, 2002, p. 183). Já no contexto de uso da iniciativa privada, a palavra 'empreendedor' refere-se a uma pessoa, cujas características de personalidade e talento preenchem um padrão determinado, que o leva a agir de tal forma que chega ao sucesso, alcançando seus objetivos (PEREIRA, 1995). Um empreendedor busca a realização e é autorientado para atingir metas próprias. Assim, a palavra 'empreendedor' pode indiciar tanto quem financiou a elaboração do PDA Santa Tereza I quanto um discurso típico da iniciativa privada, contexto de uso mais comum dessa palavra.

O PDA, por sua vez, faz-se um texto oficial/institucional do Governo Federal, sob responsabilidade do INCRA, perpassado pelo discurso oficial. Isto é, em contexto institucional, textos dessa natureza não costumam apresentar essa palavra, que se faz comum em contextos da iniciativa privada, onde se preconiza acima de tudo o lucro, empreender para gerar lucro. Há um discurso, típico da iniciativa privada, que aponta para questões de mercado, preconização de obtenção de lucro. O uso dessa palavra parece evocar um discurso que se contrapõe ao discurso do governo brasileiro, em tempos de elaboração dos PDAs, sobre reforma agrária.

Além de aparecer a palavra 'empreendedor' no nome do subitem, no conteúdo do texto há designação do ator empreendedor no PDA: "Razão social: Instituto Nacional de Colonização e Reforma Agrária - INCRA”(COOPVAG, 2007, p. 2). Neste ponto, há atribuição da instituição que financiou a elaboração do PDA, uma vez que se utiliza a expressão 'razão social', apontando para questões financeiras, no caso, quem contratou a COOPVAG para realizar a elaboração de tal PDA foi o INCRA, representante do governo federal. Também aparece o nome de quem responde legalmente pela instituição: "Representante legal: Edvaldo Soares de Oliveira" (COOPVAG, 2007, p. 2). Nomeia-se o 
representante legal do INCRA. Assim, o INCRA contratou os serviços da COOPVAG para elaborar o PDA. Logo, essa cooperativa deveria elaborar o PDA de acordo com os critérios e normas determinados pelo INCRA, cabendo a ela a elaboração de um texto de acordo com a legislação brasileira sobre reforma agrária, ou seja, materializa o discurso oficial. À medida que o INCRA aprova o texto do PDA elaborado pela COOPVAG, o representante do governo federal está de acordo com os discursos e representações materializados nele, como o uso da palavra 'empreendedor' para referir-se a si mesmo.

O texto do PDA é perpassado pelo discurso oficial, todavia o uso de 'empreendedor' leva a um apontamento sobre sua representação, considerando seus contextos de uso texto e, consequentemente, a que discurso(s) se filia no texto. De acordo com as políticas públicas concernentes à Reforma Agrária no Brasil, onde está inserida a elaboração dos PDA's, há um discurso que preconiza a agricultura familiar. A agricultura de subsistência das famílias assentadas é que parece ter relevo. Ademais, não se pode deixar de salientar que em nossa sociedade a palavra 'empreendedor' é utilizada com frequência no âmbito do mercado, da competição.

Para Fairclough (2001, p. 115), "os sentidos das palavras entram em disputa dentro de lutas mais amplas, são formas de hegemonia". De certa forma, parece haver um discurso mercadológico, voltado, pelo menos, para um papel do INCRA ao elaborar o PDA: a produtividade do assentamento, prescrição sobre o que deve ser produzido, como deve ser produzido e como o/a assentado/a deve agir em grupo para que possa continuar utilizando a terra, já que não é proprietário/a de terra alguma do assentamento.

Além do mais, Rajagopalan (2003, p. 82) sustenta que "o processo de nomeação é um ato eminentemente político". A exposição do gênero PDA no meio público começa no ato de sua nomeação. Fala-se no tipo de texto e discurso no ato mesmo de nomear. O nome "Plano de Desenvolvimento do Assentamento" (PDA) remete realmente a um planejamento dos/as assentados/as ou do governo para os/as assentados/as? Que tipo de desenvolvimento agrário se deseja para o Brasil?

No que concerne à interdiscursividade, a partir do apresentado acima, a estrutura genérica também promove estabilidade em termos de discursos no gênero, um alto grau de compartilhamento, fazendo ecoar o discurso que aqui chamamos de discurso oficial (do governo) juntamente com um discurso técnico e um discurso mercadológico. Os pré-gêneros “injunção" e "argumentação" configuram o discurso oficial. A partir disso, o PDA parece materializar somente um discurso informativo/descritivo e instrucional acerca de informações 
sobre o PA, características físicas e humanas do assentamento e suas potencialidades produtivas.

Outro subitem é a Identificação da entidade responsável pela elaboração do PDA: "Razão social: Cooperativa de Profissionais Liberais Vale Araguaia - COOPVAG" (COOPVAG, 2007, p. 2). Também se nomeia quem responde legalmente pela COOPVAG: "Representante legal: Helvécio Mesquita Melo" (COOPVAG, 2007, p. 2). Nessa identificação, configura tanto um discurso capitalista por ser contratar uma cooperativa para executar o trabalho que seria da instituição federal, no caso, o INCRA; quanto um discurso tecnicista pela COOPVAG por essa ser composta por técnicos.

Da mesma forma, o conteúdo do título Plano de ação para o desenvolvimento sustentável é a parte do PDA onde se materializa as 'ações' para o desenvolvimento do PA e, por isso, deve ser discutida em termos da interdiscursividade. Seu subtítulo Apresentação configura o resultado desse plano de ação:

(97) O Plano de Ação do PA Santa Tereza I foi construído a partir do olhar coletivo, onde o resultado desse trabalho é fruto do planejamento da comunidade, que se reuniu, discutiu e decidiu o que fazer para sair da situação em que se encontram e chegar onde querem. Por essa razão, os Programas de Desenvolvimento do Assentamento apresentados nessa parte são expressão para a realizacão das necessidades e sonhos da comunidade, considerando o ambiente e o contexto regional nos quais estão inseridos.

(COOPVAG, 2007, p. 67)

Considera-se que o Plano de ação é o resultado de um planejamento da comunidade assentada. O texto expõe que o plano de ação para o PA Santa Tereza I foi produzido a partir de "necessidades e sonhos da comunidade" e isso se faz motivo para sua efetiva execução. O discurso tecnicista tenta se eximir das escolhas contidas nesse plano de ação, atribuindo-as aos/às assentados/as e o discurso oficial, no mínimo, é conivente com o discurso tecnicista à medida que o aprovou.

Também as ações a serem desenvolvidas, prescrições do PDA, de acordo com o excerto - "o resultado desse trabalho é fruto do planejamento da comunidade, que se reuniu, discutiu e decidiu o que fazer para sair da situação em que se encontram e chegar onde querem" -, foram construídas de forma participativa. Mesmo havendo um discurso indicador de que o plano é evocado a partir de "desejos" dos/as assentados/as, há um discurso que "instrui", "prescreve" ações a serem executadas por esses/as mesmos/as assentados/as. Ocorre o discurso oficial. 
Nos Objetivos, também há predomínio do uso do pré-gênero injunção, ou seja, da prescrição de ações para o/a assentado/a:

(98) Assegurar as condições necessárias para viabilização do processo de desenvolvimento sustentável das famílias (...), Dar suporte ao processo de desenvolvimento (...), Promover o desenvolvimento do capital humano, Promover a integração e organização das famílias (...), Priorizar a segurança alimenta $\mathrm{r}$ e o uso sustentável dos recursos naturais.

(COOPVAG, 2007, p.71)

O excerto (98) materializa um discurso de prescrição de ações que garantam o desenvolvimento do PA. Se o PDA fosse realmente elaborado pelo/a assentado/a, não seria necessário dizer nele que é preciso "alguém" dizer no objetivo geral que é necessário "assegurar as condições necessárias para viabilização do processo de desenvolvimento sustentável das famílias". Além disso, os verbos aparecem em sua maioria como formas nominalizadas de infinitivo e de gerúndio (assegurar, dar, promover, respeitando, resgatando), parecendo que a "ação verbal" é uma informação. Novamente, também há avaliação de ações do PDA. Repete-se o uso das palavras: "famílias e comunidade", referindo-se às ações desempenhadas pelas famílias do assentamento para fazerem cumprir o PDA.

Já no item Programas, o texto aparece em tabelas, mas continuam ocorrendo as nominalizações:

(99) Implantação e melhoramento genético de rebanho bovino voltado para produção de leite, visando melhoria da qualidade de vida dos agricultores familiares.

(COOPVAG, 2007, p. 85)

O pré-gênero "injunção", mesmo sob as formas de formas verbais nominalizadas, tende instruir, conduzir, o/a assentado/a a uma determinada ação, de acordo com o que "opinou" e de acordo com o que os técnicos acham adequado para o assentamento. Quando se usa o verbo no infinitivo, há uma representação de preocupação com a ação do/a assentado/a no assentamento em relação à produtividade do mesmo - cumpra-se a atividade proposta ou não haverá mais direito ao uso da terra.

Da mesma forma, o pré-gênero "descrição" apresenta as características físicas e humanas do assentamento, construídas somente como informativas. Faz-se uma representação por meio do discurso oficial, à medida que a elaboração e execução do PDA são exigências para que o/a assentado/a permaneça no assentamento. Ao "ajudar" elaborar e ser informado 
sobre as características, as potencialidades do assentamento, o/a assentado/a deve executar o que é prescrito no PDA.

Constata-se que o PDA é materializado linguisticamente por vários discursos e, nessa articulação, tende a ofuscar o discurso "prescritivo" do governo em detrimento do discurso do/a assentado/a, já que o PDA é construído, a priori, a partir do "desejo coletivo" de assentados/as.

Além disso, há um discurso voltado para a preservação do meio ambiente (sustentabilidade) e um discurso mercadológico (produção). Há uma heterogeneidade em termos de articulação de diferentes discursos e essa heterogeneidade parece materializar a argumentação da necessidade de execução do que é prescrito no PDA.

$\mathrm{Na}$ seção seguinte, discutiremos como se constitui a representação dos atores sociais no PDA do PA Santa Tereza I.

\subsubsection{Atores sociais $e(m)$ ações}

Nesta subseção, os atores sociais de proeminência no PDA Santa Tereza I serão apresentados e analisados em termos da representatividade. Para tanto, utilizarei as categorias de análise propostas por van Leeuwen (2008) no que concernem as "escolhas representacionais" relacionadas a "realizações linguísticas particulares". Van Leeuwen, como refletido no Capítulo 2, apresenta um sistema a partir do qual é possível analisar a representação dos atores sociais no discurso. Sendo assim, a representação dos atores sociais é utilizada nesta pesquisa como uma das formas de análise da atuação das pessoas envolvidas na elaboração do PDA do PA Santa Tereza I. De acordo com a rede de sistemas apresentada por Van Leeuwen (1997; 2008), procura-se verificar quais são os principais modos pelos quais os atores sociais são representados nesses discursos.

Com isso, a tabela, a seguir, apresenta os atores sociais mais recorrentes no texto do PDA Santa Tereza I. A construção dessa tabela foi possível devido ao uso do programa computacional WordSmith Tools 6.0 (SCOTT, 2012) e duas de suas ferramentas. Primeiramente, aqui, foi utilizada a lista de palavras (wordlist), que admite a criação de uma lista de palavras ordenada por frequência de ocorrências. Depois, foi utilizado o concordanciador (concordancer), o que permitiu o estudo do contexto de ocorrências das palavras. 
Tabela 4.4 - Atores sociais mais frequentes no PDA Santa Tereza I

\begin{tabular}{l|l|c|c|ll}
\hline $\mathrm{N}$ & \multicolumn{1}{|c|}{ Word } & Freq. & $\%$ & \multicolumn{1}{|c}{ Lemmas } \\
\hline 1 & COMUNIDADE & 487 & 0,56 & $\begin{array}{l}\text { comunidade [359] } \\
\text { população [60] } \\
\text { sociedade[6] }\end{array}$ \\
\hline 2 & PDA & 326 & 0,43 & Plano [323] \\
\hline 3 & FAMÍLIA & 271 & 0,37 & Famílias [177] família [94] \\
\hline 4 & COOPVAG & 311 & 0,41 & $\begin{array}{l}\text { COOPVAG [113] assessoria[83] assistência } \\
\text { [42] equipe [36] técnicos [31] equipes [4] } \\
\text { entidade [2] }\end{array}$ \\
\hline 5 & PREFEITURA & 198 & 0,26 & $\begin{array}{l}\text { município[121] prefeitura[74] prefeituras[2] } \\
\text { prefeitos[1] }\end{array}$ \\
\hline 6 & AGRICULTOR & 130 & 0,17 & agricultores [98] agricultor [32] \\
\hline 7 & MORADORES & 93 & 0,11 & Associação [61] moradores [23] \\
\hline 8 & ASSENTADOS/AS & 90 & 0,10 & assentados [77] assentada [32] \\
\hline 9 & INCRA & 44 & 0,06 & INCRA [43] INCRA-TO [1] \\
\hline 10 & GOVERNO & 19 & 0,03 & governo [19] \\
\hline
\end{tabular}

A Tabela 4.4 apresenta os atores sociais com maior ocorrência no PDA e é uma análise quantitativa da recorrência dos atores sociais no PDA. A ocorrência desses atores também é considerada de acordo com uma seleção por categorias lexicais relacionadas a esses atores em termos do campo semântico ao qual implica no texto, o que resulta na seleção de quatro categorias apresentadas também pela quantidade de ocorrências: pessoas acampadas, PDA, governo federal e governo municipal. A primeira categoria lexical remete às pessoas acampadas: comunidade (487), família (271), agricultor (130), moradores (93) e assentados/as (90). A segunda categoria faz referência ao texto produzido: PDA (326). Outra categoria remete ao governo federal: COOPVAG (311), INCRA (44) e governo federal (19). A última faz referência ao governo municipal: prefeitura (198). A partir dos dados apresentados na Tabela 4.4 sobre a inclusão de atores sociais no texto do PDA, vale ressaltar, como bem coloca van Leeuwen (2008), que a 'exclusão' tem sido, por direito, um aspecto importante da análise de discurso crítica

Com isso, é configurada uma análise qualitativa no que concernem à inclusão e à exclusão de atores sociais no texto do PDA a partir da utilização do concordanciador. Observa-se, primeiramente, conforme a frequência, a inclusão mais presente no texto analisado, sobretudo, referente à categoria lexical de ator social 'pessoas acampadas'. Há também, porém, representações de atores sociais relegadas a um nível com menor proeminência. A categoria que remete ao governo federal se faz um caso de ator social colocado em segundo plano, haja vista aparecer somente dezenove vezes em todo o texto do PDA. Ao que parece, a ações das pessoas acampadas, denominadas comunidade, possuem 
relevante consideração, sobretudo no que se referem às ações a serem implantadas a partir do PDA, isto é, ações para o desenvolvimento do PA.

Além do mais, a constituição da inclusão e da exclusão de atores sociais em um texto está diretamente relacionada ao estudo das estruturas do Sistema de Transitividade participantes, processos, circunstâncias - por meio da 'ativação' ou da 'passivação' dos atores sociais. As estruturas gramaticais utilizadas configuram se os atores sociais ativados estão no papel de 'experienciador' nos processos mentais, 'atribuidor/portador/identificador' nos processos relacionais, 'ator' nos processos materiais, 'dizente' nos processos verbais e 'comportado' nos processos comportamentais (VAN LEEUWEN, 1997).

Dos dez atores sociais mais recorrentes no PDA do PA Santa Tereza I, cinco referemse à categoria lexical de pessoas que pleiteavam um lote no PA ou aos/às futuros/as assentados/as: comunidade, família, agricultor, moradores e assentados. Desses cinco, dois estão na lista dos cinco atores mais frequentes: comunidade e família. Com isso, pode-se considerar tal representatividade em função do tipo de texto - um plano de desenvolvimento de um projeto de assentamento, ou seja, um planejamento para assentados/as -, em função da representatividade a quem se atribui mais ações tanto para a implementação quanto para a execução do PDA.

Além disso, os dois atores mais frequentes que se referem às/aos futuros/as assentados/as, fazem alusão à coletividade, as pessoas acampadas vivem em coletividade, os/as futuros/as assentados/as viverão em comunidade; as pessoas que obtiverem o direito de uso de um lote possuem família.

A partir dessas reflexões, os atores sociais no texto do PDA em termos de 'inclusão' podem ser representados como ator (agente) ou meta (paciente) ao se considerar as ações representadas por processos materiais. Nesta perspectiva, os papeis exercidos pelos atores sociais nas práticas sociais e os papeis gramaticais atribuídos a eles nos textos devem estar em coerência (VAN LEEUWEN, 2008). Essas representações de atores sociais podem corroborar para a definição de funções que cada ator exerce, principalmente, na elaboração do PDA, mas também na sua implementação, estabelecendo relações sociais entre eles.

Os fragmentos (100) a (103), apresentados a seguir, identificam o uso dos atores mais frequentes no texto do PDA que se referem às pessoas acampadas na propriedade onde seria o PA Santa Tereza I, nomeadas em termos de vida em comunidade: a categoria mais recorrente é comunidade (com 487 ocorrências) e a terceira categoria mais recorrente é família (com 271 ocorrências). Desse modo, esses fragmentos fazem parte da análise da inclusão dos atores sociais no texto do PDA Santa Tereza I. 
(100) Enfim, a comunidade do PA Santa Tereza I [identificado] é [processo relacional identificativo] a responsável [identificador] pela construção deste Plano de Desenvolvimento, o qual se inicia com a discussão do parcelamento e se estende para discussão de todas as outras ações de desenvolvimento do Assentamento.

(COOPVAG, 2007, p. 68)

(101) De acordo com o diagnóstico, a comunidade do PA Santa Tereza I [portador] se encontra [processo relacional atributivo] em estado de completa carência no que se refere ao acesso à infra-estrutura [atributo]. Nessas condições, não teve dificuldades em apontar as necessidades sobre a infra-estrutura. Vale lembrar que sem a implantação dessas infra-estruturas muitas ações previstas nos outros programas de desenvolvimento não poderão ser executadas.

(COOPVAG, 2007, p. 72)

Observamos, nos fragmentos (100) e (101), a ocorrência da inclusão por ativação do ator social 'comunidade', considerando a representação dos atores sociais. A 'comunidade', a pessoa acampada é 'identificada' como responsável pela elaboração do PDA e também é a 'portadora' de completa carência de infra-estrutura. No decorrer do texto do PDA Santa Tereza I, esse tipo de agência ora tenta protagonizar as pessoas acampadas no que concerne às propostas materializadas no PDA para o desenvolvimento do PA e por isso elas são ditas autoras do texto; ora tenta vitimizar as pessoas acampadas no que concerne ao diagnóstico do modo de vida no acampamento, o que se faz argumento para a implementação das propostas do PDA. A configuração de protagonista, responsável pelo PDA, por sua vez, ao se constituir no texto, também aponta uma forma de exclusão do ator social COOPVAG por encobrimento (segundo plano), já que aparece em outras partes do PDA, como na capa e na identificação dos responsáveis, sendo elaboradora e assinante do texto do PDA. Além disso, esse ator representa outros dois atores: o INCRA e o governo federal. Enquanto que a configuração de vítima, por apresentar o atributo 'estado de completa carência', constitui também inclusão por sujeição, realizada através da participação, uma vez que o ator social é portador em um processo relacional atributivo (VAN LEEUWEN, 2008).

Por um lado, considerando que o atributo é pejorativo em termos dos modos de sobrevivência da comunidade, essa sujeição se faz no texto um argumento para a execução das propostas do PDA, cujo objetivo é se constituir uma ferramenta para o desenvolvimento do PA. Por outro lado, essa sujeição também implica na manutenção do convênio do INCRA com a assistência técnica - COOPVAG -, não somente o período de elaboração do PDA, mas também no período de execução do mesmo, já que o texto do PDA traz os papeis da 
assistência técnica para os programas de desenvolvimento propostos nele e, com isso, os/as assentados/as podem deixar de 'o estado de completa carência'.

Os fragmentos (102) e (103) também permitem apontar uma categoria de ator social que remete à coletividade em termos de uma sociedade com traços culturais patriarcais, onde as pessoas constituem famílias e necessitam de recursos para sustentá-las, ou seja, os recursos financeiros de uma família servem a uma coletividade e por isso se justificam.

(102) As famílias [portador] estão [processo relacional atributivo] acampadas [atributo] desde a criação do PA [circunstância] e não foi possível, nesse período, executar nenhuma atividade produtiva, uma vez que não estão em seus lotes.

(COOPVAG, 2007, p. 49-50)

(103) Este foi o trabalho [meta] realizado [processo material concreto] com as famílias do Projeto de Assentamento Santa Tereza I [beneficiário], que participaram ativamente de todo o processo e contribuíram com o conhecimento da realidade, elencando prioridades, intenções e expectativas ora apresentadas na forma desse documento.

(COOPVAG, 2007, p.1)

A categoria de ator apontada nos excertos é família, representando pessoas acampadas com algum grau de parentesco. No excerto (102), a representação desse ator social se constitui por inclusão por ativação do ator social 'família', estando portador do atributo 'acampadas'. Essa representação de ator social por inclusão e ativação se dá por sujeição e é realizada através da participação. Como no (103), o atributo também se constitui pejorativo no contexto de uso, considerando a circunstância de tempo que o acompanha (desde a criação do PA, ou seja, famílias acampadas há dois anos), aponta para um modo de vida avaliado como inadequado. Essas escolhas configuram também uma representação de vitimização e, consequentemente, argumentam a favor da necessidade de execução do PDA. No excerto (103), a representação do ator social família se constitui, porém, por inclusão e passivação. O ator social 'as famílias do Projeto de Assentamento Santa Tereza I se configura beneficiário da meta 'trabalho' e, de acordo com o contexto de uso, o trabalho realizado é as oficinas. O texto concebe as pessoas acampadas como beneficiadas por terem participado das oficinas realizadas pela COOPVAG para a elaboração do PDA. Ocorre, porém, uma representação de exclusão por encobrimento do ator social COOPVAG/assistência técnica. Nesse excerto, como em muitos outros, há encobrimento do ator COOPVAG, é relegado a segundo plano em termos de agência na elaboração do PDA.

Há de se destacar também que entre os atores com maior ocorrência no PDA no que se referem às pessoas acampadas, além de categorias que remetem à coletividade, ocorrem 
categorias de atores nomeadas por alguma característica como ao grupo acampado: agricultor (130), moradores (93) e assentados/as (108). As pessoas acampadas devido a algumas nomeações são representadas, no texto, ora como agricultor por estarem acampadas há dois anos na área rural onde seria o PA, mesmo que nunca tivessem exercido anteriormente a função de agricultor. Ora são representadas como moradores, por estarem acampadas há dois anos e, parece que para o INCRA, ser morador de um acampamento de 'sem-terra' por um longo período, faz da pessoa um homem rural, agricultor, estando apto a um lote de um projeto de assentamento. Ora são representadas como assentados/as mesmo não os/as sendo ainda.

Essa representação também deixa implícita novamente a concepção de que a 'pessoa estar acampada' implica probabilidade de ser tornar assentada, vista a tentativa de indicar que ela não possui terra, mas deseja possuir o direito de uso dela para sobreviver. Em outras palavras, o fato de as pessoas pleiteadoras de um lote em um futuro PA estarem acampadas sugere que morar no acampamento é um requisito para se tornar assentados/a sob o olhar do INCRA/governo federal. Essa representação se confirma à medida que muitos usos da categoria que designa as pessoas acampadas no texto do PDA se materializam, principalmente, no título Diagnóstico do projeto de assentamento, parte do PDA que caracteriza o espaço físico onde será o PA e os seres humanos que são candidatos a um lote nesse PA, no caso, caracterizados, denominados assentados por estarem acampados há dois anos, como ilustram os segmentos (104) a (106).

(104) Os assentados [experienciador] reconhecem [processo mental cognitivo] que a prefeitura é instituição fundamental para o desenvolvimento do Assentamento [fenômeno], pois é de responsabilidade da prefeitura municipal a implementação de políticas públicas essenciais como educação, saúde, estradas, transporte, etc. e como o assentamento está iniciando, há necessidade de se implantar todos esses serviços.

(COOPVAG, 2007, p. 55)

(105) Há um ônibus que faz linha para Ponte Alta do Tocantins que passa duas vezes por semana há três quilômetros do PA. Assim, quando precisam [circunstância de tempo] os assentados [ator] percorrem [processo material abstrato] esse caminho [meta] a pé [circunstância de modo]. A distância da sede do município e as péssimas condições das estradas têm sido fatores limitantes do acesso ao serviço de transporte.

(COPVAG, 2007, p. 57)

(106) Segundo dados levantados com os assentados [circunstância], o número de matrizes [meta] será delimitado [processo material 
abstrato] em 05 animais e 01 reprodutor coletivo, sendo este adquirido por no mínimo três famílias. Atualmente cada família teria que investir $\mathrm{R} \$ 834,00$ reais na aquisição de um reprodutor LA.

(COOPVAG, 2007, p. 82)

Nos segmentos (104) a (106), quanto à representação de atores sociais, há inclusão por ativação do ator 'os assentados', oitavo mais frequente. Em (104), o ator 'assentados' corresponde ao experienciador do processo mental cognitivo 'reconhecem' e 'a prefeitura é instituição fundamental para o desenvolvimento do Assentamento' corresponde ao participante fenômeno. Assim, as pessoas acampadas, ditas assentadas no texto, atribuem ao ator social passivado por sujeição 'prefeitura de Ponte Alta' a agência de 'implementação de políticas públicas essenciais como educação, saúde, estradas, transporte' no PA Santa Tereza I. Nessa perspectiva, muitas das propostas de infraestrutura inseridas no PDA são atribuídas à prefeitura. Isso corrobora para esse ator social ser o quinto mais frequente no texto do PDA, com 198 materializações linguísticas. Além disso, ainda que seja no mundo da consciência, a inclusão por ativação do ator 'assentados' em relação à designação da prefeitura como executora de muitas propostas do PDA sobre infraestrutura, exclui da COOPVAG responsável pela escrita do PDA e representante do INCRA - a agência de apontar essa prefeitura com o dever de execução de obras de infraestrutura do PA.

O segmento (105) também ilustra uma inclusão por ativação ao ator 'assentados'. Nessa escolha representacional, há uma impersonalização, de modo que as pessoas acampadas no texto são designadas também através do substantivo 'assentados'. Observe-se, com o uso desse substantivo, uma objetivação por espacialização (VAN LEEUWEN, 1997). Esse ator social é representado por meio de uma referência a um local ao qual está, no caso, o acampamento. Esse ato de estar acampado faz referência, por sua vez, a estar inserido em um movimento social de luta pelo uso da terra, luta para se tornar um/a assentado/a. Ainda, as circunstâncias participantes 'quando precisam' e 'a pé' funcionam também, no contexto de uso, como uma avaliação pejorativa do tipo de vida das pessoas acampadas.

Há, porém, outro tipo de representação do ator 'assentados'. No segmento (106), ocorre uma inclusão por passivação do tipo sujeição, sendo tratado como um objeto da representação através da circunstancialização do sintagma onde está inserido 'Segundo dados levantados com os assentados'. Esse sintagma aponta para a proposta de que 'o número de matrizes ser delimitado' é uma escolha feita pelas pessoas acampadas. Há, pois, uma representação de agência encoberta pela passivação. Similarmente, no PDA Santa Tereza I, há 
outra representação da categoria lexical 'pessoas acampadas' de acordo com o segmento abaixo.

(107) Dessa forma, está sendo proposto um sistema produtivo ligado à pecuária bovina que deverá ser implantado pela comunidade do PA e a Assistência Técnica. Os agricultores [experienciador] pretendem [processo mental desiderativo] adquirir o rebanho [fenômeno] através de financiamentos [circunstância de modo], mas para isso é necessário que haja implantação de uma área de pastagem com recursos próprios, conforme a demanda de cada sistema.

(COOPVAG, 2007, p. 78)

No segmento (107), há ocorrência do ator social 'agricultores. Essa representação também atribui uma característica atrelada à condição de 'morar' na área rural em um acampamento: ser representada como agricultora, mesmo não a sendo, como discutido anteriormente. No entanto, nem todos/as são até então agricultores/as e nem 'assentados/as'. Além do mais, quanto à representação de atores sociais, há inclusão por ativação do ator 'os agricultores'. O ator agricultores se faz experienciador do processo mental desiderativo 'pretendem'. Tanto a nomeação desse ator/experienciador 'agricultores' quanto o fenômeno 'rebanho' constituem uma representação 'de pertencer ao meio rural' à pessoa acampada. Pelo menos no mundo das ideias, da subjetivação, esse ator deseja a aquisição de um rebanho. Essa escolha representacional também implica em uma impersonalização do tipo objetivação por espacialização. A representação agricultor é constituída uma vez que a pessoa que recebe tal representação está sendo designada como relacionada a um local, o acampamento na área rural. Ademais, culturalmente, na sociedade brasileira, as pessoas que residem em uma região rural costumam ser nomeadas de agricultores. Vale destacar também a exclusão textual do ator social que a circunstância de modo 'através de financiamentos' remete. $\mathrm{O}$ ator excluído é o governo federal, provável ator financiador.

A segunda categoria lexical de ator social mais frequente no texto analisado é PDA, com 326 concretizações. Vejamos a seguir.

(108) O Plano de Desenvolvimento do Assentamento - PDA deverá se constituir em um importante instrumento de desenvolvimento para os Projetos de Assentamentos de Reforma Agrária. A sua construção é parte integrante da Política de Reforma Agrária, que visa garantir a permanência do homem no campo, com todas as condições necessárias para o desenvolvimento sustentável e melhoria da qualidade de vida de toda a comunidade. 
(COPVAG, 2007, p. 1)

No excerto (108), observe-se o 'PDA' como um ator social constituído por inclusão e ativação, codificado como ator e meta (partícula '-se' reflexiva) do processo material 'deverá se constituir'. A meta '-se/PDA' também apresenta o atributo 'importante instrumento de desenvolvimento para os Projetos de Assentamentos de Reforma Agrária', que tanto designa o papel de instrumento para o desenvolvimento quanto avalia apreciativamente esse papel através do uso do adjetivo 'importante'. Sobre a inclusão e ativação do PDA como um ator social, há implicação de atribuição a esse documento de agência com habilidade humana de realizar a ação de 'constituir-se'. Em termos de representação, essa escolha linguísticodiscursiva configura uma impersonalização por objetivação do tipo autonomização do enunciado, uma vez que o PDA, um plano de desenvolvimento, é constituído como um agente com habilidade humana. De acordo com van Leeuwen (1997, p. 209), quando ocorre a autonomização do enunciado, o ator social é representado por meio de uma referência aos seus enunciados, uma vez que empresta uma autoridade impessoal a eles. Por isso, costuma ser muito utilizada em textos oficiais/institucionais e com elevado estatuto social. Isto é, a constituição do PDA está sob responsabilidade técnica-humana da COOPVAG - representante do INCRA/governo federal -, mas a organização dessa atividade humana (PDA) apresenta a negação de responsabilidade dessa agência, sendo governadas por procedimentos impessoais.

Já a terceira categoria lexical de ator social mais frequente é governo federal, com 311 ocorrências. Dentre as representações dela, no PDA, formam parte 'COOPVAG' (311), 'INCRA' (44) e 'governo federal' (19). Vale esclarecer que o ator social COOPVAG/assistência técnica está inserido nessa categoria por ser contratada pelo INCRA para a função de assistência técnica, no contexto do PDA, para os futuros/as assentados/as. O INCRA, por sua vez, representa os interesses do governo federal.

(109) A comercialização do produto será realizada no primeiro momento no mercado regional (feiras, supermercados etc.). Portanto, existe viabilidade de mercado para atender a demanda. A Assistência Técnica [ator] propõe [processo material concreto] que a comercialização seja feita de maneira coletiva, com a maior quantidade possível [meta], a fim de agregar maior valor ao produto [circunstância de causa]. O valor atual de frangos com peso médio de 1,5 a $2,0 \mathrm{~kg}$ está estimado em $\mathrm{R} \$ 10,00 /$ cabeça (dez reais), e a produção de ovos a preço de $\mathrm{R} \$ 3,00 /$ dúzia (três reais), segundo avaliação de mercado realizado pela COOPVAG [circunstância de ângulo]. 
No fragmento (109), o ator social 'assistência técnica' se constitui por inclusão e é ativado através do processo material 'propor', com habilidade de agente. Desse modo, apresenta personalização, já que seu sentido no contexto de uso inclui a característica humana 'dar assistência'. Os atores sociais dessa categoria lexical, ao partilharem a mesma função, referidos em termos de uma atividade, são personalizados por categorização do tipo funcionalização. $\mathrm{O}$ ator social assistência técnica é representado no PDA tanto, em princípio, pela função que lhe é atribuída pelo INCRA - assistência técnica junto às pessoas acampadas para a elaboração do PDA -, quanto pela agência assumida ao propor um tipo de comercialização de um produto proposto pelo PDA. Ainda, no mesmo fragmento, há a escolha pelo uso de outro ator da mesma categoria lexical 'COOPVAG' que corrobora para essa interpretação. No texto, ator social COOPVAG' constitui o sintagma nominal circunstancial de ângulo por ponto de vista: 'segundo avaliação de mercado realizado pela COOPVAG'. Essa circunstância de ângulo, ao materializar um ponto de vista da COOPVAG sobre o mercado de um produto proposto pelo PDA, também representa uma agência em termos de escolhas de conteúdo inserido no PDA e prescrito nele.

Por um lado, apesar de em várias partes do texto analisado se materializar o dito de que a categoria lexical pessoas acampadas é a responsável pela elaboração do PDA por optarem nas escolhas dos programas produtivos propostos, as escolhas linguísticas do fragmento (109) configuram a representação do ator social assistência técnica como agente em relação à elaboração do PDA, também em termos de escolhas constituintes dos programas produtivos propostos. Por outro lado, o ator social 'assessoria técnica', no fragmento (110), é representado por inclusão e ativação, mas a agência apresentada é a de assistência técnica com outra competência. Analisemos.

(110) A Assessoria Técnica [portador] será [processo relacional atributivo] responsável pelo processo de organização da comunidade [atributo], através da instrumentalização dos grupos gestores, da associação e, mais adiante, da cooperativa [circunstância de causa propósito]. Será responsável pela realização de atividades de capacitação acompanhamento às reuniões, elaboração de projetos específicos e assistência ao sistema produtivo.

(COOPVAG, 2007, p. 194-195)

O ator social assistência técnica, em (110), é ativado como o portador do processo relacional 'ser' e como possuidor do atributo 'responsável pelo processo de organização da comunidade'. Esse atributo configura-se como uma função do ator social, a função de 
executar a capacitação das pessoas acampadas, tanto durante a elaboração do PDA quanto depois, para a implementação do mesmo. Há, pois, outra agência para a assistência técnica. Parece que essa segunda agência, mais recorrente no texto do PDA, tenta encobrir a primeira, atribuída, a priori, às pessoas acampadas. Já o fragmento (111) elucida a representação 'INCRA' dessa categoria.

(111) $\mathrm{O}$ recurso do crédito habitação a ser liberado pelo INCRA [identificado] será [processo relacional identificativo] no valor de $\mathrm{R} \$$ 7.000,00 (sete mil reais) [identificador], por família. O restante será complementado através de um convênio estabelecido com a Caixa Econômica Federal - CEF, no valor de R \$ 6.000,00 (seis mil reais), totalizando um crédito de $\mathrm{R} \$ 13.000,00$ (treze mil reais) para a construção de cada casa.

(COOPVAG, 2007, p. 122)

Em (111), o processo relacional identificativo 'são' apresenta o identificado e o identificador, mas a composição do identificado 'O recurso do crédito habitação a ser liberado pelo INCRA' apresenta uma nominalização que parece tentar ofuscar a agência do INCRA representante do governo federal - diante o identificador 'no valor de $\mathrm{R} \$ 7.000,00$ '. O recurso do crédito habitacional, mesmo para a época, é considerado pequeno para se construir uma moradia para uma família (um dos modos utilizados para se referir às pessoas acampadas ao longo do texto do PDA). No entanto, mesmo que velada, há o papel de agente do INCRA representante do governo federal - diante a disponibilização de recursos habitacionais para as pessoas recebedoras do direito de uso de um lote de um PA.

Os excertos (112) e (113) emolduram, por sua vez, outra representação do ator governo federal.

(112) Alguns medicamentos [meta] são disponibilizados [processo material concreto] na Farmácia Popular [circunstância de lugar], mantida com recursos do governo federal [circunstância de modo] e do município, ao qual cabe a maior parte do investimento. O município também desenvolve os Programas de Atendimento ao Idoso e Saúde da Mulher.

(COOPVAG, 2007, p. 23)

(113) Anteriormente à implantação do Plano, os agricultores enquadrados neste sistema não possuíam nenhuma atividade produtiva no estabelecimentos familiares do PA Santa Tereza I. Não podemos considerar que não possuíam nenhuma renda, pois, mesmo sendo bastante reduzidas, algumas famílias [portador] realizam algumas atividades agropecuárias de forma aleatória ou são [processo 
relacional atributivo] beneficiários [atributo] de programas do Governo Federal.

(COOPVAG, 2007, p. 124)

O excerto (112) refere-se aos serviços de saúde oferecidos pelo município de Ponte Alta. O processo material concreto 'disponibilizar' aparece com a meta 'medicamentos' em destaque uma vez que o ator dessa ação está omitido através do uso da voz passiva. No entanto, apesar de haver apagamento do participante ator, há o uso de duas circunstâncias que destacam um papel agenciador. Tanto 'na farmácia popular' quanto 'com recursos do governo federal' apontam para o papel de agente do governo federal de disponibilizar medicamentos às pessoas tidas como 'beneficiadas', no caso, as acampadas. Essas escolhas linguísticodiscursivas especificam e valorizam o serviço oferecido - medicamentos - e quem o possibilita - governo federal.

Da mesma maneira, o excerto (113) também apresenta um papel de agente para o governo federal. O processo relacional atributivo 'são' apresenta como portador 'algumas famílias' e como atributo 'beneficiários de programas do governo federal'. Assim, serem beneficiadas por um programa do governo federal faz-se um atributo, uma característica, para as pessoas acampadas. As pessoas acampadas são beneficiárias de serviços do governo federal, no caso, de programas assistenciais. Isto é, as pessoas acampadas estão em tal situação de pobreza, que necessitam receber ajuda financeira do governo federal para sobreviver. No excerto, parece que receber auxílio de programas do governo federal é um beneficio a mais, um diferencial, para a pessoa acampada, mas não o é. Fica implícita também aqui a situação degradante das pessoas acampadas.

Por último, a quarta categoria lexical de ator social mais frequente corresponde também a governo, mas no âmbito municipal por apresentar outro tipo de agência no PDA, com 198 ocorrências, configurada no segmento a seguir.

(114) A recuperação da estrada [portador] já está [processo relacional atributivo] comprometida [atributo] com a prefeitura [circunstância], onde o gestor municipal [ator], no ato de negociação das ações [circunstância], assumiu [processo material abstrato] essa responsabilidade [meta]. A infra-estrutura do poço artesiano será negociada com o INCRA, mediante projeto elaborado para esse fim, e a escola, quadra e parquinho infantil [meta], será negociada [processo material abstrato] primeiramente com a prefeitura [circunstância], e, posteriormente, com outros parceiros, a partir da elaboração de um projeto pela Assessoria Técnica e o grupo gestor [circunstância], no segundo semestre de 2007 [circunstância].

(COOPVAG, 2007, p. 78) 
Em (114), a categoria lexical de ator social governo municipal revela representações 'prefeitura' e 'gestor municipal' -, como participantes diferentes de tipos de processos diferentes, mas com o mesmo papel agenciador. Primeiramente, como participante do processo relacional 'está', aparece como uma circunstância - com a prefeitura -, no entanto apresenta um papel de agente para 'a recuperação da estrada' (participante portador). Depois é que aparece como ator do processo material abstrato 'assumiu'. O ator 'gestor municipal' reforça essa agência de desenvolvimento de ações propostas no PDA para o PA. Ainda ocorre o processo material abstrato 'será negociada' com a meta 'a escola, quadra e parquinho infantil' e a circunstância 'com a prefeitura', o ator foi apagado, mas a circunstância possui papel de agente executor. Vale destacar também o uso da circunstância 'a partir da elaboração de um projeto pela Assessoria Técnica e o grupo gestor', pois configura, ao mesmo tempo, três premissas para a execução de obras no PA: a primeira é que tanto a assessoria técnica quanto o grupo gestor são agentes em relação às propostas do PDA, a segunda é que a prefeitura de Ponte Alta somente poderá executar as obras determinadas no PDA a partir de um projeto e a terceira é que a prefeitura de Ponte Alta é subordinada à assistência técnica/INCRA/governo federal no que se refere às propostas do PDA. Aqui, como nas outras duas representações, é designado ao ator governo municipal o papel de agente em termos de executor de ações propostas no PDA. Ao longo do texto do PDA, perfila-se ao governo municipal de Ponte Alta a execução de todas as obras de infraestrutura do PA Santa Tereza I.

Faz-se necessário, ainda, destacar as raras configurações de alguns poucos usos de discurso direto por atores sociais representados no texto do PDA. Os excertos (115) e (126) são uma das poucas vezes onde ocorre o discurso direto no PDA.

(115) Neste arranjo são encontrados agricultores com média a alta capacidade produtiva, tanto na quantidade de mão-de-obra quanto na idade dos membros da família. Estes ainda apresentam o desejo de investir dentro do estabelecimento familiar, com alta diversificação, que pode ser observada na fala de um dos membros do grupo responsável pela elaboração desse tipo de sistema: “... tem que pensar que tem que vestir, crescer e não plantar só arroz e feijão...”.

(COOPVAG, 2007, 121)

(116) Além disso, as condições de moradia e saneamento precárias, o grande número de caninos no PA, causa doenças que abrange reincidência de enfermidade típica do subdesenvolvimento, a verminose, gripe, desnutrição, hanseníase, leishmaniose e doença do aparelho bucal. A necessidade de executar ações concretas no PA é real e urgente: "Nós precisamos dessas coisas pra ontem", diz uma assentada que reconhece a necessidade da comunidade também fazer a sua parte: 
"cada um deve limpar o terreno e exigir que seu vizinho limpe o seu também". Assim, o grupo propôs ações que, com o mínimo de esforço e vontade política, proporcionará grande qualidade de saúde aos moradores do PA Santa Tereza I.

(COOPVAG, 2007, 148-149)

Nos excertos (115) e (116), o discurso direto é atribuído ao ator da categoria lexical pessoas acampadas. No entanto, no primeiro, a representação da categoria diz respeito a agricultor; enquanto que, no segundo excerto, o discurso direto faz referência à representação assentada. Além disso, as poucas vezes que o discurso direto é linguisticamente concretizado no texto do PDA está vinculado a um ator da categoria lexical pessoas acampadas. Em relação ao conteúdo proferido, remete a reclamações sobre a falta de recursos e reivindicações por melhores condições de vida. Desse modo, tanto a escolha do ator quanto o conteúdo exposto relacionados às pessoas acampadas fazem-se uma estratégia de "afastamento do dito" de quem se responsabiliza, "assina" o texto e, ao mesmo tempo, tende responsabilizar o ator que disse. No entanto, as ocorrências de discurso direto no texto do PDA Santa Tereza I perdem essa característica comum de atribuir a quem disse a responsabilidade do dito, visto que os ditos atribuídos às pessoas acampadas foram inseridos no texto e a autoria deles foi desconsiderada, omitida. Isso descredibiza a inserção daquilo que se diz ser discurso direto no texto enquanto estratégia linguístico-discursiva.

Desse modo, as representações dos atores sociais, no texto do PDA Santa Tereza I, propiciaram a (re)distribuição de papeis que cada um realiza - em inclusão e em exclusão no referido PDA.

\subsection{Da identidade de direitos aos deveres em grupos verbais do PDA}

O significado identificacional da linguagem concretiza, por sua vez, a representação dos atores sociais (FAIRCLOUGH, 2003), visto que os estilos constituem o aspecto discursivo de identidades. Há sistemas de poder na sociedade os quais evocam valores simbólicos produzidos, reproduzidos e transformados nela e para ela. $\mathrm{Na}$ materialização linguística do PDA do PA Santa Tereza I, processos identificatórios são construídos socialmente, ou seja, ao descrever, informar, argumentar pode ocorrer atribuição de valores, construção de julgamentos. No PDA, 'valores' são atribuídos aos participantes dos processos e julgamentos também o são, seja através de grupos nominais, como já exposto no decorrer deste capítulo, seja por meio do uso de grupos verbais, interpretado e discutido nesta seção. 
São recursos léxico-gramaticais da metafunção interpessoal e, aqui, são instrumentos para a constituição da análise do significado identificacional da linguagem.

Observe-se que o uso recorrente de recursos linguístico-discursivos 'modalizadores', em princípio, parece ser justificado por o PDA ser um texto com a função social voltada para o planejamento do desenvolvimento de projetos de assentamentos e, como um 'plano', costuma ser constituído de atribuição de papeis, de certa maneira, com avaliações e julgamentos deles e das ações planejadas.

De acordo com o já discutido na subseção 4.3.2, os processos materiais predominam no PDA Santa Tereza I, o que leva a uma análise mais acurada desses processos. Dos 1.513 processos materiais encontrados no PDA, 1077 aparecem na 'voz ativa', enquanto que 436 aparecem na 'voz passiva'. Dos 436 na voz passiva, 46 se constituem com partícula de índice de indeterminação do sujeito (-se) e 390 com verbo ser e particípio do verbo principal. O Gráfico 4.14 detalha o uso da voz ativa e passiva com os processos materiais no PDA Santa Tereza I.
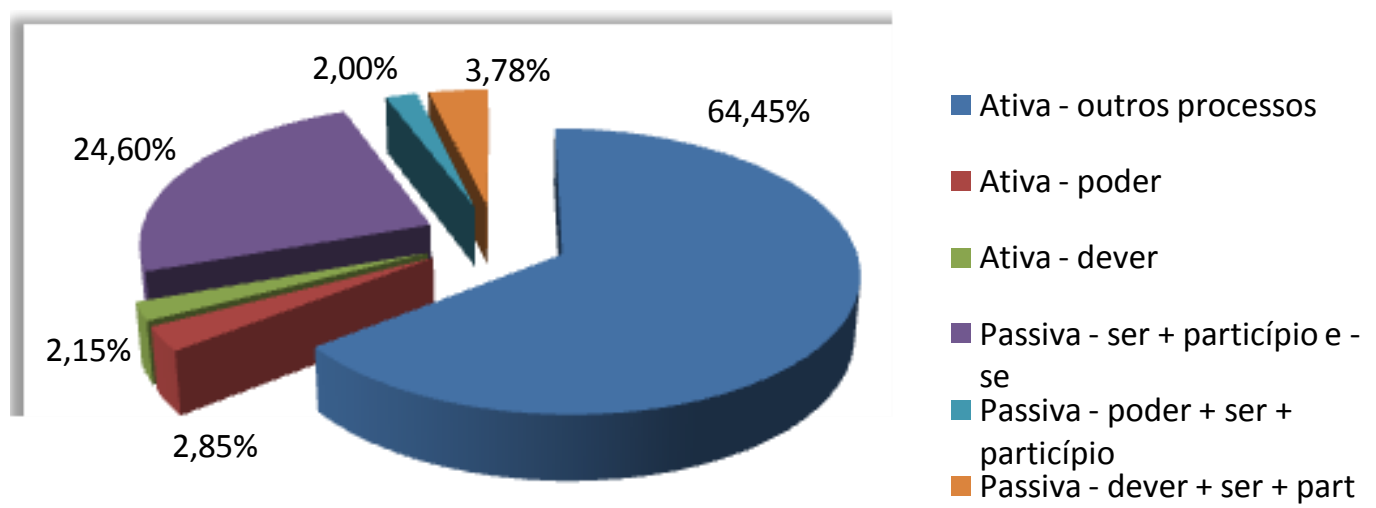

\section{Gráfico 4.14 - Ocorrência de vozes e seus respectivos operadores modais}

O Gráfico 4.14 ilustra os processos materiais divididos em seis grupos no texto do PDA pesquisado: o primeiro grupo evidencia que 64,45\% são processos materiais - Gráfico 4.1 (no total de 2.138 processos materiais) - na 'voz ativa' sem um modalizador verbal (1380). O segundo e o terceiro grupos mostram modalizadores verbais constituindo a 'voz ativa': $2,85 \%$ são com modalizador verbal 'poder' (61) e 2,15\% com modalizador verbal 'dever' (46). O quarto grupo evidencia que $24,60 \%$ são processos materiais na 'voz passiva' sem um modalizador verbal (526). O quinto e sexto grupos mostram modalizadores verbais constituindo a 'voz passiva: $2 \%$ são com modalizador verbal 'poder' (44) e 3,78\% com modalizador verbal 'dever' (81). Sobre a voz passiva, observe-se que ela é marcada em 
relação à ativa, visto que em muitas interações os/as interlocutores/as de uma língua dão preferência ao uso da voz ativa. Segundo Thompson (2004), quando o/a interlocutor/a faz uso de uma oração na voz passiva, ocorre uma quebra de constituintes por uma razão particular. No caso da língua portuguesa, essa quebra (o uso da passiva) interfere na relação entre papeis semânticos e relações gramaticais. O ator tende a ocupar uma posição pós-processo ou é omitido da oração enquanto que a meta tende a ocupar o início da oração.

Os segmentos (117) e (118) indicam a recorrência no texto do PDA do uso de processos materiais vinculados a verbos modais.

(117) Deverá ser realizada correção do solo para que o pH seja elevado próximo a neutralidade $(6,0$ a 7,0$)$. O solo deve ser preparado para que haja uma melhor aeração. Devem ser realizadas capinas de controle a ervas invasoras, pois as plantas de mamona não toleram competição com outras plantas.

O plantio deve ser manual, em covas com profundidade de 5 a $10 \mathrm{~cm}$ e plantadas três sementes por cova, com espaçamento de $3 \times 2 \mathrm{~m}$. A adubação pode ser feita na mesma cova, tendo-se o cuidado de deixar a semente afastada do adubo para evitar morte da semente. O plantio deve ser realizado em áreas onde as plantas fiquem totalmente expostas ao sol. Pode ser realizado consórcio com outras culturas, principalmente as alimentares. O consórcio mais comum é com o feijão, que é uma planta de ciclo rápido que contribui com o enriquecimento do solo com nitrogênio e concorre pouco com a mamoneira.

(COOPVAG, 2007, 101)

(118) A cana-de-açúcar deve ser bem despontada e o palmito totalmente retirado. Deve também se apresentar limpa, a partir da retirada de todas as folhas laterais dos colmos que, depois de cortados e transportados, deverão ser mantidos em galpões cobertos, cujo piso não venha a sujar a cana com a terra.

(COOPVAG, 2007, 116)

Os processos materiais configurados com verbos modais nos segmentos (117) e (118) estão na voz aviva e na voz passiva. Quando aparecem na voz passiva, há deslocamento do participante meta ou do próprio processo verbal para o início da oração e ocorre a omissão do ator, configurando uma topicalização para a meta ou para o processo envolvido com traços de 'modalidade'. Isto é, em 'O solo deve ser preparado', A cana-de-açúcar deve ser bem despontada' e 'O plantio deve ser realizado' ocorre o uso de processos materiais concretos na voz passiva, com modulação no grau de obrigação (modalidade deôntica) e com topicalização dos participantes 'meta' através do seu deslocamento para o início das orações. As ações propostas estão figuradas em termos de especificar e restringir sua execução a somente uma 
maneira, o que caracteriza a obrigatoriedade dessas ações. No entanto, ações foram modalizadas no grau de obrigação para algum ator/agente cumpri-las, mas nas três ocorrências o participante ator foi apagado.

Destaque-se também que esses processos modalizados e na voz passiva encontram-se, principalmente no título mais extenso do PDA, o que apresenta a maioria das ações propostas no texto para o desenvolvimento do PA. Sendo assim, onde há proposição de ações do 'mundo físico, do fazer', também deveria haver indicação dos agentes que recebem a atribuição de executar as ações propostas, principalmente, em se tratando de um planejamento de ações que envolvem meios de vida de seres humanos, mas isso não ocorre em (117) e nem em (118). Além do mais, ao flexionar o processo no futuro do presente do modo indicativo, ocorre dúvida quanto à realização da "ação proposta por ele". O uso desse recurso é mais um indício de não realização das ações propostas, mesmo fazendo parte de processos com trações de modalidade deôntica (no caso, modulação no grau de obrigação).

O segmento (117) ainda indica o uso da modalização (modalidade epistêmica): 'A adubação pode ser feita' e 'Pode ser realizado consórcio'. Em ambas as ocorrências, há modalização no grau de probabilidade, o que distancia a ação da sua efetiva realização. Já o segmento (119), abaixo, indica outro tipo de composição do recurso 'modal' no texto do PDA.

(119) Para que esta seja sustentável, será necessário planejar o início da atividade, ou seja, adquirir animais voltados para a produção leiteira, respeitando a capacidade de suporte do pasto, tendo em vista o número determinado de animais que vão compor o rebanho final, evitando a superlotação e, conseqüentemente, o desgaste da pastagem. É importante avaliar o desempenho produtivo das matrizes e do reprodutor, descartando os animais que não se enquadram nos resultados esperados, além de manejar as pastagens introduzindo forrageiras adaptadas, retirando os animais do piquete no período correto para proporcionar uma boa rebrota.

(COOPVAG, 2007, p. 80)

Halliday e Matthiessen (2004) denominam 'será necessário' e 'é importante' como expressões modais, integrantes do sistema de modalidade (metafunção interpessoal). Enquanto 'será necessário' faz referência à modalidade deôntica no grau de obrigação, 'é importante' diz respeito à modalidade epistêmica no grau de usualidade. Essa última expressão sinaliza também uma avaliação positiva sobre 'o ato de avaliar parte do rebanho', mas há o apamento linguístico do agente avaliador. O uso dessas expressões também é 
marcado pela omissão do participante 'agente'. As expressões modais são recorrentes no texto do PDA, sobretudo, no título Plano de Desenvolvimento.

Os excertos (120), (121) e (122) também formam parte do título Plano de ação, apresentam o recurso modalidade de forma mais recorrente que nos outros excetos e reitera um uso desse recurso por todo o Plano de ação do PDA Santa Tereza I.

(120) Identificou-se, também, a presença de profissionais como pedreiros e ajudantes que deverá contribuir para a construção das moradias. No entanto, com a efetivação do convênio com a CEF, foram criados critérios que deverão ser obedecidos. A forma de utilização dos recursos existentes deverá ser discutida entre as instituições parceiras, bem como o planejamento de como será conduzido o processo de construção das casas.

No entanto, acredita-se que a comunidade deverá estar incluída no processo de discussão e deverá ser ouvida, uma vez que é a principal interessada. A proposta é que seja criado o grupo gestor do Programa e que este grupo, juntamente com a Assessoria Técnica, comissão do INCRA e parceiros discutam todo o processo e forma de construção de suas casas. É importante ressaltar que a comunidade é bastante propensa a atuar em união, portanto não deverá ser problema chegar a um consenso que seja bom para todos.

(COOPVAG, 2007, 154)

(121) A execução das ações planejadas depende da assessoria técnica permanente, devendo ser garantida através de convênio com o INCRA. A prestadora deverá garantir uma assessoria de qualidade feita por uma equipe multidisciplinar, constituída por profissionais devidamente capacitados em áreas de nível superior e nível médio. A equipe deverá, em todo o seu trabalho, ter como base o documento ora elaborado e exercerão suas atividades conforme um cronograma de trabalho, elaborado junto com representantes do assentamento, visando atender as demandas de cada atividade projetada.

(COOPVAG, 2007, 194)

(122) Este cronograma, no entanto, deverá obedecer a lógica de desenvolvimento do trabalho e cada capacitação estará atrelada a um resultado concreto. Sendo assim, mediante a demanda colocada de cada curso, oficina, palestra deverá ser previsto época certa de fazer atividade, quem poderá exercê-la, quantos deverão participar, quantas atividades deverão ser feitas para se atingir o objetivo proposto.

O documento resultante desse planejamento deverá ser seguido pelo grupo e pela Assessoria Técnica, fazendo ajustes quando necessário.

(COOPVAG, 2007, 196)

Nos três excertos acima, como nos outros apresentados, os verbos modais aparecem na constituição de processos materiais na voz ativa e na voz passiva e com a modulação no grau de obrigação. Uma diferença entre o excerto (121) é os outros apresentados é o aparecimento do 'agente' explícito em uma oração e está vinculado ao participante ator: ' $\underline{\text { A prestadora }}$ 
deverá garantir uma assessoria de qualidade feita por uma equipe multidisciplinar'. O uso da modulação na constituição do papel semântico do processo material 'deverá garantir' indica obrigatoriedade de o agente "a prestadora' - no caso, também participante ator - executar a função que lhe está sendo designada. Ao flexionar o grupo verbal 'deverá garantir' no futuro do presente do modo indicativo, como no excerto (121) está flexionado, é criada uma dúvida sobre a realização da ação. A execução de ações no tempo futuro não é certa, mesmo que o recurso da modulação no grau de obrigação integre a constituição desse processo flexionado no futuro. Da mesma maneira, o aparecimento explícito do ator com papel de agente, não cria a certeza de que a prestadora de serviços garantirá uma assessoria de qualidade.

Destaque-se também uma oração no final do excerto (122): 'O documento resultante desse planejamento deverá ser seguido pelo grupo e pela Assessoria Técnica, fazendo ajustes quando necessário'. Nesse excerto, o processo 'deverá ser seguido' está na voz passiva, com uma modulação no grau de obrigação Há vinculação desse processo à meta ' $O$ documento resultante desse planejamento', que faz referência ao próprio PDA. Com a meta no início da oração, ocorre um destaque para 'o que deve ser seguido', no caso, o PDA/O documento resultante desse planejamento. Observe-se também que a escolha lexical caracterizou o texto final do PDA como um documento. Ainda há explicitação de dois atores: 'pelo grupo' e 'pela Assessoria Técnica'. O ator 'grupo' remete às pessoas assentadas no PA enquanto que o outro ator faz referência tanto ao INCRA quanto a qualquer outra instituição que preste assistência ao PA. A presença desses atores com o papel de agente, atrelado a uma modulação no grau de obrigatoriedade, confere ao PDA um "status" de documento institucional que deve ser levado a cabo tanto pelo INCRA/assistência técnica quanto pelos/as assentados/as. Ainda, ao comparar a constituição linguística das duas nomeações dos atores, o participante ator 'grupo' é representado de forma generalizada por estar escrito com a letra inicial em "minúsculo", um nome comum. Já o participante 'Assistência Técnica' é representado de forma individualizada quanto a sua concretização linguística, constituindo um nome próprio por estar escrito com as letras iniciais em "maiúsculo".

\section{Algumas considerações}

As análises desenvolvidas no Capítulo 4 perfilam aproximação com a questão de pesquisa referente, sobretudo, às representações configuradas linguisticamente no Plano de Desenvolvimento do Projeto de Assentamento Santa Tereza I. Desse modo, o breve paralelo estabelecido entre alguns aspectos do texto do II PNRA e do texto da Norma de Execução no. 
71, enquanto textos orientadores para que o PDA viesse a existir como uma ferramenta para o planejamento do desenvolvimento de PAs, assim como a breve análise da estrutura composicional do texto do PDA do PA Santa Tereza I apontaram para a perspectiva da ADC de que elementos de um texto são incorporados em outros 'intertextualmente'. e de que discursos são incorporados; como outros textos são dialogados no texto do PDA Santa Tereza I. Em relação às proposições do II PNRA, o PDA é configurado com a perspectiva de desenvolvimento de políticas públicas voltadas para a organização da reforma agrária no Brasil, como do planejamento de ações para o desenvolvimento dos assentamentos. A Norma de Execução no. 71, por sua vez, diz respeito à normatização de programas de assistência técnica, sob responsabilidade do INCRA, para o desenvolvimento dos PAs, tentando também colocar em prática algumas orientações do II PNRA. Ainda, os PDAs devem ser concretizados linguisticamente, assim, a partir das prescrições da Norma de Execução no. 71 quanto à sua forma e ao seu conteúdo.

Observe-se, aqui, o uso da ferramenta computacional WordSmith Tools v.6 (SCOTT, 2012), pois esse instrumento propiciou uma descrição mais detalhada de aspectos da composição lexical do PDA Santa Tereza I e facilitou a análise de componentes da Gramática Sistêmico-Funcional referentes ao Sistema de Transitividade ao Sistema de Modo (HALLIDAY \& MATTHIESSEN, 2004), no que remete à quantificação de processos e de seus participantes, à visualização da recorrência das categorias de análise e à interpretação dos dados, principalmente devido à extensão do PDA analisado - 236 páginas. Da mesma forma, esse programa computacional contribuiu para a análise do Sistema de Representação dos Atores Sociais (VAN LEEUWEN, 1997; 2008).

A análise dos dados de natureza documental - do PDA - foi constituída a partir do Sistema de Transitividade. Seu desenvolvimento ocorreu por meio da divisão dos títulos em duas partes devido à extensão do texto, em que o título com maior número de páginas possui o dobro da soma de páginas dos outros títulos do PDA. O título seis tenta dar visibilidade e detalhamento aos programas de ação para o PDA, contendo maior parte do planejamento de desenvolvimento para o PA. Além desses motivos de ordem organizacional dos dados para a análise em tentativa de facilitá-la, essa disposição dos dados também contribuiu para a análise comparativa entre os títulos, levando em conta o que cada um se propõe.

Em relação à análise de processos nesses títulos, observou-se o uso muito maior de processos materiais do que de outros processos ao longo do texto, o que pode ser explicado em função do próprio gênero textual. Sobre isso, destaque-se que o INCRA não somente atribuiu uma função social ao PDA e que diz respeito a "funcionar" como uma ferramenta de 
desenvolvimento para o planejamento de assentamentos, como também normatizou sua forma e seu conteúdo na tentativa corroborarem apara a concretização de sua função social.

Quanto à representação dos atores sociais (VAN LEEUWEN, 1997; 2008), as ações propostas para as pessoas acampadas, denominadas comunidade, possuem relevante consideração, sobretudo no que se referem às ações a serem implantadas a partir do PDA, isto é, sinalizam os/as agentes das ações para o desenvolvimento do PA e a ausência desses agentes. Outro aspecto da análise desenvolvida é a configuração da representação dos atores sociais (VAN LEEUWEN, 1997; 2008).

Conforme a análise desenvolvida neste capítulo, há predomínio de processos materiais concretos e abstratos no texto do PDA do PA Santa Tereza I. São processos do mundo do 'fazer', que apontam ações mais próximas de uma execução. Observe-se, no entanto, entre muitos processos desse tipo, a ocorrência da flexão do processo no futuro do presente do modo indicativo e esse recurso pode gerar dúvida quanto à realização da ação, o que torna o processo em 'abstrato'. Essa opção de representação por certa 'abstração' parece ser comum e explorada em textos com função social de "planejar algo", como em inúmeros textos institucionais com esse fim. Ademais, esse recurso pode ser utilizado para a construção de realidades futuras, no campo das abstrações e distante da execução, levando muitas proposições do PDA Santa Tereza I somente para o âmbito dos planejamentos, no 'interior' das ideias.

O Capítulo 5 é dedicado, por sua vez, à análise e à discussão dos dados de natureza etnográfica com o intuito de contribuir para uma análise mais detalhada dos dados de natureza documental. 


\section{CAPÍTULO 5}

\section{AVES PIONEIRAS E OS ORGANIZADORES DO NINHO E(M) A REVOADA SOBRE O PDA}

Um passarinho pediu a meи irmão para ser sua árvore. Мeu irmão aceitou de ser a árvore daquele passarinho. No estágio de ser essa árvore, meu irmão aprendeu de sol, de céu e de lua mais do que na escola.

(Manoel de Barros, 2000)

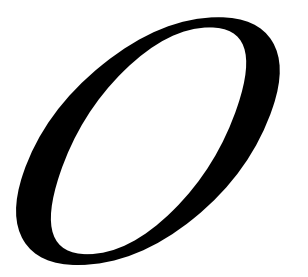

segundo capítulo analítico está dividido em cinco seções. Para tanto, envolve uma investigação linguístico-discursiva de representações tanto de assentados/as pioneiros/as quanto de funcionários do INCRA-SR26 sobre o PDA do PA Santa Tereza I, sendo os últimos os responsáveis técnicos pela elaboração do referido PDA. Trata-se, sobretudo, da investigação realizada a partir de análises de documentos de língua oral. A primeira seção e a segunda seção envolvem a análise de dados gerados e coletados a partir de entrevistas semiestruturadas com assentados/as convocados/as para as reuniões com a COOPVAG para a elaboração do PDA Santa Tereza I. Já a terceira seção e a quarta seção configuram o envolvimento de funcionários do INCRA/Superintendência Regional 26 - superintendência do INCRA no estado do Tocantins - com a elaboração do PDA Santa Tereza I. Na última seção, há as considerações preliminares do capítulo. 


\subsection{Aves pioneiras e(m) a busca do ninho}

Os dados analisados nesta seção foram originados por meio de entrevistas semiestruturadas e de notas do diário de capo durante o tempo de convívio no projeto de assentamento (PA) Santa Tereza I, em Ponte Alta - TO. Os/as assentados/as entrevistados/as, na época, ainda acampados/as, participaram das reuniões com a COOPVAG para construção do PDA do mesmo PA. As reflexões analíticas estão balizadas a partir das seguintes questões de pesquisa: (i) ola assentadola do PA Santa Tereza I se identifica como elaborador/a do PDA do PA Santa Tereza I? (ii) ola assentado/a se identifica com as representações expressas no PDA do seu PA?

Cabe, aqui, destacar o critério utilizado para a escolha dos/as assentados/as entrevistado/as. Das quarenta e sete pessoas que possuem, ainda, a concessão de uso dos lotes do PA Santa Tereza I, vinte e duas participaram das reuniões com a COOPVAG para a elaboração do PDA em 2007/2008, uma vez que já se encontravam acampadas há 2 anos (desde 2006) na propriedade onde seria implantado esse PA. Por esse motivo, as mesmas também são nomeadas pessoas pioneiras do assentamento. Em consonância com o objetivo geral da pesquisa, centrado no estudo das discursividades no PDA do PA Santa Tereza I, as entrevistas foram levadas a cabo junto a esse grupo pioneiro.

Naquela ocasião, o INCRA-SR26 convocou as pessoas acampadas, de modo específico um representante de cada família, para a participação em todas as reuniões com a instituição contratada para a elaboração do PDA, a COOPVAG, no próprio acampamento. Ressalte-se, aqui, o termo "convocação", devido ao fato de as pessoas acampadas serem obrigadas a participar dessas reuniões, caso contrário perderiam o direito de se candidatarem ao uso de um lote no PA. Além do mais, na época, por exigência do governo federal, somente depois da elaboração do PDA, os lotes do PA poderiam ser sorteados e distribuídos. 
O grupo pioneiro entrevistado participou das reuniões com a COOPVAG para a elaboração do PDA. Sendo assim, entrevistei 21 assentados/as, dos/as 22 que ainda residem no PA Santa Tereza I. ${ }^{34}$ O Quadro 5.1, a seguir, apresenta o perfil das 21 pessoas entrevistadas.

Quadro 5.1 - Perfil das aves pioneiras do PA Santa Tereza I ${ }^{35}$

\begin{tabular}{|c|c|c|c|c|c|c|c|c|c|c|}
\hline $\mathbf{N}$ & Nome & $\begin{array}{c}\text { Tempo } \\
\text { no ninho }\end{array}$ & $\begin{array}{c}\text { Pouso } \\
\text { atual }\end{array}$ & $\begin{array}{c}\text { Cultivo } \\
\text { no ninho }\end{array}$ & $\begin{array}{c}\text { Pouso antes } \\
\text { do ninho }\end{array}$ & $\begin{array}{c}\text { Auxílio } \\
\text { governo }\end{array}$ & Idade & Sexo & Origem & Estudo \\
\hline 1 & $\begin{array}{l}\text { Arara- } \\
\text { Canindé }\end{array}$ & 8 anos & PA & mandioca & agricultor & $\begin{array}{l}\text { - Bolsa Família } \\
\text { - aposentadoria }\end{array}$ & 63 & M & TO & $2^{\mathrm{a}}$ \\
\hline 2 & $\begin{array}{l}\text { Mãe-da- } \\
\text { Lua }\end{array}$ & 8 anos & PA & sem produção & agricultor & - aposentadoria & 65 & M & MA & não \\
\hline 3 & $\begin{array}{l}\text { Gavião- } \\
\text { Vaqueiro }\end{array}$ & 8 anos & PA & $\begin{array}{c}\text { arroz, feijão, } \\
\text { milho, fava, } \\
\text { mandioca }\end{array}$ & cidade & $\begin{array}{l}\text { - Bolsa Família, } \\
\text { - Bolsa Verde }\end{array}$ & 39 & M & TO & $6^{\mathrm{a}}$ \\
\hline 4 & Xexéu & 8 anos & PA & $\begin{array}{l}\text { arroz, milho, } \\
\text { feijão }\end{array}$ & agricultor & $\begin{array}{l}\text { - Bolsa Família, } \\
\text { - Bolsa Verde }\end{array}$ & 67 & M & PI & não \\
\hline 5 & Cigana & 8 anos & PA & $\begin{array}{l}\text { arroz, milho, } \\
\text { feijão }\end{array}$ & cidade & - Bolsa família & 29 & $\mathrm{~F}$ & TO & $1^{\circ} . \mathrm{EM}$ \\
\hline 6 & $\begin{array}{l}\text { Garça- } \\
\text { real }\end{array}$ & 8 anos & PA & $\begin{array}{c}\text { arroz, } \\
\text { mandioca, } \\
\text { feijão }\end{array}$ & agricultor & $\begin{array}{l}\text { - pensionista do } \\
\text { INSS }\end{array}$ & 74 & M & TO & não \\
\hline 7 & João-Bobo & 8 anos & PA & $\begin{array}{c}\text { arroz, feijão, } \\
\text { milho, gado }\end{array}$ & cidade & não & 56 & M & TO & não \\
\hline 8 & Irerê & 8 anos & PA & $\begin{array}{l}\text { mandioca, } \\
\text { abóbora, } \\
\text { feijão, gado }\end{array}$ & cidade & não & 62 & $\mathrm{~F}$ & GO & não \\
\hline 9 & $\begin{array}{l}\text { Periquito- } \\
\text { Rei }\end{array}$ & 8 anos & PA & $\begin{array}{l}\text { arroz, feijão, } \\
\text { mandioca, } \\
\text { gado }\end{array}$ & agricultor & não & 48 & M & TO & não \\
\hline 10 & $\begin{array}{l}\text { Gavião- } \\
\text { Carijó }\end{array}$ & 8 anos & PA & $\begin{array}{c}\text { mandioca, } \\
\text { arroz, galinha }\end{array}$ & cidade & $\begin{array}{l}\text { - Tocantins sem } \\
\text { Fome }\end{array}$ & 42 & $\mathrm{~F}$ & TO & $8^{\mathrm{a}}$. \\
\hline 11 & Carão & 8 anos & PA & $\begin{array}{c}\text { arroz, feijão, } \\
\text { milho, } \\
\text { hortaliça }\end{array}$ & cidade & não & 50 & $\mathrm{~F}$ & MA & EM \\
\hline 12 & $\begin{array}{l}\text { Quero- } \\
\text { Quero } \\
\end{array}$ & 8 anos & $\mathrm{PA}$ & sem produção & cidade & - Bolsa Família & 59 & $\mathrm{~F}$ & PI & $5^{\mathrm{a}}$ \\
\hline 13 & Tuiuiu & 8 anos & PA & mandioca & agricultor & - aposentadoria & 63 & M & TO & $2^{\mathrm{a}}$ \\
\hline 14 & Savacu & 8 anos & $\mathrm{PA}$ & $\begin{array}{l}\text { mandioca, } \\
\text { arroz, milho }\end{array}$ & agricultor & não & 51 & $\mathrm{M}$ & TO & $6^{\mathrm{a}}$ \\
\hline 15 & $\begin{array}{l}\text { Sanhaçu- } \\
\text { do- } \\
\text { Coqueiro }\end{array}$ & 8 anos & PA & $\begin{array}{l}\text { mandioca, } \\
\text { milho }\end{array}$ & agricultor & $\begin{array}{l}\text { - Bolsa Família, } \\
\text {-Bolsa,Verde }\end{array}$ & 46 & M & TO & $2^{\mathrm{a}}$ \\
\hline 16 & Suiriri & 8 anos & PA & $\begin{array}{l}\text { milho, arroz, } \\
\text { mandioca, } \\
\text { gado }\end{array}$ & cidade & -Bolsa Família & 41 & M & TO & $4^{\mathrm{a}}$. \\
\hline 17 & Tico-Tico & 8 anos & PA & $\begin{array}{l}\text { mandioca, } \\
\text { hortaliça, } \\
\text { abelha }\end{array}$ & não informou & - Bolsa Família & 52 & M & TO & $4^{\mathrm{a}}$. \\
\hline 18 & Bem-te-Vi & 8 anos & PA & $\begin{array}{l}\text { arroz, feijão, } \\
\text { mandioca, } \\
\text { milho }\end{array}$ & agricultor & não & 67 & M & TO & $2^{\mathrm{a}}$ \\
\hline
\end{tabular}

${ }^{34}$ Dois dos assentados pioneiros não foram entrevistados por estarem ausentes do PA durante os dias da realização das entrevistas em julho de 2014.

${ }^{35}$ Os/as participantes da pesquisa são apresentados com pseudônimos por questão de ética na pesquisa. No caso dos/as colaboradores/as assentados/as, os pseudônimos referem-se à fauna do Tocantins, especificamente, às aves (pássaros), "em vôo e em busca do pouso". . 


\begin{tabular}{|c|l|c|c|c|c|c|c|c|c|c|}
\hline 19 & $\begin{array}{l}\text { Rolinha- } \\
\text { Vaqueira }\end{array}$ & 8 anos & PA & $\begin{array}{c}\text { arroz, milho, } \\
\text { feijão, } \\
\text { mandioca }\end{array}$ & cidade & não & 60 & F & TO & $8^{\text {a. }}$ \\
\hline 20 & $\begin{array}{l}\text { Andorinha- } \\
\text { Azul }\end{array}$ & 8 anos & PA & $\begin{array}{c}\text { mandioca, } \\
\text { feijão, fava, } \\
\text { arroz, gado }\end{array}$ & cidade & $\begin{array}{c}\text {-Bolsa Família, } \\
\text { - Bolsa Verde }\end{array}$ & 30 & F & TO & $6^{\mathrm{a}}$. \\
\hline 21 & $\begin{array}{l}\text { Gralha-do- } \\
\text { Campo }\end{array}$ & 8 anos & PA & $\begin{array}{c}\text { mandioca, } \\
\text { feijão, fava, } \\
\text { hortaliça }\end{array}$ & agricultora & - Bolsa Família & 54 & F & GO & não \\
\hline
\end{tabular}

O Quadro 5.1 sintetiza aspectos paralelos entre o perfil dos pássaros pioneiros diferentes aves em revoada, atraídas por um lugar seguro para a construção do ninho. Observe-se que a leitura proposta do quadro se faz na horizontal, da esquerda para direita, seguindo a ordem das colunas; e na vertical, em ordem crescente em número de linhas. No que concerne similaridade de informações, as colunas Tempo no ninho (PA), Pouso atual (trabalho) e Cultivo no ninho revelam as mesmas informações nas duas primeiras e o mesmo tipo de agricultura, cultivo na terceira coluna. Todas as aves fazem morada, ninho nas terras onde é o PA desde o período do acampamento, há oito anos. Lá, até hoje, labutam - fazem pouso - em agricultura familiar. A produção indica basicamente uma agricultura de subsistência, com quase os mesmo produtos em cada lote. Somente duas aves declaram não haver produção nos lotes. Enquanto Mãe-da-Lua declarou estar doente e por esse motivo não consegue mais labutar com a terra, Quero-Quero apontou não haver água disponível no lote de modo que seja possível qualquer cultivo.

A construção metafórica de alusão aos pássaros se desfaz na medida em que as aves continuam no céu e as aves pioneiras se apegam, ainda que de maneira nayve ao húmus - terra -, uma vez que tentam debruçar no solo para sobrevivência num pouso seguro. A fartura que os pássaros têm, as aves pioneiras buscam em um projeto de assentamento. Já as outras seis colunas perfilam informações diferentes.

A sexta coluna Pouso antes do ninho permite identificar que a metade trabalhava em alguma propriedade rural como agricultor/a antes de receber a concessão de uso de um lote no PA e a outra metade labutava em áreas urbanas com serviços diversos, não eram homens e mulheres ditos do campo. A consideração das informações da coluna três, aqui, permite apontar que a produção muitos/as pioneiros/as, apesar de agricultores/as antes do PA, é típica da agricultura familiar como também o é a dos/as pioneiros/as que trabalhavam fora da agricultura antes do PA. Isto é, em princípio, possuir experiência como agricultor/a parece não influenciar no tipo de cultivo. Fica implícito que outros fatores como características do 
solo, disponibilidade de água, assessoria técnica, recursos financeiros é que podem influenciar ou não no tipo de produção.

A próxima coluna, Auxílio do governo, indica se as aves pioneiras se sustentam com recursos provenientes do trabalho realizado no próprio lote, como declarado por todas, ou participam de algum programa assistencial de governos. No Brasil, o governo federal e alguns governos estaduais mantêm programas assistenciais de complementação de renda, as designadas "Bolsas", para famílias que comprovem vulnerabilidade para sobrevivência, famílias mais carentes da sociedade. No caso do PA Santa Tereza I, onze pioneiros/as recebem algum desses auxílios de governos, de modo que quatro recebem tanto a Bolsa Família (do governo federal) quanto a Bolsa Verde (do governo do Tocantins). Três estão aposentados pelo Instituto Nacional de Previdência e Seguridade Social (INSS) e um está pensionista através do mesmo órgão governamental. Nesses dois casos de afastamento do trabalho, tanto por aposentadoria quanto por problema de saúde, os quatro são beneficiários de um salário mínimo para que não exerçam sua função como trabalhador, o que teoricamente retira a exigência da legislação sobre reforma agrária de trabalharem em seus lotes, pelo menos, com o cultivo do que foi informado na coluna cinco. Menos da metade, somente sete, não recebe auxílio financeiro algum de governo. Destaca-se também que o governo, ao concederem auxílio(s) financeiro(s) para complementação de renda a essas pessoas, sinaliza que já ser beneficiado/a pelo programa de reforma agrária, participar de um PA, não seria suficiente para garantir condições mínimas de sobrevivência. Faz-se necessário ainda, muitas vezes, ser beneficiado/a com um ou mais auxílio(s) governamental.

A oitava coluna Idade sinaliza que, dos vinte e um entrevistados/as, quatorze pioneiros/as possuem mais de cinquenta anos. No entanto, a força de trabalho manual, comumente utilizada na agricultura de subsistência, exigida, em princípio, do trabalhador/a de um PA, provavelmente diminui aos poucos por motivo de desgaste do corpo humano ao longo de anos de trabalho, especialmente rural. Desse/as quatorze, sete possuem mais de sessenta anos. Por um lado, a concessão do uso do lote de um PA se constitui com a exigência de uso da terra, produção, por quem possui essa concessão. Por outro lado, esses/as pioneiros/as estão na dita "melhor idade/terceira idade" e com, no mínimo, proximidade ao direito de aposentadoria por idade e por isso não se faz adequado exigir dele/as a produção do lote do PA através do trabalho "braçal".

Já a nona coluna Sexo identifica tanto pioneiros quanto pioneiras entrevistados/as: treze do sexo masculino e oito do sexo feminino. Observe-se que as entrevistas foram realizadas com as pessoas que estavam acampadas no período de reuniões para elaboração do 
PA e que, atualmente, continuam no PA Santa Tereza I. Como na época das reuniões com a COOPVAG, o INCRA exigia a participação de, pelo menos, um membro de cada família acampada, em caso de casal, esposo ou esposa, homem ou mulher, entrevistei uma pessoa de cada lote de pioneiro/a assentado/a, independente do sexo. Reitera-se, aqui, como já observado em Capítulo 1, que a diferença de gênero marca a inserção crescente na estrutura familiar monogâmica (mãe e filhos/as ou pai e filhos/as) também no campo. Nesse sentido, tanto homem quanto mulher podem se candidatar a um programa de projeto de assentamento.

À semelhança das aves encontradas no território tocantinense, na coluna Origem, há aves pioneiras tanto originárias do Tocantins, quanto originárias de outros estados, mas todas buscam pouso nessas terras. Quinze assentados/as pioneiros/as são do próprio estado do Tocantins e outros seis são oriundos/as de outros estados, apesar de que já residiam em terras tocantinenses antes de estar em acampamento para pleitear um lote no PA.

A última coluna Estudo permite sinalizar sete pessoas, todas praticamente sem escolaridade, de modo que uma delas não sabia escrever nem o próprio nome. Quatro possuem o ensino fundamental, com primeiro ciclo incompleto. Das vinte e uma, somente duas mulheres chegaram a cursar o ensino médio, mas somente uma finalizou. Além do mais, essas duas, antes de residirem no PA, residiam em áreas urbanas, talvez por isso conseguiram maior escolaridade. Neste ponto, questiono a metodologia utilizada pela COOPVAG nos grupos para a discussão dos programas produtivos a serem propostos no PDA.

No diário de campo, registrei que a COOPVAG apresentava os programas produtivos através de projeções de slides ao/às pioneiros/as, depois os/as dividia os/as em grupos por tipo de programa produtivo para que lessem os textos sobre esse programa e decidissem se seria proposto no PDA. Ao que parece, mais da metade os/as pioneiros/as não possui quase escolaridade alguma. Com isso, devem ter tido dificuldades para lerem os textos de modo a fazerem escolhas ponderadas com as características físicas dos lotes, conhecimentos técnicos sobre agricultura e pecuária, recursos financeiros disponíveis, sobre o que deveria compor o PDA.

Apresento, a seguir, informações que apontam uma lista de razões relatadas pelos/as pioneiros/as entrevistados/as acerca de fatores que o/as levaram procurar participação no programa de reforma agrária do governo federal. Esses dados serão retomados na análise dos dados empíricos mais adiante. Vejamos o 5.2, que permite destacar.

\section{Quadro 5.2 - Razões para situação de projeto de assentamento}

\begin{tabular}{|c|c|c|}
\hline $\mathbf{N}$ & Nome & Razões \\
\hline
\end{tabular}




\begin{tabular}{|l|l|l|}
\hline $\mathbf{N}$ & \multicolumn{1}{|c|}{ Nome } & \multicolumn{1}{c|}{ Razões } \\
\hline 1 & Arara-Canindé & Busca de um sonho ligado às propostas do INCRA/COOPVAG \\
\hline 2 & Mãe-da-Lua & Sonho de uma propriedade rural \\
\hline 3 & Gavião-Vaqueiro & $\begin{array}{l}\text { Sonho de uma propriedade rural, busca de um sonho ligado às } \\
\text { propostas do INCRA/COOPVAG }\end{array}$ \\
\hline 4 & Xexéu & Sonho de uma propriedade rural \\
\hline 5 & Cigana & Busca de um sonho ligado às propostas do INCRA/COOPVAG \\
\hline 6 & Garça-Real & Sonho de uma propriedade rural \\
\hline 7 & João-Bobo & Sonho de uma propriedade rural \\
\hline 8 & Irerê & Busca de um sonho ligado às propostas do INCRA/COOPVAG \\
\hline 9 & Periquito-Rei & Busca de um sonho ligado às propostas do INCRA/COOPVAG \\
\hline 10 & Gavião-Carijó & Trabalho por conta própria \\
\hline 11 & Carão & Busca de um sonho ligado às propostas do INCRA/COOPVAG \\
\hline 12 & Quero-Quero & Saída do aluguel, trabalho por conta própria \\
\hline 13 & Tuiuiu & Busca de um sonho ligado às propostas do INCRA/COOPVAG \\
\hline 14 & Savacu & Sonho de uma propriedade rural \\
\hline 15 & Sanhaçu-do-Coqueiro & Sonho de uma propriedade rural \\
\hline 16 & Suiriri & Sonho de uma propriedade rural \\
\hline 17 & Tico-Tico & Saída do aluguel, trabalho por conta própria \\
\hline 18 & Bem-te-Vi & Sonho de uma propriedade rural \\
\hline 19 & Rolinha-Vaqueira & Busca de um sonho ligado às propostas do INCRA/COOPVAG \\
\hline 20 & Andorinha-Azul & Busca de um sonho ligado às propostas do INCRA/COOPVAG \\
\hline 21 & Gralha-do-Campo & Sonho de uma propriedade rural \\
\hline
\end{tabular}

No Quadro 5.2, a coluna mais à direita emoldura quatro razões motivadoras para os/as assentados/as pleitearem um lote no PA e, consequentemente, conduziram os/as à situação de vida no "acampamento" por um período de dois anos. Como registrado em diário de campo, é frequente o procedimento de "permanecer acampado/a", adotado pelos/as pioneiros/as como etapa para participarem de um programa de reforma agrária no Brasil. O processo 'permanecer' relaciona-se com um estado permanente, já 'acampado; se relaciona com um estado transitório. Apesar de parecer o tempo em acampamento curto, passageiro, o/a candidato/a necessita passar vários meses ou anos acampado/a com intuito de participar de um PA.

Em poucas palavras, por um lado, relataram "busca de um sonho ligado às propostas do INCRA/COOPVAG; sonho de uma propriedade rural; trabalho por conta própria; e saída do aluguel". Por outro lado, ao que parece, os/as pioneiros/as possuíam emprego, algum meio de sobrevivência antes de irem para o PA, mas devido à perspectiva de melhoria de condições de sobrevivência, razão crucial, candidataram-se ao programa de reforma agrária. Com isso, ficaram acampados e participaram das reuniões com a COOPVAG para a elaboração do PDA e tomaram parte das entrevistas realizadas para essa pesquisa, cujo tópico guia é: “Gostaria que ola senhorla me contasse como foi elaborado o Plano de Desenvolvimento do Projeto de assentamento Santa Tereza I, o PDA”. Faz-se necessário elucidar, porém, uma nota do diário de campo sobre o tópico guia: 
(123) Logo, na primeira entrevista, ocorreu uma situação também recorrente em outras entrevistas em relação ao tópico guia da minha pesquisa para geração de dados orais sobre o processo de elaboração do PDA Santa Tereza I. Ao pronunciar o tópico guia para a primeira pioneira entrevistada, esperava um relato sobre a elaboração do PDA, mas, para minha surpresa, obtive uma pergunta. A assentada me perguntou: Mas $o$ que é o PDA? Diante do desconhecimento sobre o que é o PDA ou não entendimento do tópico guia, necessitei alterar o tópico guia. Além disso, às vezes, a alteração do tópico guia não foi suficiente. Para obtenção do relato, houve necessidade de várias explicações sobre o que eu gostaria que o/a assentado/a me contasse.

(Nota 13 PA, 19 de julho de 2014)

O tópico guia foi elaborado pela pesquisadora, baseado na descrição configurada no PDA Santa Tereza I, no que concerne a participação de assentados/as pioneiros/as nas reuniões realizadas pela COOPVAG para elaboração do mesmo. A partir dele, havia a expectativa de que os/as pioneiros/as, por motivo de participação nas reuniões para a elaboração do PDA, soubessem que, a partir do conteúdo exposto, discutido nelas, resultaria um PDA para o PA onde são assentados/as. No entanto, essa expectativa não se configurou no início de várias entrevistas.

Por fim, faz-se necessário destacar os critérios de escolha das entrevistas inseridas aqui. A escolha se deve aos tipos de regularidades linguístico-discursivas configuradas nas entrevistas. Essas regularidades integram categorias de análise referentes à metafunção ideacional e à metafunção interpessoal, respectivamente, significado representacional e significado identificacional (FAIRCLOUGH, 2003), Como essas categorias de análise, são recorrentes no discurso de todas as aves pioneiras. Por necessidade de recorte, introduzi excertos de relatos no que se refere ao objetivo geral da pesquisa - as discursividades do PDA Santa Tereza I -, com vistas a uma triangulação na análise de dados de documento de língua oral (entrevistas) e análise de dados de língua escrita (PDA). Ademais, entre as entrevistas, por uma questão de representatividade de gênero, escolhi inserir excertos de entrevistas realizadas com assentados pioneiros e com assentadas pioneiras, com idades variadas, como exposto no quadro sinóptico a seguir.

Quadro 5.3 - Aves pioneiras com excertos na tese

\begin{tabular}{|c|c|c|c|}
\hline $\mathrm{N}$ & Pioneiro/a & Sexo & Idade \\
\hline 1 & Gavião-Carijó & $\mathrm{F}$ & 42 \\
\hline 2 & Carão & $\mathrm{F}$ & 50 \\
\hline 3 & Periquito-Rei & $\mathrm{M}$ & 48 \\
\hline 4 & Gralha-do-Campo & $\mathrm{F}$ & 54 \\
\hline
\end{tabular}




\begin{tabular}{|c|c|c|c|}
\hline 5 & Garça-Real & M & 74 \\
\hline 6 & Xexéu & M & 67 \\
\hline 7 & Gavião-Vaqueiro & M & 39 \\
\hline 8 & Suiriri & M & 41 \\
\hline 9 & Quero-Quero & $\mathrm{F}$ & 59 \\
\hline 10 & Bem-te-Vi & M & 67 \\
\hline
\end{tabular}

As vinte e uma entrevistas na íntegra estão à disposição nos anexos deste trabalho, sobretudo, como forma de incentivo a novas análises, além de significar um compromisso ético da pesquisadora em termos de imprimir validade ao trabalho de campo levado a cabo.

\subsection{O planejamento de pouso sob perspectiva das aves pioneiras}

As entrevistas realizadas no PA Santa Tereza I com foco, sobretudo, no processo de elaboração do PDA do mesmo, atendem ao propósito de distinguir representações linguísticodiscursivas de inclusão e/ou exclusão que o grupo de assentados/as pioneiros/as confere a si mesmo e que funcionários do INCRA-SR26 também o faz. De acordo com o propósito de distinguir representações linguístico-discursivas no PDA, optou-se pela realização de entrevistas semiestruturadas, a partir de um tópico guia a fim de obter relatos espontâneos, sem interferência da pesquisadora.

Para tanto, o tópico guia desenvolvido a partir da análise linguístico-discursiva do PDA, em período anterior ao início das entrevistas, foi: “Gostaria que o/a senhor/a me contasse como foi elaborado o Plano de Desenvolvimento do Projeto de assentamento Santa Tereza I, o PDA”. Como já exposto, esse primeiro tópico guia não foi suficiente para obtenção do relato dos/as assentados/as pioneiros/as sobre o processo de elaboração do PDA. Por isso, em algumas entrevistas, outro tópico guia foi utilizado: "Então eu gostaria que o/a senhorla me contasse como foram aquelas reuniões com a COOPVAG durante o período de acampamento".

As categorias utilizadas para análise da representação, nos dados de natureza oral, envolvem tanto a metafunção ideacional quanto a metafunção interpessoal. Especificamente, aqui, a primeira metafunção emoldura o Sistema de Transitividade (HALLIDAY \& MATHIESSEN, 2004), no que concernem processos, participantes e circunstâncias envolvidos. A segunda envolve o Sistema de MODO (HALLIDAY \& MATHIESSEN, 2004), sobretudo, no que se refere à modalidade e à polaridade. Ambos os sistemas são tratados no 
Capítulo 2. Ademais, cada enunciado analisado corresponde ao que se adota como unidade de informação. ${ }^{36}$

Os excertos, a seguir, integram partes das entrevistas semiestruturadas com os/as assentados/as referentes, sobretudo, ao tópico guia e envolvem regularidades linguísticodiscursivas entre si. A análise desses dados permitiu identificar entre três regularidades no que concerne o sistema de transitividade, especificamente, no que perfila a configuração dos tipos de processos materiais e suas vinculações tanto com o participante ator quanto com o participante circunstância, uma vez que esse tipo de processo aponta ações do mundo do fazer e do acontecer e representações dos seus participantes na elaboração do PDA Santa Tereza I. Nas entrevistas, também ocorrem regularidades em termos da metafunção interpessoal modalidade -, especificamente, no que se refere ao significado identificacional (FAIRCLOUGH, 2003).

A primeira regularidade revelada consiste na identificação da recorrência de processos materiais nos relatos das aves pioneiras sobre o processo de elaboração do PDA Santa Tereza I. O excerto (134) revela a utilização de processos materiais, com ações do mundo físico do fazer, realizáveis, principalmente, na voz ativa quando envolvem o participante ator 'COOPVAG' diretamente no processo de elaboração do PDA. O segmento (124) abaixo forma parte da entrevista do participante Gavião-Carijó.

(124) Gavião-Carijó: Não, ela chegava e: botava as proposta dela, trazia o telão, colocava aí. A gente olhava aí no que os projetos deles, trabalho deles, que era pra gente fechar com eles... E aí era só isso que eles vinha e fazia. Mostrava telão toda vez que vinha, mostrava o quê que era o trabalho deles que eles fazia em outros lugar, e aqui eles ia fazer do mesmo jeito... E aí só ficava nisso, num...

Pesquisadora: E todos os assentados que estavam no acampamento participavam da reunião?

Gavião-Carijó: Ah, a maioria participava. Quando a mulher não ia, o homem tava lá. Sempre quem ia mais era o meu marido, eu na época trabalhava. Aí, aí quando eles vinha, era no horário do meu serviço, eu num ia. Eles... a maioria era velho.

(Gavião-Carijó, 42 anos)

No segmento (124), primeiramente, há de se destacar o desconhecimento ave GaviãoCarijó, pelo menos em princípio, sobre o PDA e sua elaboração: “Aí é que tál que eu não sei...". Fez-se necessária, como em outras entrevistas, uma explicação mais detalhada da

\footnotetext{
${ }^{36}$ De acordo com Silva (2001), a unidade de informação equivale a uma porção do discurso concernente à estrutura da informação e que implica a interação de duas partes complementares: o que é dado e o que é novo, na concepção hallidayana (1989).
} 
pesquisadora no que refere ao processo de elaboração do PDA para que fosse possível a pioneira iniciar seu relato sobre o tópico guia. Além disso, a primeira regularidade linguísticodiscursiva configurada consiste na identificação da recorrência de processos materiais nos relatos das aves pioneiras sobre o processo de elaboração do PDA Santa Tereza I. Os processos materiais concretos - botava, trazia e colocava - configuram ações concretas realizadas pela COOPVAG em termos de agência não somente para apresentar propostas para o PDA, mas também para que essas propostas apresentadas fossem escolhidas e votadas pelos/as pioneiros/as. Ocorrem, nos excertos, ações do mundo físico do fazer, realizáveis, principalmente, na voz ativa quando envolvem diretamente o participante ator 'COOPVAG' no processo de elaboração do PDA.

Em relação à representação do participante ator, incide a segunda regularidade identificada, relacionada ao sistema de transitividade, tratando dos modos de configuração do participante ator em vinculação com os processos materiais. Há um tipo de recorrência do participante ator quando se refere à COOPVAG e outro tipo quando o ator se refere ao/à assentado/a. Isso se comprova na unidade de informação 'A gente olhava aí no que os projetos deles, trabalho deles, que era pra gente fechar com eles... E aí era só isso que eles vinha e fazia'. Nessa unidade de informação, há o uso da forma pronominal indefinida ' $a$ gente', no caso, faz-se participante experienciador do processo mental perceptivo 'olhava' e dos fenômenos 'projetos deles' e 'trabalhos deles'. A expressão 'a gente', de certa forma, é "apassiva" os pioneiros/as na relação com os outros participantes. Esse participante se constitui como observador das propostas elaboradas, como beneficiário, uma vez que os fenômenos atribuem "posse" e autoria dos projetos e dos trabalhos apresentados à COOPVAG: 'deles'.

A entrevista da pioneira Gavião-Carijó também envolve a terceira regularidade linguístico-discursiva em termos de metafunção interpessoal, principalmente, a recorrência de modalidade.

(125) Gavião-Carijó: Não, ela chegava e: botava as proposta dela, trazia o telão, colocava aí. A gente olhava aí no que os projetos deles, trabalho deles, que era pra gente fechar com eles... E aí era só isso que eles vinha e fazia. Mostrava telão toda vez que vinha, mostrava o quê que era o trabalho deles que eles fazia em outros lugar, e aqui eles ia fazer do mesmo jeito... E aí só ficava nisso, num... 
Gavião-Carijó utiliza duas vezes o adjunto modal/advérbio modalizador 'só'. Ressalte-se que os advérbios modalizadores expressam, segundo Neves (2000), alguma intervenção quanto à validade e ao valor do enunciado pelo falante, que mobiliza quanto ao valor da verdade, quanto ao dever, restringe o domínio, define a atividade e avalia a própria formulação linguística. Em termos do significado identificacional, há avaliações sobre as ações realizadas pela assistência (apresentação de projetos e trabalhos). A pioneira emite uma declaração com juízo de valor sobre o trabalho da COOPVAG. Há, pois, uma avaliação de apreço negativo representada pela polaridade negativa 'só', julgando o trabalho como "pouco". Os adjuntos modais são utilizados com frequência pelos/as pioneiros/as.

Nessa perspectiva, a entrevista da pioneira Carão indica tanto regularidades encontradas e analisadas na de Gavião-Carijó, quanto outras.

(126) Carão: Hum, através da: COOPVAG, prestadora de serviço aqui, assistência técnica nossa, né? Depois de várias reuniões, muitas, muitas é:.. reuniões que a gente foi fazendo, teve: alguns fórum... não fórum, uma, ai meu Deus, umas oficinas, cursos, oficinas, né? vários cursos, oficinas e tudo. Eles elaboraram o PDA, assim colocando todas as nossas necessidade:, incluindo todos o, a:, no momento o que mais necessitamos aqui, né? o que temos, o que não temos, né? O que precisa vir, né? Principalmente a água, que é pouca.

(Carão, 50 anos)

Observe-se, no início da entrevista, a compreensão da pioneira Carão, diferentemente de outras aves, sobre o tópico guia. Após ouvi-lo, imediatamente, colaborou com a entrevista, mencionando a COOPVAG com papel agenciador na elaboração do PDA, afirmando que ocorreram várias reuniões para elaboração do PDA.

Parte do relato de Carão elucida processos materiais, entre eles o processo material concreto 'elaboraram' na voz ativa e seus participantes 'meta' 'PDA' e 'ator' 'eles' estão explícitos. O ator 'eles', que retoma COOPVAG, os funcionários dela, envolve o papel de agente na elaboração do PDA. Há presença explícita do participante ator dos processos do sistema de transitividade, quando emoldura o participante 'COOPVAG' e o participante 'assentado/a', no entanto, o modo de configuração se faz diferente.

No que concerne outra regularidade, a regularidade do participante ator, a 'COOPVAG' assume o papel de ator da ação de 'fazer', elaborar o PDA: 'Eles elaboraram o PDA, assim colocando todas as nossas necessidade:, incluindo todos o, a:, no momento o que mais necessitamos aqui, né? o que temos, o que não temos, né?'. O fato de a COOPVAG expor os programas produtivos entre outras demandas, apresentar as necessidades do PA, 
parece sinalizar que, aos/às pioneiros/as, somente compete concordarem com esses “esclarecimentos", serem beneficiários. Também, o fato dela ter sido secretária da associação de moradores do PA na época de elaboração do PDA parece fazê-la crer que a COOPVAG inseriu todas as necessidades dos/as assentados/as no documento, cumprindo seu papel de assistência técnica, além dela também se sentir representada no texto pelo mesmo motivo. Observa-se ainda que, dentre os/as assentados/as entrevistados, Carão foi a única a relatar já ter visto o PDA e que o mesmo foi apresentado aos/às assentados/as na associação do projeto de assentamento.

Ressalte-se, da mesma forma, o papel desse ator e o papel do participante 'a gente' como participantes de processos materiais no excerto. Enquanto o processo material concreto 'elaboraram', que envolve o ator 'COOPVAG', aponta uma ação realizada no tempo passado, com início e fim determinados; o processo material concreto 'foi fazendo' envolve um ator 'a gente', indefinido e aponta uma ação realizada no tempo passado com início, mas fim indeterminado. Faz-se uma ação mais vaga que a primeira em termos de especificação de realização. Além disso, o ator 'COOPVAG' é individualizado no papel de agente, é determinado de forma direta; já o ator 'a gente', enquanto forma pronominal indefinida na visão de Silva (2013), não envolve um papel de agente único, inclui "eu” (Carão), os/as outros/as pioneiros/as e a COOPVAG, a agência de realização da ação faz-se coletiva, há agentes. Nessa perspectiva, a forma gramaticalizada 'a gente' tende neutralizar o sujeito do discurso que estava presente nos encontros com a COOPVAG para a discussão sobre o planejamento de desenvolvimento do futuro projeto de assentamento em detrimento do uso do pronome pessoal de primeira pessoa.

No âmbito do excerto analisado, em termos do significado representacional, a forma pronominal indefinida 'a gente' sugere uma estratégia de apagamento da participação específica da pioneira Carão na elaboração do PDA ou do pronome pessoal de primeira pessoa, pois tal forma inclui a participação de todos/as pioneiros/as, inclusive Carão, ou seja, sugere que participação nos encontros promovidos pela assistência técnica foi coletiva e não individual. Todavia, a agência “maior” nessas ações continua sendo da COOPVAG.

Ao participante INCRA é atribuída a mesma agência que a COOPVAG assume, uma vez que esta última representa o INCRA. Para tanto, o processo relacional atributivo circunstancial 'estava' aparece com o portador 'INCRA', o atributo/ circunstância de modoqualidade 'junto' e a circunstância de localização-tempo 'sempre'. Esses participantes descrevem e avaliam a participação do órgão governamental. A avaliação também se remete ao significado identificacional e se constitui tanto com o atributo/circunstância ‘junto' que 
caracteriza o portador 'INCRA' e, igualmente, avalia positivamente o modo como ele participava quanto com a circunstância 'sempre' que também avalia de maneira positiva o órgão no que concerne o tempo, a duração da participação, já que é dita constante.

Em termos de representações configuradas através da análise do sistema de transitividade, na entrevista de Carão acontece também a terceira regularidade: recorrência do participante circunstância, envolvido em processos materiais. No fragmento (136), a circunstância de localização-tempo 'no momento o que mais necessitamos' e a circunstância de localização-lugar 'aqui' reiteram a agência da assistência técnica com papel de agente tanto no processo de elaboração do PDA como no momento de transição dos/as pioneiros/as do acampamento para os lotes do PA (marcadores de tempo-lugar). Ao que parece esses marcadores circunstanciais tentam "solidarizar" o trabalho da COOPVAG naquele momento e naquele lugar. Nessa entrevista, também aparecem outros marcadores circunstanciais. Vejamos.

(127) Carão: Ah::: como foi uma:, é tudo muito claro, muito franco, abertamente as coisas, os esclarecimento deles, né? Então a gente, a participação foi de todo mundo concordar com as coisas, do que tinha que ser seguido ali, né? Um PDA que foi feito exclusivamente na nossa necessidade, né? Em vista nossas, nosso dia a dia aqui, como seria, né? E creio que cada PDA tenha a sua história, né?

(Carão, 50 anos)

Em (127), a circunstância de localização-lugar 'ali' situa, em termos de espaço, onde ocorriam as reuniões com a COOPVAG, remete ao acampamento, local onde seria o PA. Ainda, o uso do processo material concreto 'foi feito' e de duas circunstâncias 'exclusivamente' (circunstância de modo-qualidade) e 'na nossa necessidade' (circunstância de causa-propósito) apontam para a justificativa do trabalho da COOPVAG. Essas circunstâncias, de certa forma, também avaliam positivamente "a ação" da assistência técnica de fazer o PDA.

No excerto acima, há também regularidade quanto o uso do recurso léxico-gramatical adjunto modal, como na entrevista de Gavião-carijó. A pioneira relata a participação dos/as assentados/as através da avaliação dos procedimentos da COOPVAG nas reuniões no que se refere ao significado identificacional. O processo relacional atributivo 'é' envolve o portador 'os esclarecimento deles/tudo' e os atributos 'muito claro', 'muito franco', de modo que o portador também remete à participação da COOPVAG ao invés de relatar a participação dos/as pioneiros/as na elaboração do PDA, de acordo com a unidade de informação anterior 
da pesquisadora. O atributo 'tudo', por sua vez, caracteriza positivamente as ações da COOPVAG. Essas caracterizações constituídas, em termos de significado identificacional, configuram avaliações de apreço através do uso de adjuntos modais e predicativos: 'muito claro' (Valor/circunstância de modo-grau), 'muito franco'(Valor/circunstância de modograu), 'abertamente as coisas' (Valor/circunstância de modo-grau). As avaliações, feitas por Carão, sobre os esclarecimentos da COOPVAG em relação ao PDA, são de apreço positivo e apontam para a interpretação de que a pioneira considera a participação dos/as pioneiros/as atrelada à avaliação positiva dos esclarecimentos da COOPVAG.

No excerto (127), ainda ocorre outra regularidade quanto à modalidade em termos de verbos modalizadores. A concordância com os esclarecimentos da COOPVAG (deles) faz-se atributo, característica, para o tipo de participação dos/as pioneiros/as na elaboração do PDA. Isto é, essa participação se caracteriza somente pela aprovação do que é exposto pela COOPVAG, à medida que o atributo 'de todo mundo concordar com as coisas, do que tinha que ser seguido ali, né?' aponta uma justificativa para o tipo de participação dos/as pioneiros/as, 'todo mundo'. Fica implícito que essa participação configura na concordância com 'os esclarecimentos deles', com as propostas expostas pela COOPVAG. Uma vez já avaliada positivamente, ainda reitera-se a participação da assistência técnica com o uso da modulação em comando no grau de obrigação (HALLIDAY \& MATHIESSEN, 2004) 'tinha que ser'. Os/as pioneiros/as tinham obrigação de concordar com esclarecimentos, proposições feitas pela COOPVAG acerca do PDA, haja vista a COOPVAG tê-lo elaborado 'somente por motivo de necessidades' do PA e, consequentemente, dos/as futuros/as assentados/as.

De acordo com o fragmento (128), a seguir, a entrevista do assentado pioneiro Periquito-Rei configura as mesmas regularidades linguístico-discursivas das entrevistas analisadas anteriormente, mas com uma incoerência em relação ao mundo factual relatado por outros/as pioneiros/as.

(128) Periquito-Rei: Aqui, pra começar foi feito pelo... pelo sindicato de Santa Tereza, né? Na época, não tinha sindicato de Ponte Alta. Aí depois é que, através do de Santa Tereza, foi fundado o sindicato de Ponte Alta. Aí, na época, foi feita a reunião e eu sempre não ficava aqui muito, né? Agora, no dia da reunião, eu tava. E sobre as aplicação... Eu não tenho muito o que reclamar não, né? Porque certas coisinha a gente vai deixando, né? E, às vezes, a gente é... a gente deixa a desejar, mas acho que tinha mais umas coisas que precisava ter sido mais correto, né? Além de tudo, demorou de ser cortado a terra e... Depois disso, acho que o dinheiro das casas também não foi bem aplicado porque teve umas sobras de, dinheiro... 
Pesquisadora: Uhum. E qual foi o papel do senhor na elaboração desse documento?

Periquito-Rei: Nas reunião, eu não tava não. Sempre eu tava trabalhando fora, né? Daí pra cá, eu não trabalhei mais fora não. Depois que cortou, a gente mudou pra cada um... cada um mudou pra dentro da parcela. Eu quase num trabalhei mais pra fora.

(Periquito-Rei, 48 anos)

O fragmento (128) configura, como na entrevista de Gavião-carijó já analisada, o desconhecimento de Periquito-Rei sobre a elaboração do PDA. Além disso, há de se destacar uma incoerência no que concerne um fato real ocorrido durante a elaboração do PDA. O pioneiro atribui ao ator 'sindicato de Santa Tereza' a agência de elaboração do PDA, sendo incoerente com a realidade. O PDA do PA Santa Tereza I não foi elaborado pelo sindicato do município de Santa Tereza, até pelo motivo de que o PA, em questão, faz parte do município de Ponte Alta. O pioneiro relatou não possuir conhecimento sobre a origem da equipe técnica responsável pela elaboração do PDA, nem citou o ator COOPVAG. O uso do processo material concreto na voz passiva 'foi feito' comprova isso através do ator 'sindicato de Santa Tereza'.

O relato do pioneiro Periquito-Rei também envolve várias vezes o participante circunstância como 'na época, sempre, aqui muito, nas reunião, depois que cortou'. O enunciado 'Depois que cortou, a gente mudou pra cada um' constrói, de certa forma, uma relação de "causa-consequência" com os dois primeiros. No primeiro, o processo material concreto na 'foi feita' na voz passiva explicita a meta 'reunião' e a circunstância de localização-tempo 'naquela época' e apaga o ator. Desse modo, a circunstância remete à localização do período de ocorrência da informação relatada - época do acampamento -, a meta indica o conhecimento sobre a existência das reuniões e o apagamento do ator/agência responsável pela 'ação do fazer' reforça a informação de desconhecimento da equipe elaboradora do PDA. A expressão circunstancial 'Depois que cortou', não só localiza no tempo o período em que as terras do PA foram “cortadas" (loteadas, parceladas) como também determina o período informado pelo Periquito-rei de alteração de seu domicílio para o assentamento. Assim, esse enunciado se faz uma causa que pode ter sido usada para justificar certa "dificuldade" do pioneiro para estar presente nas reuniões no acampamento, haja vista não residir nesse acampamento. Ele passou a residir no PA quando os lotes foram marcados/divididos e sorteados. Vale ressaltar ainda que essa declaração difere das declarações de outros/as pioneiros/as, uma vez que relataram, nas entrevistas, terem residido no acampamento por dois anos e terem participado das reuniões promovidas pela COOPVAG. 
O pioneiro também justifica a baixa presença nas reuniões: 'eu sempre não ficava aqui muito, né?'. O processo relacional identificativo circunstancial 'ficava' identifica que Periquito-rei, de modo geral, não permanecia no acampamento através do identificador/circunstância de localização-lugar 'aqui' e das circunstâncias/adjuntos modais 'sempre' e 'muito'. A circunstância de localização-tempo 'sempre' e a circunstância de localização-tempo 'muito' se relacionam com o processo relacional.

Notadamente, o enunciado 'Nas reunião, eu não tava não', reitera a representação de pouco conhecimento sobre o processo de elaboração do PDA por parte do Periquito-rei e, no âmbito do significado identificacional, envolve o processo relacional identificacional circunstancial 'tava' (estava), a circunstância de localização-lugar 'Nas reunião'.

Os relatos dos/as pioneiros/as também permitem identificar outra regularidade linguístico-discursiva referente à metafunção interpessoal, especificamente, no que concerne o significado identificacional. Faz-se recorrente o uso do recurso léxico-gramatical polaridade negativa.

(129) Periquito-Rei: Aí, na época, foi feita a reunião e eu sempre não ficava aqui muito, né? Agora, no dia da reunião, eu tava. E sobre as aplicação... Eu não tenho muito o que reclamar não, né? Porque certas coisinha a gente vai deixando, né? E, às vezes, a gente é... a gente deixa a desejar, mas acho que tinha mais umas coisas que precisava ter sido mais correto, né? (...)

Periquito-Rei: Nas reunião, eu não tava não. Sempre eu tava trabalhando fora, né? Daí pra cá, eu não trabalhei mais fora não. Depois que cortou, a gente mudou pra cada um... cada um mudou pra dentro da parcela. Eu quase num trabalhei mais pra fora.

(Periquito-Rei, 48 anos)

Por um lado, o pioneiro Periquito-Rei não somente fez uso da polaridade negativa 'não' para apontar sua ausência no dia-a-dia do acampamento, como fez uso da circunstancia de localização-tempo 'sempre' para intensificar a representação de ausência dele no acampamento, a polaridade negativa é reforçada. Por outro lado, também há o uso da polaridade positiva - 'Agora, no dia da reunião, eu tava' - em oposição à polaridade negativa intensificada no que se refere ausência do acampamento. Ao que parece, o uso da polaridade positiva tenta neutralizar o uso da polaridade negativa intensificada, justificando a ausência no acampamento com a presença no dia das reuniões. Devido ao motivo de estar pouco no acampamento, por trabalhar e residir fora de lá, teve baixa participação nas reuniões ditas para elaboração do PDA. Todavia, no mesmo relato, o pioneiro também através do uso da polaridade negativa se contradiz em relação à presença nas reuniões para elaboração do PDA. 
Para tanto, a polaridade negativa ' $n \tilde{a} o$ ' se repete duas vezes. O uso repetido da polaridade negativa amplia uma identificação negativa do pioneiro em relação às reuniões promovidas pela COOPVAG na época do acampamento e, consequentemente, ao processo de elaboração do PDA.

Já o excerto (130) integra parte da entrevista da pioneira Gralha-do-Campo enfatiza o papel agenciador da COOPVAG em relação às propostas para o PDA Santa Tereza I.

(130) Gralha-do-Campo: Não, eu mermo, eu mermo pra dizer assim... Eu lembro, assim, muitas coisa, mas só que ... é é de explicar, assim, num dou conta, sabe? Tem muitas coisa que, devido o tempo, a gente já esqueceu, que eu vivo com problema de esquecimento. Acho que é da idade, sei lá. Aí tanta preocupação a gente tem, né?

Pesquisadora: Hum rum. /.../Mas eu vou lembrando a senhora então. Naquela época, a COOPVAG se reunia com vocês. Eu gostaria de saber como a COOPVAG fazia essas reuniões?

Gralha-do-Aampo: Trazia, hum rum. Eles mesmo que escolhia, escolhia. Nós num escolhia não. Eles escolhia e acabava não fazendo nada. Igualmente, a gente inté hoje mesmo, a gente não tem. E aí, como diz, sairo e ... não deixaro nada definitivo assim pra gente. Então eu digo que ela não, não ... queria trazer alguma coisa boa, mas ao mesmo tempo num trazia, por causa que projeto não aprovou ... não foi aprovado.

Pesquisadora: Hum rum. E a senhora acha que, naquelas reuniões, quando surgiu o PDA, houve uma elaboração participativa, ou seja, entre COOPVAG, o INCRA e os assentados?

Gralha-do-Campo: Foi o INCRA e a COOPVAG. Acho que foi os dois. A:cho não, tenho certeza. Porque tinha reunião que eles tava junto. E nós também, né? Porque nóis ... assim, nós falar é ... alguma opinião que pedia a nóis, nóis ... falava.

(Gralha-do-Campo, 54 anos)

Em primeiro lugar, há de se observar o início da entrevista com a ave Gralha-doCampo, uma vez que a mesma sugere uma dificuldade do entrevistado para relatar o processo de elaboração do PA Santa Tereza I, embora o/a falante utilize processos mentais, do mundo da consciência, e não de materiais como outros/as pioneiros/as. já no primeiro enunciado: ' $E u$ lembro, assim, muitas coisa, mas só que... é é de explicar, assim, num dou conta, sabe?'. Os processos 'lembro', 'explicar', 'dou conta' (sei) são mentais cognitivos, representam relações do mundo da consciência em relação, principalmente, ao pensar. Destacam-se os participantes relacionados a esses processos mentais, pois o experienciador 'Eu', pronome pessoal de primeira pessoa no singular, envolve a própria pioneira de modo que assume e individualiza sua experiência em termos de pensamento ('Eu lembro de muitas coisas, mas eu não sei 
explicá-las'); e o fenômeno 'muitas coisa', ao considerá-lo como retomada de parte do tópico guia, refere-se às reuniões realizadas pela COOPVAG.

Além do mais, destaca-se que o ator relacionado à ação material de "trazer" as propostas para a reunião é atribuída à COOPVAG. Já o processo material 'escolhia' ('Eles mesmo que escolhia, escolhia. Nós num escolhia não. Eles escolhia e acabava não fazendo nada') é repetido quatro vezes no enunciado analisado. Esse processo se relaciona, em três dos usos, ao ator 'Eles' explícito (COOPVAG) e à meta implícita 'propostas' (propostas para o PDA), como ocorre com o processo 'trazia'. Fica implícito que essas repetições do processo 'escolhia' - também do mundo do "fazer" - e a repetição explícita do ator "enfatizam a agência no que concerne a "ação de escolher" as propostas inseridas no PDA. A pioneira, em um quarto uso, também utiliza o processo 'escolhia' ('Nós num escolhia não.') relacionado à mesma meta implícita dos outros 'propostas', mas relacionado a um outro ator: 'Nós'. Nesse enunciado, o ator se refere não só ao "eu" (Gralha-do-Campo), mas aos outros/as pioneiros/as. É um ator de ação coletiva no "mundo físico do agir", que inclui todos/as pioneiros/as na ação de 'escolher' as propostas para o PDA.

Parte da entrevista da pioneira Gralha-do-Campo também elucida a recorrência da modalidade, sobretudo o recurso verbos modais. Ao apontar o INCRA/COOPVAG como elaborador do PDA, o discurso da Gralha-do-Campo modaliza repetidamente a participação do INCRA e da COOPVAG em tal elaboração. O uso da forma modal 'acho' e da expressão 'tenho certeza' corrobora para a construção de valores de julgamento da opinião da pioneira sobre as participações de atores na elaboração do PDA no que concerne a modalização, tanto a modalidade epistêmica quanto a deôntica. Como já explicado no Capítulo 2, enquanto na modalidade epistêmica ou modalização, as ações dos agentes estão no campo da probabilidade ou da usualidade; na modalidade deôntica ou modulação, as ações dos agentes estão no campo da obrigação ou inclinação (HALLIDAY \& MATHIESSEN, 2004).

Por um lado, o verbo modal 'acho', no contexto de uso aqui, sugere baixo grau de probabilidade (modalização), uma modalidade epistêmica. Por outro lado, o segundo uso desse verbo modal se atrela à polaridade negativa 'não' e sugere maior grau de probabilidade, ou seja, há a negação do que ele "acha”, pensa em princípio. A 'COOPVAG', que representa o 'INCRA' envolve a agência tanto de levar e escolher propostas para inserção no PDA assim como de elaborar o mesmo. Ademais, o uso da expressão 'tenho certeza' reitera e amplia a negação, pois não está mais no contexto da probabilidade e, sim, no da obrigação (modulação, modalidade deôntica). Os recursos linguístico-discursivos usados pela pioneira revelam um alto valor de julgamento dela em relação ao agente elaborador do PDA. Para a pioneira, a 
COOPVAG/INCRA elaborou, pois, o PDA, o que evoca o pensamento de Fairclough (2003, p. 166), para quem “com o que você se compromete é parte significante do que você é”. Isto é, a pioneira ao modular o seu discurso em termos de "obrigação" de elaboração do PDA à COOPVAG e ao INCRA, ela argumenta não ser participante agente dessa elaboração. Parte do processo de textualização da identidade do falante (no caso, da pioneira) se constitui nas escolhas de modalidade.

O excerto (130) parte da entrevista da pioneira Gralha-do-Campo também ocorre o uso do recurso léxico-gramatical polaridade negativa: 'Nós num escolhia não. Eles escolhia e acabava não fazendo nada'. O uso da polaridade negativa 'não' faz-se frequente relacionado a processos materiais. A polaridade negativa 'não', usada duas vezes - 'num' e 'não'-, está envolvida com o processo material 'escolhia'. A repetição dessa polaridade negativa reforça a não escolha dos/as pioneiros/as no que se refere às propostas para o PDA. Também avalia, em termos de significado identificacional, negativamente a agência da COOPVAG. De acordo com Gralha-do-Campo, a assistência técnica tanto levava para as reuniões as propostas dela como também escolhia as propostas a serem inseridas no PDA, cabendo aos/às pioneiros/as um papel passivo em relação a essas duas ações.

A entrevista de Garça-Real também sinaliza regularidades referentes à metafunção ideacional (significado representacional) e à metafunção interpessoal (significado identificacional) e, principalmente, sinaliza um papel passivo e de beneficiário dos/as pioneiros/as, como se identifica nos fragmentos (131) e (132).

(131) Garça-Real: Eles trazia pra mostrar. No dia da reunião, nós todos ia. Todo mundo ia. Só que eles passava na tela que ia acontecer aqui::lo, que ia fazer aquilo pra nós e pe lê lê e tá tá tá. E nada saia. Até a casa foi diferente. Então, nada aconteceu ... até hoje.(...)

Pesquisadora: Então, qual foi a participação do senhor nesse plano de desenvolvimento do assentamento?

Garça-Real: Bom, eu creio que ajudou produzir, porque eu era uns dos que, né? Aí, eu creio que foi um que foi ajudado. E todo mundo conversava um poquim e eles escutava, né? Eu creio que, no meu entendimento, é esse, não sei se é isso.

(Garça-Real, 74 anos)

Nessa parte da entrevista, os processos utilizados para relatar o processo de elaboração do PDA em termos de participação de agentes são os processos materiais 'trazia' e 'passava'. Os dois processos materiais são concretos, de ações realizadas no mundo físico do "fazer" envolvem a mesma meta implícita: as propostas projetadas iriam ocorrer ('que ia acontecer aquilo'). Além disso, esses processos elucidam o mesmo beneficiário: o/as acampado/as na 
época ('para nós'). Assim, o pioneiro Garça-Real, como outros, parece mero beneficiário das ações propostas e futuramente realizadas pela COOPVAG: 'Só que eles passava na tela que ia acontecer aqui::lo, que ia fazer aquilo pra nós e pe lê lê e tá tá tá.'. No enunciado, também o processo material 'ia fazer' está configurado de maneira modalizada no tempo futuro do pretérito do modo indicativo. Isto é, trata-se de uma ação do mundo físico 'não realizada' e comporta-se, aqui, como processo material abstrato.

Em relação ao participante ator, a entrevista de Garça-Real também envolve o mesmo modo de configuração de outras entrevistas analisadas aqui. A configuração do participante ator com referência à COOPVAG é 'Eles', atrelado ao processo material concreto 'trazia' e 'passava'. A esse ator e sugerida a agência da ação de passar "as propostas" e também se sugere a agência da COOPVAG em apontar que uma possível realização no futuro das propostas, uma vez o processo 'ia acontecer' aparece no futuro do pretérito do indicativo aconteceria. Já o ator que se refere ao/à assentado/a se configura em três formas: 'nós, todo mundo e eu'.

O próximo fragmento (132) já faz parte da parte da entrevista sobre a situação de vida dos/as pioneiros/as no acampamento e sobre as “(não) ações” da COOPVAG e do INCRA no período do PA posterior ao acampamento.

(132) Garça-Real: Não. Eu quero dizer pra senhora a verdade, que não foi feito nada. Era só reunião, reunião e o que eles prometia nada fez, nunca saiu nada. Quando a gente chegou aí, eles sustentava o povo aí, aqui acolá. Eles dava umas cestinhas lá pro povo num morrer de fome. INCRA era cesta, do INCRA era cesta só. Todo mundo sentado aí, muitos queria trabalhar, num podia sair porque se saísse, perdia, né? Era aquela coisa... É que primeiramente a proposta do INCRA era a seguinte: se nós afastasse ao menos duas semana, já não ganhava a terra. Se passasse 30 dia fora daqui, era mandado embora, despejado. É abandono ... E aí, nós aguentava, aguentando aqui . Outros num aguentava, porque isso aqui dói mermo. Abria fora. Outros aí tinha muito fílho...

(Garça-Real, 74 anos)

Os recursos léxico-gramaticais utilizados por Garça-Real são, de certa forma, parte do desabafo em relação a informações negativas sobre as condições de sobrevivência a que acabam sendo submetidos/as no acampamento. O uso dos marcadores discursivos 'Não' e 'dizer a verdade' introduzem a percepção do pioneiro da falta de ações concretas realizadas de infraestrutura no PA. A polaridade negativa ' $n \tilde{a} o$ ', recurso da metafunção interpessoal, inicia o discurso e envolve uma avaliação de apreço negativo sobre ações da COOPVAG. O processo mental desiderativo 'quero', no tempo presente, também representa o desejo do 
experienciador ' $e u$ ' (do próprio pioneiro) em relatar a sua experiência, a sua verdade, sobre o tipo de vida naquele período. Essa vontade de externar a experiência é projetada na oração 'dizer pra senhora a verdade'. Por sua vez, a 'verdade' é esclarecida na oração projetada pelo processo 'dizer': 'Eu quero dizer [que não foi feito nada]'. No caso, a verdade do pioneiro aponta para a falta de ações da COOPVAG no PA. O processo material concreto 'foi feito' na voz passiva omite o ator (COOPVAG), mas explicita a meta 'nada', enfatizando-a tanto por que está explicita quanto pelo uso da polaridade negativa 'não'. Além disso, a polaridade negativa 'num', em 'Eles dava umas cestinhas lá pro povo num morrer de fome.', também denuncia a situação de vulnerabilidade social, econômica vivida, bem como aponta que a distribuição de cestas básicas no acampamento servia tanto para manter as pessoas vivas' quanto para prover a permanência das pessoas no acampamento. Ideia que é reforçada por outra polaridade negativa 'Todo mundo sentado aí, muitos queria trabalhar, num podia sair porque se saísse, perdia, né?'. Segundo Garça-Real, as pessoas acampadas eram ameaçadas a perderem a candidatura a um lote no novo assentamento, caso deixassem o local, até mesmo para trabalharem. Para Garça-Real, as propostas ficaram somente nas propostas projetadas durante as reuniões: 'Era só reunião, reunião e o que eles prometia nada fez, nunca saiu nada'. As propostas ficaram no plano das promessas.

O segmento (133) trata de parte da entrevista do pioneiro Xexéu, que reforça e amplia a representação das aves pioneiras com papel passivo no que concerne à elaboração do PDA. Vejamos.

(133) Xexéu: Eles fazia umas coisas assim, sabe, que a gente ficava assim quase assim vendido, sabe? Umas coisas a gente entendia e outras coisa aquilo passava e a gente ficava em dúvida com aquele negócio. Num era quase assim... A gente ficava naquela dúvida: "Será que isso vai acontecer ou esse negócio não vai acontecer?" A gente ficava naquela dúvida.

Pesquisadora: Mas quem o senhor acha que elaborou?

Xexéu: Quem nóis que acha? Era a COPVAG com o presidente, num é? Então eles combinava e fazia aquele documento junto. O INCRA fazia aquele relatório e entregava pro presidente. Entregava pro presidente e o presidente resolvia com a COOPVAG. Era isso que eles fazia.

(Хexéu, 67 anos)

A entrevista do pioneiro Xexéu envolve as mesmas categorias linguístico-discursivas das entrevistas anteriores e relata, sobretudo, a relação de dependência, de subordinação dos/as pioneiros/as diante o INCRA, a COOPVAG devido à esperança das propostas e promessas se concretizarem: 'Eles fazia umas coisas assim, sabe, que a gente ficava assim quase assim vendido, sabe?'. Isso ocorre logo no início do segmento (133), onde há uma 
regularidade de um processo material emoldurar "ações concretas do mundo físico do fazer" ligada ao agente 'Eles', o que distancia essa ação do eu falante, no caso, o próprio pioneiro. $\mathrm{O}$ processo material 'fazia' emoldura o participante ator 'Eles', o qual faz referência à COOPVAG, e o participante meta 'umas coisas', a qual faz referência às propostas e promessas da COOPVAG/INCRA.

Destaque-se também que esse enunciado se faz motivo, causa para uma característica apontada aos/às pioneiros/as: 'que a gente ficava assim quase assim vendido'. O processo relacional atributivo 'ficava' envolve, por sua vez, o portador 'a gente', no caso, os/as pioneiros/as e o atributo circunstancial 'quase assim vendido'. Esse atributo configura uma característica pejorativa, conferida a si próprio e aos pares. Ao mesmo tempo, a expressão 'quase assim vendido' também se faz um adjunto modal de modo-comparação, com uma avaliação negativa. As aves pioneiras são caracterizadas e, de certo modo, avaliadas como "subornadas" pela COOPVAG, devido ao fato de serem levadas a concordarem com o que era proposto pela assistência técnica para que conseguissem participar do PA Santa Tereza I. Tal conformidade é reforçada pelo uso do processo 'fazia' duas vezes logo em seguida: 'Então eles combinava e fazia aquele documento junto. O INCRA fazia aquele relatório e entregava pro presidente. Entregava pro presidente e o presidente resolvia com a COOPVAG'. A agência de ações do mundo concreto está relacionada ao ator COOPVAG/INCRA, cabendo à/ao acampado/a um papel de passividade. Como já refletido anteriormente, nas entrevistas, as ações materiais concretas se relacionam, sobretudo, ao ator/agente COOPVAG/INCRA, enquanto que muitos processos que envolvem as aves pioneiras são do "mundo das relações abstratas", configurando, às vezes, uma representação pejorativa, de submissão às/aos pioneiros/as.

Durante a entrevista o pioneiro também relatou em detalhes alguns procedimentos da COOPVAG durante as reuniões, conforme o excerto (134) a seguir.

(134) Xexéu: Eles fazia o seguinte: eles se projetava uma coisa dizendo assim: "- Fulano, você tem que agir dessa forma, aqui, você pega uma foice, faz um mutirão". Pensa bem, "faz um mutirão, e põe a foice no cerrado e joga capim". Eu digo:

_. Meu Deus, pelo amor de Deus, isso aí não funciona, eu quem quiser fazer isso pode fazer. Eu, Xexéu, que nasci e me criei na roça, isso aí não, não tem saída. Como é que um capim ia formar num cerrado seco, sem o trator passar? Só com roçado de foice ele ia prestar? Ele ia funcionar?

Aí eu digo:

_ Não, eu não faço. Aí ainda teve uns que fizero. Aí pro lado de Santonópolis, fiquei sabendo que fizero, nunca funcionou, nunca. Nem 
gramar não gramou. E aí eles vinha com essas coisas. Eu digo: não, essas coisas aí eu vou eu vou pela minha parte, tá dispensada.

(Xexéu, 67 anos)

Já no início do excerto (134) há o uso de um processo material concreto 'fazia' referente ao plano físico do fazer (realização de uma ação concreta), acompanhado pelo participante ator 'Eles' e pela meta 'o seguinte': 'Eles fazia o seguinte: eles se projetava uma coisa dizendo assim:'. O ator 'Eles' faz referência à COOPVAG, o que afasta esse ator do ' $e u$ ' assentado, além de ser configurado como o agente da ação de 'realizar algo', no caso, a meta. Já a meta (o seguinte) desse processo projeta uma oração com uma fala de um técnico da COOPVAG em relação a uma orientação para o plantio de capim, durante uma reunião para elaboração do PDA: ““- Fulano, você tem que agir dessa forma, aqui,’. Essa projeção inicia, por sua vez, com o uso de uma modulação de obrigação (modalidade deôntica) 'tem que' relacionada ao processo material concreto 'agir', ao ator 'você' e à circunstância 'dessa forma'. Isto é, segundo Xexéu, Os/as técnicos/as da COOPVAG tentavam determinar, em termos de obrigar, as ações das pessoas, na época, acampadas. Além disso, a circunstância de modo meio - dessa forma - explicitam algumas ações determinadas pela assistência técnica para os/as acampados/as, os modos de "agir" necessários: você pega uma foice, faz um mutirão”. Pensa bem, “faz um mutirão, e põe a foice no cerrado e joga capim”. Ao explicitar essas determinações da assistência, ele enfatiza essas ações com o uso da repetição delas, introduzida pela oração 'Pensa bem' com função de uma expressão de modulação de obrigação para levar a sua interlocutora (no caso, a pesquisadora) a partilhar da avaliação negativa que ele começa a construir com a repetição das orações e com a introdução da repetição através da expressão 'pensa bem'. E essa avaliação negativa é confirmada pela próxima fala do pioneiro: - Meu Deus, pelo amor de Deus, isso aí não funciona, eu quem quiser fazer isso pode fazer. Eu, Xexéu, que nasci e me criei na roça, isso aí não, não tem saída. Essa fala avalia negativamente as ações da assistência com o uso de três recursos linguístico-disursivos, seja com a escolha do tipo de retomada da ação, com o participante 'isso aí' repetido duas vezes, seja com o uso da polaridade negativa 'não' três vezes e ainda seja com o uso de duas orações interrogativas, questionando as ações "prescritas" por meio do contraste entre uma característica do solo do PA ('cerrado seco') e a ferramenta escolhida para roçar esse solo ('foice'). Desse modo, o pioneiro além de avaliar de forma pejorativa as ações da COOPVAG, de certa forma, também questiona o conhecimento técnico da COOPVAG se comparado ao seu, que é a experiência de agricultor de uma vida inteira: ' $E u$, Xexéu, que nasci e me criei na roça, isso aí não, não tem saída'. 
Já a parte da entrevista de Bem-Te-Vi relacionada à elaboração do PDA, além de configurar as mesmas regularidades, relata sobre o tipo de funcionamento, organização de ações das reuniões com a COOPVAG.

(135) Bem-Te-Vi: É! Tinha essas reuniões. Nós fazia os grupos separado, aí eles davam uma planilha pra nós, pra nós fazer os plano nosso... pra eles aprovar. Aí: nós fizemos, um bocado deles fez. Nós... Eles passavam dois, três dias de reunião e:: eles falava assim:

_ Olha, vocês num sabe de nada, quem sabe somos nós. Então vocês é os alunos nossos, vocês tem que aguentar o que nós falar. Vocês não entende. Eles no começo, eles tinha aquele... gostava muito de querer explicar as coisas. Do meio pro fim, não. Chegava, tinha reunião aí, falava algumas coisinha e ia embora.

(Bem-Te-Vi, 67 anos)

O início do discurso do pioneiro Bem-Te-Vi, no excerto (135), sinaliza que, durante as reuniões, os/as pioneiros/as eram divididos/as em grupos para fazerem o planejamento para o PDA, mas logo em seguida entra em contradição com um discurso atribuído aos técnicos da COOPVAG. Observe-se ali o uso do processo material concreto 'fazia' relacionado ao ator 'nós' e à meta 'os grupos separado'. Apesar de o ator estar ligado às aves (nós), a agência continua atrelada à assistência técnica determinava, quem determina as ações nas reuniões, uma vez que o/a acampado/a somente organizava os grupos e discutia as propostas apontadas pela assistência. No entanto, as discussões dos grupos eram aceitas ou não pelos técnicos, o que se permite identificar com o uso do adjunto modal 'pra eles aprovar'.

Nessa perspectiva, Bem-Te-Vi insere, em seu discurso, um discurso de um técnico para justificar o agenciamento da COOPVAG em escolher propostas para o PDA: ‘_Olha, vocês num sabe de nada, quem sabe somos nós. Então vocês é os alunos nossos. Vocês tem que aguentar o que nós falar. Vocês não entende’. Esses enunciados são constituídos, principalmente, por processos mentais cognitivos. São processos "do mundo da consciência", relacionados a ao pensamento de posse ou não de conhecimento acerca do conteúdo a ser inserido no PDA. O processo mental cognitivo 'sabe' é utilizado duas vezes seguidas, mas com experienciadores diferentes. No primeiro uso, o participante experienciador é 'vocês' acampados/as - e o fenômeno é 'de nada' - falta de conhecimento -, que apontam um desconhecimento do/a acampado/a sobre as propostas para o PDA. Além do mais, no âmbito da forma verbal, o processo 'sabe' também está atrelado à polaridade negativa 'num' (não), de modo que permite identificar uma ampliação da falta de conhecimento dos/as pioneiros/as em oposição ao segundo uso do processo mental 'sabe', que atribui conhecimento ao experienciador 'nós', os técnicos da COOPVAG. Em termos do significado identificacional, 
ocorre avaliações sobre detenção de conhecimento. O experienciador 'vocês' é avaliado negativamente enquanto o experienciador 'nós' é avaliado positivamente. Ainda, no final dessa unidade de informação, faz-se o uso de outra polaridade negativa - 'Vocês não entende' -, que também avalia negativamente as aves pioneiras, desqualificando o entendimento das mesmas.

O processo relacional identificativo 'é' também representa e avalia a relação entre COOPVAG e acampado/as no que se refere posse de conhecimento ligado às decisões tomadas nas reuniões. Esse processo relacional está envolvido com o participante identificado 'vocês' e com o participante identificador 'os alunos nossos', emoldurando uma subordinação em termos de "posse de conhecimento" da assistência técnica em relação os/as pioneiros/as: 'Então vocês é os alunos nossos'. O identificador, no caso, ao identificar o/a acampado/a como aluno, o avalia negativamente, já que instaura uma relação de dependência do aluno para com quem é concebido o papel, a agência de "ensinar e saber", a assistência técnica. Essas várias atribuições negativas de valores aos/às pioneiros/as formam parte da justificativa para subordinação do ser avaliado: 'Vocês tem que aguentar o que nós falar'. O recurso léxico-gramatical configurado pelo verbo modal 'tem' revela uma modulação (modalidade deôntica) de obrigação. Isto é, como 'vocês' em todo o excerto (135) é representado e identificado de forma pejorativa em relação ao conhecimento acerca das discussões sobre o planejamento para o conteúdo do PDA, cabe a esse, um papel passivo, de obrigação em aceitar as propostas da assistência técnica (nós). Cabe, por sua vez, à assistência um papel ativo, de agente, por ser avaliada como detentora de conhecimento.

Enquanto parte da entrevista de Bem-Te-Vi relata que, nas reuniões, os/as pioneiros/as se dividiam em grupo, mas quem decidia a escolha do conteúdo do PDA era a COOPVAG; em parte da entrevista de Gavião-vaqueiro, há o relato sobre o conteúdo das discussões dos grupos. Além disso, em princípio, parece estar em oposição ao dito sobre a escolha do conteúdo do PDA, de acordo com o fragmento (136).

(136) Gavião-Vaqueiro: No negócio da COOPVAG, eles concordaram para nós decidir o que nós queria. Aí nós decidimo vários fator, né? Negócio da terra, pra trabalhar na terra toda, aí diziam que ia botar no livro pra ver os projeto, o que que nós queria. Aí o povo escolheu vários tipos de projeto, né?! Pra gado, outros pra galinha, eu queria pra peixe, né? Mas dizendo que tinha que tirar licença. Aí eu falei:

_ É, pra tirar licença, tem que ter organização do assentamento. Agora o assentamento não é cadastrado em nenhum assentamento, aí fica tudo trabalhando irregular, sem a nota fiscal do IBAMA. Tem que tirar a licença no IBAMA. Aí nós concordamos e fizemos. O povo concordou de fazer, aí botemos vários tipos de fatores de... né? 
(Gavião-Vaqueiro, 39 anos)

No fragmento (136), a circunstância de localização-lugar 'No negócio da COOPVAG' situa decisões entre assistência técnica e pioneiros/as nas reuniões ocorridas durante o período de acampamento. Os processos 'concordaram', 'decidir' e 'queria' são mentais, estão no mundo da consciência, embora envolvam participantes diferentes: "No negócio da COOPVAG, eles concordaram para nós decidir o que nós queria. Aí nós decidimo vários fator, né?'. Ou seja, é relatado, em outras palavras, que os técnicos da COOPVAG concordaram com decisões, escolhas dos/as pioneiros/as tomadas durante as discussões nos grupos. No caso, estabelecem-se relações do mundo do pensamento e não ações do mundo material concreto, como ocorrerem nos excertos analisados anteriormente. Os fenômenos, aqui, são escolhas e desejos elencados nos grupos: 'Aí o povo escolheu vários tipos de projeto, né?! Pra gado, outros pra galinha, eu queria pra peixe, né?'. As pessoas acampadas se dividiam em grupos para discutir sobre programas produtivos apresentados pela assistência técnica ${ }^{37}$ como possibilidades para comporem o PDA Santa Tereza I. Não ocorre, porém, um ator com papel de agente, como nos excertos já analisados, e sim ocorrem experienciadores e fenômenos.

No fragmento (137), Gavião-Vaqueiro acrescenta informações sobre o funcionamento dos grupos criados para planejamento de ações para o assentamento.

(137) Pesquisadora: Nesse momento, vocês recebiam alguma instrução? Gavião-Vaqueiro: Não, decisão do povo, não era tanto deles. Só que eles dizia que o povo tinha que esforçar para botar no livro, que precisava de fazer o livro o mais rápido possivel, eles falavam. Porque o livro, não tinha muito tempo pra fazer, porque já estava be:m já aguardando. Os lotes já estava cortado e precisava do livro para poder ir adiante, né? que ela falou, e não podia porque estava vencendo o prazo deles.

(Gavião-Vaqueiro, 39 anos)

O discurso do pioneiro, em (137), inicia com o uso da polaridade negativa 'não', o uso dos adjuntos modais 'tanto' e 'só' e o uso do verbo modal 'tinha que esforçar' no que concerne a metafunção interpessoal e, especificamente, o significado identificacional. Diferentemente do fragmento (136), aqui, essa polaridade negativa ' $n \tilde{a} o$ ' atrelada ao adjunto modal 'tanto' configura uma modificação no discurso sobre as escolhas feitas durante as reuniões: 'não era tanto deles'. As decisões são atribuídas tanto ao 'povo' (acampado/a)

\footnotetext{
${ }^{37}$ Tanto nas entrevistas já analisadas, aqui, quanto nas notas de campo, é atribuído, aos técnicos da COOPVAG, o papel de apresentar as propostas para o PDA às pessoas acampadas.
} 
quanto aos técnicos ('deles'). Ademais, os recursos léxico-gramaticais adjunto modal 'só', o verbo modal 'tinha' e a circunstância de localização-tempo 'o mais rápido possivel' configuram, no caso, modulação de obrigação contraargumento para o papel exclusivo de tomada decisões sobre ao conteúdo do PDA para as pessoas acampadas: 'Só que eles dizia que o povo tinha que esforçar para botar no livro, que precisava de fazer o livro o mais rápido possível, eles falavam'. Esse enunciado relaciona o esforço das pessoas acampadas a um condicionamento de tempo para a tomada de decisão. Quando as pessoas são obrigadas a tomarem várias decisões sobre o andamento de suas vidas sobre pressão, em um curto espaço de tempo, costuma-se questionar o tipo de reflexão constituída para a tomada de decisão e também a qualidade das decisões e futuras consequências para a vida dessas pessoas. Com isso, também se pode considerar que as pessoas acampadas estavam sendo pressionadas em relação ao prazo para as discussões nos grupos como condição para a elaboração do PDA e a conseqüente possibilidade de se ir para os lotes do PA, uma vez que a elaboração do PDA se fazia condição para o sorteio dos lotes do PA.

Já o excerto (138) integra parte da entrevista de Suiriri com o relato sobre o processo de elaboração do PDA, o qual indica tanto os participantes das reuniões quanto o tipo de participação do próprio pioneiro e de outro/as acampado/as.

(138) Suiriri: Olha, aqui só tinha reunião direto. $O X X X X$ (funcionário do INCRA) vinha e: o menino, o XXXX, era o técnico, né?! Aí:, foi eles que começou a mexer aí. Era só eles mesmo que vinha. Daí só o pessoal mesmo, nós aqui, todo mundo, os assentados. (...)

Pesquisadora: Qual foi a participação do senhor na elaboração do PDA? Como o senhor acha que foi a sua participação na elaboração desse documento?

Suiriri: Não, eu gosto de ir pra reunião, eu gosto só de ouvir, eu não gosto de falar nada. Na reunião, eu vou. Às vezes tem muitos que manifesta falar alguma coisa, eu não. Eu gosto de ouvir, não gosto de falar. Tinha pessoas que, às vezes, tinha alguma sugestão, né? Mas... Eu mesmo num tinha sugestão nenhuma, num gosto dessas coisas.

(Suiriri, 41 anos)

As regularidades referentes aos usos tanto de processos materiais quanto de participante ator COOPVAG com papel agentivo ocorrem na entrevista do pioneiro Suiriri. Os processos materiais 'vinha' e 'começou a mexer' (iniciou) envolvem o ator COOPVAG com papel de agente que iniciou as reuniões para elaboração do PDA com a participação das pessoas acampadas ('nós', 'todo mundo', 'os assentados'), de acordo com outras entrevistas. 
A parte do relato que difere de outros se relaciona à representação e à avaliação do tipo de participação nas reuniões.

Assim como Gavião-Vaqueiro, Suiriri faz uso da polaridade negativa 'não' com recorrência na mesma unidade de informação - 'Não, eu gosto de ir pra reunião', 'eu não gosto de falar nada', 'eu não', 'não gosto de falar', 'Eu mesmo num tinha sugestão nenhuma', 'num gosto dessas coisas' -, e faz uso do adjunto modal 'só' - 'Não, eu gosto de ir pra reunião, eu gosto só de ouvir, eu não gosto de falar nada' -, o que caracteriza de modo específico o seu tipo de participação nas reuniões. Esses recursos léxico-gramaticais indicam que a participação de Suiriri nas reuniões é a de ouvinte, de observador, com um papel passivo em termos de externar opiniões. Além disso, faz uso do adjunto modal 'às vezes' em duas ocasiões para relatar a participação de outros/as pioneiros/as: 'Às vezes tem muitos que manifesta falar alguma coisa, eu não' e 'Tinha pessoas que, às vezes, tinha alguma sugestão, né?'. Aqui, o pioneiro infere que, além dele, outro/as acampado/as participavam das reuniões através de suas presenças e ainda modaliza a participação de outro/as. Há modalização de usualidade (modalidade epistêmica) referente à periodicidade de participação de alguns/mas pioneiros/as ('Às vezes tem muitos' e 'Tinha pessoas que, às vezes'), que é avaliada como baixa. De acordo com esse acampado, mesmo as pessoas que externavam suas opiniões, não as externam com alta frequência.

Ainda, o discurso da pioneira Quero-Quero elucida, primeiramente, uma insistência no relato de desconhecimento sobre o PDA. Depois, mesmo ao afirmar a ocorrências das reuniões com a COOPVAG, avalia essas reuniões e continua afirmando que não sabe sobre esse documento, como se configura no segmento (139) abaixo.

(139) Quero-Quero: O: documento, esse documento mesmo eu num tô por dentro não porque eu nunca nem vi esse documento, cê tá entendendo? SÓ... é o: documento da COOPVAG mesmo... eu não tô sabendo.

(Quero-Quero, 59 anos)

No segmento (139), a pioneira utiliza a polaridade negativa em alto nível, já que a repete várias vezes na mesma unidade de informação para destacar seu desconhecimento sobre o PDA: 'num', 'ñ̃o', 'nunca', 'nem'. O recurso léxico-gramatical da polaridade negativa em um nível alto situa o discurso de Quero-Quero em uma avaliação pejorativa acerca do documento, no caso, o PDA, de modo que essa polaridade aparece repetidamente quando relacionada a algumas formas verbais. Tanto em 'eu num tô por dentro não' quanto em 'eu nunca nem vi' ocorrem usos da polaridade negativa duas vezes, referindo-se a uma 
mesma forma verbal e ambas envolvem o sentido de 'eu desconheço o PDA'. Parece haver uma tentativa de distanciamento da pioneira do PDA, o que é reforçado pela atribuição de "posse", autoria do documento à COOPVAG: 'SÓ... é o: documento da COOPVAG mesmo... eu não tô sabendo'. Isto é, o enunciado sinaliza o documento ser da COOPVAG, pertencer a ela. Apesar de, em outra parte da entrevista, a pioneira Quero-Quero relatar a ocorrência de reuniões com a COOPVAG, nega ainda o conhecimento sobre a existência do PDA, como aponta o segmento (140).

(140) Pesquisadora: Como que eram feitas aquelas reuniões com a COOPVAG?

Quero-Quero: Eh, era, tinha isso. Geralmente, mais era: a: COOPVAG que trazia as coisa. Tinha vez que era o INCRA: sabel é assim... Uma hora pra outra era um, uma hora pra outra fazia essas reuniãozinha por aí, uma hora pra outra... Mas só que: eu: num tô lembrada desses documento aí não. Num tô sabendo não.

(Quero-Quero, 59 anos)

O segmento (140), além de configurar regularidades léxico-gramaticais no que concerne a metafunção ideacional, especificamente, o significado representacional; configura também regularidades da metafunção interpessoal, especificamente, do significado ideacional. O processo material concreto 'trazia' emoldura o ator 'COOPVAG' e a meta 'as coisa'. Como em outras entrevistas analisadas, há escolha pelo uso do processo material, principalmente, concreto, que envolve o ator COOPVAG; assim como cabe a esse ator o papel de agente em relação às proposições para o PDA Santa Tereza I. O processo 'trazia' se configura como uma ação do mundo concreto do fazer, integra parte do mundo real, e evoca para essa ação o ator 'COOPVAG' com papel de agente realizador, que concretiza a ação a que se propõe.

Ainda, de acordo com o excerto (140), há também escolha pelo uso de recursos que indica julgamento da pioneira sobre as reuniões com o COOPVAG no que se refere à metafunção interpessoal. A pioneira reconhece, assim, a existência das reuniões com a COOPVAG durante o período de vida no acampamento. No mesmo enunciado, a escolha pelo uso do participante existente 'isso', de certa forma, modaliza o discurso da pioneira e configura um julgamento acerca dessas reuniões. $\mathrm{O}$ uso desse pronome demonstrativo, em termos do significado identificacional, faz-se um recurso léxico-gramatical que aponta um ponto de vista específico sobre os acontecimentos aos quais se refere. No caso, atribui uma generalização a essas reuniões, no sentido de acontecimentos, de algum modo, com importância e resultado duvidosos. Esse ponto de vista negativo se ratifica e se estende através de outros recursos léxico-gramaticais. O processo existencial 'tinha' está atrelado ao 
participante existente 'isso' e retoma o acontecimento 'reuniões', de modo a integrar parte a um julgamento negativo sobre as reuniões ao generalizá-las. A escolha da meta 'as coisa', que alude as propostas apresentadas pela COOPVAG, sinaliza também uma avaliação pejorativa às propostas, uma vez que sugere generalização, parecendo propostas sem importância para a pioneira.

Os três usos da circunstancia de localização-tempo 'uma hora pra outra era um' situa a frequência de ocorrência das reuniões como baixa, além de aparecer como um adjunto modal, que constitui uma modalização de usualidade/modalidade epistêmica em termos de significado identificacional. Esse adjunto modal compõe a emissão de um valor de julgamento negativo em relação ao grau de usualidade, ocorrências das reuniões. Para a pioneira, as reuniões são caracterizadas e julgadas como esporádicas.

Na mesma unidade de informação, a pioneira ainda caracteriza de maneira negativa as reuniões ao usar duas vezes o adjunto modal, que indica a periodicidade delas, atrelado ao uso de um sufixo diminutivo, que forma parte da meta 'essas reuniãozinha' envolvida, por sua vez, com o processo material concreto 'fazia' e o ator COOPVAG/INCRA: 'uma hora pra outra fazia essas reuniãozinha por aí, uma hora pra outra'. O sufixo diminutivo '-inha' implica, da mesma forma outros recursos já utilizados, inclusive um julgamento de valor negativo sobre os eventos promovidos pela assistência técnica, no acampamento, para a elaboração do PDA.

\subsection{Organizador institucional do ninho}

Os dados analisados nesta seção foram gerados a partir de entrevistas semiestruturadas com funcionários do INCRA no Estado do Tocantins. No caso, o INCRA-SR 26 representa o governo federal, entre outras representações, no que se refere à implantação da Reforma Agrária no Tocantins. Compete, pois, a alguns funcionários a responsabilidade de elaboração do Plano de Desenvolvimento Agrário (PDA) de cada Projeto de Assentamento (PA). O PDA faz-se, pois, uma das ferramentas - constituinte de políticas públicas do governo federal acerca da Reforma Agrária no Brasil - utilizada pelo INCRA para desenvolvimento dos projetos de assentamento. O INCRA terceiriza, no entanto, o trabalho de elaboração de PDA, perfilando o papel de fiscalizador do trabalho desempenhado pela instituição contratada para elaboração do mesmo. Especificamente, em relação do PDA do PA Santa Tereza I, o INCRASR 26, contratou a Cooperativa de Profissionais Liberais do Vale Araguaia - COOPVAG através de licitação. 
As reflexões analíticas estão balizadas, aqui, a partir das questões de pesquisa referentes à identificação e interpretação de discursos e representações configurados por funcionários do INCRASR26 ao relatarem acerca da elaboração do PDA do PA Santa Tereza I. Essa delimitação analítica corrobora para elucidação dos objetivos específicos da pesquisa no que concerne à investigação de representações de representantes do governo - INCRA SR26 - e assentados/as pioneiros/as do PA Santa Tereza I acerca tanto da elaboração do PDA Santa Tereza I quando da sua implantação; e ao estabelecimento da configuração de identificações de atores sociais constitutivos do PDA por meio de análise discursiva linguisticamente orientada.

Destaca-se também o critério utilizado para a escolha de funcionários do INCRASR26 entrevistados. Tais funcionários foram escolhidos para participarem da pesquisa através de concessão de entrevistas em virtude de, na época de elaboração do PDA Santa Tereza I, ocuparem cargos que incluíam a função de acompanhamento da elaboração dos PDAs. Em consonância com o objetivo geral da pesquisa centrado no estudo das discursividades no PDA do PA Santa Tereza I, as entrevistas foram levadas a cabo junto aos dois funcionários com responsabilidade institucional sobre a elaboração do PDA. O Quadro, a seguir, apresenta o perfil desses funcionários na época da entrevista.

Quadro 5.4 - Perfil dos funcionários do INCRA-SR26 ${ }^{38}$

\begin{tabular}{|c|c|c|c|c|c|c|}
\hline $\mathbf{N}$ & Nome & Idade & Sexo & Cargo & $\begin{array}{c}\text { Tempo } \\
\text { no } \\
\text { INCRA }\end{array}$ & $\begin{array}{c}\text { Participação na } \\
\text { elaboração do PDA } \\
\text { Santa Tereza I }\end{array}$ \\
\hline 1 & $\begin{array}{c}\text { Capim } \\
\text { Dourado }^{39}\end{array}$ & 43 & $\mathrm{M}$ & $\begin{array}{c}\text { Perito federal } \\
\text { agrário }\end{array}$ & 9 anos & $\begin{array}{c}\text { Chefia do setor } \\
\text { responsável pelo } \\
\text { convênio - COOPVAG - } \\
\text { que elaborou o PDA }\end{array}$ \\
\hline 2 & Babaçu $^{40}$ & 36 & $\mathrm{M}$ & $\begin{array}{c}\text { Coordenador } \\
\text { estadual do }\end{array}$ & 8 anos & $\begin{array}{c}\text { Elaboração da } \\
\text { ferramenta para a }\end{array}$ \\
\hline
\end{tabular}

38 Enquanto os pseudônimos dos/as assentados/as pioneiro/as e entrevistado/as fazem referência à fauna, especificamente, às aves do Tocantins; os pseudônimos dos funcionários do INCRA-SR26 entrevistados são assinalados com referência à flora tocantinense, uma vez que "estão na terra, organizam a terra para a reforma agrária”.

${ }^{39}$ Uma das preciosidades do Cerrado são os fios dourados da sempre-viva que brota em campos do Mato Grosso, Mato Grosso do Sul, Minas Gerais, Goiás, Tocantins, Distrito Federal e Bahia. O capim-dourado (nome científico: Syngonanthus nitens), apesar do nome, não é um capim, ou seja, não pertence à família das gramíneas, sendo, na verdade, a haste de uma pequena flor branca da família das sempre-vivas (família Eriocaulaceae). Na região do Jalapão, o Instituto Natureza do Tocantins definiu regras para a colheita das hastes de capim-dourado utilizadas na confecção de artesanato, que resultaram na Portaria 092/2005, reeditada como Portaria 362/2007 com o objetivo de evitar a extinção da espécie. As medidas a serem tomadas são: as hastes apenas podem ser colhidas após 20 de setembro, ou seja, somente após a maturação das sementes; os frutos devem ser cortados e dispersos no solo logo após a colheita; as hastes de capim dourado não podem sair da região in natura, apenas em forma de artesanato (ISPN, 2014a). 


\begin{tabular}{|l|l|l|c|l|c|}
\hline & & $\begin{array}{c}\text { programa de } \\
\text { ATES }\end{array}$ & $\begin{array}{c}\text { construção do convênio } \\
\text { com a COOPVAG }\end{array}$ \\
\hline
\end{tabular}

O Quadro 5.4 sintetiza aspectos do perfil profissional dos organizadores do ninho que os designam, de alguma forma, como responsáveis pela implantação e organização do ninho das aves pioneiras. Observe-se que a leitura proposta para esse quadro se faz a idêntica à proposta no Quadro 5.1: na horizontal, da esquerda para direita, seguindo a ordem das colunas; e na vertical, em ordem crescente em número de linhas.

A segunda coluna do quadro emoldura os pseudônimos dos funcionários do INCRASR26 entrevistados: Capim Dourado e Babaçu. Esses pseudônimos se trazem a baila plantas, não somente típicas das terras tocantinenses, mas também típicas e representantes importantes da região do Jalapão, lugar onde se situa o PA Santa Tereza I. Destaque-se que essa região do Tocantins faz-se conhecida nacionalmente e internacionalmente por suas belezas naturais, com destaque para o capim dourado, uma espécime símbolo da flora tocantinense. Além do mais, o artesanato tanto com o babaçu quanto com o capim dourado se tornou a fonte de renda importante para muitas famílias do Jalapão, incluindo as do PA Santa Tereza I.

Observe-se, sobre isso, que o babaçu e o capim dourado estão diretamente arraigados às características das terras do Tocantins. Fazem-se parte integrante da natureza, enraizados em terras tocantinenses; e parte integrante de fonte de renda para famílias assentadas, ou seja, fazem referência tanto à natureza genuína, arraigadas às características da terra onde nascem e se desenvolvem quanto à natureza geradora de renda. Os funcionários do INCRA, por sua vez, também estão diretamente arraigados às (funções das) terras tocantinenses no que diz respeito à reforma agrária, sua organização, tanto em relação à natureza genuína referente à preservação ambiental quanto em relação à natureza como fonte de renda para as famílias assentadas.

As colunas três, quatro e seis elucidam características semelhantes aos funcionários. Ambos possuem faixa etária próxima (43 e 36 anos), apresentam o mesmo sexo (masculino) e trabalham no INCRA-SR 26 por quase o mesmo período (9 e 8 anos).

\footnotetext{
${ }^{40} \mathrm{O}$ babaçu (nome cientifico: Attalea ssp.), também conhecido como baguaçu, coco-de-macaco e, na língua tupi, uauaçu, é uma nobre palmeira nativa da região Norte e das áreas de Cerrado. Encontra-se em formações conhecidas como babaçuais, que cobrem cerca de $196 \mathrm{mil} \mathrm{km}^{2}$ no território brasileiro, com ocorrência concentrada nos estados do Maranhão, Tocantins e Piauí, na região conhecida como Mata dos Cocais (transição entre Caatinga, Cerrado e Amazônia). Costuma-se dizer que tudo se aproveita desta palmeira, desde a raiz até as folhas (ISPN, 2014b).
} 
Já a coluna cinco emoldura o cargo que os funcionários entrevistados ocupam no INCRA-SR 26. Enquanto Capim dourado exerce o cargo de perito federal agrário, Babaçu ocupa cargo de Coordenador Estadual do Programa de Assessoria Técnica, Social e Ambiental à Reforma Agrária. Ambas as funções relacionam-se com o tipo de responsabilidade técnica que desempenhavam na elaboração do PDA do PA Santa Tereza I.

Sobre o cargo do Capim Dourado, a LEI N ${ }^{0}$ 10.550, DE 13 DE NOVEMBRO DE 2002 dispõe sobre a estruturação da Carreira de Perito Federal Agrário, a criação da Gratificação de Desempenho de Atividade de Perito Federal Agrário - GDAPA e da Gratificação Especial de Perito Federal Agrário - GEPRA, e dá outras providências: ${ }^{41}$

(141) Art. $2^{\circ}$ Os ocupantes do cargo de Engenheiro Agrônomo do Quadro de Pessoal do INCRA que integrarem a Carreira de Perito Federal Agrário têm por atribuições o planejamento, a coordenação, a orientação, a implementação, o acompanhamento e a fiscalização de atividades compatíveis com sua habilitação profissional inerentes às políticas agrárias e, mais especificamente:

I - a vistoria, avaliação e perícia de imóveis rurais, com vistas na verificação do cumprimento da função social da propriedade, indenização de imóveis rurais e defesa técnica em processos administrativos e judiciais referentes à obtenção de imóveis rurais;

II - o pronunciamento técnico a respeito de alienações de terras em projetos de regularização fundiária, reforma agrária e colonização;

III - o pronunciamento conclusivo sobre a viabilidade técnica, econômica e ambiental, relativo à obtenção de áreas para fins de reforma agrária ou colonização;

IV - a participação em equipes interdisciplinares no planejamento e acompanhamento dos projetos de reforma agrária e de assentamento;

Em acordo com a legislação federal sobre as múltiplas atribuições de um perito agrário descritas no excerto acima, Capim Dourado exerceu a 'chefia do setor responsável pelo convênio entre o INCRA e a COOPVAG para a elaboração de PDAs', conforme a sétima coluna do Quadro 5.4

Já Babaçu exerce o cargo de Coordenador Estadual do Programa de Assessoria Técnica, Social e Ambiental à Reforma Agrária (ATES). ${ }^{42} \mathrm{Na}$ época de elaboração do PDA,

\footnotetext{
${ }^{41}$ Disponível em: http://www.planalto.gov.br/ccivil_03/Leis/2002/L10550.htm. Acesso em: 10 dez. 2014.

${ }^{42}$ O Programa de Assessoria Técnica, Social e Ambiental à Reforma Agrária (ATES), implantado pelo Instituto Nacional de Colonização e Reforma Agrária (INCRA), tem como premissa aliar o saber tradicional dos assentados aos conhecimentos científicos dos técnicos. Essa união de prioriza fazer com que os assentamentos tornem-se unidades de produção mais estruturadas, competitivas e integradas à dinâmica do desenvolvimento municipal e regional, de forma socialmente justa e ambientalmente sustentável. Desde 2004, o Ates atua com equipes de técnicos em ciências agrárias, sociais, ambientais e econômicas. Os grupos trabalham nos assentamentos executando atividades como: elaboração de planos de desenvolvimento ou recuperação de projetos de assentamento, extensão rural, capacitação continuada, visando à formação de competências e à
} 
por exercer a função de coordenador do programas de assessoria técnica Ates, cabia a esse funcionário coordenar uma equipe multidisciplinar nos assentamentos para a execução de várias atividades voltadas para o desenvolvimento desses locais.

\subsection{O INCRA-SR26 e uma das ferramentas para organização do ninho}

Com já explicitado no início da seção anterior (5.3), a realização das entrevistas objetivou a coleta de dados de natureza oral, a partir da colaboração de pessoas envolvidas no processo de elaboração do PDA do PA Santa Tereza I, objeto de estudo desta pesquisa. No caso desta seção 5.4, as entrevistas analisadas fazem referência à questão de pesquisa: 'Quais são as representações dos funcionários do INCRA-SR26 em relação ao processo de elaboração do PDA do PA Santa Tereza I?'. Para aproximar um apontamento em relação à resposta, o tópico guia das entrevistas com os dois funcionários do INCRA-SR 26 remete à elaboração do PDA do PA Santa Tereza I. Em relação às categorias utilizadas para análise dos dados coletados, elas envolvem o Sistema de Transitividade (HALLIDAY \& MATHIESSEN, 2004) e o Sistema de MODO (HALLIDAY \& MATHIESSEN, 2004), como também envolveram a análise das entrevistas com os/as assentados/as pioneiros/as.

Os excertos, a seguir, fazem referência, principalmente, ao tópico guia e também envolvem regularidades linguístico-discursivas entre si. A análise desses dados de natureza etnográfica permitiu identificar essas regularidades no que se refere à transitividade dos processos, como a configuração de tipos de processos vinculados a um tipo de agente social determinado e ao uso de muitas circunstâncias no decorrer das duas entrevistas; e no que se refere ao Sistema de Modo, como a utilização de recursos léxico-gramaticais que constituem a modalização (modalidade epistêmica), a modulação (modalidade deôntica) e a polaridade.

A primeira regularidade revelada consiste na identificação da recorrência de processos materiais concretos na voz passiva com a omissão do participante ator, quando o participante meta refere-se ao PDA. Outra regularidade dessas entrevistas também ocorre no excerto em relação ao uso do participante circunstância com atribuição de alguma avaliação ao elemento ao qual se refere na oração. Vejamos o excerto (140).

mudança de atitudes e procedimentos dos atores sociais, que potencializem os objetivos de melhoria da qualidade de vida e promoção do desenvolvimento rural sustentável, adotando metodologias participativas. Disponível em: http://www.emater.pr.gov.br/modules/conteudo/conteudo.php?conteudo=126. Acesso em: 10 dez. 2014. 
(142) Capim Dourado: O PDA Santa Tereza, ele foi feito, elaborado, seguindo... o esqueleto que o INCRA atribuiu e que a gente, ... baseado numa parte de conversação com as famílias, explicação, uma parte inicial de embasamento teórico, o que seria um PDA. Depois, as famílias em conjunto, em oficinas iriam discutir o plano. Depois, esse documento ia passar pela fase de elaboração, pela equipe contratada, que, no caso, foi a COOPVAG.

(Capim Dourado, 43 anos)

O excerto (142) forma parte da entrevista do funcionário do INCRA Capim Dourado, que indica a forma com que a estrutura e o conteúdo do PDA Santa Tereza I foram elaborados. No início do excerto, ocorre o uso do processo material concreto na voz passiva 'foi feito' junto com a meta PDA Santa Tereza. Já o participante ator, no caso, com a agência de executar a ação material concreta de "fazer o PDA", foi apagado da oração. Além disso, a circunstância de ângulo recurso 'seguindo... o esqueleto que o INCRA atribuiu e que a gente, ... baseado numa parte de conversação com as famílias, explicação, uma parte inicial de embasamento teórico, o que seria um PDA' atribui a determinação da estrutura do PDA aos agentes INCRA/instância superior a dele e a ele próprio por causa da função que exercia. Essa parte do excerto corrobora com uma análise do início do Capítulo 4 relacionada à estrutura do texto do PDA. O texto do PDA Santa Tereza I possui certa estabilidade em termos de estrutura e de conteúdo devido à rigidez empreendida da Norma de Execução no. 71, que lhe deu origem, em termos do INCRA fazer cumpri-la. Depois ainda há uso no excerto de dois processos modalizados - iriam discutir' e 'ia passar' -, devido à escolha do tempo verbal futuro do pretérito do indicativo, isto é, estão no campo da abstração em função do sentido de "uma discussão que poderia ocorrer, mas que algum motivo não ocorreu ('iriam discutir $o$ plano'). Enquanto que os próximos três segmentos apontam o tipo de participação de alguns agentes na elaboração do PDA.

(143) Capim Dourado: TO:das as as famílias que estavam lá participaram dessa dessa dessa fase construtiva, e o INCRA acompanhou no sentido de fiscalizar essas essas esses trabalhos acontecendo, como oficinas, cursos, encontros, é. O INCRA esteve presente, e eu também estive lá presente em um destes trabalhos. Até mesmo o prefeito se encontrava presente.

Pesquisadora: de Ponte Alta?

Capim Dourado: De Ponte Alta.

(Capim Dourado, 43 anos)

Em (143), primeiramente, há o uso do processo material abstrato na voz ativa 'participaram', do participante ator explícito 'TO:das as as famílias que estavam lá', da meta 
'dessa dessa dessa fase construtiva'. O ator aparece enquanto agente por participar da elaboração do PDA e por enfatizar a entonação aplicada à quantificação das famílias nas reuniões. Essa entonação, por sua, vez parece apontar tanto a participação maciça das pessoas acampadas nas reuniões com a COOPVAG, além de contribuir para a análise do início do Capítulo 4 que diz respeito à exigência do INCRA de presença de, pelo menos, um membro da cada família nas reuniões, o que é confirmada através do uso circunstância de localização lugar 'lá', referente ao local onde as famílias se encontravam e que era o mesmo local onde as reuniões com a COOPVAG ocorriam: o acampamento.

Ainda o uso do ator explícito contrasta com o excerto anterior no que diz respeito à omissão do ator com papel de agente social. Em relação à meta, há configuração de avaliação da fase de elaboração do PA, pois a fase é considerada 'construtiva'. Capim Dourado avalia positivamente a fase de elaboração do PA. Além do mais, na oração seguinte, a agência do ator INCRA não é emitida para se relacionar-se com o processo do mundo concreto do fazer o PDA: 'o INCRA acompanhou no sentido de fiscalizar essas essas esses trabalhos acontecendo, como oficinas, cursos, encontros, é.'. No caso, o papel agentivo recai sobre o processo de fiscalizar ações tanto da COOPVAG quanto das pessoas acampadas. Ainda é atribuído um papel de agente ao prefeito de Ponte Alta referente à sua participação em algumas reuniões com a COOPVAG: 'Capim Dourado: Participou! Participou! Não vou dizer de TO: das as fases, mas de uma dessas fases que eu estive participou, que era a fase de você fazer o plano geral, discutir o mapa do /.../ de você estabelecer as médias daquilo que seria feito. De acordo com a análise do texto do PDA, a prefeitura de Ponte Alta possui papel de agente em relação à execução de obras de infraestrutura do PA, prescritas no PDA. Devido à atribuição desse papel, ocorreu a participação do prefeito em algumas reuniões com a COOPVAG.

Já no segmento (144), Capim Dourado relata o tipo de participação do INCRA na elaboração do PDA.

(144) Capim Dourado: Olha bem, o papel do INCRA ... é ... garantir que o PDA fosse feito, não somente lá nesse nesse PA, mas em todos os PA's, por isso que fez lá um convenio com a entidade COOPVAG. $O$ convenio, não sei o caso desse, que a gente fez uns três convênios com ele, mas um número $X$ de assentamentos, 10 assentamento, 15 assentamentos. Feito lá o convênio, ... que tem repasse de recurso público, o papel do INCRA seguinte é fiscalizar que o serviço está sendo feito, porque não era somente fazer o PDA, mas era fazer ATE também, ATES que é a Assistência Técnica, o Apoio Técnico. E a gente tinha que fiscalizar pra pagar as parcelas... para a prestadora COOPVAG. 
No segmento (144), o tipo de papel agentivo atribuído ao INCRA quanto à elaboração do PDA é configurado através do uso do processo relacional identificativo 'é' duas vezes. Na primeira ocorrência no excerto, um processo relacional 'é' está acompanhado pelo identificador 'O papel do INCRA' e pelo identificado 'garantir que o PDA fosse feito'. Na segunda, o identificado faz referência a 'fiscalizar que o serviço está sendo feito'. Destaque-se que em ambas ocorrências do processo relacional remeter ao papel do INCRA, o papel de agente atribuído está em um plano mais abstrato, “do ser". Além disso, em relação ao participante identificado nas duas orações, que se refere à representação do papel atribuído em si ao INCRA, corresponde à agência de 'fazer' com que os outros agentes envolvidos no processo de elaboração do PDA 'cumpram' as determinações da instituição. Isto é, o papel dos "fazer cumprir": garantia de elaboração do PDA bem como a fiscalização as atividades realizadas pela COOPVAG.

Ainda no segmento (145), esse funcionário entrevistado sinaliza o tipo de agência atribuída por ele à COOPVAG e aos/às pioneiros/as do PA.

(145) Capim Dourado: O papel da COOPVAG era, digamos assim, cumprir aquilo que estava estabelecido no convênio, que seria fazer o PDA e prestar serviço de ATES.

Pesquisadora: E do assentado?

Capim Dourado: $O$ assentado, ele ele como cidadão livre, seria absorver esse trabalho, usufruir dessa desse benefício que o INCRA estava concedendo.

Pesquisadora: E a COOPVAG ela ela ficou até em que parte desse processo? Ela chegou a fazer parte das ATES, da assistência técnica? Ou ela somente elaborou, ou ela implementou também?

(Capim Dourado, 43 anos)

Considerando que no segmento anterior a agência atribuída ao INCRA foi a de 'fazer cumprir' a elaboração do PDA de acordo com as prescrições da Norma de Execução no. 71 do INCRA, pode-se pressupor que algum agente envolvido tenha o papel de 'cumprir' o que o INCRA determina, escolhe, a partir da legislação federal sobre reforma agrária vigente. No caso, Capim Dourado atribuiu esse papel à COOPVAG: 'O papel da COOPVAG era, digamos assim, cumprir aquilo que estava estabelecido no convênio, que seria fazer o PDA e prestar serviço de ATES. Observe-se, aqui, também o uso do processo relacional identificativo 'era' para se referir ao tipo de agência do participante identificador - 'O papel da COOPVAG -. Essa agência não está configurada através de processo do mundo físico, concreto do 'fazer'. 
Já o tipo de papel vinculado aos/às assentados/as está configurado, primeiramente, através do uso de uma circunstancia de modo por comparação 'como cidadão livre', que atribui a característica de 'cidadão livre' ao participante identificador ' $O$ assentado' para justificar a introdução do tipo de papel atribuído a seguir na oração: 'seria absorver esse trabalho, usufruir dessa desse benefício que o INCRA estava concedendo'. Esse papel atribuído está configurado, por sua vez, a partir de um processo relacional identificativo modalizado 'seria' (devido ao processo estar no tempo futuro do pretérito do modo indicativo), que sinaliza um mundo hipotético em relação, no caso, ao que é 'identificado' e ao que é 'identificador'. Além disso, o participante identificado, relacionado ao processo 'seria', aponta um papel 'passivo', de beneficiário aos/às assentados/as - 'absorver'e 'usufruir'.

Quanto à entrevista do funcionário Babaçu, ela se inicia com o apontamento da justificativa para a elaboração do PDA, conforme o excerto (146).

(146) Babaçu: Bem, o PDA Santa Tereza I, ele faz parte ... das obrigações contidas no convênio, cujo objetivo era a prestação de serviço e assistência técnica em diversos projetos de assentamento; e o PDA Santa Tereza I era um projeto, um plano de desenvolvimento entre outros seis né, cuja entidade executora é a COOPVAG, chama uma Cooperativa de Profissionais Liberais do Vale do Araguaia, que se iniciou os trabalhos em 2008 e tinha uma vigência de execução até o final de 2011, que a gente até 'postergou' por um pouco tempo. Então era um de, dentre o o instrumento, era um dos objetivos que eles tinham era de constituição desse documento.

(Babaçu, 36 anos)

No excerto (146), o PDA é caracterizado como uma 'das obrigações contidas no convênio, cujo objetivo era a prestação de serviço e assistência técnica em diversos projetos de assentamento'. Como na entrevista de Capim Dourado, na entrevista do funcionário Babaçu, há recorrência do uso de processos relacionais atributivos. Para tanto, foi utilizado o processo relacional atributivo 'faz' (faz, integra, é, está), seguido do portador 'o PDA Santa Tereza I, ele' e do participante atributo 'parte... das obrigações contidas no convênio'. Esse atributo faz referência ao convênio entre à COOPVAG e o INCRA para a elaboração de PDAs, dentre eles o PDA Santa Tereza I. Sendo assim, Babaçu também atribui um papel de agente à COOPVAG em relação à elaboração do PDA estudado. Além disso, no final do excerto, há configuração de outra característica, avaliação, ao PDA: 'Então era um de, dentre o o instrumento, era um dos objetivos que eles tinham era de constituição 
desse documento'. O primeiro processo relacional atributivo 'era' está vinculado ao atributo 'instrumento', que retoma o motivo pelo qual os PDAs foram criados: serem um dos instrumentos utilizados pelo INCRA para o desenvolvimento de PAs.

O excerto (147) faz referência ao processo de fiscalização do INCRA sobre as atividades de elaboração do PDA, desempenhadas pela COOPVAG.

(147) Babaçu: Eles encaminham a versão ... uma versão ... original ... é, ela é avaliada aqui dentro dos escot/ dos roteiros. A análise é baseada nos roteiros, faz a ... tanto o setor técnico quanto o setor de meio ambiente e esses setores eles emitem uma espécie de parecer ou análise, onde solicitam as correções ou apontam quais são os tópicos que precisariam ser alterados e ... Aí esse resumo dessas análises é encaminhado para eles procederem a atualização. É normal, depois disso, retornar-nos fazer mais algumas considerações ... até: ter um recebimento final. Recebíamos então na parte física o documento e na parte de mídia também, digital.

(Babaçu, 36 anos)

Já no excerto (147), ocorre a configuração de processos materiais concretos, seguidos das metas, mas há omissão dos atores dessas ações do mundo físico do fazer: 'A análise é baseada nos roteiros'. Nessa oração, o processo material concreto 'é baseada' está na voz passiva, com a concretização da meta 'A análise' e da circunstância de ângulo por recurso 'nos roteiros', mas com apagamento do participante ator, que indicaria o agente responsável pela análise do PDA, feita no INCRA. Como esses processos tratam de uma das responsabilidades dos funcionários do INCRA em relação à elaboração do PDA, a omissão dos atores parece figurar uma estratégia de apagamento dos agentes dessas 'ações concretas' de fiscalizar tanto o trabalho de elaboração do PDA, a ação em si, mas também de fiscalizar o conteúdo materializado no texto do PDA e se esse conteúdo cumpre as exigências da Norma de Execução no. 71 - 'nos roteiros'.

No final da entrevista, Babaçu avalia o PDA enquanto uma ferramenta para o desenvolvimento dos PAs, assim como sugere uma maneira para que essa ferramenta funcionasse de acordo com o propósito para o qual surgiu. Vejamos no excerto (148).

(148) Babaçu: Pois é, o PDA, eu eu imagino que é um instrumento importante, mas é um, mas pra ele ser efetivo ele tem de ser muito factível assim, tem que estar atrelado a uma uma execução imediatamente à sua conclusão. Do contrário, a gente acaba gerando num documento uma expectativa, né, atemporal. 
No início do excerto (148), ocorre o uso do processo mental cognitivo 'imagino', seguido de um participante experienciador ' $e u$ ' - que o individualiza, o especifica -, e de um fenômeno, constituído a partir de uma projeção de orações vinculadas em termo de construção de uma avaliação para o PDA: 'que é um instrumento importante, mas é um, mas pra ele ser efetivo ele tem de ser muito factível assim, tem que estar atrelado a uma uma execução imediatamente à sua conclusão'. Essa projeção é configurada a partir de um processo relacional atributivo 'é', do portador ' $P D A$ ' e do atributo 'um instrumento importante'. Desse modo, no início dessa projeção, há uma avaliação positiva do PDA quanto uma ferramenta para o desenvolvimento de PA, através da adjetivação do atributo 'importante'. No entanto, Babaçu dá continuidade à sua projeção através de uma oração que condiciona, restringe a avaliação positiva do PDA (instrumento importante) mediante a execução do que é proposto nele assim que ele é elaborado. Caso não seja cumprida essa condição, o entrevistado avalia o PDA como 'atemporal', torna-se um planejamento no âmbito da elaboração, das ideias, não se concretiza, não se torna real. Sendo assim, o uso de um processo mental, do mundo da consciência, no início de uma fala que contém algumas avaliações sobre algo, no caso, o PDA, parece sinalizar ser uma estratégia para, de certa forma, afastar essas avaliações do mundo exterior, mais próximo do concreto.

\section{Algumas considerações}

As análises levadas a cabo, no Capítulo 5, formam parte da aproximação das questões de pesquisa referentes à perspectiva de assentados/as pioneiros/as e funcionários do INCRA sobre representações e identificações de ambos, tanto na elaboração quanto no próprio texto do PDA Santa Tereza I. A análise dos dados selecionados a partir das entrevistas realizadas aponta a configuração dos mesmos participantes envolvidos, de alguma maneira, com a elaboração do PDA do PA Santa Tereza I, considerando o objeto de estudo em questão remeter a discursividades e representações no texto do referido PDA.

As categorias linguístico-discursvivas recorrentes nas entrevistas e relacionadas ao significado ideacional não foram as mesmas. Já as categorias do significado interpessoal foram quase as mesmas. Essa realização está atrelada ao tipo de agente e ao tipo de agência que os/as entrevistados/as atribuem aos/às participantes envolvidos/as nesse processo.

Nas entrevistas com assentados/as pioneiros/as, as categorias mais frequentes fazem referência à ocorrência de processos materiais, de vários elementos constituintes tanto da modalidade epistêmica quanto da modalidade deôntica (verbos modais, adjuntos modais, 
expressões modais) e da polaridade negativa, seja para representar e identificar o papel 'ativo' ou 'passivo' de participantes em termos de agente social seja para representar e identificar as ações desempenhadas por esses participantes. Esse tipo de concretização linguística, na análise ora desenvolvida, está diretamente articulado ao papel atribuído pelos/as assentados/as à COOPVAG e ao INCRA. De modo recorrente nessas entrevistas, o papel de agente no processo de elaboração do PDA foi atribuído tanto à COOPVAG quanto ao INCRA, mas a COOPVAG aparece com mais frequência. Também no que concerne às ações desenvolvidas por esses/as participantes, os mesmos recursos léxico-gramaticais foram utilizados, mas o tipo de representação e de identificação configurada, por sua vez, não foi a mesma. Os recursos referentes ao tipo de agência dos/as assentados/as representam a tentativa de colocá-los/as como pacientes em relação ao processo de elaboração do PDA e, consequentemente, também representam suas poucas ações na luta na terra (no PDA), reflexividade desse papel, principalmente devido à falta de recursos financeiros, aos recursos naturais indisponíveis nos lotes, assim como à falta de capacitação técnica. Como bem argumenta Sen (2010, p. 26), "uma concepção de economia e do processo de desenvolvimento centrada na liberdade é em grande medida uma visão orientada para o agente". Com oportunidades sociais adequadas, assentados/as podem efetivamente moldar seu próprio destino e ajudar uns/umas aos/às outros/as de modo que não necessitem ser vistos/as, sobretudo, como beneficiários/as passivos/as de programas de desenvolvimento.

Nas entrevistas com os funcionários do INCRA, as categorias que mais aparecem fazem referência à ocorrência de processos relacionais, do mundo do 'ser'; de elementos constituintes tanto da modalidade epistêmica quanto da modalidade deôntica, mas com menos variedade; e de polaridade com menor frequência ainda. Nessas entrevistas, o papel de agente no processo de elaboração do PDA foi atribuído à COOPVAG e aos/às assentados/as pioneiros/as, mas a COOPVAG também aparece com mais frequência, como nas entrevistas com os/as pioneiros/as. Em relação aos recursos referentes ao tipo de agência dos funcionários do INCRA, há representação deles como fiscalizadores das atividades da desenvolvidas pela COOPVAG para a elaboração do PDA, como também há representação dos/as pioneiros/as como passivos/as, beneficiários/as das ações tanto da COOPVAG quanto do INCRA. Destaque-se também que os recursos que dizem respeito ao Sistema de Modo, usados pelos funcionários do INCRA, "funcionaram" nas entrevistas mais para avaliarem pejorativamente o PDA enquanto uma das ferramentas institucional para o desenvolvimento de PAs. 
Sobre isso, Silva (2008a) sinaliza, por um lado, que as pessoas são capazes de usar diferentes modos de pensamento e diferentes representações de acordo com o grupo específico ao qual pertencem. Por outro lado, transformar em material de trabalho o discurso de pessoas em situação de exclusão ao longo de suas vidas constitui uma maneira de arquivar conhecimentos para fortalecimento da identidade de uma classe oprimida pela pobreza. 


\section{O POUSO}

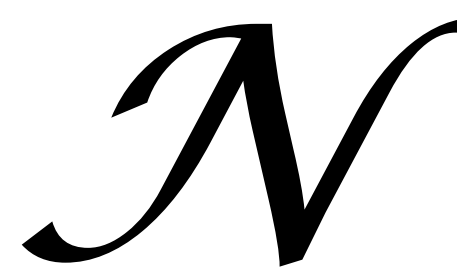

no que concerne ao cumprimento de políticas públicas voltadas para a reforma agrária no Brasil. A investigação se revestiu do propósito de apontar práticas discursivas transformadoras que beneficiem essa parcela da sociedade sedenta por inclusão social.

$\mathrm{O}$ interesse em estudar esse objeto de pesquisa surgiu com a minha chegada no Tocantins, estado mais novo do país, mas que possuía, em 2008, mais de trezentos e cinquenta projetos de assentamentos de terras, com cerca da metade da população rural do estado composta de assentados/as. Interessei-me sobre a investigação do tipo de reforma agrária implantado, sobretudo em relação aos modos de vida das pessoas assentadas, muitas vezes em situação de risco. No que concerne ao PDA do PA Santa Tereza I, em princípio, é configurado como uma das ferramentas propostas do INCRA para o planejamento do desenvolvimento do PA. O problema de pesquisa, destacado nesta tese, refere-se, assim, ao estudo de representações linguístico-discursivas configuradas no PDA do PA Santa Tereza I, localizado no município de Ponte Alta, no Tocantins. A partir desse problema, aventurei-me no vôo sobre a investigação de discursos (re)contextualizados nesse PDA, com vistas a desvelar facetas de práticas sociais (re)produzidas, por vezes ratificadas em textos oficiais.

Diante do objetivo proposto e, apesar de alguns obstáculos encontrados no percurso, teço algumas considerações acerca dos resultados alcançados durante este vôo - trabalho de tese -, mediante a retomada das questões de pesquisa, motivadoras do desenvolvimento da pesquisa. As questões de pesquisa fazem referência a discursos e representações constituídas na configuração linguístico-discursiva do PDA Santa Tereza I; às representações de assentados/as participantes de reuniões para elaboração do PDA em entrevistas cujo tópico guia se remete à elaboração do PDA; às identificações dos/as assentados/as do PA Santa Tereza I com PDA; às representações dos funcionários do INCRA-SR26, responsáveis técnicos pela elaboração do PDA do PA Santa Tereza I, em entrevistas com o mesmo tópico guia.

A partir da configuração do Capítulo 1, pode-se dizer que o PDA Santa Tereza I, primeiramente, está inserido no processo de luta pela terra devido à sua elaboração estar 
atrelada a uma exigência do INCRA/Governo Federal para que houvesse o sorteio dos lotes do PA Santa Tereza I e a consequente mudança das pessoas acampadas para os lotes. A elaboração do PDA formava parte da agenda de ações do INCRA com a premissa de participação de pessoas candidatas a um lote do PA, geralmente acampadas, como forma de mobilização para a redistribuição fundiária. Em segundo, o PDA, enquanto ferramenta para o desenvolvimento de PAs, está inserido no processo de luta na terra. De certa forma, percorrer algum caminho dessa luta, avanços e retrocessos, pode corroborar para a fundamentação do entendimento sobre o tipo de reforma agrária implantado no país.

Nessa perspectiva, a implantação de um PDA envolve a necessidade de entendimento das pessoas assentadas sobre a função desse instrumento proposto pelo INCRA, pois a materialização linguística do seu texto possui respaldo institucional. No caso do PDA do PA Santa Tereza I, foi elaborado sob a responsabilidade técnica do INCRA-SR26, apontando ações de desenvolvimento para o assentamento, como infraestrutura (estradas, moradia, escola, posto de saúde, energia elétrica, água), capacitação técnica, assim como aquisição de recursos financeiros para subsidiar a produção agropecuária. Além disso, essa implantação depende do INCRA fazer cumprir o que ele próprio, enquanto representante do governo federal, propôs através da Norma de Execução no. 71.

No Capítulo 2, para levar fundamentar a descrição e interpretação de dados, alcei vôo sob as luzes da Análise de Discurso Crítica (FAIRCLOUGH, 2003; 2010) em interface com a Linguística Sistêmico-Funcional (HALLIDAY \& MATTHIESSEN, 2004). O interesse na LSF foi constituído por ser uma teoria precursora da ADC e por disponibilizar, através da GSF, recursos léxico-gramaticais referentes ao Sistema de Transitividade e o Sistema de Modo e Modalidade. A microanálise da linguagem forma parte da análise textualmente orientada, proposta por Fairclough (2003). Na proposta fairclougheana de análise, por meio dos significados da linguagem, pude reconhecer e interpretar modos de agir e ações, modo de representar e representações e modos de ser e identificações, presentes, sobretudo, nas duzentas e trinta e seis páginas do texto do PDA Santa Tereza I. As facetas sociais e discursivas da preocupação em foco são configuradas em questões sócio-discursivas, por envolver questões sobre discurso(s). A pesquisa revestiu-se, pois, da preocupação de pesquisa como um problema social sob as dimensões textual, interpretativa e explicativa para a realização da análise de discurso crítica em dados de natureza documental e etnográfica.

No Capítulo 3, no que remete à inclusão social de assentados/as em situação de risco, optei pela metodologia proposta nas pesquisas qualitativas. A pesquisa qualitativa permite interpretar fatos sociais e, em condições propícias, pode apontar práticas transformadoras que 
suscitam reflexões sobre possibilidades de diminuição de injustiças sociais. Nessa perspectiva, a triangulação de teorias, de dados e de estratégias de investigação - com várias práticas interpretativas interligadas - propiciou uma visão mais acurada do problema estudado. Com isso, a partir do estudo de aspectos da conjuntura da reforma agrária no Brasil e do aporte da ADC e LSF em termos de teoria e de metodologia, busquei mais especificamente a aproximação de respostas para as questões de pesquisa deste trabalho nos Capítulos 4 e 5.

No Capítulo 4, apesar do foco da pesquisa estar voltado para os significados representacional e identificacional da linguagem (FAIRCLOUGH, 2003), realizei, a análise do PDA sob a perspectiva do significado acional. A estrutura composicional do PDA Santa Tereza I sinaliza que a COOPVAG atua como um agente social na elaboração desse documento e possui seus próprios 'poderes causais'. Esses poderes não são simplesmente reduzíveis aos poderes causais, no caso, do INCRA (agente contratante) e dos/as assentados/as (teoricamente beneficiados/as com o PDA). A análise da estrutura composicional, também sinalizou a atenção da COOPVAG - na elaboração do PDA - voltada para prescrição da execução de 'ações', principalmente, aos/às agentes assentados/as e poder público municipal de Ponte Alta. Ademais, a maioria das ações propostas está voltada para o campo das abstrações e distante de execução, o que torna muitas proposições desse PDA somente 'planejamentos', estando no âmbito do 'interior' das ideias. Para isso, faz-se recorrente também o apagamento de agentes responsáveis pelas ações propostas.

Em relação ao significado identificacional, no Capítulo 4, o usos de recursos da modalidade e da polaridade parecem ser justificados por o PDA apresentar como função social voltada o planejamento do desenvolvimento de projetos de assentamentos. Como um 'plano', foi constituído com atribuição de papeis sociais, de certa maneira, com avaliações e julgamentos dos agentes e das ações propostas. Além disso, o uso de 'verbos modais', adjuntos modais e expressões modalizadoras junto aos processos materiais apontou especificação e restrição às ações propostas no PDA. A execução de muitas ações propostas aparece restrita a somente uma maneira, o que caracteriza obrigação. Essas ações no grau de obrigação são dirigidas com recorrência ao/à agente assentado/a. Cabe aos/às assentados/as a execução de grande parte das ações propostas, mas não há especificação, pelo menos, de garantias de recursos financeiros e de capacitação técnica para que sejam executadas. $\mathrm{O}$ tipo de agência configurado no PDA Santa Tereza I está atrelado aos papeis discursivos desempenhados. Dos dez atores sociais mais recorrentes, cinco fazem referência à categoria lexical de pessoas candidatas a um lote no PA, pessoas acampadas, futuros/as assentados/as. 
Ao mesmo tempo, essas pessoas são beneficiárias de políticas públicas sobre e reforma agrária, mas também são agentes responsáveis pela execução da maioria das ações prescrita no PDA. A agência que deveria ser atribuída ao 'agente' governo federal/INCRA/COOPVAG, como parte envolvida na elaboração do PDA, é colocada em segundo plano ou é apagada. Nas poucas vezes que ocorre a agência do governo federal/INCRA/COOPVAG, há a representação do agente encoberta pela passivação. Somente ocorre explicitação de agência de gestor público, quando faz referência ao agente Prefeitura de Ponte Alta, apontada como responsável por toda a infraestrutura do PA.

No Capítulo 5, o propósito de investigação dos dados de natureza etnográfica, sobretudo a partir entrevistas com pessoas envolvidas no processo de elaboração do PDA do PA Santa Tereza I, está relacionado às questões de pesquisa referentes a representações e identificações de assentados/as pioneiros/as e funcionários do INCRA sobre o processo de elaboração do PDA. Nas entrevistas com assentados/as, alguns/as pioneiros/as demonstraram desconhecimento do PDA estudado e nem se lembraram do objetivo das reuniões com a COOPVAG quando estavam acampados/as. Além disso, de modo recorrente, os/as assentados/as atribuíram a agência de elaboração do PDA à COOPVAG e ao INCRA, mas a primeira aparece com mais frequência. No que concerne às ações desenvolvidas por esses/as participantes, há a representação de os/as assentados/as tentarem se colocar como pacientes em relação ao processo de elaboração do PDA e, consequentemente, representam poucas ações na luta na terra (no PDA), reflexividade desse papel, principalmente devido à falta de recursos financeiros, naturais nos lotes, assim como à falta de capacitação técnica. Nas entrevistas com funcionários do INCRA, há de se destacar maior ocorrência de processos relacionais, do mundo do 'ser', distante do 'mundo do fazer e do acontecer'. Já o papel de agente na elaboração do PDA foi atribuído à COOPVAG e aos/às assentados/as pioneiros/as, mas a primeira com mais frequência, como nas entrevistas com os/as pioneiros/as. Em relação à representação dos funcionários do INCRA sobre si mesmos, são representados como fiscalizadores das "ações" da COOPVAG na elaboração do PDA. Nessas entrevistas, houve também a representação dos/as pioneiros/as como passivos/as, beneficiários/as da 'assistência' prestada pela COOPVAG e pelo INCRA. Destaquem-se, ainda, os recursos que os recursos da modalidade, pois "funcionaram" para avaliarem o PDA pejorativamente enquanto uma ferramenta institucional para o desenvolvimento de PAs.

A pesquisa, ora apresentada, significa uma contribuição para trabalhos futuros, que contemplem no campo político-social, estudos sobre textos institucionais ou não que 
representem questões relativas a modos de vida nas regiões rurais do Brasil. São necessários estudos que apoiem práticas sociais que favoreçam condições dignas de sobrevivência.

As pessoas com luta na terra, muitas vezes, estão sendo submetidas à situação de risco e necessitam de mínimas condições de sobrevivência, apesar de essas pessoas já estarem sendo 'atendidas' por, pelo menos, um programa assistencial do governo - possuir a concessão de uso de um lote em um projeto de assentamento. Desse modo, é preciso repensar a elaboração e o uso de textos institucionais brasileiros acerca de questões relativas aos modos de vida existentes em muitos projetos de assentamentos.

Isso posto, a Tese foi sistematizada no esquema abaixo, o qual representa a sua estrutura de organização.

\begin{tabular}{|c|c|}
\hline \multicolumn{2}{|c|}{$\begin{array}{l}\text { Discursividades em um Plano de Desenvolvimento Agrário: } \\
\text { facetas de práticas sociais (re)produzidas }\end{array}$} \\
\hline \multicolumn{2}{|c|}{$\begin{array}{l}\text { O problema de pesquisa, destacado nesta tese, faz referência ao estudo de discursividades e representações } \\
\text { linguístico-discursivas configuradas no Plano de Desenvolvimento Agrário do Projeto de Assentamento Santa Tereza } \\
\text { I, em Ponte Alta-Tocantins, em termos de discussões sobre justiça social no contexto brasileiro, a partir de políticas } \\
\text { públicas voltadas para a reforma agrária, como os PDAs, considerando a inclusão social de assentados/as, } \\
\text { historicamente, à margem da sociedade brasileira. }\end{array}$} \\
\hline \multicolumn{2}{|c|}{$\begin{array}{l}\text { O objetivo geral é investigar as discursividades e as representações configuradas no texto do PDA Santa Tereza I, } \\
\text { com o propósito de favorecer a reflexão sobre práticas discursivas transformadoras e que beneficiem parte da } \\
\text { sociedade sedenta por mais justiça social no que remete à questão agrária no Brasil. }\end{array}$} \\
\hline \multicolumn{2}{|c|}{$\begin{array}{l}\text { Para tanto, a pesquisa foi constituída de acordo com o aporte teórico-metodológico da Análise de Discurso Crítica } \\
\text { (FAIRCLOUGH, 2003, 2010) e da Gramática Sistêmico-Funcional (HALLIDAY \& MATTHIESSEN, 2004) como } \\
\text { ferramenta para a microanálise da linguagem, que forma parte da análise proposta pela primeira. } \\
\text { Há também aspectos da abordagem acerca da representação de atores sociais, sugerida por van Leuween (1997, } \\
\text { 2008), de interesse aqui. }\end{array}$} \\
\hline $\begin{array}{c}\text { Análise dos dados de natureza documental: } \\
\text { o PDA Santa Tereza I }\end{array}$ & $\begin{array}{l}\text { Análise dos dados de natureza etnográfica: } \\
\text { entrevistas com assentados/as e funcionários do } \\
\text { INCRA-SR26 }\end{array}$ \\
\hline $\begin{array}{c}\text { Categorias de análise: } \\
\text { aspectos das metafunções ideacional e interpessoal }\end{array}$ & $\begin{array}{c}\text { Categorias de análise: } \\
\text { aspectos das metafunções ideacional e interpessoal }\end{array}$ \\
\hline
\end{tabular}

\begin{tabular}{|c|c|c|c|c|}
\hline \multicolumn{5}{|c|}{$\begin{array}{c}\text { Análise dos dados de natureza documental: } \\
\text { o PDA Santa Tereza I }\end{array}$} \\
\hline \multicolumn{5}{|c|}{$\begin{array}{c}\text { Categorias de análise: } \\
\text { aspectos das metafunções ideacional e interpessoal }\end{array}$} \\
\hline Processos & \multicolumn{2}{|c|}{ Participantes } & Modalidade e polaridade & $\begin{array}{l}\text { Representação de } \\
\text { atores Sociais }\end{array}$ \\
\hline $\begin{array}{l}\text { - Muitos } \\
\text { materiais } \\
\text { abstratos; } \\
\text { - Futuro } \\
\text { presente } \\
\text { indicativo }\end{array}$ & $\begin{array}{l}\text { Voz passiva: } \\
\text { topicaliza- } \\
\text { cão da } \\
\text { 'meta' }\end{array}$ & $\begin{array}{l}\text { Voz } \\
\text { passiva: } \\
\text { omissão } \\
\text { 'agentes' }\end{array}$ & $\begin{array}{l}\text {-Modulação e modalização; } \\
\text { - Polaridade negativa }\end{array}$ & $\begin{array}{l}\text { Inclusão e exclusão } \\
\text { de atores sociais }\end{array}$ \\
\hline \multicolumn{5}{|c|}{$\begin{array}{c}\text { Questões de pesquisa: } \\
\text { Que representações de atores sociais são constituídas na configuração linguística do PDA Santa Tereza I? } \\
\text { Como os as assentados'as do PA Santa Tereza I são representados as em seu PDA? }\end{array}$} \\
\hline \multicolumn{3}{|c|}{$\begin{array}{l}\text { A maioria das ações propostas está no } \\
\text { campo das abstrações e distante de } \\
\text { execução, seja pelo uso de processos } \\
\text { materiais abstratos seja pelo uso do } \\
\text { futuro do presente do indicativo. }\end{array}$} & $\begin{array}{l}\text { O uso de 'verbos modais' e expressões } \\
\text { modais e adjuntos modais junto aos } \\
\text { processos materiais aponta especificação } \\
\text { e restrição das ações propostas. A } \\
\text { execução dessas ações caracteriza }\end{array}$ & $\begin{array}{l}\text { Os atores sociais mais } \\
\text { recorrentes no PDA Santa } \\
\text { Tereza I, fazem referência às } \\
\text { pessoas candidatas a um lote } \\
\text { no PA, na época, acampadas. }\end{array}$ \\
\hline
\end{tabular}




\begin{tabular}{|c|c|c|}
\hline $\begin{array}{l}\text { Ocorre também o apagamento dos } \\
\text { agentes responsáveis pelas ações } \\
\text { propostas ao longo do texto, o que } \\
\text { torna difícil a atribuição especificada de } \\
\text { papeis sociais. }\end{array}$ & $\begin{array}{l}\text { obrigatoriedade além de serem dirigidas } \\
\text { ao agente assentado/a com recorrência no } \\
\text { texto. }\end{array}$ & $\begin{array}{l}\text { Com isso, o governo } \\
\text { federal/INCRA/COOPVAG é } \\
\text { colocado em segundo plano. } \\
\text { Somente ocorre explicitação } \\
\text { de agência desse tipo, quando } \\
\text { o agente faz referência à } \\
\text { Prefeitura de Ponte Alta, } \\
\text { apontada como a responsável } \\
\text { pela execução de toda a } \\
\text { infraestrutura do PA. } \\
\text { Os/as futuros assentados/as } \\
\text { são configurados/as como } \\
\text { beneficiários/as de políticas } \\
\text { públicas sobre e reforma } \\
\text { agrária, mas também são } \\
\text { agentes responsáveis pela } \\
\text { execução da maioria das } \\
\text { ações prescrita. }\end{array}$ \\
\hline
\end{tabular}

\begin{tabular}{|c|c|}
\hline \multicolumn{2}{|c|}{$\begin{array}{l}\text { Análise dos dados de natureza etnográfica: } \\
\text { entrevistas com assentados/as e funcionários do INCRA-SR26 }\end{array}$} \\
\hline \multicolumn{2}{|c|}{ Categorias de análise: aspectos das metafunções ideacional e interpessoal: } \\
\hline Entrevistas no assentamento & Entrevistas no INCRA \\
\hline $\begin{array}{l}\text { Modulação e modalização, } \\
\text { Polaridade negativa }\end{array}$ & Modulação e modalização \\
\hline $\begin{array}{l}\text { Questão de pesquisa: } \\
\text { O/a assentado/a entrevistado/a se identifica com as } \\
\text { representações expressas no PDA? }\end{array}$ & $\begin{array}{l}\text { Questão de pesquisa: } \\
\text { Que representações são constituídas quando } \\
\text { funcionários do INCRA-SR26, responsáveis técnicos } \\
\text { pela elaboração do PDA, relatam sobre a constituição } \\
\text { do mesmo? }\end{array}$ \\
\hline $\begin{array}{l}\text { Nas entrevistas com assentados/as, alguns/as pioneiros/as } \\
\text { demonstraram desconhecimento do PDA estudado e nem } \\
\text { se lembraram do objetivo das reuniões com a COOPVAG } \\
\text { quando estavam acampados/as. } \\
\text { Além disso, de modo recorrente, os/as assentados/as } \\
\text { atribuíram a agência de elaboração do PDA à COOPVAG } \\
\text { e ao INCRA, mas a primeira aparece com mais frequência. } \\
\text { Também no que concerne às ações desenvolvidas por } \\
\text { esses/as participantes, há a representação de os/as } \\
\text { assentados/as tentarem se colocar como pacientes em } \\
\text { relação ao processo de elaboração do PDA e, } \\
\text { consequentemente, também representam suas poucas ações } \\
\text { na luta na terra (no PDA), reflexividade desse papel, } \\
\text { principalmente devido à falta de recursos financeiros, aos } \\
\text { recursos naturais indisponíveis nos lotes, assim como à } \\
\text { falta de capacitação técnica. }\end{array}$ & $\begin{array}{l}\text { Nas entrevistas com os funcionários do INCRA, há de } \\
\text { se destacar uma maior ocorrência de processos } \\
\text { relacionais, do mundo do 'ser'. } \\
\text { o papel de agente no processo de elaboração do PDA } \\
\text { foi atribuído à COOPVAG e aos/às assentados/as } \\
\text { pioneiros/as, mas a primeira também aparece com mais } \\
\text { frequência, como nas entrevistas com os/as } \\
\text { pioneiros/as. } \\
\text { Em relação aos recursos referentes ao tipo de agência, } \\
\text { há representação dos funcionários do INCRA, de si } \\
\text { mesmos, como fiscalizadores das atividades } \\
\text { desenvolvidas pela COOPVAG para a elaboração do } \\
\text { PDA, como também há representação dos/as } \\
\text { pioneiros/as como passivos/as, beneficiários/as da } \\
\text { 'assistência' prestada pela COOPVAG e pelo INCRA. } \\
\text { Destaque-se também que os recursos que dizem } \\
\text { respeito ao Sistema de Modo, usados pelos } \\
\text { funcionários do INCRA, "funcionaram" nas entrevistas } \\
\text { mais para avaliarem pejorativamente o PDA enquanto } \\
\text { uma das ferramentas institucional para o } \\
\text { desenvolvimento de PAs. }\end{array}$ \\
\hline
\end{tabular}

Parece não ter havido interesse em garantir direitos em relação ao uso da terra. O PDA foi elaborado há sete anos (em 2007) e quase ação alguma 'planejada' foi executada. As ações propostas no PDA foram constituídas no âmbito de um 'planejamento' e até hoje continuam no mesmo âmbito. Poucas ações foram executadas. 


\section{REFERÊNCIAS}

ANDRE, M. E. D. Etnografia da prática escolar. Campinas: Papirus, 1995.

ANGROSINO, M. Etnografia e observação participante. Trad. José Fonseca. Porto Alegre: Artmed, 2009.

ASSUNÇÃO, A. L. Discurso e representação social: o trabalho ideológico da/na linguagem. In: LYSARDO-DIAS, D (Org.). Discurso, representação social e ideologia. São João DelRei: PROMEL, UFSJ, 2005.

BAKHTIN, M. Marxismo e Filosofia da Linguagem. São Paulo: Hucitec, 1979.

BARBARA, L. \& MACÊDO, C. M. M.. "Linguística Sistêmico-Funcional para a Análise de Discurso: um panorama introdutório". In: SILVA, D. E. G. (Org.). Cadernos de linguagem e sociedade, v. 10, nº 1, Brasília: Thesaurus. 2009, p.89-107.

BARBOUR, R.. Grupos focais. Trad. Marcelo Figueiredo. Porto Alegre: Artmed, 2009.

BARROS, M. Poesia Completa. São Paulo: Leya, 2011.

Ensaios fotográficos. Rio de Janeiro: Editora Record, 2000.

BARROS, S. M. P. Análise crítica do discurso e realismo crítico: reflexões teóricometodológicas. Linguasagem (São Paulo), v. 16, 2011, p. 01-12.

Realismo crítico (RC), análise de discurso crítica (ADC) e gramática sistêmicofuncional (GSF): reflexões para a formação do educador de línguas em processo de emancipação e transformação social. Cadernos de Linguagem e Sociedade, v. vol.10, 2009, p. 68-98.

Prática Pedagógica Emancipatópria: O Professor Reflexivo em Processo de Mudança. Um Exercício em Análise Crítica do Discurso. São Carlos: Pedro \& João Editores, 2008.

BAUER, M. W.; GASKELL, G. (Editores). Pesquisa qualitative com texto, imagem e som: um manual prático. Trad. Pedrinho Guareschi. 7 ed. Petrópolis: Vozes, 2008.

BERGAMASCO, S.; NORDER, L. A. Assentamentos rurais e o MST em São Paulo. In: CARTER, M. (Org.). Combatendo a desigualdade social: o MST e a reforma agrária no Brasil. Trad. Cristina Yamagami. São Paulo: Editora UNESP, 2010.

BHASKAR, R. From Science to Emancipation. Alienation and the Actuality of Enlightenment. New Delhi, London: Sage Publications, 2002.

Critical Realism. Essential Readings. In: ARCHER, M. et al. Centre For Critical Realism. London: Routledge, 1998.

Scientific Realism and Human Emancipation. London: Verso, 1986. 
BORDIEU, P. Capital cultural, escola e espaço social. México: Século XXI, 1997.

BRASIL. Lei no. 8.666, de 21 de junho de 1993 e alterações. Brasília: Presidência da República, Casa Civil, Subchefia para Assuntos Jurídicos. Disponível em: <http://www.planalto.gov.br/ccivil_03/leis/18666cons.htm>. Acesso em: 25 jun. 2014a.

IN/STN/01, de 15 de janeiro de 1997 e alterações. Brasília: Ministério da Fazenda, Tesouro Nacional.

Disponívelem:<http://www3.tesouro.fazenda.gov.br/legislacao/download/estados/IN_STN_1 _1997_Convenios/IN_stn_01_15jan1997_convenios.htm>. Acesso em: 25 jun. 2014b.

Decreto $n^{\circ}$ 6170/2007 e alterações. Brasília: Presidência da República, Casa Civil, Subchefia para Assuntos Jurídicos.

Disponívelem:<http://www.planalto.gov.br/ccivil_03/_ato20072010/2007/decreto/d6170.htm >. Acesso em: 25 jun. 2014c.

; MINISTÉRIO PÚBLICO FEDERAL. Lei $\mathbf{N}^{0} \mathbf{1 0 . 5 5 0}$, de 13 de novembro de 2002. Brasília: Presidência da República, Casa Civil, Subchefia para Assuntos Jurídicos. Disponível em: <http://www.planalto.gov.br/ccivil_03/Leis/2002/L10550.htm>. Acesso em: $10 \mathrm{dez}$. 2014d.

Lei no. 8.629, de 25 de fevereiro de 1993. Brasília: Presidência da República, Casa Civil, Subchefia para Assuntos Jurídicos. Disponível em: http://www.planalto.gov.br/ccivil_03/leis/18629.htm. Acesso em: 30 out. 2013.

Decreto no 1.110, de 9 de julho de 1970. Brasília: Presidência da República, Casa Civil, Subchefia para Assuntos Jurídicos. Disponível em: http://www.planalto.gov.br/ccivil_03/decreto-lei/1965-1988/Del1110.htm. Acesso em: 11 jul. 2012.

Lei no. 4.504, de 30 de novembro de 1964. Brasília: Presidência da República, Casa Civil, Subchefia para Assuntos Jurídicos Disponível em: <http://www.planalto.gov.br/ccivil/leis/L4504.htm>. Acesso em: 26 out. 2010.

. Constituição da República Federativa do Brasil. Brasília: Senado Federal, Subsecretaria de Edições Técnicas, 2008.

CAMERON, D. et al. Researching language. London: Routledge, 1992.

CAMPÊLO, S. R. S. Adolescência, pobreza e inclusão digital: práticas discursivas e identidades (re)construídas no espaço virtual. Brasília: Programa de Pós-Graduação em Linguística da Universidade de Brasília, 2014. Dissertação de Mestrado em Linguística.

CARTER, M. Desigualdade social, democracia e reforma agrária no Brasil. In: CARTER, M. (Org.). Combatendo a desigualdade social: o MST e a reforma agrária no Brasil. Trad. Cristina Yamagami. São Paulo: Editora UNESP, 2010.

CHOULIARAKI, L.; FAIRCLOUGH, N. Discourse in late modernity: rethinking critical discourse analysis. Edinbourg: Edinbourg University, 1999. 
CLIFFORD, J. Notes on field(notes). In: SANJEK, R. (Org.). Fieldnotes. London: Cornell University Press, 1993.

COOPERATIVA DE PROFISSIONAIS LIBERAIS DO VALE DO ARAGUAIA (COOPVAG). Plano de Desenvolvimento do Projeto de Assentamento Santa Tereza I. 2007.

CUNHA, M. A. da; SOUZA, M. M. de. Transitividade e seus contextos de uso. São Paulo: Corteza, 2011.

DELGADO, G. C. A questão agrária e o agronegócio no Brasil. In: CARTER, M. (Org.). Combatendo a desigualdade social: o MST e a reforma agrária no Brasil. Trad. Cristina Yamagami. São Paulo: Editora UNESP, 2010.

DELL'ISOLLA, Regina Lúcia Péret. Retextualização de gêneros escritos. Rio de Janeiro: Lucerna, 2007.

DENZIN, N. K. O planejamento da pesquisa qualitative: teorias e abordagens. Trad. Sandra Regina Netz. 2 ed. Porto Alegre: Artmed, 2006.

Interpretive interactionism. Newbury Park: Sage, 1989.

DURKHEIM, É. Représentions individualles et representations collectives. In: Sociologie et philosophie. Paris: PUF, 1898.

EDIÇÕES POLIGLOTAS. Dicionário de Português. São Paulo: Editora Melhoramentos Ltda, 2002.

EGGINS, S. An introduction to Systemic Functional Linguistics. New York; London: Continuum, 2nd Edition, 1994.

EMATER. Programa de Assessoria Técnica, Social e Ambiental à Reforma Agrária ATES/INCRA. Disponível em: http://www.emater.pr.gov.br/modules/conteudo/conteudo.php?conteudo=126. Acesso em: 10 dez. 2014.

FAIRCLOUGH, N. Critical Discourse Analysis: The Critical Study of Language. London: Routledge, 2010.

Language and globalization. London: Routledge, 2006.

Analysing discourse: textual analysis for social research. London: Routledge, 2003.

. Discurso e mudança social. Coord. trad., revisão e prefácio à ed. bras. I. Magalhães.

Brasília: Editora Universidade de Brasília, 2001.

Discourse and Social Change. 3 ed. Cambridge: Polity Press, 1995a.

Critical discourse analysis. London: Longman, 1995 b. 
; KRESS, G. Critical discourse analysis. Mimeo, 1993.

Discourse end Social Change. Cambridge: Polity Presse, 1992.

Language and power. London: Longmam, 1989.

. Critical and descriptive goals in discourse analysis. Journal of Pragmatics, n. 9, 1985, p. 739-763.

FLICK, U. Qualidade na pesquisa qualitativa. Trad. Roberto Cataldo Costa. Porto Alegre: Artmed, 2009.

FREIRE, P. Pedagogia do Oprimido. 17 ed. Rio de Janeiro, Paz e Terra, 1987.

GASKELL, G. Entrevistas individuais e grupais. In: BAUER, M. W.; GASKELL, G. (Editores). Pesquisa qualitative com texto, imagem e som: um manual prático. Trad. Pedrinho Guareschi. 7 ed. Petrópolis: Vozes, 2008.

GIBBS, G. Análise de dados qualitativos. Trad. Roberto Cataldo Costa. Porto Alegre: Artmed, 2009.

GIDDENS, A. As consequências da modernidade. Trad. Raul Fiker. São Paulo: Editora Universidade Estadual Paulista, 1991.

GOMES, M. C. A. A prática sócio-institucional do Licenciamento Ambiental: a tensão entre os gêneros discursivos, discursos e vozes, Ano de obtenção: 2003. Tese de Doutorado (Estudos Linguísticos). Universidade Federal de Minas Gerais, 2003.

GOHN, M. G. Movimentos sociais na atualidade: manifestações e categorias analíticas. In: GOHN, M. G. (Org.). Movimentos sociais no início do século XXI. Antigos e novos atores sociais. Petrópolis: Vozes, 2003, p. 13-32.

HALLIDAY, M. A. K. Halliday's Introduction to Functional Grammar. $4^{\text {nd }}$ ed. London, New York: Routledge, Taylor and Francis Groups, 2004a.

; MATTHIESSEN, C. M. I. M. An Introduction to Functional Grammar. $3^{\text {nd }}$ ed. London: Arnold, 2004b.

An Introduction to Functional Grammar. $2^{\text {nd }}$ edition. Londres: Arnold, 1994.

; HASAN, R. Language, context, and text: aspects of language in a social-semiotic perspective. Oxford: Oxford University Press, 1989.

An introduction to functional grammar. London: Edward Arnold, 1985.

Language as Social Semiotic: the social intepretation of language and meaning. Baltimore, MD: University Park Press, 1978.

HAMMERSLEY, M.; ATKINSON, P. Ethnography: principles in practice. London: Tavistock.1983. 
INCRA. O INCRA. Disponível em: http://www.incra.gov.br/content/o-incra. Acesso em: 15 jun. 2014a.

História da Reforma Agrária. Disponível em: http: //www.incra.gov.br/reformaagrariahistoria. Acesso em: 13 mai. 2014b.

INSTITUTO SOCIEDADE, POPULAÇÃO E NATUREZA - ISPN. Cerratinga. Capim Dourado. Disponível em: http://www.cerratinga.org.br/babacu/. Acesso em: 10 dez. 2014a.

Cerratinga. Babaçu. Disponível em: http://www.cerratinga.org.br/babacu/. Acesso em: 10 dez. 2014b.

JOVCHLOVITCH, S. \& BAUER, M. W. Entrevista Narrativa. In: BAUER, M. W.; GASKELL, G. (Editores). Pesquisa qualitativa com texto, imagem e som: um manual prático. Trad. Pedrinho Guareschi. 7 ed. Petrópolis: Vozes, 2008. p. 91-113

KRESS, G. Against arbitrariness: the social production of the sign as a foundational issue in critical discourse analysis. Discourse \& society, v.4, n.2, 1993, p. 169-191.

Critical Discourse Analysis. In: GRABE, W. (Org.), Annual Review of Applied Linguistic 11, 1990, p. 84-99.

History and language: towards a social account of linguistic change. Journal of Pragmatics, v. 13, n. 3, n.3, 1989, p. 445-466.

LUDKE; M.; ANDRÉ, M. E. D. A. Pesquisa em educação: abordagens qualitativas. São Paulo: EPU, 1986.

LYSARDO-DIAS, D. Discursos e representações sociais. In: LYSARDO-DIAS, D. Discurso, representação social e ideologia (Org.). São João Del-Rei: PROMEL, UFSJ, 2005.

MAGALHAES, I. Introdução: a Análise de Discurso Crítica. D.E.L.T.A., volume 21, número especial. São Paulo: EDUC, 2005, p.1-11.

Eu e tu: a constituição do sujeito no discurso médico. Brasília: Thesaurus, 2000.

MARCUSCHI, L. A. Gêneros textuais: configuração, dinamicidade e circulação. In: KARWOSKI, A. M.; GAYDECZKA, B.; BRITO, K. S. (Orgs.). Gêneros textuais: reflexões e ensino. 2a edição. Rio de Janeiro: Lucerna, 2006, p.23-36.

MARÉS, C. F. A função social da terra. Porto Alegre: Fabris, 2003.

MARTIN, J. R.; WHITE, P. The language of evaluation: appraisal in English. New York: Palgrave, 2005.

; ROSE, D. Working with Discourse: meaning beyond the clause. New York: Continuun, 2003. 
MEDEIROS, L. S. de. Movimentos sociais no campo, lutas por direitos e reforma agrária na segunda metade do século XX. In: CARTER, M. (Org.). Combatendo a desigualdade social: o MST e a reforma agrária no Brasil. Trad. Cristina Yamagami. São Paulo: Editora UNESP, 2010.

MENDONÇA, S. M.; STEDILE, J. P. (Orgs.). A questão agrária no Brasil: a classe dominante agrária - natureza e comportamento 1964-1990. São Paulo: Expressão Popular, 2006.

MESZAROS, G. O MST e o Estado de Direito no Brasil. In: CARTER, Miguel (Org.). Combatendo a desigualdade social: o MST e a reforma agrária no Brasil. Trad. Cristina Yamagami. São Paulo: Editora UNESP, 2010.

MEURER, J. L. Gêneros: teorias, métodos, debates. São Paulo: Parábola Editorial, 2005.

MILLER, C. R. Genres as social action. Quarterly Journal of Speech, 70, 1984, p.151-167.

MINISTÉRIO DO DESENVOLVIMENTO AGRÁRIO; INSTITUTO NACIONAL DE COLONIZAÇÃO E REFORMA AGRÁRIA. II Plano Nacional de Reforma Agrária. Brasília, 2004.

MINISTÉRIO PÚBLICO FEDERAL (MPF). Procuradoria da República na Bahia. Glossário de Termos Jurídicos. Disponível em: http://www.prba.mpf.mp.br/sala-deimprensa/glossario. Acesso em: 24 jun. 2014.

MISHLER, E. G. Validation in inquiry-guided research: the role of exemplars in narrative studies. Harvard Educational Review, 60, 1990, p. 415-442.

MORGAN, D. Focus groups. Annual Review of Sociology, 22, 1996.

Focus Groups as qualitative Research. London: Sage, 1988.

MOREIRA, K. C. de A. Representações linguístico-discursivas pertinentes a crianças e adolescentes em situação de risco: perspectivas para a inclusão educacional. Brasília: Programa de Pós-Graduação em Linguística da Universidade de Brasília, 2013. Tese de Doutorado em Linguística.

NEVES, M. H. de M. Gramática de usos do Português. São Paulo: Editora UNESP, 2000.

PARDO, M. L (Org.). El discurso sobre la pobreza en América Latina. Santiago: Frasis, 2008.

PARDO ABRIL, N. G. Qué nos dicen? Que vemos? Que és... pobreza? Análisis crítico de los médios. Bogotá: Universidad Nacional de Colombia, Faculdade de Ciencias Humanas, Departamento de Linguística, Instituto de Estudio em Comunicación y Cultura, 2008.

PEREIRA, H. J. Criando seu próprio negocio: Como desenvolver o potencial empreendedor. Brasília: Editora Sebrae, 1995. 
PRADO JÚNIOR, C. A revolução brasileira; A questão agrária no Brasil. 1ed. São Paulo: Companhia das Letras, 2014.

RAJAGOPALAN, K. Por uma linguística crítica. São Paulo: Parábola, 2003.

RAMALHO, V.; RESENDE, V. de M. Análise de Discurso (para a) Crítica: o texto como material de pesquisa. Campinas: Pontes Editoras, 2011.

RESENDE, V. de M. A negociação de significados em uma reunião do Movimento Nacional de Meninos e Meninas de Rua. In: SILVA, D. E. G. da (Editora Chefe). Cadernos de linguagem e sociedade, v. 11, $\mathrm{n}^{\circ}$ 1, Brasília: Thesaurus. 2010a, p.160-191.

Between the European legacy and critical daring: epistemological reflections for critical discourse analyses. Journal of Multicultural Discourses, v.5 (3), 2010b, p.193-212.

. Análise de discurso crítica e realismo crítico. Campinas: Pontes Editores, 2009.

RESENDE, V. de M. Análise de Discurso Crítica e Etnografia: o Movimento Nacional de Meninos e Meninas de Rua, sua crise e o protagonismo juvenil. Brasília: Programa de Pós-Graduação em Linguística da Universidade de Brasília, 2008. Tese de Doutorado em Linguística.

; RAMALHO, V. Análise de Discurso Crítica. São Paulo: Contexto, 2006.

ROSA, M. C. Para além do MST: os impactos nos movimentos sociais brasileiros. In: CARTER, M. (Org.). Combatendo a desigualdade social: o MST e a reforma agrária no Brasil. Trad. Cristina Yamagami. São Paulo: Editora UNESP, 2010.

SAMPAIO, P. de A. O impacto do MST no Brasil de hoje. In: CARTER, M. (Org.). Combatendo a desigualdade social: o MST e a reforma agrária no Brasil. Trad. Cristina Yamagami. São Paulo: Editora UNESP, 2010.

SARDINHA, T. B. Linguística de Corpus. Barueri: Manole, 2004.

SÁ-SILVA et al.. Pesquisa documental: pistas teóricas e metodológicas. Revista Brasileira de História \& Ciências Sociais, São Leopoldo, ano I, jul. 2009.

SCOTT, M. WordSmith Tools 6.0: software for text analysis. Liverpool: Lexical Analysis Software, 2012.

SEN, A. Desenvolvimento como liberdade. Trad. Laura Teixeira Motta. São Paulo: Companhia das Letras, 2010.

SILVA, D. E. G. da. A gramática da pobreza em práticas discursivas de atores sociais: uma perspectiva crítica. In: PINTO, J. P.; FABRÍCIO, B. F. (Orgs.). Exclusão social e microresistências: a centralidade das práticas discursivo-identitárias. Goiânia: Cânone Editorial, 2013a.

'A gente' no lugar de um elemento pronominal perdido. IV Simpósio Mundial de Estudo de Língua Portuguesa (SIMELP). Anais : Língua Portuguesa : ultrapassando 
fronteiras, unindo culturas, 02 a 05 de julho de 2013/Comissão organizadora: Vânia Cristina Casseb Galvão [et al.]. Goiânia: FUNAPE, 2013b.

Estudos críticos do discurso no contexto brasileiro (por uma rede de transdisciplinaridade). Eutomia, edição 9, ano V, p. 224-243, julho2012. Disponível em: <http://www.revistaeutomia.com.br>. Acesso em: 05 dez. 2012. p.721-731.

Representações discursivas da pobreza e gramática. DELTA, PUC-SP, v. 25, 2009,

A pobreza no contexto brasileiro: da exclusão econômica e social à ruptura familiar. In: PARDO, L. (Org.), Revista Discurso y Sociedad, vol. 2(2), 2008a. Disponível em: <http://www.dissoc.org.>. Acesso em 10 ago. 2014. p. 265-296.

; RAMALHO, V. Análise de Discurso Crítica: representações sociais na Mídia. In: LARA, G. et al, Estudos do Discurso hoje, vol. 2. Rio de Janeiro: Editora Nova Fronteira, 2008b.

. Identidades enfraquecidas versus cidadania cultural. In: Joachin Sèbastien (Org.). Diversidade cultural, linguagens e identidades. Recife: Elógica, vol. 1, 2007a, p. 51-68.

Critical Discourse Analysis and the functional bases of language. In: BARBARA, L. \& SARDINHA, T. B. (Eds.). Proceedings of The 33rd International Systemic Functional Congress. PUCSP, São Paulo, Brazil, 2007b, p. 932-949.

A repetição em narrativas de adolescentes: do oral ao escrito. $1^{a}$. ed. Brasília: Editora Universidade de Brasília: Plano Editora: Oficina Editorial/Instituto de Letras - UnB, 2001.

A oralidade no discurso narrativo escrito de adolescentes. Brasília: Programa de Pós-Graduação em Linguística da Universidade de Brasília, 1991. Dissertação de Mestrado em Linguística.

SOUZA, C. A. L. de; SILVA, D. E. G. da. Discurso e reforma agrária em alguns textos institucionais do Brasil. In: RESENDE, V. de M. (Org.) \& SILVA, D. E. G. (Ed.). Cadernos de Linguagem e Sociedade/Papers on Language and Society, v. 14, número especial. Brasília: Thesaurus Editora, 2013.

STEDILE, J. P. (Org.). A questão agrária no Brasil: história e natureza das ligas camponesas 1954-1964. São Paulo: Expressão Popular, 2006.

SWALES, J. M. Genre analysis: english in academic and research settings. New York: Cambridge University Press, 1990.

THOMPSON, G. Introductional Functional Grammar. 2 ed. London: Arnold, 2004.

Ideologia e cultura moderna: teoria social crítica na era dos meios de comunicação de massa. Trad. Grupo de Estudos sobre Ideologia, comunicação e representações sociais da pós-graduação do Instituto de Psicologia da PURCS. 6 ed. Petrópolis: Vozes, 1995. 
VAN DIJK, T. Principles of critical discourse analysis. Discourse \& Society, vol 4 (2), 1993, p. 249-28.

Racism in the press. London: Arnold, 1986.

VAN LEEUWEN, T. Discourse and Practice: New Tools for Critical Discourse Analysis. New York: Oxford University Press, 2008.

A representação dos actores sociais. In: PEDRO, E. R. (Org.). Análise Crítica do Discurso. Lisboa: Editorial Caminho, 1997, p. 169-222.

WILKINSON, S. How useful are focus groups in feminist research?. In: BARBOUR, R. S.; KITZINGER, J. (Eds.). Developing focus group research: politics, theory and practice. London: Sage, 1999.

WODAK, R. Do que trata a ADC - Um resumo de sua história, conceitos importantes e seus desenvolvimentos. Linguagem em (Dis)curso-LemD, Tubarão, v. 4, n.esp, 2004, p. 223-243.

YOUNG, L.; HARRISON, C. (Eds.). Systemic Functional Linguistics and Critical Discourse Analysis. Studies in social change. London; New York: Continuum, 2004. 
ANEXOS 


\section{Apresentação do CD ROM}

Anexo A - Plano de Desenvolvimento Agrário do PA Santa Tereza I

Anexo B - II Plano Nacional da Reforma Agrária

Anexo C - Norma de Execução/INCRA/DD/no. 71

Anexo D - Termo de Assentimento INCRA-SR26

Anexo E - Termo de Consentimento Livre e Esclarecido - INCRA-SR26 (Modelo)

Anexo F - Termo de Consentimento Livre e Esclarecido - PA Santa Tereza I (Modelo)

Anexo G - Diário de campo

Anexo H - Protocolos das entrevistas realizadas no PA Santa Tereza I

$\mathrm{H} 1$ - Bem-te-Vi

H2 - Carão

H3 - Garça-Real

H4 - Gavião-Carijó

H5 - Gavião-Vaqueiro

H6 - Gralha-do-Campo

H7 - Periquito-Rei

H8 - Quero-Quero

H9 - Suiriri

H10 - Xexéu

H1 1 - Arara-Canindé

H12 - Cigana

H13 - Mãe-da-Lua

H14 - Irerê

H15 - João-Bobo

I16 - Rolinha-Vaqueira

I17 - Sanhaçu-do-Coqueiro

I1 8 - Tico-Tico

I19 - Andorinha-Azul

I20 - Savacu

I21 - Tuiuiu

Anexo I - Protocolos das entrevistas realizadas INCRA-SR26

I1 - Capim Dourado

I2 - Babaçu

Anexo J - Fotografias do PA Santa Tereza I 


\section{INSTITUTO DE CIENCIAS HUMANAS / UNIVERSIDADE DE BRASÍLIA / CAMPUS}

\section{PARECER CONSUBSTANCIADO DO CEP}

\section{DADOS DO PROJETO DE PESQUISA}

Título da Pesquisa: Discursividades em um Plano de Desenvolvimento Agrário (PDA): facetas de prática sociais (re)produzidas

Pesquisador: Carina Aparecida Lima de Souza

Área Temática:

Versão: 2

CAAE: 23078113.2 .0000 .5540

Instituição Proponente:

Patrocinador Principal: Financiamento Próprio

\section{DADOS DO PARECER}

Número do Parecer: 527.256

Data da Relatoria: 31/01/2014

\section{Apresentação do Projeto:}

Trata-se de projeto de pesquisa de doutorado, do Programa de Pós-graduação em Linguística (PPGL), da Universidade de Brasília (UnB),intitulado "Discursividades em um Plano de Desenvolvimento Agrário (PDA): facêtas de práticas sociais (re)produzidas", de autoria da doutoranda/pesquisadora Carina Apareceida Lima de Souza, e orientado pela Prof.Dra Denise Helena Garcia,com fianciamento próprio, que tem como objetivo geral analisar discursos (re)contextualizados no Plano de Desenvolvimento Agrário Santa Tereza I, no município de Ponte Alta, Tocantins - TO.

\section{Objetivo da Pesquisa:}

O objetivo da pesquisa é investigar discursos (re)contextualizados no Plano de Desenvolvimento Agrário (PDA) Santa Tereza I, em Ponte Alta-TO, e que institucionalizam e tentam organizar o Projeto de Assentamento Santa Tereza I, no município de Ponte Alta-

TO. A partir desse objetivo inicial, a pesquisdora pretende identificar e analisar as representações linguístico -discursivas constituídas no referido PDA.

\section{Avaliação dos Riscos e Benefícios:}

A pesquisa não oferece riscos aos participantes. O projeto apresenta relevância social e acadêmica, especialmente, no que se refere aos estudos de linguística, por se inserir na esferea da Análise de

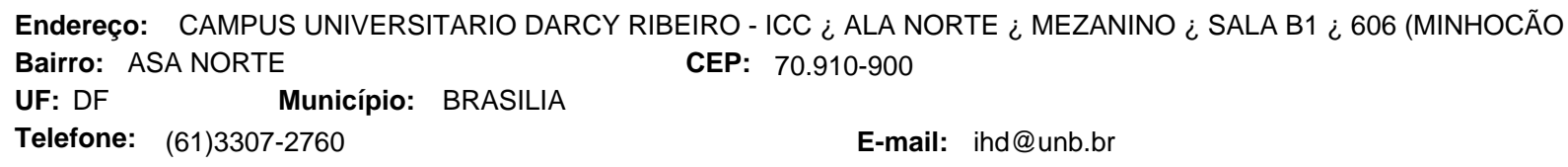




\section{INSTITUTO DE CIENCIAS HUMANAS / UNIVERSIDADE DE BRASÍLIA / CAMPUS}

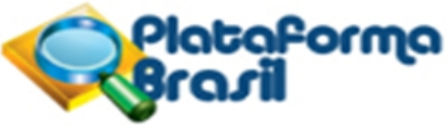

Continuação do Parecer: 527.256

Discurso Crítica (ADC),que busca mecanismos de análise dos usos da linguagem e suas práticas, no sentido de compreender as condições de vida de um grupo à margem da sociedade nas usas interações. Desse modo, a interação entre o homem e a sociedade e as perspectivas de propagação e transformação de crenças e valores sociais constituem benefícios.

\section{Comentários e Considerações sobre a Pesquisa:}

A pesquisa envolve procedimentos de seleção de dados documentais e de geração de dados de natureza etnográfica. No primeiro caso, os dados serão gerados e coletados no PDA Santa Tereza I e em textos da legislação brasileira que normatizam a sua constituição. Os dados de natureza etnográfica, por sua vez, serão obtidos no INCRA-Palmas e no Projeto

de Assentamento Santa Tereza I, por intermédio de observação participante, de entrevistas semiestruturadas e de notas de campo, para fins de comparação. Os pressupostos teórico-metodológicos propostos apoiam-se nas contribuiuções de Fairclough $(2003,2010)$, para a análise da exterioridade da linguagem; e de Halliday e Matthiessen (2004), para a análise da interioridade da linguagem, considerando que o foco de interesse é a análise das discursividades e das representações constituintes do PDA Santa Tereza I. O número total de sujeitos da pesquisa (amostra) é de 50 . Destes, 47 vivem no assentamento de Santa

Tereza I e serão entrevistados. Os outros 3 entrevistados são Funcionários do INCRA-SR26 (PalmasTocantins). Como ações de intervenção no campo, a pesquisadora propõe: (a) Realização de oficinas de leitura de alguns textos do PDA Santa Tereza I, a partir da perspectiva de gênero discursivo (FAIRCLOUGH, 2003), sendo a escolha de tais textos feita com a colaboração de assentados ¿as; (b) Reflexões com assentados sobre as representações e identificações constituídas no PDA Santa Tereza I a partir da análise dos dados linguísticos coletados;(c) Articulação de pressupostos teórico-metodológicos da Análise de Discurso Crítica, da Linguística Sistêmico-Funcional e dos Estudos Etnográficos.

\section{Considerações sobre os Termos de apresentação obrigatória:}

No rol de documentos a pesquisadora apresentou duas folhas de rosto; seu CV Lattes e o da orientadora; cronograma detalhado dos procedimentos da pesquisa e da elaboração da Tese de doutorado; 1 TCLE detalhado para os sujeitos (funcionários do INCRA) e 1 TCLE detalhado para os assentados; Carta de revisão ética; um Termo de Autorização para Utilização de Imagem para fins de pesquisa; aceite institucional com autorização do Superintendente Regional do INCRA, para a realização da pesquisa. No que se refere aos instrumentos de pesquisa, além da análise documental, a pesquisadora indicou como técnicas de coleta de dados, notas de campo, observação participante e entrevistas

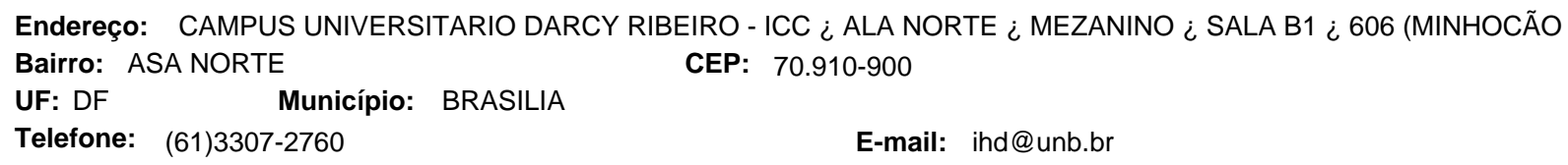




\section{INSTITUTO DE CIENCIAS HUMANAS / UNIVERSIDADE DE BRASÍLIA / CAMPUS}

Continuação do Parecer: 527.256

semiestruturadas, no sentido de obter uma triangulação de dados com finalidade comparativa. Nos instrumentos anexados, constam orientações relativas aos procedimentos, esclarecimentos acerca das técnicas e da coleta de dados, além da indicação das questões específicas que serão feitas aos assentados ou funcionários do INCRA nas entrevistas.

\section{Recomendações:}

Não há recomendações.

Conclusões ou Pendências e Lista de Inadequações:

Diante do exposto, considerando que a pesquisadora atendeu a pendência relativa aos instrumentos de pesquisa, o parecer é favorável à aprovação do projeto.

\section{Situação do Parecer:}

Aprovado

Necessita Apreciação da CONEP:

Não

Considerações Finais a critério do CEP:

BRASILIA, 11 de Fevereiro de 2014

Assinador por:

Soraya Fleischer

(Coordenador)

Endereço: CAMPUS UNIVERSITARIO DARCY RIBEIRO - ICC ¿ ALA NORTE ¿ MEZANINO ¿ SALA B1 ¿ 606 (MINHOCÃO

Bairro: ASA NORTE

UF: DF

Município: BRASILIA

CEP: $70.910-900$

Telefone: (61)3307-2760

E-mail: ind@unb.br 